\title{
Regulação da atenção à saúde bucal no Brasil: ações regulatórias sobre os serviços públicos e privados
}

\section{Pola Alessandra Kalamatianos}

Tese apresentada ao Programa de PósGraduação em Saúde Pública da Universidade de São Paulo para obtenção do título de Doutor em Saúde Pública.

Área de Concentração: Serviços de Saúde Pública

Orientador: Prof. Dr. Paulo Capel Narvai

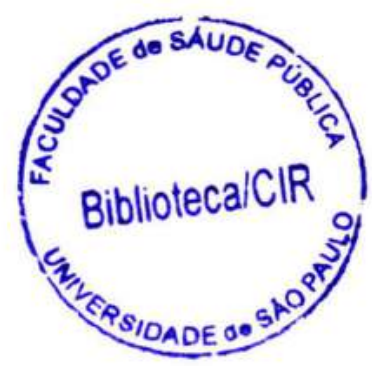

São Paulo 
É expressamente proibida a comercialização deste documento tanto na sua forma impressa como eletrônica. Sua reprodução total ou parcial é permitida exclusivamente para fins acadêmicos e científicos, desde que na reprodução figure a identificação do autor, título, instituição e ano da tese/dissertação.

$$
49678 / 2008 \text { da }
$$




\section{AGRADECIMENTOS}

Ao Professor Paulo Capel Narvai, por sua orientação, generosidade e confiança.

Ao Dr. José Carlos de Moraes e equipe do Departamento de Regulação, Avaliação e Controle de Sistemas do Ministério da Saúde e ao Dr. Afonso Teixeira dos Reis da Agência Nacional de Saúde Suplementar, pelas explicações sobre a Política de Regulação do setor Saúde no Brasil.

À Dra. Tânia Izabel Bighetti Forni da Coordenadoria de Planejamento da Secretaria de Estado da Saúde de São Paulo pelas explicações relativas às ações e aos serviços de Saúde Bucal do SUS-SP.

À Sra. Beatriz de Fátima Pereira, pelas incansáveis orientações sobre informática.

Aos meus colegas de trabalho pelo carinho e incentivo.

À Secretaria Municipal de Saúde de São José dos Campos pelo apoio e compreensão dispensados durante a realização desta pesquisa. 
Kalamatianos PA. Regulação da atenção à saúde bucal no Brasil: ações regulatórias sobre os serviços públicos e privados. [Tese de Doutorado]. São Paulo. Faculdade de Saúde Pública da USP; 2008.

\section{RESUMO}

Introdução - Para o Ministério da Saúde, sistemas de saúde são complexas estruturas sociais compostas por elementos que se inter-relacionam para produzir respostas em saúde. No Brasil, tais respostas ainda se mostram insuficientes e ineficazes no campo da Saúde Bucal, no que se refere à integralidade da atenção, ao acesso à assistência e aos índices epidemiológicos da população. A regulação estatal sobre a atenção à Saúde Bucal atua na produção de bens e serviços, através de regulamentações e ações específicas. Tais instrumentos, aliados aos projetos de grupos sociais, conformam o modelo de atenção, em determinado período. Objetivo - Identificar os instrumentos criados pelos poderes de Estado para fazer a regulação sobre a atenção à Saúde Bucal e analisar o seu emprego pelos órgãos e instituições competentes. Método - Pesquisa documental da produção Legislativa Federal publicada entre 1824 e julho de 2007, dos atos normativos ministeriais do setor Saúde publicados entre 1946 e julho de 2007 e dos documentos aprovados pelo Conselho Nacional de Saúde - CNS entre 1988 e julho de 2007. Foram identificadas em base de dados (SICON, SAUDE LEGIS e página da internet do CNS) regulamentações relacionadas ao objeto, empregando-se termos de busca como "bucal", "odontologia", "cárie", "dente", e derivações dos radicais "fluor", "dent", entre outros relacionados à odontologia. Os documentos foram submetidos à análise de conteúdo. Resultados - Localizaram-se 591 atos normativos ministeriais, 495 atos da produção Legislativa e 109 documentos do CNS. A temática emergente da análise demonstra que, até a Constituição Federal de 1988, as regulamentações relativas ao Ensino Superior da Odontologia, à Gestão de Pessoal na Administração Pública Civil e Militar e ao Exercício Profissional da Odontologia tiveram prioridade no processo de implementação das ações e serviços de Saúde Bucal no Brasil. A partir de 1989, com a regulamentação do Sistema Único de Saúde, ganharam destaque os temas como Transferências de Recursos, Tabelas e Procedimentos Odontológicos e Regulamentação sobre as Operadoras e Planos Odontológicos, a partir da criação de mecanismos financeiros para a indução da política nos estados e municípios e a partir da Regulamentação da Saúde Suplementar. Somente a partir de 2002, os Programas e as Ações de Saúde Bucal começaram a se inserir de forma mais consistente nos documentos selecionados, principalmente no CNS. Entre as instituições analisadas, constataram-se diferenças nas prioridades temáticas. Conclusões - As prioridades estabelecidas nas normas e nas regulamentações demonstram que o modelo de atenção à Saúde Bucal no Brasil foi conformado a partir de propostas técnicas e políticas de cada gestão de governo e por demandas de grupos corporativos, profissionais e de mercado, a cada período. A aplicação desses instrumentos de regulação deve ser reavaliada para a construção de uma Política Nacional de Saúde Bucal consistente e de longo prazo.

Descritores: Saúde bucal; Regulação; Saúde pública; Saúde suplementar; Instrumentos de regulação; Legislação. 


\begin{abstract}
Kalamatianos PA. Oral Health Care Regulation in Brasil: regulations acts on public and private services. [Doctorate Thesis] São Paulo (BR). Faculdade de Saúde Pública da USP; 2008.
\end{abstract}

Introduction - In the Health Department's view health systems consist of complex social structures made up of elements that interact to find the answers to health issues. In Brasil, such answers are still immature and inefficient in the Oral Health field, regarding the completeness of the care, the access to assistance and to epidemiological indexes of the population. The official regulation on the Oral Health Care implies the production of goods and services according to specific regulations and acts. Such instruments, together with projects of social groups, conform to the care model in a definite period. Objective - Identify the instruments created by the Official Entities to create a regulation on the care with the Oral Health and analyse its employment by the proper institutions. Method - Documental research of the legislative production approved between 1824 and July 2007, of the normative production published by the Health Ministry (Executive Power) between 1946 and July 2007 and of the documents approved by the Health National Council - HNC between 1988 and July 2007. Regulations related to the object were identified in the database (SICON, SAUDELEGIS and CNS homepage) by means of searching terms like "bucal", "odontologia", "cárie", "dente", and derivatives of the radicals "fluor", "dent", and other dentistry terms. The documents were submitted to a content analysis. Results Five hundred and ninety one Normative Acts of the Health Ministry were found, 495 of the Legislative Power and $109 \mathrm{HNC}$ documents. The emerging matter of the analysis demonstrates that until the Federal Constitution back in 1988, the regulations related to Dentistry College Education, Human Resources issues in Military and non-military Administration and the Dentistry Professional Practice had priority in the implementation process of Oral Health actions and services in Brasil. Effective from 1989, with the regulation of the Health Central System, themes like Funds Transference, Tables and Dental Procedures and regulations on Service Centers and Dental Plans were highlighted after the creation of financial mechanisms for political induction in the states and cities and after the Supplementary Health regulation. Nevertheless, from 2002 on, the Programs and the Oral Health Actions started being introduced in a more consistent way in the selected documents, mainly at the HNC. Amongst the institutions under analysis, differences in thematic priority were seen. Conclusions - The priorities established in the norms and regulations have demonstrated that the model of care to Oral Health in Brasil was conformed as per technical and political proposals of each government administration and by requirement from corporative, professional and market groups in each period. The application of these regulation instruments must be reassessed for the construction of a solid, long-termed Oral Health National Policy.

Key-words: Oral Health. Regulation. Public Heath Care. Supplementary Health Care. Regulation Instruments. Legislation. 


\section{ÍNDICE}

Página

Parte I - Contexto e caracterização da pesquisa

1 INTRODUÇÃO 1

1.1 AÇÃO ESTATAL E A GARANTIA DOS DIREITOS 4

1.2 CONCEITO DE REGULAÇÃO 11

1.3 REGULAÇÃO DO SETOR SAÚDE 21

1.4 GESTÃO E FORMAÇÂO DO SISTEMA DE SAÚDE NO BRASIL 27

1.5 SAÚDE SUPLEMENTAR $\quad 85$

1.5.1 A Ação Regulatória das Agências

1.5.2 A Agência Nacional de Saúde Suplementar - ANS 98

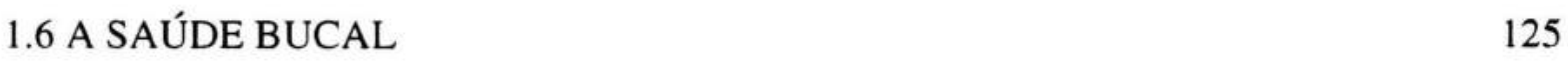

2 OBJETIVO 156

3 MATERIAL E MÉTODO 157

4 RESULTADOS 162

4.1 REGULAÇÃO NA PRODUÇÃO LEGISLATIVA FEDERAL 162

4.2 REGULAMENTAÇÃO DOS ATOS NORMATIVOS MINISTERIAIS 170

4.3 O CNS E A REGULAÇÃO SOBRE A SAÚDE BUCAL 184

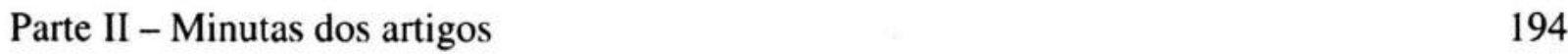

Artigo 1 -Regulação da atenção à saúde bucal no Brasil e a produção legislativa 195 Federal, entre 1824 e julho de 2007.

Artigo 2-Regulamentação da atenção à saúde bucal no Brasil: análise dos atos 226 normativos ministeriais entre 1946 e julho de 2007.

Parte III - Referências e Anexos 284

5 REFERÊNCIAS 285

Anexo A - Instrumento de coleta de dados 291

Anexo B - Quadros 9 a 13

Anexo C - Quadro 14 e 15

Anexo D - Aprovação COEP 295 


\section{Lista de Figuras}

Figura 1 - Produção Legislativa Federal sobre Saúde Bucal segundo o setor regulamentado e o período - Brasil - 1824 a julho 2007.

Figura 2 - Produção Legislativa Federal selecionada sobre Saúde Bucal, segundo 166 os eixos-temáticos, por períodos - Brasil - 1824 a julho de 2007.

Figura 3 - Produção Legislativa Federal selecionada sobre Saúde Bucal, segundo os setores regulamentados e os temas - Brasil - 1824 a julho 2007.

Figura 4 - Produção Legislativa Federal sobre Saúde Bucal, segundo os temas e setores regulamentados - Brasil - 1824 a julho 2007.

Figura 5 - Produção Legislativa Federal selecionada sobre Saúde Bucal no setor Administração, segundo os temas Gestão e Programas - Brasil - 1824 a julho de 2007.

Figura 6 - Atos normativos ministeriais sobre Saúde Bucal por eixos-temáticos e períodos - Brasil -1946 a 1988.

Figura 7 - Atos normativos ministeriais sobre Saúde Bucal, eixo-temático Outras, por períodos - Brasil - 1946 a 1988.

Figura 8 - Atos normativos ministeriais sobre Saúde Bucal, eixo-temático Gestão, por períodos - Brasil - 1946 a 1988.

Figura 9 - Atos normativos ministeriais sobre Saúde Bucal, eixo-temático Programas e Ações, por períodos - Brasil - 1946 a 1988.

Figura 10 - Atos normativos ministeriais sobre Saúde Bucal por eixos-temáticos 176 Gestão, Financiamento, Programas e Outras - Brasil - 1989 a julho de 2007.

Figura 11 - Atos normativos ministeriais sobre Saúde Bucal, eixo-temático Financiamento - Brasil - 1989 a julho de 2007.

Figura 12 - Atos normativos ministeriais sobre Saúde Bucal - subtema Tabelas e Procedimentos, segundo o nível da atenção - Brasil - 1989 a julho de 2007.

Figura 13 - Atos normativos ministeriais sobre Saúde Bucal - subtema Transferências de recursos segundo o nível de atenção e programa Brasil - 1989 a julho de 2007.

Figura 14 - Atos normativos ministeriais sobre Saúde Bucal - Gestão e organização do sistema - Brasil - 1989 a julho de 2007. 
Figura 15 - Atos normativos ministeriais sobre Saúde Bucal - subtema

Regulamentação do sistema - Brasil - 1989 a julho de 2007.

Figura 16 - Atos normativos ministeriais sobre Saúde Bucal - subtema Programas e Ações - Brasil - 1989 a julho de 2007.

Figura 17 - Atos normativos ministeriais sobre Saúde Bucal - Programas e Ações - segundo os assuntos dispostos nas regulamentações a cada ano Brasil - 1989 a julho de 2007.

Figura 18 - Número de documentos examinados e selecionados sobre Saúde Bucal - CNS - 1988 a julho de 2007.

Figura 19 - Número de documentos examinados no CNS e selecionados sobre 186 Saúde Bucal, segundo os períodos dos Governos pós-1985 - Brasil 1988 a julho de 2007.

Figura 20 - Número de abordagens sobre Saúde Bucal nos documentos selecionados do CNS, segundo os eixos-temáticos e os períodos dos Governos pós-1985 - Brasil - 1988 a julho de 2007.

Figura 21 - Número de abordagens sobre Saúde Bucal nos documentos selecionados do CNS, segundo eixos-temáticos e ano - Brasil - 1988 a julho de 2007.

Figura 22 - Número de abordagens sobre Saúde Bucal nos documentos 189 selecionados do CNS, segundo eixo-temático Outras - Brasil - 1988 a julho de 2007.

Figura 23 - Número de abordagens sobre Saúde Bucal nos documentos selecionados do CNS - inserção Programas e Ações - Brasil - 1988 a julho de 2007.

Figura 24 - Número de abordagens sobre Saúde Bucal nos documentos selecionados do CNS - eixo-temático Financiamento - Brasil - 1988 a julho de 2007.

Figura 25 - Número de abordagens sobre Saúde Bucal nos documentos 192 selecionados do CNS - eixo-temático Gestão - Brasil - 1988 a julho de 2007.

Figura 26 - Número de abordagens sobre Saúde Bucal nos documentos selecionados do CNS - Assuntos - Brasil - 1988 a julho de 2007. 


\section{Lista de Quadros}

Quadro 1 - Regulamentação principal - ANS - 25/05/2007

Quadro 2 - Regulamentações complementares normativas e operacionais - 112 ANS - 25/05/2007

Quadro 3 - Outras normas relacionadas à Saúde Supletiva - ANS - 25/05/2007 113

Quadro 4 - Legislação segundo a origem e a ocorrência - ANS - 25/07/2005 114

Quadro 5 - Legislação segundo o tipo de norma - ANS - 25/05/2007

Quadro 6 - Comparação entre as metas propostas pela OMS/FDI para o ano 130 2000 com relação à cárie dentária e os resultados do Projeto SB Brasil, 2003.

Quadro 7 - Produção ambulatorial total e odontologia SUS segundo níveis de 149 complexidade nos anos 2000, 2003 e 2006 - Brasil.

Quadro 8 - Número de beneficiários de planos odontológicos da assistência 151 suplementar segundo a modalidade de plano nos anos 2001, $2003 \mathrm{e}$ 2007.

Quadro 9 - Produção Legislativa selecionada sobre Saúde Bucal segundo a AnexoB origem e a regra legal - Brasil - 1824 a julho 2007.

Quadro 10- Produção Legislativa selecionada sobre Saúde Bucal por setor/área regulamentados e períodos - Brasil - 1824 a julho de 2007.

Quadro 11 - Produção Legislativa Federal selecionada sobre Saúde Bucal, segundo o setor regulamentado e temas - Brasil - 1824 a julho de 2007.

Quadro 12 - Produção Legislativa sobre Saúde Bucal segundo o tema Pessoal no setor Administração (exceto pessoal militar, ensino superior) Brasil - 1824 a julho de 2007.

Quadro 13 - Legislação Federal selecionada sobre Saúde Bucal relativa aos temas Gestão e Programas - Brasil - 1824 a julho de 2007.

AnexoB

AnexoB

AnexoB

AnexoB

Quadro 14 - Atos normativos ministeriais sobre Saúde Bucal, segundo a origem AnexoC da norma e período de publicação - Brasil - 1946 a julho de 2007.

Quadro 15 - Documentos selecionados sobre Saúde bucal segundo os eixosAnexoC temáticos, temas e assuntos - CNS - 1988 a julho de 2007. 


\section{Siglas utilizadas}

ABI - Aviso de Beneficiários Identificados

ACS - Agente Comunitário de Saúde

AIH - Autorização de Internação Hospitalar

AMB - Associação Médica Brasileira

ANS - Agência Nacional de Saúde Suplementar

ANVISA - Agência Nacional de Vigilância Sanitária

APAC - Autorização de Procedimentos Ambulatoriais de Alta Complexidade

ARPS - Adequação de Registro de Planos de Saúde

ASTEC - Assessoria Técnica

BID - Banco Interamericano de Desenvolvimento

BPA - Boletim de Produção Ambulatorial

CACON - Centros de Assistência de Alta Complexidade em Oncologia

CADIN - Cadastro Informativo

CADOP - Cadastro de Registro de Operadoras

CAPS - Centro de Apoio Psicosocial

CBO - Código Brasileiro de Ocupações

CCD - Coordenadoria de Controle de Doenças

CCS - Câmara de Saúde Suplementar

CEO - Centro de Especialidades Odontológicas

CERAC - Central Estadual de Regulação em Alta Complexidade

CFM - Conselho Federal de Medicina

CFO - Conselho Federal de Odontologia

CGCSS - Coordenação-Geral de Controle de Serviços e Sistemas

CGRA - Coordenação-Geral de Regulação e Avaliação

CGSI - Coordenação-Geral dos Sistemas de Informação

CGSS - Coordenação-Geral de Suporte Operacional dos Sistemas

CGVAN - Coordenação Geral de Vigilância em Saúde Ambiental

CIB - Comissão Intergestora Bipartite

$\mathrm{CIH}$ - Controle de Internações Hospitalares

CIR - Comissão Intergestora Regional

CIT - Comissão Intergestora Tripartite 
CNC - Confederação Nacional do Comércio

CNES - Cadastro Nacional de Estabelecimentos de Saúde

CNI - Confederação Nacional da Indústria

CNRAC - Central Nacional de Regulação em Alta Complexidade

CNS - Confederação Nacional de Saúde, Hospitais, Estabelecimentos e Serviços

CNS - Conselho Nacional de Saúde

CNSB - Coordenação Nacional de Saúde Bucal

COFEN - Conselho Federal de Enfermagem

CONASEMS - Conselho Nacional de Secretários Municipais de Saúde

CONASS - Conselho Nacional de Secretários Estaduais de Saúde

CONSU - Conselho de Saúde Suplementar

CPA - Coordenação de Programação Assistencial

CPOD - Índice de Dentes Cariados, Perdidos e Obturados

CPS - Coordenadoria de Planejamento de Saúde

CRO - Conselho Regional de Odontologia

CRS - Coordenadoria de Regiões de Saúde

CSS - Câmara de Saúde Suplementar

CUT - Central Única dos Trabalhadores

CVS - Centro de Vigilância Sanitária

DAB - Departamento de Atenção Básica

DAE - Departamento de Atenção Especializada

DAPE - Departamento de Ações Programáticas Estratégicas

DATASUS - Departamento de Informática do SUS

DECAS - Departamento de Controle e Avaliação de Sistemas

DENASUS - Departamento Nacional de Auditoria do SUS

DERAC - Departamento de Regulação, Avaliação e Controle de Sistemas

DIDES - Diretoria de Desenvolvimento Setorial

DIFES - Diretoria de Fiscalização

DIGES - Diretoria de Gestão

DIOPE - Diretoria de Normas e Habilitação das Operadoras

DIOPS - Informações Periódicas das Operadoras

DIPRO - Diretoria de Normas de Habilitação dos Produtos 


\section{DNCR - Departamento Nacional da Criança}

DNF - Departamento Nacional de Fiscalização

DNS - Departamento Nacional de Saúde

DORT - Distúrbios Osteomusculares Relacionados ao Trabalho

DST - Doença Sexualmente Transmissível

EPATESPO - Encontro Paulista de Administradores e Técnicos em Saúde Pública Odontológica

ESB - Equipe de Saúde Bucal

ESF - Equipe de Saúde da Família

FAEC - Fundo de Ações Estratégicas e de Compensação

FBH - Federação Brasileira de Hospitais

FENASEG - Federação Nacional das Empresas de Seguros Privados e de Capitalização

FIP - Formulário de Informações Periódicas Econômico-Financeiras das Seguradoras

FNS - Fundo Nacional de Saúde

FNSA - Fundação Nacional de Saúde

FOSP - Fundação Oncocentro de São Paulo

FPO - Programação Física - Orçamentária

FUNASA - Fundação Nacional de Saúde

GAP prestador - Guia de Autorização de Pagamento

GGAFI - Gerência - Geral de Administração e Finanças

GGTAP - Gerência - Geral Técnico-Assistencial dos Produtos

GM - Gabinete do Ministro

GPAB - Gestão Plena da Atenção Básica

GPABA - Gestão Plena da Atenção Básica Ampliada

IAPI - Incentivo para a Assistência Ambulatorial, Hospitalar e de Apoio Diagnóstico à População Indígena

ID - Índice de Desempenho

IDEC - Instituto Brasileiro de Defesa do Consumidor

IDI - Índice de Desempenho Institucional

IDSS - Índice de Desempenho de Saúde Suplementar

IN - Instrução Normativa

INAMPS - Instituto Nacional de Assistência Médica da Previdência Social

INAN - Instituto Nacional de Alimentação e Nutrição

INCA - Instituto Nacional de Câncer 
INTEGRASUS - Incentivo de Integração ao Sistema Único de Saúde

IS - Instituto de Saúde

LER - Lesão por Esforço Repetitivo

LRPD - Laboratório Regional de Prótese Dentária

MAC - Teto Financeiro de Média e Alta Complexidade Ambulatorial e Hospitalar

MC1 - procedimentos de Média Complexidade nível de hierarquia 1

MC2 - procedimentos de Média Complexidade nível de hierarquia 2

MC3 - procedimentos de Média Complexidade nível de hierarquia 3

MJ - Ministério da Justiça

MP - Medida Provisória

MS - Ministério da Saúde

NOAS - Norma Operacional de Assistência à Saúde

NOB - Norma Operacional Básica

NTRP - Nota Técnica de Registro de Produto

NURAF - Núcleos Regionais de Fiscalização

PAB - Piso da Atenção Básica

PABA - Piso da Atenção Básica Ampliado

PACS - Programa Agente Comunitário de Saúde

PDCRA - Plano Diretor de Controle, Regulação e Avaliação

PDI - Plano Diretor de Investimentos

PDR - Plano Diretor de Regionalização

PNASH - Programa Nacional de Avaliação dos Serviços Hospitalares

PNASS - Programa Nacional de Avaliação dos Serviços de Saúde

PPI - Programação Pactuada e Integrada

PROÁGUA - Programa de Vigilância da Qualidade de Água para Consumo Humano

PROCON - Programa de Orientação e Proteção ao Consumidor

PSF - Programa de Saúde da Família

RDC - Resolução da Diretoria Colegiada

RN - Resolução Normativa

RO - Resolução Operacional

RPC - Reajuste de Planos Coletivos

RPS - Planilha de Controle de Reajuste de Planos de Saúde

SAA/CGRL - Subsecretaria de Assuntos Administrativos / Coordenação-Geral de Assuntos Logísticos 
SADT - Serviço de Apoio Diagnóstico e Terapêutico

SAS - Secretaria de Atenção à Saúde

SAMU - Serviço de Atendimento Móvel de Urgência

SCI - Sistema de Controle de Processos de Impugnação de Ressarcimento

SCNES - Sistema Cadastro Nacional de Estabelecimentos de Saúde

SCPA - Sistema de Cadastro de Planos Antigos

SDS - Social Democracia Sindical

SESSP - Secretaria de Estado da Saúde de São Paulo

SE - Secretaria Executiva

SGTES - Secretaria de Gestão do Trabalho e Educação na Saúde

S I A - Sistema de Informações Ambulatoriais

SIAB - Sistema de Informações da Atenção Básica

SIAR - Sistema de Arrecadação

SIF - Sistema Integrado de Fiscalização

SIG - Sistema de Controle de Processos de Impugnação de Ressarcimento

SIH - Sistema de Informações Hospitalares

SIHD - Sistema de Informações Hospitalares Descentralizado

SIM - Sistema de Informações de Mortalidade

SNA - Sistema Nacional de Auditoria

SINAMGE - Sindicato Nacional das Empresas de Medicina de Grupo

SINAN - Sistema de Notificações de Agravos Nutricionais

SNAS - Serviço Nacional de Assistência à Saúde

SINASC - Sistema de Informações de Nascidos Vivos

SINOG - Sindicato Nacional das Empresas de Odontologia de Grupo

SNVS - Sistema Nacional de Vigilância Sanitária

SINVSA - Sistema Nacional de Vigilância Ambiental em Saúde

SIP - Sistema de Informação de Produtos

SISAGUA - Sistema de Vigilância da Qualidade da Água para Consumo Humano

SNEPS - Serviço Nacional de Programas Especiais de Saúde

SNFO/DNS - Serviço Nacional de Fiscalização de Odontologia

SPS - Secretaria de Políticas de Saúde

SISPPI - Sistema da Programação Pactuada e Integrada

SISREG - Sistema de Regulação em Saúde

SISTETO - Sistema Informatizado de acompanhamento de limites financeiros 
SNFMF - Serviço Nacional de Fiscalização de Medicina e Farmácia

SNIS - Sistema Nacional de Informações sobre Saneamento

SUDS - Sistema Unificado Descentralizado de Saúde

SUS - Sistema Único de Saúde

SVS - Secretaria de Vigilância em Saúde

TABNET - Aplicativo do DATASUS para a confecção de tabelas on line

TABWIN - Aplicativo de Tabulação para Windows

TCU - Tribunal de Contas da União

TFD - Transporte Fora do Domicílio

TISS - Troca de Informação em Saúde Suplementar

TRS - Terapia Renal Substitutiva

UNIDAS - União Nacional das Instituições de Autogestão em Saúde

UNIMED - Confederação Nacional das Cooperativas Médicas

UNIODONTO - Cooperativas de Serviços Odontológicos

UEME - União das Empresas Médicas

UTI - Unidade de Terapia Intensiva

VIGIAGUA - Vigilância em Saúde Ambiental relacionada à Qualidade de Água para Consumo Humano

VIGISUS - Vigilância em Saúde Ambiental relacionada à Qualidade de Água para Consumo Humano

VISA - Vigilância Sanitária 


\section{PARTE I}

CONTEXTO E CARACTERIZAÇÃO DA PESQUISA 


\section{INTRODUÇÃO}

Analisar a atenção à Saúde Bucal no Brasil em termos de Regulação, pressupõe certa compreensão sobre as práticas e as finalidades da ação Estatal como garantidora de direitos, assim como uma análise da Política de Regulação sobre o Setor Saúde.

Da mesma forma, a construção e a implementação da política pública de saúde no Brasil devem ser abordadas como cenário dos processos políticos que definiram as escolhas de prioridades para a atenção à Saúde Bucal. Tais escolhas, identificadas nas regulamentações, podem refletir uma ação positiva do Estado para a proteção e a garantia de benefícios ou, como afirma BOBBIO (1992), um não-agir do Estado.

$\mathrm{Na}$ literatura acadêmica, são relatadas inúmeras experiências e estudos de caso. A opção neste trabalho foi por analisar uma política pública a partir do referencial da Regulação, tratando-se de um estudo abrangente com enfoque sobre a regulamentação dos poderes Executivo e Legislativo do nível Federal e sobre os atos ministeriais do setor.

O referencial teórico tomado foi o da Regulação, enquanto ação social, ou seja, "o conjunto de ações meio que dirigem, ajustam, facilitam ou limitam determinados processos (...), abarcando tanto o ato de regulamentar (elaborar leis, regras, normas, instruções, etc) as próprias regulamentações, quanto as ações e técnicas que asseguram o cumprimento destas, como fiscalização, controle, avaliação, auditoria, sanções e premiações" (SCHILLING e col 2006, p.34).

Contudo, este estudo não teve como objetivo verificar a totalidade dos instrumentos regulatórios abarcados por esse conceito, na medida em que a Regulação das ações e dos serviços do SUS $^{1}$ prevê inúmeras atribuições, instrumentos e ações específicas em cada nível de governo, o que demandaria um projeto mais audacioso.

\footnotetext{
' Portaria SAS/MS 423, de 09/07/2002 - aprova o detalhamento das atribuições em cada nível de governo no controle, avaliação e regulação da assistência à saúde no SUS.
} 
Também, analisar a totalidade da regulamentação do sistema de Saúde Suplementar ${ }^{2}$ exigiria outro projeto, inserido no campo de conhecimentos da Economia, na medida em que as atribuições $e$ as ações regulatórias desse setor encontram-se associados à eficiência econômica e à atuação dos mercados.

No Brasil, do ponto de vista organizacional das ações e dos serviços de saúde bucal, observa-se a realização por múltiplos prestadores que atuam de forma independente, não articulada e sem obedecer a uma orientação ou coordenação geral, sendo o exercício da odontologia predominantemente privado e a prática liberal de consultório isolado a principal forma de atendimento (PINTO 2000). A essa complexidade, acrescentam-se os formatos jurídico-institucionais dos serviços de saúde bucal que variaram ao longo da história, tendo sido objetos de diferentes tipos de intervenção Estatal.

Assim, este estudo teve como principal interesse a forma de construção e implementação da política de atenção à Saúde Bucal, utilizando-se como referencial as regulamentações, enquanto instrumentos de regulação estatal.

Muitos autores afirmam haver "brechas de implementação" nas políticas públicas que merecem ser investigadas, uma vez que a legislação isoladamente, muitas vezes não vem sendo suficiente para a efetivação de mudanças ${ }^{3}$. ВОВBIO (1992) afirma que, o parlamento na sociedade industrial avançada "não é mais o centro do poder real, mas apenas, freqüentemente, uma câmara de ressonância de decisões tomadas em outro lugar..." (p.151).

Para CARVALHO (2002), "nem sempre as leis resolvem e explicam tudo. São os decretos, as portarias, as normas técnicas, as instruções normativas e as circulares que acabam detalhando aquilo que se deva fazer. Por vezes extrapolam e se colocam acima das leis. O SUS dispõe de todos esses mecanismos legais para que venha a funcionar bem" (p.20).

\footnotetext{
${ }^{2}$ Lei 9656 , de 15 de maio de 1998 - regulamenta o setor de planos e seguros, com 44 Medidas Provisórias aguardando consolidação pelo Congresso Nacional e a Lei 9961, de 28 de janeiro de 2000 - cria a Agência Nacional de Saúde Suplementar - ANS.

${ }^{3}$ BAPTISTA 2003
} 
A proposta deste trabalho foi 0 de analisar as regulamentações e as normas pertinentes à Saúde Bucal identificadas na produção Legislativa Federal, entre 1824 e julho de 2007, e nos atos ministeriais do setor saúde, entre 1946 e julho de 2007, tomando como eixo de discussão a implementação da política de Saúde Bucal e as prioridades regulamentadas (ou não) nos diferentes períodos.

Optou-se por analisar a produção Legislativa Federal e os atos normativos ministeriais no processo de operacionalização da política de saúde bucal, destacando-se a atuação do Executivo Federal na condução dessa política e sua capacidade de traduzir as demandas sociais vocalizadas pelo CNS. Da mesma forma, as funções de regulação e controle exercidas pelo Poder Legislativo ${ }^{4}$ junto a outras instâncias de poder foram analisadas, tendo em vista sua importância na garantia de processos democráticos.

Os documentos identificados do Conselho Nacional de Saúde foram analisados para servir de contraponto na análise das prioridades políticas estabelecidas e das demandas sociais surgidas entre 1988 e julho de 2007.

Os eixos-temáticos emergentes da análise dos documentos poderão ser os pontos de partida para a realização de estudos mais detalhados e demorados que possam esgotar a análise de recortes temporais, temáticos ou das relações sociais, políticas e jurídicas estabelecidas na regulação das ações e dos serviços de Saúde Bucal.

\footnotetext{
${ }^{4}$ Segundo BOBBIO (1992), a separação dos poderes do Estado e a subordinação de todo poder estatal ao direito surgiram como recursos para a garantia da ordem social. Para esse autor, a separação das principais funções e responsabilidades do Estado se dá verticalmente (Executivo, Legislativo e Judiciário), mas também de forma horizontal entre os órgãos centrais e órgãos periféricos nas várias formas de governo, que vão da descentralização político-administrativa até o federalismo. Relativamente ao Estado de direito, BOBBIO (1992) afirma ser um processo dominante em todas as teorias políticas do século IX, no qual "todo poder é exercido no âmbito das regras jurídicas que delimitam sua competência e orientam (ainda que com certa margem de discricionariedade) suas decisões (...) corresponde ao processo de transformação do poder tradicional, fundado em relaç̃̄es pessoais e patrimoniais, num poder legal, racional e impessoal" (p. 148). Esse autor também considera como recursos ou "remédios" contra a usurpação do poder legítimo a constitucionalização da oposição - que torna lícita a formação de um poder alternativo - e a investidura popular dos governantes - com a verificação periódica dessa investidura por parte do povo.
} 


\subsection{AÇÃO ESTATAL E A GARANTIA DE DIREITOS}

DALLARI (2005) afirma que as sociedades humanas, mesmo nas formas mais rudimentares, revelam a presença de uma ordem jurídica e de um poder. A organização da sociedade pressupõe a constituição de um poder que, embora político, é suscetível à qualificação jurídica, não sendo possível admiti-lo como estritamente político ou exclusivamente jurídico. Embora o poder não chegue a ser totalmente jurídico, ele age concomitante com o direito, buscando uma coincidência entre os objetivos de ambos.

Esse autor conceitua Estado como a “ordem jurídica soberana ${ }^{5}$ que tem por fim o bem comum ${ }^{6}$ de um povo situado em determinado território" (p.119). Assim, a noção de poder estaria implícita na de soberania, a política afirmar-se-ia na referência ao bem comum de um povo e a territorialidade seria a limitadora da ação jurídica e política do Estado, contemplando os elementos que constituem o Estado.

Segundo DALLARI (2005), o Estado implica um entrelaçamento de situações, de relações, de comportamentos, de justificativas, de objetivos, que compreende aspectos jurídicos e, ao mesmo tempo, um conteúdo político que lhe dá a função de coordenar os grupos e os indivíduos em vista de fins a serem atingidos, impondo a escolha dos meios adequados.

Para esse autor, as decisões políticas devem ser enquadradas num sistema jurídico eficaz e flexível para permitir o aparecimento e a integração de novos meios e para assegurar a reformulação da concepção de objetivos fundamentais, quando isto for exigido pela alteração substancial das condições de vida social.

\footnotetext{
${ }^{5}$ Miguel Reale (1960), citado por DALLARI (2005), conceitua soberania como "o poder de organizar-se juridicamente e de fazer valer dentro de seu território a universalidade de suas decisões nos limites dos fins éticos de convivência" (p.80).

${ }^{6}$ DALLARI (2005) considera universal o conceito de "bem comum" formulado pelo Papa João XXIII (Pacem in Terris): "O bem comum consiste no conjunto de todas as condiçøes de vida social que consintam e favoreçam o desenvolvimento integral da personalidade humana" (p.24). Para esse autor, a ordem jurídica integraria um conjunto de condições que favoreceriam o desenvolvimento integral da personalidade humana.
} 
BOBBIO (1992) sustenta que as necessidades nascem em função da alteração das condições de vida social, num momento em que o desenvolvimento técnico permite satisfazê-las e afirma que o reconhecimento e a proteção dos direitos do homem estão na base das Constituições democráticas modernas.

Durante as revoluções liberais dos séculos XVII e XVIII Independência dos EUA e Revolução Francesa - encontraram-se presentes as condições sociais para que os direitos fundamentais do homem fossem formulados, porém sem a garantia das condições sócio-econômicas necessárias para que pudessem ser exercidos em sua plenitude. Para a burguesia, classe social e econômica mais forte, o direito à liberdade revestiu-se de importância para limitar o poder do Estado, reduzindo ao mínimo sua atuação (BOBBIO 1992; ADÃO 1999).

Como conseqüência, o século XIX foi tomado pela normatização do primeiro desses ideais: os direitos fundamentais de liberdade, denominados "direitos de primeira geração". Naquele século, ganharam densidade normativa os direitos civis e políticos, direitos do indivíduo contra o Estado (BOBBIO 1992; DALLARI 2005; ADÃO 1999).

Para DALLARI (2005), o Estado liberal trouxe, inicialmente, benefícios para a coletividade, como o progresso econômico, criando condições para a Revolução Industrial, no entanto, no século XIX e no início do século $\mathrm{XX}$, as péssimas condições de trabalho, o excesso de mão-de-obra e a baixa remuneração do proletariado estimularam o surgimento dos movimentos socialistas.

No século $\mathrm{XX}$, com a crise do Estado liberal e com a necessidade de se implementar os direitos de igualdade surgiu uma "segunda geração" de direitos fundamentais: os chamados direitos econômicos e sociais, operando-se um fenômeno de expansão qualitativa dos próprios direitos de liberdade ${ }^{7}$. 0 "Estado-mínimo" é substituído pelo "Estado de serviço" que passa a intervir na economia.

\footnotetext{
${ }^{7}$ BOBBIO (1992) afirma que "o elenco de direitos do homem se modificou, e continua a se modificar, com a mudança das condições históricas, ou seja, dos carecimentos e dos interesses, das classes no poder, dos meios disponíveis para a realização dos mesmos, das transformações técnicas" (p.18). Segundo esse autor, "todas as declaraçōes recentes dos direitos do homem compreendem, além dos direitos individuais tradicionais que consistem em liberdades, também os chamados direitos sociais, que consistem em poderes. Os primeiros exigem da parte dos outros (inclú́dos os órgãos públicos)
} 
Com a II Guerra Mundial, o "Estado de serviço" empregou seu poder para amenizar algumas conseqüências da desigualdade econômica, levando a ação estatal a todos os campos da vida social. Ao final da II Guerra, o intervencionismo acentuou-se, restaurando os meios de produção, reconstruindo as cidades, readaptando as pessoas à vida social e financiando estudos e projetos. (DALLARI 2005).

Durante o século $\mathrm{XX}$, nasceram os direitos de "terceira geração" que, segundo BOBBIO (1992), se constituem numa categoria heterogênea e vaga, sendo difícil identificar do que realmente se trata. Para esse autor, o mais importante deles é o reivindicado pelos movimentos ecológicos, ou seja, o direito de viver num ambiente não poluído.

De acordo com ZAVASCKI (1998), surge o terceiro setor composto por entes quase públicos, representados por segmentos nãogovernamentais da sociedade civil organizada, as Organizações Não Governamentais - ONGs, incumbidas de lutar por interesses coletivos e difusos, "direitos esses que dificilmente poderiam merecer a tutela estatal, por ausência de representação política adequada e pela excessiva exposição daquele indivíduo que decidia enfrentar o Estado" (p.30).

No entanto, SANTOS (1999) afirma que o terceiro setor é uma designação residual e vaga para caracterizar o conjunto de organizações sociais que não são nem estatais nem mercantis, ou seja, "organizações sociais que, por um lado, sendo privadas, não visam fins lucrativos, e, por outro lado, sendo animadas por objetivos sociais, públicos ou coletivos, não são estatais" (p.5).

Para esse autor, qualquer que seja a ambigüidade conceitual do terceiro setor, nos países centrais se ressurgimento está ligado à crise do Estado-Providência ${ }^{8}$.

obrigações puramente negativas, que implicam em abstenção de determinados comportamentos; os segundos só podem ser realizados se for imposto a outros (incluídos os órgãos públicos) certo número de obrigações positivas" (p. 21).

${ }^{8}$ SANTOS (1999) afirma que "sendo muito diferentes os contextos políticos e operacionais do terceiro sector no centro e na periferia do sistema mundial, não surpreende que sejam igualmente distintos os temas de debate que o terceiro sector tem suscitado num e noutro caso. Há obviamente alguns pontos de comum nessa discussão. Quanto mais não seja, porque, por um lado, o ressurgimento do terceiro sector ocorre no contexto da expansão de uma ortodoxia transnacional, o neoliberalismo e 
Os direitos de "quarta geração", também surgidos no século $\mathrm{XX}$, referem-se aos efeitos das pesquisas biológicas e da possibilidade de manipulação do patrimônio genético de cada indivíduo (BOBBIO 1992).

Para esse autor, embora as exigências de direitos apresentem-se em fases ou gerações, suas espécies são sempre duas, com relação aos poderes constituídos: ou impedir os malefícios de tais poderes ou obter seus benefícios. Nos direitos de terceira e quarta geração podem existir tanto de uma quanto de outra espécie.

Para BOBBIO (1992) e DALLARI (2005), o verdadeiro problema da nossa época consiste em criar mecanismos para garantir a efetividade dos direitos sociais básicos previstos nos textos legislativos.

FREITAS (2007) afirma que, as Constituições Brasileiras de 1824 e 1891 deram positividade e juridicidade aos direitos do homem e às garantias individuais, sem preocupação com os direitos sociais. Com a Constituição de 1934, os direitos econômicos e sociais foram incorporados como direitos trabalhistas, sendo mantidos nas Constituições de 1937, 1946 e 1967.

Segundo essa autora, somente com a Constituição de 1988 os direitos humanos foram positivados, tanto os individuais, como os difusos e coletivos, trazendo instrumentos constitucionais para garantir a eficácia desses direitos.

Relativamente ao direito à saúde, MEZZOMO (2006) afirma ser este um direito que pode ser analisado sob vários prismas:

É um direito individual, na medida em que qualquer pessoa tem direito à sua integridade física e psíquica como corolário do seu direito de personalidade. Neste caso, dispõe de ação e pode exercer pretensão objetivando a abstenção de comportamento de terceiros que venham a por em risco sua saúde. $O$ direito à saúde também é um direito social e como tal é expressamente previsto nos artigos $6^{\circ}$, caput, e $196 \mathrm{da} \mathrm{CF/88.}$ Nesta condição, sua invocação pode ser feita como base de pretensões a comportamentos positivos por parte do Poder Público. Por fim, a saúde

o Consenso de Washington, e porque, por outro lado, uma parte do terceiro sector nos países centrais, as Organizações não Governamentais para o desenvolvimento, vai ter um papel decisivo na promoção, financiamento e operação das organizações não governamentais nos países periféricos e semiperiféricos" (p.9). 
também é direito difuso ${ }^{9}$ e apresenta uma faceta política. De fato, a comunidade como um todo é titular de direito a comportamentos positivos e negativos em relação a particulares e ao próprio Estado. A gestão da saúde, de seu turno, deve ser democrática, de forma que também condensa direito político de participação democrática (p.4).

Conforme afirma CARVALHO (2002), a Saúde é um direito essencial contemplado na Constituição de 1988 como dever do Estado, que só se efetivará se todos exercerem a cidadania plena ${ }^{10}$, como "contribuir com o fisco, sem sonegação; praticar a não corrupção passiva e ativa; proteger o patrimônio, bem e serviços públicos; exercer o controle da sociedade tanto do público como do privado para que ambos utilizem bem os recursos públicos" (p. 23).

Para ADÃO (1999), o equilíbrio entre a liberdade individual e a autoridade estatal, somente pode ser atingido através da lei geral estatal elaborada segundo regras preestabelecidas e aceitas pela coletividade: "a lei limitadora do conteúdo da liberdade individual precisa ser normal, moral e legítima, no sentido de ser consentida por aqueles que a liberdade restringe" (p.1).

Segundo esse autor, a liberdade geral está ligada ao princípio da Legalidade, na medida em que somente a legalidade garante a liberdade:

Na Constituição Federal brasileira de 1988, percebe-se esta ligação no artigo $5^{\circ}$, inciso II que menciona que: "ninguém será obrigado a fazer ou deixar de fazer alguma coisa senão em virtude da lei" (destaque do autor). A liberdade somente poderia ser limitada pela lei. Esta forma de considerar-se a legalidade frente à liberdade é baseada em um conteúdo negativo, sendo a liberdade o conceito geral e a restrição da lei a exceção. Não há uma relação no sentido de poder-se fazer tudo o que a lei permite, mas de poder-se fazer tudo, exceto o que a lei expressamente proíbe (p.2).

\footnotetext{
${ }^{9}$ Lei 8078 , de 11/09/1990 - dispõe sobre a proteção do consumidor.

TÍTULO III - Da Defesa do Consumidor em Juízo CAPITULO I - Disposições Gerais

Art. 81. A defesa dos interesses e direitos dos consumidores e das vítimas poderá ser exercida em juízo individualmente, ou a título coletivo. Parágrafo único. A defesa coletiva será exercida quando se tratar de: I - interesses ou direitos difusos, assim entendidos, para efeitos deste código, os transindividuais, de natureza indivisível, de que sejam titulares pessoas indeterminadas e ligadas por circunstâncias de fato; II - interesses ou direitos coletivos, assim entendidos, para efeitos deste código, os transindividuais, de natureza indivisível de que seja titular grupo, categoria ou classe de pessoas ligadas entre si ou com a parte contrária por uma relação jurídica base; III - interesses ou direitos individuais homogêneos, assim entendidos os decorrentes de origem comum.

${ }^{10}$ Para Jellinek (1954), citado por DALLARI (2006), a designação de cidadãos cabe a todos os que participam da constituição do Estado, havendo, entretanto, uma categoria especial de cidadãos, que são os que têm cidadania ativa, isto é, exercem certas atribuições que o próprio Estado reconhece como suas.
} 
ADÃO (1999) afirma que o princípio da Legalidade tem uma aplicação diferenciada para os indivíduos particulares e para a Administração Pública" e que, ao contrário dos particulares, aos agentes públicos somente é facultado agir por imposição ou autorização legal. Inexistindo lei, não haverá atuação administrativa legítima. Os Poderes Públicos somente podem praticar os atos determinados pela lei e, como decorrência, tudo aquilo que não resulta de prescrição legal é vedado ao administrador.

Assim, o poder estatal, visando o bem comum, deve garantir os direitos e as condições para seu pleno exercício. Para tal, as decisões devem ser enquadradas num sistema jurídico eficiente e flexível. O Estado, pautado pelo princípio da Legalidade, age sobre os setores privados e na própria Administração Pública, sendo, na atualidade, cada vez mais estimulada a sua intervenção.

DALLARI (2005) explica o surgimento de um novo tipo de intervencionismo, em que a atuação do Estado passa a ser vista como benéfica, na medida em que esse assume os papeis de gerador da economia, financiador de tecnologias e de pesquisas, além de ser capaz de garantir mercados. Na visão desse autor, "desaparecem os limitem público e privado, e o Estado, antigo mal necessário passou à condição de financiador, sócio e consumidor altamente apreciado, tendo cada vez mais estimulada sua atitude intervencionista" (p.285).

Esse autor destaca também que a evolução da sociedade trouxe exigências, sendo o Estado cada vez mais solicitado a agir, ampliando sua esfera de ação e intensificando sua participação nas áreas tradicionais. Tudo isso impôs uma legislação mais numerosa e mais técnica incompatível com os modelos de separação de poderes ${ }^{12}$, uma vez que "o legislativo não tem condições de fixar

\footnotetext{
"Constituição Federal de 1988 - CAPítulo VII - DA ADMINISTRAÇÃO PÚBLICA - Seção IDisposições Gerais - Art.37. A administração pública direta e indireta de qualquer dos Poderes da União, dos Estados, do Distrito Federal e dos Municípios obedecerá aos princípios de legalidade, impessoalidade, moralidade, publicidade e eficiência (...).

${ }^{12}$ De acordo com a teoria denominada sistema de freios e contrapesos, surgida com a separação dos poderes de Estado, os atos que o Estado pratica podem ser de duas espécies: atos gerais e atos especiais. Os atos gerais praticados pelo legislativo consistem na emissão de regras gerais e abstratas, de forma a não atuar concretamente na vida social, sem meios para cometer abusos de poder nem para beneficiar ou prejudicar a uma pessoa ou a um grupo em particular. S6́ depois de emitida a regra geral, abre-se a possibilidade de atuação do poder executivo para os atos especiais. $O$ executivo, apesar de
} 
regras sem ter conhecimento do que já foi ou está sendo feito pelo executivo, e o executivo não pode ficar à mercê de um lento processo de elaboração legislativa" (p. 2).

As tentativas para se aumentar a eficiência do Estado têm sido a delegação de poderes, sobretudo a delegação de poder legislativo, e a transferência constitucional de competências por meio de reformas constitucionais ou até a promulgação de novas Constituições, no sentido de se aumentar as competências do executivo, mantendo-se a aparência de separação de poderes. No Brasil, a criação das Agências Reguladoras ${ }^{13}$ pode servir como exemplo de delegação do poder legislativo junto a instituições autônomas.

Para DALLARI (2005), o sistema de separação de poderes possui um caráter formalista e jamais foi praticado, destacando as principais críticas ao sistema: a) interpenetração de atos que a rigor seriam de um órgão de poder, sendo feitos por outro; b) a influência de fatores "extralegais" faz com que algum dos poderes predomine sobre os demais; c) as injustiças criadas pelo liberalismo (desigualdades sociais e a não garantia de liberdades) foram construídas sob esse sistema; d) "executivos" antidemocráticos que transacionam com o poder legislativo; e) falta de representatividade democrática em muitos legislativos; f) emissão de atos gerais do poder legislativo que obedecem às determinações do executivo; entre outras.

BAPTISTA (2003) afirma que, historicamente, a forma de relação entre os poderes no Brasil sempre tendeu a uma preponderância do executivo sobre o legislativo, na medida em que o primeiro domina o processo legislativo pelo

\footnotetext{
dispor de meios para agir, fica impossibilitado de atuar discricionariamente, devido aos atos gerais praticados pelo legislativo. Em havendo exorbitância de qualquer dos poderes, há a ação fiscalizadora do poder judiciário que estabelece limites de competências nas respectivas esferas (DALLARI 2005).

${ }^{13}$ Formatos jurídico-institucionais sob os quais a Administração Pública pode se constituir para atuar no desenvolvimento social e/ou na economia (atividade pública descentralizada): Administração Direta, Autarquia, Fundação de Direito Público, Consórcio de Direito Público, Empresa Dependente, Empresa Pública e Sociedade de Economia Mista. Atualmente, discute-se mais amplamente a Fundação Estatal.

Formatos jurídico-institucionais sob os quais a iniciativa privada pode se constituir para atuar no desenvolvimento social e/ou na economia (atividade de interesse público executada em parceria ou contratação): Organização Social (Lei 9637/98); Empresa de Propósito Específico (Lei 10973/04), Setor Social Autônomo, Concessionária (Lei 8987/95), Organização da Sociedade Civil de Interesse Público - OSCIP (Lei 9790/99), Fundação de Apoio (Lei 8958/94), Fundação Privada, Empresa Privada, Associação (SALGADO 2007).
} 
poder de agenda votada pelo legislativo que segue as regras partidárias, segundo interesses negociados com o executivo.

Da mesma forma, essa autora destaca sempre ter havido troca de favores políticos entre esses Poderes, na medida em que o executivo sustenta suas políticas oferecendo cargos, nomeações, entre outros benefícios, ao que o legislativo responde com apoio político às propostas de governo. Essa situação é relativizada quando o executivo é obrigado a submeter-se a processos de negociação com partidos e líderes da oposição ou com sua própria base de sustentação.

BAPTISTA (2003) destaca que, enquanto o judiciário e o executivo propõem leis que visam à regulamentação de políticas sistêmicas e de caráter institucional, o legislativo adota uma postura individual e de interesses mais específicos dos próprios parlamentares ou dos grupos que representa. Os projetos do legislativo podem apresentar um caráter mais coletivo, a partir das idéias dos partidos, das comissões ou dos grupos de trabalho.

\subsection{CONCEITO DE REGULAÇÃO}

MEDEIROS (2001) afirma que, apesar de existirem controvérsias sobre o significado dos termos Welfare State, Estado-Providência e Estado Social, essas categorias podem ser consideradas fenômenos de natureza política semelhante. Após a II Guerra Mundial, os Estados centrais desenvolveram políticas públicas para a criação de sistemas de proteção e seguridade social que acabaram por transformar a natureza política das relações Estado/sociedade civil, dando origem a uma nova forma política denominada Estado- Providência.

Segundo esse autor, utiliza-se uma definição ampla desse termo que pode ser entendido como "a mobilização em larga escala do aparelho de Estado em uma sociedade capitalista a fim de executar medidas orientadas diretamente ao bem-estar de sua população" (p.1). 
O Welfare State é também um mecanismo de regulação política da sociedade, na medida em que o crescimento da organização política dos trabalhadores fez com que o Estado passasse a incluir na agenda política nacional os interesses dos trabalhadores organizados, regulando compromissos como a legitimação da propriedade privada, a mediação de relações privadas por instituições políticas democráticas, em troca da redistribuição de ganhos de produtividade e pleno emprego.

$\mathrm{Na}$ América do Norte e na Europa Ocidental, aspectos relacionados à cultura política e à organização estatal foram relevantes para explicar o desenvolvimento do Welfare State, cuja conformação foi determinada pelo padrão e nível de industrialização, pela capacidade de mobilização dos trabalhadores, pela cultura política da Nação, pela estrutura de coalizões políticas e pela autonomia da máquina burocrática em relação ao Estado (MEDEIROS 2001).

SANTOS (2002), ao analisar a conformação do EstadoProvidência em relação aos sistemas capitalistas, afirma que a especificidade de cada ordem constitucional fez com que, em termos de relações sociais e institucionais, não houvesse um só capitalismo e, em decorrência, um único Estado-Providência. Assim, identifica quatro diferentes trajetórias e configurações do capitalismo contemporâneo:

I. capitalismo mercantil - EUA, Inglaterra, Canadá, Nova Zelândia e Austrália: o mercado é a instituição central e suas insuficiências são supridas por agências de regulação. $O$ interesse individual e a competição dominam todas as esferas da sociedade e as relações sociais de mercado e de trabalho são reguladas pelo direito privado de forma extremamente flexível. É dada prioridade à inovação tecnológica promovida por diferentes tipos de incentivos e protegida pelo direito de patentes e de propriedade intelectual. Grandes desigualdades sociais são toleradas, bem como o sub-investimento em bens públicos ou de consumo coletivo (transportes, educação, saúde, etc.);

II. capitalismo mesocorporativo - Japão: o capitalismo é liderado pela grande empresa, onde se obtêm os ajustes econômicos principais, através dos bancos e da rede de empresas afiliadas controlados pela grande empresa. A regulação pública atua em estreita coordenação com as grandes empresas, havendo 
dualidade entre trabalhadores "regulares" e "irregulares", sendo a linha divisória a entrada ou não na carreira estruturada no interior do mercado interno da grande empresa. São altos os níveis de educação generalista e da formação profissional propiciadas pelas empresas. Se aceita a estabilidade de desigualdades;

III. capitalismo social-democrático - Suécia, Finlândia, Áustria, Noruega e Dinamarca e, em menor grau, a Alemanha: baseia-se no consenso entre os parceiros sociais, representados pelas as organizações dos patrões, dos trabalhadores e o Estado. Os compromissos são mutuamente vantajosos para garantir a compatibilidade entre ganhos de competitividade, inovação e produtividade, por um lado, e ganhos salariais e melhoria do nível de vida, por outro. Prevalência da justiça social com alto investimento em educação e organização do mercado de trabalho de modo a minimizar a flexibilidade e a promover a qualificação como resposta ao aumento da competitividade e à inovação tecnológica. Elevada proteção social contra os riscos e minimização das desigualdades sociais;

IV. capitalismo estatal - França, Itália e Espanha: centralidade da intervenção estatal como princípio de coordenação em face da fraqueza da ideologia do mercado e das organizações dos parceiros sociais. Sistema público de educação para a produção de elites empresariais públicas e privadas, porém com fraca formação profissional e mercado de trabalho altamente regulado. Investigação científica pública com deficiente articulação com o setor privado. Elevada proteção social.

SANTOS (2002) afirma que, desde a década de 1980, vêm sendo detectadas a desestruturação e a adaptação dos capitalismos mesocorporativo, social-democrático e estatal, em função da evolução da globalização e das linhas de força $^{14}$ que compõem o caráter hegemônico da globalização econômica, com efeitos sobre a prosperidade econômica que podem ser minoradas por medidas compensatórias que não prejudiquem o funcionamento dos mecanismos de mercado.

\footnotetext{
${ }^{14}$ SANTOS (2002) explica as 'linhas de força': vulnerabilidade dos compromissos capital e trabalho; rigidez salarial; redução das despesas públicas; coexistência da diferenciação entre salários e preços; diminuição do papel redistributivo das políticas sociais; proteção social sujeita à pressão privatizante, sobretudo no domínio das pensões e aposentadorias dado seu interesse por parte dos mercados financeiros; papel do Estado voltado para o incentivo às inovações e às exportações; atividades empresariais do Estado eliminadas ou fortemente reduzidas; pauperização dos grupos sociais vulneráveis e; aumento das desigualdades.
} 
Com base no Índice de Desmercadorização ${ }^{15}$, EspingAndersen (1990), citado por SANTOS (2002), afirma que o Estado-Providência assumiu diversas formas em diferentes países e identifica três ${ }^{16}$ tipos de EstadoProvidência:

I. Estado-Providência liberal - EUA e Inglaterra: baixo grau de desmercantilização com proteção pública seletiva $\mathrm{e}$ residual, especificamente, dirigida às classes com menor rendimento, através da promoção de um sistema dual de proteção pública e privada. Promoção ativa da intervenção do mercado à subscrição de esquemas privados e à limitação de níveis mínimos de proteção pública;

II. Estado-Providência corporativo - Alemanha e Áustria: elevada garantia de direitos sociais circunscritos aos trabalhadores e seus desempenhos no mercado de trabalho. Paralelamente, há um sistema de assistência social generoso para os que estão fora do regime contributivo. A desmercadorização da proteção social tem como contrapartida, o acionamento de efetivos mecanismos de controle social;

III. Estado-Providência social-democrático - países escandinavos: com acesso quase universal aos benefícios, de modo a suprir as necessidades e os gastos da classe média, sendo que o acesso aos direitos se dá pela condição de cidadão ou residência, com elevado grau de desmercadorização. Benefícios financiados por impostos, com esquemas complementares de seguridade social.

SANTOS (2002) identifica congruências entre as tipologias citadas. No capitalismo mercantil tem-se um Estado-Providência fraco (liberal), enquanto no capitalismo europeu, social-democrático ou estatal, observamse Estados-Providência fortes.

\footnotetext{
15 Indice de Desmercadorização - grau em que os indivíduos ou famílias podem manter um nível de vida aceitável, independentemente da participação no mercado, variando com o nível dos benefícios sociais, mas também com as condições de elegibilidade e restrições nos direitos. Também encontrado como Índice de Desmercantilização.

${ }^{16}$ Ferrera (1996), citado por SANTOS (2002), propõe, um quarto tipo, o Estado-Providência vigente no Sul da Europa (Itália, Espanha, Portugal e Grécia) constituído por um sistema corporativo de proteção social, altamente fragmentado em termos ocupacionais, gerador de injustiças e disparidades. Polarização entre esquemas generosos de proteção e grandes lacunas de proteção, com um sistema universal de saúde com baixa qualidade. Baixos níveis de despesas públicas sociais e persistência de clientelismos e misturas altamente promíscuas entre instituições públicas e privadas.
} 
MEDEIROS (2001) afirma que as circunstâncias do surgimento e do desenvolvimento do Welfare State no Brasil foram diferentes dos observados nos países europeus e nos EUA, surgindo a partir de decisões autárquicas, com o caráter de regular aspectos relativos à organização dos trabalhadores e assalariados dos setores modernos da economia e da burocracia.

De acordo com esse autor, a falta de autonomia da burocracia foi um dos elementos que comprometeram a capacidade redistributiva do Welfare State, visto seu comprometimento com os governos resistentes à promoção de gastos sociais. Por outro lado, o autoritarismo, a ausência de coalizões entre o trabalho industrial e não industrial e a forte segmentação do mercado de trabalho, presente em boa parte da história do país, limitou a capacidade de o movimento dos trabalhadores influenciar positivamente a sistematização de programas sociais extensivos a toda a população.

MEDEIROS (2001) relata que, até os anos de 1930, as políticas sociais eram fragmentadas e emergencistas, sendo que os conflitos entre o capital e o trabalho eram regulados por legislação esparsa com tratamento por forte aparato policial. As questões de saúde pública eram tratadas pelas autoridades locais, não havendo programas de ação por parte do governo central, cuja ação restringia-se às situações de emergência durante as epidemias nos centros urbanos. Da mesma forma, não havia uma política global de educação e a previdência era predominantemente privada e organizada por empresas e categorias profissionais.

Segundo esse autor, a partir de 1930, constituiu-se no Brasil um Welfare State com políticas de caráter conservador e autoritário, em que os antagonismos entre classes eram encarados como nocivos ao bem-comum representado pelo Estado.

Entre os anos de 1930 e 1943, o Brasil definiu as bases modernas de seu sistema de seguridade social com políticas voltadas para os trabalhadores urbanos permanecendo intactas até 1966. De acordo com Draibe (1989), citada por MEDEIROS (2001), a legislação produzida nesse período apresentava graus elevados de nacionalização sob a forma de centralização de 
recursos e instrumentos institucionais e administrativos no Executivo Federal, destacando as principais características do período:

- consolidação da legislação trabalhista em 1943;

- políticas de saúde e de educação centralizadas nos Ministérios dos Negócios de Educação e Saúde Pública;

- previdência social estatizada, deixando de ser organizada por empresas e sim por categorias profissionais;

- contribuições previdenciárias passaram a ter participação paritária da União, desonerando o capital no que diz respeito a gastos com seguros sociais, legitimando politicamente o Estado;

- aumento do papel do Estado na regulação da economia e da política nacionais, como estratégia de desenvolvimento;

- inclusão controlada e seletiva de segmentos de trabalhadores nas políticas sociais, com prioridade para os trabalhadores urbanos organizados; $\mathrm{e}$

- sistema de previdência social promoveu a rápida expansão do Estado burocrático, tornando-se uma das fontes mais importantes de emprego público no país.

Entre 1945 e 1964, não foram observadas mudanças significativas na construção do Welfare State, embora o país tivesse adotado um regime democrático a partir de 1945 . Esse período foi marcado pela criação de instrumentos legais para o funcionamento de um governo democrático, permanecendo inalteradas as estruturas corporativas do Welfare State.

Entretanto, as mudanças na economia e na política exigiram do Estado a ampliação e a articulação de suas funções para suprir as necessidades advindas da urbanização e da modernização do país. Assim, ocorrem a unificação administrativa e a uniformização dos benefícios e dos serviços da previdência social, sendo que na saúde o enfoque se deu sobre as questões relacionadas às doenças de massa e à assistência médica. No trabalho, a ocorrência de lutas sindicais e a política salarial, na educação, a democratização do ensino e a qualificação profissional e a habitação passa a ser considerada questão social. (MEDEIROS 2001). 
Esse período foi caracterizado pelos avanços nos processos de centralização institucional e de extensão da proteção social a novos grupos sociais, permanecendo, porém, o padrão seletivo, heterogêneo e fragmentado de beneficiários, benefícios e instituições.

Esse autor afirma que, a partir de 1964, foram implementadas "políticas de massa de cobertura relativamente ampla, mediante a organização de sistemas nacionais públicos ou estatalmente regulados para a provisão de serviços sociais básicos (....) $\mathrm{O}$ progresso social seria derivado do crescimento econômico com a necessidade de se acumular renda para garantir as bases do crescimento. A redistribuição de renda ocorreria, posteriormente" (MEDEIROS 2001, p.14).

Esse autor afirma que, de 1964 a 1970, o modelo de Welfare State perde o caráter populista, assumindo um caráter produtivista:

(...) o grande volume de recursos aplicados nas políticas sociais estimulou a participação da iniciativa privada nos setores de habitação, educação, saúde, previdência e alimentação. A privatização da política social cria tensão entre os objetivos redistributivistas e as necessidades do processo de acumulação, com a transferência de recursos para extratos de maior renda que conseguiam orientar as políticas sociais, de modo a atender a seus interesses políticos e particulares, produzindo ações ineficazes ineficientes e regressivas (p.16).

Entre 1970 até o final da década de 1980, as reformas ocorridas foram caracterizadas pela centralização política e financeira em nível federal, pela fragmentação institucional, pelo tecnocratismo, pelo autofinanciamento, pela privatização e uso clientelista das políticas sociais, sem funcionar como mecanismo redistributivo do produto da economia ${ }^{17}$, resultando em ineficiência e ineficácia dos programas sociais (MEDEIROS 2001).

Com o início da Nova República em 1985 e a consolidação da democracia em 1988, ocorreram avanços na área política através do crescimento

\footnotetext{
${ }^{17}$ Esse autor aponta as conseqüências ocorridas pelas reformas: regressividade dos gastos sociais; altos custos de implementação e administração; distância entre formuladores, executores e beneficiários das políticas públicas; insuficiência de avaliação dos programas sociais; instabilidade e descontinuidade das políticas públicas; e peso desproporcional dos interesses burocráticos, corporativos e privados nas definições e na dinâmica de funcionamento da máquina social do Estado.
} 
da atividade partidária e sindical e do aumento da participação popular no processo eleitoral. Ao mesmo tempo, seguiu-se a retração e o desmantelamento das políticas sociais, num contexto de pressões para cortes nos gastos públicos e mudanças institucionais e organizacionais no governo.

Em termos econômicos, BOYER (1990) afirma que, a partir dos anos de 1980, a implementação do programa neoliberal foi caracterizada pela abolição do controle de preços, pela desregulamentação do mercado de trabalho, e pela desestatização. Ao mesmo tempo, as formas de organização coletiva, de intervenção estatal e de regulamentação passaram a ser vistas sob suspeita de serem "intrinsecamente ineficazes e fonte de perturbação e de atrasos nos ajustamentos necessários de uma nova onda tecnológica (...)” (p.14).

As análises, em termos de regulação, inserem-se nesse contexto, fornecendo várias interpretações para esse período conturbado ${ }^{18} \mathrm{e}, \mathrm{em}$ alguns casos, recomendações sobre as formas de superar tais ameaças.

BRAGA (2003) considera relevantes as formulações dos regulacionistas no âmbito acadêmico, dadas à difusão e a influência exercidas entre os pesquisadores e as instituições acadêmicas de inúmeros países, sendo utilizadas em diversos temas das ciências sociais e, em especial, nos estudos sobre o trabalho. Tais análises tomam o crescimento, as crises e a sua variação no tempo e no espaço como uma questão central da análise econômica, ligando estes fenômenos às formas sociais vigentes.

Para BOYER (1990), a regulação não é uma teoria, uma escola ou um modelo definido para análises empíricas, mas sim um esforço de teorização que toma as formas institucionais, os regimes de acumulação e os modos de regulação como base para suas análises ${ }^{19}$, também denominadas noções de base.

\footnotetext{
18 BRAGA (2003) afirma que, a teoria da regulação surgiu da tradição reformista da socialdemocracia européia (Mitterand) em reação e como alternativa ao neoliberalismo (Thatcher e Reagan), apresentando um novo modelo de Estado regulador, mediador e menos interventor, situado entre dois modelos econômicos e sociais: o liberal (EUA) e o comunista/socialista (China e Cuba), com a mudança do papel do Estado que passa de provedor para regulador. Os trabalhos dos primeiros autores regulacionistas são provenientes, em sua maioria, de economistas e engenheiros do governo Mitterand.

${ }^{19}$ BOYER (1990) define 'forma institucional' como "toda codificação de uma ou várias relações sociais fundamentais" (p.73). Em termos de capitalismo, assinala a importância das articulaçōes entre
} 
Para BRAGA (2003), as formulações dos regulacionistas acerca do papel do Estado estão sustentadas na hegemonia das mediações, onde o Estado passa a ser considerado um mediador de conflitos e do progresso social, assumindo uma forma ambivalente dotada de neutralidade.

BOYER (1990) identifica três princípios básicos de ação para as formas institucionais:

(...) a lei, a regra ou o regulamento que têm a função de impor pela coerção um tipo de comportamento econômico aos grupos e indivíduos. Em sociedades democráticas a lei pressupõe o voto e um mínimo de concordância entre os representantes políticos, pois quando a lei entra em conflito com as relações de poder vigentes ou com a lógica dos interesses privados, corre-se o risco de que seja esvaziada, contornada e caia em desuso (...) o compromisso resultante de negociações entre os agentes privados ou grupos que, partindo de seus proprios interesses, estabelecem convenções que regem seus engajamentos. Um compromisso pode ser estendido, pela lei ou pelo regulamento, a um conjunto maior do que o das partes inicialmente envolvidas (...) na ausência de leis ou convenções pode-se ter um sistema de valores ou de representações, válidos para as crenças religiosas, para as regras de boa conduta, mas também para a economia (p.82).

A noção de regulação quando traduzida para a língua inglesa não encontra seu correspondente, confundindo-se com regulamentação regulation. Uma noção de regulação foi definida por BOYER (1990):

Designaremos sob o termo de regulação a conjunção dos mecanismos que viabilizam a reprodução do conjunto do sistema, em função do estado das estruturas econômicas e sociais (p.181).

as formas de concorrência, as relações salariais, a articulação do Estado com a sociedade e a participação do Estado-nação nas relações internacionais.

Esse autor conceitua 'modo de regulação' como "todo o conjunto de procedimentos e de comportamentos, individuais ou coletivos, com a tripla propriedade de reproduzir as relações sociais fundamentais; sustentar e 'pilotar' o regime de acumulação em vigor; e garantir a compatibilidade de um conjunto de decisões descentralizadas, sem que seja necessária a interiorização dos princípios de ajustamentos do sistema como um todo por parte dos atores econômicos" (p.80).

Da mesma forma, define 'regime de acumulação' como "conjunto das regularidades que asseguram a progressão geral e relativamente coerente da acumulação de capital, ou seja, que permitam absorver ou repartir no tempo as distorções de desequilíbrios que surgem permanentemente ao longo de todo o processo" (p.72). 
Em FERREIRA (1998), as palavras regulamentação e

regulação são assim definidas:

Regulamentação. S.f. 1. Ato ou efeito de regulamentar. 2. Redação e publicação de regulamentos de associação ou instituto.

Regulamentar. V.t.d. Sujeitar a regulamento; regular, regularizar.

Regulamento. S.m. 1. Ato ou efeito de regular (....) 3. Prescrição, regra, norma, preceito. 4. Conjunto de regras ou normas. (....)

Regulação. S.f. Ato ou efeito de regular.

Regular. V.t.d. 1. Sujeitar a regras; dirigir, regrar. 2. Encaminhar conforme a lei. 3. Esclarecer e facilitar por meio de disposições (a execução da lei); regulamentar (....) 5. Estabelecer ordem, parcimônia, em. 6. Acertar, ajustar. 7. Conter, moderar, reprimir. 8. Conformar, aferir, confrontar, comparar (p. 559).

Di Pietro (2002), citada por CUNHA (2003), afirma que a função

inerente à regulação não se confunde com a de regulamentação:

\begin{abstract}
Regular significa estabelecer regras, independentemente de quem as dite, seja o Legislativo ou o Executivo, ainda que por meio de órgãos da Administração direta ou entidades da Administração indireta. Trata-se de um vocábulo de sentido amplo, que abrange, inclusive, a regulamentação, que tem um sentido mais estrito.

Em conseqüência, quando se fala em desregular, como um dos instrumentos ora utilizados para a reforma do Estado, quer-se significar que deve diminuir o regramento da atividade privada, para diminuir a intervenção do Estado nas liberdades do cidadão. Por outras palavras, quer-se diminuir o poder de polícia do Estado, pela diminuição das limitações ao exercício dos direitos individuais. (....)

Regulamentar significa também ditar regras jurídicas, porém, no direito brasileiro, como competência exclusiva do Poder Executivo. Perante a atual Constituição, o poder regulamentar é exclusivo do Chefe do Poder Executivo (art.84, IV), não sendo incluído, no parágrafo único do mesmo dispositivo, entre as competências delegáveis (p.53).
\end{abstract}

Para CUNHA (2003), a regulamentação é política, enquanto a tendência de regulação é técnica, uma vez que essa utiliza conceitos jurídicos indeterminados: eficiência, modicidade de tarifas, serviço adequado, segurança e por meio de ponderação entre custos e benefícios na intervenção econômica sobre a liberdade privada. Esse autor considera a regulação um importante instrumento de criação, correção e organização de um mercado, com defesa da concorrência e do consumidor, ponderando e maximizando os interesses envolvidos. 
CUNHA (2003), afirma que as atividades administrativas estatais voltadas para a regulação, desenvolvem-se por meio da polícia, da prestação de serviços públicos, do ordenamento social e do ordenamento econômico. Neste último, busca-se atender a princípios constitucionais na defesa da concorrência e na defesa do consumidor, surgindo, no Brasil, dois diplomas legais distintos: a Lei da Defesa da Concorrência (Lei $n^{\circ}$. 8.884, de 11 de junho de 1994) e o Código de Defesa do Consumidor (Lei $n^{\circ}$. 8.078, de 11 de setembro de 1990).

Em relação ao ordenamento social, surgem as atividades de previdência social, assistência social, saúde, proteção da família, do idoso, do adolescente, do meio ambiente, incentivo à educação, cultura, desporto e pesquisa, independentemente da finalidade econômica (CUNHA 2003).

Relativamente à saúde pública, esse autor destaca: "a saúde pública implica numa atividade administrativa empreendida pelo Estado (ainda que com eventuais meios privados, nos termos do art. 197 da Constituição da República), não se confundindo com a atividade econômica de saúde, que é livre à iniciativa privada (art.199) desenvolvida em regime de livre iniciativa, mas sujeita a uma regulação estatal - art.197 e 174" (p.57).

Para CARVALHO (2005) e CARVALHO (2003), o termo Regulação vem sendo adotado de modo indevido, uma vez que na legislação brasileira a Regulação ou Regulamentação refere-se à formulação de regras, segundo os trâmites legais observados na Constituição Federal, nas leis, nos decretos, nas portarias, nas normas, entre outras. Para esses autores, o termo Regulação não abrangeria as ações relativas à execução dessas regras, embora considerem essas ações de suma importância para a operacionalização do sistema de saúde.

\subsection{REGULAÇÃO DO SETOR SAÚDE}

HEIMANN e col. (2005) afirmam que, no Brasil, a regulação do setor saúde, se assenta, por um lado, na Constituição Federal de 1988 e na Lei Federal 8.080/1990, com artigos direcionados à regulação do Sistema de 
Saúde e, por outro, na definição macropolítica de ajuste econômico e da Reforma do Estado ocorrida nos anos de 1990, a partir da privatização de setores em que o Estado era provedor.

Segundo esses autores, a legislação do SUS define, de forma ampla e abrangente, as atribuições e as competências necessárias à fiscalização, ao controle e ao estabelecimento de regras para o sistema, enquanto que a regulação com base na Reforma do Estado direciona-se à estruturação do mercado de planos de saúde, descaracterizando a assistência à saúde como direito universal.

Não obstante, a concepção e as finalidades da regulação em saúde ainda não serem uniformes e não se apresentarem plenamente desenvolvidas no âmbito do SUS, as concepções de controle, avaliação e auditoria também variaram ao longo do tempo, resultando na criação de estruturas e práticas que foram incorporadas e reproduzidas pelas Secretarias Estaduais e Municipais de Saúde.

Para o Ministério da Saúde, a regulação enquanto ação social $^{20}$ é conceituada como o "conjunto de ações mediatas, de sujeitos sociais sobre outros sujeitos sociais, que facilitam ou limitam os rumos da produção de bens e serviços em determinado setor da economia, compreendendo tanto o ato de regulamentar, as regulamentações, quanto as ações que asseguram o cumprimento destas" (SCHILLING e col. 2006; p.34).

Segundo esse conceito, as regulamentações e as ações são conformadas pelos rumos hegemônicos da produção social, numa sociedade específica em contextos histórico-sociais concretos. Para esses autores, "no Brasil, a regulação deve ser compreendida segundo as características próprias do desenvolvimento de um capitalismo tardio, imerso num fluxo do mercado mundial em expansão, marcado pela presença de um Estado protagonista e empreendedor e

\footnotetext{
20 "A sociologia política de Max Weber se baseia numa distinção entre a essência da economia e a essência da política, estabelecida a partir do sentido subjetivo das condutas humanas. A economia tem que ver com satisfação das necessidades, e também com o objetivo determinado pela organização racional da conduta: a política se caracteriza pela dominação exercida por um homem ou por alguns homens sobre outros homens. Tanto o agir econômico como o agir político são derivados da idéia de Weber sobre a ação social, que vem a ser o comportamento humano; a conduta ou uma atitude interior ou exterior voltada para a ação ou abstenção, sendo esse comportamento social de acordo com sentido atribuído pelo sujeito no seu relacionamento com outras pessoas. Do conceito sobre a ação social decorrem as várias séries de condutas ou comportamentos humanos, isolados ou em grupo, como a relação social, a ordem legítima, o combate, comunidade, agrupamento, empresa, associação, instituição, poder e dominação, todos regidos pelo signo da probabilidade" (BENETON 2001; p.63).
} 
atravessado por interesses privados e, ao mesmo tempo, de soberania limitada" (p.35)

O conceito ampliado de Regulação compreenderia tanto o ato de elaborar regulamentações, quanto às ações de fiscalização, de controle, de avaliação e de auditoria destinadas a assegurar o cumprimento das regulamentações definidas por uma esfera de governo. Regular "não se resumiria ao ato de regulamentar, mas também incluiria uma gama de ações que verificam se a produção em saúde se dá conforme as regras estabelecidas" (SCHILLING e col. 2006; p.36).

Segundo esses autores, "a regulação no Setor Saúde tem como objetivo geral a produção de todas as ações e, em decorrência, tem como principais objetos $^{21}$ : os estabelecimentos, equipamentos, profissionais, habilitação a graus de complexidade, as relações contratuais, o exercício das profissões de saúde, a oferta e a demanda por serviços, os protocolos assistenciais, os fluxos de atendimento, a produção, a venda, a incorporação e o uso de insumos, medicamentos e outras tecnologias, condições de trabalho e ambientes relativos ao setor Saúde, além do controle e da avaliação dos custos e gastos em saúde" (p.36)

Nesse sentido, o controle, a avaliação e a auditoria são instrumentos integrantes da Regulação:

O controle pode ser tomado como a supervisão contínua que se faz para verificar se o processo de execução de uma ação está em conformidade com o que foi regulamentado, para conferir se algo está sendo cumprido, conforme um parâmetro próximo de um limite pré-fixado, se estão ocorrendo ou não extrapolações. $O$ controle pode se dar de forma antecipada, concomitantemente ou subsequentemente ao processo de execução das atividades. A avaliação é um conjunto de ações que permitem emitir um juízo de valor sobre algo que está acontecendo (sendo observado), a partir de um parâmetro (ótimo, desejável, preceito legal, etc). Avaliar consiste em atribuir um valor ao encontrado a partir do esperado, uma medida de aprovação ou de desaprovação. Assim, a avaliação pode se constituir em uma ferramenta para se fazer fiscalização, controle, auditoria, planejamento e replanejamento, para se melhorar desempenhos e qualidades (...) A auditoria é um conjunto de técnicas que visam avaliar processos e resultados e a apliçação de recursos financeiros, mediante o confrontamento entre uma situação encontrada com determinados critérios técnicos, operacionais ou legais.

${ }^{21}$ A regulação compreendida como ação social tem como sujeitos de regulação: o Estado, sujeitos coletivos da sociedade civil, organizações não governamentais, segmentos de capital, corporações de profissionais, não sendo apenas função do Estado, mas da sociedade civil e no mercado por meio da concorrência ou do monopólio. 
É uma importante técnica de exame especializado de controle, na busca da melhor alocação de recursos, visando evitar ou corrigir desperdícios, irregularidades, negligências e omissões. A finalidade da auditoria é comprovar a legalidade e a legitimidade dos atos e fatos e avaliar os resultados alcançados quanto aos aspectos de eficiência, eficácia e efetividade da gerência ou gestão orçamentária, financeira, patrimonial, operacional, contábil e finalística de unidades ou sistemas (p.33).

\title{
Relativamente à abrangência da ação regulatória e as
}

estratégias de regulação para o setor Saúde, o MS vem adotando os seguintes conceitos:

\begin{abstract}
Regulação sobre Sistemas de Saúde - tem como objeto os sistemas municipais, estaduais e nacional e, como sujeitos, o gestor federal e os gestores estaduais e municipais. Comporta ações de regulação do gestor da saúde na esfera federal sobre estados e municípios; do gestor da esfera estadual sobre municípios e prestadores; e dos municípios sobre os prestadores, assim como a auto-regulação de cada uma dessas esferas. Também comporta a regulação do Estado sobre o setor privado de produção de bens e serviços de saúde não conveniados e nem contratados pelo SUS. Suas principais ações são: regulamentação geral, controle e avaliação dos sistemas, regulação da atenção à saúde, ações de auditoria, ações de integração com outras esferas de controle público (MP, TC), e ações de controle social, ouvidoria, algumas de vigilância sanitária e a regulação sobre a saúde suplementar (...)

Regulação da Atenção à Saúde - tem como objeto a produção de todas as ações diretas e finais da atenção à saúde, dirigida aos prestadores de serviços de saúde, públicos e privados. As ações da Regulação da Atenção à Saúde compreendem a Contratação ${ }^{22}$, a Regulação do Acesso à Assistência ou Regulação Assistencial, o Controle Assistencial, a Avaliação da Atenção à Saúde, a Auditoria Assistencial e as regulamentações da Vigilância Epidemiológica e Sanitária (...) Regulação do Acesso à Assistência ou Regulação Assistencial conjunto de relações, saberes, tecnologias e ações que intermedeiam a demanda dos usuários por serviços de saúde e o acesso a estes (...) Complexo Regulador - estratégia da Regulação Assistencial, consistindo na articulação e integração de Centrais de Atenção Préhospitalar e Urgências, Centrais de Internação, Centrais de Consultas e Exames e Protocolos Assistenciais com a contratação, controle assistencial, avaliação, programação e regionalização. Os complexos reguladores podem ter abrangência intra-municipal, municipal, micro ou macro regional, estadual ou nacional, devendo esta abrangência e respectiva gestão, serem pactuadas em processo democrático e solidário, entre as três esferas de gestão do SUS (SCHILLING e col. 2006; p.39) (...) Auditoria Assistencial ou Clínica - processo regular que visa aferir e induzir qualidade do atendimento amparada em procedimentos,
\end{abstract}

${ }^{22}$ Contratação - conjunto de atos que envolvem desde a habilitação dos serviços/prestadores até à formalização do contrato na sua forma jurídica 
protocolos e instruções de trabalho normatizados e pactuados. Deve acompanhar e analisar criticamente os históricos clínicos com vistas a verificar a execução dos procedimentos e realçar as não conformidades (MS $2006 \mathrm{~g}$; p.35).

Por sua vez, a gestão de um sistema público de saúde deve contemplar a definição da política de saúde e do correspondente projeto tecno-assistencial implementados por meio do planejamento, financiamento, ornamentação, programação, informação/informática, gestão do trabalho e educação, ciência e tecnologia, funções administrativas e financeiras, macrorregulação e dos modelos de atenção à saúde (SCHILLING e col. 2006).

Sob o ponto de vista jurídico, CUNHA (2003) considera que a regulação do setor da saúde suplementar envolve atividades normativas, executivas e judicantes:

A regulação normativa dos produtos pode ser representada pelos róis de procedimentos médicos explicitadas na legislação básica e aos quais as operadoras reguladas devem sujeitar-se ou, por exemplo, pela norma relativa às segmentações dos planos de saúde. A regulação executiva dos produtos regulados pode ser notada no registro que a operadora deve fazer na ANS, como ato de consentimento de polícia administrativa, tanto dos produtos regulados quanto da entidade em si. A regulação judicante em matéria de produtos é evidenciada na autuação da ANS por meio de processos administrativos que objetivam a penalização da comercialização de produto(s) não registrado(s) (p.77).

Esse autor adota as mesmas concepções para classificar os instrumentos de regulação daquele setor:

Os instrumentos da regulação normativa abrangem toda a produção de atos gerais da ANS, como as Resoluções da Diretoria Colegiada (RDC), posteriormente substituídas pelas Resoluções Normativas (RN), emanados pelos dirigentes da Administração Reguladora destinados a fins normativos, de intervenção, por meio das quais era detalhada a área de ação das operadoras de saúde. Essas decisões normativas destinam-se a regular a implementação da política de saúde suplementar nacional e a prestação dos serviços de assistência à saúde, através de instrumentos e sistemas de coleta periódica de informações a serem analisadas e a partir das quais serão gerados novos estudos para aplicação no mercado regulado. Também as Resoluções (RE), que são atos gerais e abstratos (mas não do Colegiado) para fins autorizativos, homologatórios, 
certificatórios, cancelatórios ou de definição, detalhamento, orientação ou organização de procedimentos administrativos dentro de cada Diretoria: as Instruções Normativas, que são atos destinados a detalhamento de procedimentos de alcance externo previstos nas Resoluções Normativas e as Resoluções do Conselho de Saúde Suplementar - CONSU, incumbido de produzir as políticas de saúde privada enquanto não era criada a ANS (mas que, atualmente, ainda tem composição) (...) No tocante à regulação executiva, figuram nessa categoria o consentimento de polícia identificado pelo registro da operadora ou pelo registro do produto, assim como pela aprovação de índices de reajustes a serem aplicados pelas operadoras junto a seus consumidores. Outro exemplo seria a fiscalização de polícia aferida pela ANS, que pode culminar com a indicação da adoção de regimes interventivos de direção fiscal e técnica (...) $A$ regulação judicante, observada nos atos consequientes da fiscalização de polícia, que ensejem uma sanção de polícia (....) mediante processo administrativo sancionador que tenha por base o auto de infração, a representação ou a denúncia positiva dos fatos irregulares, resumindo-se cada um no fato de serem provocados, respectivamente, por ato de um fiscal competentemente investido na função, de um servidor público reconhecido para tanto ou qualquer cidadão. (....) Nessa categoria também são classificadas as penalidades administrativas a serem ministradas aos potenciais inadimplentes (RDC $n^{\circ} 24$, de 13 de junho de 2000 que dispõe sobre a aplicação de sanções às operadoras de planos privados de assistência à saúde que, de alguma maneira, exerçam a atividade sem observância às regras postas (....) a inscrição da operadora infratora no regime de liquidação extrajudicial, quando a operadora apresentar insolvência econômico-financeira, não alcançar o objetivo de saneamento da insuficiência nas garantias do equilibrio proposto pela direção fiscal ou de anormalidades administrativas que coloquem em risco a continuidade ou a qualidade do atendimento à saúde, proposto pelo regime de direção técnica (p.78).

Para HEIMANN e col (2005), o termo Regulação associado às agências reguladoras estaria associado à eficiência econômica e ao incentivo de investimentos para o desenvolvimento econômico, sendo que o Estado passaria a estabelecer normas definidas para a atuação dos mercados (Estado regulador). Essa forma de regular também se integraria às iniciativas de instituições e organizaçð̃es defesa dos consumidores.

CUNHA (2003) e HEIMANN e col. (2005) apontam à necessidade de uma melhor delimitação das competências e das atribuições das agências reguladoras e de um melhor posicionamento das mesmas dentro da estrutura do Estado. As principais competências das agências podem ser agrupadas: 
- concessão e fiscalização (semelhante à ação executiva / regulação executiva);

- criação de regras e procedimentos normativos (semelhante à ação legislativa / regulação normativa); e

- julgamentos, imposição de penalidades, interpretação de contratos e obrigações (semelhante à ação judiciária / regulação judicante).

\subsection{GESTÃO E FORMAÇÃO DO SISTEMA DE SAÚDE NO BRASIL}

Para ALMEIDA e col. (2001), a organização dos serviços públicos no Brasil vem sendo a expressão da concepção de política pública vigente nos diferentes momentos do Estado brasileiro. Até os anos 1930, a saúde foi voltada para amparar o modelo econômico agro exportador e a presença do Estado brasileiro não significou uma atuação semelhante ao modelo de Estado-social. No início do século XX, o sistema de saúde voltou-se para uma política de saneamento dos espaços de circulação de mercadorias e para a erradicação e controle de doenças que pudessem prejudicar a exportações.

Ao longo das primeiras décadas do século $\mathrm{XX}$, as pessoas que necessitassem de assistência médica procuravam profissionais liberais ou o auxílio das Santas Casas. De acordo com esses autores, a industrialização e o enfraquecimento do modelo agroexportador acarretaram o esvaziamento das ações campanhistas e o crescimento da atenção médica através da Previdência Social, contribuindo para a conformação de um novo modelo na saúde: o modelo médicoassistencial privatista.

Alguns marcos históricos ${ }^{23}$ tornam-se importantes para a compreensão do cenário no qual a regulação sobre a atenção à Saúde Bucal vem

\footnotetext{
${ }^{23}$ Grande parte das informações neste subcapítulo foi coletada do artigo de ALMEIDA e col (2001). Parte das informações históricas aqui relacionadas teve origem na Fundação Oswaldo Cruz, através do Projeto Memória de Manguinhos e da Revista História, Ciência, Saúde - Manguinhos acessíveis pelo Portal Fiocruz www.fiocruz.br. Da mesma forma, foram consultados legislações, documentos e artigos dos conselhos profissionais, das associações de classe e das faculdades de medicina e
} 
sendo implementada no país. A debilidade das instituições, a escassez de mecanismos de controle social, a questão das escolhas dos governantes adquirem centralidade em cada período.

Como afirma PIMENTEL (2001),

Embora alguns personagens, instituições e acontecimentos não pertençam ao cenário atual, isto não significa que estejam confinados ao esquecimento. Ao contrário, eles estão presentes de alguma forma em cada um de nós, em nossa atuação e em nossa produção de conhecimentos, pois estamos envolvidos e partimos exatamente do que anteriormente foi elaborado (p.92).

Assim, foram selecionados ${ }^{24}$ e analisados alguns documentos que servem como instrumento complementar para a concretização desta pesquisa, no que tange à contextualização sócio-histórica do setor saúde. Para tal, os cortes temporais definidos foram os seguintes: até 1891; 1891 a 1930; 1930 a 1934; 1934 a $1937 ; 1937$ a $1945 ; 1945$ a $1964 ; 1964$ a $1967 ; 1967$ a $1985 ; 1985$ a 1988 e 1988 a julho de 2007.

Até 1891:

\section{5 e 1692}

Primeiras manifestações de Febre Amarela em Recife e Salvador;

1808

Criados os cursos de cirurgia do Rio de Janeiro (Escola Anatômica, Cirúrgica e Médica) e da Bahia (Escola de Cirurgia da Bahia);

1832

Convertem-se em Faculdades de Medicina, as Academias Médico-Cirúrgicas do Rio de Janeiro e da Bahia;

1837

Vacinação contra a varíola torna-se obrigatória para as crianças e em 1846 para adultos, porém reapareciam as epidemias;

odontologia, bem como documentos do CONASS, CONASEMS, Ministério da Saúde, Ministério da Previdência e Assistência Social, Ministério das Relações Exteriores, Senado Federal e Conselho Nacional de Saúde.

${ }^{24}$ Frente ao objetivo da pesquisa, as referências sobre Saúde Bucal foram destacadas em itálico. 


\section{7}

Imunizante contra a varíola começa a ser produzido, por iniciativa do Barão Pedro Affonso, então diretor da Santa Casa de Misericórdia do Rio de Janeiro. Posteriormente, seria criado o Instituto Vaccínico do Rio de Janeiro.

\section{8}

Criação simultânea dos Institutos Pasteur de Paris e do Rio de Janeiro.

\section{0}

Institui-se a aposentadoria para os empregados da Estrada de Ferro Central do Brasil, posteriormente ampliada a todos os ferroviários.

Criação do Montepio Obrigatório dos Empregados do Ministério da Fazenda.

\section{1}

No âmbito das políticas sociais a Constituição de 1891 deixou a cargo dos estados e dos municípios a responsabilidade e as práticas das ações de saúde, saneamento e educação. Nesse período, a não interferência do governo federal levou o país a um quadro sanitário catastrófico (CONASS 2007).

\section{Entre 1891 e 1930:}

\section{3}

Em São Paulo, cria-se o Instituto Adolfo Lutz.

\section{6}

Cria-se o Departamento Geral de Saúde Pública vinculado ao Ministério da Justiça e Negócios Interiores, com as seguintes atribuições: direção dos serviços sanitários dos portos marítimos e fluviais; fiscalização do exercício da medicina e farmácia; estudos sobre doenças infecto-contagiosas; organização de pesquisas demógrafo-sanitárias. As políticas de saúde implementadas no período estavam relacionadas aos problemas da integração nacional. Para colocá-las em prática, a tomada de consciência por parte da elite política sobre o quadro sanitário catastrófico existente no país, era de extrema importância. 
Em Santos, surto de peste bubônica investigado por Oswaldo Cruz, Vital Brasil e Adolfo Lutz. A partir disso, surgiriam os Institutos Soroterápicos em São Paulo e Rio de Janeiro.

\section{0}

No Rio de Janeiro, fundado em Manguinhos o Instituto Soroterápico Federal, posteriormente, Instituto Oswaldo Cruz (1908), Fundação Oswaldo Cruz (1970).

\section{1}

Em São Paulo, é fundado o Instituto Butantã. Inicialmente, ligado ao Instituto Bacteriológico (hoje Instituto Adolfo Lutz), tornou-se autônomo, como Instituto Soroterápico do Estado de São Paulo, mais tarde rebatizado Butantã.

1902

Oswaldo Cruz torna-se diretor do Departamento Federal de Saúde Pública, com a meta 'sanear' os portos e a cidade do Rio de Janeiro. Dentre as principais medidas adotadas pelo modelo campanhista destacam-se: reforma urbana, reforma do porto, saneamento, vacinação obrigatória contra a varíola. Devido à falta de informação da população e às arbitrariedades cometidas por pelos agentes sanitários, a população rebelou-se ocasionando um motim denominado Revolta da Vacina.

1903

Oswaldo Cruz cria o Serviço de Profilaxia Específica da Febre Amarela junto ao DGSP, para intervir no Rio de Janeiro.

\section{4}

Oswaldo Cruz inicia o combate à peste bubônica no Rio de Janeiro, através da vacinação e do combate aos ratos. Aprovada a Lei da vacinação obrigatória. Ocorre a Revolta da Vacina. Revogada a Lei da vacinação obrigatória.

\section{5}

Carlos Chagas realiza a primeira campanha de profilaxia contra a malária em Santos. 1907

Cria-se o Instituto Oswaldo Cruz.

1910

Expedição de Oswaldo Cruz e Belisário Pena a pedido da empresa que construía a ferrovia Madeira-Mamoré para Belém (PA). Combate à Febre Amarela. 
Início da atuação da missão da Fundação Rockfeller no Rio de Janeiro, em cooperação com o governo federal.

1917

Morre Oswaldo Cruz. Carlos Chagas assume a direção do Instituto Oswaldo Cruz. 1918

Epidemia de Gripe Espanhola. Criação da Liga Pró-Saneamento no Brasil.

1919

Decreto regula as obrigações resultantes dos acidentes de trabalho, instituindo o conceito de risco profissional, tornando compulsório o seguro contra acidentes de trabalho em certas atividades.

\section{0}

Criado o Departamento Nacional de Saúde Pública - DNSP e início da vigência de um novo código de Saúde Pública elaborado por Carlos Chagas. Período considerado como a segunda reforma sanitária no país: grande programa de saneamento e controle de endemias.

\section{3}

Decreto Legislativo $n^{\circ}$. 4.682, de 24 de janeiro de 1923 - Lei Eloy Chaves determinou a criação das Caixas de Aposentadorias e Pensões (CAPs) para cada empresa ferroviária. A primeira foi a Caixa de Assistência e Previdência Social dos Ferroviários dos empregados da Great Western do Brasil, em 20 de março de 1923. Financiamento tripartite (empresa, empregado e governo), sem regulação por parte do Estado. Estas caixas eram organizadas por empresas ou categorias profissionais e excluíam muitos segmentos da população. Entre os benefícios: aposentadoria por invalidez, por tempo de contribuição, pensão por morte e assistência médica. Segundo ALMEIDA e col. (2001), em 1930, 47 CAPs davam cobertura a 142.464 beneficiários, com a exclusão do acesso aos serviços de saúde da maioria da população.

1930

Revolução de 1930, fim da República Velha e início do Governo Provisório de Getúlio Vargas.

A partir de 1930, o Estado brasileiro passa a regulamentar e a uniformizar a prática de assistência médica, ocorrendo a extensão dos serviços 
hospitalares aos associados das CAPs e a assistência médica passa a fazer parte da Previdência Social.

Entre 1930 e 1934:

\section{0}

Decreto $\mathrm{n}^{\circ}$ 19.433, de 26 de novembro de 1930, criou o Ministério do Trabalho, Indústria e Comércio, tendo como uma das atribuições orientar e supervisionar a Previdência Social, inclusive como órgão de recursos das decisões das Caixas de Aposentadorias e Pensões.

1931

Decreto 19.850, de 11 de abril de 1931, cria o Conselho Nacional de Educação e os Conselhos Estaduais de Educação. Decreto 19.851, de 11 de abril de 1931, institui o Estatuto das Universidades Brasileiras que dispõe sobre a organização do ensino superior no Brasil e adota o regime universitário.

1933

Decreto 22.872, de 29 de junho de 1933 - criou o Instituto de Aposentadoria e Pensões dos Marítimos, considerada "a primeira instituição brasileira de previdência social de âmbito nacional, com base na atividade genérica da empresa". Os IAPs, modelos de pensões vinculadas a gênero ou categoria profissional, foram organizados a partir de 1933 de forma a abranger as mesmas categorias em todo o território nacional. Muitas Caixas de Aposentadorias e Pensões (CAPs) foram transformadas em IAPs, como foi o caso dos trabalhadores de trapiches e armazéns, que passou a constituir o Instituto de Aposentadorias e Pensões dos Empregados de Transportes e Cargas (IAPETC).

Entre 1933 e 1945, foram criados sete IAPs (Marítimos, Industriários, Transportadores de Carga, Bancários, Comerciários, Estiva e Servidores do Estado). Em 1945, o IAP da estiva foi incorporado ao dos transportadores de carga, reduzindo para seis o número de Institutos. Esta nova organização manteve o modelo de financiamento tripartite. No final dos anos 50 , somente $30 \%$ da força de trabalho do país estava vinculada a algum Instituto. Trata-se de modelo contratual de previsibilidade atuarial, na qual a extensão dos benefícios estaria relacionada à 
capacidade financeira do indivíduo e dos segmentos profissionais (sistema de Previdência segmentado) - ‘cidadania regulada’ pela via autoritária.

Conforme relatam ALMEIDA e col (2001), nos IAPs, a assistência médica passa a ser secundária, sendo que seus recursos financeiros foram utilizados para o desenvolvimento da indústria de base, entre os anos de 1930 e 1945;

\section{4}

Promulgada a Terceira Constituição dos Estados Unidos do Brasil em 16/07/1934. A importância dos estados foi assegurada pela vitória do princípio federalista. Ao mesmo tempo, ampliou-se o poder da União nos novos capítulos referentes à ordem econômica e social. As minas, jazidas minerais e quedas de água deveriam ser nacionalizadas, assim como os bancos de depósito e as empresas de seguro. No plano da política social foram aprovadas medidas que beneficiavam os trabalhadores, como a criação da Justiça do Trabalho, o salário mínimo, a jornada de trabalho de oito horas, férias anuais remuneradas e descanso semanal. A Constituição estabeleceu ainda que a primeira eleição presidencial após sua promulgação seria feita indiretamente, pelo voto dos membros da Assembléia Nacional Constituinte. As futuras eleições deveriam realizar-se pelo voto direto. No dia 17 de julho de 1934 , Getúlio Vargas foi eleito.

\section{Entre 1934 e 1937:}

\section{7}

Lei 378, de 13 de janeiro de 1937, dispõe sobre a reorganização do Ministério da Educação e Saúde e define conferências com intervalos máximos de dois anos. Em 1937, foi criado o primeiro órgão de saúde pública de dimensão verdadeiramente nacional, o Serviço Nacional de Febre Amarela, em cooperação com a Fundação Rockefeller e dirigidos pelos técnicos da Fundação. A primeira vacina contra a febre amarela seria desenvolvida pelo americano Max Theiler, da Fundação Rockefeller, em 1937, ano em que começou a ser produzida também no Instituto Oswaldo Cruz, garantindo a imunização por dez anos. 
Criado em 1937, através da mesma Lei, o Conselho Nacional de Saúde que tinha como atribuição assessorar o então Ministério da Educação e Saúde, em conjunto com o Conselho Nacional de Educação. Ao longo de sua história, este primeiro Conselho Nacional de Saúde caracterizou-se como um colegiado formado por especialistas em assuntos de saúde pública, com caráter consultivo e normativo, ou seja, estabelecia normas e diretrizes técnicas assim como emitia pareceres sempre que convocado.

Golpe de Estado de Getúlio Vargas e outorgada a Quarta Constituição dos Estados Unidos do Brasil em 10/11/1937. A Constituição de 1937 rompeu com a tradição liberal dos textos constitucionais anteriormente vigentes no país. Sua principal característica era a enorme concentração de poderes nas mãos do chefe do Executivo. Do ponto de vista político-administrativo, seu conteúdo era fortemente centralizador, ficando a cargo do presidente da República a nomeação das autoridades estaduais, os interventores. A intervenção estatal na economia, tendência que na verdade vinha desde 1930, ganhava força com a criação de órgãos técnicos voltados para esse fim.

\section{Entre 1937 e 1945 :}

\section{8}

No Estado Novo, cria-se o Departamento Administrativo do Serviço Público (DASP) - órgão previsto pela Constituição de 1937, diretamente subordinado à Presidência da República, com o objetivo de aprofundar a reforma administrativa destinada a organizar e a racionalizar o serviço público no país. Pretendia assim estabelecer uma maior integração entre os diversos setores da administração pública e promover a seleção e aperfeiçoamento do pessoal administrativo por meio da adoção do sistema de mérito. Entre suas principais realizações nessa fase figura a sistematização dos direitos e deveres do funcionalismo, definidos no Estatuto dos Funcionários Públicos Civis da União, primeiro documento desse tipo no Brasil. Com a queda de Vargas em outubro de 1945, o DASP passou por um profundo processo de reestruturação, que resultou no seu parcial esvaziamento, assumindo um caráter de assessoria.

\section{9}

Criado com a Fundação Rockfeller, o Serviço de Malária do Nordeste. 
1940

Criado o Departamento Nacional da Criança, vinculado ao Ministério de Educação e Saúde. Início da criação das Secretarias Estaduais de Saúde, que se fortaleceram e passaram a desempenhar mais ações em favor da saúde pública e, conseqüentemente, passaram a enfrentar os graves problemas de financiamento dos serviços de saúde.

\section{1}

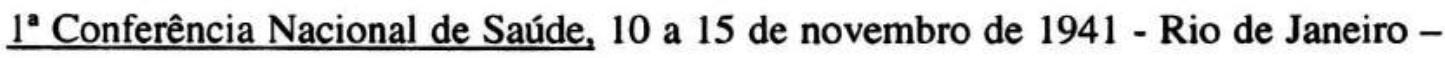
A $1^{\text {a }}$ Conferência, apesar de ter sido um encontro com caráter técnico, marcou a história da saúde brasileira por causa de algumas demandas: criação do Ministério da Saúde e mudança das relações entre os estados, municípios e a União, pois a gestão da saúde era centralizada no governo federal.

\section{Temário Oficial:}

1 - Organização sanitária estadual e municipal;

2 - Ampliação e sistematização das campanhas nacionais contra a lepra e a tuberculose;

3 - Determinação das medidas para desenvolvimento dos serviços básicos de saneamento;

4 - Plano de desenvolvimento da obra nacional de proteção à maternidade, à infância e à adolescência.

Recomendações decorrentes:

a) instituir um código sanitário para todo território nacional;

b) criação de carreiras para os técnicos dos serviços de saúde, com ênfase na de médico sanitarista, vinculado a regime de trabalho integral;

c) a regionalização da organização estadual de saúde;

d) a intensificação da política de imunização pelo BCG;

e) a ampliação das atividades de educação sanitária, dando preferência aos aspectos ligados à proteção da criança, à alimentação pública e ao controle da tuberculose;

f) conseguir dos municípios as obras de saneamento básico, de preferência a outros melhoramentos urbanos; e

g) a obrigatoriedade da instituição, nos estados, de serviço de epidemiologia e bioestatística. 
Até 1986, as Conferências tiveram o caráter de fóruns de discussões técnicas, e a partir da $8^{a}$ Conferência realizada no mesmo ano passaram a ter conotações políticas importantes com a inclusão da participação de usuários da saúde. $\mathrm{Na} 1^{\text {a }}$ Conferência, relativamente à odontologia, um questionário foi distribuído entre os técnicos com somente uma pergunta a ser respondida sobre o assunto "Há no Estado gabinetes dentários dirigidos por dentistas não diplomados? Quanto? Onde estão localizados?".

\section{2}

Criação dos Serviços Especiais de Saúde Pública - SESP, com a interiorização das ações de saúde para o Norte e o Nordeste, em função das atividades econômicas ligada à produção de borracha.

\section{3}

Decreto-Lei $\mathrm{n}^{\circ} 5.452$, de $1^{\circ}$ de maio de 1943 , aprovou a Consolidação das Leis do Trabalho, elaborada pelo Ministério do Trabalho, Indústria e Comércio e que elaborou também o primeiro projeto de Consolidação das Leis de Previdência Social. 1945

Getúlio Vargas é deposto por um movimento militar, ocorrendo eleições em dezembro, sendo eleito Eurico Gaspar Dutra.

\section{Entre 1945 e 1964:}

\section{$1946^{25}$}

Promulgada a Quinta Constituição dos Estados Unidos do Brasil em 18/09/1946. Carta liberal e democrática; preserva o regime republicano, federativo e presidencialista; voto secreto e universal para maiores de 18 anos, excetuando-se analfabetos, cabos e soldados; liberdade à associação de classe, greve, de

\footnotetext{
${ }^{25}$ Em 1946, deu-se início a sequiência numérica em vigor do atual Ordenamento Jurídico Brasileiro, caracterizado por provisões legais superpostas e por ser mal coordenado. Esse fragmentado ordenamento jurídico brasileiro é composto por milhares de textos obscuros, fartos de inconsistências, de comandos repetitivos e antinomias (contradição entre duas leis ou princípios), com o agravante de existirem controvérsias sobre o que foi ou não revogado, com o famoso "revogam-se disposiçð̃es em contrário" (MARTINS 1999).
} 
pensamento, de expressão, garantia dos direitos conquistados; cinco anos de mandato presidencial com reeleição proibida; oito anos para senadores, quatro anos para deputados com reeleição permitida. Liberalismo econômico, rejeitando a intervenção estatal na economia.

1950

2a Conferência Nacional de Saúde, 21 de novembro a 2 de dezembro de 1950 - Rio de Janeiro. A $2^{\mathrm{a}}$ Conferência (1950) se destacou na defesa de leis referentes à higiene e segurança do trabalho e à prestação de assistência médica sanitária e preventiva para trabalhadores e gestantes.

Proposta: levar às autoridades superiores os 'pontos de vista dominantes entre os sanitaristas do País para o estudo de orientação mais satisfatória e de normas suscetíveis de emprestar maior uniformidade à resolução dos problemas de saúde brasileiros'.

A Organização Pan-Americana de Saúde (OPAS) estimulou e patrocinou na América Latina, a partir dos anos de 1950, seminários sobre o ensino de medicina preventiva. Após os seminários promovidos pela OPAS, ocorreu o reconhecimento de uma situação problemática na área da saúde que poderia ter como solução a formação de médicos com uma nova atitude.

1951

Segundo Governo de Getúlio Vargas

1953

Lei 1920, de 25/07/1953, criação do Ministério da Saúde, instalado em 1954. A partir da sua criação, o Ministério passou a encarregar-se especificamente das atividades até então de responsabilidade do Departamento Nacional de Saúde.

1954

Suicídio de Vargas.

1956

Eleito Juscelino Kubitschek, mandato entre 31/01/1956 a 31/01/1961, com política desenvolvimentista. Utilização do Estado como elemento coordenador do desenvolvimento estimulando a entrada de capital estrangeiro, quer na forma de 
empréstimo, quer na forma de investimento direto. Diversificação da economia e desenvolvimento da indústria. A abertura ao capital estrangeiro se tornou a principal alavanca do desenvolvimento industrial, acentuando-se a dependência brasileira com relação às economias dos países industrializados, principalmente os EUA. Finanças abaladas, inflação.

Criação do Serviço Nacional de Fiscalização da Odontologia - SNFO ligado ao Departamento Nacional de Saúde, para a fiscalização do exercício da odontologia (desdobramento do SNFM).

1958

Início dos cursos de especialização em Saúde Pública para CD na FSPUSP por Viegas e Chaves - odontologia sanitária.

Implementação do SNFO.

No início dos anos 1960, ganha dimensão o discurso dos sanitaristas em torno das relações entre saúde e desenvolvimento. $O$ planejamento de metas de crescimento e de melhorias conduziu o governo federal ao planejamento global e ao planejamento ${ }^{26}$ em saúde. As propostas para adequar os serviços de saúde pública à realidade diagnosticada pelos sanitaristas desenvolvimentistas tiveram marcos importantes, como a formulação da Política Nacional de Saúde, em 1961, com o objetivo de redefinir a identidade do Ministério da Saúde e colocá-lo em sintonia com os avanços verificados na esfera econômico-social.

1960

Lei 3.807, de 26 de agosto de 1960 - promulgação da Lei Orgânica da Previdência Social de 1960 - LOPS, que unificou a legislação referente aos Institutos de Aposentadorias e Pensões, abrindo-se o caminho para a unificação e uniformização da Previdência. Com seis Institutos - Instituto de Aposentadorias e Pensões dos Marítimos (IAPM), Instituto de Aposentadorias e Pensões dos Comerciários (IAPC),

\footnotetext{
26 Introdução do planejamento (técnica) e plano de metas globais e setoriais para a Saúde, tomando como base o trabalho de Testa e o modelo do planejamento econômico, que elaborou o método de planejamento em saúde conhecido como "método Cendes/Opas". Este método foi editado pela OPAS, em 1965, na sua Publicação Científica número 111, sob o título: Problemas Conceptuales y Metodológicos de la Programación de la Salud (OPAS/OMS, 1965).
} 
Instituto de Aposentadorias e Pensões dos Bancários (IAPB), Instituto de Aposentadorias e Pensões dos Industriários (IAPI), Instituto de Aposentadorias e Pensões dos Empregados de Transporte de Carga (IAPETEC) e Instituto de Aposentadorias e Pensões dos Ferroviários e Empregados em Serviços Públicos (IAPFESP) - o Decreto 4895-a, de 19/09/1960, aprovou um regulamento com a criação de um esquema geral de funcionamento e financiamento único para os seis IAPs existentes. A LOPS representou, na prática, a cobertura potencial de todos os trabalhadores urbanos, exceto empregados domésticos e ministros religiosos, incluídos em 1972 - os primeiros, de forma compulsória, e os outros, de forma facultativa.

Decreto $\mathrm{n}^{\circ}$. 48.959-a, de 19 de setembro de 1960, aprova o regulamento geral da Previdência Social. Sobre a assistência médica:

(...) Art. 119. A assistência médica visa a proporcionar aos beneficiários da previdência social, assistência clínica, cirúrgica, farmacêutica e odontológica, em ambulatório, hospital, sanatório ou domicílio, com a amplitude que os recursos financeiros e as condições locais permitirem, na conformidade do disposto neste Regulamento (...)

Art. 121. I - Será assegurada, quanto possível, a liberdade de escolha do profissional, por parte dos beneficiários, dentre aquêles que forem credenciados, segundo os critérios de seleção que forem estabelecidos para atendimento em seus consultórios ou clínicas, na base de percepção de honorários per capita ou segurado tabelas de serviços profissionais, observadas as limitações do custeio dos serviços e tendo em vista a capacidade profissional (...)

III - o beneficiário que utilizar os serviços médicos em regime de livre escolha, participará do custeio de cada serviço que lhe fôr prestado, na proporção da remuneração ou do provento efetivamente auferido (...)

VI - nas localidades onde não houver conveniência de manterem-se serviços de assistência médica próprios da previdência social, a prestação local dessa assistência deverá ser preferentemente adjudciada aos de entidades sindicais, emprêsas ou organizações públicas ou privadas, notadamente para os grupos a que já venham servindo, o que será feito mediante convênios, em que se assegurem a boa qualidade e a eficiência do serviço (...) 
XV - a previdência social não se responsabilizará pela indenização de despesas com serviços de assistência médica que não tenham sido previamente autorizados pela autoridade administrativa competente, ressalvadas as situações de urgência comprovada, que impossibilite o beneficiário de obter essa autorização, ou de falta comprovada de atendimento oportuno por parte dos serviços da própria previdência social, caso em que poderá haver o reembôlso até quantia equivalente à que seria dispendida se a execução se fizesse por parte dêsses serviços (...).

De acordo com ALMEIDA e col (2001), nos governos de Getúlio Vargas e Kubitschek, os IAPs tiveram sua estrutura ampliada, com a construção de hospitais públicos e a incorporação tecnologia de alto custo, adotandose o modelo de saúde americano, numa visão hospitalocêntrica que fortaleceu a indústria de medicamentos e de equipamentos hospitalares.

Neste ano, é publicado o Manual de Odontologia Sanitária de Mário Chaves e ocorre a proposta de criação dos Departamentos de Odontologia Social nas escolas de odontologia.

\section{3}

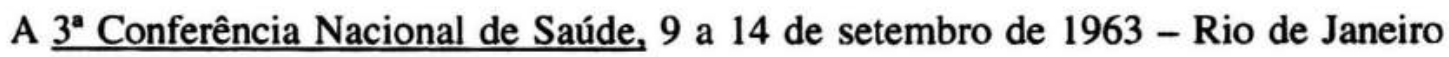
elaborou a primeira proposta efetiva de descentralização na área da saúde e foi a primeira realizada após a criação do Ministério da Saúde, em 1953.

Temário Oficial: 1 - A situação sanitária da população brasileira; 2 - A distribuição e coordenação das atividades médico-sanitárias nos níveis federal, estadual e municipal; 3 - A municipalização dos serviços de saúde; 4 - A fixação de um plano nacional de saúde.

Recomendações:

a) a integração dos programas de saúde pública no programa global de desenvolvimento;

b) a integração das atividades preventivas e curativas nas unidades sanitárias;

c) intensificar a fabricação de produtos profiláticos e terapêuticos pelos órgãos oficiais que operam nesse setor e expandir a indústria químico-farmacêutica nacional; 
d) que os governos federal, estaduais e municipais estabeleçam, no menor prazo possível, em nível municipal, a estrutura sanitária básica do país; os serviços de saúde a serem implantados nos municípios deverão levar em conta, na sua estrutura, as necessidades e possibilidades de cada um, tendo no mínimo: medidas elementares de saneamento do meio; fiscalização dos gêneros alimentícios, das habitações e dos estabelecimentos que lidam com a produção e comércio de alimentos; imunização contra doenças transmissíveis; prestação do primeiro atendimento de assistência aos doentes; programa de proteção à maternidade e infância; educação sanitária; levantamento dos dados de estatística vital.

O golpe militar de 1964 interrompeu o processo democrático no país, e não permitiu a continuidade do movimento de descentralização da área da saúde em curso no início dos anos 1960 e definido nas propostas da III Conferência Nacional de Saúde.

As reformas institucionais promovidas pelos governos militares afetaram profundamente a saúde pública, principalmente a medicina preventiva, priorizando a mercantilização da saúde com ênfase no modelo hospitalocêntrico. Criaram-se as condições institucionais para a emergência e o desenvolvimento de um sistema de saúde privado financiado pelos cofres públicos, através de uma sistemática de convênios com a rede privada. (CORDEIRO 1984).

Os IAPs são concentrados no Instituto Nacional de Previdência Social -INPS "com extensão da cobertura previdenciária para a quase totalidade da população urbana e rural; ênfase na prática curativa individual, assistencialista, em detrimento da saúde pública; criação de um complexo médicoindustrial; organização do sistema de saúde orientado pela lucratividade e realização de privilégios para o produtor privado de serviços de saúde", surgindo as primeira formas de contratação do setor privado (ALMEIDA e col. 2001; p. 25).

Inicia-se a expansão da assistência odontológica no setor público, através de credenciamentos e convênios sem fiscalização.

A Reforma Administrativa Federal, de 25 de fevereiro de 1967, estabeleceu que o Ministério da Saúde fosse o responsável pela formulação e 
coordenação da Política Nacional de Saúde, com as seguintes competências: política nacional de saúde; atividades médicas e para médicas; ação preventiva em geral, vigilância sanitária de fronteiras e de portos marítimos, fluviais e aéreos; controle de drogas, medicamentos e alimentos e pesquisa médico-sanitária.

Entre 1964 e 1967:

1964

Golpe Militar em 31/03/1964 - Governo Marechal Castelo Branco (15/04/1964 a 15/03/1967). A orientação da política econômica foi traçada pelo Plano de Ação Econômica do Governo (PAEG), administrado pelo Ministro do Planejamento, Roberto Campos. Propunham-se medidas antiinflacionárias e de fortalecimento do capitalismo privado.

Lei Federal $n^{\circ}$. 4.324, de 14 de abril de 1964, cria o Conselho Federal de Odontologia.

1966

Decreto-Lei 72, de 21 de novembro de 1966 - reuniu os seis Institutos de Aposentadorias e Pensões no Instituto Nacional de Previdência Social - INPS. Extingue os IAPs, reunindo suas estruturas no Instituto Nacional da Previdência Social - INPS. Estende os benefícios da assistência médica aos trabalhadores formalmente empregados vinculados pela Carteira de Trabalho e Previdência Social - CTPS (herança da Era Vargas - 'cidadania regulada' pela via autoritária).

Lei $n^{\circ}$. 5.081, de 24/08/1966, que regulamenta a profissão de cirurgião-dentista. 1967

4 Conferência Nacional de Saúde, 30 de agosto a 4 de setembro de 1967 - Rio de Janeiro As quatro conferências posteriores, ocorridas durante os governos militares, voltaram a ter um caráter predominantemente técnico e burocrata. A $4^{\mathrm{a}}$ Conferência (1967) teve como tema central a questão dos recursos humanos e a necessidade de se identificar o tipo de profissional necessário às demandas do país.

\section{Entre 1967 a 1985 :}


1968

Ato Institucional $n^{\circ} .5$, de 13/12/1968 - reforça os poderes discricionários do regime militar com a suspensão das garantias constitucionais. Vigorou até 31/12/1978.

1969

Emenda Constitucional $\mathrm{n}^{\circ}$. 1, de 17 de outubro de 1969 - reforma substancial da Constituição. A Emenda nº 1 manteve o esquema da Constituição de 1967, mas na prática, a matéria dos capítulos: "Direitos e garantias individuais e da Ordem econômica e social", sofreu diferentes restrições em virtude do artigo 182, que manteve em vigor o Ato Institucional $n^{\circ} .5$, de 13 de dezembro de 1968, e os demais atos posteriormente baixados. Fixa mandato em cinco anos.

1971

Decreto $\mathrm{n}^{\circ}$. 69.014, de 4 de agosto de 1971, estruturou o Ministério do Trabalho e Previdência Social - MTPS, com ampliação de cobertura previdenciária para os trabalhadores rurais (FUNRURAL 1971) e trabalhadores autônomos (1973).

Decreto $n^{\circ}$. 68.704, de 3 de junho de 1971, dispõe sobre os Conselhos Federal e Regionais de Odontologia, autarquia dotada de personalidade juridica de direito público.

Lei 5.764, de dezembro de 1971, institui as cooperativas médicas e odontológicas como sociedades sem fins lucrativos que operam Planos de Saúde.

Com o fim do "milagre econômico" e início dos questionamentos das políticas sociais, cria-se o Ministério da Previdência e Assistência Social - MPAS com a separação da área da assistência médica da área da previdência.

Nessa época, implantou-se o Plano de Pronta Ação - PPA, com a extensão do atendimento de urgência e emergência aos não-previdenciários e o Fundo de Apoio e Desenvolvimento Social - FAS, para financiamento do parque hospitalar privado. O FAS, criado em 1974, chegou a destinar ao setor privado (com exceção das filantrópicas), em 1977, 80\% do valor dos financiamentos aprovados na área da saúde. Boa parte da expansão desta rede foi financiada com recursos públicos oriundos do FAS, através de recursos das loterias federal e esportiva, bem como por saldos operacionais da Caixa Econômica Federal (CEF). 
Surgem as primeiras modalidades supletivas de prestação de serviços como o convênio-empresa, assumindo a responsabilidade pela assistência médica em troca de subsídios da Previdência, e a medicina de grupo (ALMEIDA e ool 2001).

Em 1974, General Ernesto Geisel (mandato 15/03/1974 a 15/03/1979) substitui o general Emílio Médici na 'Presidência da República com o objetivo de promover a abertura política.

Em 1975, com o II Plano Nacional de Desenvolvimento, "estabelecem-se as competências da iniciativa privada e as do setor estatal na área da saúde, por meio da divisão de competência para as ações de saúde pública (não rentáveis) e as da atenção médica (rentáveis), intermediadas peta Previdência Social" (ALMEIDA e col. p.26).

1974

Lei 6036 , de $1^{\circ}$ de maio de 1974 , desdobrou o Ministério do Trabalho e Previdência Social - MTPS em dois outros, o do Trabalho e o da Previdência e Assistência Sacial (MPAS).

Lei 6.050, de 24 de maio de 1974, prevê a fluoretação e o tratamento das águas de abastecimento público nas esferas federal, estadual e municipal.

Plano de Pronta Ação (PPA) 1974 - sistemática de convênios com a rede privada, de todos os serviços de assistência médica existente e oriação do FAS.

II Plano Nacional de Desenvolvimento - PND, preverilto a distribuição de renda e crescimento da indústria pesada.

1975

Lei 6.229, de 17 de julho lde 1975 - criação do Sistema Nacional de Saúde. Extinção do SNFO.

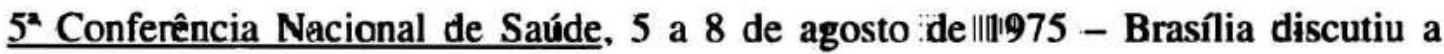
institucionalização e a implementação do Sistema Nacional de Saúde, o programa de saúde materno-infantil, o sistema de vigilância epidemiolágica, o controle das grandes endemias e a extensão das ạ̧ões de saúde às populạ̧ões rurais. 
Contexto: criação do MPAS, Plano Nacional de Saneamento, Campanha Nacional contra a Meningite, Imunizações, ampliação do campo de atendimento médico individual pela Previdência Social.

Portaria MS 635/Bsb, de 26 de dezembro de 1975, aprova as normas e os padrões sobre a fluoretação da água, tendo em vista a Lei $n^{\circ}$. 6050/74.

1976

Decreto 78.307, de 24 de agosto de 1976 - cria o Programa de Interiorização das Ações de Saúde e Saneamento - PIASS.

Em 1977, com a criação do Sistema Nacional da Previdência Social (SINPAS), em conjunto com a lei do Sistema Nacional de Saúde, buscou-se reorganizar, racionalizar e centralizar administrativamente a previdência. Nesse período, surgiu o Movimento Sanitário, a partir, principalmente, do movimento de trabalhadores da saúde, da discussão de proposta alternativas ao modelo privatista, do movimento municipalista, do Movimento Popular da Saúde e de mudanças de caráter democratizantes no sistema político (ALMEIDA e col. 2001).

Em conseqüência, estabeleceu-se para a Seguridade Social um orçamento global, que passou a integrar o financiamento das ações de saúde, previdência e assistência social, além das ações relacionadas à proteção ao trabalhador desempregado. As fontes de financiamento potenciais para a Seguridade passaram a ser a Contribuição sobre a Folha de Salários (empregados, empregadores e trabalhadores por conta própria); a Contribuição sobre o Lucro Líquido; o Finsocial, posteriormente transformado em Contribuição para o Financiamento da Seguridade (Cofins); e o PIS/Pasep, voltado para compor o Fundo de Amparo ao Trabalhador (FAT), gerido pelo Ministério do Trabalho e dedicado ao financiamento do seguro-desemprego. Tanto os benefícios rurais como os assistenciais mantiveram sérias deficiências quanto ao seu custeio.

1977

A 6a Conferência Nacional de Saúde, 1 a 5 agosto de 1977 - Brasília, tratou principalmente do controle das grandes endemias e da interiorização e extensão dos serviços de saúde. 406 delegados - documento base PIASS e a interiorização dos 
serviços. Temas Gerais: 1 - Situação Atual do Controle das Grandes Endemias; 2 Operacionalização dos Novos Diplomas Legais Básicos aprovados pelo Governo Federal em matéria de Saúde (VIEP, VISA); 3 - Interiorização dos Serviços de Saúde; 4 - Política Nacional de Saúde.

Temas Específicos:

a) Diretrizes Programáticas para a Saúde Mental

b) Instituição do Grupo-Saúde Pública: importância na política de desenvolvimento de recursos humanos para a saúde

c) Ação interinstitucional e inter-setorial do PRONAN - Programa Nacional de Alimentação e Nutrição

d) A Medicina Previdenciária e a nova Instituição de Assistência Médica

e) Programa Especial de Combate à Esquistossomose

Lei 6.439, de 1 de setembro de 1977, instituiu o Sistema Nacional de Previdência e Assistência Social - SINPAS, orientado, coordenado e controlado pelo Ministério da Previdência e Assistência Social, responsável "pela proposição da política de previdência e assistência médica, farmacêutica e social, bem como pela supervisão dos órgão que lhe são subordinados" e das entidades a ele vinculadas, vizando a integração das ações de seis órgãos básicos: Instituto Nacional de Assistência Médica da Previdência Social - INAMPS ${ }^{27}$ (autarquia - assistência médica); Instituto de

27 (...) Art. $6^{\circ}$ - Ao INAMPS compete prestar assistência médica, de acordo com os seguintes programas:

I - programas de assistência médica aos trabalhadores urbanos, abrangendo os serviços de natureza clínica, cinúrgica. farmacêutica e odontológica. e a assistência complementar. devidos aos segurados do atual INPS e respectivos dependentes, na forma do disposto nos itens I e IV do artigo anterior;

II - programas de assistência médica aos servidores do Estado, abrangendo os serviços de natureza clínica, cirúrgica, farmacêutica e odontológica, devidos aos funcionários públicos civis da União e de suas autarquias e do Distrito Federal, e respectivos dependentes, na forma do disposto no item II do artigo anterior;

III - programas de assistência médica aos rurais, abrangendo os serviços de saúde e a assistência médica devidos, respectivamente, aos trabalhadores e aos empregadores rurais, na forma do disposto no item III do artigo anterior.

IV - programas especiais de assistência médica, abrangendo os serviços médicos atualmente mantidos pela Fundação Legião Brasileira de Assistência - LBA e os que forem prestados em determinadas regiōes à população carente. seja ou não beneficiária da previdência social, mediante convênios com instituiç̧̃es públicas que assegurem ao INAMPS os necessários recursos.

$\$ 1^{\circ}$ - A assistência médica de que trata este artigo será prestada a cada categoria de beneficiários na forma das respectivas legislaçōes e com a amplitude que as condiçð̄es locais e os recursos próprios permitirem.

$\$ 2^{\circ}$ - Fica o Poder Executivo autorizado a instituir um esquema de participacăo direta dos beneficiários, em função do seu nível de renda no custeio dos serviços médicos de que se utilizarem e dos medicamentos que lhes forem fornecidos em ambulatórios.

$\S 3^{\circ}$ - No esquema de participação, de que trata o parágrafo anterior, o Poder Executivo poderá considerar outros fatores, além do nível de renda, tais como a natureza da doença, o vulto das despesas gerais e o porte do custeio.

$\$ 4^{\circ}$ - A assistência médica e farmacêutica aos acidentados do trabalho năo está sujeita às limitaçðes nem ao esquema de participação dos parágrafos anteriores. 
Administração Financeira da Previdência e Assistência Social - IAPAS (autarquia arrecadação); Instituto Nacional da Previdência Social - INPS (previdência); Legião Brasileira de Assistência - LBA (fundação - assistência social); Fundação Nacional do Bem-Estar do Menor - FUNABEM (fundação - assistência ao menor); Empresa de Processamento de Dados da Previdência Social - DATAPREV (empresa pública gerenciamento do sistema de informática) e; Central de Medicamentos (CEME) (órgão do MS - fornecimento de medicamentos).

\section{8}

Entre 6 e 12 de setembro de setembro de 1978, a Assembléia Geral da Organização Mundial da Saúde, realizou a Conferência Internacional sobre Cuidados Primários de Saúde Declaração de Alma Ata - Cazaquistão, vizando reorientar os sistemas de saúde, através da ampliação da Atenção Básica. Como meta: 'Saúde para Todos no Ano 2000'. Saúde é vista como a mais importante meta social e a desigualdade do estado de saúde entre os povos deve ser preocupação dos organismos internacionais para o contínuo desenvolvimento econômico e social, para a paz e para a melhor qualidade de vida.

Instituto Nacional de Assistência Médica e Previdência Social - INAMPS substitui o INPS, abrangendo o pagamento dos benefícios previdenciários.

Segundo ALMEIDA e col. (2001), a partir de 1980, com a redemocratização e a crise econômica, estabeleceu-se como prioridade um novo padrão de desenvolvimento - crescimento com distribuição - e a definição de um novo arcabouço jurídico-institucional, que culminou com a convocação da Assembléia Nacional Constituinte, em 1986. Aliada a isso, a crise da Previdência Social possibilitou o discurso em defesa do direito universal à saúde.

As secretarias de estado e os próprios prefeitos municipais, não tinham condições de prestar serviços na área da saúde. Antes de acabar a ditadura, em 1985, começam a pressionar politicamente a Previdência

$\S 5^{\circ}$ - A participação a que se referem os $\S_{\S} 2^{\circ}$ e $3^{\circ}$ não será exigida dos beneficiários que perceberem remuneração ou benefícios até 5 (cinco) valores de referência.

Art. $7^{\circ}$ - Os programas de assistência médica a cargo do INAMPS serão organizados de forma a manter inteira compatibilidade com o Sistema Nacional de Saúde, nos termos da Lei $n^{\circ} 6.229$, de 17 de julho de 1975 , e com as normas de saúde pública constantes da legislaçăo própria (...). 
Social para fazer os primeiros entendimentos entre as secretarias estaduais e a superintendência regional do Inamps nos estados, surgindo os primeiros convênios.

No mesmo contexto histórico político, econômico e social iniciou-se um movimento impulsionado por grupos de intelectuais localizados em espaços acadêmicos e instituições de serviços, articulados com partidos de esquerda que discordavam dos rumos dados à saúde no país, constituindo-se na base político-ideológica da Reforma Sanitária Brasileira (CONASS 2007).

\section{0}

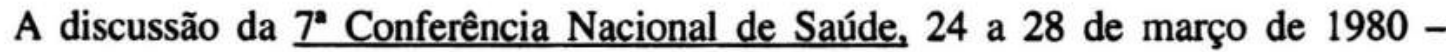
Brasília, foi norteada, principalmente, pela criação do Programa Nacional de Serviços Básicos de Saúde - PREV-SAÙdE, inspirado no Programa de Interiorização das Ações de Saúde e Saneamento - PIASS - 1976. Abordou assuntos sobre os serviços de saúde nas universidades federais e a articulação dos serviços básicos com os serviços especializados no sistema de saúde.

Finalidade: promover debate sobre a implantação do Programa Nacional dos Serviços Básicos de Saúde PREV-SAÚDE ${ }^{28}$ e a expansão dos serviços básicos de saúde, com base na Declaração de Alma-Ata.

Tema Central: Extensão das Ações de Serviços através dos Serviços Básicos

Subtemas: 1 - regionalização e organização dos serviços de saúde nas Unidades Federadas - Expansão Nacional do PIASS $^{29}$ (MS / MPAS / MIN. INTERIOR / SEPLAN); 2 - saneamento e habitação nos serviços básicos de saúde - PLANASA e o Saneamento Simplificado; 3 - desenvolvimento de recursos humanos para os serviços básicos de saúde; 4 - supervisão e educação continuada para os serviços básicos de saúde; 5 - responsabilidade e articulação institucional (níveis estadual,

\footnotetext{
${ }^{28}$ O PREV-SAÚDE sofreu pressões por parte de todos os grupos de interesses privatistas. Na medida em que defendia um serviço integrado de saúde, pautado pelos princípios da atenção primária à saúde, em bases regionais e hierarquizadas, jamais foi apresentado oficialmente (CONASS 2007).

${ }^{29}$ Teve como sua área de ação privilegiada a região Nordeste, especialmente aquelas localizadas que não interessavam as empresas de saúde e, portanto, não se chocava com setores privatizantes da prática médica e da Previdência Social. Concebido originalmente como uma rede de minipostos e ações de saneamento, constatou-se a extrema dificuldade de sustentação e manutenção desta rede, sem articulação com níveis mais complexos (CONASS 2007).
} 
federal e municipal); 6 - desenvolvimentos institucional e da infra-estrutura de apoio nos Estados; 7 - alimentação e nutrição nos serviços básicos de saúde; 8 - Saúde Mental e doenças crônico-degenerativas e os serviços básicos de saúde; 9 informação e vigilância epidemiológica nos serviços básicos de saúde; 10 Participação comunitária. Os serviços básicos de saúde e as comunidades e; 11 articulação dos serviços básicos com os serviços especializados no Sistema de Saúde. Pela primeira vez na história das Conferências, houve destaque nas discussões relativas à Odontologia, num painel denominado a Odontologia e os serviços básicos de saúde $O$ grupo de debates analisou e ofereceu sugestões à incorporação das atividades de odontologia aos serviços básicos de saúde, "considerando importante deixar registrada ser a primeira vez, na história das Conferências Nacionais de Saúde, em que se dá destaque e se enseja de forma específica à discussão da odontologia num programa nacional de saúde. Adjetivar a odontologia como especialidade não deveria servir para reforçar a sua não participação ou participação desintegrada em um programa baseado na atenção primária, sendo conveniente e oportuno integrá-la ao programa geral de atenção primária, sem estruturá-la de forma à parte. Há entre a forma de prática e organização do modelo assistencial odontológico (ineficaz, ineficiente, descoordenado, má distribuido, com baixa cobertura, com enfoque curativo, mercantilista, alta complexidade monopolista, com preparo de recursos humanos inadequados) e a filosofia de atenção primária um grande abismo ${ }^{30}$ (...)" (CNS 1980).

1981

Decreto n. 86.329, de 2 de setembro de 1981, criou um órgão no Ministério da Previdência e Assistência Social, o Conselho Consultivo da Administração de Saúde

\footnotetext{
${ }^{30}$ Recomendações feitas durante a $77^{a}$ Conferência pertinentes à Saúde Bucal: a) participação das instituições empregadoras junto às universidades para a definição do perfil dos profissionais; b) ênfase à formação de recursos humanos técnico e auxiliar; c) formação do técnico dental, como recurso a aumentar a cobertura e reduzir custos operacionais; d) tornar impeditiva a utilização de equipamentos de alta complexidade tecnológica; e) incluir na CEME linha de pesquisa e de produção de insumos básicos; f) redirecionar a subvenção financeira do setor público para formulação de convênios junto às secretarias estaduais, municipais e universidades em detrimento da compra de serviços do setor privado; g) institucionalizar um núcleo técnico no MS para a definição politica existente na área; $h$ ) que a odontologia de integre de forma hierarquizada em três niveis de assistência: $1^{\circ}$ nivel prevenção (fluoretação das águas e métodos alternativos de prevenção), problemas de dor e infeç̧ão; $2^{\circ}$ nivel prioridade aos escolares de 6 a 14 anos e programa incremental; $3^{\circ}$ nivel subsistema de referência para casos complexos (CNS 1980).
} 
Previdenciária - CONASP que deveria operar como órgão organizador e racionalizador da atenção médica, sugerir critérios para alocação dos recursos previdenciários do setor saúde, bem como analisar e avaliar a operação e o controle da Secretaria de Assistência Médica da Previdência Social.

1982

Criação do CONASS - Conselho Nacional de Secretários de Saúde, ligada à história dos Secretários Estaduais de Saúde. No encontro, foram discutidos os pontos da Ação Trilateral da Política de Saúde, entre Ministérios da Saúde e da Previdência Social e Secretarias Estaduais de Saúde. Os Secretários Estaduais defenderam no encontro a unificação da política de saúde no país, que na época se dividia entre o Ministério da Saúde e Ministério da Previdência Social. Essa proposta já era uma visão do princípio da direção única em cada esfera de governo que veio a ser incorporado à Constituição Federal de 1988.

\section{3}

Ações Integradas de Saúde - AIS $^{31}$ - 1983 - Política de descentralização do setor saúde $-1^{2}$ fase da descentralização: num contexto de recessão econômica, criaram-se instâncias colegiadas para reduzir os gastos com a assistência médica oferecida pelo INAMPS, privilegiando estados e municípios na programação e execução do orçamento do país. Participação de representantes das entidades civis (COSTA 2002).

\section{4}

Resolução 06/84, MS/MPAS/MEC/ CIPLAN - Ações Integradas de Saúde. Anexo: normas gerais aplicáveis às AIS.

\footnotetext{
${ }^{31}$ PAIM (1986) avaliou positivamente as AIS, a partir de princípios defendidos pelo Movimento Sanitário: $1^{\circ}$ - Princípios e objetivos consistentes com os do movimento de democratização da saúde. $2^{\circ}$ - Planejamento e administração descentralizados. $3^{\circ}$ - Instâncias deliberativas permeáveis à negociação política. $4^{\circ}$ - Possibilidade concreta de participação popular organizada $5^{\circ}$ - Percurso para o estabelecimento do Sistema Unificado de Saúde. $6^{\circ}-$ Respeito ao princípio federativo. $7^{\circ}-$ Respaldo de forças sociais atuantes no setor $8^{\circ}-$ Perspectivas mais concretas de viabilidade (CONASP). $9^{\circ}$ - Incorporação do planejamento à prática institucional $10^{\circ}-$ Responsabilidade das universidades na formulação e implementação de políticas de saúde.

Da mesma forma o CONASS (2007) destaca pontos positivos sobre as AIS, relatando que em 1984, todos os estados brasileiros haviam adotado as Ações Integradas de Saúde, sendo esse um convênio que deu um impulso não só para atender mais a população, como para estados e municípios romperem com a herança campanhista do Ministério da Saúde (CONASS 2007).
} 
Resolução 07/84, MS/MPAS/MEC/ CIPLAN; Ações Integradas de Saúde. Anexo: orientação para programação anual e avaliação.

\section{5}

Fim da ditadura militar. Início do Governo de José Sarney.

Decreto $\mathrm{n}^{\circ}$ 91.439, de 16 de julho de 1985, transferiu a Central de Medicamentos (CEME) do MPAS para o MS.

\section{Entre 1985 e 1988:}

\section{6}

O processo de realização da $8^{\mathrm{a}}$ Conferência Nacional de Saúde, 17 a 21 de março de 1986 - Brasília, foi resultado de um movimento de âmbito nacional na defesa da saúde, que se originou nos grupos dos profissionais que se opunham às propostas $\mathrm{e}$ programas executados pelos governos militares e formavam o movimento da reforma sanitária. Constituíram-se como referenciais desta Conferência: a) saúde como "resultante das condições de alimentação, habitação, educação, renda, meio ambiente, trabalho, transporte, emprego, lazer, liberdade, acesso e posse da terra e acesso a serviços de saúde"; b) saúde como direito da cidadania e dever do Estado; c) instituição de um sistema único de saúde, organizado pelos princípios da universalidade, integralidade, descentralização e participação da comunidade. (CNS 1986b).

Com 4.000 participantes e 1000 delegados (50\% instituições e $50 \%$ sociedade civil). Finalidade: “obter subsídios visando contribuir para a reformulação do Sistema Nacional de Saúde e proporcionar elementos para se debater a saúde na futura Constituinte".

Temas: 1 - Saúde como dever do Estado e direito do cidadão - ampliação do conceito de saúde; 2 - Reformulação do Sistema Nacional de Saúde, extinção do INAMPS, gestão única, princípios; 3 - Financiamento Setorial - fontes

Pontos de destaque para toda a Conferência:

Reforma Sanitária: as modificações ao setor saúde transcendem aos limites de uma reforma administrativa e financeira, na medida em que exigem a ampliação do conceito de saúde e sua correspondente ação institucional, além da revisão da 
legislação no que diz respeito à promoção, proteção e recuperação da saúde. A Reforma Sanitária, nos primeiros 10 anos, foi contra-hegemônica, tendo a ousadia de propor um sistema universal, enquanto outros países focalizavam suas políticas sociais.

Estatização: SUS não estatizado, necessários o fortalecimento e a expansão do setor público; participação do setor privado deve se dar sob o caráter de serviço público concedido e o contrato regido sob as normas do Direito Público;

Separação Saúde e Previdência

Financiamento-indicativo, exigindo-se maior aprofundamento.

O Relatório Final da $8^{a}$ Conferência serviu de base para a Assembléia Nacional Constituinte de 1987 (ALMEIDA e col 2001).

1 a Conferência Nacional de Saúde Bucal, 10 a 12 de outubro de 1986 - Brasilia, (vinculada à $8^{a}$ Conferência Nacional de Saúde), com 1000 participantes, patrocinada pelo Ministério da Saúde e Universidade de Brasília, com apoio do INAMPS, Conselho Federal de Odontologia e algumas Secretarias Estaduais de Saúde.

Saúde bucal como parte integrante e inseparável da saúde geral do individuo, Diagnóstico $^{32}$ da situação de Saúde Bucal, apontando rumos para a inserção da

\footnotetext{
${ }^{32}$ A situação de Saúde Bucal, da população brasileira, é caracterizada como caótica, com o modelo de prática odontológica cobre as necessidades de somente $5 \%$ da população, caracterizando-se por sua ineficácia e ineficiência, sendo ainda monopolizador, de altos custos, de tecnologia densa, elitista, iatrogênico e mutilador. O Relatório Final aponta a inexistência de uma Política Nacional de Saúde Bucal voltada para os interesses da maioria da população, inexistência de recursos financeiros necessários próprios do setor. falta de participação e controle da população nos programas, inexistência de uma política de produção de equipamentos e insumos odontológicos nacionais $e$ inexistência de dados epidemiológicos fidedignos e outras informaçzes sobre a Saúde Bucal da população. Os programas de saúde bucal caracterizam-se pela desvinculação junto a outros programas de saúde, além da não utilização de métodos preventivos de caráter coletivo, de forma sistematizada e do descumprimento da legislação vigente no que se refere à fluoretação das águas. Relativamente a recursos humanos, o documento destaca a pouca utilização de pessoal auxiliar de nivel elementar e médio e uma tendência à valorizar a especialidade em detrimento da clínica geral. além da ausência de uma política salarial justa e de programas de educação continuada, vinculados a um plano de cargos e salários que valorize os recursos humanos na área. Por fim, o Relatório destaca a proliferação irracional de Faculdades de Odontologia, com a queda do nivel de ensino e a inadequação do profissional formado à realidade social em que vive e às necessidades da comunidade (CNS 1986a).
} 
odontologia no processo de implementação SUS: necessidade de estruturação de um Programa Nacional e organização dos programas locais.

Levantamento Epidemiológico em Saúde Bucal (zona urbana)- MS.

1987

Decreto 94.657 de 20 de julho de 1987, criação do Sistema Unificado e Descentralizado de Saúde - SUDS.

Para COSTA (2002), o SUDS representa a $2^{\mathbf{a}}$ fase da política de descentralização do setor saúde, com a transferência de recursos a estados e municípios que se dispusessem a criar conselhos municipais ou estaduais de saúde e elaborassem planos de saúde. Na mesma época, ocorre o fechamento dos escritórios regionais do INAMPS ${ }^{33}$, com a transferência de atribuições para os estados.

Esse autor afirma ter havido resistência à descentralização, pelos grupos médico-empresariais, burocratas do INAMPS e alguns partidos políticos (PFL). Da mesma forma, alguns governos estaduais temiam a assinatura dos convênios sem o repasse de recursos.

\section{8}

A $7^{a}$ Constituição da República Federativa do Brasil, promulgada em 05/10/1988 criou o Sistema Único de Saúde que deve ser organizado segundo as seguintes diretrizes: descentralização, atendimento integral/integralidade e participação da comunidade. A Constituição Federal de 1988 criou o Sistema Único de Saúde (SUS), regulamentado pelas Leis Federais $n^{\circ} .8 .080$ e $n^{\circ} .8 .142$ de 1990 , definiu o setor privado da saúde como complementar quando vende serviços ao SUS e como suplementar quando atua no livre mercado.

\footnotetext{
${ }^{33}$ Entre 1988 e 1990, apesar da implantação do Sistema Unificado e Descentralizado de Saúde SUDS, da constituição legal do SUS e das Leis Orgânicas da Saúde, manteve-se a mesma prática de controle e avaliação sob a coordenação do INAMPS sem a participação dos estados ou municípios e sem a estadualização do controle e avaliação prevista pelo SUDS. Nesse período, as Leis 8.080/90 e $8.142 / 1990$ definiram, de forma genérica, as ações e competências das esferas de gestão no controle, avaliação, auditoria e regulação dos serviços e estabeleceram os Conselhos de Saúde como controladores e avaliadores das políticas, ações e serviços de saúde (ALMEIDA e col 2001; SCHILLING e col 2006.).
} 
Em 1988, a Constituição incorpora conceitos, princípios e uma nova lógica de organização da saúde: “o conceito de saúde entendido numa perspectiva de articulação de políticas econômicas e sociais; a saúde como direito social universal, derivado do exercício da cidadania plena e não mais como direito previdenciário; a caracterização dos serviços e ações de saúde como de relevância pública; criação do SUS (descentralizado, com comando único em cada esfera de governo, atendimento integral e participação da comunidade); e integração da saúde na Seguridade Social" (ALMEIDA e col. 2001, p.32).

Para COSTA (2002), a criação do SUS representou a $3^{a}$ fase da política de descentralização do setor saúde: definição de um comando único, descentralização da assistência a estados e municípios e co-responsabilidade do financiamento dos recursos.

\section{Entre 1988 e 2007:}

\section{0}

Primeira eleição direta para Presidente, sendo eleito Fernando Collor/Vice Itamar Franco (mandato 15/03/1990 até 02/10/1992). Hegemonia política das propostas neoliberais: abertura comercial, desregulamentação da economia brasileira, política de controle fiscal dos gastos públicos, arrocho do crédito e diminuição de liquidez no sistema financeiro. Vetos de vários artigos da Lei Orgânica da Saúde que impuseram restrições ao avanço da Reforma Sanitária ${ }^{34}$.

Lei $\mathrm{n}^{\circ}$ 8.029, de 12 de abril de 1990, extinguiu o Ministério da Previdência e Assistência Social - MPAS e restabeleceu o Ministério do Trabalho e da Previdência Social - MTPS.

Decreto 99.350, de 27 de junho de 1990, criou o Instituto Nacional do Seguro Social - INSS, mediante a fusão do IAPAS com o INPS, vinculando o Instituto Nacional de Assistência Médica da Previdência Social - INAMPS ao Ministério da Saúde.

\footnotetext{
${ }^{34}$ Inicia-se o período da falência da Saúde Pública (1990 a 1994) - universalização x corte de gastos. Gasto federal do MS em 1996 - 10\% da arrecadação da União e em 1989 era de 19\% (Dain apud OPAS/OMS, 1998, p. 29).
} 
Extinguem-se s Escritórios Regionais do INAMPS e os Serviços Locais de Medicina Social.

O Instituto Nacional da Previdência Social (INPS) passou a se denominar Instituto Nacional de Seguridade Social (INSS) e foi refundido ao Instituto de Administração da Previdência e Assistência Social (IAPAS), passando a ter como atribuições básicas a arrecadação, a administração e o pagamento de benefícios da Previdência Social.

Implantação do Sistema de Informações Hospitalares (SIH) e o Sistema de Informações Ambulatoriais (S I A).

Decreto 99.438, de 1990, criado o novo Conselho Nacional de Saúde, com base nos princípios e diretrizes do Sistema Único de Saúde. Além de congregar diversos segmentos da sociedade, este novo CNS possui caráter deliberativo: pode analisar e deliberar sobre assuntos de saúde pública, através de resoluções, que devem ser adotadas pelo Ministério da Saúde. O CNS deve articular-se com o ME quanto à criação de novos cursos de ensino superior na área da saúde, no que concerne à caracterização das necessidades sociais.

Lei Federal 8.078, de 11 de setembro de 1990 - criação do Código de Defesa do Consumidor.

Lei Federal 8.080, de 19 de setembro de 1990 - Lei Orgânica da Saúde - A regulamentação foi feita pela Lei 8080/90, que disciplina a descentralização políticoadministrativa do SUS, destacando seus aspectos de gestão e financiamento, e estabelecendo princípios para sua promoção, proteção e funcionamento. Devido a vetos presidenciais no texto da Lei $8080 / 90$, foi necessária a Lei $8142 / 90$ para regulamentar a participação da comunidade na gestão do sistema, bem como as transferências inter-governamentais de recursos financeiros. Essa Lei foi resultado da reação da sociedade civil organizada aos vetos presidenciais.

Lei Federal 8.142, de 28 de dezembro de 1990 - Fundo de Saúde, Conselhos de Saúde, Plano de Cargos, Carreiras e Salários. Esta lei teve que ser promulgada devido aos vetos do Presidente Collor na Lei 8080/90.

No período posterior à promulgação da Constituição Federal de 1988 , houve uma política de governo que notadamente desfigurou as conquistas 
da Carta Magna, ocorrendo uma grande expansão do setor privado e do mercado na saúde e na previdência social por meio das seguradoras privadas (ALMEIDA e col 2001; SCHEFFER e BAHIA 2005; CONASS 2007).

Entre o final dos anos de 1980 e meados da década de 1990, ocorreu a grande expansão do segmento da assistência suplementar, coincidindo com a transição epidemiológica e demográfica do País e com o crescente desfinanciamento da saúde pública. Esse segmento tornou-se atraente aos investimentos de grupos econômicos, implicando no reposicionamento das burocracias governamentais e do papel do Estado (SCHEFFER e BAHIA 2005).

PAIM (2005) afirma que, durante as décadas de $1970 \mathrm{e}$ 1980, a atuação do Movimento Sanitário teve como foco principal a defesa de um SUS público ou estatal diante das ameaças do movimento neoliberal representadas pela Reforma do Estado e pela redução de recursos financeiros e gastos públicos. Naquele momento, não houve espaço para uma investigação ou posição política mais clara em relação ao setor privado.

Para esse autor, a relação público-privado no SUS começou a ser mais discutida, a partir da década de 1990, em função de impasses políticos, econômicos e ideológicos ocorridos no período pós-constituinte e "mesmo em tempos recentes, essa relação público-privado não tem sido uma questão para a agenda política do governo, talvez por ser ela um pouco espinhosa para os governos atuais" (p.120).

Da mesma forma, PAIM (2005) acrescenta que, a partir dos anos de 1990, com o recuo do Movimento Sanitário e os novos atores representados, particularmente, pelo Conselho Nacional de Secretários Municipais de Saúde (CONASEMS) e pelo Conselho Nacional de Secretários Estaduais de Saúde (CONASS), adotou-se uma postura pragmática permeada de interesses intrínsecos à condição de gestores políticos, que não parece ser suficiente para construir pactos com o setor privado ou com as modalidades "não-SUS".

CAMPOS (2005), ao estudar os diversos conceitos de público, privado, particular e estatal, propõe um esquema teórico-conceitual para a análise dessa questão, no sentido de se evitarem maniqueísmos do tipo "público ineficiente / privado-eficiente": 
Na tese sustento que o par dialético, o par oposto de público é o caráter particular. $O$ público refere-se ao caráter de projetos e programas de uma organização que abrangem interesses coletivos (....). Por outro lado, o seu funcionamento seria particular quando se dirige a alguns sujeitos individuais. Agora, o privado opõe-se ao estatal, indica o caráter da propriedade e a forma de organização. São organizações privadas as que atuam no mercado $\mathrm{e}$ as privadas filantrópicas ou mesmo comunitárias. Já a propriedade estatal pode ocorrer mediante a administração direta, pelas autarquias, fundações públicas e empresas públicas (p.90).

Para esse autor, a política de saúde tem caráter e interesse públicos, apresentando uma dimensão pública (coletivo) que deve ser identificada tanto nas organizações estatais como nas particulares e, da mesma forma, uma dimensão particular (individual) que pode ser identificada, tanto na relação médicopaciente quanto na composição de interesses particulares sobre um programa de saúde, reconhecendo a necessidade de haver regulação por parte do Estado, para que os interesses particulares não venham a diminuir o caráter público das organizações estatais e privadas no setor saúde.

De 1991 a 1993, manteve-se a prática de controle e avaliação contábil financeira sob a gestão regionalizada do INAMPS, cabendo aos estados e municípios uma atuação marginal representada pelo repasse de dados. As Normas Operacionais Básicas - NOB 91 e NOB 92 estabeleceram a transferência de recursos do INAMPS para estados e municípios via convênio e pagamento por produção.

\section{1}

Resolução INAMPS $\mathrm{n}^{\circ}$. 258, de 7 de janeiro de 1991, e reeditada com alterações pela Resolução INAMPS n. 273, de 17 de julho de 1991 - Norma Operacional Básica/91 equiparou prestadores públicos e privados, no que se refere à modalidade de financiamento que passou a ser, em ambos os casos, por pagamento pela produção de serviços. Essa medida legal centralizou a gestão do SUS no nível federal (INAMPS) e estabeleceu o instrumento de convênio como forma de transferência de recursos do INAMPS para os estados, Distrito Federal e municípios, considerou como "municipalizados" no SUS, os municípios que atendessem aos requisitos básicos: 
a) criação dos Conselhos Municipais de Saúde; b) criação do Fundo Municipal de Saúde; c) Plano Municipal de Saúde aprovado pelos respectivos Conselhos; d) Programação e Orçamentação da Saúde (Pros) como detalhamento do Plano de Saúde; e) contrapartida de recursos para a saúde do seu orçamento; f) constituição de Comissão de Elaboração do Plano de Carreira, Cargos e Salários (PCCS) com o prazo de dois anos para a sua implantação.

Essa norma instituiu a Unidade de Cobertura Ambulatorial (UCA) definindo os valores a serem repassados aos estados, Distrito Federal e municípios. Modificou o sistema de pagamento aos prestadores de serviços com a implantação do Sistema de Informações Ambulatoriais do SUS (SIA/SUS).

Decreto $\mathrm{n}^{\circ}$ 100, de 16 de abril de 1991, institui a Fundação Nacional de Saúde FUNASA.

1992

OSV - 198 /INAMPS/MS, assinada em 08/01/1992 e publicada em 13/01/1992 institui tabela dos procedimentos coletivos em Saúde Bucal.

Portaria SAS/MS $n^{\circ}$ 234, de 07 de fevereiro de 1992, aprova a NOB/92, sendo o resultado de um consenso obtido entre CONASS, CONASEMS e INAMPS. Seus objetivos foram o de normatizar a assistência à saúde no SUS, estimular a implantação, o desenvolvimento e o funcionamento do sistema e dar forma concreta e fornecer instrumentos operacionais à efetivação dos preceitos constitucionais da saúde. Entretanto, essas iniciativas não foram implementadas. A NOB/92 manteve o INAMPS como órgão responsável pelo repasse de recursos financeiros aos municípios e estados, dando continuidade em linhas gerais ao que estava previsto na NOB/91, não regulamentando os repasses financeiros regulares aos municípios.

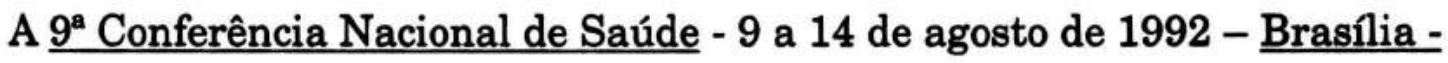
Saúde: Municipalização é o Caminho, foi realizada com 3000 delegados, após sucessivos adiamentos (última em 1986), tendo como base de discussão a Lei Orgânica da Saúde. Finalidade: indicar o caminho para a descentralização, municipalização e participação popular.

Os resultados finais foram apresentados em três vertentes: 
1) Reafirmação do texto constitucional, diante das ameaças de retrocesso às conquistas sociais representadas pela reforma da Seguridade Social que apontavam para a privatização da Saúde e da Previdência - e pela Reforma Fiscal que alterava as bases de arrecadação e distribuição de recursos para esses Setores;

2) Reafirmação do Sistema Único de Saúde e a adoção de estratégias para a implementação do SUS: implementação da Lei Orgânica da Saúde e a correção de desvios observados na sua implantação (pagamento complementar, reduzida capacidade operacional do setor público $\mathrm{e}$ descentralização do INAMPS/CEME/FNS).

2.1 Financiamento do SUS: repúdio è Reforma Fiscal, especificação de fontes e ampliação de receitas para a Saúde, consolidação do papel estabelecido para o FNS, implantação de mecanismos de transferência automática de recursos do Fundo Nacional de Saúde, sem transferências negociadas.

2.2 Recursos Humanos - realizar Conferência de Recursos Humanos

2.3 Controle Social - fortalecimento

3) O debate intenso sobre as crises do Estado e do governo: FORA COLLOR e crise ética. Em linhas gerais propôs reafirmar responsabilidades do Poder Público, respeitar preceitos constitucionais, garantir recursos à Seguridade Social, garantir direitos sociais conquistados, não à privatização do SUS, promover implantação efetiva do SUS, normatizar a relação público-privado, extinguir INAMPS, descentralizar a FNS, maior atuação do Ministério Público, realização de Conferências específicas como Saúde Bucal (CNS 1993b).

Impeachment do presidente Collor e renúncia em 02/10/1992.

Lei $n^{\circ} .8 .490$, de 19 de novembro de 1992, dispôs sobre a organização da Presidência da República e dos Ministérios, extinguindo o Ministério do Trabalho e da Previdência Social e restabelecendo o Ministério da Previdência Social (MPS). 
Após três anos da Lei Orgânica, a NOB/93 cria os critérios para os repasses de recursos do governo federal para estados e municípios, estabelecendo-se responsabilidades, requisitos e prerrogativas para a gestão local: gestão incipiente, parcial e semiplena.

O município assume total responsabilidade sobre a gestão da prestação de serviços, gerenciamento da rede pública (exceto sobre regulação estadual) e recebimento mensal de recursos financeiros para o custeio dos tetos ambulatorial e hospitalar, sendo que apenas na modalidade de gestão semiplena pode-se falar em efetiva municipalização de recursos e da administração da saúde pública COSTA (2002).

Após a NOB/SUS/01/93, surgiram conflitos de ordem político-institucional sobre as concepções relativas à relação entre os Estado e os Municípios (ALMEIDA e col.2001).

\section{3}

Portaria MS 545, 20 de maio de 1993, Norma Operacional Básica do Sistema Único de Saúde - NOB 01/93. Os principais avanços dessa Norma Operacional Básica foram:

a) criar a transferência regular e automática (fundo a fundo) do teto global da assistência para municípios em gestão semiplena, assumindo a contratualização e o pagamento do setor privado complementar;

b) habilitar municípios como gestores, sendo que o governo federal não poderia mais tratar estados e municípios como simples executores dos programas federais;

c) definir, de forma frágil, o papel dos estados, que ainda assim passaram a assumir o papel de gestor do sistema estadual de saúde;

d) constituir as Comissões Intergestores Bipartite (de âmbito estadual) e Tripartite (nacional) importantes espaços de negociação, pactuação, articulação, integração entre gestores.

Lei Federal 8.666, de 21 de junho de 1993, regulamenta o art. 37, inciso XXI, da Constituição Federal, institui normas para licitações e contratos da Administração Pública.

Lei Federal 8.689, de 27 de julho de 1993, extingue o INAMPS. 
A $\underline{2}^{a}$ Conferência Nacional de Saúde Bucal, 25 a 27 de setembro de 1993 - Brasilia atrelada à $9^{a}$ CNS - 1992, teve como base de discussão NOB/93, numa conjuntura marcada pela perspectiva de ampla revisão da Constituição de 1988, em face do projeto neoliberal em curso no Brasil "responsável pelo desmonte do Estado (Estado Minimo), da Seguridade Social e pela piora das condições de vida" (CNS 1993a).

Em linhas gerais, o diagnóstico sobre a situação da Saúde Bucal realizado nesta conferência permanece o mesmo em relação à $1^{a}$ Conferência: o modelo de saúde bucal vigente no Brasil, caracteriza-se pela limitadíssima capacidade de resposta às necessidades da população brasileira, ineficaz para intervir na prevalência das doenças bucais que assolam o pais. É elitista, descoordenado, difuso, individualista, mutilador, iatrogênico, de alto custo, baixo impacto social e desconectado da realidade epidemiológica e social da nação. Demonstram a falência do sistema, os vergonhosos indicadores de saúde e de morbidade bucal existentes, traduzidos pelos elevados índices de mutilações, cáries dentárias, doenças periodontais, câncer bucal, má oclusão e anomalias congênitas que colocam o Brasil entre os países de piores condições de saúde bucal no mundo. $\dot{E}$ inadmissivel o comportamento adotado pelo poder público quanto à fluoretação das águas de abastecimento público, condenando $70 \%$ da população brasileira a sobreviverem sem esse beneficio. Ao mesmo tempo, é eticamente questionável a passividade e a apatia da classe odontológica brasileira, quanto à exigência do cumprimento da Lei 6.050/74 que determina a obrigatoriedade da fluoretação. Ressalta a não incorporação da cárie enquanto doença infecto-contagiosa, prevenivel e tratável, no contexto do planejamento das ações de saúde e a ausência de programas coletivos de prevenção em saúde bucal, principalmente no interior e na zona rural. Falta de levantamento epidemiológico das doenças bucais, com o desconhecimento da situação de cada municipio, tanto no aspecto sócio-econômico como na área específica da saúde bucal. Insuficiência de cobertura assistencial odontológica à população, bem como a falta de oferta de horários compativeis para atendimento ao trabalhador.

Dentro das principais recomendações destacam-se: a necessidade de se implantar a NOB/93, Distritos Sanitários, rever parâmetros, estruturas, serviços, garantindo o atendimento secundário e terciário e a implementação dos procedimentos coletivos. 


\section{4}

Decreto $\mathrm{n}^{\circ} .1 .232$, de 30 de agosto de 1994 - dispõe sobre as condições e forma de repasse regular e automático de recursos do Fundo Nacional de Saúde para os fundos estaduais, municipais e do Distrito Federal ${ }^{35}$.

\section{5}

Início do Governo $\mathrm{FHC}^{36}$ (01/01/1995 a 01/01/1999)

Medida Provisória $\mathrm{n}^{\circ} 813$, de $1^{\circ}$ de janeiro de 1995 , dispôs sobre a organização da Presidência da República e dos Ministérios, transformando o Ministério da Previdência Social (MPS) em Ministério da Previdência e Assistência Social (MPAS).

Lei 8.987, de 13 de fevereiro de 1995, dispõe sobre o regime de concessão e permissão da prestação de serviços públicos, previsto no art. 175 da Constituição Federal.

Lei Municipal 11.866, 13 de setembro de 1995, institui o Plano de Atendimento à Saúde - PAS na cidade de São Paulo durante o mandato de Paulo Maluf. Módulos assistenciais gerenciados por cooperativas médicas (COOPERPAS universitários e COOPERPLUS não universitários).

\footnotetext{
${ }^{35}$ Conforme Santos, citado por CONASS (2007), "Em 1993, aconteceu uma grande derrota, porque o bolo do orçamento da seguridade social, cujo maior componente era a folha de pagamento do empregador, foi retirado como base de financiamento do SUS. O Ministério da Saúde foi a zero. O SUS quase acaba em 1993, pois o Ministério da Fazenda, junto com o Ministério da Previdência, autoritariamente retiraram esses recursos. Isso demonstrou como a política econômica interfere hegemonicamente e truculentamente contra as políticas sociais. O Ministério da Saúde entrou em colapso e foi obrigado a pedir um empréstimo". Apesar dessa "derrota", em 1994, o SUS teve uma das suas maiores conquistas, que foi a implantação da transferência automática e regular de recursos financeiros federais para os respectivos fundos de saúde estaduais e municipais, contemplando o previsto na Lei 8142/90 (p.73).
}

${ }^{36}$ No governo FHC houve a continuação do processo de "modernização" da economia brasileira na perspectiva do mercado financeiro internacional e das agências multilaterais, com agenda política determinada pelo diagnóstico das crises econômicas internacionais, frente às quais surge a necessidade de ajustes vitais para a estabilidade macroeconômica: redução do custo - Brasil e redução da regulamentação excessiva das relações entre o capital e trabalho - para a abertura da economia ao capital estrangeiro. Para COHN (2000), ocorreu uma flexibilização de direitos, surgindo um sistema dual de proteção social: um subsistema contributivo (renda e saúde suplementar) e um redistributivo financiado com os recursos da União (focalização). 
Plano Diretor da Reforma do Aparelho do Estado - Ministério da Administração Federal e Reforma do Estado.

Para ALMEIDA e col. (2001), questões como o financiamento, as competências e atribuições das três esferas de governo, o relacionamento público/privado e a restrição de recursos financeiros, vêm determinando um período de retração no processo de implantação do SUS.

Esses autores destacam que nesse período em que o sistema privado passou a contar com forte apelo ideológico, diminuíram as pressões pela implementação do SUS, apesar das alterações institucionais ocorridas.

Entre 1993 e 2000, com a extinção do INAMPS e a publicação das NOBs 93 e 96, ocorre o início e o desenvolvimento da atuação do Ministério da Saúde, dos estados e dos municípios sobre a gestão dos recursos, das ações e dos serviços de saúde, ainda com visão contábil e financeira do extinto INAMPS, baseada no controle sobre as Autorizações de Internações Hospitalares AIH e o Sistema de Informações Ambulatoriais - SIA. Nesse período, criou-se o Sistema Nacional de Auditoria - SNA com competências de controle, avaliação e auditoria da execução orçamentária, dos sistemas, das ações e serviços de saúde em cada esfera de gestão.

A NOB/SUS/01/96 diminui o repasse por produção, aumentando o repasse fundo a fundo, criando duas condições de gestão: básica e plena do sistema municipal de saúde. Somente em 1998, ocorreram as primeiras habilitações municipais pela NOB/96.

NOB 96 instituiu a Gestão Plena do Sistema e a Gestão Plena da Atenção Básica, estabelecendo o Piso da Atenção Básica, PACS, o Programa de Saúde da Família - PSF, o Piso Básico da Vigilância Sanitária - PBVS, a Programação Pactuada e Integrada - PPI, além da exigência dos requisitos comuns para a habilitação de gestão como: capacidade de contratação, de controle, de avaliação, de auditoria e de pagamento de serviços por parte de estados e municípios. Relativamente ao controle, enfatiza-se o controle sobre as consultas especializadas, os SADTs, os leitos e as referências intermunicipais. 
1996

Brasil 1996 - Levantamento Epidemiológico em Saúde Bucal - cárie dentária

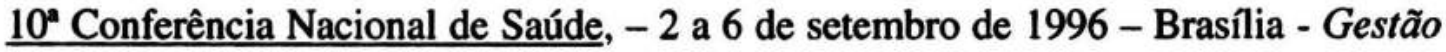
e Organização dos Serviços de Saúde.

Base para discussão $1^{a}$ versão da NOB-96 teve sugestões da Conferência.

Critica a proposta neoliberal da Reforma do Aparelho do Estado (Estado Mínimo para as políticas públicas e Estado Máximo para o capital privado), mobilização para a aprovação da PEC 169, exige discussão do MARE, contra modelos alternativos de gestão privatista (PAS).

Principais recomendações:

1) Saúde, cidadania e políticas públicas: rejeição a propostas privatistas e ao enxugamento do Estado, além da regulamentação das Organizações Sociais; rejeição às políticas de ajuste econômico e social impostas pelas agências internacionais. Defende o Estado como o executor das políticas públicas, Ministério Público como tutor da legislação em saúde e política de saneamento.

2) Gestão e organização dos serviços de saúde: qualificar a descentralização e a municipalização (Sistema de Controle, Avaliação e Auditoria), incorporar dispositivos que definam a relação do setor público e privado, incluindo os Planos e Seguros de Saúde e a terceirização, acelerar o processo de descentralização e enquadramento segundo NOB 96, investimentos em municípios-pólo, Centros de Atendimento Regionais (territorialização), descentralizar e integrar a FUNASA. Implementar o Sistema Nacional de Auditoria em todos os níveis, filantropia $60 \%$ SUS, regulamentar Planos e Seguros Privados de Assistência à Saúde, acionar o Ministério Público para o PAS, sistemas informatizados de saúde. Campanhas de divulgação em Saúde Bucal

3) Controle social na Saúde - implementar as comissões intersetoriais em saúde.

4) Financiamento na Saúde - defende PEC 169 (30\% recursos da Seguridade Social para a Saúde e no mínimo $10 \%$ de cada nível de governo). Busca por novas fontes de financiamento.

5) Recursos humanos - pede-se REFORSUS, CNS deve reativar a Comissão Interinstitucional de RH e estabelecer critérios para abertura de novos cursos; 
indicadores sócio-econômicos, necessidade de profissionais, infra-estrutura técnicocientífica, etc.

6) Atenção integral à Saúde - acolhida, acesso, vínculo, internação domiciliar, Central Regulação de Leitos. Atenção ao Idoso: saúde bucal para a terceira idade.

Relativamente à Saúde Bucal: atenção integral; priorizar as atividades preventivas exigindo a fluoretação das águas, conforme deliberação da $2^{a}$ Conferência Nacional de Saúde Bucal e, para tanto, os municipios deverão implantar um sistema de vigilância e avaliação de Saúde Bucal e dos niveis de flúor na água para consumo humano, conforme Resolução $n^{\circ}$. 142/94 do CNS, implantando medidas de caráter coletivo segundo a legislação. Qualificação de equipes multidisciplinares para o atendimento em geral e de clientelas especificas com ações integradas às demais ações de atenção integral. Formação continuada.

Lei 9.279, de 1996 - Lei das Patentes - até 1995 o Brasil não respeitava patentes.

Lei 9.311, de 24 de outubro de 1996, institui a Contribuição Provisória sobre Movimentação ou Transmissão de Valores de Créditos e Direitos de Natureza Financeira-CPMF.

Uma das questões centrais para o SUS, a partir do momento em que foram retirados os recursos referentes à seguridade social da área da saúde, foi a busca de uma fonte estável de recursos financeiros. Uma alternativa encontrada pelo Ministro da Saúde, em 1995, Adib Jatene, para minimizar esse problema foi a propor a criação de uma contribuição que incidisse sobre as movimentações financeiras, cujos recursos arrecadados deveriam ser utilizados na área da saúde. A gestão e o ressarcimento dos planos privados ao SUS passam a se caracterizar como desafios frente à precariedade da Saúde Pública (CONASS 2007).

Portaria 2.203, de 5 de novembro de 1996 - Norma Operacional Básica do Sistema Único de Saúde - NOB 01/96.

Os objetivos gerais da NOB/96 podem ser assim resumidos:

a) promover e consolidar o pleno exercício, por parte do poder público municipal, da função de gestor da atenção à saúde de seus habitantes com 
a respectiva redefinição das responsabilidades dos estados, do Distrito Federal e da União;

b) caracterizar a responsabilidade sanitária de cada gestor seja na prestação de ações e serviços ou na garantia da referência, explicitando um novo pacto federativo para a saúde;

c) reorganizar o modelo assistencial, passando aos municípios a responsabilidade pela gestão e execução direta da atenção básica de saúde;

d) aumentar a participação percentual da transferência regular e automática ("fundo a fundo") dos recursos federais a municípios e implementar esta modalidade de transferência aos estados, reduzindo a transferência por remuneração de serviços produzidos;

e) fortalecer a gestão do SUS, compartilhada entre os governos municipais, estaduais e federal, por meio da CIT e das CIBs, espaços permanentes de negociação e pactuação entre gestores;

f) estabelecer vínculo entre o cidadão e o SUS, conferindo visibilidade quanto à autoridade responsável pela sua saúde, provendo o cadastramento e adscrição da clientela.

COSTA (2002) destaca o fortalecimento dos Estados na coordenação de programas vinculados ao SUS, revertendo o poder de gestão concedido aos municípios pela NOB 93.

Para esse autor, a NOB/96 reorganizou o sistema de saúde enfocando a Atenção Básica, conforme proposto pelos organismos financeiros internacionais, ou seja, aos estratos mais pobres da população, reproduzindo uma política segmentada consoante a renda. Alterou as modalidades de gestão: gestão plena da atenção básica (PAB) e plena do sistema de saúde ${ }^{37}$.

\footnotetext{
${ }^{37} \mathrm{Em} \mathrm{13/12/1996,} \mathrm{houve} \mathrm{a} \mathrm{substituição} \mathrm{do} \mathrm{Ministro} \mathrm{Adib} \mathrm{Jatene} \mathrm{pelo} \mathrm{Ministro} \mathrm{Carlos} \mathrm{Albuquerque,}$ gerando uma reorientação na condução do Ministério da Saúde e uma rediscussão sobre alguns conceitos contidos na versão original, principalmente em relação ao PAB e o financiamento necessário para a sua implementação.

A série de portarias editadas pelo Ministério da Saúde ao final de 1997 e início de 1998, mais do que regulamentar a NOB/96, introduz profundas mudanças na sua concepção original (CONASS 2007).
} 
1997

Portaria GM/MS 1.882, de 18 de dezembro de 1997 - estabelece o Piso de Atenção Básica - PAB, definindo uma parte fixa e outra variável. PAB FIXO R\$10,00 hab/ano com o valor máximo da parte fixa do PAB estipulado em R\$ 18,00 habitante/ano (reunião da CIT de 27 de janeiro de 1998).

Portaria GM/MS 1.886, de 18 de dezembro de 1997 - aprova normas e diretrizes do Programa dos Agentes Comunitários de Saúde e do Programa de Saúde da Família.

\section{8}

Ministro José Serra (31/03/1998).

Lei 9.656, de 3 de junho de 1998 - regulamenta o setor de planos e seguros, com 44 Medidas Provisórias aguardando consolidação pelo Congresso Nacional - área da saúde é o locus regulador.

Portaria MS 3.916, de 30 de outubro de 1998, cria a Política Nacional de Medicamentos.

Portaria GM/MS 3.925, de 13 de novembro de 1998 - aprova o Manual para a Organização da Atenção Básica no SUS.

$\mathrm{N}$ - Lei 9.637, de 15 de maio de 1998, dispõe sobre a qualificação de entidades como organizações sociais, a criação do Programa Nacional de Publicização, a extinção dos órgãos e entidades que menciona e a absorção de suas atividades por organizações sociais, e dá outras providências.

Lei 9.649, de 27 de maio de 1998, define medidas de organização administrativa específicas para as autarquias e fundações qualificadas como Agências Executivas e dá outras providências.

Emenda Constitucional n. 19 - de 04 de junho de 1998 - DOU de 5/6/98 modifica o regime e dispõe sobre princípios e normas da Administração Pública, servidores e agentes políticos, controle de despesas e finanças públicas e custeio de atividades a cargo do Distrito Federal, e dá outras providências.

Emenda Constitucional $\mathrm{n}^{\circ}$. 20, de 15 dezembro de 1998, modifica o sistema de previdência social, estabelece normas de transição e dá outras providências. Constituiu-se no eixo da reforma da Previdência. Paralelamente, um conjunto de medidas provisórias que tratam do tema foi convertido em leis e, posteriormente, em 1999, foram enviados ao Congresso Nacional uma série de projetos de lei ordinárias 
e complementares para regulamentar as alterações constitucionais, alterando os planos de custeio, benefícios e organização do RGPS.

1999

Governo FHC - reeleição (01/01/1999 a 01/01/2003)

Lei 8.689 , de 27 de julho de 1999 - cria o Sistema Nacional de Auditoria, no âmbito do SUS.

Lei 9.787, de 10 de fevereiro de 1999, conhecida como a Lei dos Genéricos.

Lei 9.782, de 26 de janeiro de 1999 - define o Sistema Nacional de Vigilância Sanitária e cria a ANVISA.

Lei 9.790, de 1999 cria as Organizações da Sociedade Civil de Direito Público OSCIP (Lei do Terceiro Setor).

Portaria GM/MS 476, de 14 de abril de 1999 - regulamenta o processo de acompanhamento e de avaliação da atenção básica, conforme expresso no Manual para a Organização da Atenção Básica e na NOB 01/96.

Resolução CNS n. 291, de 6 de maio de 1999 - aprovar o Regimento Interno do Conselho Nacional de Saúde em sua versão final, após parecer da Consultoria Jurídica do Ministério da Saúde. Artigo 3 - XVII - Deliberar sobre a necessidade social de novos cursos de nível superior na área da saúde e cooperar na melhoria da qualidade da formação dos trabalhadores da saúde.

Portaria GM/MS 832, de 28 de junho de 1999 - regulamenta o processo de acompanhamento e de avaliação da atenção básica, conforme expresso no Manual para a Organização da Atenção Básica e na NOB 01/96.

Portaria 3.916, de 30 de outubro de 1999, dispõe sobre a Política Nacional de Medicamentos no SUS.

Portaria GM/MS 1.399, de 15 de dezembro de 1999 - cria o Teto Financeiro de Epidemiologia e Controle de Doenças. Regulamenta a NOB 01/96 nessas áreas e define a sistemática de financiamento. 
Entre 2000 e 2002, os executantes das ações de regulação, controle, avaliação e auditoria no setor saúde, no Brasil, passam a ser o Ministério da Saúde, a ANVISA, a ANS, os estados e os municípios ${ }^{38}$.

Em 2000, criou-se a ANS - Agência Nacional de Saúde Suplementar - Lei $\mathrm{n}^{\circ} .9 .961$, de 28 de janeiro de 2000, dando-se início às atividades de regulação sobre a saúde suplementar. Nesse mesmo ano, a ações de auditoria desvinculam-se das ações de controle e de avaliação, passando a ser competência do SNA "o controle dos recursos repassados aos estados, municípios e Distrito Federal e o exame analítico, a verificação 'in loco' e pericial da regularidade dos procedimentos executados. Ao controle e avaliação caberia o monitoramento contínuo das ações e serviços desenvolvidos no âmbito do SUS" (SCHILLING e col. 2006, p.22).

\section{0}

Lei 9.961, de 28 de janeiro de 2000 - cria a Agência Nacional de Saúde Suplementar - ANS e dá outras providências.

Portaria GM/MS 1.469, de 2000 - dispõe sobre as ações de vigilância sobre o controle da água.

Portaria SAS/MS n. 376, de 3 de outubro de 2000, institui o Cadastro Nacional de

\section{Estabelecimentos de Saúde - CNES}

Emenda Constitucional $n^{\circ}$. 29, de 13 de dezembro de 2000 - altera os artigos 34, 35 , 156, 160, 167 e 198 da CF e acrescenta artigo ao ato das disposições constitucionais transitórias, para assegurar os recursos mínimos para o financiamento para as ações e serviços públicos de saúde. Vinculou o mínimo a ser aplicado em ações e serviços de

${ }^{38}$ Segundo CARVALHO 2001, o "Ministério Público é responsável por zelar para que os serviços de relevância pública respeitem os direitos constitucionais, como é o da saúde CF Artigol29 II. Portanto, responsável pela saúde pública e privada. Na própria CF, além dessa conotação, existe uma correlação com as funções do Ministério Público, entre as quais está a de zelar pelo efetivo respeito dos poderes públicos e dos serviços de relevância pública aos direitos assegurados na Constituição, promovendo as medidas necessárias à sua garantia. Portanto, o Ministério Público tem, como obrigação, zelar para que os serviços de saúde garantam o direito à saúde das pessoas (...) Definir claramente os papéis e responsabilidades na ação controladora sobre o financiamento federal do SUS, nas várias instâncias do Controle Público Externo e Interno: Ministério Público Federal, Tribunal de Contas da União, Secretaria Federal de Controle Interno, Sistema Nacional de Auditoria do SUS, em seu componente Federal (p.26 e 350). 
saúde: estados, $12 \%$ e municípios, $15 \%$ das receitas próprias. No caso da União, o limite mínimo de gasto foi estabelecido como o valor empenhado em 1999, acrescido de 5\%, nos anos subseqüentes, e a variação nominal do Produto Interno Bruto.

A não regulamentação da $\mathrm{EC} \mathrm{n}^{\circ} 29$, juntamente com a Desvinculação das Receitas da União (DRU), têm sido mecanismos utilizados para limitar os recursos públicos na saúde. A falta de uma definição precisa sobre o que são "ações e serviços de saúde" tem levado a introdução nos orçamentos públicos de uma série de ações e serviços que são questionáveis. Isso resulta em menos recursos para o financiamento do SUS (CONASS 2007).

A luta política por mais recursos públicos para a saúde encontra-se hoje centrada na regulamentação, pelo Congresso Nacional, da EC $n^{\circ}$. 29, por meio do Projeto de Lei Complementar (PLC) 01/2003.

11* Conferência Nacional de Saúde , 15 a 19 de dezembro de 2000 - Brasília, com 2.500 delegados - "O Brasil falando como quer ser tratado: efetivando o SUS acesso, qualidade e humanização na atenção à saúde com controle social".

Carta da $10^{\circ}$ Conferência

Crítica ao projeto de ajuste econômico e social do governo FHC que privilegia o ajuste econômico em detrimento das políticas sociais. Redução do Estado com a privatização de empresas e serviços públicos e a precarização das relações de trabalho. Intervenções de saúde de cunho campanhista. Suspensão e proibição de quaisquer contratos e convênios substitutivos da gestão pública, a exemplo do PAS, consoante Procuradoria Geral da República. Cumpridor das determinações do Fundo Monetário Internacional.

Diagnóstico da situação:

A "Reforma do Estado" no Brasil contempla, resumidamente, os seguintes aspectos: a transferência dos serviços públicos potencialmente lucrativos ao setor privado; a concentração da ação direta do Estado em programas de baixo custo e voltados para as populações pobres; a ampliação dos recursos dos planos de saúde para as camadas médias da população, submetendo-os a certa regulação para refrear a voracidade das empresas do setor. Ausência dos Estados que não cumprem seu papel de assessorar 
tecnicamente e financeiramente os municípios, não sendo articuladores. Instrumentos de avaliação e regulação inadequados ao acompanhamento do setor privado. Tetos financeiros insuficientes, invasão, PPI inadequada.

Não há profissionalização da gestão, falta de protocolos.

O MP atrelado ao poder Executivo reproduz traços de submissão ao poder econômico e político, manifestos em posturas de conivência com os problemas da saúde, atuando de forma fragmentada, pontual e ocasional, com excesso de burocracia e lentidão.

Propostas:

Garantir a participação do CNS na elaboração e no acompanhamento dos instrumentos de gestão instituídos pelo SUS, na aplicação de recursos financeiros, bem como aproximação e parceria junto ao MP, promotorias de justiça e Tribunais de Conta e articulação junto aos Poderes Executivo e Judiciário via Ministério Público. Capacitação de promotores.

Convoca a realização de várias conferências setoriais, dentre elas a $3^{a}$ Conferência Nacional de Saúde Bucal a ser realizada em 2001.

Quanto ao Financiamento, aplicar o mínimo de financiamento de R\$32 bilhões, regulamentar a EC 29, definição de fontes complementares, acabar com a institucionalização de recursos voltados a programas como PSF, PACS, etc, extinção do FAEC e a forma convenial de transferência de recursos para a FUNASA.

Quanto à regulação, observa-se especificação e maior detalhamento dos instrumentos de regulação (maior ênfase do que na $10^{a}$ Conferência) como, criar formas de regulação da oferta e distribuição dos serviços de saúde, regular nacionalmente o pagamento dos prestadores privados, de modo a garantir o acesso, agilizar a implantação do Cartão SUS em $100 \%$ dos municípios, garantir monitoramento físico-financeiro, implantar centro de custos, implantar a PPI, implantar a Câmara de Compensação Nacional para desajustes de tetos. Município é o regulador. Impedir a privatização da saúde através das Agências Executivas ou Reguladoras. Regulamentar o cargo de Auditor do SUS. Criar Ouvidoria no município. Concluir a revisão do Cadastro de Estabelecimentos de Saúde. Implantar Complexos Reguladores com Centrais de Vagas com fluxo regulado por médicos reguladores, adotar protocolos. 
Quanto à Saúde Bucal, rever e integrar as políticas para idosos, carcerária, indigena, portadores de deficiências no que se refere à saúde bucal. Monitorar a oferta de consultas médicas e odontológicas, garantindo a qualidade $e$ resolutividade e a realização de exames complementares/laboratoriais necessários. Incorporar odontólogos ao PSF - uma das estratégias da Atenção Básica. Regulamentar as profissões THD, ACD, etc. Implantar um programa nacional de saúde bucal que abranja a atenção básica, controle da fluoretação e especialidades. Portaria SAS/MS nº. 511, de 29 de dezembro de 2000, dispõe sobre o processo de cadastramento dos estabelecimentos de saúde em todo Território Nacional (CNS 2001).

As Normas Operacionais de Assistência à Saúde (NOAS 01/2001 e 01/2002) buscaram organizar a regionalização da assistência, cabendo aos estados organizar o fluxo da assistência municipal por meio do PDR - Plano Diretor de Regionalização, mantendo-se as mesmas condições de gestão da NOB 96, exceto para os municípios com Gestão Plena da Atenção Básica substituída por Gestão da Atenção Básica Ampliada, com financiamento pelo PABA - Piso da Atenção Básica Ampliado $^{39}$.

CARVALHO (2001) destaca que a NOAS/2001 possui uma série de incongruências e indefinições, representando um retrocesso na implantação do SUS, na medida em que tenta 'recentralizar' a gestão da saúde junto aos Estados.

Esse autor enumera os principais pontos de divergência: 1) definição de tetos e valores de procedimentos sem estudo prévio e sem consulta ao

\footnotetext{
${ }^{39}$ Para CARVALHO (2001), "as indefinições da NOB-96 não resolvidas e a impossibilidade de continuarem os municípios a se habilitarem na NOB-93 foram motivos para que novas forças tomassem conta do processo descentralizatório do SUS e modificassem radicalmente a NOB-96. Os técnicos quase que foram os mesmos, mas os dirigentes mudaram e, sob novo comando, estes e aqueles deram asas e pernas ao maior processo recentralizatório do SUS, continuado mais tarde e, de forma definitiva, com a NOAS-2001. Nunca se tinha avançado tanto, como a partir da NOB-1993. Nunca se conseguiu regredir tão rapidamente após a "NOB-98", chegando aos absurdos na NOAS2001"(p.203). Esse autor acrescenta "completar as ilegalidades e o processo recentralizatório, já foi engendrada a NOAS 2002 que faz alguns remendos na NOAS 2001, confirmando erros, equívocos e política inconstitucional e ilegal de saúde. Não se corrigem os problemas, aprofundam-se as mudanças, na contramão das leis" (p.264).
} 
CNS ou à CIT; 2) indefinição de novos valores para a pactuação dos municípios; 3) gestor estadual adota critérios para habilitação dos municípios e para a organização regional em micro-regiões, sem considerar a autonomia municipal; 5) pactuação com a valor médio da $\mathrm{AIH}$, desconsiderando o risco de haver redução do atendimento devido ao teto financeiro; 6) indefinição da função da Auditoria e do conceito de Regulação; 7) número excessivo de planos exigidos dos municípios, como PPA, LDO, LO, Plano Regional, Plano de Saúde, Quadro de Metas, Pacto Indicadores da Atenção Básica; 8) risco de habilitações cartoriais, já que grande parte dos municípios não têm condições para habilitação, entre outros questionamentos.

\section{1}

Portaria GM/MS 17, de 5 de janeiro de 2001 republicada em 16 de fevereiro de 2001 - institui o Cadastro Nacional de Usuários do Sistema Único de Saúde e regulamenta sua implantação.

Portaria GM/MS 95, de 26 de janeiro de 2001 - cria a Norma Operacional de Assistência à Saúde - NOAS SUS 01/2001.

A NOAS/01 estabeleceu o processo de regionalização como estratégia de hierarquização dos serviços de saúde e de busca de maior eqüidade. Instituiu o Plano Diretor de Regionalização (PDR) como instrumento de ordenamento do processo de regionalização da assistência em cada estado e no Distrito Federal, cabendo às Secretarias Estaduais de Saúde a sua elaboração, em consonância com o Plano Estadual de Saúde, e submetido a aprovação na Comissão Intergestores Bipartite e no Conselho Estadual de Saúde.

Portaria GM/MS 145, de 1 de fevereiro de 2001 republicada em 8 de fevereiro de 2001 - regulamenta as transferências Fundo-a-Fundo para o financiamento das ações de média e alta complexidade executadas pelos Estados, Municípios e Distrito Federal.

Lei 10.195 , de 12 de fevereiro de 2001 , dispõe sobre a especialização das sociedades seguradoras em planos privados de assistência à saúde.

Portaria GM/MS 393, de 29 de março de 2001 - institui a Agenda de Saúde.

Portaria GM/MS 548, de 12 de abril de 2001 - cria os Instrumentos de Gestão.

III Conferência Nacional de Saúde Indígena 14 a 18 de maio de 2001 - Luziânia-GO 
Priorizar a formação em serviço de indígenas como Auxiliares de Consultórios Dentários e Téonicos de Higiene Dental.

Decreto $n^{o}$. 3.860, de 9 de julho de 2001, Dispõe sobre a organização do ensino superior, a avaliação de cursos e instituiçães, e dá outras pnovidências.

Art. 27. A criação de cursos de graduação em medicina, em adontologia e em psicologia, por universidades e demais instituições de ensino superior, deverá ser submetida à manifestação do Conselho Nacianal de Saúde. $\S 1$ o O Conselho Nacional de Saúde deverá manifestar-se no prazo máximo de cento e vinte dias, oontados da data do recebimento do processo remetido pela Secretaria de Educação Superior do Ministério da Educação. $\S 20$ A criação dos cursos de que trata o caput dependerá de deliberação da Câmara de Educação Superior do Conselho Nacional de Educação homologada pelo Ministro de Estado da Educação.

III Conferência Nacional de Saúde Mental - 11 a 15 de dezembro de 2001 - Brasilia “Guidar sim, excluir não".

133. Garantir o acesso do portador de transtornos mentais ao tratamento odontológico, de Fonoaudiologia e de Terapia Ocupacional na Rede Básica de Saúde. 396. Garantir a assistência odontológica aos portadores de transtornos mentais na rede pública, adequando e capacitando a rede para este fim. 567. Apoiar as deliberações da $11^{n}$ Conferência Nacional de Saíde, que fala da realização de Corferências Temáticas, incorporando as questăes relativas à saúde da população negra, recursos humanos, saúde bucal, saúde da mulher e assistência farmacêutica. Portaria GM/MS n'. 2.309, de 19 de dezembro de 2001, institui no âmbito da SAS a CNRAC, com o objetivo de coordenar a referência interestadual de pacientes que necessitem de assistência hospitalar de alta complexidade.

A NOAS 2002 aprofundou as exigências às gestões plenas dos sistemas municipais e estaduais para a operacionalização de centrais de controle de procedimentos ambulatoriais e hospitalares e para a viabilização de referências intermunicipais, definindo a regulação assistencial como "a disponibilização da alternativa assistencial mais adequada à necessidade do cidadão, de forma equânime, ordenada, oportuna e qualificada efetivada por meio de complexos reguladores que 
congreguem unidades de trabalho responsáveis pela regulação das urgências, consultas, leitos e outros que se fizerem necessários" (BRASIL 2002).

Posteriormente, as Portarias SAS/MS n. 423 e 729 de 2002 ratificaram as diretrizes da política de regulação descritas na NOAS, buscando definir competências em cada esfera de gestão do SUS e alguns indicadores para orientar a elaboração dos Planos de Controle, Regulação e Avaliação dos estados e municípios.

Em 2002, o termo Regulação, como regulação do acesso à assistência, ganhou maior divulgação a partir da Norma Operacional da Assistência à Saúde (NOAS 01/2002), quando o conceito de regulação assistencial passa a se disseminar no âmbito do SUS. Através do Decreto $n^{\circ}$. 4.726, de 09/06/2003, o termo Regulação passou a fazer parte da denominação de um Departamento do MS, o Departamento de Regulação, Avaliação e Controle de Sistemas (DRAC).

\section{2}

Portaria GM/MS 373, de 27 de fevereiro de 2002 - cria a Norma Operacional de Assistência à Saúde - NOAS SUS 01/2002

Resolução 316 do CNS, de 4 de abril de 2002 - aprova diretrizes para a aplicação da EC 29

Portaria GM/MS 1.020, de 31 de maio de 2002 - regulamentação da Programação Pactuada e Integrada da NOAS SUS 01/2002.

Portaria GM/MS 1.101, de 12 de junho de 2002, dispõe sobre os parâmetros de necessidades e de produção da assistência à saúde.

Portaria SAS/MS $n^{\circ} 423$, de 9 de julho de 2002, aprova o detalhamento das atribuições básicas inerentes a cada nível do Governo no controle, regulação e avaliação da Assistência à Saúde no SUS.

Portaria SAS/MS $n^{\circ} 729$, de 14 de outubro de 2002, estabelece os indicadores de avaliação, bem como os requisitos básicos a serem contemplados no Plano de Controle, Regulação e Avaliação da Assistência, previsto no item 47 do Capítulo II. 3 da NOAS 01/2002, visando à implementação da organização e do funcionamento dos componentes de planejamento, controle, regulação e avaliação assistencial dos 
Estados e Municípios habilitados, ou que vierem a ser habilitallos, na Gestão Plena do Sistema de Saúde pela NOAS SUS 01/2002.

Partaria Conjunta SE/MS e ANE $\mathrm{n}^{\circ}$ 6, de 23 de outubro de 2002, aprova a sistemática de acompanhamento e avaliação do desempenho da ANS, através de Contratos de Gestão.

Portaria GM/MS 2.047, de 5 de novembro de 2002 - aprova, na forma do Anexo a esta partaria, as Diretrizes Operacionais para a aplicação da $\mathrm{EC} \mathrm{n}^{\circ} .29$, de 2000.

2003

Início do Governo Lula (01/01/2003 a 01/01/2007)

SB Brasil 2003 - Levantamento das Condições de Saúde Bucal da População Brasileira (início em 2000 e término em 2003)

Decreto 4.726, de 9 de junho de 2003, aprova a estrutura regimental básica do Ministério da Saúde, compondo a Secretaria de Atenção à Saúde (SAS) e o DRAC. O termo Regulação passa a fazer parte da denominação de um Departamento do MS. I Lei $n^{\circ} 10.741$, de 1 de outubro de 2003, institui o Estatuto do Idoso a fim de regular os direitos assegurados a pessoas oom mais de 60 anos.

$12^{\mathrm{a}}$ Conferência Nacional de Saúde - Conferència Sérgio Arouca - "Sauide um direiso de fodos e um dever do Estado: a saúde que temos, o SUS que queremos. " - 7 a 11 de dezembro de 2003 - Brasília, com 1.536 delegados.

Temas - 10 eixos temáticos e a finalidade de se definir uma Política Nacional de Saúde.

Diretrizes Gerais e algumas recomendações relativas à Saúde Bucal:

\section{OFinanciamento da Saúde}

Desvinculação de receitas será problemático ao SUS, necessário regulamentar a EC 29 (12\% Estado, $15 \%$ municípios e ao\% União), a Reforma Tributária e Previdenciária deve garantir mais recursos às ações e serviços de saúde do SUS, condicionantes e determinantes da saúde devem ser financiados por outras fontes (saneamento).

O Projeto de Lei Complementar (PLC) 01/2003 pretende corrigir distorções na vinculação dos recursos da União e esclarecer o que são ações e serviços de saúde. O texto estabelece que a União aplique anualmente em ações e serviços de saúde, no mínimo, o montante 
equivalente a $10 \%$ de suas receitas correntes brutas, constantes dos orçamentos Fiscais e da Seguridade Social. A estimativa de acréscimo, em 2006, com a aprovação da regulamentação da EC $n^{\circ}$. 29, segundo estimativas do CONASS era de aproximadamente $R \$ 13$ bilhões no orçamento federal com o financiamento da Saúde.

Ampliar os recursos do SUS com transferências per capita para atendimento integral na área odontológica, com garantia da oferta de atendimentos especializados de média e alta complexidade como próteses dentárias, procedimentos cirúrgicos, endodônticos e ortodônticos.

\section{O Trabalho na Saúde}

Regulamentar a Lei n. ${ }^{\bullet} 10.507 / 02$, relativa aos agentes comunitários de saúde (ACS). Assegurar a criação e regulamentação das profissões de técnico em higiene dental e de auxiliar de consultório dentário no SUS.

\section{Controle Social e Gestão Participativa}

Realizar, em 2005, a 1ª Conferência da Seguridade Social nas três esferas de governo, tendo em vista a implantação e implementação dos Conselhos Nacional, Estaduais e Municipais da Seguridade Social. Realizar a $3^{a}$ Conferência Nacional de Saúde Bucal;

\section{A Organização da Atenção à Saúde}

Ampliar a cobertura dos serviços em todos os níveis de complexidade, com ênfase na atenção básica, priorizando a estratégia da Saúde da Família e outras semelhantes que possibilitem a mudança de orientação do modelo de atenção. Garantir o atendimento integral, em especial o acesso à atenção secundária e terciária, incentivando estados e municípios a criarem centros de referência de especialidades de média e alta complexidade. Criar centros regionais de referência com equipes interdisciplinares para atender pessoas com necessidades especiais e com deficiência, com cirurgia buco-maxilo-facial, disfunção de ATM. Garantir o acesso a todos os insumos necessários para a efetiva atenção, inclusive serviços odontológicos completos. Implantar as centrais públicas de regulação de consultas especializadas, internação e exames, consolidando a referência e contra-referência. Ampliação do acesso às ações de saúde bucal implantação de mecanismos regulatórios, com definição da vocação de cada unidade prestadora de serviço, 
respeitando as necessidades de cada região, os princípios do SUS e os fluxos estabelecidos, garantindo, quando necessário, o acesso da população a serviços fora do municipio. equipes multiprofissionais de apoio às equipes de Saúde da Familia, de acordo com as necessidades locais com, odontólogo.

Ampliar e assegurar o acesso às ações integrais de saúde bucal em todo o SUS, estendendo-as a todas as faixas etárias, segundo a recomendação da OMS, incluindo:I atendimento básico, prótese, endodontia, tratamentos correlatos de reabilitação, atenção a pessoas com necessidades especiais, e outras especialidades; II. promoção e prevenção à saúde bucal em todas as faixas etárias mediante a orientação para a escovação e para limpeza da cavidade bucal dos recém-nascidos após a mamada; III. a ênfase para as crianças e outros grupos de maior risco; IV. a distribuição trimestral gratuita de escova e creme dental fluoretado em todas as escolas públicas desde a creche até a oitava série do ensino fundamental; $V$. as equipes de saúde bucal, que devem incluir um dentista, um técnico em higiene dental (THD) e um atendente de consultório dentário (ACD), com trabalho em tempo integral, com isonomia salarial, em conformidade com a Norma Operacional Básica de Recursos Humanos (NOB-RH/SUS) e realização de concurso público para seleção e contratação dos profissionais; VI. a garantia de fornecimento trimestral de kits de higiene bucal para o desenvolvimento de atividades educativas nos municipios; VII. a exigência de "escovatórios" próximos aos refeitórios das creches, das escolas de ensino fundamental e nas unidades básicas; VIII. o fornecimento de orientação alimentar nas creches e escolas, com vistas a uma merenda mais saudável e menos cariogênica, com recomendação do consumo de alimentos prescritos por nutricionistas e prevenção de doces e refrigerantes nas cantinas escolares; IX. a formação de agentes promotores de saúde bucal e educação nutricional nos curriculos das $7^{a}$ e $8^{a}$ séries das escolas de ensino fundamental para garantir os programas de promoção e prevenção em saúde bucal das crianças na faixa etária entre 2 e 14 anos; $X$. a garantia de aumento do volume de recursos destinados a essas ações $e$ incentivo financeiro em todas as esferas de governo destinado às equipes de saúde bucal; XI. o incentivo à implantação de referência de especialidades definindo no Plano Diretor Regional as responsabilidades dos gestores que o integram. Relação entre o SUS e os Serviços Privados: Saúde 
Suplementar: 105. Divulgação imediata e regular pela ANS dos dados referentes ao número de beneficiários de planos e seguros de saúde por município e estado com o objetivo de subsidiar os gestores na formulação, acompanhamento e avaliação das políticas de saúde. 106. Proibir o atendimento diferenciado aos beneficiários de planos de saúde e particulares nas unidades do SUS e hospitais universitários. 107. Proibir a propaganda e a comercialização de planos de saúde privados dentro de qualquer órgão público vinculado ao SUS, assim como nos eventos promovidos pelo SUS.

\section{As Três Esferas de Governo e a Construção do SUS}

Incrementar, aperfeiçoar e implementar, nas três esferas de governo, o processo de trabalho, o sistema, as ações e os serviços de planejamento, acompanhamento, controle, avaliação e auditoria do sistema de saúde por meio das seguintes estratégias: I. criação de instrumentos integrados;

\section{A Intersetorialidade das Ações de Saúde}

Romper com a prática de políticas setoriais isoladas, As atividades de intermediação do financiamento dos serviços de saúde e as atividades de regulação da assistência médico-hospitalar não pode ser livre à iniciativa privada. Essas atividades são de relevância pública e o direito social ao acesso aos serviços de saúde é um valor universal em defesa da vida. Assim, elas devem ser da exclusividade do estado democrático e de direito. A concessão de serviços públicos viola a garantia do direito à saúde. Implementação da Portaria GM/MS n. ${ }^{\circ} 1.469 / 00$, como garantia de exercício de cidadania, criando padronização dos procedimentos universais para fluoretação da água e alternativas viáveis para os casos de fluorose. Formular, implementar e articular a implantação de uma política de saúde nas escolas, envolvendo os setores de educação, saúde (promoção e prevenção em saúde bucal);

\section{Ciência e Tecnologia e a Saúde}

\section{Informações e Comunicação na Saúde}

\section{Direito à Saúde}

Governo mantenedor de uma rede de Seguridade Social, cumprimento da EC 29, via Ministério Público, Estado regulador das relações entre os setores público e privado, Planos de Saúde com regulamentação voltada para a garantia do direito à saúde, equidade, integralidade, acesso às populações indígenas, criação de varas 
especializadas em Direito à Saúde com a divulgação de protocolos clínicos ao Ministério Público.

\section{A Seguridade Social e a Saúde}

Integração das ações da Seguridade Social (saúde, previdência e assistência social) com articulação política entre os três ministérios através de ações e indicadores intersetoriais, políticas habitacionais, Assegurar que os recursos próprios da seguridade social (COFINS, CPMF, loterias, $50 \%$ do Seguro Obrigatório de Acidentes de Trânsito, Salário Educação, contribuições obrigatórias do INSS) não sofram qualquer tipo de contingenciamento. Propor Emenda à Reforma da Previdência. Rever os critérios de definição das cotas para programas sociais nos municípios, a partir do Índice de Desenvolvimento Humano (IDH) e de outros indicadores, e instituir a contrapartida dos estados.

Moção $n^{\circ} 028$ O plenário da $12^{\circ}$ Conferência Nacional de Saúde aprova o apoio ao Projeto de Lei $n^{\circ} 1.140 / 03$, do Deputado Rubens Otoni, que regulamenta o exercício das profissões dos Auxiliares e Técnicos de Odontologia com definição de piso salarial e carga horária. Há mais de vinte anos estas categorias vêm cumprindo um papel social muito importante, tanto no serviço público como no serviço privado, principalmente com a política do Ministério da Saúde de incorporar a equipe de Saúde Bucal em todas as equipes do PSF. Mocão $n^{\circ} 072$ O plenário da $12^{\circ}$ Conferência Nacional de Saúde aprova o apoio para que seja realizada a $3^{n}$ Conferência Nacional de Saúde Bucal em 2004. Na última pesquisa realizada pelo IBGE - PNAD ficou demonstrado que 30 milhões de brasileiros e brasileiras jamais tiveram qualquer tipo de contato com a atenção odontológica e, que $76 \%$ da população brasileira depende do SUS para ter atendimento. Soma-se a essa realidade a pequena oferta de atenção odontológica no setor público no país. A $11^{a}$ Conferência Nacional de Saúde deliberou pela realização de várias conferências temáticas dentre elas a de saúde bucal e essa ainda não foi realizada, lembrando que a última Conferência Nacional de Saúde Bucal aconteceu em 1993 (CNS 2003). Portaria GM/MS n. 2.429, de 23 de dezembro de 2003, cria a Câmara de Regulação do Trabalho em Saúde e dá outras providências. 
Portaria GM/MS no. 36, de 14 de janeiro de 2004, constitui Comissão de Assessoramento da Coordenação Nacional de Saúde Bucal.

Portaria GM/MS n $n^{o}$. 74, de 20 de janeiro de 2004, reajusta os valores dos incentivos financeiros às Ações de Saúde Bucal no âmbito do Programa Saúde da Familia; inclui procedimento de moldagem para prótese e dá outras providências.

Governo Federal cria, em 17 de março de 2004, a Política Nacional de Saúde Bucal - Brasil Sorridente.

Portaria GM/MS 518, de 25 de março de 2004, aprova a Norma de Qualidade da Água para Consumo Humano de uso obrigatório em todo território nacional e sobre os padrões de potabilidade da água, bem como as atribuições e as responsabilidades sobre o controle e a vigilância sobre a qualidade da água.

Lei 10.850 , de 25 de março de 2004 , fixa as diretrizes para a definição de normas de implantação do Programa de Incentivo à Adaptação de Contratos, anteriores à Lei 9.656, de 03/06/1998.

Lei 10.871 , de 20 de maio de 2004 , dispõe sobre a criação de carreiras e organização de cargos efetivos das autarquias especiais denominadas Agências Reguladoras.

Portaria GM/MS no 1.570, de 29 de julho de 2004, estabelece os critérios para o credenciamento e o cadastramento dos Laboratórios Regionais de Prótese Dentária, Centro de Especialidades Odontológicas I (CEO I) e Centro de Especialidades Odontológicas II (CEO II).

Portaria GM/MS $n^{\circ} 1.572$, de 29 de julho de 2004, estabelece o pagamento de próteses dentárias totais nos LRPD.

$\underline{3^{a} \text { Conferência Nacional de Saúde Bucal : acesso e qualidade superando a exclusão }}$ social Brasilia-DF, de 29 de julho a $1^{\circ}$ de agosto de 2004, 883 delegados

Objetivo principal "construir um Plano Nacional de Saúde que reflita os reais anseios da população sobre suas condições de vida com saúde, em que a atenção em saúde bucal deve estar inserida como uma das prioridades nacionais relacionadas ao setor Saúde do atual governo" (CNS 2005; p. 5).

Temas:

1) Educação e construção da cidadania

2) Controle social, gestão participativa e Saúde Bucal.

3) Formação e trabalho em Saúde Bucal 


\section{4) Financiamento e organização da atenção em Saúde Bucal}

Reiteram-se os principios constitucionais do SUS na conformação de uma proposta de Política Nacional de Saúde Bucal para o país, através da discussão de propostas voltadas para a assistência e a atenção em Saúde Bucal. Da mesma forma, dá-se ênfase à Atenção Básica (PSF e equipes de Saúde Bucal), às prioridades definidas pela epidemiologia e pela vulnerabilidade social e aos Sistemas de Referência e Contra-Referência em Saúde Bucal, avançando na integralidade e no acesso da assistência para toda a população e para grupos populacionais vulneráveis como as populações indigenas, portadores de necessidades especiais, populações carcerárias, etc. Relativamente à Regulação, destacam-se as propostas de aprimoramento de instrumentos de Gestão, fiscalização de Planos de Saúde, Controle Social e formação de Complexos Reguladores da Assistência.

Lei 10.973 , de 2 de dezembro de 2004, dispõe sobre incentivos à inovação e à pesquisa científica e tecnológica no ambiente produtivo - "Lei da Inovação".

Lei 11.079, de 30 de dezembro de 2004, institui normas gerais para licitação e contratação de parceria público-privada no âmbito da administração pública.

2005

Decreto 5.440, de 4 de maio de 2005, estabelece definições e procedimentos sobre controle de qualidade da água de sistemas de abastecimento e institui mecanismos e instrumentos para divulgação de informação ao consumidor sobre a qualidade da água para consumo humano.

Portaria GM/MS n. 1.160, de 7 de julho de 2005, dispõe sobre a construção de um Sistema Unificado de Informações de Atenção à Saúde e sobre a Tabela Unificada.

Em 2006, o Ministério da Saúde, o Conselho Nacional de Secretários da Saúde (CONASS) e o Conselho Nacional de Secretários Municipais de Saúde (CONASEMS) pactuaram responsabilidades no campo da gestão do sistema e da atenção à saúde, com vistas a superar a fragmentação das políticas e programas por meio da organização de uma rede regionalizada e hierarquizada de ações e serviços e da qualidade da gestão. $O$ documento intitulado Diretrizes do Pacto pela Saúde em 2006 - Consolidação do Sistema Único de Saúde, publicado na Portaria GM/MS n ${ }^{\circ} 399$, de 22/02/06, contempla o Pacto firmado entre os gestores 
do SUS em suas três dimensões: pela Vida, em Defesa do SUS e de Gestão (MS $2006 \mathrm{~g})$.

O Pacto de Gestão estabelece diretrizes da gestão do sistema para a Descentralização, a Regionalização, o Financiamento, o Planejamento, a Programação Pactuada e Integrada (PPI), a Regulação, a Participação e o Controle Social, a Gestão do Trabalho e a Educação na Saúde.

\section{6}

Portaria SAS/MS nº. 39, de 6 de fevereiro de 2006, dispõe sobre a descentralização do processo de autorização dos procedimentos que fazem parte do elenco da Central Nacional de Regulação de Alta Complexidade - CNRAC, através da estruturação e da transferência do processo autorizador para as Centrais de Regulação da Alta Complexidade (CERAC).

Portaria SAS/MS $n^{\circ}$. 95, de 14 de fevereiro de 2006, excluir da Tabela de Procedimentos do Sistema de Informação Ambulatorial do Sistema Único de Saúde SIA/SUS, o procedimento de código 03.011.01-1 Procedimentos Coletivos (paciente/mês).

Portaria GM/MS n. 399, de 22 de fevereiro de 2006, define as Diretrizes do Pacto pela Saúde (Pacto pela Vida, Pacto em Defesa do SUS e Pacto de Gestão).

As diretrizes reafirmam princípios, consolidam processos como a regionalização e instrumentos de planejamento e programação como o Plano Diretor de Regionalização (PDR), Plano Diretor de Investimentos (PDI) e a Programação Pactuada Integrada (PPI) e possibilitam a reorganização dos processos de gestão e de regulação do sistema de saúde no âmbito dos estados com vistas a melhorar e qualificar o acesso do cidadão às ações e serviços de saúde.

Segundo o MS (2006), a partir das discussões envolvendo o Pacto de Gestão houve a compreensão pelos gestores do SUS da necessidade de se pactuar também metas e objetivos sanitários a serem alcançados, assim como da necessidade de envolver a sociedade na defesa do SUS. Então se estabeleceu a organização de um Pacto pela Saúde, com capacidade de responder aos desafios atuais da gestão e organização do sistema, para dar respostas concretas às 
necessidades de saúde da população brasileira, e tornar a saúde uma política de Estado mais do que uma política de governo.

Nesse sentido foram definidas três dimensões no Pacto pela Saúde 2006: Pacto em defesa do SUS, Pacto pela Vida e Pacto de Gestão. ' O Pacto pela Saúde representa um compromisso inequívoco das três esferas de governo com a responsabilidade sanitária e de gestão e se materializa por meio do Termo de Compromisso de Gestão municipal, estadual e federal. Esse termo reflete as atribuições e responsabilidades assumidas pelos gestores do SUS perante a sociedade, e representa a superação dos mecanismos de habilitação até então vigentes nas normas operacionais do SUS' (CONASS 2007).

Portaria SAS/MS $n^{\circ} 494$, de 30 de junho de 2006, estabelece incentivo financeiro destinado à implantação e/ou implementação de Complexos Reguladores para as Secretarias de Saúde cuja definição se dará no âmbito da CIB.

Portaria GM/MS n 599, de 23 de março de 2006, define critérios, normas e requisitos para a implantação e o credenciamentos dos CEOs.

Portaria GM/MS $n^{\circ} 600$, de 23 de março de 2006, institui o financiamento e o repasse dos recursos financeiros dos CEOs entre as esferas de governo.

Portaria GM/MS n 648, de 28 de março de 2006, aprova a Política Nacional de Atenção Básica, estabelecendo a revisão de diretrizes e normas para a organização da Atenção Básica para o Programa Saúde da Família (PSF) e o programa Agentes Comunitários de Saúde (PACS).

Portaria GM/MS n 649, de 28 de março de 2006, define valores de financiamento para o ano de 2006, com vistas à estruturação de Unidades Básicas de Saúde para as equipes Saúde da Família, como parte da Política Nacional de Atenção Básica.

Portaria GM/MS $\mathrm{n}^{\circ} 650$, de 28 de março de 2006 , define valores de financiamento do PAB fixo e variável mediante a revisão de diretrizes e normas para a organização da Atenção Básica, para a estratégia de Saúde da Família e para o Programa de Agentes Comunitários de Saúde, instituídos pela Política Nacional de Atenção Básica.

Portaria GM/MS n 699, de 30 de março de 2006, regulamenta as Diretrizes Operacionais dos Pactos Pela Vida e de Gestão e Termo de Compromisso. Portaria GM/MS n 822, de 17 de abril de 2006, altera critérios para definição de modalidade das ESF dispostos na Política Nacional de Atenção Básica. 
Portaria GM/MS n 1.097 , de 22 de maio de 2006, define o processo da Programação Pactuada e Integrada da Assistência à Saúde no âmbito do SUS, com parâmetros para subsidiar a programação de ações de saúde.

Decreto 4.726, de 9 de junho de 2006 - reestruturação administrativa do MS e descrição das competências do Departamento de Regulação, Avaliação e Controle de Sistemas (DRAC) vinculado à SAS.

2007

Portaria 1.318, de 5 de junho de 2007, aprova as diretrizes nacionais para a Instituição ou Reformulação do Planos de Carreiras, Cargos e Salários, à título de subsídios técnicos à instituição de regime jurídico de pessoal no âmbito do SUS, que se recomendam a seus gestores, respeitada a legislação de cada ente da federação.

\subsection{A SAÚDE SUPLEMENTAR}

O setor de saúde suplementar já existia há pelo menos trinta anos no Brasil, funcionando sempre, como um setor não regulado, sendo exigido que diversos dispositivos fossem regulamentados, pois quase tudo carecia de definição, principalmente na dimensão da assistência à saúde.

CARVALHO (2003) pontua os marcos históricos sobre a expansão desse mercado:

- 1930, já existiam autoprogramas de saúde (modalidade Autogestão) organizados por empresas, sindicatos ou entidades jurídicas e destinados a empregados, ex-empregados e seus grupos familiares, administrados por gestão própria, sem fins lucrativos. Essa modalidade expandiu-se na década de 1980, sendo que, em 1977, cerca de 4.699 convênios cobriam $10 \%$ dos trabalhadores da Previdência, em especial os mais qualificados e de maior poder organizativo;

- a modalidade Plano Empresa surgiu na década de 1950, quando apareceram os serviços médicos organizados sob a forma de Empresas de medicina de 
grupo na região do ABC paulista, ampliando-se, a partir de 1959, como conseqüência do processo de industrialização ocorrido naquela região;

- a modalidade Cooperativa Médica surgiu em 18/12/1967 na cidade de Santos, onde foram criadas empresas assentadas no trabalho cooperativo entre os médicos, tornando-se um sistema nacional sob a denominação de UNIMED;

- a modalidade Seguro-Saúde surgiu em 1977, após a autorização da Superintendência de Seguros Privados - SUSEP.

MONTONE (2004) afirma que, antes da regulamentação do setor, as empresas se organizavam livremente para atuar, submetendo-se apenas à legislação do tipo societário escolhido, definindo livremente o produto a ser oferecido, a população de consumidores e as condições de operação e preço. Com o processo de regulamentação iniciado em 1988, as empresas passaram a ter uma atuação mais controlada no que se refere à autorização do funcionamento, às regras operacionais uniformes (balanços), a sujeição às intervenções/liquidações, à exigência de reservas financeiras, à obrigatoriedade da assistência integral à saúde, à proibição da seleção de risco e da rescisão unilateral de contratos, à limitação das carências e aos reajustes controlados dos produtos. Esse autor identifica quatro etapas no processo de regulamentação desse setor:

- a primeira etapa foi representada pelos dez anos transcorridos entre a Constituição Federal de 1988, que definiu a atuação privada no setor saúde e a definição do marco legal representado pela promulgação da Lei Federal $n^{\circ} 9.656$, de 03/06/1998, que dispõe sobre "os planos e seguros privados de assistência à saúde", além da Medida Provisória $n^{\circ} 1.665$, de 05/06/1998, com as alterações exigidas pelo Senado (reeditada quase que mensalmente, até agosto de 2001, por força da legislação vigente, tratando-se, hoje, da Medida Provisória $n^{\circ} 2.177$ 44/01);

- a segunda etapa ocorreu entre os meses de janeiro a setembro de 1999 com a vigência do modelo bipartite de regulação (Ministérios da Fazenda e da Saúde), ocasionando uma falta de unidade estratégica no processo de regulação;

- na terceira etapa do processo ocorrida entre os meses de setembro de 1999 à janeiro de 2000, criou-se a Agência Nacional de Saúde Suplementar vinculada ao 
Ministério da Saúde (Lei Federal $n^{\circ}$ 9.961/2000), como novo instrumento de atuação do Estado que assumiu todas as atribuições da regulação do setor;

- a quarta etapa é representada pelo início da atuação da ANS (janeiro de 2000) até os dias atuais, com a complementação do arcabouço normativo da regulamentação para o aperfeiçoamento dos instrumentos já implantados, a ampliação de sua efetividade e os ajustes decorrentes dos próprios impactos do processo na organização e gerenciamento do sistema. Dentre os principais desafios dessa etapa, destacam-se: a necessidade de acelerar a migração dos usuários de contratos antigos, anteriores à regulação, para planos novos e o monitoramento dos impactos do ajuste no modelo de gerenciamento do setor.

MALTA e col. (2004) apresentam alguns dados representativos da expansão do setor da saúde suplementar, bem como da distribuição desse mercado segundo as modalidades de Planos e Seguros Privados PSP:

- dados estimados pelo PNAD/98 demonstram que 38,7 milhões de brasileiros são cobertos por pelo menos um PSP, o que corresponderia a $24,5 \%$ da população do país;

- segundo CIEFAS (2000) e Bahia (2001), as autogestões - subsegmento não comercial do mercado de planos e seguros - totalizam 300 empresas e aproximadamente 4,7 milhões de beneficiários ou $12 \%$ dos beneficiários de PSP;

- segundo Médici (1992), as seguradoras vinculadas ou não a bancos representariam $16 \%$ do contingente de beneficiários dos PSP, as cooperativas de trabalho médico $25 \%$ e as medicinas de grupo $40 \%$.

Para MONTONE (2004), evidenciam-se desafios estruturais e conjunturais para o setor:

- Desafios Estratégicos: 1) ampliação da cobertura assistencial dos planos antigos; 2) repactuação da relação entre operadoras e prestadores, em face do acirramento de tensões; 3) mobilidade dos consumidores de planos individuais - portabilidade de carência - que lhes permita maior mobilidade no sistema; 4) maior disseminação de mecanismos de resseguro e co-seguro por parte do segurador, com o objetivo de reduzir os custos dos planos, 
aumentando-se a viabilidade das operadoras de menor porte; 5) integração ao SUS, com aprofundamento da discussão sobre o ressarcimento ao SUS; 6) introdução do benefício da assistência farmacêutica, principalmente nos planos coletivos; 7) garantia da continuidade de atendimento aos usuários de operadoras liquidadas extrajudicialmente; 8) segurança jurídica contra ações de inconstitucionalidades (ações contra o ressarcimento ao SUS, o controle de reajustes, a proibição do limite de consultas, a suspensão de internações, etc); 9) previsibilidade e segurança regulatória (conversão da MP 2.177-44/01 em Lei e revisão do modelo das agências reguladoras); e 10) preocupação com a transparência das ações.

- Desafios conjunturais: 1) coibir falsos planos de saúde (cartão-desconto); 2) apressar a aplicação de multas; 3) coibir "falsa coletivização" dos planos individuais para fugir às regras mais rígidas dos contratos individuais quanto à proibição de rompimento e controle de reajustes; 4) concluir o saneamento do mercado, ampliando as ações contra as operadoras que se mantêm à margem da regulação, buscando parceria como Ministério Público e o Conselho Administrativo de Defesa Econômica - CADE.

MALTA e col. (2004) ao analisarem os modelos assistenciais vigentes na saúde suplementar, afirmam existir uma grande heterogeneidade nos padrões de qualidade do setor, com fragmentação e descontinuidade da atenção, que comprometem a efetividade e a eficiência do sistema como um todo, atingindo as redes de cuidados básicos, especializados e hospitalares que atendem a clientela de planos de saúde.

Esses autores afirmam que esses modelos assistenciais consistem em práticas fragmentadas, centradas em produção de atos, predominando a desarticulação e as queixas dos usuários e propõem que "cada usuário deva ser acompanhado segundo determinado projeto terapêutico instituído, comandado por um processo de trabalho cuidador, e não por uma lógica indutora de consumo" (p.443).

CUNHA (2003) afirma que, para efeito de aplicação da legislação, a ANS classificou, por meio da Resolução de Diretoria Colegiada $n^{\circ} 39$, 
de 27 de outubro de 2000, as seguintes modalidades de operadoras, também denominadas como agentes regulados:

Administradoras - Empresas que administram planos ou serviços de assistência à saúde; no caso de administração de planos, são financiados por operadora, não assumem o risco decorrente da operação desses planos e não possuem rede própria, credenciada ou referenciada de serviços médico-hospitalares ou odontológicos.

Cooperativas - Sociedades de pessoas sem fins lucrativos constituídas, conforme o disposto na Lei $n^{\circ}$ 5.764, de 16 de dezembro de 1971, que operam Planos Privados de Assistência à Saúde ou Odontológicos.

Autogestões - Entidades que, por intermédio de seu departamento de recursos humanos ou órgão assemelhado, se responsabilizam pelo Plano Privado de Assistência à Saúde destinado, exclusivamente, a oferecer cobertura aos empregados ativos, aposentados, pensionistas ou ex-empregados, bem como seus respectivos grupos familiares definidos, limitado ao terceiro grau de parentesco consangüíneo ou afim, de uma ou mais empresas, ou ainda a participantes e dependentes de associações de pessoas físicas ou jurídicas, fundações, sindicatos, entidades de classe profissionais ou assemelhados.

Filantropias - Entidades sem fins lucrativos que operam Planos Privados de Assistência à Saúde e que tenham obtido certificado de entidade filantrópica junto ao Conselho Nacional de Assistência Social - CNAS, assim como declaração de utilidade pública federal junto ao Ministério da Justiça ou declaração de utilidade pública estadual ou municipal junto aos Órgãos dos Governos Estaduais e Municipais.

Medicinas de grupo - Entidades que operam Planos Privados de Assistência à Saúde, excetuando-se aquelas classificadas na modalidade de administradora, cooperativa, autogestão e filantropia.

Odontologias de grupo - Entidades que operam exclusivamente Planos Odontológicos, excetuando-se aquelas classificadas na modalidade de cooperativa.

CASTRO (2002) afirma que as leis da oferta e demanda se aplicam ao "mercado da saúde" e que esse, por possuir inúmeras falhas, necessita da intervenção do Estado para alcançar a otimização na alocação e na distribuição dos recursos, a fim de maximizar o bem-estar na sociedade. Dentre as falhas de mercado no setor da saúde, essa autora cita:

- a ocorrência de riscos e incerteza: frente à impossibilidade de se planejar individualmente o consumo futuro de cuidados de saúde, as operadoras tendem a elevar o custo do prêmio do seguro que passa a ser maior que o custo efetivo com possíveis cuidados que o segurado venha a necessitar. 
Como os indivíduos são avessos ao risco, eles se dispõem a pagar para garantirem-se contra perdas financeiras;

- a deseconomia de escala: essa ocorre quando muitas pequenas companhias competem entre si, cada qual com custos diferentes, acarretando um custo final de seguro mais elevado para o consumidor;

- a seleção adversa: é a exclusão de alguns grupos do acesso ao seguro-saúde. As companhias de seguro, por desconhecerem o risco a que cada indivíduo está submetido, calculam o valor do prêmio com base num risco médio. 0 consumidor, ao perceber que seu risco é menor do que a média, opta por não participar do seguro, acarretando o aumento do risco médio do grupo remanescente e a elevação do valor do prêmio. Como resultado, tem-se a elevação do valor do prêmio para os grupos de maior risco (crônicos e idosos) que não terão condições de pagar e serão excluídos do seguro. A seleção adversa termina por excluir dois grupos: o de menor risco e os de maior risco;

- o risco moral: ocorre em sistemas de saúde baseados em seguros públicos e privados e também naqueles sistemas que cobrem totalmente os gastos com os cuidados de saúde, existindo uma tendência a ocorrer excesso de demanda por parte do consumidor e do prestador. A utilização do pagamento por procedimentos induziria o profissional a executar trabalhos desnecessários. Como resultado, ocorre o aumento dos gastos em saúde e o aumento dos custos dos prêmios aos consumidores finais;

- a existência de externalidades: são os efeitos colaterais da produção ou do consumo de um bem auferido por um terceiro. Num mercado não regulado, a existência de externalidades leva a sociedade a produzir bens e serviços num ponto que não é o de equilíbrio de mercado. Por exemplo, se a produção tiver externalidades negativas (poluição), e o produtor não tiver que pagar pelos custos destas, ele produzirá muito, porém se tiver que adicionar aos seus custos de produção os custos das externalidades negativas, o preço do bem ou serviço aumentará, diminuindo a demanda e a produção;

- a distribuição desigual de informações na relação entre produtores e consumidores: há diferença do grau de informação detidas pelo consumidor e o produtor. $O$ prestador numa posição privilegiada atua em nome do 
consumidor influenciando a oferta e a demanda de seus serviços, induzindo-o a consumir a mais do que necessitaria; e

- a existência de barreiras: as barreiras podem ser representadas pelas regulamentações, controle dos licenciamentos para a atuação profissional, restrições no número de consultas, natureza das patologias assistidas, etc.

A regulação, ainda recente, sobre o setor saúde suplementar deve ser objeto de preocupação do poder público, no sentido de se corrigirem distorções como as falhas de mercado e a fragmentação do atendimento aos beneficiários. Para tal, é importante se conhecer a lógica de ação das agências reguladoras, considerando-se a autonomia e a independência que caracterizam essas instituições.

\subsubsection{A Ação Regulatória das Agências}

A questão da responsabilização dos governantes vem se constituindo em um tema central da agenda pública. Na América Latina, os episódios de corrupção fazem com que o desempenho das instituições, a responsabilização e o controle exercido pelos dirigentes adquiram grande importância (MELO 2001).

Para esse autor, as instituições regulatórias independentes surgidas recentemente são peças centrais da gestão econômica, influenciando o desempenho macroeconômico e o bem-estar do cidadão.

A criação e a evolução das agências regulatórias como forma institucional têm como referência os EUA e, nesse processo, sempre estiveram presentes três tipos de questões: o controle do Legislativo sobre as agências independentes, a responsabilização dos governantes e da burocracia e a delegação de autonomia às agências regulatórias, como forma de se adquirir credibilidade (MELO 2001).

Os tipos de ação regulatória podem ser agrupados em duas formas básicas: a regulação pela estatização (endógena) e a regulação por agência regulatória (exógena). Para MELO (2001), esse dois tipos de regulação pública apresentam falhas: 
- regulação pela estatização: não há controle efetivo das empresas públicas pelo Congresso, tribunais ou ministério gestor; o gerenciamento das empresas públicas é influenciado por políticos e sindicatos; há excesso de pessoal; há monopólio público na ação; os gestores públicos são orientados por metas ambíguas e inconsistentes e; há débil coordenação entre as empresas públicas;

- regulação por agência regulatória: há insuficiente responsabilização política das agências regulatórias independentes; captura dos reguladores pelas empresas reguladas (sic); regulação não-competitiva; interesse público com objetivos difusos e; coordenação débil entre diferentes reguladores.

Esse autor afirma que a insuficiente responsabilização política das agências regulatórias independentes está imbricada com questões do controle democrático dessas agências e com as relações entre a representação política e a responsabilização.

No Brasil, o programa de desestatização iniciada em 1990 culminou na criação das agências regulatórias independentes: Agência Nacional de Telecomunicações (Anatel - 1997); Agência Nacional de Energia Elétrica (Aneel 1997); Agência Nacional do Petróleo (ANP - 1997); Agência Nacional de Vigilância Sanitária (ANVS - 1998); Agência Nacional de Saúde Suplementar (ANS - 2000); Agência Nacional das Águas (ANA - 2000). Em 1999, foi criada a Associação Brasileira das Agências de Regulação (ABAR), com 26 agências associadas, até 2005. Essas entidades estão assentadas no modelo institucional americano com as seguintes características:

As agências são autarquias sob regime especial, parte da administração pública indireta, caracterizadas por independência administrativa, estabilidade de seus dirigentes, autonomia financeira e ausência de subordinação hierárquica. Tais agências apresentam um certo isomorfismo organizacional, mas na realidade existem diferenças marcadas entre elas, ao mesmo tempo em que elas operam conforme regras informais bastante variadas. (....) Tipicamente, o formato institucional das agências é caracterizado por: nomeação do diretor pelo presidente, após aprovação pelo Senado; proibição de vínculo a agente ou órgãos representativos do setor; mandatos não coincidentes de 4 anos; exoneração imotivada de diretor só nos quatro meses iniciais do mandato; quarentena de doze meses. Por outro lado, as estruturas de responsabilização envolvem ouvidorias, conselhos de consumidores e conselhos consultivos. As agências também têm contrato de gestão (MELO 2001, p. 56 e 65). 
As formas de controle e monitoramento do Congresso americano sobre a atuação das agências regulatórias são indiretas, distinguindo-se dois tipos de controle:

O controle tipo "patrulha de polícia" estaria associado ao escrutínio e monitoramento sistemático, de custos elevados, exercidos pelos parlamentares em relação a todo o desvio potencial no funcionamento das burocracias e nos programas implementados (....) também chamado de controle compreensivo, o controle tipo "alarme de incêndio" refere-se ao monitoramento seletivo, de custo eficiente, voltado para a identificação dos desvios ou comportamento oportunista da burocracia que são denunciados pela base parlamentar dos congressistas. $O$ controle é exercido a partir do receio que aqueles a quem foram delegados poderes têm de escândalos ou denúncias apontadas por atores ou constituencies dos parlamentares, em um contexto em que os parlamentares, através dos comitês do Congresso, detêm controle sobre os orçamentos das agências (p.61).

Antes de propor normas de um determinado assunto para o Congresso, a agência deve comunicar sua intenção a todos os interessados potenciais e solicitar evidências e opiniões sobre a questão, explicitando as justificativas para a norma proposta, à luz das evidências coletadas sobre o assunto.

O grau de delegação de poder do Congresso junto às agências regulatórias varia em função de seu interesse, ou seja, a delegação ocorre quando os custos da delegação forem menores que os custos políticos de decisões impopulares ou quando houver falta de informação e de expertise em certas áreas. Desse modo, a delegação será maior nas questões que requerem mais informações para a tomada de decisões.

Nos anos de 1990, o déficit orçamentário estatal e a crise fiscal, caracterizados pela crescente perda de crédito do Estado e pela poupança pública negativa, determinaram a reforma do aparelho do Estado brasileiro como resposta à superação dessa crise (CUNHA 2003). A idéia da reforma ou reconstrução do Estado para resgatar a sua capacidade de implementar políticas públicas teve como principais objetivos: o ajustamento fiscal duradouro, as reformas econômicas direcionadas para o mercado, a reforma da Previdência Social e a inovação dos instrumentos de política social. 
Em 1995, o Plano Diretor da Reforma do Estado publicado pelo Ministério da Administração e Reforma do Estado - MARE gerou uma tendência de diminuição dos custos e do tamanho do Estado, bem como de suas funções, a fim de que o mercado e a sociedade assumissem atividades por ele desempenhadas. O Estado deixa de ser o responsável direto pelo desenvolvimento econômico-social pela via da produção de bens e serviços, para fortalecer-se na função de promotor e regulador desse desenvolvimento, através de quatro setores:

NÚCLEO ESTRATÉGICO. Corresponde ao governo, em sentido lato. É o setor que define as leis e as políticas públicas e cobra seu cumprimento. É, portanto, o setor onde as decisões estratégicas são tomadas. Corresponde aos Poderes Legislativo e Judiciário, ao Ministério Público e, no Poder Executivo, ao Presidente da República, aos ministros e seus auxiliares e assessores diretos, responsáveis pelo planejamento e formulação das políticas públicas.

ATIVIDADES EXCLUSIVAS. É o setor em que são prestados serviços que só o Estado pode realizar. São serviços em que se exerce o poder extroverso do Estado - o poder de regulamentar, fiscalizar, fomentar. Como exemplos, temos: a cobrança e fiscalização dos impostos, a polícia, a previdência social básica, o serviço de desemprego, a fiscalização do cumprimento de normas sanitárias, o serviço de trânsito, a compra de serviços de saúde pelo Estado, o controle do meio ambiente, o subsídio à educação básica, o serviço de emissão de passaportes etc.

SERVIÇOS NÃO-EXCLUSIVOS. Corresponde ao setor onde o Estado atua simultaneamente com outras organizações públicas não-estatais e privadas. As instituições desse setor não possuem o poder de Estado. Este, entretanto, está presente porque os serviços envolvem direitos humanos fundamentais, como os da educação e da saúde, ou porque possuem "economias externas" relevantes, na medida que produzem ganhos que não podem ser apropriados por esses serviços através do mercado. As economias produzidas imediatamente se espalham para o resto da sociedade, não podendo ser transformadas em lucros. São exemplos desse setor: as universidades, os hospitais, os centros de pesquisa e os museus.

PRODUÇÃO DE BENS E SERVIÇOS PARA O MERCADO. Corresponde à área de atuação das empresas. É caracterizado pelas atividades econômicas voltadas para o lucro que ainda permanecem no aparelho do Estado como, por exemplo, as do setor de infra-estrutura. Estão no Estado seja porque faltou capital ao setor privado para realizar o investimento, seja porque são atividades naturalmente monopolistas, nas quais o controle via mercado não é possível, tornando-se necessária, no caso de privatização, a regulamentação rígida (MARE 1995). 
Segundo CUNHA (2003), “o núcleo estratégico da administração centralizada ficará encarregado da formulação de políticas públicas, cabendo a implementação de políticas públicas a agências autônomas (agências reguladoras e agências executivas) ou a entidades da sociedade (concessões, permissões, terceirizações, organizações sociais), conforme exijam ou não a presença do Estado; já as funções de produção de bens e serviços para o mercado (exploração direta de atividade econômica) deverão ser objeto de privatização" (p.81).

Nesse contexto se inserem as agências reguladoras: entes administrativos autônomos, criados por lei, com personalidade jurídica de direito público, patrimônio e receitas próprios para exercer atividades próprias da Administração, com prerrogativas estatais típicas, em função da supremacia do interesse geral sobre o interesse particular. (CUNHA 2003).

Esse autor afirma que:

em razão de suas características de prolongamento da ação estatal, a função de intervenção no domínio econômico (ordenamento econômico) é atribuída a algumas autarquias dotadas não só de autoridade como, também, de maior independência técnica e autonomia administrativa, que são as agências reguladoras (não cabendo sua instituição como empresas públicas ou de economia mista ou mesmo como fundaçōes, dada a personalidade jurídica de direito privado a elas inerente) (p.82).

Di Pietro (2002), citada por CUNHA (2003), explica que a agência reguladora é uma figura introduzida pela Reforma Administrativa, que se valeu do modelo norte-americano, onde, com exceção dos três Poderes Estatais, as demais autoridades públicas organizam-se sob a forma de agências e destaca:

Enquanto no sistema europeu-continental em que se inspirou o direito brasileiro, a Administração Pública tem uma organização complexa, que compreende uma série de órgãos que integram a Administração Direta e entidades que compõem a Administração Indireta. Nos Estados Unidos, toda a organização administrativa se resume a agências (vocábulo sinônimo de ente administrativo, em nosso direito), a tal ponto que se afirma que 'o direito administrativo norte-americano é o direito das agências (....) A função reguladora das agências norte-americanas só pode ser exercida se expressamente delegada pelo Legislativo. No exercício dessa função, a agência não se limita a exercer o poder regulamentar, tal como entendido no direito brasileiro, no sentido de baixar normas para fiel execução da lei. Nos Estados Unidos, as leis se limitam a estabelecer parâmetros, princípios, conceitos indeterminados, 
standards, ficando para as agências a função de baixar normas reguladoras (p.86).

Nos países onde a delegação origina-se no Executivo, como no Brasil, o governante renuncia a seu poder de decisão para evitar flexibilidade na obediência a regras (benefícios políticos de curto prazo) e assegurar credibilidade política (benefícios futuros) necessária à governança ${ }^{40}$ regulatória de um país, num contexto de globalização econômica (MELO 2001).

MELO (2001) destaca a importância das noções de representação e responsabilização para o controle democrático de governos representativos eleitos com base em compromissos:

Os governantes e seus agentes diretos, o conjunto de atores da burocracia pública, implementam as decisões legislativas, e o desempenho dos governos no exercício do mandato irá informar futuras escolhas do eleitorado no sentido de punir ou premiar seus representantes com sua recondução ou não ao cargo. (....) Governantes responsáveis são, portanto, aqueles que fazem as escolhas que o eleitorado faria se detivesse todas as informações relevantes, ou preferências formadas. Esse constrangimento importante à responsabilização também ocorre no plano das relações entre burocracia e governantes. Escolhas políticas são informadas por escolhas técnicas sobre as quais os governantes não têm informação relevante (p.59).

Para MELO (2001), da mesma forma que a população não detém toda a informação relevante para avaliar o desempenho dos seus representantes, também ocorre a busca por certo grau de insulamento (delegação) das burocracias. Nas sociedades modernas complexas a questão da responsabilização torna-se dupla: “de responsabilização dos políticos e governantes pelos cidadãos, e de responsabilização dos burocratas em relação aos políticos eleitos" (p.59).

MALTA e col. (2004) classificam os campos de intervenção no processo de regulação da Saúde Suplementar no Brasil:

\footnotetext{
${ }^{40} \mathrm{~A}$ expressão governance surge a partir de reflexões conduzidas principalmente pelo Banco Mundial, para o qual, o importante, é aprofundar o conhecimento das condições que garantam um Estado eficiente, deslocando o foco da atenção das implicações estritamente econômicas da ação estatal.
} 
- a macrorregulação ou a regulação da regulação, como o campo constituído pela legislação e regulamentação (Legislativo, Executivo/ ANS, CONSU Conselho de Saúde Suplementar), as Leis Federais nº 9.656/98 e 9.961/2000, as resoluções normativas, operacionais, instruções, dentre outras); e

- a auto-regulação ou regulação operativa, sendo as formas de regulação que se estabelecem entre as operadoras, os prestadores e os beneficiários.

Esses autores acrescentam que, para fazer frente à legislação, as operadoras e prestadores têm desenvolvido mecanismos microrregulatórios para sobreviver ao mercado e à regulação da ANS, tais como a instituição de protocolos, de mecanismos de referência e fluxos que dificultam a solicitação de alguns procedimentos, o co-pagamento e fatores moderadores, resultando "na fragmentação do cuidado, que se torna centrado na lógica da demanda e da oferta do que foi contratado e não na lógica da produção da saúde, do cuidado" (p.438).

Para que as operadoras/prestadores na saúde suplementar pudessem ser gestores do cuidado, caberia ao Estado mapear como as operadoras estão impondo os seus mecanismos regulatórios ao mercado, como os prestadores reagem a esses mecanismos e, principalmente, como os mecanismos de microrregulação vêm atuando no sentido de garantir a integralidade do cuidado em saúde, através da intervenção sobre o modelo de assistência praticado (MALTA e col. 2004).

Esses autores citam alguns fatores que podem fragmentar a

linha do cuidado:

- a ausência das práticas de promoção e prevenção;

- a deficiência da rede de serviços (insuficiência do apoio diagnostico terapêutico), inexistência de ofertas específicas (alta complexidade, exames não cobertos, carências);

- a segmentação dos planos (plano hospitalar, plano ambulatorial, plano obstétrico, plano odontológico) ou a contratação de planos com cobertura limitada;

- atitudes de desresponsabilização do cuidador (não vinculação, saber insuficiente, negação ou cerceamento de uso de tecnologias adequadas, 
retardo ou não fechamento de diagnóstico e inexistência de mecanismo de acolhida às demandas agudas);

- atitudes de cerceamento ao acesso por parte da operadora (passos e autorizações para o acesso ao cuidado, filas de espera, limites de exames, limites de diárias de UTI, restrição a retornos); e

- qualidade questionável do serviço (prestador apresenta falta de insumos necessários à prestação da assistência).

\subsubsection{A Agência Nacional de Saúde Suplementar - ANS}

No Brasil, o setor de saúde suplementar reúne mais de 2.000 empresas operadoras de planos de saúde, milhares de médicos, dentistas e outros profissionais, hospitais, laboratórios e clínicas. Toda essa rede prestadora de serviços de saúde atende a mais de $\mathbf{4 0}$ milhões de consumidores que utilizam planos privados de assistência à saúde para realizar consultas, exames ou internações (ANS 2002).

Conforme dispõe o inciso I do Art. $1^{\circ}$ da Lei 9.656/98, de 3 de junho de 1998, Plano Privado de Assistência à Saúde é a prestação continuada de serviços ou cobertura de custos assistenciais a preço pré ou pós-estabelecido, por prazo indeterminado, com finalidade de garantir, sem limite financeiro, assistência à saúde, pela faculdade de acesso e atendimento por profissionais ou serviços de saúde, livremente escolhidos, integrantes ou não de rede credenciada, contratada ou referenciada, visando a assistência médica, hospitalar e odontológica, a ser paga integral ou parcialmente às expensas da Operadora contratada, mediante reembolso $e$ pagamento direto ao prestador, por conta e ordem do consumidor.

A Lei 9.961, de 28 de janeiro de 2000, criou a Agência Nacional de Saúde Suplementar - ANS, autarquia sob o regime especial, vinculada ao Ministério da Saúde, com sede e foro na cidade do Rio de Janeiro - RJ, como o órgão de regulação, normatização, controle e fiscalização das atividades que garantam a assistência suplementar à saúde, definindo ainda sua finalidade, estrutura, atribuições e receita. 
A Agência Nacional de Saúde Suplementar - ANS tem por finalidade institucional promover a defesa do interesse público na assistência suplementar à saúde, regular as operadoras setoriais - inclusive quanto às suas relações com prestadores e consumidores, contribuindo para a construção de um mercado sólido, equilibrado e socialmente justo.

A diretoria da ANS é colegiada, composta por até cinco diretores com mandatos não coincidentes, que recebem um mandato de três anos, com possibilidade de prorrogação por mais três anos. $\mathrm{O}$ diretor-presidente, escolhido entre os membros da Diretoria Colegiada pelo Presidente da República, acumula as funções de Diretor-Geral da agência, de Presidente da Diretoria Colegiada, de Presidente da Câmara de Saúde Suplementar e de Secretário-Executivo do Conselho de Saúde Suplementar. Estão implantados, ainda, 10 Núcleos Regionais de Fiscalização para receber as demandas dos cidadãos pelo país.

A Câmara de Saúde Suplementar - CSS, criada pela Lei 9.656/98, é um órgão consultivo formado por representantes de todos os segmentos da sociedade que conformam as relações desse setor, com um quadro composto por entidades representantes dos protagonistas do setor e por órgãos de governo.

Relativamente às regras de funcionamento do setor, o texto legal estabeleceu critérios para entrada, funcionamento e saída de operação de empresas no setor, discriminando os padrões de cobertura e de qualidade da assistência. Além disso, transferiu para o Poder Executivo Federal a responsabilidade pela regulação da atividade econômica das Operadoras e da assistência à saúde por elas prestada, com o dever de fiscalização do cumprimento das normas vigentes.

A legislação definiu os atributos essenciais e específicos dos planos de saúde que servem de referência para todos os contratos que venham a ser celebrados. Citado expressamente na Lei 9.656/98, o Plano Referência é o modelo mínimo de cobertura a ser oferecida pelos planos de saúde em comercialização.

Desde 1999, as Operadoras que desejem atuar no setor têm que obter na ANS um registro provisório de funcionamento até que as normas de autorização definitiva de funcionamento sejam regulamentadas. Da mesma forma, cada plano de saúde precisa estar registrado na ANS para ser comercializado. Para 
requerer registro provisório, as empresas ou entidades que atuam no mercado de assistência à saúde deverão, obrigatoriamente, enquadrar-se em um dos tipos de atenção, segmentação e classificação, conforme o disposto nos capítulos II, III e IV da RDC 39. Os tipos de atenção prestada pelas operadoras podem ser de dois:

1. Atenção médico-hospitalar - a atenção oferecida por entidades ou empresas que operam exclusivamente planos médico-hospitalares ou médico-hospitalares e odontológicos e que podem oferecer, adicionalmente, prestação de serviços médico-hospitalares ou odontológicos a terceiros não contratantes do plano. Esta regra não se aplica às autogestões nem às administradoras.

2. Atenção odontológica - a atenção oferecida por entidades ou empresas que operam exclusivamente planos odontológicos, e que podem oferecer, adicionalmente, prestação de serviços odontológicos a terceiros não contratantes do plano. Esta regra não se aplica às autogestões.

A RDC $n^{\circ} .39$, de 27 de outubro de 2000 , definiu oito modalidades de operadoras:

1. Administradoras: administram planos ou serviços de assistência à saúde. No caso de administração de planos, são financiados por operadora, não assumem o risco decorrente da operação e não possuem rede própria, credenciada ou referenciada de serviços médico-hospitalares ou odontológicos. Podem ser de dois tipos:

1.1. Administradoras de planos: administram exclusivamente Planos de Saúde, não assumem o risco decorrente da operação e não possuem rede própria, credenciada ou referenciada de serviços médico-hospitalares ou odontológicos, para oferecer aos beneficiários da sua contratante, sendo esses planos financiados por operadoras.

1.2. Administradoras de serviços: administram exclusivamente serviços de assistência.

2. Cooperativa médica: sociedades sem fins lucrativos que operam Planos de Saúde, coordenadas por médicos e oferecem serviços médicos, sendo constituídas segundo a Lei ${ }^{\circ}$. 5.764, de dezembro de 1971. 
3. Cooperativa odontológica: sociedades sem fins lucrativos, que oferecem serviços odontológicos e são coordenadas exclusivamente por dentistas, sendo constituídas segundo a Lei $\mathrm{n}^{\circ}$. 5.764, de dezembro de 1971, e operam exclusivamente Planos Odontológicos.

4. Medicina de grupo: operam Planos de Saúde, cujas características não se adeqüem às outras definições.

5. Odontologia de grupo: operam exclusivamente Planos Odontológicos, excetuando-se aquelas classificadas na modalidade de cooperativa odontologica.

6. Autogestão: entidades que operam serviços de assistência à saúde ou empresas que, por intermédio de seu departamento de recursos humanos ou órgão assemelhado, responsabilizam-se pelo Plano Privado de Assistência à Saúde destinado, exclusivamente, a oferecer cobertura aos empregados ativos de uma ou mais empresas, aposentados, pensionistas ou ex-empregados, bem como a seus respectivos grupos familiares definidos, limitado ao terceiro grau de parentesco consangüíneo ou afim, ou ainda, a oferecer cobertura a participantes e dependentes de associações de pessoas físicas ou jurídicas, fundações, sindicatos, entidades de classes profissionais ou assemelhados.

A autogestão divide-se em:

6.1. Patrocinadas: autogestão ou empresa que, por intermédio de seu departamento de recursos humanos ou órgão assemelhado, responsabiliza-se pelo Plano Privado de Assistência à Saúde destinado, exclusivamente, a oferecer cobertura aos empregados ativos, aposentados, pensionistas ou ex-empregados, bem como a seus respectivos grupos familiares definidos, limitado ao terceiro grau de parentesco consangüíneo ou afim, de uma ou mais empresas, e que possuam gestão própria;

Ela poderá ser:

6.1.1. Singular: sistema de autogestão vinculado apenas a um patrocinador; 6.1.2. Multipatrocinada: autogestão que congrega mais de um patrocinador.

6.2. Não Patrocinadas: autogestão que não se classificam como patrocinadas, conforme definido no inciso anterior. 
Obs.: As autogestões deverão operar por meio de rede de profissionais e instituições diretamente credenciadas, só podendo contratar rede de prestação de serviços de assistência à saúde de outra operadora nos seguintes casos:

I . mediante convênios de reciprocidade com entidades congêneres; II. em regiões com dificuldade de contratação direta.

7. Instituições filantrópicas: entidades sem fins lucrativos que operam Planos Privados de Assistência à Saúde e que tenham obtido certificado de entidade filantrópica junto ao Conselho Nacional de Assistência Social (CNAS) e declaração de utilidade pública federal junto ao Ministério da Justiça ou declaração de utilidade pública estadual ou municipal junto aos Órgãos dos Governos Estaduais e Municipais.

8. Seguradoras especializadas em saúde: sociedades com fins lucrativos que comercializam "seguros de saúde" e que oferecem, obrigatoriamente, reembolso das despesas médico-hospitalares ou odontológicos. Os consumidores de seguros de saúde têm definido em contrato (denominado apólice) as condições e os limites de reembolso, cobertura, abrangência geográfica, entre outras.

As operadoras deverão promover suas inscrições nos Conselhos Profissionais respectivos e encaminhar comprovante da inscrição para a ANS junto com a documentação de solicitação do registro provisório de funcionamento.

O Representante Legal será o indicado na solicitação de registro provisório de funcionamento, com poderes para representar a operadora e que participe da administração e, uma vez designado, será o legítimo responsável para tratar de todos os assuntos entre a ANS e a operadora. A operadora poderá designar um substituto (que também deve participar da administração), para o que será necessário o envio de procuração à ANS, outorgando os poderes necessários.

As Operadoras são impedidas de recorrer à concordata ou de seus credores pedirem a sua falência, pois uma operadora só pode ser liquidada a pedido da ANS, fórmula encontrada para assegurar os direitos dos consumidores. A regulamentação também institui a obrigatoriedade de informações, permitindo à ANS promover diversas análises e, em especial, acompanhar a evolução dos custos, 
condição essencial para a autorização de aumento das mensalidades dos planos individuais.

Nenhuma empresa pode sair de operação se tiver clientes em sua carteira. A existência de clientes impede, também, o cancelamento dos registros dos produtos. A operadora que deseje cancelar o seu registro tem que cumprir todas as exigências legais (RDC 05).

As regras de garantias financeiras consistem em um conjunto de exigências a serem observadas pelas operadoras de planos de saúde para manutenção do seu equilíbrio econômico-financeiro, minimizando os riscos de insolvência. Tais regras prevêem a constituição de provisões técnicas, bem como parâmetros de margem de solvência e capital mínimo para o mercado regulado.

Considerando-se que o mercado de saúde suplementar não estava sujeito à regulação até a vigência da Lei $n^{\circ}$. 9.656/98, exceto as sociedades seguradoras, as regras de garantias financeiras foram discutidas numa Câmara Técnica específica, da qual participaram representantes dos diversos segmentos do mercado, resultando na publicação da RDC $n^{\circ} .77$ de 17 de julho de 2001.

Posteriormente, foram publicadas a $\mathrm{RN} \mathrm{n}^{\circ}$. 14, de 24 de outubro de 2002 e a $\mathrm{RN} \mathrm{n}^{\circ}$. 57, de 17 de dezembro de 2003, alterando as regras de margem de solvência vigentes para as operadoras de planos de saúde.

Os impactos da regulamentação também foram sentidos após a promulgação da Lei 10.850/04 que fixa as diretrizes para a definição de normas de implantação do Programa de Incentivo à Adaptação de Contratos. Planos de saúde, anteriores à lei 9656/98, foram proibidos de serem comercializados, sendo que os novos contratos firmados entre os consumidores e as operadoras de planos de saúde têm garantia de assistência a todas as doenças reconhecidas pela Organização Mundial de Saúde, além de impedimento às restrições de número de consultas $\mathrm{e}$ internações, dentre outros benefícios.

Mesmo os contratos antigos também obtiveram algumas garantias com a nova legislação: não podem ser rescindidos de forma unilateral pela operadora; as internações não podem ser encerradas a não ser por alta médica; e as mensalidades dos planos individuais ou familiares só podem ser aumentadas com autorização expressa da ANS. 
Os regimes especiais de direção fiscal e direção técnica e as liquidações extrajudiciais de empresas sem condições de operar são procedimentos a que a ANS pode recorrer sempre que verificar alguma grave ou insanável irregularidade que coloque em risco o atendimento à saúde contratado no plano. Para o consumidor, a segurança do usuário de planos privados de assistência à saúde aumentou com a regulamentação pela ANS de medidas necessárias à manutenção da integridade das operadoras e da garantia da continuidade da prestação dos serviços de assistência contratados.

Os planos privados de assistência à saúde oferecidos pelas Operadoras seguem as diretrizes estabelecidas na Lei 9.656/98, sendo que determinadas características - como a modalidade da contratação, a data da assinatura, a cobertura assistencial e a abrangência geográfica - submetem os contratos de forma diferenciada à legislação.

A Lei reconhece a diferença entre os contratos negociados exclusivamente por um indivíduo para si e para a sua família e aqueles negociados para grupos maiores de pessoas.

Quanto à forma de contratação, os planos classificam-se em:

1) individual ou familiar - contrato assinado entre um indivíduo e uma Operadora de planos de saúde para assistência à saúde do titular do plano (individual) ou do titular e de seus dependentes (familiar);

2) coletivo com patrocinador - planos contratados por pessoa jurídica com mensalidade total ou parcialmente paga à operadora pela pessoa jurídica contratante. Inclui também os contratos mantidos por autogestão em que o beneficiário paga parcialmente a mensalidade; $\mathrm{e}$

3) coletivo sem patrocinador - planos contratados por pessoa jurídica com mensalidade integralmente paga pelo beneficiário diretamente à operadora.

Em relação à data de sua assinatura, os planos foram assim classificados: 
1) contrato novo - contrato celebrado depois da vigência da Lei 9.656/98. Todos os contratos celebrados a partir de $1^{\circ}$ de janeiro de 1999 têm que ter registro na ANS e estão totalmente sujeitos à nova legislação;

2) contrato adaptado - é o contrato antigo adaptado às normas estabelecidas na lei 9.656/98. O contrato adaptado tem que ter registro na ANS e está totalmente submisso à nova legislação; $\mathrm{e}$

3) contrato antigo - são contratos antigos os contratos celebrados antes da vigência da Lei 9.656/98 que não foram adaptados às novas regras estabelecidas. Os contratos antigos não podem mais ser comercializados. Eles permanecem válidos apenas para os consumidores que não optarem pela adaptação às novas regras, mas são intransferíveis (sua transferência é vedada a terceiros sob qualquer pretexto) e suas condições são garantidas apenas ao titular e aos dependentes já inscritos. É permitida, somente, a inclusão de novo cônjuge e filhos.

A cobertura assistencial é a denominação dada ao conjunto de direitos (tratamentos, serviços, procedimentos médicos, hospitalares e/ou odontológicos) a que um usuário faz jus pela contratação de um plano de saúde. Independente da forma de contratação - contrato individual ou coletivo - desde a entrada em vigor da Lei 9.656/98, para evitar futuras negativas de assistência, é obrigatório constar de forma clara no contrato a cobertura assistencial que está sendo oferecida.

A Lei 9.656/98 instituiu o Plano-Referência de assistência à saúde, com cobertura assistencial médico-ambulatorial e hospitalar, compreendendo partos e tratamentos, realizados exclusivamente no Brasil, com padrão de enfermaria, centro de terapia intensiva, ou similar, quando necessária a internação hospitalar, das doenças listadas na Classificação Estatística Internacional de Doenças e Problemas Relacionados com a Saúde, da Organização Mundial de Saúde.

Excluem-se da obrigatoriedade do Plano Referência as pessoas jurídicas que mantêm sistemas de assistência à saúde pela modalidade de autogestão e as pessoas jurídicas que operem exclusivamente planos odontológicos.

De acordo com a legislação, um plano de saúde pode oferecer dois tipos de cobertura: a) cobertura integral do Plano Referência; e b) 
cobertura integral por segmento (ambulatorial, hospitalar, hospitalar com obstetrícia ou odontológico). A lei permite a comercialização de planos com coberturas e características superiores às do Plano Referência, como aqueles com diferentes condições de acomodação ou com cobertura para procedimentos não obrigatórios como, por exemplo, as cirurgias estéticas.

A cobertura integral por segmento pode apresentar, ainda, as seguintes derivações:

- hospitalar com obstetrícia + ambulatorial + odontologia;

- hospitalar com obstetrícia + ambulatorial;

- hospitalar com obstetrícia + odontologia;

- hospitalar com obstetrícia;

- hospitalar com ou sem obstetrícia + ambulatorial;

- hospitalar com ou sem obstetrícia + odontologia;

- hospitalar com ou sem obstetrícia;

- hospitalar sem obstetrícia + ambulatorial + odontologia;

- hospitalar sem obstetrícia + ambulatorial;

- hospitalar sem obstetrícia + odontologia;

- hospitalar sem obstetrícia;

- ambulatorial + odontologia;

- ambulatorial; $\mathrm{e}$

- odontologia (ANS Tabnet 2006).

O Rol de Procedimentos é a listagem dos procedimentos em saúde cuja cobertura é garantida a todos os usuários dos planos adquiridos a partir de 2 de janeiro de 1999.

Em relação à Saúde Bucal, o Rol de Procedimentos Odontológicos foi elaborado para regulamentar os eventos em odontologia, em consonância aos Artigos 10 e 12 da Lei 9.656/98. Ambos são revisados periodicamente por Câmaras Técnicas designadas especificamente para este fim, que contam com a participação de representantes dos diversos segmentos da sociedade envolvidos na assistência à saúde suplementar. 
O Rol de Procedimentos com cobertura obrigatória na assistência odontológica exigida nos planos contratados após a Lei 9.656/98 seguiu as seguintes regulamentações:

- Resolução CONSU $n^{\circ} .10$, de 03 de novembro de 1998 - definiu o rol de Procedimentos do Plano Odontológico Ambulatorial.

- Resolução da Diretoria Colegiada (RDC) 21, de 12 de maio de 2000, - dispõe sobre a definição do Rol de Procedimentos Odontológicos, que constituirá referência básica do plano odontológico e fixa diretrizes para a cobertura assistencial.

- Resolução Normativa (RN) 9, de 26 de junho de 2002 - rol de procedimentos odontológicos cuja cobertura da assistência é apenas a nível ambulatorial. Atualiza o Rol de Procedimentos Odontológicos instituído pela Resolução CONSU $n^{\circ}$. 10, de 03 de novembro de 1998 e alterado pela RDC $\mathrm{n}^{\circ} .21$ de 12 de maio de 2000 e dá outras providências.

- Resolução Normativa (RN) 82, de 28 de setembro de 2004 -estabelece o Rol de Procedimentos que constitui a referência básica para cobertura assistencial nos planos privados de assistência a saúde contratados a partir de 01 de janeiro de 1999 e revoga o Rol de Procedimentos do Plano Odontológico Ambulatorial e a Resolução RDC $\mathrm{n}^{\circ}$. 21, publicada em 12 de maio de 2000. Esse rol contempla os tanto os procedimentos buco-maxilo-faciais que necessitam ser realizados a nível hospitalar, como os procedimentos ambulatoriais de Alta Complexidade.

O termo cobertura também é utilizado para especificar a abrangência geográfica onde o beneficiário poderá ser atendido, devendo ser especificada no contrato e pode alcançar:

1) um município (abrangência municipal);

2) um conjunto de municípios;

3) um estado (cobertura estadual);

4) um conjunto de estados; ou

5) todo o país, a chamada cobertura nacional.

O plano de saúde também é diferenciado pela forma de organização da rede de serviços que deve garantir a cobertura assistencial contratada, 
independentemente do tipo de contratação ou da cobertura. A modalidade apenas define como se organiza a rede de serviços que deve garantir ao consumidor individual ou coletivo - a cobertura assistencial contratada.

Lei 9.961/2000 atribuiu à ANS a responsabilidade de controlar os aumentos de mensalidade dos planos de saúde e este controle difere de acordo com tipo de contrato de prestação de serviços de saúde (pessoa física ou jurídica) e de acordo com o motivo do aumento.

A correção do valor da mensalidade de um plano pode se dar em três situações:

1) pela necessidade de atualização da mensalidade decorrente da alteração dos custos assistenciais;

2) pela mudança de faixa etária do consumidor; ou.

3) em decorrência de uma reavaliação do plano.

Algumas características dos planos de saúde atualmente ativos têm influência direta na atuação da ANS: ao aprovar a Lei dos Planos de Saúde, o Poder Legislativo considerou que os planos contratados por pessoas físicas precisavam de uma proteção especial, em vista do poder de negociação de um indivíduo com uma operadora ser desproporcional. Dessa forma, foi dado à ANS um poder de ação e de controle maior sobre esse universo de planos.

De outro lado, os planos contratados antes de 2 de janeiro de 1999 (chamados de planos antigos) não estão ao alcance das novas regras e podem ser reajustados pelas operadoras em índices acertados nos contratos.

Em tese, é possível um plano sofrer, num só ano, aumentos derivados de reajuste por variação de custos, por variação de faixa etária e por revisão técnica. Mas, no caso de haver mais de um aumento num período de 12 meses, é aconselhável consultar a ANS para verificar se são aumentos autorizados.

Nos planos assinados antes da entrada em vigor da Lei 9.656/98, as variações por mudança de faixa etária devem cumprir o estabelecido no contrato. Através da RN 56/03, a ANS determina que as operadoras informem a existência e o conteúdo das cláusulas de faixa etária dentre outras características destes planos, possibilitando a verificação, por parte da ANS, do cumprimento da cláusula. 
Nos planos assinados ou adaptados entre 2 de janeiro de 1999 e $1^{\circ}$ de janeiro de 2004 , as variações por mudança de faixa etária devem cumprir o estabelecido no contrato.

A Resolução CONSU n ${ }^{\circ}$. 6/98 determina que o preço da última faixa (70 anos ou mais) poderá ser, no máximo, seis vezes maior que o preço da faixa inicial ( 0 a 17 anos). A variação deve constar do contrato e obedecer às seguintes faixas etárias:

a) 0 a 17 anos; b) 18 a 29 anos; c) 30 a 39 anos; d) 40 a 49 anos; e) 50 a 59 anos; f) 60 a 69 anos; g) 70 anos ou mais.

Contratos de consumidores com 60 anos ou mais e dez anos ou mais de plano não podem sofrer a variação por mudança de faixa etária. Os contratos assinados ou adaptados depois de lo de janeiro de 2004 devem respeitar as dez faixas etárias determinadas pela $\mathrm{RN} n$. $^{\circ} .63 / 03$, que são:

a) 0 a 18 anos ; b) 19 a 23 anos; c) 24 a 28 anos; d) 29 a 33

anos; e) 34 a 38 anos; f) 39 a 43 anos; g) 44 a 48 anos; h) 49 a 53 anos; i) 54 a 58 anos; e j) 59 anos ou mais.

A alteração visou atender à determinação do Estatuto do Idoso que veda a variação por mudança de faixa etária aos contratos de consumidores com 60 anos ou mais de idade. Esta resolução também estabelece que o valor fixado para a última faixa etária (59 anos ou mais) não pode ser superior a seis vezes o valor da primeira faixa $(0$ a 18$)$ e, ainda, que a variação acumulada entre a sétima e a décima faixas não pode ser superior à variação acumulada entre a primeira e a sétima faixas.

Anualmente, a ANS elabora instrumentos de gestão com a pactuação de seus compromissos junto à União / MS e os resultados obtidos são disponibilizados integralmente na Internet. Os principais instrumentos contratuais para a avaliação periódica do desempenho institucional são os Contratos de Gestão, os Termos Aditivos e os Relatórios de Gestão.

Há uma agenda comum entre os gestores do Sistema Único de Saúde (SUS) e a ANS, em parceria com o Conselho Nacional de Secretários Municipais de Saúde - CONASEMS, para tratar de assuntos como o ressarcimento ao SUS, os sistemas de informação, a qualificação da atenção, entre outros. 
Relativamente ao ressarcimento ao SUS, as Unidades Prestadoras de Serviços ao SUS emitem para cada paciente internado uma Autorização de Internação Hospitalar (AIH), em meio magnético, que comprova a internação realizada. Essa AIH contém, além dos procedimentos realizados, dados de identificação do paciente. Esses dados são cruzados com o banco de dados de beneficiários das operadoras e as AIH relativas aos atendimentos prestados a beneficiários de planos de saúde são identificadas. As informações referentes a essas internações dão origem ao ABI - Aviso de Beneficiários Identificados, que são disponibilizados às operadoras visando o ressarcimento ao SUS.

As unidades prestadoras de serviço de saúde ao SUS são ressarcidas pelas despesas de atendimentos a pacientes das operadoras de planos privados de assistência à saúde. Algumas Secretarias Estaduais e Municipais de Saúde haviam se habilitado para analisar os processos de impugnação das cobranças de Ressarcimento ao SUS. Diversos processos foram analisados nos estados e municípios obedecendo-se à rotina determinada por regulamentação. A alteração das normas de ressarcimento modificou a sistemática de análise dos processos de impugnação e centralizaram na ANS o fluxo de análise dos pedidos de impugnação.

Relativamente às Contas Públicas, a ANS divulga a Prestação de Contas encaminhada ao Tribunal de Contas da União, cumprindo o disposto no art. $2^{\circ}$ da Instrução Normativa - TCU nº. 028/99 (Diário Oficial da União de 10/05/99), mantendo os documentos originais à disposição para conferência na Gerência Geral de Administração e Finanças - GGAFI da ANS. Da mesma forma, todas as aquisições da ANS são divulgadas em jornais de grande circulação nacional, no Diário Oficial da União e na Internet. Sem custo, os fornecedores têm acesso aos editais e às instruções sobre o cadastramento para participar de licitações (Consulta, Edital de Pregão, Concorrência, Tomada de Preço), permitindo-se o envio de perguntas e o recebimento de respostas aos fornecedores que desejarem ser avisados, via e-mail, das modalidades de compra de seu interesse.

Para balizar suas decisões, a ANS realiza Consultas Públicas para receber sugestões e comentários dos interessados. Encontrava-se, em 2006, a Consulta Pública $n^{\circ}$. 26, que dispunha sobre os critérios e a metodologia para avaliação da qualidade da atenção à saúde e a suficiência da rede assistencial, para 
fins de registro de produtos, monitoramento e análise de alterações na rede assistencial das operadoras de planos privados de assistência à saúde.

Desde 2003, a ANS vem divulgando notas aos veículos de comunicação para informar atos administrativos, normativos e operacionais, eventos e demais ações de interesse da sociedade. Para a pesquisa sobre a legislação do setor de saúde suplementar, a ANS mantém em seu site a Regulamentação Principal do setor (Leis), as Regulamentações Complementares (normativas ou operacionais) e as normas indiretamente relacionadas ao setor ${ }^{41}$ :

Quadro 1 - Regulamentação principal - ANS - 25/05/2007

- Lei $\mathbf{n}^{\circ}$. 9.656, de 03/06/1998, dispõe sobre os planos e seguros privados de assistência à saúde, trazendo a Regulamentação do Setor, apresentando-se combinada a 45 Medidas Provisórias.

- Lei ñ. 9.961, de 28/01/2000, dispõe sobre a criação da Agência Nacional de Saúde Suplementar - ANS, apresentando-se combinada a 4 Medidas Provisórias.

- Lei $n^{\circ}$. 10.195, de 12/02/2001, dispõe sobre a especialização das sociedades seguradoras em planos privados de assistência à saúde.

- Lei $n^{\circ}$. 10.850, de 25/03/2004, fixa as diretrizes para a definição de normas para a implantação de Programas Especiais de Incentivo à Adaptação de Contratos anteriores à Lei $n^{\circ}$. 9.656, de 03/06/1998.

Fonte: extraído de www.ans.gov.br/legislação

${ }_{41}$ Número de normas editadas até 25/05/2007 
Quadro 2 - Regulamentações complementares normativas e operacionais segundo a ocorrência - ANS-25/05/2007

\section{Normativas}

- Resoluções da Diretoria Colegiada (RDC e RN) - resoluções que estabelecem políticas para o setor de saúde suplementar, expedidas pela Diretoria Colegiada da ANS - 217.

- Resoluções CONSU - resoluções que estabelecem políticas para o setor de saúde suplementar, expedidas pelo Conselho de Saúde Suplementar - 26.

- Resoluções de Diretoria (RE e IN) - resoluções que estabelecem políticas para o setor de saúde suplementar, expedidas pelas Diretorias da ANS - 76.

- Súmulas Normativas - expressam a interpretação da legislação de saúde suplementar, com caráter vinculativo - 12.

\section{Operacionais}

- Resoluções da Diretoria Colegiada (RDC e RO) - resoluções da Diretoria Colegiada, que expressam decisões de alcance externo, para fins de implementação de ações ou procedimentos operacionais específicos -458 .

- Portarias do Diretor-Presidente da ANS - portarias do presidente da ANS, que expressam as decisões relativas a assuntos de gestão administrativa de recursos humanos e de construção de comissões, grupos de trabalho e assemelhados -14 .

- Despachos do Diretor-Presidente da ANS - despachos do Diretor-Presidente da ANS que expressam decisões finais ou interlocutórias de processos administrativos da ANS - 2 .

Fonte: www.ans.gov.br/legislação 
Quadro 3 - Outras normas relacionadas à Saúde Supletiva - ANS - 25/07/2007

- Lei $n^{\circ}$. 8.078, de 11/09/1990, dispõe sobre a proteção do consumidor Código de Defesa do Consumidor.

- Lei $n^{\circ} .8 .080$, de 19/09/1990, dispõe sobre as condições para a promoção, proteção e recuperação da saúde, a organização e o funcionamento dos serviços correspondentes.

- Lei $n^{\circ}$. 8.142, de 28/12/1990, dispõe sobre a participação da comunidade na gestão do Sistema Único de Saúde (SUS) e sobre as transferências intergovernamentais de recursos financeiros na área da saúde.

- Lei $n^{\circ}$. 9.986, de 18/07/2000, dispõe sobre a gestão de recursos humanos das Agências Reguladoras.

- Lei $n^{\circ}$. 10.522, de 19/07/2002, dispõe sobre o Cadastro Informativo (CADIN) dos créditos não quitados de órgãos e entidades federais.

- Portaria Conjunta no. 6 da SE/MS e ANS, de 23/10/2002, aprova a sistemática de acompanhamento e avaliação do desempenho da ANS, através de Contratos de Gestão.

- Lei $\mathrm{n}^{\circ}$. 10.741, de 01/10/2003, institui o Estatuto do Idoso a fim de regular os direitos assegurados a pessoas com mais de 60 anos.

- Portaria GM nº 1.171 , de 15/06/2004, dispõe sobre a concessão de audiências a particulares por agentes públicos em exercício no Ministério da Saúde.

- Lei ñ. 10.871 , de 20/05/2004, dispõe sobre a criação de carreiras e organização de cargos efetivos das autarquias especiais denominadas Agências Reguladoras.

- Comunicados da Diretoria Colegiada - instrumentos decisórios da Diretoria Colegiada - 49 .

Fonte: www.ans.gov.br/legislação 
A busca pela legislação pode ainda se dar pela Origem ou pelo Tipo de Norma, conforme os Quadros 4 e 5 :

Quadro 4 - Legislação segundo a origem e a ocorrência - ANS - 25/07/2005

\section{Todas as Origens - 857}

- Diretoria Colegiada - 705

- Diretor Presidente - 42

- DIDES - Diretoria de Desenvolvimento Setorial - 32

- DIGES - Diretoria de Gestão - 3

- DIOPE - Diretoria de Normas Habilitação de Operadoras - 16

- DIPRO - Diretoria de Normas Habilitação dos Produtos - 18

- DIFIS - Diretoria de Fiscalização - 6

- CONSU - Conselho de Saúde Suplementar - 26

- GM - Gabinete do Ministério da Saúde - 9

Fonte: www.ans.gov.br/legislação

Quadro 5 - Legislação segundo o tipo de norma e a ocorrência - ANS - 25/05/2007

\section{Todas as Normas - 942}

- Lei -63

- IN - Instrução Normativa - 55

- CONSU - Resolução do Conselho de Saúde Suplementar - 26

- RDC - Resolução da Diretoria Colegiada - 91

- RE - Resolução da Diretoria - 21

- RN - Resolução Normativa - 153

- Súmulas da Diretoria Colegiada - 12

- RO - Resolução Operacional - 441

- Despachos - 2

- Portarias - 14

- Comunicados da Diretoria Colegiada - 62

- MP - Medida Provisória - 2

Fonte: Extraído de www.ans.gov.br/legislação 
Beneficiários, prestadores, operadoras e gestores do SUS têm a seu dispor várias informações adequadas ao interesse de cada um desses segmentos, podendo ser consultadas no site da ANS. A maior parte dessas informações está disponível ao público em geral, outras são de acesso restrito a um perfil específico de usuário. Dentre os principais itens, destacam-se:

- Operadoras que não enviaram documentação para obter autorização de funcionamento no mercado de saúde suplementar, por registro e por estado;

- Comprovante da situação cadastral das operadoras e registro na ANS;

- Comprovante da situação cadastral dos beneficiários;

- Registro de operadoras e dos planos de saúde;

- Índice de Desempenho de Saúde Suplementar (IDSS) da Operadora;

- Resultados referentes à $2^{\mathrm{a}}$ fase do Programa de Qualificação da Saúde Suplementar das operadoras registradas na agência;

- Lista de operadoras com registro na ANS;

- Decisões de Processo de fiscalização, doenças pré-existentes e notificação fiscal de lançamento de débito;

- Relação das carteiras de planos antigos com autorização de oferecimento de adequação à Lei 9.656/98;

- Consulta aos planos antigos com autorização da ANS para adequação;

- Reajustes Autorizados;

- Novos percentuais de reajuste por faixas etárias;

- Reajuste por variação de custo em contratos assinados por pessoa física;

- Encaminhamentos ao Ministério Público por cobrança irregular de cheque-caução por parte dos prestadores de serviços;

- Depósitos para Unidades Prestadoras de Serviço de Saúde ao SUS;

- Resultado dos Processos de Ressarcimento ao SUS;

- Consultas Públicas;

- Contas públicas, licitações, processos seletivos e pesquisas de opinião; 
- Biblioteca com livros, guias, trabalhos técnicos, monografias, artigos e relatórios de pesquisa, Memória de Eventos, teses, dissertações e links de interesse.

Uma Cartilha de Reajustes encontra-se disponível ao consumidor com o esclarecimento das principais dúvidas sobre a situação cadastral das operadoras e dos planos de saúde, a vigência dos contratos, os reajustes, coberturas e carências, doenças e lesões preexistentes, ofertas de novos contratos a ex-beneficiários de operadoras liquidadas extra judicialmente pela ANS, decisões dos processos de fiscalização, além de todos os outros arquivos.

A informação disponibilizada pela ANS visa permitir o conhecimento da dimensão e da dinâmica do setor de saúde suplementar por meio de análises espaciais, temporais, demográficas, econômico-financeiras e de dados específicos sobre a atenção à saúde no setor, sendo fundamental para avaliações clínicas, epidemiológicas, gerenciais e para embasar as estatísticas da ANS e de outros órgãos governamentais.

Os principais sistemas corporativos da ANS são:

- Sistema de Informações de Produtos - SIP (sistema);

- Sistema Integrado de Fiscalização - SIF (sistema);

- Informações Periódicas das Operadoras - DIOPS (sistema);

- Informações Periódicas Econômico-Financeiras das Seguradoras FIP (sistema);

- Publicação de Beneficiários Identificados no SUS - ABI (planilha);

- Controle de Processos de Impugnação de Ressarcimento - SCI (sistema);

- Sistema de Informações Gerenciais - SIG (sistema);

- Sistema de Arrecadação - SIAR (internet);

- Adequação de Registro de Planos de Saúde - ARPS (sistema);

- Reajuste de Planos Coletivos - RPC (sistema);

- Controle de Reajuste de Planos de Saúde - RPS/Reajuste (planilha);

- Planilhas de Notas Técnicas Atuariais (planilha);

- Registro de Planos de Saúde (cadastro);

- Cadastro de Planos Antigos - SCPA (cadastro); 
- Sistema de Informações de Beneficiários - SIB (cadastro);

- Registro de Operadoras - CADOP (cadastro).

Em maio de 2003, a ANS iniciou o trabalho de pesquisa e elaboração da TISS - Troca de Informação em Saúde Suplementar, a partir de convênio com o Banco Interamericano de Desenvolvimento - BID. O grupo de trabalho criado na Agência analisou os padrões e as informações já trocadas no mercado, com o objetivo de propor um modelo unificado de troca de informações em saúde suplementar.

A ANS estabeleceu um padrão para registro e intercâmbio de dados entre as operadoras de planos privados de assistência à saúde e os prestadores de serviços de saúde, com o intuito de estabelecer a padronização da informação trocada entre operadoras e prestadores. A proposta utiliza padrões já existentes e disponíveis em outros bancos de dados e sistemas de informações, permitindo compatibilizar os sistemas de informação em saúde existentes para a melhoria na utilização das informações coletadas.

Cerca de 50 guias utilizadas entre as operadoras e prestadores foram analisadas, além de visitas feitas a prestadores e operadoras no intuito de se conhecer e identificar dificuldades no processo de troca de informação. Foram ainda analisados os sistemas nacionais de informações em saúde, como o SIB e SIP (sistemas da ANS); e o SIM, SINAN, CNS; CNES e CIH, do Ministério da Saúde.

Há uma Agenda de Compromissos das Operadoras para com a ANS onde constam as características e os objetivos das informações a serem encaminhadas por meio de arquivos digitais, os meios de transmissão e a periodicidade do envio dos arquivos à ANS e as respectivas resoluções normativas.

Dentre as informações que devem ser encaminhadas pelas operados à ANS e suas periodicidades destacam-se:

- mensalmente, o Sistema de Informação dos Beneficiários (RN nº 88 e IN/DIPES $n^{\circ}$. 15) com os cadastros de beneficiários e o Formulário de Informações Periódicas - FIP, com as informações das seguradoras (RN nº. 28 e Lei $n^{\circ}$. 10.185); 
- trimestralmente, o DIOPS - Documento de Informações Periódicas das Operadoras de Planos de Assistência à Saúde tem por objetivo fornecer condições para que a DIOP possa efetuar o controle, o monitoramento e o acompanhamento da situação econômico-financeira e cadastral das operadoras ( $\mathrm{RN} \mathrm{n}^{\circ}$. 29) e o SIP - Sistema de Informação dos Produtos tem a finalidade de acompanhar a assistência de serviços prestados aos beneficiários $\left(\mathrm{RN} \mathrm{n}^{\circ}\right.$. 96).

Os sistemas SIP, DIOPS e FIP contêm as informaç̃os contábeis e cadastrais das empresas, sendo ferramentas importantes para o trabalho da ANS de organizar e planejar ações para o desenvolvimento do mercado.

As seguradoras especializadas em saúde devem informar seus dados econômico-financeiros e cadastrais através do FIP e do Plano de Contas $\left(\mathrm{RN} \mathrm{n}^{\circ} .28\right) \mathrm{e}$ as Operadoras das demais modalidades devem utilizar o DIOPS.

Assentados nesses sistemas de informações, a Taxa de Saúde Suplementar por Plano de Assistência à Saúde deve ser recolhida trimestralmente, sendo seu valor determinado pela quantidade de beneficiários, cobertura oferecida e área de abrangência geográfica dos planos privados $\left(\mathrm{RN} \mathrm{n}^{\circ} .89\right.$ alterada pela $R N n^{\circ}$. 101) e, anualmente, a NTRP - Nota Técnica de Registro de Produto deve ser atualizada e acompanhar a solicitação de registro de planos de saúde (Resolução RDC nº. 28).

Aperiodicamente deve ser feito o Comunicado de Reajuste, com qualquer variação positiva ou negativa na contraprestação pecuniária dos planos individuais ou familiares, planos coletivos com ou sem patrocinador e daqueles operados por entidades de autogestão não patrocinada, cujo financiamento se dê exclusivamente por recursos de seus beneficiários. Da mesma forma, o RPS Registro de Planos de Saúde deve apresentar o produto para registro, no momento de sua solicitação (Resolução RN nº 100 e IN DIPRO nº. 11).

Tais informações encontram-se disponíveis no ANS TabNet, que possibilita a tabulação de dados dos diversos sistemas de informação da ANS, além de publicações que reúnem produções técnicas da agência e folders direcionados aos diversos perfis setoriais. 
Informações gerais, dados estatísticos e econômicofinanceiros do setor apresentam-se no site da ANS por temas da regulação, como por exemplo:
a) vínculos a planos de saúde

- vínculos a planos de assistência médica com ou sem odontologia, exceto os exclusivamente odontológicos;

- vínculos a planos exclusivamente odontológicos;

- todos os vínculos a planos privados de assistência à saúde;

- vínculos a planos médico-hospitalares com ou sem odontologia; e

- vínculos a planos exclusivamente odontológicos.

$$
\text { b) situação das operadoras }
$$

- operadoras que não cumpriram os termos da RDC 77/01;

- distribuição por estado e modalidade das operadoras que não cumpriram as Garantias Financeiras quanto às Provisões Técnicas e/ou Capital Mínimo;

- demonstrações contábeis - operadoras de pequeno porte

- demonstrações contábeis - operadoras de médio e grande porte

- dados econômico-financeiros de seguradoras especializadas em saúde - julho de 2001 a dezembro de 2006;

- informações contábeis históricas do mercado segurador especializado em saúde;

- inconsistências e características observadas no preenchimento do DIOPS;

c) informações gerais sobre planos de saúde

d) informações gerais sobre a utilização dos serviços

e) informações sobre a assistência

- monitoramento da situação de envio do SIP;

- freqüência de utilização da assistência médico-hospitalar com ou sem odontologia e da assistência exclusivamente odontológica;

- custo médio dos eventos da assistência médico-hospitalar com ou sem odontologia e da assistência exclusivamente odontológica;

- atendimentos na rede hospitalar do SUS.

f) índice de reclamações a partir dos contatos efetuados pelos usuários de planos de saúde com indício de irregularidade. 
Os principais projetos da ANS para os próximos anos são:

- o planejamento e a regulação da demanda e oferta de serviços;

- os Complexos Reguladores;

- a integração com o SUS;

- o ressarcimento ao SUS;

- a informação em saúde e a informação em saúde suplementar; e

- a gestão da incorporação tecnológica: protocolos e diretrizes clínicas.

O Ressarcimento ao SUS é um instrumento de regulação que visa desestimular o descumprimento dos contratos celebrados e impedir o enriquecimento injusto das operadoras de forma a evitar-se o subsídio de atividades lucrativas com recursos públicos.

A identificação de beneficiários para fins de ressarcimento ao Sistema Único de Saúde - SUS é feita exclusivamente pela ANS, mediante o cruzamento dos dados relativos aos atendimentos realizados pelo SUS com os dados cadastrais das operadoras de planos privados de assistência à saúde. Com base nas informações resultantes do processo de identificação, a ANS torna disponível às operadoras o Aviso de Beneficiário Identificado - ABI.

A avaliação da qualidade institucional é um componente do processo de qualificação da saúde suplementar e deverá medir os graus de desempenho da Agência Nacional de Saúde Suplementar em produzir os processos que realizem sua missão institucional. As diretrizes adotadas para a reorientação assistencial na saúde suplementar são:

- a integralidade do cuidado, através da produção de ações de promoção, proteção, recuperação e reabilitação da saúde dos pacientes;

- o estabelecimento de vínculo entre profissional de saúde e beneficiário; e

- a responsabilização das Operadoras pela saúde de seus beneficiários.

A mudança do foco da regulação do setor de saúde suplementar busca uma crescente qualificação de todos os atores envolvidos (operadores, prestadores, beneficiários e do próprio órgão regulador), sendo, hoje, o principal desafio da ANS. A idéia central é o "reconhecimento da saúde suplementar 
como local de produção de saúde, onde as operadoras de planos passam a ser consideradas gestoras de saúde, os prestadores de serviços em produtores de cuidado de saúde e os beneficiários em usuários com consciência sanitária" (ANS 2006).

De maneira similar, a própria ANS também busca qualificar-se para corresponder à tarefa de regular um setor com objetivo de produzir saúde.

As principais estratégias da ANS para a implantação da Política de Qualificação são:

a) o Projeto de Qualificação da Saúde Suplementar que institui a prática de trabalhar com indicadores e informações epidemiológicas;

b) o Programa de Promoção à Saúde e Prevenção de Doenças; e

c) o estímulo à implementação das Linhas de Cuidado, como diretriz para a atenção individual e de gestão da Atenção à Saúde (protocolos).

O Programa de Qualificação da Saúde Suplementar institui a prática de se trabalhar com indicadores e informações epidemiológicas, enquanto que os Programas de Promoção à Saúde e Prevenção de Doenças tentam induzir a mudança do modelo assistencial através do estímulo à implementação das Linhas de Cuidado como diretriz para a atenção individual e para a gestão da Atenção à Saúde.

A regulamentação do Programa de Qualificação da Saúde Suplementar tem como base a Resolução Normativa $n^{\circ}$. 94, de 24/03/2005, que dispõe sobre os critérios para o diferimento da cobertura com ativos garantidores da provisão de risco condicionada à adoção, pelas operadoras, de programas de promoção à saúde e prevenção de doenças de seus beneficiários e da Instrução Normativa $\mathrm{n}^{\circ}$. 10 - DIPRO, de 24/03/2005, que estabelece procedimentos de apresentação e critérios para a avaliação dos programas de promoção à saúde e prevenção de doenças.

A operadora que adotar o Programa de Promoção à Saúde e Prevenção de Doenças (Instrução Normativa 10) poderá parcelar a cobertura da provisão de risco contabilizada, previsto na Resolução Normativa $n^{\circ} .94$.

Os programas deverão ser informados através de formulários e serão avaliados pela ANS. Para participar, a operadora deve realizar, 
no mínimo, um programa em, pelo menos, duas linhas de cuidado. As operadoras deverão informar semestralmente à ANS os resultados dos programas aprovados.

Segundo a ANS (2006), dos 596 programas apresentados pelas 215 operadoras inscritas, 5\% foram de Saúde Bucal. Das 215 operadoras inscritas, 111 operadoras foram aprovadas e 39 estavam sendo analisadas.

A Qualificação da Saúde Suplementar ocorre através da avaliação de dois componentes:

1. Avaliação da Qualidade das Operadoras (Índice de Desempenho da Saúde suplementar - IDSS); e

2. Avaliação da Qualidade Institucional (Índice de Desempenho Institucional - IDI).

O estabelecimento de padrões de qualidade quanto ao modelo de atenção para a saúde suplementar se assenta nos princípios de acesso necessário e facilitado, além do atendimento qualificado, integral e resolutivo das necessidades de saúde dos beneficiários dos planos de saúde.

A pertinência das quatro dimensões foi analisada a partir da articulação e da compatibilização dos indicadores propostos nos contratos de gestão da ANS junto ao Ministério da Saúde, no Planejamento Estratégico da Agência, nos relatórios de cooperação internacional e no próprio projeto de qualificação institucional, de tal forma que não haja sobreposição e que possam refletir diferentes momentos do processo organizativo da instituição.

$\mathrm{Na}$ saúde suplementar foram priorizadas quatro linhas de cuidado (Programa de Qualificação e Programas de Promoção e Prevenção):

- materno-neonatal;

- saúde bucal;

- cuidado aos pacientes portadores de neoplasias;

- cuidado aos pacientes portadores de transtornos cardiovasculares.

Os critérios para a avaliação dos programas de promoção à saúde e prevenção de doenças utilizam-se das seguintes informações:

- perfil de morbi-mortalidade da população beneficiária;

- abrangência do programa (população-alvo);

- cobertura do programa; 
- atividades desenvolvidas: consultas, palestras, atividade física, entre outras, periodicidade e protocolos utilizados (MS, INCA, Diretrizes Clínicas da AMB); e

- avaliação: sistema de informação, utilização de indicadores de resultado para monitoramento do programa.

Para as operadoras que prestam assistência médica, há obrigatoriedade de se designar um médico responsável pelo fluxo de informações relativas à assistência prestada aos beneficiários de planos privados. Para aquelas que prestam assistência odontológica ainda não há obrigatoriedade do responsável cirurgião-dentista, uma vez que a qualidade das informações sobre saúde bucal é atribuída ao responsável técnico da operadora, devidamente registrado no respectivo conselho de classe.

A RDC $n^{\circ}$. 64, de 10/04/2001, institui a obrigatoriedade da designação do coordenador médico, enquanto que a RDC $\mathrm{n}^{\circ}$. 78, de 20/07/2001, prorrogou o prazo estabelecido no Art. $4^{\circ}$ da $\operatorname{RDC~n.} .^{\circ}$. 64, para a designação formal do Coordenador de Informações em Saúde.

O monitoramento sistemático das informações do setor através do Índice de Desempenho da Saúde Suplementar - IDSS permite a avaliação e a qualificação por índices de desempenho calculados a partir de indicadores de atenção à saúde, econômico-financeiros, de estrutura e operação e de satisfação do beneficiário.

A análise da qualidade das operadoras é feita por meio de quatro dimensões:

I. Atenção à Saúde - avaliação da qualidade da assistência à saúde prestada aos beneficiários de planos privados de saúde, buscando a identificação do impacto das ações de saúde em suas condições de vida;

II. Econômico-Financeira - identificação da situação econômico-financeira da operadora frente à manutenção dos contratos assumidos em acordo com a legislação vigente;

III. Estrutura e Operação - identificação do modo de produção da operadora; 
IV. Satisfação dos Beneficiários - identificação da visão do usuário no cumprimento ao estabelecido no contrato com a operadora.

A análise da assistência prestada pelas operadoras é feita por meio de quatro dimensões, com pesos diferenciados na composição do IDSS Índice de Desempenho da Saúde Suplementar:

- $50 \%$ para a dimensão Atenção à Saúde;

- $50 \%$ para as demais dimensões (econômico-financeira $30 \%$; estrutura e operação $10 \%$; e satisfação do beneficiário $10 \%$ ).

O Índice de Desempenho (ID) é um valor calculado pela razão entre a pontuação obtida pela operadora $(O)$ e pontuação esperada pela ANS (E), sendo calculado a partir do monitoramento sistemático de indicadores com resultados apresentados conforme os seguintes intervalos: 0 으 0,$25 ; 0,25$ 0,50 ; 0,50 - 0,75 e $0,75 \vdash 1$ (situação ideal).

Para o IDSS, as operadoras foram classificadas segundo o número de usuários de suas carteiras: 1 a $9.9999 ; 10.000$ a 99.999; e $>100.000$ usuários. As operadoras exclusivamente odontológicas seguiram os seguintes Portes: 1 a 4.999; 5.000 a 19.999; e > 20.000 usuários.

A implantação do Programa vem ocorrendo de forma gradativa. $\mathrm{Na} \mathrm{l}^{\mathrm{a}}$ fase de monitoramento de indicadores foram utilizados os já existentes nos bancos de dados da ANS em 2003 e 2004, sendo acrescentados outros novos nas duas fases subseqüentes que correspondem à $2^{\mathrm{a}}$ fase, elaborada com os dados referentes a 2005, e à $3^{\mathrm{a}}$ fase.

Relativamente à Saúde Bucal, a construção dos indicadores e a graduação da pontuação do Programa de Qualificação da Saúde Suplementar foram definidas através de um consenso estabelecido por um grupo técnico de saúde bucal com representantes da ANS, MS, SMS/RJ e especialistas da academia.

Para tal, considerou-se o levantamento epidemiológico SB Brasil (2003) e as informações sobre a condição de saúde bucal e a necessidade de tratamento da população brasileira, além das informações do setor suplementar coletadas no SIP.

Os principais desafios da ANS, para os próximos anos, são aprofundar a Política de Qualificação nos eixos de Acreditação de prestadores e de 
operadoras, fortalecer a descentralização dos Núcleos Regionais de Fiscalização (NURAF) da Agência, aumentar a interface entre a ANS e os beneficiários por intermédio dos órgãos de defesa do consumidor e estabelecer uma agenda regulatória comum junto aos gestores do SUS.

\subsection{A SAÚDE BUCAL}

Para CHAVES (1986), a odontologia evoluiu a partir da prática exercida, inicialmente, sob a forma de ocupação indiferenciada, por indivíduos de determinada comunidade, até a fase em que a profissão "chega ao auge", isto é, "uma profissão estruturada, com escolas universitárias, ensino de pósgraduação, associações profissionais fortes, exercício profissional praticamente resolvido a ponto de poder delegar funções na cavidade oral..." (p.154).

As cinco etapas evolutivas sistematizadas por CHAVES (1986) tentam reproduzir a evolução da odontologia, numa perspectiva atemporal e não localizada, sem vincular os resultados em termos de benefícios na condição de saúde bucal das populações.

Para Narvai e Frazão (2006), citados por NARVAI (2006), a saúde bucal das populações não resulta apenas da prática odontológica, mas de construções sociais operadas conscientemente pelos homens, em cada situação concreta. Como processo social, "cada situação é única, singular, histórica, não passível, portanto de replicação ou reprodução mecânica em qualquer outra situação concreta, uma vez que os elementos e dimensões de cada um desses processos apresentam contradições, geram conflitos e são marcados por negociações e pactos que Ihes são próprios, específicos" (p.144).

NARVAI (2002), ao pesquisar as relações de poder associadas ao uso da palavra odontologia, afirma que o termo tem sido insuficiente para produzir conceitos consensuais. Para suprir essa insuficiência, expressões como 'odontologia sanitária', 'odontologia social', 'odontologia preventiva', odontologia simplificada', 'odontologia integral' vêm sendo utilizadas em diferentes contextos. 
Segundo esse autor, a odontologia sanitária teve seu apogeu nos anos de 1960, assumindo o discurso oficial da época que culminou com a proposta governamental de se transformar o Serviço Nacional de Fiscalização Odontológica - SNFO em Serviço Nacional de Odontologia Sanitária - SNOS.

Odontologia social e preventiva teve seu apogeu durante a ditadura militar (1968-1978), com formulações teóricas da odontologia sanitária associadas a esse contexto autoritário, entrando em declínio nos anos 80 (NARVAI 2006).

Para NARVAI (2002), muitas são as concepções de odontologia social que, a exemplo de 'odontologia', não foram capazes de se constituir numa idéia comum, havendo associação do termo social a algo precário sem qualidade e dirigidos aos pobres.

Odontologia social e preventiva teve seu apogeu durante a ditadura militar (1968-1978), com formulações teóricas da odontologia sanitária associadas a esse contexto autoritário, entrando em declínio nos anos 80 (NARVAI 2006).

Por sua vez, a expressão odontologia integral parece incapaz de esclarecer algum significado, pois o adjetivo integral pode ser referente à integralidade dos processos biológicos quanto à integração e articulação dos processos sociais.

Diferente de todas as adjetivações referidas à odontologia no Brasil, a Saúde Bucal Coletiva apresenta uma clara perspectiva de rompimento da hegemonia da odontologia de mercado ${ }^{42}$, na medida em que seus projetos de sociedade opõem-se explicitamente aos projetos neoliberais.

Para Narvai \& Frazão, (2006), citados por NARVAI (2006), "Saúde Bucal Coletiva ${ }^{43}$ é um campo de conhecimentos e práticas [que

\footnotetext{
${ }^{42} \mathrm{~A}$ odontologia de mercado assenta - se nos aspectos biológicos e individuais - nos quais fundamenta sua prática - desconsiderando a determinação de processos sociais complexos (NARVAI 2006).

${ }^{43}$ Segundo Frazão (1999), citado por NARVAI (2006) a Saúde Bucal Coletiva pretende "substituir toda forma de 'tecnicismo' e de 'biologismo' presentes nas formulações específicas da área de odontologia social e preventiva, (....) realizando a reconstrução teórica de modo articulado e orgânico ao pensamento e a ação da Saúde Coletiva, e reforçando o compromisso histórico desta com a qualidade de vida na sociedade e com a defesa da cidadania, tanto da ação predatória do capital quanto da ação autoritária do Estado " (p. 144).
} 
integra] um conjunto mais amplo identificado como 'Saúde Coletiva' e que, a um só tempo, compreende também o campo da 'Odontologia', incorporando-o e redefinindo- o e, por esta razão, necessariamente transcendendo-o" (p.144).

Nesse sentido, NARVAI (2006) destaca que para o rompimento entre Saúde Bucal Coletiva e a prática hegemônica da odontologia de mercado, o trabalho odontológico deverá ser desenvolvido a partir das necessidades das pessoas $^{44}$ e não a partir da mercantilização dos serviços e do monopólio do acesso aos recursos.

De acordo com esse autor, o SUS assentado nos princípios de universalidade, integralidade e eqüidade, pode possibilitar a realização de ações para atender às necessidades de todas as pessoas, viabilizando seu acesso a todos os recursos odontológicos e de saúde geral de que necessitem e ofertando mais aos que mais necessitam.

No entanto, as ações assistenciais devem ser articuladas a um conjunto amplo de medidas para que os 'modelos de atenção' à saúde consigam, de maneira efetiva, produzir socialmente a saúde coletiva sem reduzir o modelo de atenção ao sistema assistencial.

Para NARVAI (2005), a atenção à saúde refere-se ao "conjunto de atividades intra e extra-setor saúde que, incluindo a assistência individual, não se esgota nela, atingindo grupos populacionais com o objetivo de manter a saúde, e requerendo ações concomitantes sobre todos os determinantes da saúde-doença" (p.4). Nesse sentido, conceitua a assistência como o "conjunto de procedimentos clínico-cirúrgicos dirigidos a consumidores individuais, doentes ou não" (p.4).

CARVALHO (2002) afirma que as ações e serviços de saúde públicos ${ }^{45}$ constituem o Sistema Único de Saúde, no entanto, o Artigo 197 da

\footnotetext{
" Relativamente às necessidades das pessoas, BOTAZZO (2006) propõe o conceito de bucalidade, como um arranjo teórico metodológico no qual são essenciais os 'trabalhos bucais' identificados como manducação (consumo do mundo para sobreviver no plano natural), linguagem (produção e consumo de palavras) e erotismo (relação amorosa e produção de atos bucais sexuais), Para esse autor, a saúde não se esgota na forma clínica e a teoria odontológica é suficiente para recuperar o homem por inteiro.

45 Segundo CARVALHO (2002), "já existe consenso de que as seguintes ações e serviços devam ser relacionados entre as ações e serviços públicos de saúde beneficiadas pela vinculação de receitas: Ações e serviços constantes nos planos de saúde dos Municípios, Estados. Distrito Federal e União; ações e serviços executados pelos órgãos do Sistema Único de Saúde; controle de qualidade, pesquisa científica e tecnológica, e produção de insumos em
} 
Constituição Federal deixa explícito que todas as ações e serviços públicos e privados são considerados de relevância pública, tendo o Ministério Público a responsabilidade por zelar para que os serviços de relevância pública respeitem os direitos constitucionais, como o é o da saúde.

CHAVES (1986) afirma que, a maioria das entidades públicas e privadas mantenedoras de serviços de saúde sempre ofertaram algum tipo de assistência dentária. $\mathrm{Na}$ área governamental, esse autor destaca que os ministérios e secretarias ofereciam atenção odontológica a seus funcionários e dependentes, sendo que os serviços odontológicos das Forças Armadas sempre tiveram expressão em todo o território nacional.

Segundo Vasconcellos (1984), citado por NARVAI (2006), os primeiros cargos de cirurgião-dentista na administração pública paulista foram direcionados ao atendimento odontológico do efetivo da Força Pública e aos cidadãos sob custódia do Estado, no âmbito da Secretaria de Justiça e Segurança Pública. Em 1929, profissionais de odontologia passaram a integrar os quadros da Inspeção Médico-Escolar da Secretaria do Interior, então responsável pelas atividades ligadas à educação e à saúde no Estado.

Em 1932, após a criação da Secretaria da Educação e da Saúde Pública, instituiu-se a Inspetoria de Higiene e Assistência Dentária no Serviço Sanitário para o atendimento da população de escolares da rede pública estadual. Em 1947, instituiu-se a recomendação de que os centros de saúde contassem com um Serviço de Higiene Buco-Dentária.

saúde (medicamentos, imunobiológicos, reagentes, sangue e hemoderivados, equipamentos para a saúde, dentre outros); vigilância sanitária; vigilância epidemiológica e farmacoepidemiológica; saúde do trabalhador; assistência terapêutica e farmacêutica; ao nível domiciliar e de pequenas comunidades, ações de saneamento básico e meio ambiente associadas a controle de vetores; e ao nível de ações complementares e específicas para grupos de risco nutricional, ações de alimentação e nutrição. Por outro lado, há consenso de que as seguintes ações e serviços não devam figurar entre as atividades beneficiadas: Gastos com pessoal inativo; serviços suplementares ao Sistema Único de Saúde, dedicados. total ou parcialmente, ao atendimento de clientelas fechadas (excluídos em função da incompatibilidade com o critério de universalidade de acesso); e serviço da dívida (juros e amortização); ações de preservação e correção do meio ambiente, realizadas pelos órgãos de meio ambiente dos entes federativos e por entidades não governamentais; ações de saneamento básico de redes públicas e tratamento de água e esgotos realizados por companhias, autarquias e empresas de saneamento com recursos provenientes de taxas e tarifas, e ações de limpeza urbana e remoção de resíduos sólidos (lixo) realizadas por órgãos municipais específicos ou empresas terceirizadas" (p.268). 
Nos sucessivos arranjos institucionais e modalidades estatais de produção de serviços que marcaram a organização da assistência odontológica pública, a odontologia de mercado jamais perdeu sua hegemonia. Embora se buscasse desenvolver ações educativas, tais profissionais reproduziam a prática clínica dos dentistas nos consultórios particulares, com abordagem individual, sem um diagnóstico de situação em termos populacionais ou programação que considerassem a saúde bucal da população como um todo (NARVAI 2006).

Para NARVAI (2006), “a concepção de prática centrada na assistência odontológica ao indivíduo doente, e realizada com exclusividade por um sujeito individual no restrito ambiente clínico-cirúrgico, não apenas predomina no setor privado, como segue exercendo poderosa influência sobre os serviços públicos" (p.143).

CHAVES (1986) relata que, durante muitos anos, a odontologia ficou sem representação na estrutura organizacional do Ministério da Saúde, no que tange às atribuições de coordenação, assistência técnica ou auxílio financeiro aos programas desenvolvidos em outras esferas federais. Segundo esse autor, essa lacuna foi preenchida pela Fundação Serviços de Saúde Pública - FSESP, criada em 1942, que durante três décadas reuniu um acervo de experiências em programas incrementais ${ }^{46}$ destinados a escolares e na implantação de sistemas de fluoretação de água de abastecimento público.

PINTO (2000) afirma que, do ponto de vista organizacional, as ações de saúde bucal têm o clássico formato de um não sistema, com prestadores de serviços que atuam de maneira independente, não articulada, sem uma orientação ou comando único. Entre o início do século $\mathrm{XX}$ até os anos de 1970, as estatísticas odontológicas demonstram que países com maior número de dentistas apresentavam maior prevalência de cárie.

\footnotetext{
${ }^{46}$ Segundo NARVAI (2006), em 1952, o Serviço Especial de Saúde Pública implementou os primeiros programas de odontologia sanitária, inicialmente em Aimorés, MG, tendo como alvo principal a população em idade escolar, tida como epidemiologicamente mais vulnerável e, ao mesmo tempo, a mais sensível às intervenções de saúde pública. A principal ferramenta teórica utilizada pela odontologia sanitária foi o sistema incremental que, posteriormente, tornou-se ineficaz à medida que foi "reproduzido acriticamente, e, em contextos de precariedade gerencial, falta de recursos e ausência de enfoque epidemiológico dos programas" (p.143).
} 
Dados epidemiológicos do levantamento Projeto SB Brasil 2003 sobre as condições de saúde bucal da população brasileira, indicam diferenças na distribuição do ataque de cárie em crianças, tanto na dentição decídua quanto na permanente, evidenciando diferenças entre regiões do país e nos componentes do Índice CPOD/ceo-d $\mathrm{d}^{47}$. Da mesma forma, o ataque de cárie e o número de dentes perdidos entre adultos e idosos são elevados (MS 2004).

Esse levantamento também indicou que cerca de $10 \%$ dos adultos brasileiros possuem bolsa periodontal em uma ou mais regiões da boca, $10 \%$ dos adultos com pelo menos um sextante da boca excluído, sendo que esse problema atinge mais da metade dos idosos. A perda precoce é grave e a necessidade de prótese começa a surgir a partir da faixa etária de 15 a 19 anos.

Segundo esse levantamento, as diferenças apontadas podem ser decorrentes do modelo de atenção em cada área geográfica, como os impactos da fluoretação da água e do creme dental e de medidas mais específicas relacionadas ao acesso e à utilização de serviços de odontologia (MS 2004).

Relativamente à fluoretação, a amostra apontou que $46 \%$ dos municípios pesquisados dispunham de água fluoretada com maior concentração nas regiões Sul e Sudeste.

Quadro 6 - Comparação entre as metas propostas pela OMS/FDI para o ano 2000 com relação à cárie dentária e os resultados do Projeto SB Brasil, 2003.

\begin{tabular}{|c|c|c|c|c|c|c|c|}
\hline Idade & & Norte & Nordeste & Sudeste & Sul & Centro-Oeste & Brasil \\
\hline \multirow[t]{2}{*}{5 a 6 anos } & Brasil 2003 & $35.04 \%$ & $34.92 \%$ & $44,92 \%$ & $43,35 \%$ & $41,73 \%$ & $40,62 \%$ \\
\hline & Meta OMS 2000 & \multicolumn{6}{|c|}{$50 \%$ livres de cárie (ceo- $d=0$ ) } \\
\hline \multirow[t]{2}{*}{12 anos } & Brasil 2003 & 3.13 & 3.19 & 2,30 & 2,31 & 3,16 & 2,78 \\
\hline & Meta OMS 2000 & \multicolumn{6}{|c|}{ CPO-D menor que 3,0} \\
\hline \multirow[t]{2}{*}{18 anos } & Brasil 2003 & $39.13 \%$ & $45,07 \%$ & $66,53 \%$ & $66,55 \%$ & $65,74 \%$ & $55,09 \%$ \\
\hline & Meta OMS 2000 & \multicolumn{6}{|c|}{$80 \%$ com $P=0$ (todos os sentes presentes na boca) } \\
\hline \multirow[t]{2}{*}{35 a 44 anos } & Brasil 2003 & $46.34 \%$ & $49,97 \%$ & $62.35 \%$ & $55,13 \%$ & $58,36 \%$ & $53,96 \%$ \\
\hline & Meta OMS 2000 & \multicolumn{6}{|c|}{$75 \%$ com 20 ou mais dentes presentes na boca } \\
\hline \multirow[t]{2}{*}{65 a 74 anos } & Brasil 2003 & $8,58 \%$ & $11,07 \%$ & $9.23 \%$ & $10,41 \%$ & $11,22 \%$ & $10,23 \%$ \\
\hline & Meta OMS 2000 & \multicolumn{6}{|c|}{$50 \%$ com 20 ou mais dentes presentes na boca } \\
\hline
\end{tabular}

Extraído de: MS (2004)

\footnotetext{
${ }^{47} \mathrm{O}$ índice CPOD é utilizado em levantamentos epidemiológicos de saúde bucal para medir e comparar a experiência de cárie dentária em populações. Seu valor expressa a média de dentes cariados, perdidos e obturados em um grupo de indivíduos. Na a dentição decídua, o índice ceo-d é obtido pela soma de dentes decíduos cariados, extraídos e obturados.
} 
Ao lado do câncer de boca, a ausência de dentes é um dos mais graves problemas da saúde bucal no Brasil. Hoje $75 \%$ dos idosos são desdentados e entre adultos, com idade entre 30 e 44 anos, esse índice é de $30 \%$. O Ministério da Saúde registra, ainda, um total de 5 mil adolescentes desdentados sem prótese na boca e estima-se que 8 milhões de pessoa precisem de prótese dentária no país (MS 2006c).

Segundo a Pesquisa Nacional de Saneamento Básico do Instituto Brasileiro de Geografia e Estatística (2000), havia 5391 municípios com serviços de abastecimento público de água por rede de distribuição, o que representa $97,9 \%$ do total dos 5.507 municípios existentes por ocasião da pesquisa.

Embora a maioria dos municípios brasileiros conte com serviços de abastecimento público de água por rede de distribuição, somente 45,74 \% do total de municípios com serviços de abastecimento público de água informaram realizar a fluoretação da água. A grande maioria dos municípios que conta com serviços de abastecimento público de água com fluoretação está localizada Sul e Sudeste $(70 \%)$, região Centro-Oeste $(41,5 \%)$ e regiões Norte e Nordeste, $7,8 \%$ e $16,55 \%$.

No Brasil, $68,8 \%$ dos municípios têm a prestação dos serviços de abastecimento público de água delegada para as empresas estaduais de saneamento. Quanto à fluoretação, observa-se que, em 53,5 \% ocorre a fluoretação da água distribuída a população.

Por outro lado, 45,5\% dos municípios brasileiros têm a prestação dos serviços de abastecimento delegada aos próprios municípios, observando-se a fluoretação em apenas $20 \%$. Portanto, a fluoretação tem maior abrangência nos municípios operados pelas companhias estaduais de saneamento. Quanto aos serviços de abastecimento público de água prestado por operadores privados, observa-se que tal modalidade de prestação ocorre em 8,4 \% dos municípios brasileiros, com 12,2\% de fluoretação (MS 2006 d).

A Coordenação Nacional de Saúde Bucal, órgão do Departamento de Atenção Básica (DAB) da Secretaria de Atenção à Saúde (SAS), tem como principal atribuição coordenar a implantação de uma Política de Saúde 
Bucal no SUS, articulada com as demais políticas de saúde, que objetive a redução das desigualdades e a inclusão social.

Em 17 de março de 2004, o Governo Federal criou a Política "Brasil Sorridente" com diretrizes de ampliação e qualificação da atenção básica, visando o acesso da atenção a todas as faixas etárias e a oferta de mais serviços. Propõe-se, também, a ampliar os atendimentos nos níveis secundário e terciário para a busca da integralidade, da equidade e da universalização do acesso às ações e serviços públicos de saúde bucal (MS 2006 b).

Até 2004 , somente $3,3 \%$ dos atendimentos odontológicos do SUS correspondiam a tratamentos especializados, sendo os demais tratamentos mais simples direcionados quase que exclusivamente às crianças e adolescentes.

A Política "Brasil Sorridente" apresenta como principais linhas de ação:

- a viabilização da adição de flúor a estações de tratamento de águas de abastecimento público;

- a reorganização da Atenção Básica, especialmente por meio da Estratégia Saúde da Família ${ }^{48}$; e

- a reorganização da Atenção Especializada, através, principalmente, da implantação de Centros de Especialidades Odontológicas e dos Laboratórios Regionais de Próteses Dentárias $^{49}$.

Os Centros de Especialidades Odontológicas (CEO) são estabelecimentos de saúde que oferecem à população o atendimento especializado em Saúde Bucal com, no mínimo, os seguintes serviços: 1) diagnóstico bucal, com ênfase no diagnóstico e deteç̧ão do câncer de boca; 2) periodontia; 3) cirurgia oral menor dos tecidos moles e duros; 4) endodontia; e 5) atendimento a portadores de necessidades especiais.

\footnotetext{
${ }^{48}$ Dados do Ministério da Saúde que demonstram a evolução do credenciamento e da implantação das Equipes de Saúde Bucal (ESB) com base nacional: em março de 2001, havia 120 ESB implantadas com cobertura populacional de $0,50 \%$; em março de 2007, havia 15.492 ESB implantadas com cobertura populacional de $40,71 \%$ ( + - 74 milhões de habitantes).

${ }^{49}$ Segundo dados do Ministério da Saúde (DAB/SB), em 2004, 100 CEOs estavam habilitados em todo Brasil. Em no final de 2007, esse número passou para 534 CEOs (178 tipo I, 339 tipo II e 17 tipo II), além de 236 LRPD (Dados Cadastro Nacional de Estabelecimentos de Saúde).
} 
As Portarias GM/MS n. 599 e 600, de 23/03/2006 definem critérios, normas e requisitos para a implantação e o credenciamento dos CEOs, bem como instituem o financiamento e o repasse dos recursos financeiros entre as esferas de governo. Os CEOs podem ser de três modalidades:

- CEO tipo I - com três cadeiras odontológicas, sendo destinados, mensalmente, $R \$ 6.600,00$ para custeio, além de $R \$ 40.000,00$, em parcela única, correspondentes a custos com reformas, ampliação do espaço físico e aquisição de equipamentos;

- CEO tipo II - com quatro ou mais cadeiras, sendo destinados,

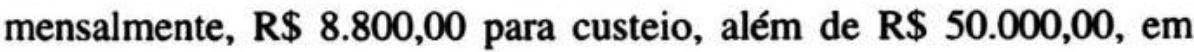
parcela única; e

- CEO tipo III - mínimo de sete cadeiras, custeio mensal de R\$ $15.400,00$ e $\mathbf{R} \$ 80.000,00$ para os investimentos necessários.

A Portaria GM/MS n. 1.572, de 29/07/2004, estabelece o financiamento dos Laboratórios Regionais de Prótese Dentária (LRPD), podendo ser unidades próprias ou terceirizadas credenciadas para a confecção de próteses totais ou próteses parciais removíveis, sendo pagas por produção, com recursos extra-teto diretamente aos municípios.

Segundo o Ministério da Saúde, até o final de 2006, o "Brasil Sorridente" receberá investimentos da ordem de R\$ 1,3 bilhão. Em 2003, investiu-se R\$ 90 milhões em incentivos para a Saúde Bucal na Estratégia Saúde da Família, superando os R\$40 milhões do ano anterior. Em 2004, o Tribunal de Contas da União reconheceu um crescimento de $45 \%$ nos atendimentos realizados.

Além das prioridades acima descritas, outras ações estratégicas vêm sendo implementadas pelo MS. O levantamento das condições de saúde bucal da população brasileira (SB Brasil), finalizado em 2003, vem orientando a condução das ações do Brasil Sorridente.

A criação da Secretaria de Vigilância em Saúde - SVS, em junho de 2003, veio reforçar uma área extremamente estratégica do Ministério, por meio do fortalecimento e da ampliação das ações de Vigilância Epidemiológica. Apesar de todas as ações de prevenção e controle de doenças estarem reunidas nesse 
Órgão, os levantamentos epidemiológicos em Saúde Bucal vêm permanecendo sob a responsabilidade da CNSB e das estruturas que a precederam.

Além disso, o desenvolvimento de ações intersetoriais para a ampliação da fluoretação das águas de abastecimento público no Brasil, de acordo com a Lei Federal n. 6.050, de 24/05/1974, com a criação e/ou desenvolvimento de sistemas de vigilância compatíveis. Com esse processo viabilizado junto à Fundação Nacional de Saúde (FUNASA) e às Secretarias Estaduais de Saúde, 430 novos projetos estão em análise e beneficiarão cerca de seis milhões de brasileiros (MS 2006 d).

Nesse sentido, a FUNASA estabeleceu como meta para 2005/2006 a implantação da fluoretação da água em cerca de 1.500 sistemas de abastecimento público, de modo a beneficiar cerca de 12 milhões de pessoas.

Durante o primeiro semestre de 2005, a FUNASA concluiu a implantação da fluoretação em 121 sistemas e continuará promovendo o apoio técnico e o financeiro aos operadores dos serviços de abastecimento para implantação da fluoretação da água nos sistemas de abastecimento em que a mesma ainda não ocorre e se mostre tecnicamente viável. $\mathrm{O}$ conjunto de ações apoiado por esse Órgão envolve:

- a orientação técnica, a capacitação e o financiamento de equipamentos e insumos;

- a implantação de uma estratégia de educação permanente em saúde para mais de 40 mil profissionais de Saúde Bucal, que contemple desde os princípios do SUS até as mais modernas técnicas de assistência odontológica;

- o fomento à pesquisa em Saúde Bucal Coletiva com o objetivo de expandir a produção do conhecimento básico aplicado à Saúde Bucal; e

- a participação na implantação do Plano Nacional de Saúde no Sistema Penitenciário, sendo previsto que cada equipe de saúde conte com um cirurgião-dentista e um auxiliar de consultório dentário (MS 2006b).

A CNSB desenvolve também atribuições operacionais específicas, tais como:

- assessorar os diversos setores do MS na elaboração das regulamentações pertinentes à Saúde Bucal , como Portarias, Notas Técnicas, etc.; 
- participar de licitações para a compra de equipamentos odontológicos, em especial, os equipamentos odontológicos do "Brasil Sorridente";

- participar de reuniões e emitir pareceres técnicos sempre que houver a necessidade de alteração dos instrumentos de regulação da Saúde Bucal, como o SIA, o SIAB, a Tabelas de Procedimentos do SUS; e

- participar da elaboração de documentos técnicos dirigidos aos gestores e aos profissionais de Saúde Bucal, como o Manual de Orientações Técnicas para a Elaboração e Apresentação de Propostas e Projetos Técnicos de Fluoretação da Água em Sistema Público de Abastecimento e a Cartilha para o Gestor.

Relativamente às informações sobre o controle e à vigilância dos teores de flúor das águas de abastecimento público, a Secretaria Nacional de Saneamento Ambiental do Ministério das Cidades, através do Sistema Nacional de Informações sobre Saneamento (SINIS), criado em 1996, vem monitorando, anualmente, a prestação dos serviços de água no Brasil.

O Ministério da Saúde possui um órgão responsável pela implementação da Política de Regulação no SUS.

O DRAC foi constituído, primeiramente, pelo Decreto $\mathrm{n}^{\circ}$. 4.726, de 09/06/2003, que aprovou a nova Estrutura Regimental Básica do MS, compondo a Secretaria de Atenção à Saúde (SAS) juntamente com os departamentos de Atenção Especializada (DAE), de Atenção Básica (DAB), de Ações Programáticas Estratégicas (DAPE) e com o Instituto Nacional do Câncer (INCA). Posteriormente, com o Decreto $\mathrm{n}^{\circ}$. 5.974, de 29/11/2006, foi incorporado à SAS o Departamento de Gestão Hospitalar no Estado do Rio de Janeiro.

O objetivo geral do DRAC é "coordenar e aprimorar a implementação da Política Nacional de Regulação, Controle e Avaliação, além de viabilizar financeiramente o desenvolvimento das ações e serviços de saúde na atenção ambulatorial e hospitalar do SUS" (SCHILLING e col. 2006, p.28).

O Decreto Federal n'. 5.974, de 29/11/2006, estabelece como competências do Departamento de Regulação, Avaliação e Controle de Sistemas (DRAC):

I - definir a política de regulação do Ministério da Saúde em relação aos Sistemas Estaduais de Saúde; 
II - subsidiar e avaliar as ações de regulação assistencial, implantadas pelos Estados, Municípios e Distrito Federal;

III - acompanhar e avaliar:

a) a prestação de serviços assistenciais de saúde, no âmbito do SUS, em seus aspectos qualitativos e quantitativos; $\mathrm{e}$

b) a transferência de recursos financeiros do Ministério a Estados, Municípios e ao Distrito Federal;

IV - prestar cooperação técnica aos gestores do SUS para a utilização de instrumentos de coleta de dados e informações;

V - subsidiar a elaboração de sistemas de informação do SUS;

VI - realizar estudos para o aperfeiçoamento e aplicação dos instrumentos de controle e avaliação dos serviços de assistência à saúde;

VII - avaliar as ações, métodos e instrumentos implementados pelo órgão de controle e avaliação dos Estados, dos Municípios e do Distrito Federal;

$$
\text { VIII - estabelecer normas e definir critérios para a }
$$
sistematização e padronização das técnicas e procedimentos relativos às áreas de controle e avaliação;

IX - definir, dentro de sua área de atuação, formas de cooperação técnica com os Estados, os Municípios e o Distrito Federal para o aperfeiçoamento da capacidade gerencial e operativa dos serviços de assistência à saúde;

$$
\mathrm{X} \text { - subsidiar os Estados, os Municípios e o Distrito Federal }
$$
na política de contratualização com os prestadores de serviços de saúde do SUS; e XI - definir, manter e atualizar o Cadastro Nacional de Estabelecimentos de Saúde (BRASIL 2006).

O DRAC sucedeu o Departamento de Controle e Avaliação de Sistemas (DECAS) da Secretaria de Assistência à Saúde, pertencente à estrutura administrativa anterior, na gestão 1999-2002, herdando grande parte de suas funções e recebendo outras atribuições num processo de reestruturação administrativa.

Dentre as atribuições herdadas pelo DRAC destacam-se: 
- controle sobre as transferências de recursos fundo a fundo aos gestores plenos estaduais e municipais para o custeio da Média e Alta Complexidade (teto MAC); pagamento direto aos prestadores privados, segundo os tetos financeiros MAC dos estados não plenos; pagamento da produção dos hospitais universitários; pagamento da modalidade co-financiamento aos estados de SP e PE; pagamentos dos procedimentos realizados com recursos centralizados no Fundo de Ações Estratégicas e Compensação - FAEC (estratégicos, terapia renal substitutiva, alta complexidade, campanhas de cirurgias eletivas, etc); pagamentos dos incentivos (Integrasus, IAPI, CAPs); e pagamento da produção por determinação de processos judiciais;

- desenvolvimento das diretrizes e coordenação da implantação das atividades de Controle sobre a produção dos serviços de saúde, nos estados e municípios;

- gerência do Cadastro Nacional de Estabelecimentos de Saúde e Profissionais (CNES);

- gerência operacional do Sistema de Informações Ambulatoriais (SIA) e do Sistema de Informações Hospitalares (SIH) e das respectivas tabelas de procedimentos;

- aperfeiçoamento do controle e avaliação da execução das ações de saúde, por meio do SIA e SIH;

- suporte operacional em informação e informática, subsidiando processos de direção, coordenação e avaliação do DRAC;

- Programa Nacional de Avaliação dos Serviços Hospitalares - PNASH e a Pesquisa de Satisfação e Prêmio de Qualidade Hospitalar;

- desenvolvimento e gerência da Central Nacional de Regulação de Alta Complexidade (CNRAC);

- encaminhamento de processos de ressarcimento da saúde suplementar junto ao SUS (SCHILING e col.2006).

No entanto, com a reorganização do Ministério da Saúde, o DRAC não assumiu todas as atribuições do extinto DECAS, uma vez que a elaboração e o controle da execução dos contratos de gestão e a habilitação dos 
serviços de Alta Complexidade ficaram com o Departamento de Atenção Especializada da nova Secretaria da Atenção à Saúde (SAS), enquanto que o Envio de Cartas aos Usuários e o Serviço de Atendimento de Demandas Espontâneas foram para a recém criada Secretaria de Gestão Estratégica e Participativa.

Dentre as novas atribuições recebidas pelo DRAC, destacam-se:

- coordenação das ações e instrumentos de Programação Pactuada e Integrada (PPI) nos estados, municípios e no Distrito Federal;

- regularização e organização dos contratos de prestadores no SUS; e

- desenvolvimento das diretrizes de regulação do acesso (centrais de internação, consultas e exames), com instrumento informatizado representado pelo SISREG, que no Governo 1999-2002, estavam com - Departamento de Descentralização da Gestão da Assistência (Departamento extinto que fazia parte da Secretaria da Assistência à Saúde).

Administrativamente, o DRAC estrutura-se em quatro coordenações formais:

- Coordenação Geral de Controle de Serviços e Sistemas (CGCSS);

- Coordenação Geral de Regulação e Avaliação (CGRA);

- Coordenação Geral dos Sistemas de Informação (CGSI); e

- Coordenação Geral de Suporte Operacional dos Sistemas (CGSOS).

Conta ainda com a Coordenação de Programação Assistêncial (CPA), com o Setor de Ressarcimento ao SUS das Operadoras de Planos de Saúde e com a Assessoria Técnica (ASTEC), que, embora tenha equipe e desempenhe funções, não consta no organograma oficial.

A Coordenação Geral de Regulação e Avaliação de Serviços de Saúde (CGRA) tem como atribuições gerais e projetos:

2.1.1 delinear uma nova Política Nacional de Regulação, partindo-se de um conceito ampliado da regulação estatal sobre o Setor Saúde, que abrangeria tanto as regulamentações como também as ações que assegurem o cumprimento destas, ficando marcadas as diferenças de conceituação entre a Regulação sobre Sistemas de Saúde, Regulação da Atenção à Saúde e Regulação do Acesso à Assistência. A 
Regulação sobre Sistemas de Saúde, enquanto regulação ampliada conteria as ações de Regulação da Atenção à Saúde e estas, enquanto ações sobre a produção direta das ações dos prestadores de serviços, conteriam as ações de Regulação do Acesso à Assistência;

2.1.2 desenvolver junto às Secretarias Estaduais e Municipais de Saúde um processo sistematizado de cooperação técnica para viabilizar a implementação do Processo de Regulação de Atenção à Saúde. $O$ documento Diretrizes para a Implantação dos Complexos Reguladores, elaborado a partir da publicação da Portaria $\mathrm{n}^{\circ}$. 399/GM/MS, de 22/02/2006, visa orientar os gestores quanto a um dos eixos da Política Nacional de Regulação: a regulação do acesso por meio dos complexos reguladores.

Essa Política é um dos componentes do Pacto pela Saúde na sua diretriz Pacto de Gestão e está focada em três eixos estruturantes:

- distribuição de recursos financeiros, definida no âmbito das Comissões Intergestoras Bipartite - CIB, para a implantação e para o custeio dos Complexos Reguladores nos Estados e Municípios;

- disponibilização de instrumentos para a operacionalização dos Complexos Reguladores, como o SISREG versão III; e

- programa de capacitação permanente de recursos humanos (MS 2006e, 2006 g).

Em parceria com o Departamento Nacional de Auditoria do SUS, foi elaborado o Curso Básico de Regulação, Controle, Avaliação e Auditoria do SUS que tem como objetivo principal "a transformação das práticas nas áreas de regulação, controle, avaliação e auditoria, incorporando saberes e adequando-se às atuais necessidades da gestão do SUS" (MS 2006 a, p.9).

O MS sistematizou parte das funcionalidades necessárias à Regulação da Assistência no Sistema de Regulação em Saúde (SISREG), que funciona por meio de navegadores instalados em computadores conectados à Internet, com servidor instalado no DATASUS/RJ, com dois módulos independentes: Central de Regulação de Consultas e Central de Internação Hospitalar. Não há ônus financeiro para se ter acesso ao SISREG, sendo permitido trabalhar com seu códigofonte e alterá-lo de acordo com as suas necessidades. 
2.1.3 avaliar os Planos Diretores de Controle, Regulação e Avaliação - PDCRA, requisitos necessários à habilitação de Estados e Municípios em Gestão Plena;

2.1.4 elaborar, desenvolver e aperfeiçoar instrumentos de avaliação das ações e serviços de atenção à saúde, tendo como diretrizes a implementação da Política Nacional de Avaliação de Serviços de Saúde (PNASS) e da Política Nacional de Contratação;

2.1.5 coordenar e acompanhar as ações de cooperação técnica e orientação às instâncias gestoras, no que se refere à implementação e ao aperfeiçoamento de sistemas de avaliação que contemplem qualidade e cobertura universal, bem como a estrutura, o processo e o resultado das ações e serviços de saúde prestados à população; e

2.1.6 avaliar e propor indicadores e parâmetros assistenciais no âmbito do SUS junto aos representantes das diversas políticas setoriais.

Em linhas gerais, essa Coordenação vem se ocupando dos Contratos, do aprimoramento do PNASS, da disponibilização e do acesso do SISREG III aos Estados e Municípios, da descentralização da CNRAC para os Estados e da implantação dos Complexos Reguladores.

Relativamente à Saúde Bucal, a CGRA não tem como atribuições específicas a avaliação e o controle sistemáticos das ações e dos serviços dessa política setoriais, pois os dados relativos à Saúde Bucal, a exemplo de outras políticas setoriais, estão inseridos nos sistemas de informações disponíveis à regulação em geral, como a Tabela de Procedimentos Ambulatoriais do SIA (Grupo 3) e do SIH, a Produção Ambulatorial e Hospitalar do SUS (sítio DATASUS), a Programação Físico-Orçamentária (FPO) e o SCNES.

As principais atribuições da Coordenação dos Sistemas de Informação - CGSI são:

2.2.1 planejar e coordenar os processos de desenvolvimento, implantação / implementação, atualização e manutenção permanente dos seguintes Sistemas de Informação:

- Sistemas de Cadastro Nacional de Estabelecimentos de Saúde-SCNES;

- Sistema de Informação Ambulatorial - S I A;

- Sistema de Informação Hospitalar - SIH/SUS. 
2.2.2 assessorar, capacitar e apoiar Estados, Municípios e Distrito Federal no processo de implantação, implementação e avaliação dos Sistemas: SCNES, SIA, SIH e os subsistemas SISAIH01, BPA e APAC;

2.2.3 apoiar as áreas técnicas do MS, buscando compatibilizar os sistemas (SCNES, SIA e SIH) às Políticas de Atenção à Saúde, proporcionando a qualidade da informação;

2.2.4 articulação permanente com o DATASUS para desenvolvimento, implantação / implementação e atualização sistemática dos sistemas SCNES/ SIA e SIH/SUS.

A CGSI também é responsável pelos seguintes projetos prioritários: a descentralização do SIH/SUS, a implantação da Tabela Unificada, a implantação da nova versão SCNES - versão 2.0, a individualização do atendimento do SIA/SUS e o monitoramento e a avaliação dos sistemas de informação.

O Cadastro Nacional de Estabelecimentos de Saúde (CNES) foi instituído pela Portaria MS/SAS $\mathrm{n}^{\circ} 376$, de 03/10/2000, permanecendo em Consulta Pública até dezembro de 2000. Em 29/12/2000, a Portaria MS/SAS n 511 passou a normatizar o processo de cadastramento em todo o Território Nacional.

O CNES tem como objetivo geral cadastrar todos os estabelecimentos de saúde, ambulatoriais e hospitalares, componentes da rede pública e privada, existentes no país e manter atualizados os bancos de dados nas bases locais e federal, visando subsidiar os gestores na implantação/implementação das políticas de saúde, sendo importante para o planejamento, regulação, avaliação, controle, auditoria e ensino/pesquisa.

Os serviços de saúde são cadastrados segundo o nível de hierarquia da NOAS (PAB, PABA, MC1, MC2, MC3 e Alta Complexidade), o tipo de clientela (demanda espontânea e referenciada), a esfera administrativa (federal, estadual, municipal e privada), o tipo de prestador (com fins lucrativos, sem fins lucrativos) entre outras classificações.

O SCNES vem sendo aprimorado desde sua criação e, em sua versão 2.0, já é possível distinguir-se, dentre os serviços cadastrados, as Equipes de Saúde da Família (ESF), o Programa do Agente Comunitário de Saúde (PACS) e os serviços que exigem processo de habilitação específica. 
O Cadastro Nacional de Estabelecimentos de Saúde (CNES) fixa permissões de produção, segundo as tabelas de classificação/tipo de serviços e o Código Brasileiro de Ocupações (CBO) e define serviços especiais passíveis de apresentarem produção em Saúde Bucal.

Dentre esses, quatro tipos de serviços especializados de Saúde Bucal exigem habilitação específica para implantação e funcionamento:

- Centro de Tratamento da Má Formação Labiopalatal - Portaria SAS/MS n 62, de 01/04/1994;

- Laboratório Regional de Prótese Dentária, Centro de Especialidades Odontológicas I (CEO I) e Centro de Especialidades Odontológicas II (CEO II) - Portaria GM/MS n 1.570, de 29/07/2004.

A Coordenação Geral de Suporte Operacional de Sistemas CGSOS tem como principal atribuição o fomento às diversas áreas do MS, no que se refere à geração de dados e informações dos Sistemas SIA e SIH, agregando informações do CNES para o controle, a avaliação e o pagamento dos prestadores e gestores do SUS, além da conformação de bases de dados municipais, estaduais e nacional. Considera-se que o gestor político do processamento de dados dos sistemas de produção do SUS seja o DRAC e que o gestor técnico desse processamento seja o DATASUS.

Além disso, outras atribuições específicas são de responsabilidade da CGSOS:

2.3.1 atualizar a homepage da SAS;

2.3.2 atualizar os bancos de dados (S I A e SIH) para utilização no TABWIN (programa para tabulação de dados do DATASUS / MS).

2.3.3 levantar dados ambulatoriais e hospitalares para as diversas áreas do MS (tabulações), sendo seu principal projeto a implementação de um sistema extrator de dados; e

2.3.4 calcular os impactos financeiros das Portarias do MS.

Relativamente ao SIA, a integração dos dados do CNES junto a esse sistema permite a geração da Programação Física - Orçamentária (FPO) dos procedimentos ambulatoriais para os prestadores públicos e privados, 
representando o limite potencial de produção de cada unidade de saúde estabelecido pela Programação Pactuada e Integrada (PPI).

$\mathrm{Na}$ Atenção Básica, a FPO apresenta limites quantitativos (físico), uma vez que o repasse financeiro para o pagamento desse grupo de procedimentos aos gestores é definido por critérios demográficos (valor per capita). Na Média e Alta Complexidade, as FPOs das unidades de saúde apresentam valores físicos e financeiros em função do Teto Financeiro da Média e Alta Complexidade e da produção.

O Fundo Nacional de Saúde aponta 190 diferentes modalidades de recursos para o pagamento dos procedimentos no SUS classificados segundo o Nível Assistencial, o Grupo de Despesa, o Programa e o Tipo de Despesa, o que dificulta a gestão e o controle sobre os recursos financeiros, sendo proposta do MS, conforme Pacto de Gestão (Portaria MS/GM nº, 399, de 22/02/06), reduzir as modalidades de recursos em cinco blocos de financiamento para o custeio:

a) Atenção Básica - de responsabilidade das três esferas de gestão, sendo que os recursos federais comporão o Bloco Financeiro da Atenção Básica dividido em dois componentes: o Piso da Atenção Básica - PAB e o Piso da Atenção Básica Ampliada - PAB Variável. O PAB Variável será destinado ao custeio de ações específicas e seus recursos serão transferidos aos municípios que aderirem e implementarem as seguintes estratégias:

I - Saúde da Família; II - Agentes Comunitários de Saúde; III - Saúde Bucal; IV Compensação de Especificidades Regionais; V - Fator de Incentivo da Atenção aos Povos Indígenas; e VI - Incentivo à Saúde no Sistema Penitenciário.

b) Atenção da Média e Alta Complexidade - esses recursos comporão o Limite Financeiro da Média e Alta Complexidade Ambulatorial e Hospitalar, sendo que os procedimentos pagos atualmente através do Fundo de Ações Estratégicas e Compensação (FAEC) serão incorporados ao Limite Financeiro de cada município, estado e Distrito Federal. O FAEC destinar-se-á ao custeio dos seguintes procedimentos:

I - Procedimentos regulados pela CNRAC - Central Nacional de Regulação da Alta Complexidade; II - Transplantes; III - Ações Estratégicas, de caráter temporário, implementadas com prazo pré-definido; e IV - Novos procedimentos: cobertura 
financeira de aproximadamente seis meses, quando da inclusão de novos procedimentos, sem correlação à tabela vigente, até a formação de série histórica para agregação ao Teto MAC.

c) Vigilância em Saúde - recursos financeiros correspondentes às ações de Vigilância em Saúde comporão o Limite Financeiro de Vigilância em Saúde, representando as ações da Vigilância Epidemiológica, Ambiental e Sanitária, sendo composto por dois componentes: Vigilância Epidemiológica e Ambiental em Saúde e Vigilância Sanitária em Saúde.

O financiamento da vigilância sanitária por procedimento dará lugar ao pagamento da cobertura para o custeio de ações coletivas. Comporão ainda, o bloco do financiamento do componente Vigilância Epidemiológica, os recursos com os seguintes repasses específicos:

I - Fortalecimento da Gestão da Vigilância em Saúde em municípios e estados (VIGISUS II); II - Campanhas de Vacinações; III - Incentivo do Programa DST I AIDS.

d) Assistência Farmacêutica - será financiada pelos três gestores do SUS, sendo organizada nos seguintes blocos específicos: Componente Básico da Assistência Farmacêutica, Componente Estratégico da Assistência Farmacêutica e Componente Medicamentos de Dispensação Excepcional.

A Política Nacional de Atenção Básica, aprovada pela Portaria MS / GM nº. 648, de 28/03/2006, estabelece a revisão de diretrizes e normas para a organização da Atenção Básica para o Programa Saúde da Família (PSF) e o Programa Agentes Comunitários de Saúde (PACS), considerando a Saúde Bucal como área estratégica para atuação em todo o território nacional (MS 2006 d).

Dentre as várias atribuições da Coordenação de Programação Assistencial - CPA destacam-se:

2.4.1 acompanhar os Limites Financeiros da Média e Alta Complexidade (MAC) dos Estados e Municípios;

2.4.2 manter o Sistema informatizado de acompanhamento dos limites financeiros (SISTETO);

2.4.3 acompanhar e avaliar o processo de Programação e Pactuação dos Estados;

2.4.4 manter o sistema para a programação assistencial (SISPPI); e 
2.4.5 assessorar, por demanda, os vários setores do MS, Estados e Municípios.

Os dois principais projetos dessa Coordenação são a reformulação da programação da assistência e o desenvolvimento de uma metodologia de avaliação da Programação Pactuada e Integrada. Para tanto, um novo aplicativo de informática vem sendo desenvolvido pelo DATASUS e será divulgado via Internet. $\mathrm{O}$ novo aplicativo, além de conter um módulo específico para a destinação dos recursos federais, o que possibilitará a revisão dos limites financeiros entre gestores.

A PPI (NOAS 01/2001) efetivou-se, com maior ou menor intensidade, nas 27 Unidades Federadas em função de vários questionamentos, entre eles o financiamento. Entretanto, possibilitou a adoção de critérios mais objetivos para a alocação de recursos financeiros federais e conferiu maior transparência às pactuações realizadas (MS $2006 \mathrm{f}$ ).

No entanto, a insuficiente apropriação dos processos gerais de planejamento local e regional, a incipiência das metodologias de estimativa de necessidades em saúde e a participação restrita dos municípios no processo de definição das diretrizes e parâmetros norteadores da PPI foram fatores limitantes no processo. Além disso, a proposta de programação foi baseada em limites financeiros estaduais históricos, definidos com base em critérios variados e pouco transparentes, não sendo possível resgatar, muitas vezes, a memória dos dados da pactuação efetuada em 2002.

Nesse contexto, observou-se grande resistência à assinatura dos Termos de Compromisso de Garantia de Acesso pelos municípios que receberam as referências de atendimento e fragilidade de mecanismos que garantissem a efetivação dos pactos firmados entre os gestores.

Com vistas a superar as limitações descritas para a construção das redes regionalizadas e hierarquizadas, a nova metodologia adota como pressupostos gerais: a necessidade da Programação estar inserida no Planejamento Geral do SUS; o estabelecimento de correlações entre as informações epidemiológicas e as ações de saúde na definição das estimativas de necessidade em saúde; e a regionalização como orientadora dos processos de negociação e de pactuação entre os gestores (BRASIL 2006 f). 
Como eixos orientadores da nova proposta da PPI foram definidos:

- a centralidade da Atenção Básica com seis prioridades pactuadas: saúde do idoso, controle do câncer do colo do útero e da mama, redução da mortalidade infantil e materna, fortalecimento da capacidade de resposta às doenças emergentes e endemias com ênfase na dengue, hanseníase, tuberculose, malária e influenza, promoção da saúde e fortalecimento da atenção básica.

Com o objetivo de permitir ao gestor uma melhor visão do processo de planejamento, foram definidos parâmetros de cobertura e de concentração para várias áreas estratégicas, entre elas a Saúde Bucal.

- as aberturas programáticas coerentes com as regras atuais de financiamento do SUS que contemplem a totalidade das ações de saúde, mesmo as que não estejam previstas na tabela, cabendo ao gestor optar pelo nível de desagregação dos procedimentos das tabelas (grupos, subgrupos, forma de organização ou procedimento).

Além dessa possibilidade, a programação terá a seguinte lógica:

a) Atenção Básica - será de responsabilidade dos municípios não sendo previstos referenciamentos;

b) Média Complexidade Ambulatorial - lógica de programação ascendente (exceto se as referências estiverem concentradas em pólos regionais), onde os municípios programam as ações de sua população e realizam encaminhamentos para outros municípios, para os quais não possuem oferta (insuficiência ou inexistência de capacidade instalada);

c) Alta Complexidade Ambulatorial - lógica de programação descendente, onde as referências serão definidas a partir dos municípios que realizam este tipo de atendimento. A programação será permeada por dois grupos: procedimentos com finalidade diagnóstica e procedimentos para tratamento clínico que compõem as redes de serviços;

d) Média Complexidade Hospitalar - lógica de programação ascendente orientada pelas clínicas, de acordo com a distribuição de leitos do CNES (cirúrgicas, 
obstétricas, pediátricas, clínicas, outras especialidades e hospitais-dia), sugerindo-se a utilização dos parâmetros para a área hospitalar da Portaria MS/GM n 1.101, de 12/06/2002;

e) Alta Complexidade Hospitalar - lógica de programação descendente orientada pelas clínicas e pelos seguintes serviços: cardiologia, neurocirurgia, oncologia e traumato-ortopedia;

f) Leitos Complementares - lógica de programação descendente para UTI adulto, UTI infantil, UTI neonatal, Unidade intermediária, Unidade intermediária neonatal e Unidade de isolamento.

- a integração da programação da assistência (PPI da Assistência) à da vigilância (PPI da Vigilância à Saúde), sendo o SISPPI o instrumento de programação, com uma plataforma comum, para a unicidade da linguagem e das inter-relações;

- a composição das fontes de recursos financeiros a serem programados com a explicitação dos aportes estaduais e municipais implicados no custeio da assistência e o estabelecimento de pelo menos quatro modalidades passíveis de aberturas orçamentárias, conforme sua fonte de financiamento:

1) co-financiamento de serviços financiados globalmente (CEO, SAMU, hospitais de pequeno porte, etc);

2) recursos alocados para a compra de serviços privados cobertos exclusivamente pelos tesouros municipais ou estaduais;

3) recursos dos tesouros estaduais ou municipais alocados para a complementação de valores das tabelas SIH e S I A; e

3) outras modalidades de alocação como subsídios globais a serviços específicos.

- o processo de programação e as relações intergestores.

A Portaria MS/GM no 1.097, de 22/05/2006, definiu que o processo da Programação Pactuada e Integrada da Assistência em Saúde instituído no âmbito do Sistema Único de Saúde e, da mesma forma, definiu parâmetros para subsidiar a programação das ações de saúde, constituindo-se em referências para orientar os gestores do SUS em todo o processo da PPI. 
Para sua elaboração, foram considerados os consensos estabelecidos pelas áreas técnicas do Ministério da Saúde, as séries históricas de produção de atendimento prestado aos usuários do SUS, a experiência de serviços de saúde e as contribuições recebidas através da Consulta Pública SAS/MS $n^{\circ} 2$, de $06 / 07 / 2005$.

Os parâmetros assistenciais de cobertura e de concentração abrangem as áreas estratégicas acima explicitadas e poderão ser aprimoradas de acordo com a avaliação de casos reais e com a pesquisa científica aplicada.

A Coordenação Geral de Controle de Serviços e Sistemas CGCSS é a responsável pelas transferências dos recursos financeiros destinados ao custeio da Alta e Média Complexidade e das ações estratégicas aos estados e municípios em Gestão Plena do Sistema de Saúde, bem como aos prestadores de serviços com 27 Estados e 667 municípios nessa modalidade de Gestão.

Dentre suas atribuições específicas, destacam-se:

2.5.1 apurar os dados, controlar e avaliar os procedimentos do Teto MAC;

2.5.2 preparar os processos das autorizações de pagamentos para as transferências de recursos financeiros;

2.5.3 controlar e acompanhar os gastos dos Estados com a Assistência Ambulatorial e Hospitalar da Média e Alta Complexidade, além dos procedimentos FAEC;

2.5.4 realizar auditorias internas à Coordenação sobre o SIH e SIA;

2.5.5 manter atualizado o banco de dados dos cadastros de Estados e Municípios habilitados em Gestão Plena;

2.5.6 manter atualizados os dados relativos aos valores transferidos e pagos aos Estados e Municípios em Gestão Plena;

2.5.7 analisar e encaminhar os processos de auditoria ao Tribunal de Contas da União e à Secretaria de Controle Interno;

2.5.8 analisar e emitir pareceres técnicos em documentações enviadas pelos Estados, Municípios, prestadores de serviços, usuários do SUS e diversas entidades públicas e privadas que solicitam orientações sobre assuntos diversos relacionados aos repasses de recursos do SUS;

2.5.9 elaborar portarias de cadastros com tetos financeiros; 
2.5.10 elaborar portarias sobre o impacto financeiro dos credenciamentos de UTIs, TRS, CACON (Projeto Expande) e dos ajustes da Tabela de Procedimentos do INTEGRASUS, IAPI, PAB indígena, de acordo com as inclusões, exclusões e alterações de ações e serviços; e

2.5.11 mais recentemente, controlar os orçamentos.

A evolução da produção ambulatorial SUS é apresentada no Quadro 7, com enfoque sobre as ações ambulatoriais de Saúde Bucal segundo os níveis de complexidade. Entre 2000 e 2006, observa-se aumento nos percentuais de procedimentos MAC ambulatoriais SUS, bem como sobre os procedimentos de odontologia.

Quadro 7 - Produção ambulatorial total e odontologia SUS segundo níveis de complexidade nos anos 2000, 2003 e 2006 - Brasil.

\begin{tabular}{|l|c|c|c|}
\hline $\begin{array}{l}\text { Produção ambulatorial } \\
\text { SUS }\end{array}$ & 2000 & 2003 & 2006 \\
& & & \\
\hline TOTAL SUS & 1.583 .844 .132 & 1.969 .314 .789 & 2.340 .915 .218 \\
\hline Atenção básica & 990.243 .733 & 1.163 .216 .381 & 1.154 .028 .700 \\
\hline MAC & 593.600 .399 & 806.098 .408 & 1.186 .886 .518 \\
\hline \multicolumn{3}{|l|}{} \\
\hline TOTAL ODONTOLOGIA & 183.605 .066 & 210.143 .769 & 211.877 .167 \\
\hline Atenção básica & 178.970 .926 & 203.530 .456 & 204.562 .408 \\
\hline MAC & 4.634 .140 & 6.613 .313 & 7.314 .759 \\
\hline média complexidade & 4.593 .353 & 6.524 .320 & 7.192 .168 \\
\hline alta complexidade & 40.787 & 88.993 & 122.591 \\
\hline
\end{tabular}

Fonte: Ministério da Saúde - SIA/SUS - TabNet Win [acesso 25/02/2007]

Notas:

MAC - soma da média e alta complexidade

Dados sujeitos a alteração.

Observa-se que entre 2000 e 2006, a produção ambulatorial total SUS apresentou um aumento de $48 \%$, enquanto suas componentes Atenção Básica e MAC tiveram um incremento de $17 \%$ e $100 \%$, respectivamente.

A prioridade geral dada aos procedimentos MAC, também pode ser verificada no aumento da composição percentual entre esses anos, ou seja, 
em 2000, 37,47\% dos procedimentos ambulatoriais era MAC, enquanto que em 2006 esse porcentual aumentou para $50,70 \%$.

No que tange à Saúde Bucal, os procedimentos ambulatoriais totais de odontologia SUS tiveram um incremento de $15,4 \%$, enquanto suas componentes Atenção Básica e MAC tiveram um aumento de $14,3 \%$ e $58 \%$, respectivamente.

Também aqui, é observado um aumento dos procedimentos MAC na composição porcentual: em $2000,2,5 \%$ dos procedimentos de odontologia ambulatorial era MAC, enquanto, em 2006, esse porcentual aumentou para 3,5\%.

Ao se avaliar, separadamente, a produção da MAC em odontologia, destaca-se que o maior incremento ocorreu na Alta Complexidade com $200,56 \%$ de aumento, enquanto que na Média Complexidade o aumento foi de $57 \%$.

Tais resultados revelam que a oferta de procedimentos MAC em Saúde Bucal, ainda que insuficiente, vem tendo alguma priorização por parte do poder público, embora estudos mais aprofundados sejam necessários para se avaliar a assistência secundária à população.

Relativamente ao setor Saúde Suplementar, tais avaliações ainda não possíveis de serem feitas, em função dos bancos de produção ainda não se apresentarem disponíveis. As avaliações se dão em função do número de beneficiários, freqüência de utilização e custos por procedimento, sendo sempre apresentadas em forma de relatórios gerenciais.

Segundo dados do Relatório de Gestão 2000-2003 da ANS, em 2001, a população cadastrada nas Cooperativas Odontológicas era de 693.415 beneficiários e nas Odontologias de Grupo era de 1.656 .799 beneficiários. Em 2003, esses números para 1.229.432 nas Cooperativas e 2.767.072 nas Odontologias de Grupo (ANS 2004), totalizando 3.996.504 de beneficiários cadastrados somente nessas duas modalidades. 
Quadro 8- Número de beneficiários de planos odontológicos da assistência suplementar segundo a modalidade de plano, nos anos 2001, 2003 e 2007.

\begin{tabular}{|l|c|c|c|}
\hline \multicolumn{4}{|c|}{ Beneficiários planos odontológicos } \\
\hline Modalidade & 2001 & 2003 & 2007 \\
\hline Cooperativa odontológica & 693.415 & 1.229 .432 & 1.733 .772 \\
\hline Odontologia de grupo & 1.656 .799 & 2.767 .072 & 5.192 .511 \\
\hline Outras (filantrópicas, etc) & $\ldots$ & $\ldots$ & 1.325 .451 \\
\hline Total & $\ldots$ & $\ldots$ & $\mathbf{8 . 2 5 1 . 7 3 4}$ \\
\hline
\end{tabular}

Fonte: ANS - www.ans.gov.br

Comparativamente aos EUA, Mayes (2002), citado pela ANS (2002), afirma que, em 1962, 1 milhão de pessoas, representando menos de $1 \%$ da população dos Estados Unidos, estavam cobertas por algum tipo de plano odontológico. Em 1970, esse número havia crescido para mais de 12 milhões de pessoas ou $6 \%$ da população daquele país. Já em 1999, a Associação Nacional de Planos Odontológicos americana estimou que 153 milhões de pessoas, representando $56 \%$ da população possuíam algum tipo de plano odontológico.

Para a ANS (2002), as formas como o setor público e o privado se organizam em determinado país é um fator que influencia diretamente o nível de saúde bucal e, caso o Estado não oferte serviços odontológicos de qualidade a todos, a parcela da população não atendida deverá demandar esses serviços no mercado privado. Assim, a renda da população passa a ser determinante para o recebimento do tratamento odontológico que estará sujeito às características do mercado.

A assistência odontológica no Brasil caracteriza-se por ser predominantemente privada. Cerca de 29 milhões de brasileiros nunca receberam nenhum tipo de assistência odontológica, sendo que a cobertura e a abrangência da assistência oferecida pelo setor público ainda são incipientes. No entanto, o Estado possui um papel relevante na melhoria dos índices de saúde bucal a partir da 
fluoretação das águas de abastecimento público e da inserção do flúor nas pastas de dentes (ANS 2002).

Segundo Zanetti (2000), citado pela ANS (2002), a expansão de novas formas de prestação de serviços odontológicos, através de credenciamentos e convênios junto a operadoras de planos odontológicos, foi decorrente dos seguintes fatores.

Até os anos de 1980, a odontologia proporcionava uma boa remuneração aos profissionais com grande procura pelos serviços privados (consultórios particulares), o que incentivou a formação de novos dentistas, aumentando a concorrência no mercado.

A partir dos anos de 1980, houve um desequilíbrio entre a oferta e a procura por assistência bucal na esfera privada, devido à redução do poder de compra da classe média brasileira (fim do milagre econômico). Em 1984, iniciouse a expansão das ações e medidas de promoção e prevenção em saúde bucal, através da expansão da cobertura por meio da fluoretação das águas de abastecimento público e dos dentifrícios comercializados no país, modificando os níveis de incidência e prevalência de cárie dentária.

Para a ANS (2002), a intervenção do Estado nos serviços odontológicos se dá de forma direta, através da oferta pública de serviços e de forma indireta pela regulação de mercados, através de instrumentos de regulação para o controle dos preços, o controle de entradas, as regras de solvência e de parâmetros de qualidade e eficiência, entre outros.

O profissional que decidir ofertar seus serviços por meio de uma operadora de planos odontológicos poderá optar por se tornar parte de sua rede credenciada ou de sua rede própria nas seguintes modalidades: odontologia de grupo; cooperativa odontológica; autogestão; administradora de serviços (cartão-desconto); ou uma operadora de plano médico que também oferte o produto odontológico, bem como uma seguradora. Para tanto, a operadora deverá atender aos requisitos das regulamentações emanadas pela ANS.

Ao abordar o mercado de planos odontológicos, a ANS (2002) destaca as principais diferenças entre os planos médicos e odontológicos no 
que refere às características do tratamento, da doença, do risco, da sensibilidade a preços e da estrutura de relacionamentos entre os agentes do mercado.

As principais doenças bucais são a cárie $\mathrm{e}$ as periodontopatias, com alta previsibilidade de ocorrência, facilmente diagnosticadas no consultório do dentista (custo do diagnóstico é baixo) e com várias possibilidades de prevenção e tratamento. Por serem doenças crônicas e não comunicáveis raramente há risco de vida, sendo que o tratamento possui alta previsibilidade de término $\mathrm{e} o$ indivíduo pode planejar livremente sobre quando realizar um tratamento odontológico, possibilitando maior liberdade na escolha do profissional que irá atendê-lo.

Na medicina há um grande número de doenças com menor previsibilidade de ocorrência, custo de diagnóstico elevado, limitadas alternativas terapêticas e o tempo de tratamento tende a não ser previsível, na medida em que a cura do paciente depende de fatores que não só medicamentos prescritos ou fisioterapia indicada. Além disso, as emergências e os casos não tratados podem ter conseqüências dramáticas na saúde dos indivíduos.

A maioria dos planos de assistência médico-hospitalares trabalha com uma alta sinistralidade ${ }^{50}$ e uma baixa freqüência de utilização de procedimentos de alto custo. Ao contrário, os planos de assistência odontológica trabalham com baixa sinistralidade e alta freqüência de utilização de procedimentos de baixo custo que tende a se estabilizar, na medida em que as necessidades acumuladas sejam tratadas.

Tais fatos justificam a maior sensibilidade dos indivíduos às mudanças de preços dos serviços odontológicos, em relação aos preços dos serviços médicos, bem como uma maior possibilidade de poder de mercado por parte das empresas médicas (ANS 2002).

A estrutura de relacionamento no mercado de Planos Odontológicos é menos complexa quando comparada à estrutura de relacionamento de Planos Médico-Hospitalares. Enquanto o dentista decide sobre as alocações de recursos dentro do seu próprio consultório, o médico decide sobre internações

\footnotetext{
${ }^{50}$ Sinistralidade - prejuízo ou dano sobre um bem assegurado.
} 
hospitalares, exames, procedimentos terapêuticos e medicamentos, resultando em estruturas de relacionamento mais complexas entre os agentes desse mercado de Planos de Saúde (beneficiários, prestadores de serviços e operadora).

No mercado dos Planos de Saúde, a demanda é sempre representada pelo usuário ou beneficiário que, avesso ao risco financeiro oriundo da ocorrência de doenças aleatórias que fogem ao seu controle, contrata um seguro ou plano de saúde. No setor de planos odontológicos, essa oferta é representada pelo dentista e no setor de planos médico-hospitalares a oferta está focada na figura do médico e de um amplo conjunto de provedores (hospitais, clínicas, laboratórios, medicamentos).

Pelo lado da demanda, a existência de um seguro, seja ele médico-hospitalar, odontológico, de acidente de trabalho ou seguro de automóvel, costuma originar o chamado risco moral ou moral hazard, que é o incentivo (sic) que o indivíduo tem por não se precaver da forma eficiente ou por utilizar um determinado serviço além do nível desejado (ANS 2002; CASTRO 2002).

Segundo esses autores, esse efeito sobre as operadoras se dá pelo aumento do custo decorrente do excesso de utilização dos beneficiários, acarretando a criação de mecanismos que impeçam ou minimizem tal comportamento. Como resultado, a adoção da co-participação ${ }^{51}$, das perícias, e das tecnologias de informação em planos odontológicos inibiria essa demanda excessiva.

Outra relação que envolve assimetria de informação entre a operadora e o beneficiário é a seleção adversa. Aqui, tanto a operadora, por desconhecer os riscos exatos dos indivíduos, pode selecionar riscos ruins ao estabelecer contratos assentados na média do mercado, como o beneficiário, ao observar num plano de saúde a alternativa menos custosa para os tratamentos dentários que deseja realizar, adquirir o plano com conseqüências graves para a viabilidade econômica da carteira (ANS 2002; CASTRO 2002).

Como solução, algumas operadoras passaram a avaliar o risco de cada indivíduo com base na história pessoal e familiar, resultando em aumentos perversos para os grupos dos doentes crônicos e dos idosos, os quais,

\footnotetext{
\$1 Co-participação - divisão de custos entre a operadora e os beneficiários.
} 
provavelmente, não terão condições financeiras de manter seu plano (CASTRO 2002)

Em relação à oferta, o risco moral pode ser observado pela indução da demanda pelos prestadores médicos e dentistas com o objetivo de aumentar de sua remuneração. Como mecanismos de contenção, estruturaram-se novas formas alternativas de remuneração de provedores, como o capitation $^{52}$ em substituição ao fee-for-service ${ }^{53}$, onde o provedor fica responsável pelo atendimento de um determinado grupo de indivíduos por um valor pactuado per capita. (ANS 2002; CASTRO 2002; SORIA 2002).

Relativamente aos recursos humanos em Saúde Bucal, o Conselho Federal de Odontologia e os 27 Conselhos Regionais de Odontologia, criados pela Lei 4324, de abril de 1964 e posteriormente instituídos pelo Decreto 68704, de 03 de junho de 1971, têm como finalidade a supervisão da ética odontológica em todo o território nacional. Dados ${ }^{54}$ de novembro de 2007 indicam o número de profissionais inscritos em todo o Brasil: 63.325 Atendentes de Consultório Dentário; 7.366 Técnicos em Higiene Dental; 17.541 Técnicos em Prótese Dentária; 3.391 Auxiliares de Prótese Dentária e; 217.890 CirurgiõesDentista.

Segundo esse órgão, existem no país 188 faculdades de odontologia: 134 particulares; 27 federais; 19 estaduais e 8 municipais. Do total, 126 encontram-se nas regiões Sul e Sudeste.

\footnotetext{
${ }^{52}$ Capitação - base no pagamento de um valor mensal fixo per capita, isto é, o profissional recebe antecipadamente uma determinada quantia por cada paciente que compõe sua rede (SORIA e col. 2002)

${ }^{53}$ Fee-for-service - remuneração por taxas por serviço

54 http://www.cfo.org.br/husca dados/totais/tot_prof cro.asp
} 


\section{OBJETIVO}

Identificar os instrumentos criados pelos poderes de Estado para fazer a regulação sobre a atenção à Saúde Bucal e analisar o seu emprego pelos órgãos e instituições competentes. 


\section{MATERIAL E MÉTODO}

Pesquisas assentadas em documentos, sejam revisões bibliográficas ou pesquisas historiográficas, extraem deles a análise, organizandoos e interpretando-os segundo os objetivos da investigação (PIMENTEL, 2001; BARDIN 2004).

Contudo, BARDIN (2004) destaca diferenças entre a análise documental e a análise de conteúdo. Enquanto a primeira classifica e indexa documentos com o objetivo de condensar a informação para a consulta e armazenagem, a análise de conteúdo se ocupa das mensagens (comunicação) que são trabalhadas para "evidenciar indicadores que permitam inferir sobre outra realidade que não a da mensagem" (p.41).

Uma das técnicas da análise de conteúdo é a análise temática, pela qual se tenta descobrir os núcleos de sentido que compõem a comunicação, através de unidades de registros denominados temas ou eixostemáticos. Tais unidades se constituem em núcleos de significado que sistematizam um conjunto de assuntos (PIMENTEL, 2001; BARDIN 2004).

Nessa lógica, o estudo buscou identificar a regulação (macroregulação) da atenção à Saúde Bucal em documentos selecionados na produção legislativa federal, nos atos normativos ministeriais editados pelo setor Saúde e nos documentos aprovados pelo Conselho Nacional de Saúde ${ }^{55}$ - CNS, tomando-se como base o conceito ampliado de Regulação Estatal sobre o Setor Saúde adotado pelo Ministério da Saúde (SCHILLING e col. 2006).

\footnotetext{
${ }^{55}$ O Conselho Nacional de Saúde foi instituído pela Lei $\mathrm{n}^{\circ} .378$, de 13 de janeiro de 1937, como um órgão consultivo. A Lei $n^{\circ} .8142$, de 28 de dezembro de 1990, conferiu ao CNS caráter deliberativo na definição de estratégias e no controle da execução da política de saúde, incluídos os aspectos econômicos e financeiros em cada esfera de governo. A partir de 1990, o CNS assume papel fundamental de articulador de propostas e das demandas de grupos sociais relacionados ao setor saúde.
} 
Numa primeira etapa, o objetivo foi o de encontrar as fontes e, nelas os documentos necessários para a pesquisa, sem preocupação com a análise.

Foram realizadas buscas nas principais bases de dados que reúnem as normas de caráter geral emanadas do Poder Legislativo e as editadas pelo Chefe do Poder Executivo no exercício de seu poder regulamentador. Da mesma forma, foram objeto de busca os atos normativos de nível hierárquico inferior (portarias, resoluções, instruções normativas, etc.) editados pelos Ministros de Estado e outras autoridades federais do Setor Saúde.

Para a produção Legislativa Federal, a opção foi por efetuar a pesquisa na base Legislação Federal ${ }^{56}$ do Sistema de Informações do Congresso Nacional - SICON ${ }^{57}$ Versão 2.1.2 - Prodasen do Senado Federal. Os atos normativos ministeriais do setor Saúde foram pesquisados junto às bases de dados do Sistema de Legislação em Saúde - SAÚDE LEGIS ${ }^{58}$.

A princípio, utilizou-se o cruzamento das palavras-chave regulação x bucal, regulamentação x bucal, legislação x odontologia. Face ao pequeno número de regras legais encontradas, reformulou-se o levantamento através da incorporação de palavras-chave isoladas como bucal, oral, odontologia, fluoretação, flúor, dentista, exercício, dentária, dente, cárie, gabinete, cirurgião, entre outras. Nessa nova busca, encontrou-se vasto número de regras legais que não correspondiam aos objetivos deste estudo, além de algumas se apresentarem, repetidamente, nos diferentes levantamentos.

\footnotetext{
${ }^{56}$ Excluídos da pesquisa os discursos dos senadores, as matérias em tramitação, os recortes de jornais e o acervo da biblioteca da Rede Virtual de Bibliotecas do Congresso Nacional - RVBI. Incluídas todas as normas, vigentes e revogadas.

${ }^{57} \mathrm{O}$ SICON se fundamenta na alimentação, processamento e manutenção de bases de dados destinadas às atividades do Senado Federal e do Congresso Nacional, englobando as áreas parlamentar, legislativa, orçamentária e administrativa. Essas bases, por sua vez, se compõem de vários registros interrelacionados e organizados de forma a atender às necessidades de informação dos usuários e a promover o intercâmbio e a interação dessas informações ( http://www6.senado.gov.br/sicon/PreparaPesquisa.action).

${ }_{58}$ O SAÚDE LEGIS objetiva disponibilizar os atos normativos da esfera federal do SUS, publicados nas Seções 1 e 2 (exceto a legislação de pessoal) do Diário Oficial da União e nos Boletins de Serviço, sendo um banco de dados único o que facilita a pesquisa, que pode ser feita por tipo de norma, número, data, assunto e órgão de origem, com textos completos dos atos normativos publicados a partir de 2003 (http://portalweb05.saude.gov.br/saudelegis/leg norma pesq_consulta.cfm).
} 
Assim, após uma seleção, optou-se pelas regras legais que pudessem responder às questões da pesquisa ou, mais especificamente, que abordassem a regulamentação de temas relativos à atenção da Saúde Bucal.

A busca realizada abrangeu as regras legais e os atos normativos aprovados em todo o período a partir do qual essas regulamentações ficaram disponíveis nos sistemas, ou seja, 1808 para o SICON e 1946 para o SAÚDE LEGIS, sendo que a amplitude geral das datas estendeu-se de 1824 a julho de 2007.

A definição desse período se deu em função da tentativa de se resgatar um histórico sobre os temas e os setores regulamentados relativos à atenção à Saúde Bucal no Brasil. Além disso, em determinados períodos a regulamentação mostrou-se escassa, fato devido, provavelmente às características do ordenamento jurídico brasileiro ${ }^{59} \mathrm{e}$ das relações entre instituições de saúde e estruturas sociais, políticas e econômicas vigentes nos vários períodos.

Outras regulamentações de interesse também foram rastreadas por vias não sistemáticas, a partir de referências secundárias, internet e leituras de rotina, destacando-se as portarias mais importantes na condução geral da política de saúde, em função de sua capacidade de regular o sistema e das mudanças introduzidas no cenário institucional ${ }^{60}$.

Para a leitura dos textos completos indisponíveis no SICON e no SAÚDE LEGIS, realizou-se pesquisa direta no site do Ministério da Saúde ${ }^{61}$, no Sistema de Legislação Informatizada - LEGIN ${ }^{62}$, entre outros.

Os documentos selecionados do Conselho Nacional de Saúde foram os previstos em seu Regimento Interno ${ }^{63}$, ou seja, as resoluções, as

\footnotetext{
${ }^{59}$ Segundo Ives Gandra da Silva Martins Filho “... o ordenamento jurídico brasileiro se apresenta como um todo não harmônico, nebuloso, repleto de incongruências e de comandos repetitivos..." (MARTINS FILHO, 1999).

${ }^{60}$ Normas Operacionais Básicas (NOB 91,92,93,96), Normas Operacionais da Assistência à Saúde (NOAS 01/2001 e 01/2002), Pacto de Gestão (2006).

${ }^{61}$ Site do Ministério da Saúde com atos normativos disponíveis a partir de 1989 http://portal.saude.gov.br/portal/saude/area.cfm? area $=960$

${ }_{62}$ LEGIN - sistema lançado pela Câmara Federal. A indexação mostrou-se inadequada, com identificação de inúmeros assuntos não pertinentes à pesquisa. Como exemplo, "arreios bucais" em feiras agropecuárias, entre outros. (http://www2.camara.gov.br/legislacao/pesquisa.html).
} 
deliberações, moções, as recomendações, as atas e as pautas aprovadas e disponíveis no site do CNS, desde 1988. A amplitude geral das datas estendeu-se 1988 a julho de 2007. Para a busca, foram utilizadas palavras-chave isoladas relacionadas à saúde bucal e à odontologia, utilizando-se a ferramenta Editar/Localizar do Microsoft Word.

Os dados foram coletados, sistematicamente, entre os meses de abril e agosto de 2007, período destinado à pesquisa, à reprodução dos documentos da amostra, à leitura e à análise das regulamentações e atos do CNS. Numa primeira leitura, excluíram-se os que não interessavam ao trabalho, sendo considerados, na seleção, o conteúdo dos mesmos e sua relação com a questão da pesquisa. Foram incluídas todas as regulamentações viventes e não vigentes e, da mesma forma, todos os assuntos relativos à saúde bucal registrados nos documentos do CNS fizeram parte da amostra.

Com nova leitura, preencheu-se o Instrumento de Coleta de Dados (Anexo A) identificando os eixos-temáticos, temas e assuntos emergentes cronologicamente. Embora fosse uma classificação grosseira, pois um documento poderia abranger várias unidades temáticas, os documentos foram agrupados de acordo com os seguintes tópicos:

- gestão e organização do sistema e da assistência à saúde bucal;

- financiamento;

- programas e ações em saúde bucal; e

- outros $^{64}$.

Considerou-se importante que os documentos da produção Legislativa também fossem classificados segundo o setor de atividade regulamentado e a origem da norma (Executivo e Legislativo). Para a análise, os

\footnotetext{
${ }^{63}$ Regimento Interno aprovado pela Resolução CNS $\mathrm{n}^{\circ}$. 291, de 6 de maio de 1998 http://www.conselho.saude.gov.br.

${ }^{64}$ Tal como a análise realizada por BAPTISTA (2003) sobre a Política de Saúde no Pós-Constituinte, aqui também houve a necessidade se adotar o eixo-temático Outros. Esse tópico congrega assuntos que não são diretamente relacionados às ações e aos serviços de saúde bucal, como a estruturação do ensino superior, a estruturação do exercício profissional, as isenções às associações e entidades de classe, etc. Contudo, essas regulamentações tiveram grande importância em todo o período analisado e serão especificadas no capítulo Resultados.
} 
documentos foram agrupados em períodos que variaram segundo as constituições federais, os períodos da história do ordenamento jurídico brasileiro ${ }^{65}$ e os períodos de governo, sendo que, após 1988, a preferência foi pela análise anual das normas editadas.

Em linhas gerais, os períodos definidos foram os seguintes:

Império e $1^{\circ}$ Governo Provisório da República (até Constituição de 24/02/1891)

República Velha (25/02/1891 a 24/10/1930)

Governo Provisório da Revolução de $30^{66}$ (03/11/1930 a 20/07/1934)

Eleições indiretas de Getúlio Vargas até Estado Novo (20/07/1934 a 10/11/1937)

Estado Novo (10/11/1937 a 29/10/1945)

Democratização ${ }^{67}(31 / 01 / 1946$ a 31/03/1964)

Golpe Militar (31/03/1964 a Constituição de 15/03/1967)

Governo Militar (15/03/1967 a 15/03/1985)

'Redemocratização' (15/03/1985 até a Constituição de 05/10/1988)

Período Pós-Constituinte (05/10/1988 até julho 2007)

Após a leitura exaustiva desses documentos, a amostra ficou

composta por 591 regras legais da produção Legislativa Federal, 495 atos normativos ministeriais e 109 documentos do $\mathrm{CNS}^{68}$.

O projeto encaminhado para a avaliação do Comitê de Ética em Pesquisa/COEP da Faculdade de Saúde Pública da Universidade de São Paulo foi aprovado em 03/02/2006 - Protocolo de Pesquisa nº 1453 (Anexo D).

\footnotetext{
${ }^{65}$ História do ordenamento jurídico: Reino Unido de Portugal e Brasil - 1808 a 1822; Império - 1822 a 1889; $1^{\circ}$ Governo Provisório da República - 1889 a 1891; República Velha - 1891 a 1930; Governo Provisório da Revolução de 1930 a 1934; Constituição de 1934 - 1934 a 1937; Estado Novo - 1937 a 1945; Democratização, Governo Militar e Redemocratização (MARTINS FILHO, 1999).

${ }^{66}$ As regras editadas no período da Junta Governativa de 24/10/1930 a 03/1 1/1930 foram incluídas no período Governo Provisório de Getúlio Vargas.

${ }^{67}$ Dois Decretos-Lei relativos à criação de cargos de dentista na Administração Pública foram editados no período da presidência interina de José Linhares (29/10/1945 a 31/01/1946). Em função do ordenamento jurídico e da característica da regra legal foram incluídos no período Estado Novo.

${ }^{68}$ Algumas atas do CNS dispunham sobre vários assuntos relacionados à saúde bucal. Logo, os 109 documentos da amostra geraram 180 unidades temáticas que foram agrupadas segundo os eixostemáticos.
} 


\section{RESULTADOS}

\section{REGULAÇÃO NA PRODUÇÃO LEGISLATIVA FEDERAL}

Foram analisadas 591 regras legais, das quais $91(15,39 \%)$ tiveram origem no Legislativo e $500(84,61 \%)$ no Executivo Federal (Quadro 9 Anexo B).

Do total, $527(89,17 \%)$ foram publicadas antes da Constituição Federal de 1988 e 64 (10,83\%) após essa data. Nesse segundo período, destacam-se 44 Medidas Provisórias referentes à regulamentação da Saúde Suplementar.

No período total pesquisado de 183 anos, $45,85 \%$ das regras legais foram publicadas durante o Golpe e o Governo Militar (1964 a 1985), 19,97\% durante a Democratização (1946 a 1964), 14,38\% durante o Governo Provisório, Eleições e Estado Novo de Getúlio Vargas (1930 a 1945), 10,83\% no período PósConstituição de 1988 (1985 a julho 2007), 5,92\% antes de 1930 e 3,04\% durante a Redemocratização (1985 a 1988).

Relativamente ao período, $50,54 \%$ das regras legais originadas no Legislativo foram publicadas durante o período Democratização do país (1946 a 1964) e 50,00\% das originadas no Executivo foram publicadas durante o Golpe e o Governo Militar (1964 a 1985).

Das 591 regras legais, 429 foram Decretos do Executivo, 73 Leis Ordinárias, 44 Medidas Provisórias, 28 Decretos-Lei e 17 Decretos do Legislativo. Encontrada uma Resolução do Senado Federal ${ }^{69}$.

\footnotetext{
${ }^{69}$ Resolução do Senado Federal - embora não seja classificada como regra de primeira hierarquia no ordenamento jurídico, o documento foi mantido na amostra.
} 
Quanto ao setor regulamentado, o Ensino Superior apresentou $262(44,33 \%)$, seguido pela Administração Federal com 188 (31,81\%), Forças Armadas e Segurança Pública ${ }^{70}$ com 101 (17,09\%), Exercício Profissional com $30(5,08 \%)$ e Entidades de Classe com 10 (1,69\%). (Quadro 10 - Anexo B).

A Figura 1 apresenta a evolução das regras legais por setor regulamentado, com destaque para as do Ensino Superior relativas à abertura de cursos de odontologia, a repasses de recursos, contratações, federalizações, estadualizações, inspeções e proibições/cassações de funcionamento. No período entre 1937 e 1945 (Estado Novo), foram encontrados sete Decretos do Executivo proibindo o funcionamento de cursos no país, entre eles Itapetininga-SP, CampinasSP, Campo Grande-SP. As demais regras legais em todos os períodos referem-se à estruturação e à ampliação do Ensino Superior de odontologia.

Figura 1 - Produção Legislativa Federal sobre Saúde Bucal segundo o setor regulamentado e o período - Brasil - 1824 a julho 2007.

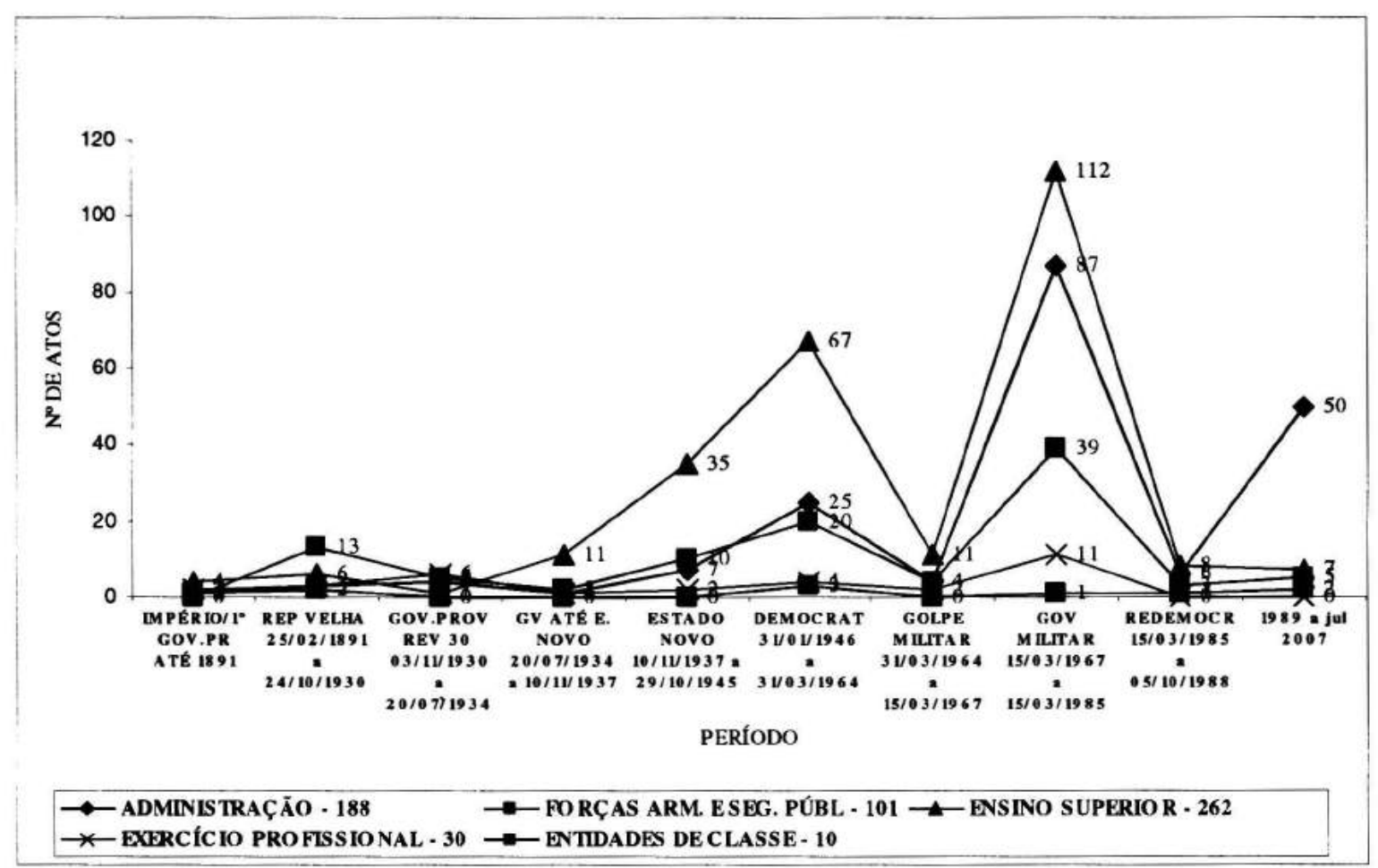

Fonte: Senado Federal - SICON

\footnotetext{
${ }^{70}$ Apesar de compor a Administração Pública, o setor das Forças Armadas recebeu uma classificação à parte, tendo em vista a maior parte das regras se referirem ao recrutamento do serviço militar e a administração de pessoal e benefícios ao pessoal militar.
} 
Os assuntos abordados nos documentos foram classificados a partir do conceito ampliado de Regulação, que tem como principais objetos os estabelecimentos, os profissionais, as relações contratuais, o exercício das profissões, a oferta e a demanda por serviços, os protocolos assistenciais, os fluxos de atendimento, a incorporação de tecnologias, além do controle e da avaliação dos custos e gastos em saúde (SCHILLING e col. 2006).

Assim, num primeiro momento, as regras legais foram classificadas por setores regulamentados. Numa segunda análise, o enfoque se deu sobre os temas regulamentados, a partir da Gestão e Regulação das ações e serviços.

Os eixos-temáticos ${ }^{71}$ ficaram assim definidos:

- Gestão e organização do sistema e da atenção à Saúde Bucal

a) Regulamentação do sistema e da atenção/assistência: regulamentações gerais da atenção à Saúde Bucal, planos, indicadores, comissões, orientações técnicas;

b) Organização da estrutura: mudanças na estrutura dos ministérios relacionados à área técnica de Saúde Bucal;

c) Regulamentação de rotinas: fluxos e práticas gerenciais;

d) Licitações e cadastros com autorização, credenciamento ou descredenciamento para o funcionamento de unidades e serviços com assistência à Saúde Bucal.

- Financiamento

a) Transferência de recursos: transferências, incentivos, isenções; b) Tabelas e procedimentos: remuneração para prestadores de serviços.

\section{- Programas e Ações de Saúde Bucal}

a) Instituição de novos programas e ações relacionadas à Saúde Bucal;

\footnotetext{
7 BAPTISTA $(2003,2007)$ elaborou classificação temática semelhante ao analisar a produção normativa do Ministério da Saúde, no Brasil, entre 1990 e 2002. Porém, no presente estudo, essa classificação sofreu variações e recebeu aberturas que permitiram evidenciar os assuntos relacionados à Saúde Bucal na produção Legislativa Federal.
} 
b) Reformulação e criação de mecanismos de controle dos programas e das ações.

\section{- Outras $^{72}$}

a) Regulamentações sobre a fiscalização e o exercício profissional, regulamentação do trabalho, regulamentação do ensino superior, cobrança de taxas e tributos, datas comemorativas, regulamentação do exercício profissional.

Dessa forma, os resultados apontaram que das 591 regras, $489(82,74 \%)$ referem-se ao eixo-temático Outras, $59(9,98 \%)$ ao eixo Gestão e organização do sistema e da assistência à saúde, 39 (6,60\%) ao eixo Financiamento/transferência de recursos e $4(0,68 \%)$ ao eixo Programas e Ações .

Figura 2 - Produção Legislativa Federal selecionada sobre Saúde Bucal, segundo os eixos-temáticos, por períodos - Brasil - 1824 a julho de 2007.

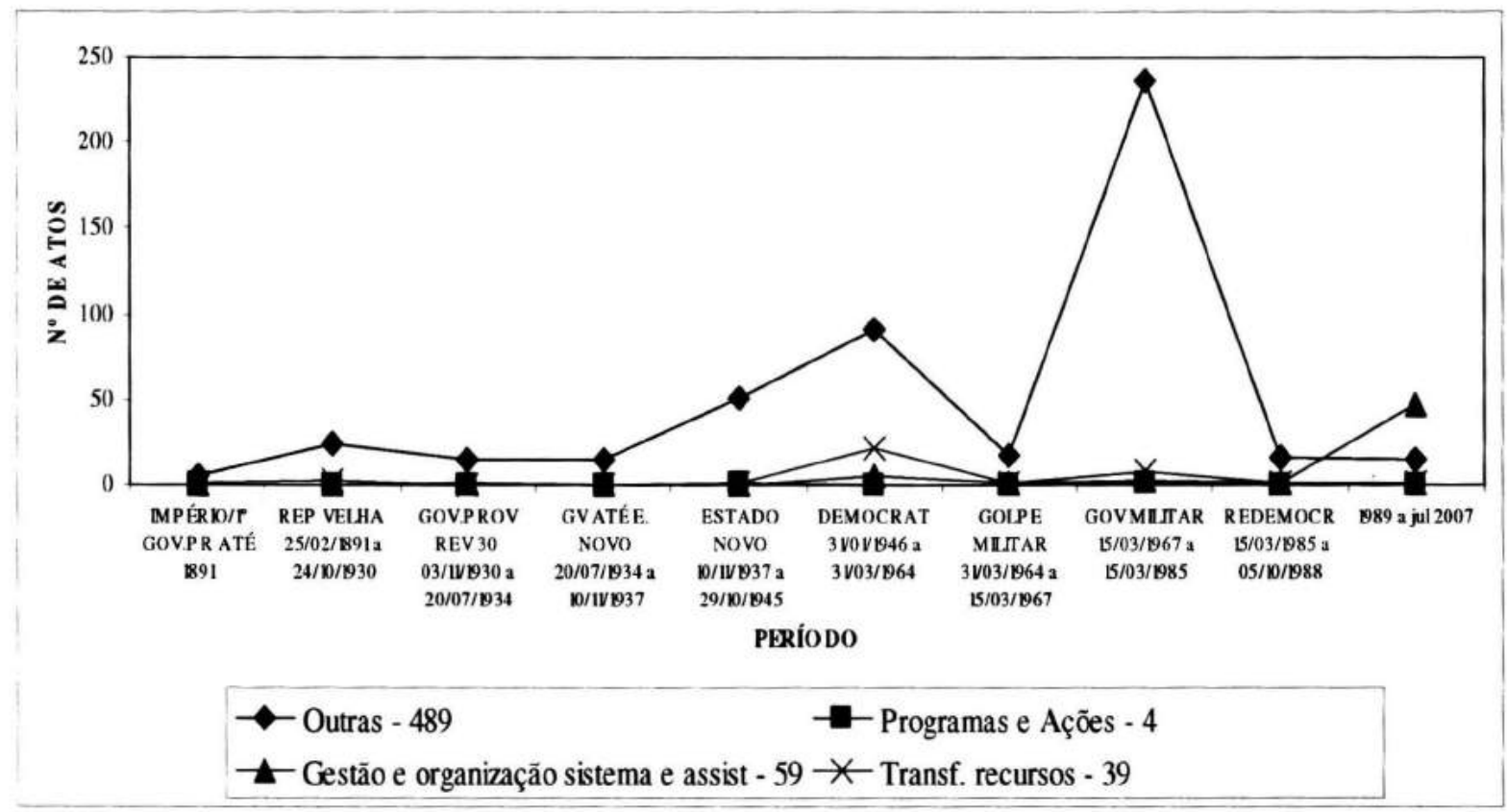

Fonte: Senado Federal - SICON

Observa-se que o eixo Programas e as Ações de Saúde Bucal não tiveram prioridade em termos de regulamentação em todo o período. Das quatro regras encontradas, duas referem-se à fluoretação das águas de abastecimento publicadas no Governo Militar, uma ao programa de assistência odontológica ao

\footnotetext{
${ }^{72} \mathrm{O}$ eixo-temático Outras aborda assuntos que não se referem diretamente à regulação das ações e serviços de Saúde Bucal, no entanto são importantes para o entendimento da conformação da profissão e das escolhas dos governantes em cada período.
} 
pessoal militar em tempos de guerra e uma à obrigatoriedade da assistência aos acidentados no trabalho, ambas publicadas durante o Estado Novo.

Na Gestão e Organização do Sistema, foram encontradas somente duas regras que regulamentam o sistema com diretrizes gerais para a saúde, citando explicitamente algum termo referente à Saúde Bucal: as Normas para Defesa e Proteção da Saúde (1954) e o Código Nacional de Saúde (1961) aprovadas durante o período Democratização (1946 a 1964). Vale destacar que mesmo nesses documentos, a ênfase se dá sobre a fiscalização dos estabelecimentos e o exercício profissional odontológico.

Das demais regras de Gestão, cinco referem-se à normatização da importação de equipamentos médico-odontológicos, uma ao controle de entorpecentes e distribuição de amostras grátis em consultórios odontológicos, quarenta e quatro relativas à regulamentação do setor de planos e seguros odontológicos e quatro relativas ao Serviço Nacional de Fiscalização Odontológica. Estas últimas, também com ênfase sobre a fiscalização de estabelecimentos.

No eixo Financiamento, observam-se vinte e nove transferências de recursos sob a forma de isenções, doações, materiais, recursos financeiros às escolas e unidades de ensino superior, nove às entidades da classe odontológica e uma à entidade assistencial.

No eixo temático Outras, mais de $65,64 \%$ das regras se referem à gestão e gerenciamento de Pessoal dos setores civil, militar, ensino superior e fiscalização de estabelecimentos e $29,24 \%$ ao Ensino Superior no que se refere à autorização de funcionamento de escolas, organização curricular e ao reconhecimento de cursos de odontologia, editadas, principalmente durante os períodos Democratização e Governo Militar.

Ainda nesse eixo, foram identificadas dezoito regras relativas à fiscalização do Exercício Profissional, sendo oito editadas no Governo Militar, sete entre o Governo Provisório de Getúlio Vargas até Estado Novo, duas antes de 1891 e uma no período Democratização. 
Em todo o período, foram identificadas 5 regras relativas à cobrança de tributos profissionais, taxas para estabelecimentos odontológicos e reajustes de alíquotas de Imposto de Renda. Destaque para duas regras sobre data e semana comemorativa da profissão e da Saúde Bucal.

$\mathrm{Na}$ Figura 3, as prioridades temáticas podem ser observadas dentro dos setores regulamentados (Quadro 11 - Anexo B).

Figura 3 - Produção Legislativa Federal selecionada sobre Saúde Bucal, segundo os setores regulamentados e os temas - Brasil - 1824 a julho 2007.

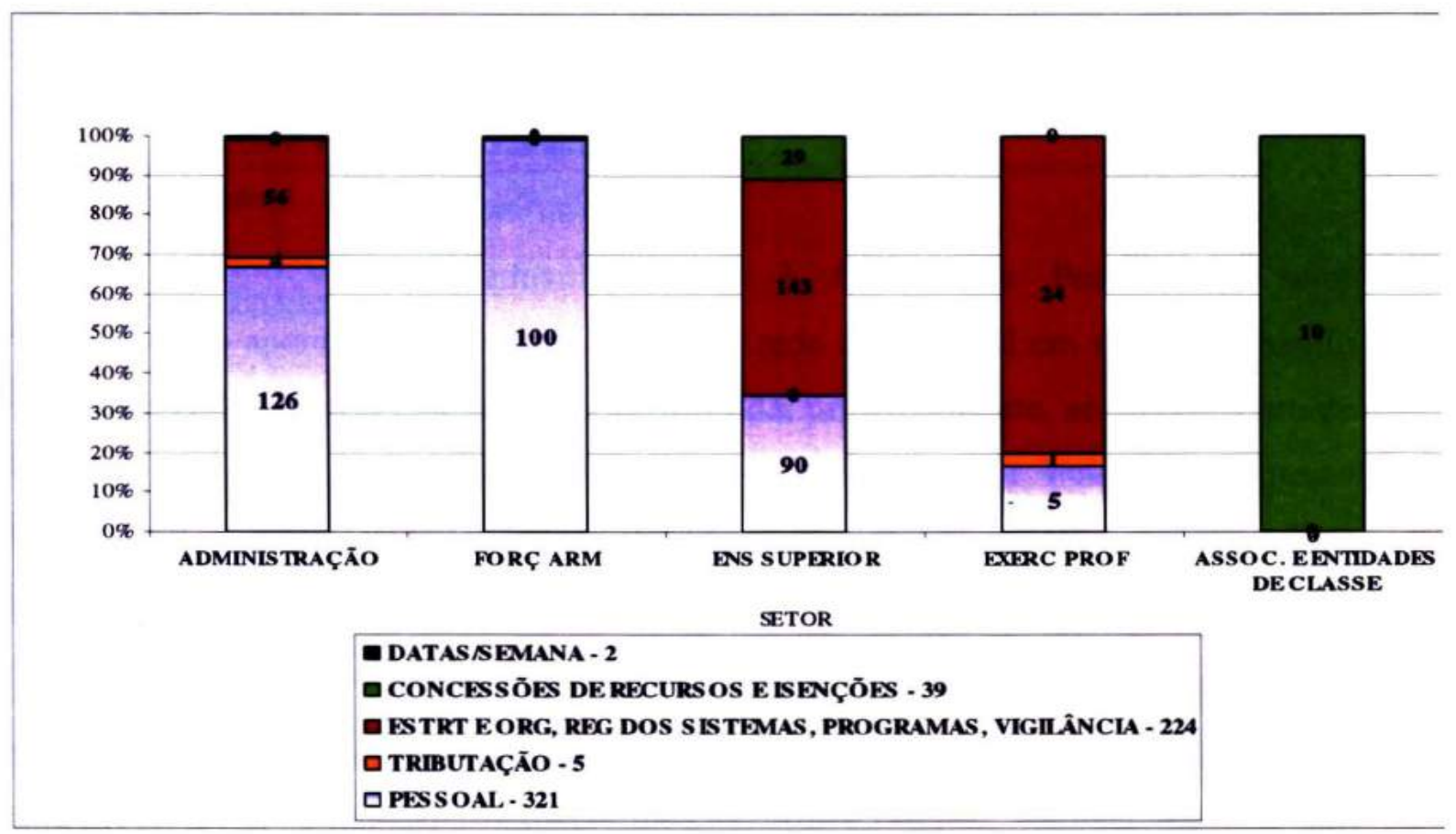

Fonte: Senado Federal - SICON 
Figura 4 - Produção Legislativa Federal sobre Saúde Bucal, segundo os temas e setores regulamentados - Brasil - 1824 a julho 2007.

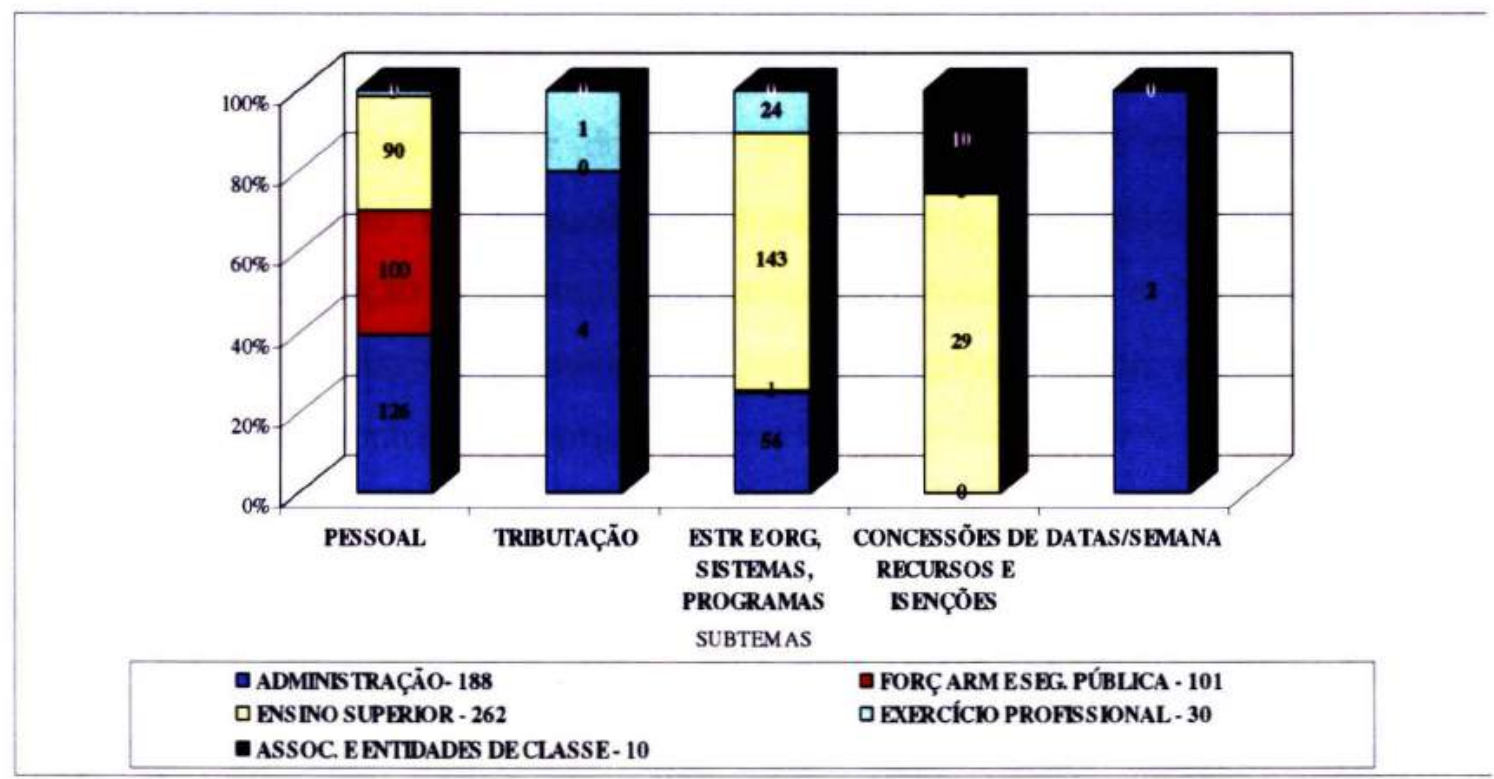

Fonte: Senado Federal - SICON

Os dados referentes à Gestão de Pessoal do setor

Administração apontam para o crescimento da rede assistencial em vários órgãos do Executivo Federal. Essa rede assistencial dirigida, principalmente, ao atendimento de funcionários públicos, pensionistas e aposentados teve seu maior crescimento durante o Governo Militar, considerando-se o ano de publicação das primeiras regulamentações identificadas (Quadro 12 - Anexo B).

Embora sejam setores regulamentados e estejam abarcados pelo conceito ampliado de Regulação utilizado neste estudo, os setores Ensino Superior, Forças Armadas, Entidades de Classe e Exercício Profissional não têm como finalidade principal a Gestão e a Organização do Sistema e da Assistência à Saúde. Assim, os atos da Administração tornam-se as principais fontes de regulamentação sobre os Programas e sobre a Gestão e Organização da Atenção.

Dessa forma, pode-se afirmar que do total de 591 regras identificadas no período, somente 56 regras legais da Administração $(9,48 \%)$ podem dizer respeito à Gestão e Programas, cabendo identificá-las para melhor análise. 
Conforme disposto no Quadro 13 - Anexo B, das 56 regulamentações identificadas, $53(94,64 \%)$ dizem respeito à Gestão e Organização do Sistema e da Assistência e 3 (5,36\%) dispõem sobre Programas.

Conforme a Figura 5, das 53 regras sobre Gestão, 45 dizem respeito à Saúde Suplementar do setor privado, 6 dispõem sobre normas de importação/exportação do mercado de equipamentos odontológicos e sobre a produção e distribuição de produtos da indústria farmacêutica e 2 dispõem sobre diretrizes gerais do sistema de saúde, com enfoque exclusivo sobre a fiscalização de estabelecimentos odontológicos privados.

Relativamente aos Programas, 1 dispõe sobre a obrigatoriedade da assistência odontológica ao contingente de trabalhadores acidentados e 2 sobre a implantação da fluoretação das águas de abastecimento público no Brasil.

Figura 5 - Produção Legislativa Federal selecionada sobre Saúde Bucal no setor Administração, segundo os temas Gestão e Programas - Brasil - 1824 a julho de 2007.

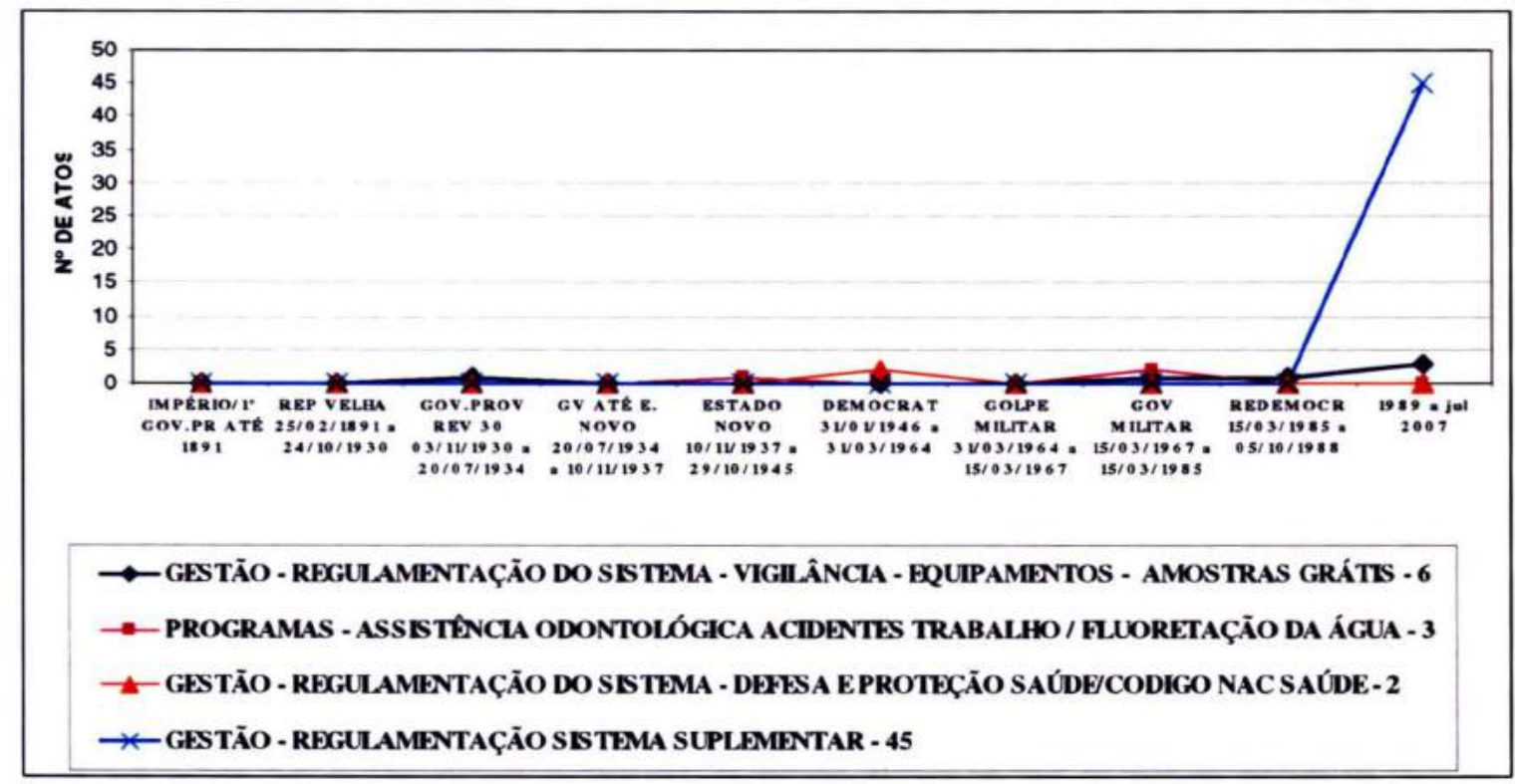

Fonte: Senado Federal - SICON 


\section{REGULAMENTAÇÃO DOS ATOS NORMATIVOS MINISTERIAIS}

No período avaliado entre 1946 e julho de 2007, foram localizadas 54.841 normas ministeriais sobre Saúde, sendo selecionadas 495 sobre Saúde Bucal.

Dos 495 atos normativos selecionados, $468(94,54 \%)$ foram publicadas a partir de 1989.

Quanto à origem da norma, 2 são do extinto Ministério dos Negócios da Educação e Saúde Pública ${ }^{73}, 492$ são do Ministério da Saúde ${ }^{74}$, sendo localizada 1 norma conjunta dos Ministérios da Justiça e Saúde (Quadro 14 - Anexo C).

O preenchimento do instrumento de coleta de dados permitiu uma primeira classificação dos atos normativos segundo suas abordagens temáticas:

- Gestão e organização do sistema e da atenção à saúde bucal

a) Regulamentação do sistema ${ }^{75} \mathrm{e}$ da atenção/assistência à Saúde Bucal: estratégias para o controle e avaliação da atenção à saúde bucal, normas para credenciamento de serviços, planos, orientações técnicas específicas para a organização da atenção, pactuações, assessorias;

\footnotetext{
${ }^{73}$ Decreto 19.402, de 14/11/1930 - criação do Ministério dos Negócios da Educação e Saúde Pública, durante o Governo Provisório da Revolução de 30. As duas áreas, antes subordinadas ao antigo Ministério da Justiça e Negócios Interiores, passaram a ter pasta própria. Essa nova estrutura incorporou o Departamento Nacional de Saúde Pública, criado em 1896.

Em 1934, com a reforma administrativa do Governo de Getúlio Vargas, o DNSP transformou-se no Departamento Nacional de Saúde - DNS (LIMA e PINTO, 2003).

${ }^{74}$ Lei 1.920, de 25/07/1953 - criação do Ministério da Saúde, durante o segundo governo de Getúlio Vargas. A partir de então, o Ministério da Saúde passou a encarregar-se especificamente das atividades do Departamento Nacional de Saúde (LIMA e PINTO, 2003).

${ }^{75}$ As regulamentações que apresentam as Normas Operacionais Básicas (NOB/SUS 91, 92, 93, 96), as Normas Operacionais da Assistência à Saúde (NOAS/SUS 2001 e 2002) e a Portaria GM/MS nº. 399, de 22/02/2006 que divulga as diretrizes do Pacto pela Saúde não foram incluídas na amostra por se constituírem em instrumentos de regulamentação geral do sistema.
} 
b) Organização da estrutura: alterações da estrutura do Ministério da Saúde, relacionadas à área técnica de Saúde Bucal;

c) Regulamentações de rotinas: organização dos fluxos e práticas gerenciais;

d) Cadastros: autorização, credenciamento ou descredenciamento para o funcionamento de unidades e serviços.

- Financiamento

a) Transferência de recursos: incentivos com recursos específicos para programas, campanhas e ações verticais;

b) Tabelas e procedimentos: inclusão e revisão de procedimentos e valores para remuneração de prestadores de serviços.

- Programas e ações em saúde bucal

a) Instituição de novos programas e ações de saúde bucal: instituição de novos programas, campanhas de cirurgia e integração das ações de saúde bucal às demais políticas setoriais;

b) Reformulação e criação de mecanismos de controle dos programas e das ações.

- Outras

a) temas diversos: conferências, datas comemorativas, exercício profissional, ensino superior, regulamentações do trabalho e educação.

Conforme a Figura 6, entre 1946 e 1988, foram publicadas 27 normas, sendo 10 sobre Gestão (37,04\%); 2 sobre Programas (7,41\%); e 15 Outras regulamentações $(55,56 \%)$. 
Figura 6 - Atos normativos ministeriais sobre Saúde Bucal por eixos-temáticos e períodos - Brasil -1946 a 1988.

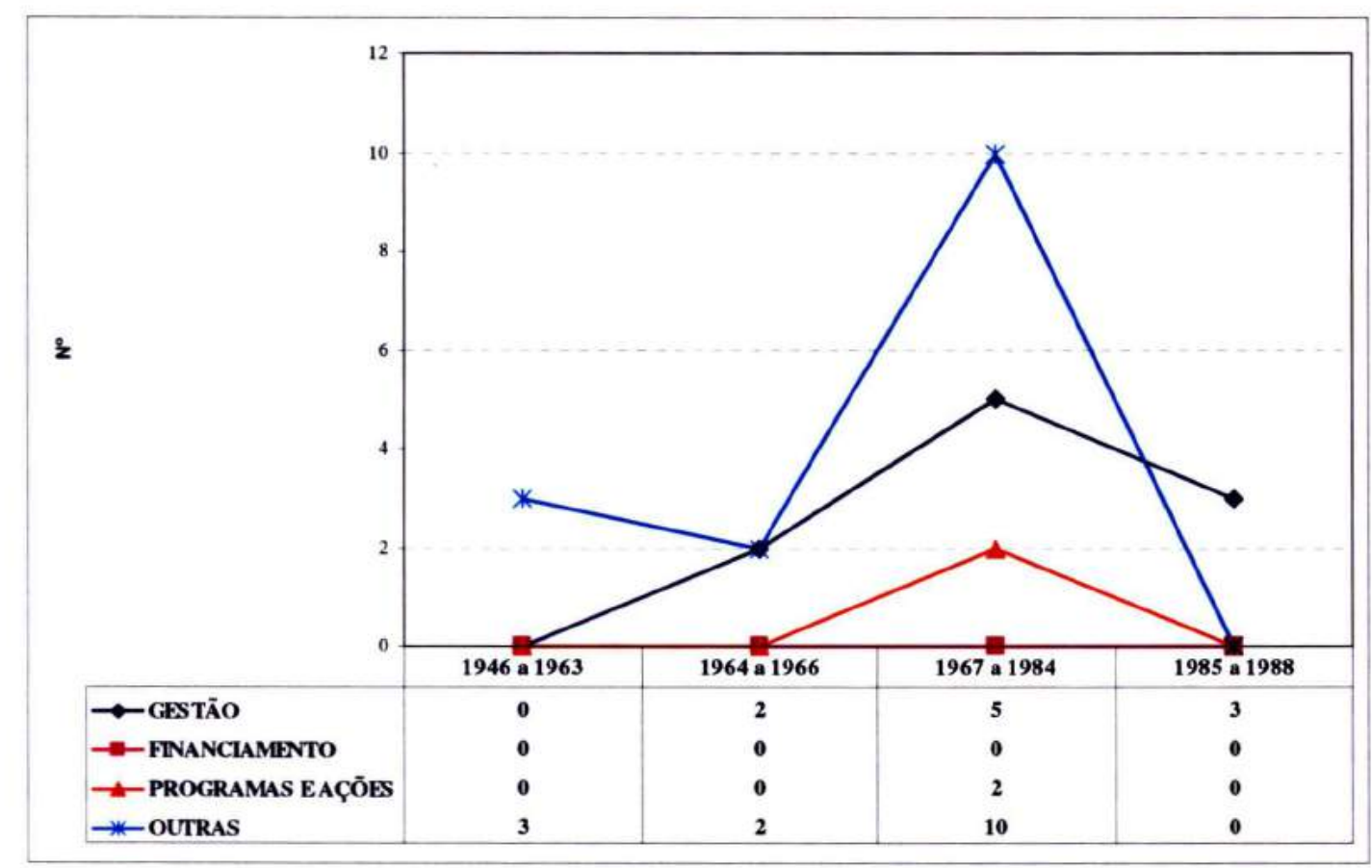

Fonte: Sistema de Legislação em Saúde - SAÚDE LEGIS - wwww.saude.gov.br/saudelegis

Nesse período, predominaram as regulamentações do eixotemático Outras (15), dispondo sobre vários assuntos desarticulados entre si que vão de data comemorativa (1989), exercício profissional, alguns aspectos sobre a gestão do trabalho e educação formal, como estágios em serviço, reconhecimento de cursos de prótese e comissões para estudo das funções de pessoal auxiliar.

Em segundo lugar, aparecem os assuntos relativos à Gestão (10) com regulamentações que dispõem sobre assessorias, consultorias, alterações de estruturas organizacionais, normas sobre equipamentos odontológicos, embalagens de produtos e proteção radiológica. Por último, os Programas e as Ações de Saúde Bucal (2) representados por duas regulamentações que dispõem sobre a fluoretação das águas de abastecimento público.

Tais regulamentações não parecem capazes de desenhar uma política de Saúde Bucal para o período, na medida em que os assuntos são tratados de forma pontual e esparsa. As Figuras 7, 8 e 9 apresentam detalhes sobre essa questão. 
Figura 7 - Atos normativos ministeriais sobre Saúde Bucal, eixo-temático Outras, por períodos - Brasil - 1946 a 1988.

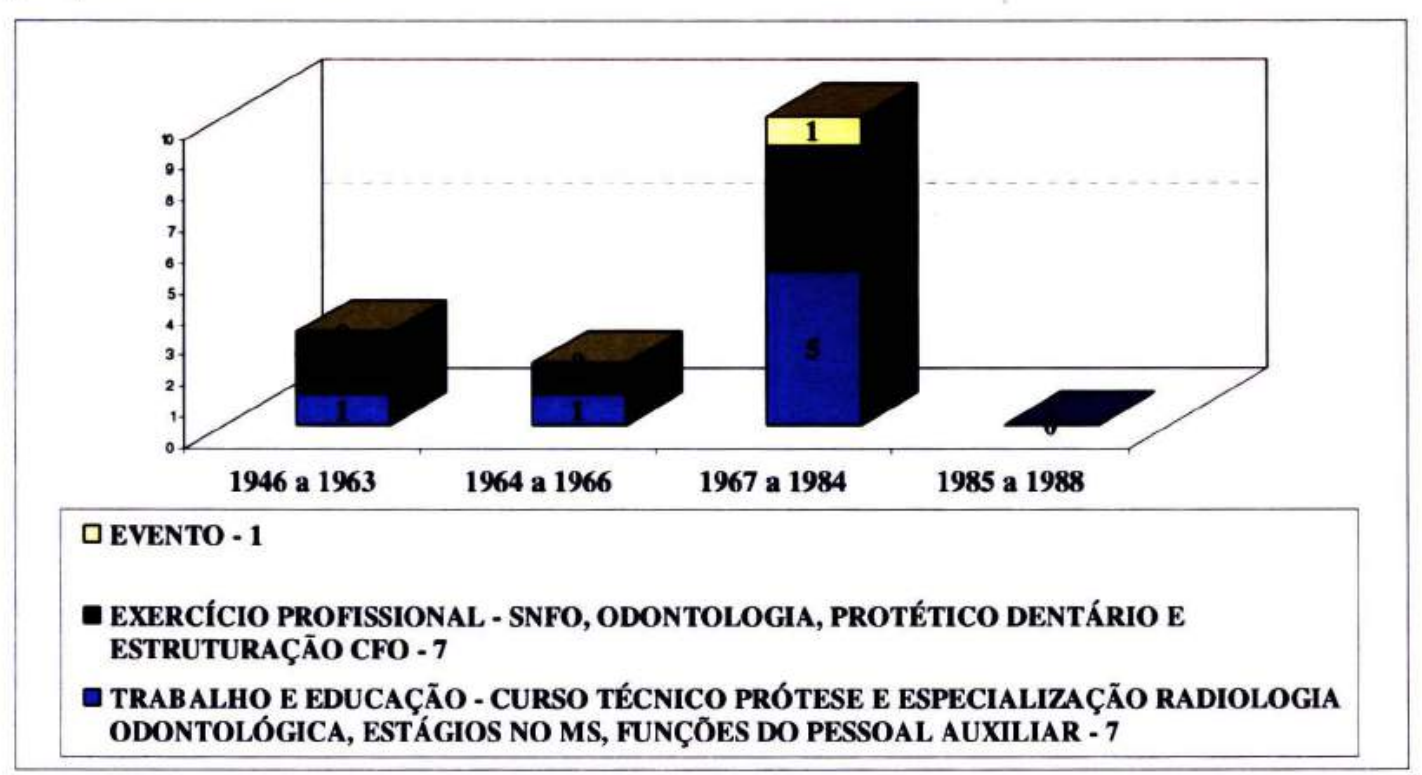

Fonte: Sistema de Legislação em Saúde - SAÚDE LEGIS - www.saude.gov.br/saudelegis

Figura 8 - Atos normativos ministeriais sobre Saúde Bucal, eixo-temático Gestão, por períodos - Brasil - 1946 a 1988.

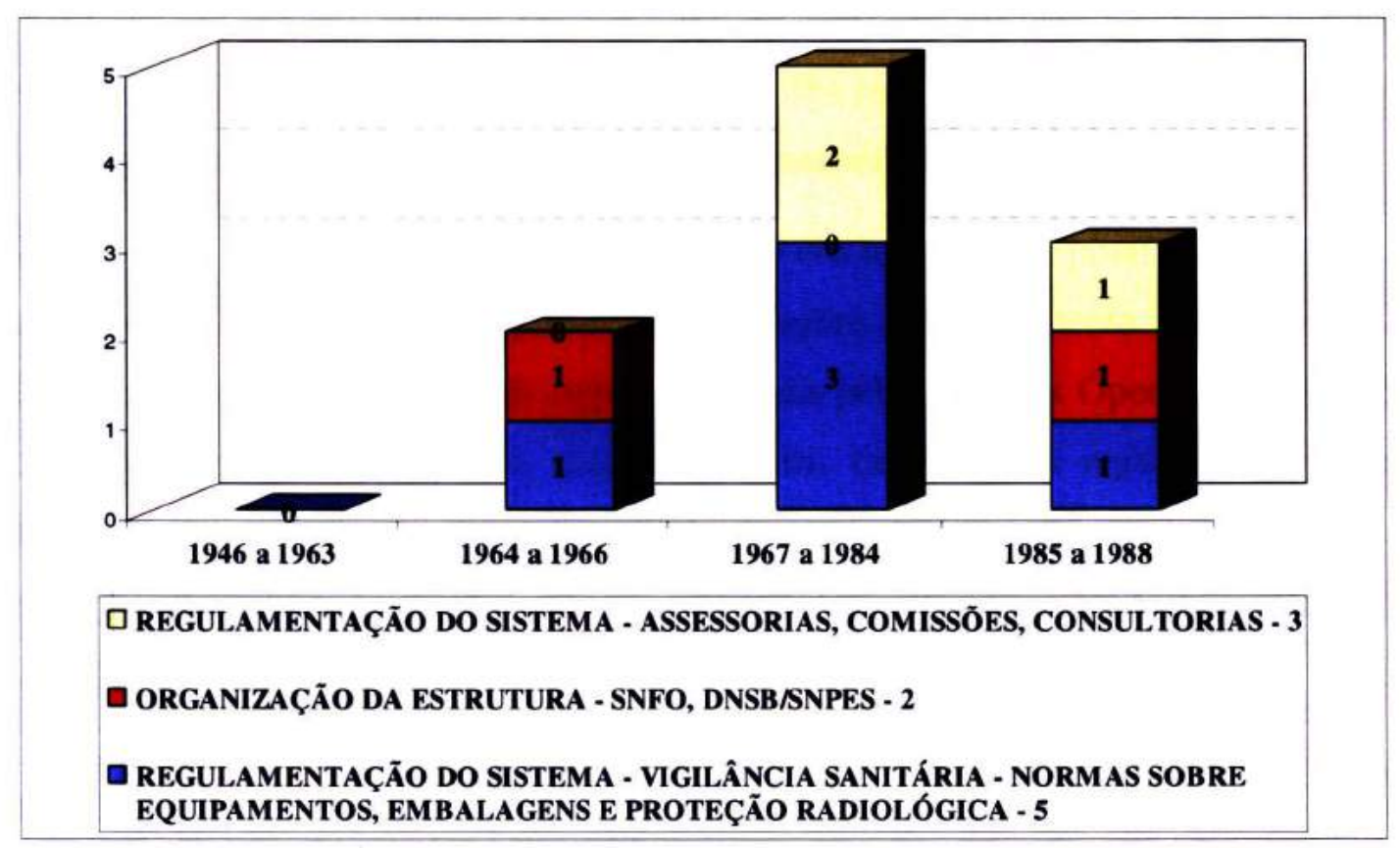

Fonte: Sistema de Legislação em Saúde - SAÚDE LEGIS - www.saude.gov.br/saudelegis 
Figura 9 - Atos normativos ministeriais sobre Saúde Bucal, eixo-temático Programas e Ações, por períodos - Brasil - 1946 a 1988.

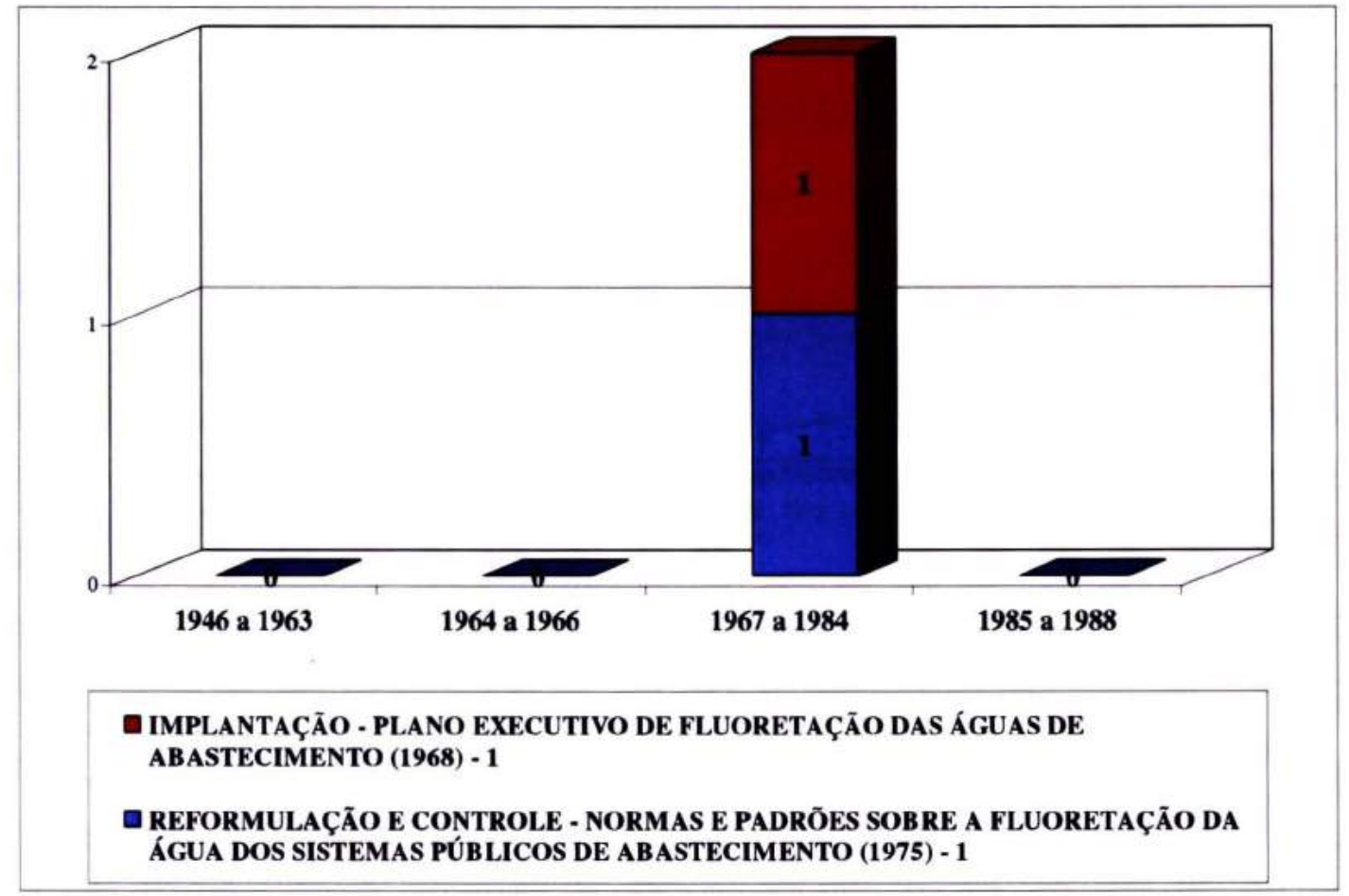

Fonte: Sistema de Legislação em Saúde - SAÚDE LEGIS - www.saude.gov.br/saudelegis

Entre 1989 e julho de 2007, foram publicadas 468 normas, sendo $128(27,35 \%)$ sobre Gestão; $297(63,46 \%)$ sobre Financiamento; $29(6,20 \%)$ de Programas; e 31(6,62\%) sobre Outras regulamentações.

Numa primeira análise dos resultados é possível observar um quantitativo superior das regulamentações sobre Financiamento. Em parte, tal fenômeno pode ser atribuído às regras propostas pelas Normas Operacionais ${ }^{76}$ entre os anos de 1991 e 1996. No entanto, a partir de 2000, as regulamentações de financiamento relativas à Saúde Bucal atingem um patamar que suplanta o número de regulamentações de gestão, com predomínio das portarias relativas à transferência de recursos (Figuras 10 e 11).

\footnotetext{
${ }^{76}$ BAPTISTA (2007) analisou o aumento do quantitativo de portarias de financiamento para toda a Saúde, atribuindo essa variação às regras emanadas das Normas Operacionais. "Em 1991 e 1992, ocorreram mudanças nos valores das tabelas de procedimentos, associadas ao pagamento por produção, conforme regras propostas pela NOB 91. Em 1993 e 1994, as tabelas de procedimentos e as regras de transferências são resultados da edição da NOB 93, com estabelecimento de tetos e incentivos financeiros. A partir de 1999, como resultado da reorganização da política proposta na NOB/96, reformulada a partir de 1998 (definição de tetos e incentivos financeiros), e da política de incentivo a programas e ações estratégicas (FAEC e novos programas)" (p.622).
} 
Figura 10 - Atos normativos ministeriais sobre Saúde Bucal por eixos-temáticos Gestão, Financiamento, Programas e Outras - Brasil - 1989 a julho de 2007.

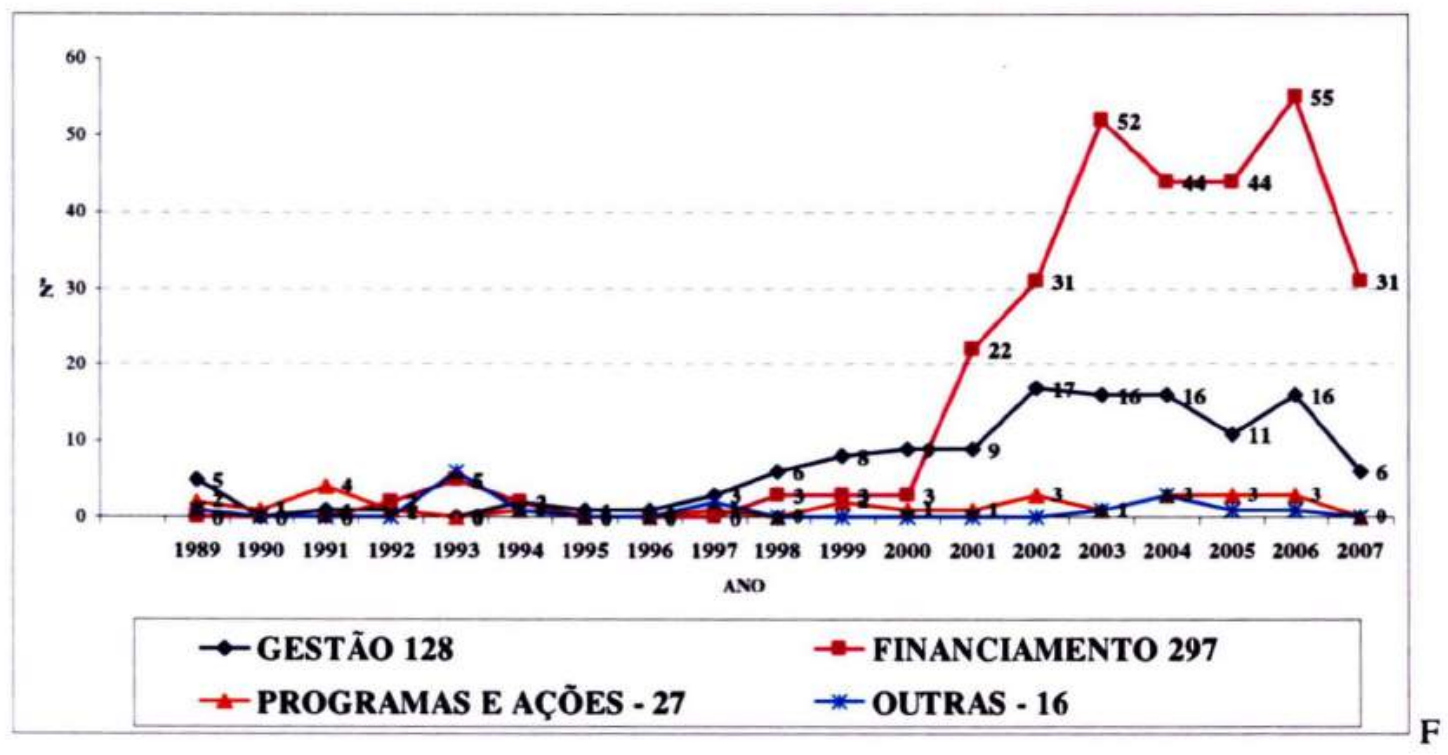

onte: Sistema de Legislação em Saúde - SAÚDE LEGIS - www.saude.gov.br/saudelegis

Figura 11 - Atos normativos ministeriais sobre Saúde Bucal, eixo-temático Financiamento - Brasil - 1989 a julho de 2007.

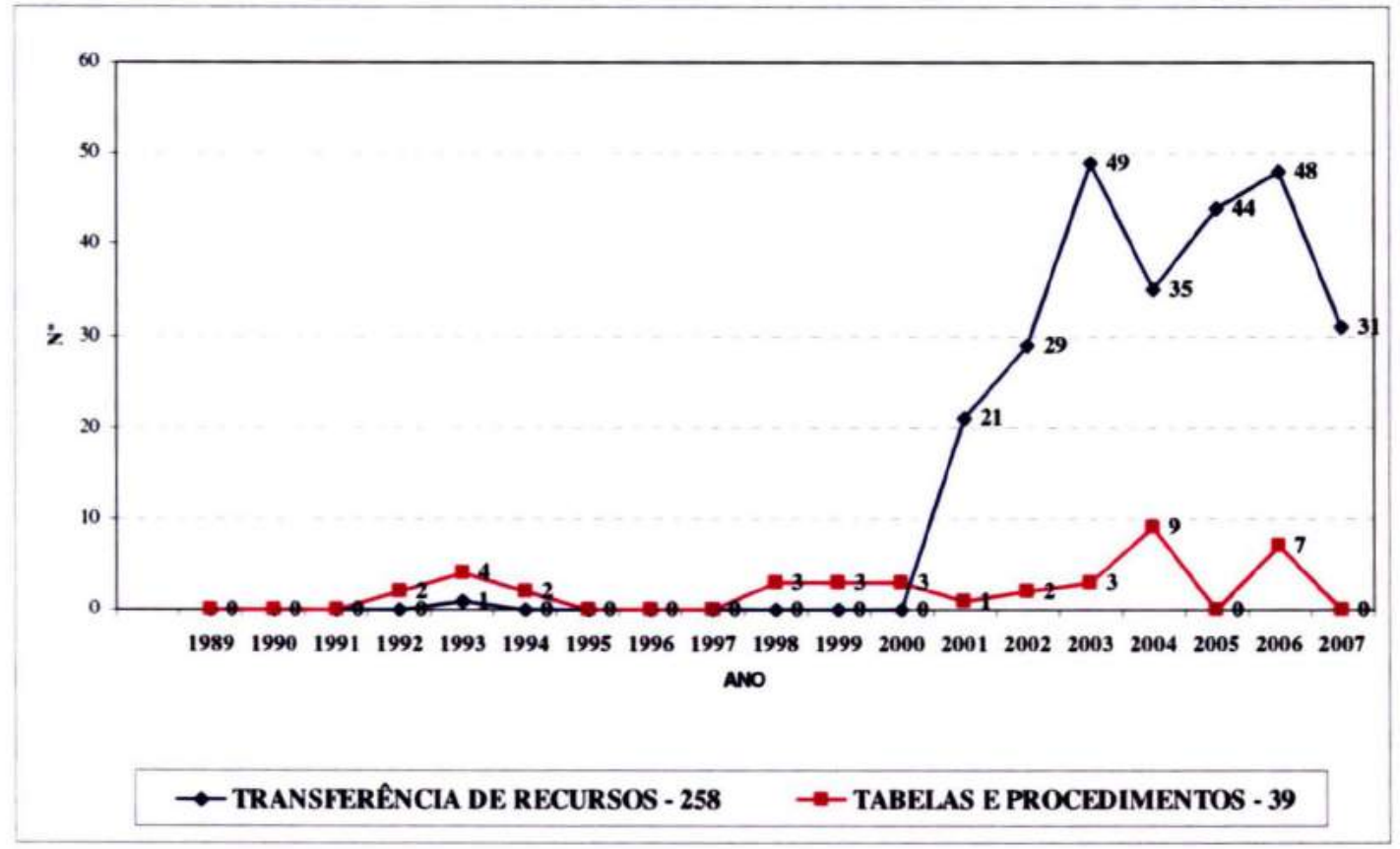

Fonte: Sistema de Legislação em Saúde - SAÚDE LEGIS - www.saude.gov.br/saudelegis. 
Entre 1991 e 1994, as portarias editadas sobre tabelas e procedimentos abordam a atenção da Média e Alta Complexidade (teto financeiro MAC) em Saúde Bucal, através de procedimentos ambulatoriais e hospitalares, destacando-se $o$ atendimento ambulatorial na especialidade de cirurgia buco-maxilofacial, atendimento hospitalar para portadores de deficiências e atendimento hospitalar para a realização de implantes e lesões-lábio palatais.

Em 1992, a atenção básica é representada pela regulamentação dos procedimentos coletivos em Saúde Bucal (Figura 12).

Entre 1998 e 2002, novamente a prioridade MAC é observada, incorporando-se ao rol de procedimentos MAC o tratamento ortodôntico aos pacientes portadores de lesões lábio-palatais.

Há um aumento no número de portarias, que pode ser atribuído aos procedimentos definidos pelo Ministério da Saúde como estratégicos e remunerados com recursos do Fundo de Ações Estratégicas e de Compensação FAEC. No ano 2000, foi localizada uma única portaria sobre a atenção básica relativa à criação de incentivos financeiros para a implantação de Equipes de Saúde Bucal (ESB) no Programa de Saúde da Família (PSF).

A partir de 2003, a ênfase se dá sobre a atenção básica através de portarias que redefinem os critérios de remuneração dos procedimentos coletivos em Saúde Bucal e dos incentivos das ESB/PSF. Além disso, são criados incentivos financeiros para assistência à saúde no sistema penitenciário, dos povos indígenas e das populações assentadas.

Em 2004, são criados os incentivos para a implantação e a atenção ambulatorial de média complexidade para a implantação dos Centros de Especialidades Odontológicas - CEO e os Laboratórios Regionais de Prótese Dentária - LRPD. 
Figura 12 - Atos normativos ministeriais sobre Saúde Bucal - subtema Tabelas e Procedimentos, segundo o nível da atenção - Brasil - 1989 a julho de 2007.

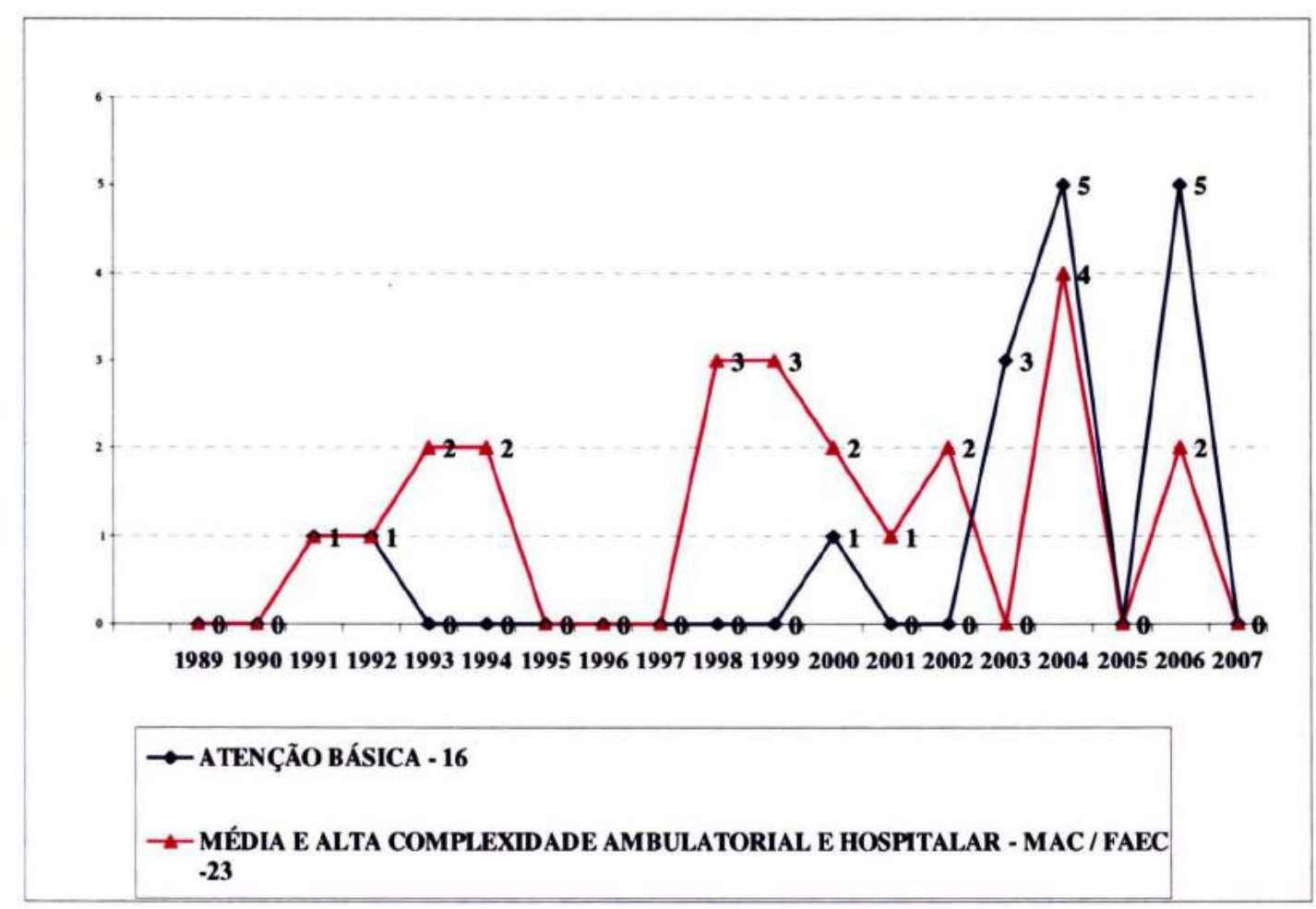

Fonte: Sistema de Legislação em Saúde - SAÚDE LEGIS - www.saude.gov.br/saudelegis

A partir de 2001, como resultado da política de incentivos estabelecida pelo Ministério da Saúde, ocorre um aumento no número de portarias que dispõem sobre Transferências de Recursos, sendo identificadas as portarias referentes à qualificação de municípios para recebimento dos incentivos financeiros ESB/PSF, à qualificação de municípios ao recebimento dos incentivos da assistência básica aos povos indígenas e à habilitação de municípios ao recebimento de incentivos do CEO/LRPD.

Destaca-se que, do total de 468 atos ministeriais editados, a partir de 1989, e selecionados para este estudo, $258(55,13 \%)^{77}$ são portarias referentes à Transferência de Recursos (Figura 13).

\footnotetext{
${ }^{77}$ BAPTISTA (2003) analisou a produção normativa do Ministério da Saúde entre os anos de 1990 e 2001 , encontrando uma relação de 939 portarias de transferência de recursos/4.555 total de portarias $=$ $20,61 \%$.
} 
Figura 13 - Atos normativos ministeriais sobre Saúde Bucal - subtema Transferências de Recursos segundo o nível de atenção e programa - Brasil - 1989 a julho de 2007.

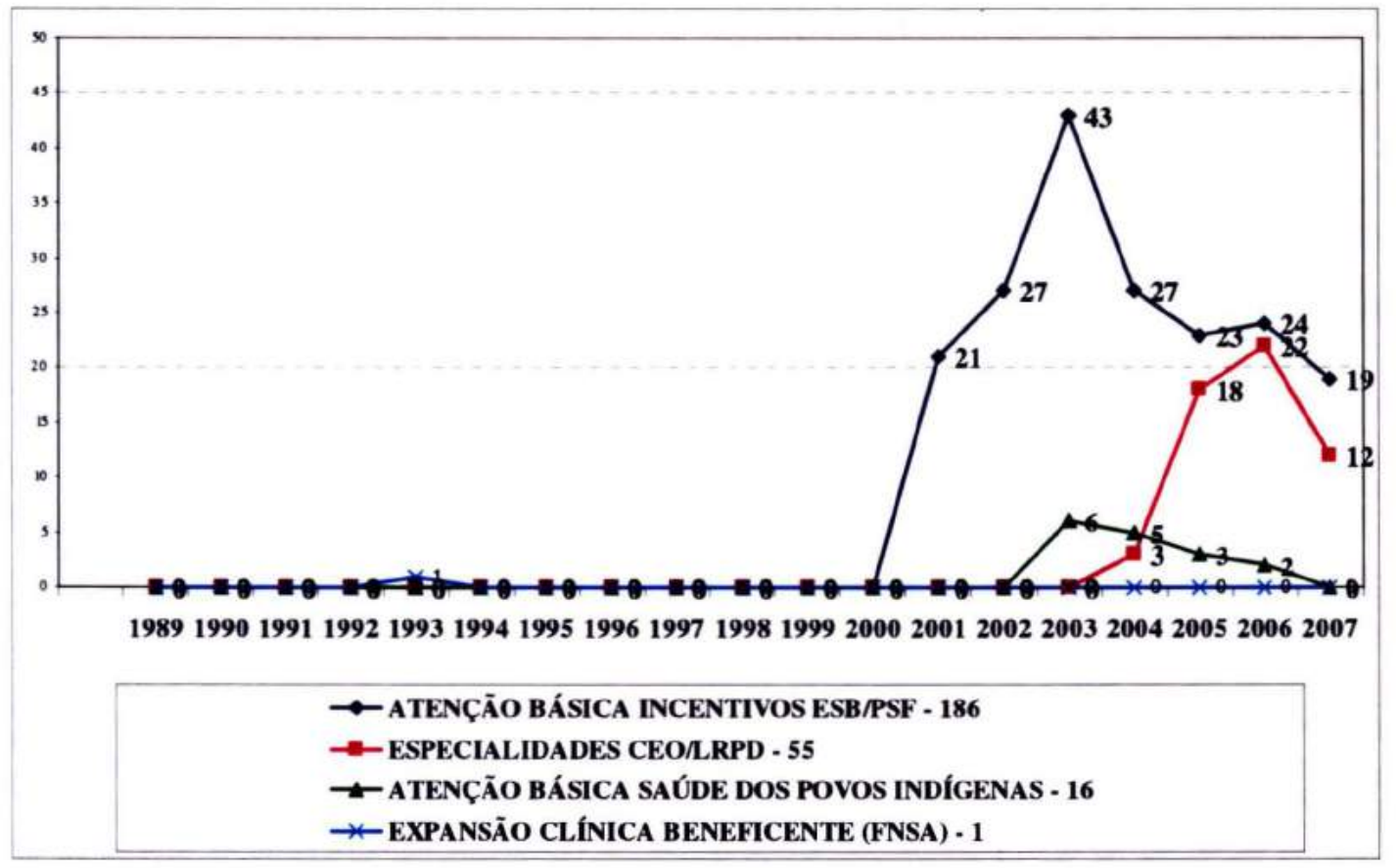

Fonte: Sistema de Legislação em Saúde - SAÚDE LEGIS - www.saude.gov.br/saudelegis

No eixo-temático Gestão, foram encontradas 128 normatizações classificadas por subtemas: 94 regulamentações do sistema ${ }^{78}, 6$ regulamentações sobre a organização e estrutura do MS, 18 sobre cadastros e 10 sobre regulamentação de rotinas (Figura 14).

As portarias referentes à Regulamentação de Rotinas encontram-se atreladas à organização dos fluxos e práticas gerenciais, com enfoque sobre a definição de procedimentos e rotinas para novas ações, programas e para a operacionalização dos mecanismos para as ações definidas como estratégicas pelo MS.

Entre 1998 e 2002, essas portarias remetem à definição de procedimentos para a implantação do Piso da Atenção Básica - PAB, instrumentos e

${ }^{78}$ Regulamentação do Sistema - nesse subtema foram incluídas as normatizações relacionadas à Saúde Bucal que dipõem sobre a regulação normativa, executiva e judicante da ANS e da ANVISA. Lei $n^{\circ}$ 9782, de 26/01/1999 - define o Sistema Nacional de Vigilância Sanitária e cria a Agência Nacional de Vigilância Sanitária - ANVISA.

Lei $n^{\circ}$ 9961, de 28/01/2000 - cria a Agência Nacional de Saúde Suplementar - ANS 
diretrizes sobre o funcionamento do Sistema de Informações Ambulatoriais - S I A e a regulamentação de rotinas sobre o registro de atividades das ESB/PSF ${ }^{79}$. A partir de 2006, foram identificadas regulamentações sobre as ESB/PSF, CEO/LRPD, Programação Físico-Financeira de procedimentos ambulatoriais e sobre os blocos de financiamento do Pacto da Saúde 2006.

No subtema Cadastros, a totalidade de regulamentações encontrada se refere ao cadastramento de hospitais para a realização de procedimentos de Alta Complexidade em Lesões Lábio Palatais.

Figura 14 - Atos normativos ministeriais sobre Saúde Bucal - Gestão e organização do sistema - Brasil - 1989 a julho de 2007.

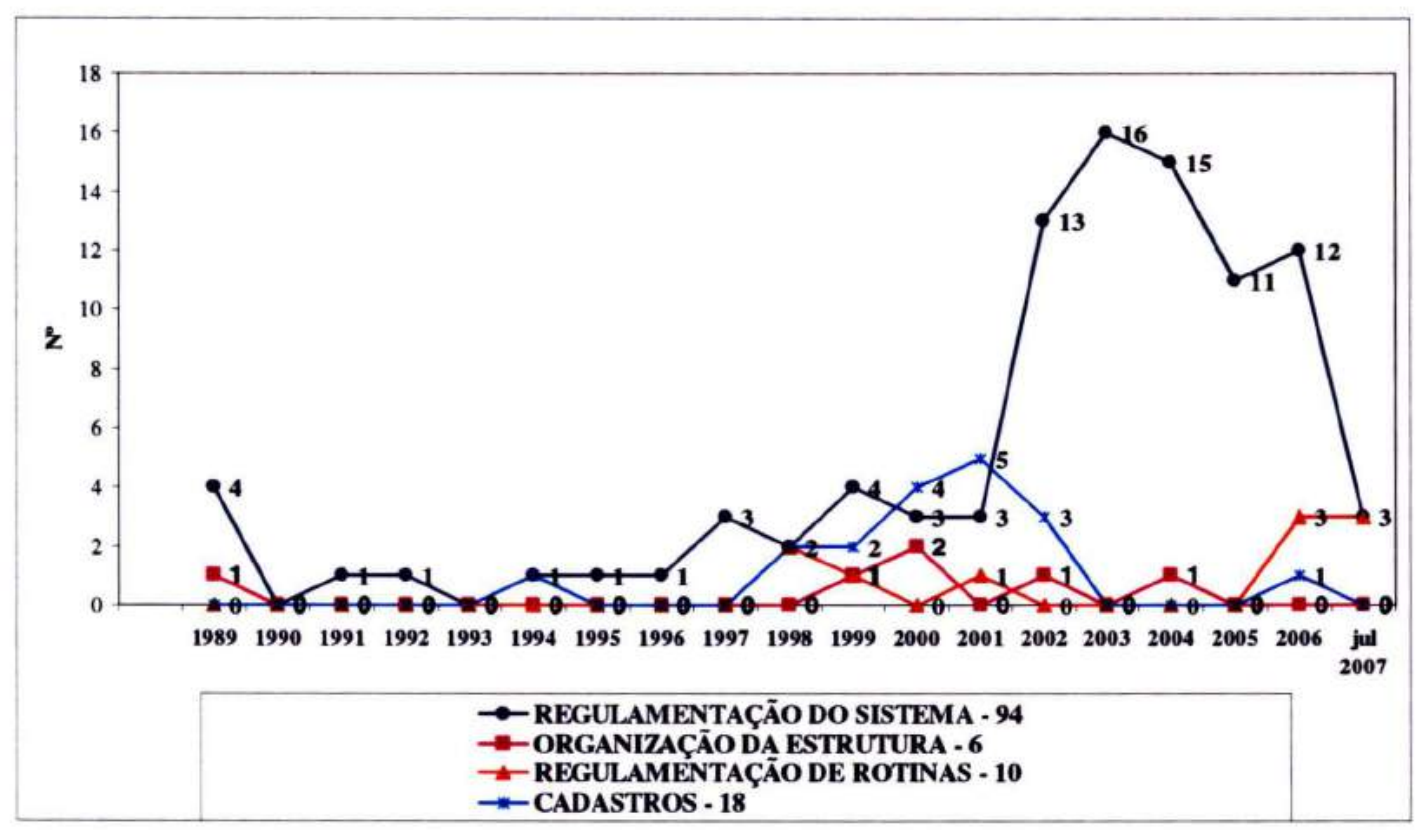

Fonte: Sistema de Legislação em Saúde - SAÚDE LEGIS - www.saude.gov.br/saudelegis

Relativamente à Organização da Estrutura, cargos, funções do MS foram identificados os seguintes assuntos:

1) 1989 - tentativa de criação de coordenações macro-regionais na Secretaria Nacional de Programas Especiais - SNPES;

2) 1999 - funções/cargos da ANVISA no que se refere às ações regulatórias sobre equipamentos, ambiente, insumos e materiais odontológicos;

\footnotetext{
${ }^{79}$ A portaria de Regulamentação de Rotinas sobre ESB/PSF é de 2001, sendo que a primeira portaria encontrada sobre Tabela e Procedimentos das ESB/PSF é de 2000. As Transferências de Recursos tiveram início em 2001.
} 
3) 2000 - dispõe sobre a criação de áreas técnicas para p PSF, incluindo as ações de Saúde Bucal/PSF;

4) 2000 - dispõe que o Departamento de Atenção Básica - DAB abrangerá as áreas técnicas, incluída a de Saúde Bucal;

5) 2002 - subdelega competências a consultor para coordenar as atividades de Saúde Bucal na DAB; e

6) 2004 - cria a comissão/função para o recebimento de materiais para a Coordenação Nacional de Saúde Bucal.

Os assuntos relativos à Regulamentação do Sistema abordam ações regulatórias normativas, executivas e judicantes sobre a Saúde Suplementar e sobre a Vigilância Sanitária, além das regulamentações sobre a atenção/assistência à Saúde Bucal (Figura 15).

Figura 15 - Atos normativos ministeriais sobre Saúde Bucal - subtema Regulamentação do Sistema - Brasil - 1989 a julho de 2007.

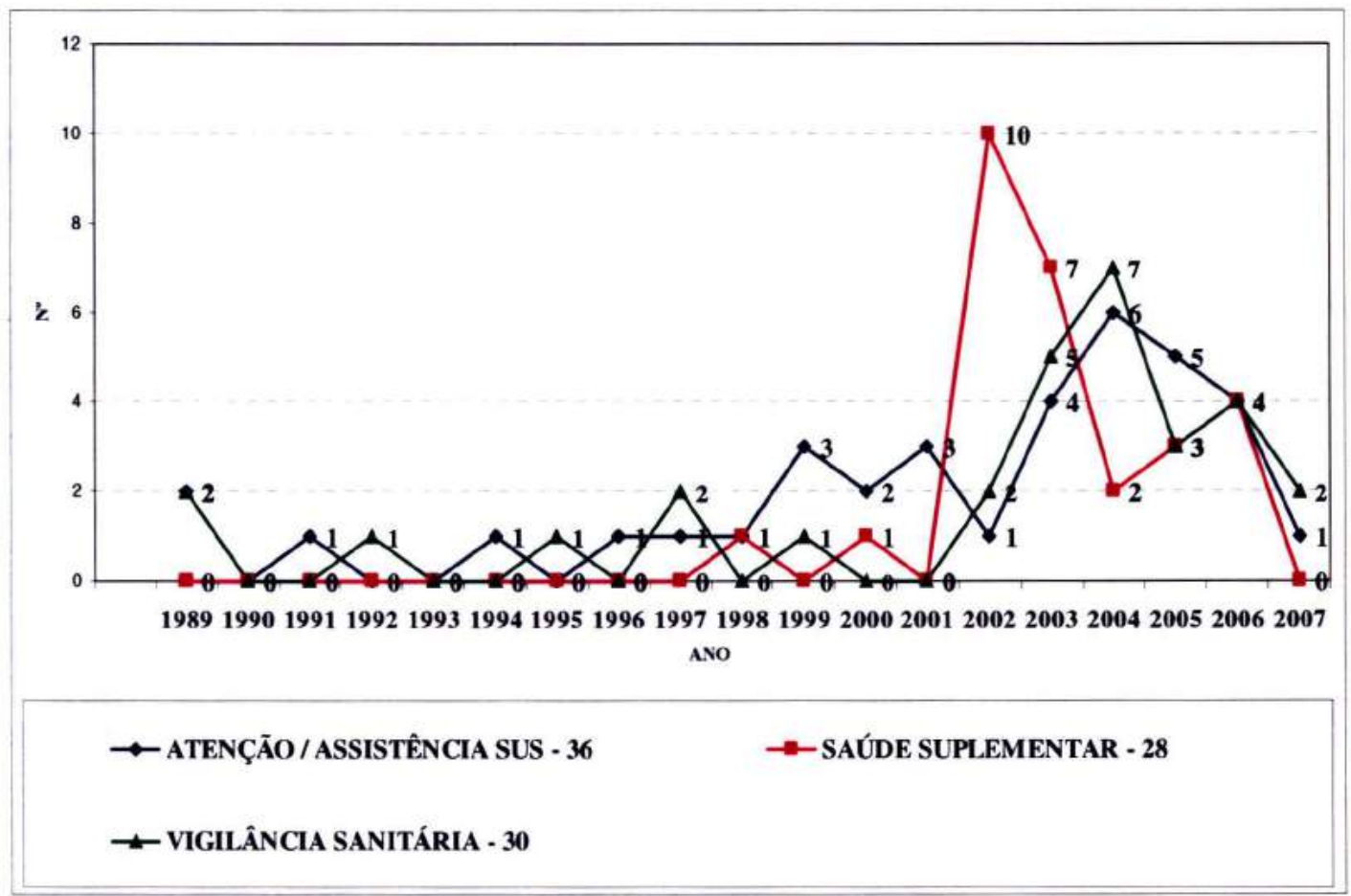

Fonte: Sistema de Legislação em Saúde - SAÚDE LEGIS - www.saude.gov.br/saudelegis

Resoluções emanadas das agências regulatórias ANS e da ANVISA foram publicadas e selecionadas nesse estudo. 
Em todo o período avaliado, as ações identificadas da ANVISA se referem aos seguintes assuntos:

1)regulação normativa: normas para equipamentos odontológicos, proteção radiológica, enxaguatórios bucais e implantação do controle e da qualidade da água; 2)regulação executiva: concessão a empresas de certificados de boas práticas de fabricação; medidas cautelares e suspensão de produtos 'anti-fumo'; interdição cautelar sobre produto creme dental com flúor; liberação da fabricação e do comércio de produto creme dental; apreensão produto escova dental falsificada; e apreensão produto escova dental por importação não informada.

Relativamente à ANS, as ações regulatórias ${ }^{80}$ referem-se à: 1) regulação normativa: delegação das ações de controle e avaliação da assistência para as operadoras ${ }^{81}$; definição do rol de procedimentos odontológicos ambulatoriais a ser utilizado como referência mínima de cobertura pelas operadoras e planos da saúde suplementar; e estabelece minuta com requisitos mínimos para a celebração dos instrumentos jurídicos firmados entre as operadoras de planos e os consultórios odontológicos;

2) regulação executiva: dispõe sobre a instauração do regime de direção fiscal em operadora;

3) regulação judicante: decretação do regime de liquidação extrajudicial em operadora; institui comissão de inquérito para apuração da situação de insolvência de operadora; e institui comissão de inquérito para apuração da situação de falência de operadora.

Quanto à Regulamentação do Sistema e da Assistência à Saúde Bucal exclusivos do SUS, os documentos foram agrupados em dois períodos, tendo apresentado os seguintes assuntos:

\footnotetext{
${ }^{80} \mathrm{Não}$ foram incluídas nessa amostra as Resoluções que instituem auditores para as operadoras, pela impossibilidade de se identificar a categoria profissional do auditor (inscrição no CFO) e o tipo de plano oferecido pela operadora (odontológico).

${ }^{81}$ Resolução CONSU $\mathrm{n}^{\circ} .8$, de 04/11/1998 - o gerenciamento das ações de saúde poderá ser realizado pelas operadoras de que trata a Lei $9656 / 1998$, através de ações de controle e regulação, tanto no momento da demanda pela utilização de serviços assistenciais, em compatibilidade com o disposto nos códigos profissionais.
} 
- entre 1989 e 2002: comissões, assessorias e consultorias para a Saúde Bucal (oito); normatização do credenciamento de hospitais para o atendimento de pacientes portadores de lesões lábio-palatais (uma); estabelecimento dos indicadores anuais do Pacto da Atenção Básica (três); e discussão de parâmetros de planejamento para a Saúde Bucal (duas);

- entre 2003 e 2007: comissões, assessorias, consultorias para a Saúde Bucal (cinco); estabelecimento/redefinição do componente de avaliação da Atenção Básica (cinco); estabelecimento dos indicadores anuais do Pacto da Atenção Básica (quatro); caderno de orientações técnicas de Auditoria em Saúde Bucal (dois); Programação Pactuada e Integrada - PPI (uma); e Plano Nacional de Saúde com itens de Saúde Bucal (duas).

Se no período de 1946 a 1964 , as regulamentações em torno do eixo-temático Outras diziam respeito ao exercício profissional e aos cursos técnicos e de especialidade em odontologia, entre 1989 e julho de 2007, o enfoque se dá sobre as regulamentações que dispõem sobre as Conferências de Saúde Bucal.

No tocante aos Programas e às Ações, foram encontradas vinte e sete regulamentações. Treze dispõem sobre a implantação de novos planos, políticas e programas, bem como a inserção das ações de Saúde Bucal em outras políticas setoriais. Catorze dispõem sobre a reformulação e o controle dos programas existentes (Figura 16).

Nesse último grupo encontram-se as portarias relativas à revogação da fluoração do sal e da aquisição da compra de uniformes para as ESB/PSF

A partir de 1997, começam a surgir demandas para a inserção e a integração das ações de Saúde Bucal junto a outras políticas setoriais, como Programa de Saúde da Família, política para portadores de deficiências, política para a saúde penitenciária, política nacional para hospitais de pequeno porte, política nacional de oncologia, Política Nacional de Atenção Básica (Figura 17). 
Figura 16 - Atos normativos ministeriais sobre Saúde Bucal - subtema Programas e Ações - Brasil - 1989 a julho de 2007

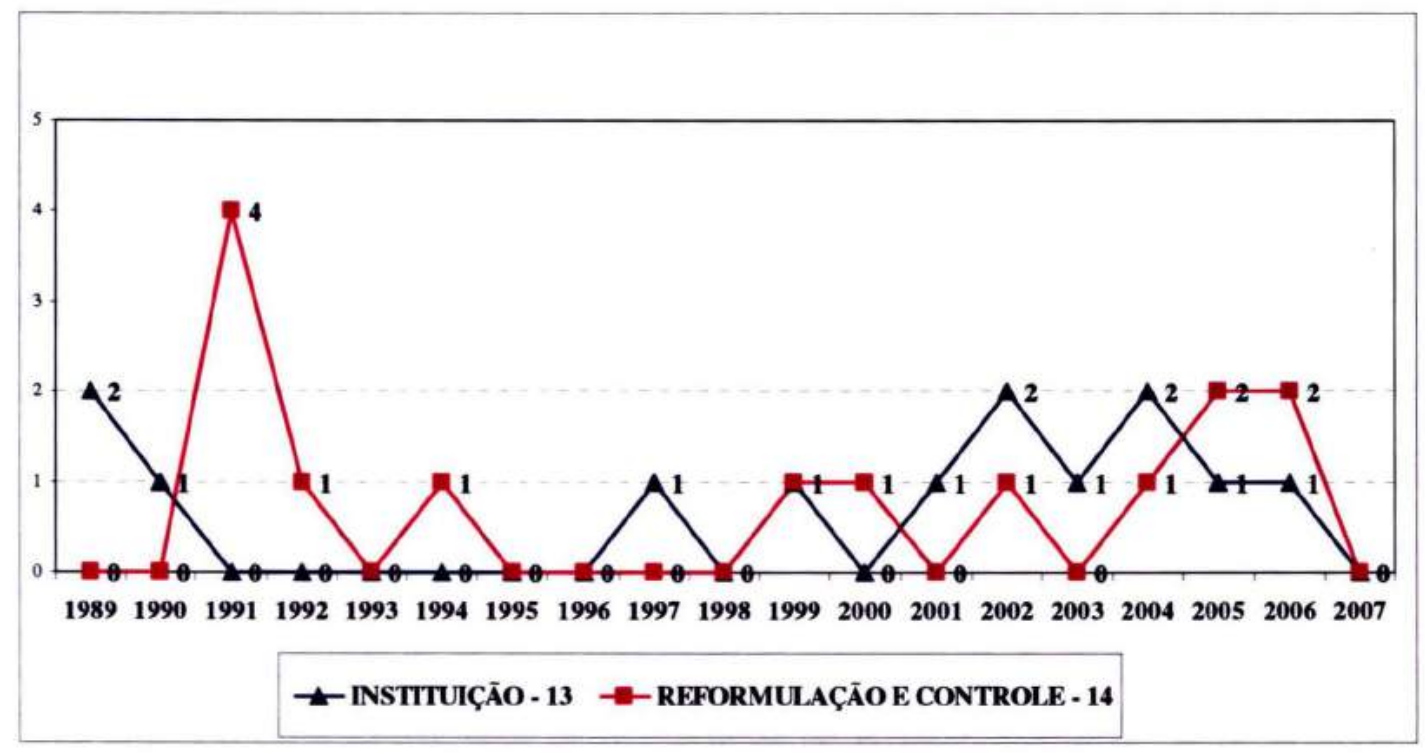

Fonte: Sistema de Legislação em Saúde - SAÚDE LEGIS - $\underline{\text { www.saude.gov.br/saudelegis }}$

Figura 17 - Atos normativos ministeriais sobre Saúde Bucal - Programas e Ações ${ }^{82}$ - segundo os assuntos dispostos nas regulamentações a cada ano - Brasil - 1989 a julho de 2007.

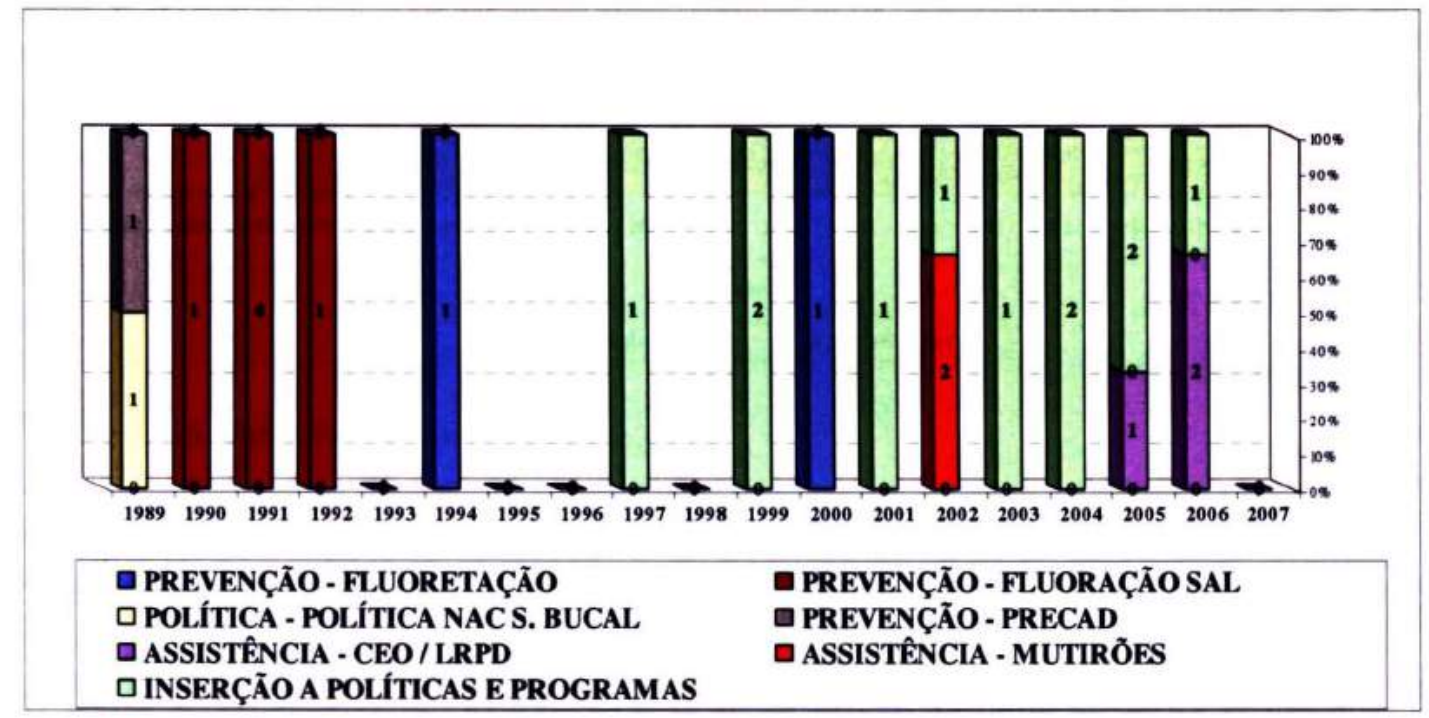

Fonte: Sistema de Legislação em Saúde - SAÚDE LEGIS - wwww.saude.gov.br/saudelegis

${ }^{82}$ As portarias relativas às ESB/PSF encontram-se no eixo INSERÇÃO A POLÍTICAS E PROGRAMAS. Conforme constatado por vários autores (ZANETTI, 2005; BAPTISTA 2003, 2007), muitas portarias do MS abordam o programa em termos financeiros. Neste estudo, a maioria das portarias das ESB/PSF também foram classificadas no subtema Financiamento. 


\subsection{O CONSELHO NACIONAL DE SAÚdE - CNS E A REGULAÇÃO SOBRE A ATENÇÃO À SAÚDE BUCAL}

Os documentos do CNS foram selecionados a partir da leitura e da identificação de 927 atos aprovados, entre 1988 e julho de 2007, e disponibilizados em sua página na internet. Para este estudo foram selecionados 109 $(11,76 \%)$ documentos, ou seja, 4 resoluções, 6 pautas e 99 atas, com assuntos relacionados à Saúde Bucal (Figuras 18 e 19).

Figura 18 - Número de documentos examinados e selecionados sobre Saúde Bucal CNS - 1988 a julho de 2007

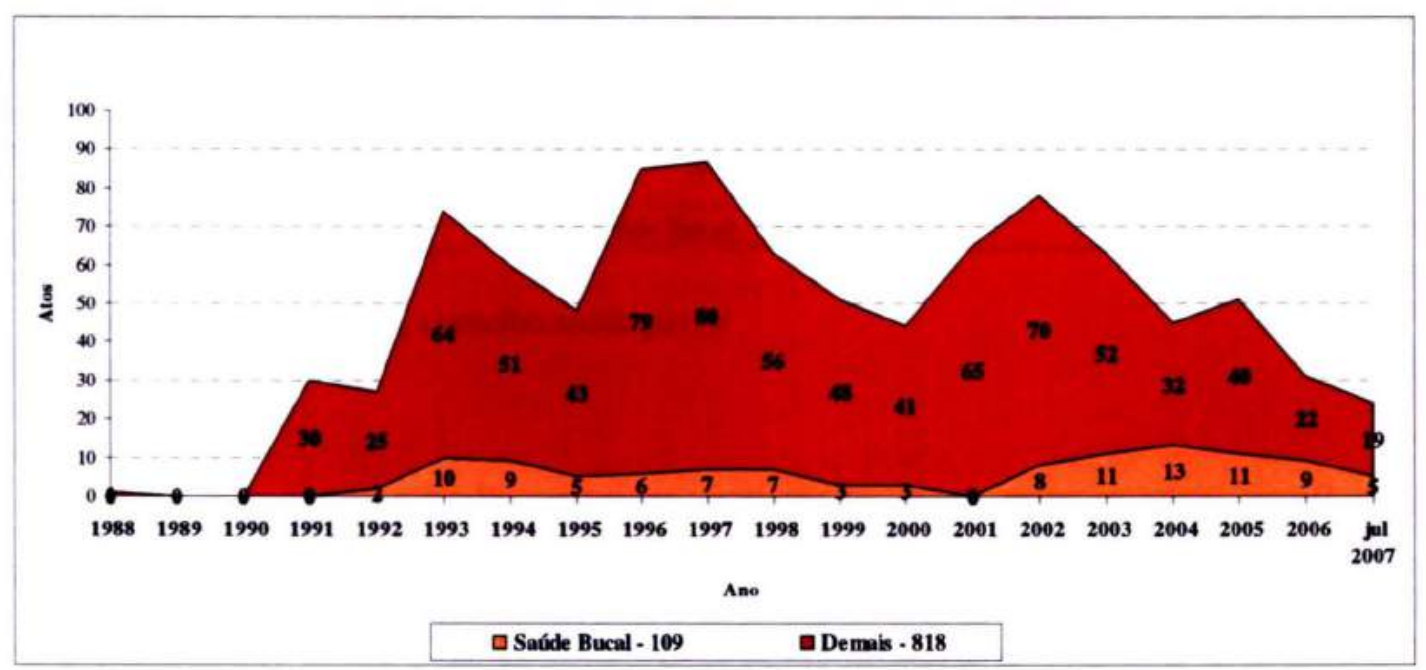

Fonte: CNS - http://www. conselho.saude.gov.br

Os assuntos sobre Saúde Bucal tratados no CNS partem de demandas apresentadas pelo Ministério da Saúde, pelos representantes dos segmentos sociais, pelas corporações, por representantes do Legislativo, pelos municípios, pela imprensa, entre outros grupos. Igualmente, apresentam-se sob várias formas: convites, informes, apresentações, discursos para aprovação de matérias, discussões, apresentações técnicas, dentre outras formas. Neste estudo, foram 
selecionados documentos com abordagens sobre Saúde Bucal, sem preocupação com a origem ou com a forma pela qual o assunto é apresentado.

Figura 19 - Número de documentos examinados no CNS e selecionados sobre Saúde Bucal, segundo os períodos dos Governos pós-1985 - Brasil - 1988 a julho de 2007

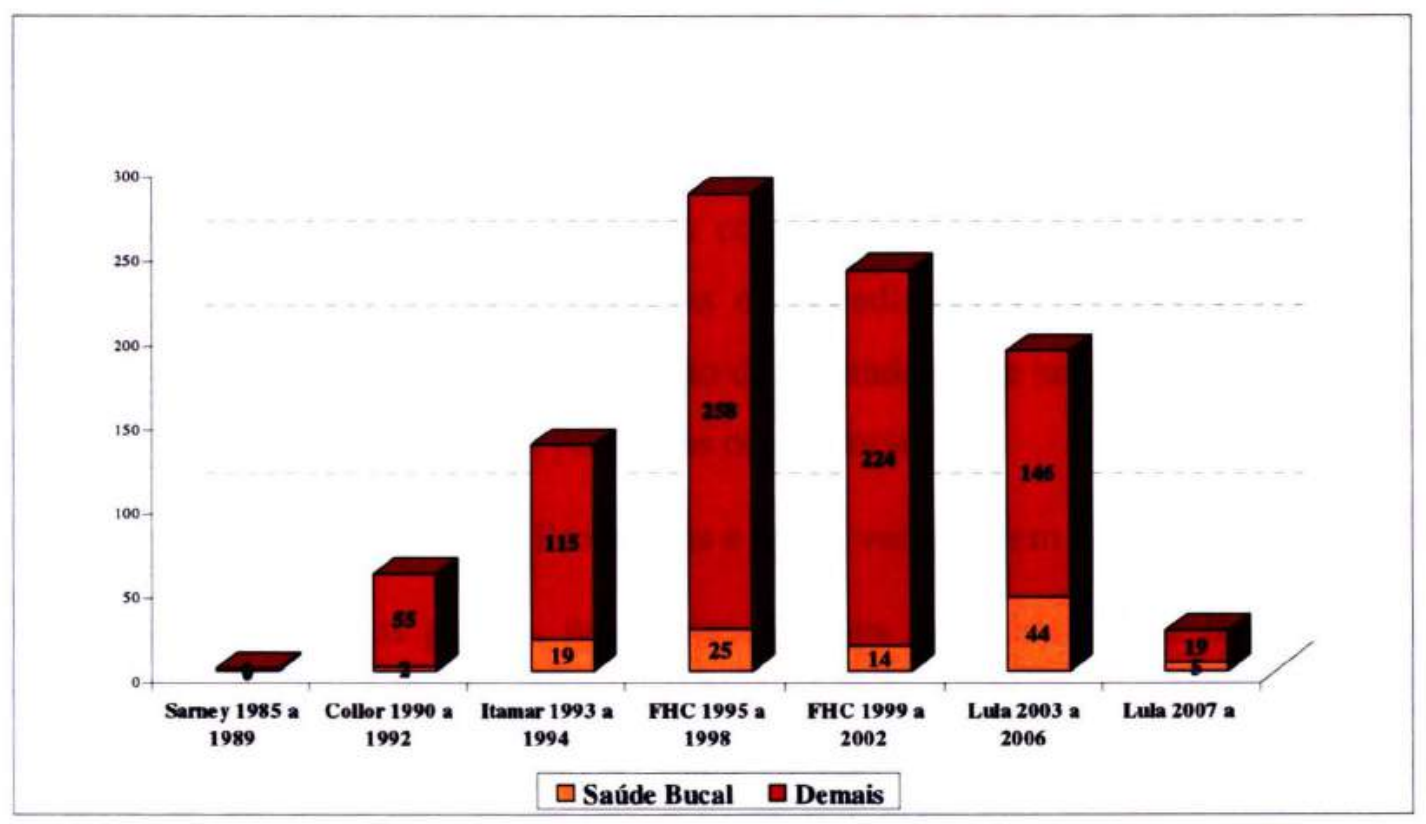

Fonte: CNS - http://www. conselho.saude.gov.br

Após criteriosa leitura das atas selecionadas, verificou-se que a Saúde Bucal era abordada sob vários aspectos numa única reunião. Após a identificação das idéias-centrais sobre as diferentes abordagens, a amostra total desse estudo ficou definida em 180 abordagens sobre Saúde Bucal (Quadro 15 - Anexo C).

O preenchimento do Instrumento de Coleta de Dados permitiu classificar as 180 abordagens sobre Saúde Bucal, segundo os seguintes eixos-temáticos:

- Gestão e Organização do Sistema e da Atenção à Saúde

a) Regulamentação do sistema e da assistência/atenção à Saúde Bucal: comissões para discussão de normas operacionais com alguma abordagem específica sobre 
Saúde Bucal; indicadores epidemiológicos, estratégias para o controle e avaliação da atenção à saúde bucal, normas para credenciamento de serviços, planos nacionais de saúde ou plurianuais, projetos de lei, assessorias/consultorias/comissões orientações técnicas específicas para a organização da atenção, pactuações; b) Organização da Estrutura: alterações da estrutura do Ministério da Saúde, relacionadas à área técnica de Saúde Bucal; c) Regulamentações de Rotinas: organização dos fluxos e práticas gerenciais; d) Licitações: licitações de materiais.

- Financiamento

a) Transferência de Recursos: incentivos com recursos específicos para programas, campanhas e ações verticais; b) Tabelas e Procedimentos: inclusão e revisão de procedimentos e valores para remuneração de prestadores de serviços; c) Orçamento: controle execução orçamentária, propostas orçamentárias.

- Programas e ações verticais em saúde bucal

a) Instituição de novos planos, programas e ações de saúde bucal: instituição de novos programas e integração das ações de saúde bucal às demais políticas setoriais, planos e projetos para a atenção à Saúde Bucal; b) Reformulação e criação de mecanismos de controle dos programas e das ações.

\section{- Outras}

a) trabalho e educação: ensino superior, recursos humanos no SUS, pesquisas com equipamentos médico-odontológicos; b) controle social: conferências, representações, convites c) datas comemorativas, d) s/classificação: 'termalismo'.

As Figuras 19 e 20 apresentam os eixos-temáticos segundo os períodos dos Governos pós-1985 e por ano. 
Figura 20 - Número de abordagens sobre Saúde Bucal nos documentos selecionados do CNS, segundo os eixos-temáticos e os períodos dos Governos pós-1985 - Brasil 1988 a julho de 2007.

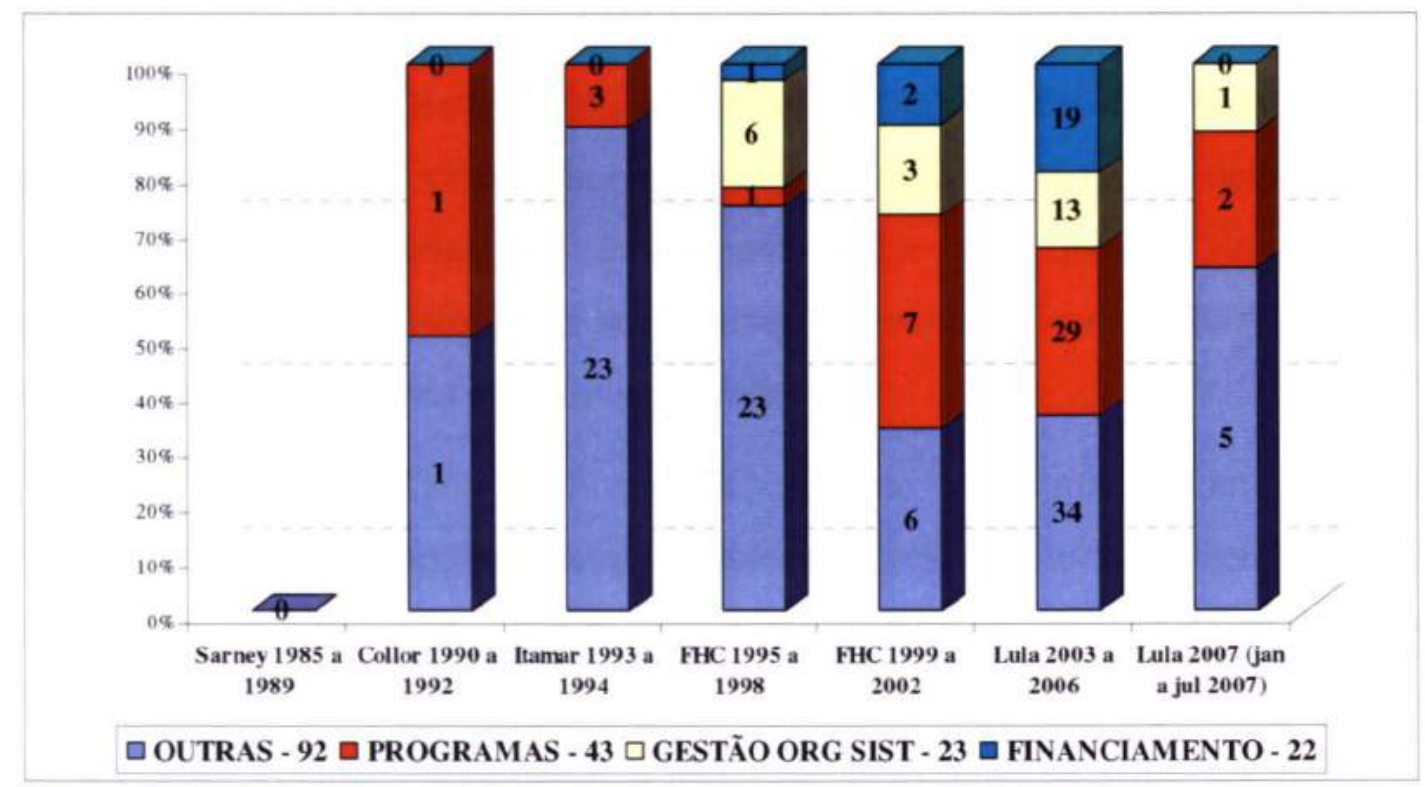

Fonte: elaborado a partir dos dados do CNS - http://www. conselho.saude.gov.br

Figura 21 - Número de abordagens sobre Saúde Bucal nos documentos selecionados do CNS, segundo eixos-temáticos e ano - Brasil - 1988 a julho de 2007.

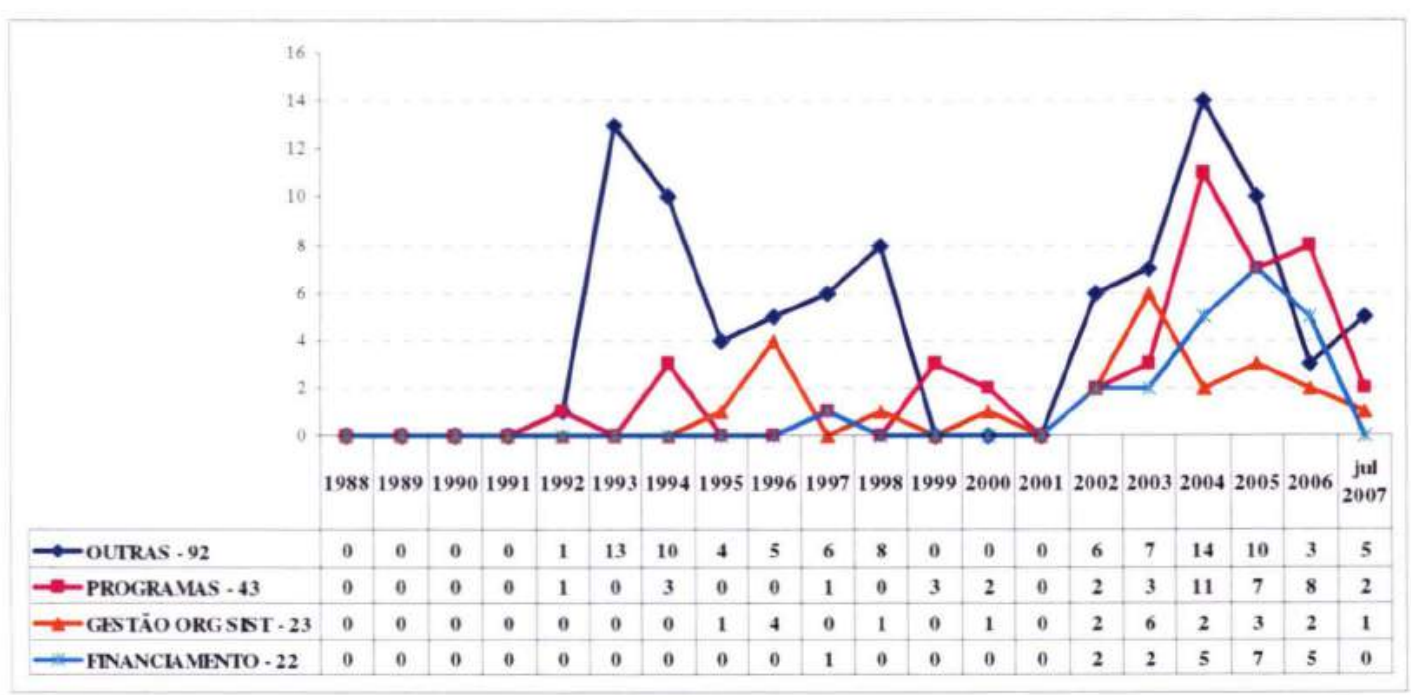

Fonte: elaborado a partir dos dados do CNS - http://www. conselho.saude.gov.br

No eixo-temático Outras, o enfoque se dá sobre o Ensino Superior, particularmente, sobre a indefinição do papel do CNS no processo de 
autorização para abertura de novos cursos de odontologia, além da falta de clareza dos critérios para a emissão de pareceres. Em várias atas analisadas, observa-se que, apesar dos indeferimentos do CNS para a abertura de novos cursos, os mesmos assuntos retornam à Pauta seguinte para reconsideração dos indeferimentos.

Desde 1997, os trabalhos da Comissão Interministerial MEC/MS e dos diversos grupos de trabalho criados pelo CNS para a definição de tais critérios, não vem sendo suficientes para resolver essa questão. Em 2004, a Plenária do CNS decide não emitir mais pareceres, retomando-os em 2005, após os encaminhamentos propostos pelo Governo Federal.

Além do Ensino Superior, no eixo-temático Outras foram identificadas ações de Controle Social inerentes ao CNS, com assuntos referentes às conferências, representações, comissões e grupos técnicos instituídos. Relativamente à Saúde Bucal, destacam-se as Conferências de Saúde Bucal e a necessidade de se criar um Grupo Técnico para analisar as demandas específicas da Saúde Bucal.

Figura 22 - Número de abordagens sobre Saúde Bucal nos documentos selecionados do CNS, segundo eixo-temático Outras - Brasil - 1988 a julho de 2007.

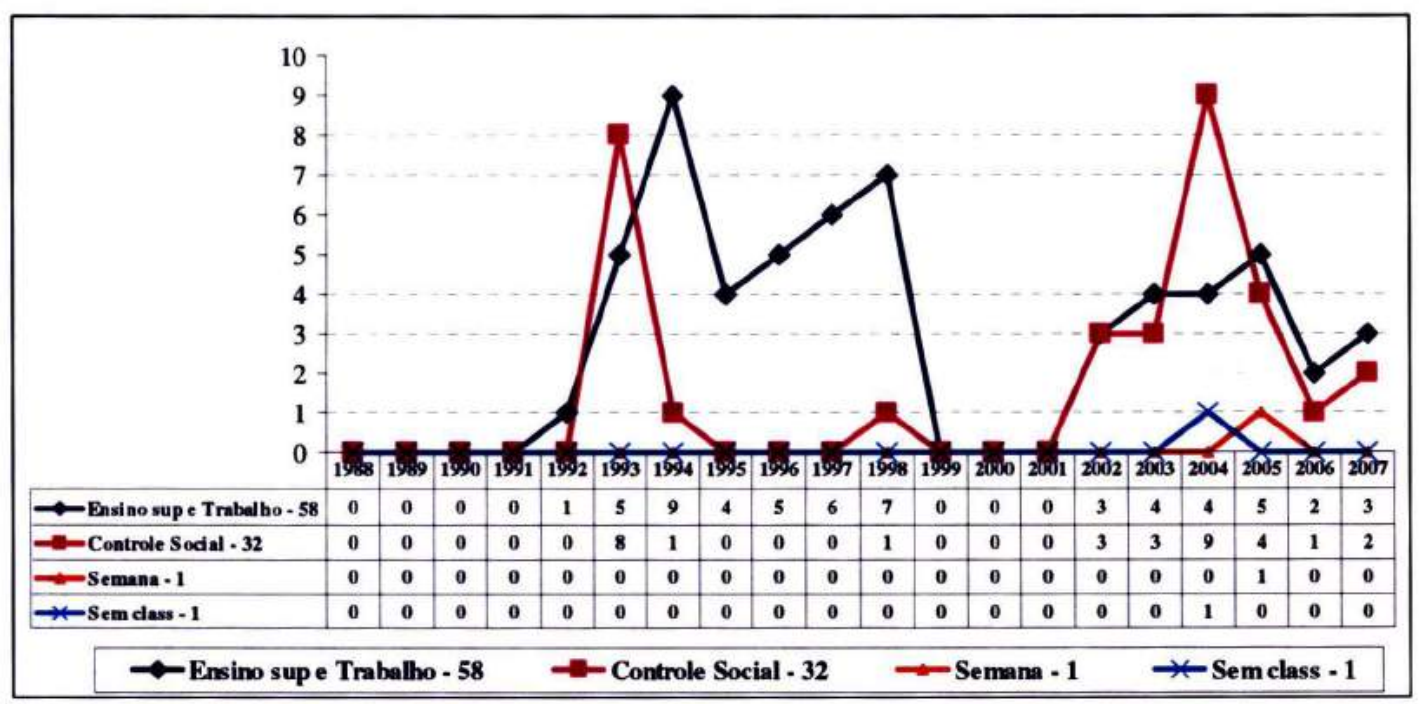

Fonte: elaborado a partir dos dados do CNS - http://www. conselho.saude.gov.br

Relativamente aos Programas e Ações de Saúde Bucal, destacam-se as abordagens e as demandas relativas à Inserção das ações de Saúde 
Bucal em diversas políticas setoriais. As primeiras abordagens foram identificadas em 1999, com o Programa do Agente Comunitário de Saúde - ACS e com a necessidade de atenção odontológica aos portadores de deficiências. Posteriormente, essa necessidade de integração vem sendo apontada junto a outras políticas públicas setoriais: PSF, saúde no sistema prisional, inserção das ações em hospitais de pequeno porte, política nacional do idoso, hanseníase, medicina natural e práticas complementares, programa nacional de atenção básica, atenção à saúde dos povos indígenas, atenção oncológica e atenção integral a jovens e adolescentes.

Com a Política Nacional de Saúde Bucal - Brasil "Sorridente" ${ }^{\text {"3 }}$ implementada pelo Governo Federal, desde 2004, o CNS vem insistindo na necessidade de se desenvolverem estratégias para controlar e avaliar o impacto dessa política sobre a saúde bucal da população, em função do montante recursos financeiros aplicados nessa Política.

Figura 23 - Número de abordagens sobre Saúde Bucal nos documentos selecionados do CNS - inserção Programas e Ações - Brasil - 1988 a julho de 2007.

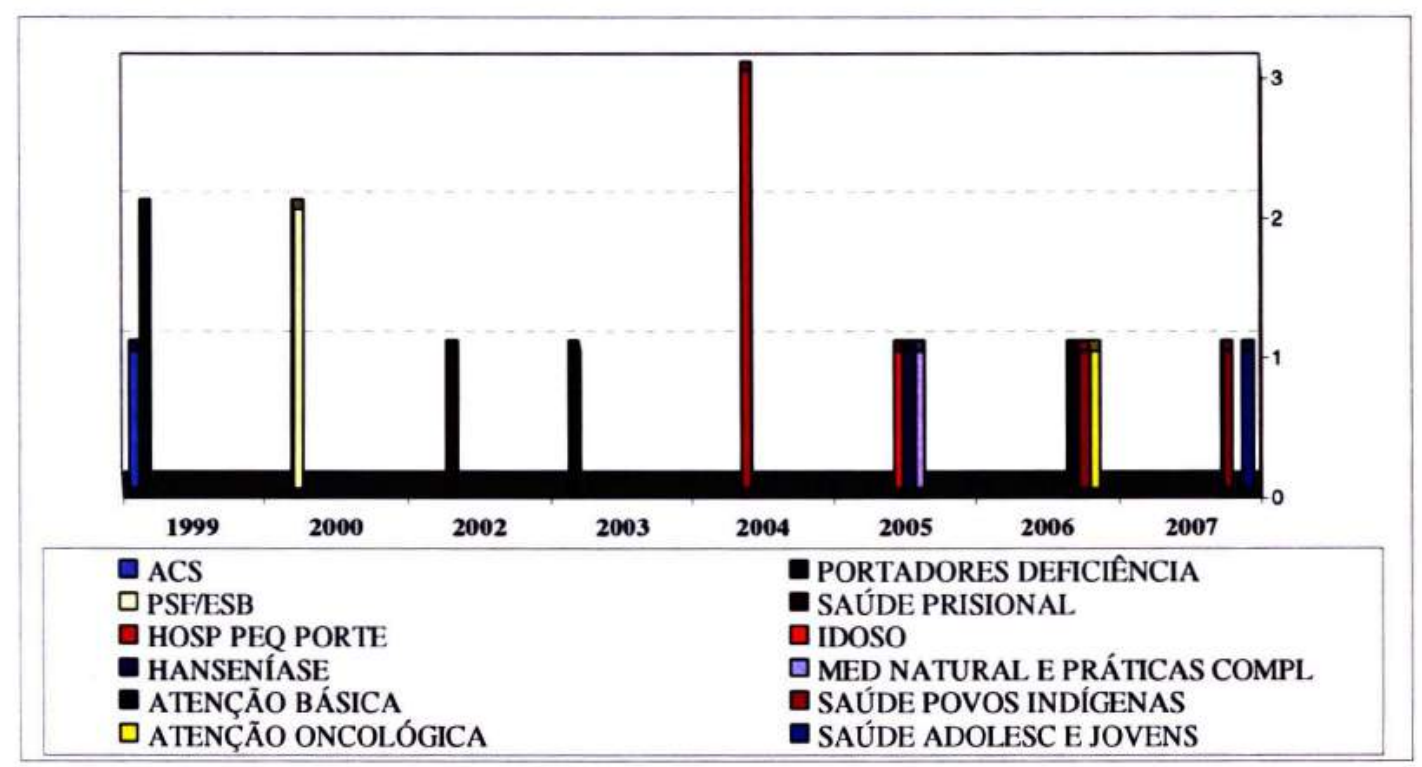

Fonte: elaborado a partir dos dados do CNS - http://www. conselho.saude.gov.br

\footnotetext{
${ }^{83}$ Eixos prioritários da Política Brasil Sorridente: expansão das ESB/PSF, implantação dos CEO/LRPD e ampliação da cobertura da fluoretação das águas de abastecimento público.
} 
No eixo-temático Financiamento, o Orçamento vem sendo um item de discussão permanente no CNS, no que tange à discussão das propostas orçamentárias, às fontes de financiamento do SUS, ao controle trimestral da execução orçamentária das rubricas de Saúde Bucal, à necessidade de compatibilidade entre o Plano Plurianual / Plano Nacional de Saúde / Orçamentos anuais e à necessidade de se melhorar a forma de apresentação do Orçamento aos Conselheiros.

Relativamente ao tema Tabelas e Procedimentos destaca-se a discussão sobre a alteração do valor dos incentivos financeiros para as ESB/PSF proposta pelo Governo Federal, como estratégia de expansão do PSF. Esse assunto foi pauta do CNS durante os anos de 2004 e 2005.

Figura 24 - Número de abordagens sobre Saúde Bucal nos documentos selecionados do CNS - eixo-temático Financiamento - Brasil - 1988 a julho de 2007.



Fonte: elaborado a partir dos dados do CNS - http://www. conselho.saude.gov.br

No eixo-temático Gestão e Organização do Sistema e da Atenção à Saúde Bucal, as primeiras referências sobre o tema Regulamentação do Sistema são do período de 1995 a 1997, tendo em vista os trabalhos da Comissão NOB 96 que discutiria o rol de procedimentos odontológicos do PAB per capita. A 
partir disso, o tema reaparece em 2003, em função da necessidade de se finalizar o Levantamento Epidemiológico 2003 para o estabelecimento de parâmetros e indicadores que subsidiariam um Plano Nacional de Saúde Bucal.

Em 1996, a Regulamentação da Saúde Suplementar insere-se na pauta do CNS, pela discussão da regulação normativa que estabelece a obrigatoriedade do registro das operadoras nos Conselhos Profissionais. Além disso, discute-se a oferta das especialidades odontológicas nos planos e os contratos e serem estabelecidos entre as operadoras e prestadores. A partir de 2004, as discussões se tornam mais estratégicas e abrangentes, permeando a política regulatória da ANS e o aporte de recursos públicos para a Saúde Suplementar.

Figura 25 - Número de abordagens sobre Saúde Bucal nos documentos selecionados do CNS - eixo-temático Gestão - Brasil - 1988 a julho de 2007.

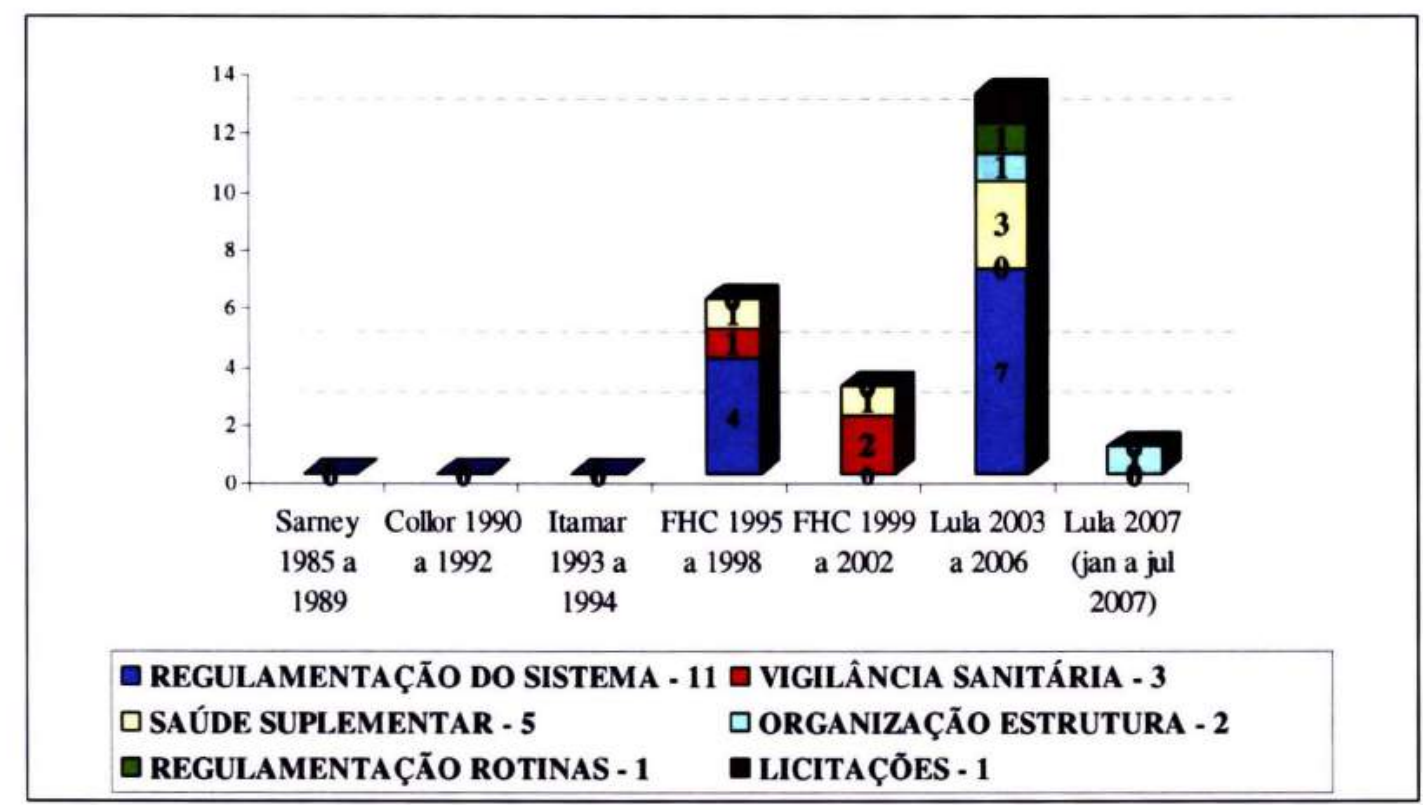

Fonte: elaborado a partir dos dados do CNS - http://www. conselho.saude.gov.br

Relativamente às ações de vigilância sanitária, numa reunião realizada em 1996, discutiu-se a necessidade de controle sobre a venda de produtos fluorados em áreas com água fluoretada, considerando-se urgente que o poder público tomasse providências no sentido de proibir a comercialização desses produtos em áreas com água fluoretada. Entre 1999 e 2002, as discussões sobre as 
ações de vigilância assumem caráter de regulamentação normativa, ao tratar de normas para o desenvolvimento e a comercialização de equipamentos odontológicos no âmbito do MERCOSUL.

Em termos de Regulamentação de Rotinas, encontrado um único registro em 2005, em que o CNS aprova as normas e os requisitos para a implantação do CEO/LRPD. No tema Licitações, o CNS vem se ocupando dos problemas ocorridos com a licitação dos kits de Saúde Bucal que não puderam ser adquiridos pelo MS.

Figura 26 - Número de abordagens sobre Saúde Bucal nos documentos selecionados do CNS - Assuntos - Brasil - 1988 a julho de 2007.

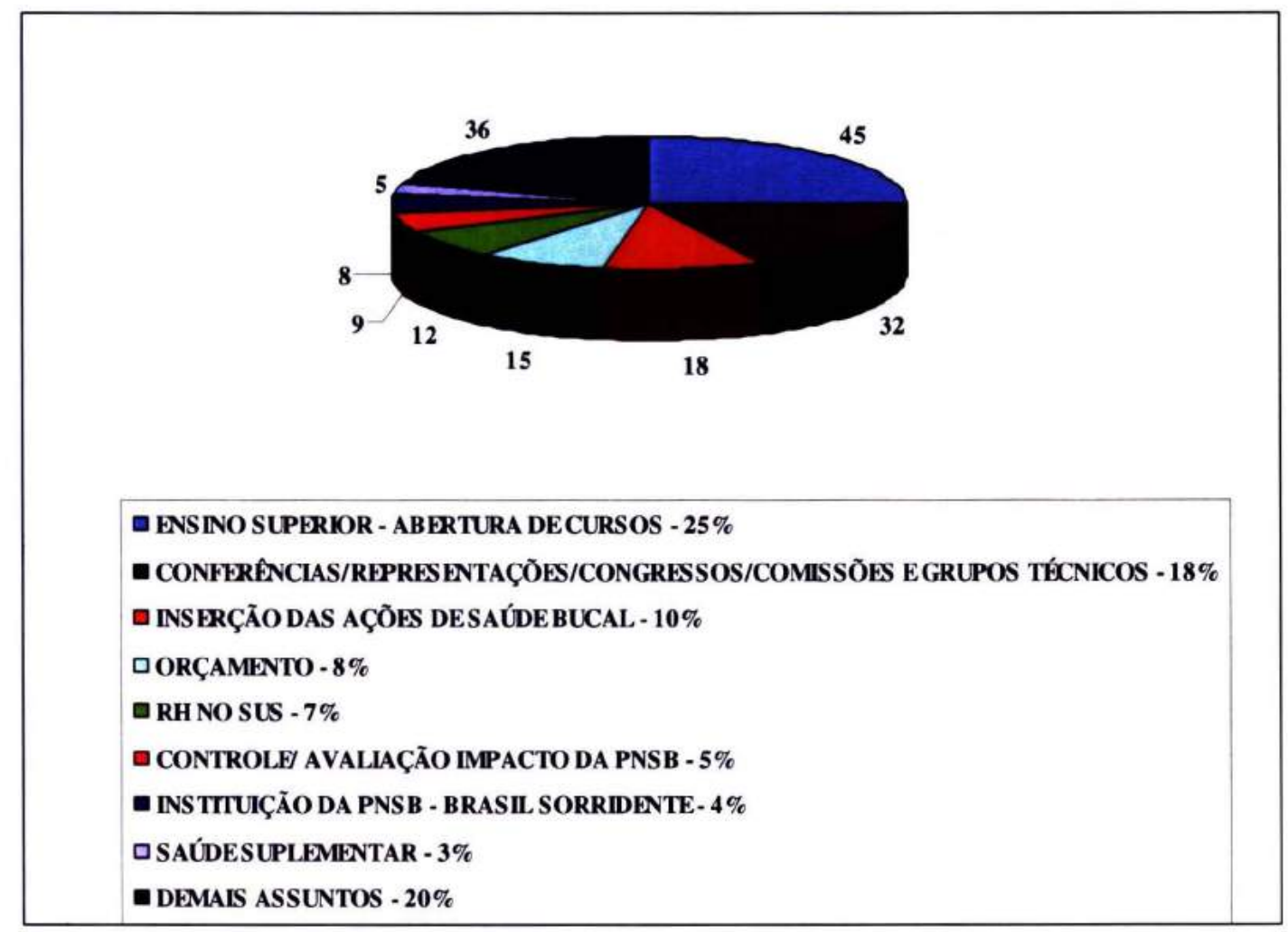

Fonte: elaborado a partir dos dados do CNS - http://www. conselho.saude.gov.br

Em linhas gerais, observa-se que as abordagens identificadas nos documentos do CNS abrangem vários aspectos da regulação da atenção à Saúde Bucal. Em especial a necessidade das ações serem inseridas nas demais políticas 
setoriais, as questões orçamentárias e a necessidade de serem instituídos mecanismos de controle e de avaliação do impacto sobre os indicadores de saúde da população.

Assim, o objetivo deste estudo foi identificar os instrumentos criados pelos poderes de Estado para fazer a regulação sobre a atenção à Saúde Bucal e analisar o seu emprego pelos órgãos e instituições competentes.

Dois artigos foram produzidos com enfoque na regulação sobre a atenção à Saúde Bucal: um trata da produção Legislativa Federal sobre Saúde Bucal publicada entre 1824 e julho de 2007; e outro, dos atos ministeriais do setor Saúde publicados entre 1946 e julho de 2007. 


\title{
PARTE II
}

\section{MINUTAS DOS ARTIGOS}

\begin{abstract}
ARTIGO 1 - Regulação da atenção à saúde bucal no Brasil e a produção Legislativa Federal entre 1824 e julho de 2007.
\end{abstract}

\begin{abstract}
ARTIGO 2 - Regulamentação da atenção à saúde bucal no Brasil: análise dos atos normativos ministeriais editados entre 1946 e julho de 2007.
\end{abstract}




\section{ARTIGO 1}

REGULAÇÃO DA ATENÇÃO À SAÚDE BUCAL NO BRASIL E A PRODUÇÃO LEGISLATIVA FEDERAL ENTRE 1824 E JULHO DE 2007 


\section{RESUMO}

Introdução - A Constituição de 1824 adotou para o Brasil a separação de Poderes Políticos, num momento histórico em que se pretendia limitar a atuação do Estado. Com a evolução da sociedade, o Estado passou a ser cada vez mais solicitado a regular a vida social, impondo-se a necessidade de uma legislação cada vez mais numerosa e técnica, com interpenetrações entre os poderes constituídos. Até a promulgação da Constituição Federal de 1988, a Legislação Federal constituiu-se num dos principais instrumentos de regulação da atenção à saúde bucal no Brasil. Com a regulamentação do Sistema Único de Saúde - SUS, os atos normativos do Ministério da Saúde (Poder Executivo) assumiram esse papel. Estudos realizados indicam uma supremacia do Poder Executivo no processo de formulação das políticas. Objetivo - Identificar a regulamentação da atenção à Saúde Bucal na produção legislativa federal $\mathrm{e}$ analisar os temas e setores regulamentados emergentes dessa análise. Método - Pesquisa documental da produção legislativa federal publicada entre 1824 e julho de 2007. Foram identificadas na base de dados Legislação Federal do Sistema de Informações do Congresso Nacional - SICON as regulamentações relacionadas ao objeto, empregando-se termos de busca como "bucal", "odontologia", "cárie", "dente", e derivações dos radicais "fluor", "dent", entre outros termos relacionados à odontologia. Os documentos foram submetidos à análise de conteúdo. Resultados - Localizaram-se 519 regras legais, sendo 500 originadas no Executivo e 91 no Legislativo. Entre 1824 a 1988, os setores de atuação mais regulamentados, em ordem decrescente foram o Ensino Superior, a Administração Federal, as Forças Armadas e Segurança Pública, o Exercício Profissional e as Entidades de Classe. Em relação aos temas, destacaram-se em ordem decrescente as regulamentações sobre Gestão de Pessoal, Abertura de Cursos de Odontologia e Estruturação e Fiscalização do Exercício Profissional. A partir de 1989, o Sistema de Saúde Suplementar passa a contar com a maioria das regras legais, em função da regulamentação do setor. Em todo o período analisado, somente três regras legais referiram-se a Programas e Ações de Saúde Bucal: duas sobre a fluoretação das águas de abastecimento público e uma sobre a assistência odontológica nos acidentes de trabalho. A partir de 2003, não foram localizadas regras legais sobre saúde bucal aprovadas pelo Congresso Nacional. Conclusão - A maior parte das regras legais publicadas teve origem no Poder Executivo, apontando um desequilíbrio entre os Poderes de Estado. Os temas prioritários durante todo o período dizem respeito à formação da odontologia no Brasil, no que tange à regulamentação da profissão, à estrutura e organização dos órgãos de fiscalização para o exercício profissional da odontologia, à estruturação e organização do ensino superior $\mathrm{e}$ à formação das associações e entidades de classe. Quanto à implantação de programas e ações na atenção à saúde bucal foi identificada a regulamentação da fluoretação das águas de abastecimento público.

Descritores: Saúde bucal. Regulação. Saúde pública. Legislação. Instrumentos de regulação. Regulamentação. 


\begin{abstract}
Introduction - The 1824 Constitution established the Political Powers in Brasil in a historical moment when it was meant to limit the Government interventions. As the society progressed, the government was more and more required to regulate the social affairs, bringing about the need of a more comprising and technical legislation with transit in the powers once established. Until the establishment of the Federal Constitution back in 1988, the Federal Legislation was the most important regulation instrument for the Oral Health Care in Brasil. Along with the establishment of the Health Central System - HCS, the normative acts of the Health Ministry (Executive Power) started playing that role. Studies have indicated a domination of the Executive Power in the process of policies formulation. Objective - Identify the Oral Health Care regulation in the federal legislative production approved and analyse the themes and regulated sectors emerging from that analysis. Method Documentary research of the legislative production approved between 1824 and July 2007. The National Congress Information System Federal Legislation - SICON, the regulations related to the object were identified in the database by searching with the terms "bucal", "odontologia", "cárie", "dente", and derivatives of the radicals "fluor", "dente" among other terms pertaining to dentistry. The documents were submitted to a content analysis. Results - Five hundred and nineteen legal rules were found, that is, 500 from the Executive Power and 91 from the Legislative Power. Between 1824 and 1988 the most regulated sectors, in descending order were College Education, Federal Administration, the Armed Forces and Public Security, the Professional Practices and Class Entities. Regarding the themes, in descending order, the regulation about Human Resources Administration, establishment of new Dentistry Courses and Structure and Inspection of the Professional Practice were highlighted. Effective from 1989, the Supplementary Health System started to count on most of legal rules as a result of the regulation of that sector. Along the period analysed, only three legal rules referred to Programs and Oral Health Care Actions: two on fluoridation of public water supplies and another on dental assistance in cases of accidents at work. Since 2003 no legal rules have been found about oral health approved by the National Congress. Conclusion - Most of legal rules approved by the National Congress had their origin in the Executive Power, indicating an unbalance between the Governmental Powers. The prior issues during all the period refer to the formation of the dentistry in Brasil, in terms of corporate regulations, the structuring and establishment of surveillance departments on the professional dentistry practice, structure and organization of College Education and the formation of associations and class entities. As for the establishment of programs and actions for the Oral Health Care, the regulation of the fluoridation of public water supplies was identified.
\end{abstract}

Key words: Oral Health, Regulation, Public Health, Legislation, Regulation Instruments, Regulation. 


\section{INTRODUÇÃO}

As regulamentações podem refletir uma ação positiva do Estado para a proteção e a garantia de benefícios ou, como afirma BOBBIO (1992), um 'não-agir' do Estado.

DALLARI (2005) afirma que a organização da sociedade pressupõe a constituição de um poder que, embora político, é suscetível à qualificação jurídica. Esse poder, sem ser totalmente jurídico, age concomitante com o direito, buscando uma coincidência entre os objetivos de ambos. Ao Estado cabe coordenar os grupos e os indivíduos em busca desses objetivos, impondo a escolha dos meios adequados.

As Constituições Brasileiras de 1824 e 1891 deram positividade e juridicidade aos direitos do homem e às garantias individuais, sem preocupação com os direitos sociais. Com a Constituição de 1934, os direitos econômicos e sociais foram incorporados como direitos trabalhistas, sendo mantidos nas Constituições de 1937, 1946 e 1967. Somente com a Constituição de 1988 os direitos humanos foram positivados, tanto os individuais, como os difusos e coletivos, trazendo instrumentos constitucionais para garantir a eficácia desses direitos (ADÃO 1999, FREITAS 2007).

Para BOBBIO (1992) e DALLARI (2005), o verdadeiro problema da nossa época consiste em criar mecanismos para garantir a efetividade dos direitos sociais básicos previstos nos textos legislativos.

ADÃO (1999) afirma que, o equilíbrio entre a liberdade individual e a autoridade estatal, somente pode ser atingido através da lei geral estatal elaborada segundo regras preestabelecidas e aceitas pela coletividade.

$O$ princípio da Legalidade tem uma aplicação diferenciada para os indivíduos particulares e para a Administração Pública e, ao contrário dos particulares, aos agentes públicos somente é facultado agir por imposição ou autorização legal. Inexistindo lei, não haverá atuação administrativa legítima. Os Poderes Públicos somente podem praticar os atos determinados pela lei e, como 
decorrência, tudo aquilo que não resulta de prescrição legal é vedado ao administrador.

A evolução da sociedade trouxe exigências, sendo o Estado cada vez mais solicitado a agir, ampliando sua esfera de ação e intensificando sua participação nas áreas tradicionais, impondo-se uma legislação mais numerosa e mais técnica (DALLARI 2005).

Historicamente, a organização dos serviços públicos no Brasil vem sendo a expressão da concepção de política pública vigente nos diferentes momentos do Estado brasileiro (ALMEIDA e col. 2001).

Até os anos de 1930, as políticas sociais eram fragmentadas e emergencistas, sendo que os conflitos entre o capital e o trabalho eram regulados por legislação esparsa com tratamento por forte aparato policial. As questões de saúde pública eram tratadas pelas autoridades locais, não havendo programas de ação por parte do governo central, cuja ação restringia-se às situações de emergência durante as epidemias nos centros urbanos (MEDEIROS 2001). Da mesma forma, não havia uma política global de educação e a previdência era predominantemente privada e organizada por empresas e categorias profissionais.

Segundo esse autor, a partir de 1930, constituiu-se no Brasil um Welfare State com políticas de caráter conservador e autoritário, em que os antagonismos entre classes eram encarados como nocivos ao bem-comum representado pelo Estado. Entre os anos de 1930 e 1943, o Brasil definiu as bases modernas de seu sistema de seguridade social com políticas voltadas para os trabalhadores urbanos permanecendo intactas até 1966. A legislação produzida nesse período apresentava graus elevados de nacionalização sob a forma de centralização de recursos e instrumentos institucionais e administrativos no Executivo Federal.

Entre 1945 e 1964, não foram observadas mudanças significativas na construção do Welfare State, embora o país tivesse adotado um regime democrático a partir de 1945 . Esse período foi marcado pela criação de instrumentos legais para o funcionamento de um governo democrático, permanecendo inalteradas as estruturas corporativas do Welfare State.

Entretanto, as mudanças na economia e na política exigiram do Estado a ampliação e a articulação de suas funções para suprir as 
necessidades advindas da urbanização e da modernização do país. Assim, ocorrem a unificação administrativa e a uniformização dos benefícios e dos serviços da previdência social, sendo que na saúde o enfoque se deu sobre as questões relacionadas às doenças de massa e à assistência médica. No trabalho, a ocorrência de lutas sindicais e política salarial, na educação, a democratização do ensino e a qualificação profissional e a habitação passa a ser considerada questão social. (MEDEIROS 2001).

Esse período é caracterizado pelos avanços nos processos de centralização institucional e de extensão da proteção social a novos grupos sociais, permanecendo, porém, o padrão seletivo, heterogêneo e fragmentado de beneficiários, benefícios e instituições.

Esse autor afirma que, a partir de 1964, são implementadas "políticas de massa de cobertura relativamente ampla, mediante a organização de sistemas nacionais públicos ou estatalmente regulados de provisão de serviços sociais básicos (....) O progresso social seria derivado do crescimento econômico com a necessidade de se acumular renda para garantir as bases do crescimento. A redistribuição de renda ocorreria, posteriormente" (MEDEIROS 2001, p.14).

Entre 1964 a 1970, o modelo de Welfare State perde o caráter populista, assumindo um caráter produtivista com a privatização das políticas sociais.

Entre 1970 até o final da década de 1980, as reformas ocorridas foram caracterizadas pela centralização política e financeira em nível federal, pela fragmentação institucional, pelo tecnocratismo, pelo autofinanciamento, pela privatização e uso clientelista das políticas sociais, sem funcionar como mecanismo redistributivo do produto da economia, resultando em ineficiência e ineficácia dos programas sociais (MEDEIROS 2001).

Segundo ALMEIDA e col. (2001), a partir de 1980, com a redemocratização e a crise econômica, estabeleceu-se como prioridade um novo padrão de desenvolvimento - crescimento com distribuição - e a definição de um novo arcabouço jurídico-institucional, que culminou com a convocação da Assembléia Nacional Constituinte, em 1986. 
Com o início da Nova República em 1985 e a consolidação da democracia em 1988, ocorreram avanços na área política através do crescimento da atividade partidária e sindical e do aumento da participação popular no processo eleitoral. Ao mesmo tempo, seguiu-se a retração e o desmantelamento das políticas sociais, num contexto de pressões para cortes nos gastos públicos e mudanças institucionais e organizacionais no governo.

A $7^{\mathbf{a}}$ Constituição da República Federativa do Brasil, promulgada em 05/10/1988, criou o Sistema Único de Saúde a ser organizado segundo as diretrizes de descentralização político-administrativa com comando único em cada esfera de governo, da integralidade do atendimento e da participação da comunidade.

O Sistema Único de Saúde (SUS), regulamentado pelas Leis Federais $\mathrm{n}^{\circ} .8 .080$ e $\mathrm{n}^{\circ} .8 .142$ de 1990 , incorporou os princípios da igualdade na assistência/eqüidade, da universalidade do acesso e uma nova lógica de organização da saúde assentada na utilização da epidemiologia para a definição de prioridades, na conjugação de recursos financeiros para a gestão e o financiamento do sistema, entre outros dispostos no Artigo $7^{\circ}$ da Lei Federal $n^{\circ} .8080 / 90$.

O conceito de saúde passa a ser entendido numa perspectiva de articulação de políticas econômicas e sociais, como direito social universal, derivado do exercício da cidadania plena e não mais como direito previdenciário. Os serviços e ações de saúde são considerados de relevância pública, e a saúde passa a integrar a Seguridade Social (ALMEIDA e col. 2001; CARVALHO 2002).

PAIM (2005) afirma que, durante as décadas de 1970 e 1980, a atuação do Movimento Sanitário teve como foco principal a defesa de um SUS público ou estatal diante das ameaças do movimento neoliberal representadas pela Reforma do Estado e pela redução de recursos financeiros e gastos públicos. Naquele momento, não houve espaço para uma investigação ou posição política mais clara em relação ao setor privado. Com o recuo do Movimento Sanitário e os novos atores representados, particularmente, pelo Conselho Nacional de Secretários Municipais de Saúde (CONASEMS) e pelo Conselho Nacional de Secretários 
Estaduais de Saúde (CONASS), adotou-se uma postura pragmática permeada de interesses intrínsecos à condição de gestores políticos, que não parece ser suficiente para construir pactos com o setor privado ou com as modalidades "não-SUS".

A partir de 1990, a hegemonia política das propostas neoliberais previa a abertura comercial a desregulamentação da economia brasileira, a política de controle fiscal dos gastos públicos, o arrocho do crédito e a diminuição de liquidez no sistema financeiro.

Entre o final dos anos de 1980 e meados da década de 1990, ocorreu a grande expansão do segmento da sáude suplementar, coincidindo com a transição epidemiológica e demográfica do País e com o crescente desfinanciamento da saúde pública. Esse segmento tornou-se atraente aos investimentos de grupos econômicos, implicando no reposicionamento das burocracias governamentais e do papel do Estado (SCHEFFER e BAHIA 2005).

As tentativas para aumentar a eficiência do Estado tem sido a delegação de poderes, sobretudo a delegação de poder legislativo, e a transferência constitucional de competências por meio de reformas constitucionais ou até a promulgação de novas Constituições, no sentido de se aumentar as competências do executivo (BAPTISTA 2003).

HEIMANN e col. (2005) afirmam que, no Brasil, a Regulação do setor Saúde, se assenta, por um lado, na Constituição Federal de 1988 e na Lei Federal 8.080/1990, com artigos direcionados à regulação do Sistema de Saúde no Brasil. Por outro, na "macropolítica de ajuste econômico e da Reforma do Estado, ocorrida nos anos de 1990, a partir da privatização de setores em que o Estado era provedor, tais como o das telecomunicações, o da energia elétrica ou da saúde" (p.177).

Para esses autores, a legislação do SUS define, de forma ampla e abrangente, as atribuições e as competências necessárias à fiscalização, ao controle e ao estabelecimento de regras para o sistema, enquanto que a regulação com base na Reforma do Estado direciona-se à estruturação do mercado de planos de saúde, descaracterizando a assistência à saúde como direito universal. 
A noção de regulação quando traduzida para a língua inglesa não encontra seu correspondente, confundindo-se com regulamentação regulation. A noção de regulação foi definida por BOYER (1990):

\begin{abstract}
Designaremos sob o termo de regulação a conjunção dos mecanismos que viabilizam a reprodução do conjunto do sistema, em função do estado das estruturas econômicas e sociais. Esta regulação está na origem da dinâmica de curto e médio prazo (...) Por seu turno, a dinâmica de período muito longo não resulta simplesmente da sucessão destas flutuações e destes ciclos, mas também coloca em cena, de modo crucial, as lutas políticas e sociais que não se reduzem à dinâmica da acumulação, ainda que sejam parcialmente por elas determinadas (p.181).
\end{abstract}

Para CARVALHO (2005) e CARVALHO (2003), o termo

Regulação vem sendo adotado de modo indevido, uma vez que na legislação brasileira a Regulação ou Regulamentação refere-se à formulação de regras, segundo os trâmites legais observados na Constituição Federal, nas Leis, nos Decretos, nas Portarias, nas Normas, entre outras. Para esse autor, o termo Regulação não abrangeria as ações relativas à execução dessas regras, embora considere essas ações de suma importância no sistema de saúde.

O conceito de Regulação adotado pelo Ministério da Saúde é o de Regulação enquanto ação social, ou seja, "o conjunto de ações mediatas, de sujeitos sociais sobre outros sujeitos sociais, que facilitam ou limitam os rumos da produção de bens e serviços em determinado setor da economia, compreendendo tanto o ato de regulamentar, as regulamentações, quanto às ações que asseguram o cumprimento destas (SCHILLING e col. 2006, p.34).

Assim, segundo esses autores, a gestão de um sistema público de saúde deve contemplar a definição da política de saúde e do correspondente projeto tecno-assistencial, implementados por meio do planejamento, financiamento, ornamentação, programação, informação/informática, gestão do trabalho e educação, ciência e tecnologia, funções administrativas e financeiras, macrorregulação e dos modelos de atenção à saúde (SCHILLING e col. 2006).

Para o Ministério da Saúde a Regulação que compreenderia tanto o ato de elaborar regulamentações, quanto às ações de fiscalização, de controle, de avaliação e de auditoria destinadas a assegurar o cumprimento das 
regulamentações definidas por uma esfera de governo. Regular "não se resumiria ao ato de regulamentar, mas também incluiria uma gama de ações que verificam se a produção em saúde se dá conforme as regras estabelecidas" (SCHILLING e col. 2006; p.36).

A proposta deste trabalho é identificar os temas de regulamentação sobre a atenção à Saúde Bucal no Brasil, a partir da produção Legislativa Federal publicada, entre os anos de 1824 a julho de 2007.

Para CHAVES (1986), a odontologia evoluiu a partir da prática exercida, inicialmente, sob a forma de ocupação indiferenciada, por indivíduos de determinada comunidade, até a fase em que a profissão "chega ao auge", isto é, "uma profissão estruturada, com escolas universitárias, ensino de pósgraduação, associações profissionais fortes, exercício profissional praticamente resolvido a ponto de poder delegar funções na cavidade oral..." (p.154).

As cinco etapas evolutivas sistematizadas por CHAVES (1986) tentam reproduzir a evolução da odontologia, numa perspectiva atemporal e não localizada, sem vincular os resultados em termos de benefícios na condição de saúde bucal das populações.

Para Narvai e Frazão (2006), citados por NARVAI (2006), a saúde bucal das populações não resulta apenas da prática odontológica, mas de construções sociais operadas conscientemente pelos homens, em cada situação concreta. Como processo social, "cada situação é única, singular, histórica, não passível, portanto de replicação ou reprodução mecânica em qualquer outra situação concreta, uma vez que os elementos e dimensões de cada um desses processos apresentam contradições, geram conflitos e são marcados por negociações e pactos que lhes são próprios, específicos" (p.144).

NARVAI (2002), ao pesquisar as relações de poder associadas ao uso da palavra odontologia, afirma que o termo tem sido insuficiente para produzir conceitos consensuais. Para suprir essa insuficiência, expressões como 'odontologia sanitária', 'odontologia social', 'odontologia preventiva', odontologia simplificada', 'odontologia integral' vêm sendo utilizadas em diferentes contextos.

Segundo esse autor, a odontologia sanitária teve seu apogeu nos anos de 1960, assumindo o discurso oficial da época que culminou com a 
proposta governamental de se transformar o Serviço Nacional de Fiscalização Odontológica - SNFO em Serviço Nacional de Odontologia Sanitária - SNOS.

Odontologia social e preventiva teve seu apogeu durante a ditadura militar (1968-1978), com formulações teóricas da odontologia sanitária associadas a esse contexto autoritário, entrando em declínio nos anos 80 (NARVAI 2006).

Para NARVAI (2002), muitas são as concepções de odontologia social que, a exemplo de 'odontologia', não foram capazes de se constituir numa idéia comum, havendo associação do termo social a algo precário sem qualidade e dirigidos aos pobres.

Odontologia social e preventiva teve seu apogeu durante a ditadura militar (1968-1978), com formulações teóricas da odontologia sanitária associadas a esse contexto autoritário, entrando em declínio nos anos 80 (NARVAI 2006).

Por sua vez, a expressão odontologia integral parece incapaz de esclarecer algum significado, pois o adjetivo integral pode ser referente à integralidade dos processos biológicos quanto à integração e articulação dos processos sociais.

Diferente de todas as adjetivações referidas à odontologia no Brasil, a Saúde Bucal Coletiva apresenta uma clara perspectiva de rompimento da hegemonia da odontologia de mercado, na medida em que seus projetos de sociedade opõem-se explicitamente aos projetos neoliberais.

Para Narvai \& Frazão, (2006), citados por NARVAI (2006), a "Saúde Bucal Coletiva é um campo de conhecimentos e práticas [que integra] um conjunto mais amplo identificado como 'Saúde Coletiva' e que, a um só tempo, compreende também o campo da 'Odontologia', incorporando-o e redefinindo- o e, por esta razão, necessariamente transcendendo-o" (p.144).

Frazão (1999), citado por NARVAI (2006) afirma que a Saúde Bucal Coletiva pretende 'substituir toda forma de 'tecnicismo' e de 'biologismo' presentes nas formulações específicas da área de odontologia social e preventiva, (....) realizando a reconstrução teórica de modo articulado e orgânico ao pensamento e a ação da Saúde Coletiva, e reforçando o compromisso histórico desta 
com a qualidade de vida na sociedade e com a defesa da cidadania, tanto da ação predatória do capital quanto da ação autoritária do Estado " (p.144).

Nesse sentido, NARVAI (2006) destaca que para o rompimento entre Saúde Bucal Coletiva e a prática hegemônica da odontologia de mercado, o trabalho odontológico deverá ser desenvolvido a partir das necessidades das pessoas e não a partir da mercantilização dos serviços e do monopólio do acesso aos recursos.

Relativamente às necessidades das pessoas, BOTAZZO (2006) propõe o conceito de bucalidade, como um arranjo teórico metodológico no qual são essenciais os 'trabalhos bucais' identificados como manducação (consumo do mundo para sobreviver no plano natural), linguagem (produção e consumo de palavras) e erotismo (relação amorosa e produção de atos bucais sexuais), Para esse autor, a saúde não se esgota na forma clínica e a teoria odontológica é suficiente para recuperar o homem por inteiro.

De acordo com esse autor, o SUS assentado nos princípios de universalidade, integralidade e eqüidade, pode possibilitar a realização de ações para atender às necessidades de todas as pessoas, viabilizando seu acesso a todos os recursos odontológicos e de saúde geral de que necessitem e ofertando mais aos que mais necessitam.

No entanto, as ações assistenciais devem ser articuladas a um conjunto amplo de medidas para que os 'modelos de atenção' à saúde consigam, de maneira efetiva, produzir socialmente a saúde coletiva sem reduzir o modelo de atenção ao sistema assistencial.

Para NARVAI (2005), a atenção à saúde refere-se ao "conjunto de atividades intra e extra-setor saúde que, incluindo a assistência individual, não se esgota nela, atingindo grupos populacionais com o objetivo de manter a saúde, e requerendo ações concomitantes sobre todos os determinantes da saúde-doença" (p.4). Nesse sentido, conceitua a assistência como o "conjunto de procedimentos clínico-cirúrgicos dirigidos a consumidores individuais, doentes ou não" (p.4).

CARVALHO (2002) afirma que o Artigo 197 da Constituição Federal deixa explícito que todas as ações e serviços públicos e 
privados são considerados de relevância pública, tendo o Ministério Público a responsabilidade por zelar para que os serviços de relevância pública respeitem os direitos constitucionais, como o é o da saúde.

CHAVES (1986) afirma que, a maioria das entidades públicas e privadas mantenedoras de serviços de saúde sempre ofertaram algum tipo de assistência dentária. $\mathrm{Na}$ área governamental, esse autor destaca que os ministérios e secretarias ofereciam atenção odontológica a seus funcionários e dependentes, sendo que os serviços odontológicos das Forças Armadas sempre tiveram expressão em todo o território nacional.

Segundo Vasconcellos (1984), citado por NARVAI (2006), os primeiros cargos de cirurgião-dentista na administração pública paulista foram direcionados ao atendimento odontológico do efetivo da Força Pública e aos cidadãos sob custódia do Estado, no âmbito da Secretaria de Justiça e Segurança Pública. Em 1929, os profissionais de odontologia passaram a integrar os quadros da Inspeção Médico-Escolar da Secretaria do Interior, então responsável pelas atividades ligadas à educação e à saúde no Estado.

Em 1932, após a criação da Secretaria da Educação e da Saúde Pública, instituiu-se a Inspetoria de Higiene e Assistência Dentária no Serviço Sanitário para o atendimento da população de escolares da rede pública estadual. Em 1947, instituiu-se a recomendação de que os centros de saúde contassem com um Serviço de Higiene Buco-Dentária.

Nos sucessivos arranjos institucionais e modalidades estatais de produção de serviços que marcaram a organização da assistência odontológica pública, a odontologia de mercado jamais perdeu sua hegemonia. Embora se buscasse desenvolver ações educativas, tais profissionais reproduziam a prática clínica dos dentistas nos consultórios particulares, com abordagem individual, sem um diagnóstico de situação em termos populacionais ou programação que considerassem a saúde bucal da população como um todo (NARVAI 2006).

CHAVES (1986) relata que, durante muitos anos, a odontologia ficou sem representação na estrutura organizacional do Ministério da Saúde, no que tange às atribuições de coordenação, assistência técnica ou auxílio financeiro aos programas desenvolvidos em outras esferas federais. Segundo esse 
autor, essa lacuna foi preenchida pela Fundação Serviços de Saúde Pública - FSESP, criada em 1942, que durante três décadas reuniu um acervo de experiências em programas incrementais destinados a escolares e na implantação de sistemas de fluoretação de água de abastecimento público.

PINTO (2000) afirma que, do ponto de vista organizacional, as ações de saúde bucal têm o clássico formato de um não sistema, com prestadores de serviços que atuam de maneira independente, não articulada, sem uma orientação ou comando único. Entre o início do século XX até os anos de 1970, as estatísticas odontológicas demonstram que países com maior número de dentistas apresentavam maior prevalência de cárie.

Dados epidemiológicos do levantamento Projeto SB Brasil 2003 sobre as condições de saúde bucal da população brasileira, indicam diferenças na distribuição do ataque de cárie em crianças, tanto na dentição decídua quanto na permanente, evidenciando diferenças entre regiões do país e nos componentes do Índice CPOD/ceo-d. Da mesma forma, o ataque de cárie e o número de dentes perdidos entre adultos e idosos são elevados (MS 2004).

Esse levantamento também indicou que cerca de $10 \%$ dos adultos brasileiros possuem bolsa periodontal em uma ou mais regiões da boca, $10 \%$ dos adultos com pelo menos um sextante da boca excluído, sendo que esse problema atinge mais da metade dos idosos. A perda precoce é grave e a necessidade de prótese começa a surgir a partir da faixa etária de 15 a 19 anos.

Segundo esse levantamento, as diferenças apontadas podem ser decorrentes do modelo de atenção em cada área geográfica, como os impactos da fluoretação da água e do creme dental e de medidas mais específicas relacionadas ao acesso e à utilização de serviços de odontologia (MS 2004).

Relativamente à fluoretação, a amostra apontou que $46 \%$ dos municípios pesquisados dispunham de água fluoretada com maior concentração nas regiões Sul e Sudeste.

Ao lado do câncer de boca, a ausência de dentes é um dos mais graves problemas da saúde bucal no Brasil. Hoje $75 \%$ dos idosos são desdentados e entre adultos, com idade entre 30 e 44 anos, esse índice é de $30 \%$. O Ministério da Saúde registra, ainda, um total de 5 mil adolescentes desdentados sem 
prótese na boca e estima-se que 8 milhões de pessoa precisem de prótese dentária no país (MS 2006b).

Segundo a Pesquisa Nacional de Saneamento Básico do Instituto Brasileiro de Geografia e Estatística (2000), havia 5391 municípios com serviços de abastecimento público de água por rede de distribuição, o que representa $\mathbf{9 7 , 9 \%}$ do total dos 5.507 municípios existentes por ocasião da pesquisa.

Embora a maioria dos municípios brasileiros conte com serviços de abastecimento público de água por rede de distribuição, somente 45,74\% do total de municípios com serviços de abastecimento público de água informaram realizar a fluoretação da água. A grande maioria dos municípios que conta com serviços de abastecimento público de água com fluoretação está localizada Sul e Sudeste $(70 \%)$, região Centro-Oeste $(41,5 \%)$ e regiões Norte e Nordeste, $7,8 \%$ e $16,55 \%$.

No Brasil, $68,8 \%$ dos municípios têm a prestação dos serviços de abastecimento público de água delegada para as empresas estaduais de saneamento. Quanto à fluoretação, observa-se que, em 53,5 \% ocorre a fluoretação da água distribuída a população.

Por outro lado, $45,5 \%$ dos municípios brasileiros têm a prestação dos serviços de abastecimento delegada aos próprios municípios, observando-se a fluoretação em apenas $20 \%$. Portanto, a fluoretação tem maior abrangência nos municípios operados pelas companhias estaduais de saneamento. Quanto aos serviços de abastecimento público de água prestado por operadores privados, observa-se que tal modalidade de prestação ocorre em 8,4\% dos municípios brasileiros, com 12,2\% de fluoretação (MS 2006 c).

A Coordenação Nacional de Saúde Bucal, órgão do Departamento de Atenção Básica (DAB) da Secretaria de Atenção à Saúde (SAS), tem como principal atribuição coordenar a implantação de uma Política de Saúde Bucal no SUS, articulada com as demais políticas de saúde, que objetive a redução das desigualdades e a inclusão social.

Em 17 de março de 2004, o Governo Federal criou a Política "Brasil Sorridente" com diretrizes de ampliação e qualificação da atenção básica, visando o acesso da atenção a todas as faixas etárias e a oferta de mais serviços. 
Propõe-se, também, a ampliar os atendimentos nos níveis secundário e terciário para a busca da integralidade, da equidade e da universalização do acesso às ações e serviços públicos de saúde bucal (MS 2006 a). 


\section{MATERIAL E MÉTODO}

Este estudo busca identificar a regulação da atenção à Saúde Bucal em documentos selecionados na produção legislativa federal, tomando por base o conceito ampliado de Regulação Estatal sobre o Setor Saúde adotado pelo Ministério da Saúde (SCHILLING e col. 2006).

Foram realizadas buscas nas principais bases de dados que reúnem as normas de caráter geral emanadas do Poder Legislativo e as editadas pelo Chefe do Poder Executivo. A opção foi por efetuar a pesquisa na base Legislação Federal do Sistema de Informações do Congresso Nacional - SICON Versão 2.1.2 - Prodasen do Senado Federal.

Para a busca, utilizou-se o cruzamento das palavras-chave regulação x bucal, regulamentação x bucal, legislação $\mathrm{x}$ odontologia. Face ao pequeno número de regras legais encontradas, reformulou-se o levantamento através da incorporação de palavras-chave isoladas como bucal, oral, odontologia, fluoretação, flúor, dentista, exercício, dentária, dente, cárie, gabinete, cirurgião, entre outras.

A pesquisa abrangeu as regras legais aprovadas em todo o período a partir do qual essas regulamentações ficaram disponíveis nos sistemas, ou seja, 1808, sendo que a amplitude geral das datas estendeu-se de 1824 a julho de 2007. 


\section{RESULTADOS}

Foram analisadas 591 regras legais, das quais 91 (15,39\%) tiveram origem no Legislativo e 500 (84,61\%) no Executivo Federal.

Do total, $527(89,17 \%)$ foram publicadas antes da Constituição Federal de 1988 e 64 (10,83\%) após essa data. Nesse segundo período, destacam-se 44 Medidas Provisórias referentes à regulamentação da Saúde Suplementar.

No período total pesquisado de 183 anos, $45,85 \%$ das regras legais foram publicadas durante o Golpe e o Governo Militar (1964 a 1985), 19,97\% durante a Democratização (1946 a 1964), 14,38\% durante o Governo Provisório, Eleições e Estado Novo de Getúlio Vargas (1930 a 1945), 10,83\% no período PósConstituição de 1988 (1985 a julho 2007), 5,92\% antes de 1930 e 3,04\% durante a Redemocratização (1985 a 1988).

Relativamente ao período, $50,54 \%$ das regras legais originadas no Legislativo foram publicadas durante o período Democratização do país (1946 a 1964) e 50,00\% das originadas no Executivo foram publicadas durante o Golpe e o Governo Militar (1964 a 1985).

Das 591 regras legais, 429 foram Decretos do Executivo, 73 Leis Ordinárias, 44 Medidas Provisórias, 28 Decretos-Lei e 17 Decretos do Legislativo. Encontrada uma Resolução do Senado Federal.

Quanto ao setor regulamentado, o Ensino Superior apresentou 262 (44,33\%), seguido pela Administração Federal com 188 (31,81\%), Forças Armadas e Segurança Pública com 101 (17,09\%), Exercício Profissional com $30(5,08 \%)$ e Entidades de Classe com 10 (1,69\%).

A Figura 1 apresenta a evolução das regras legais por setor regulamentado, com destaque para as do Ensino Superior relativas à abertura de cursos de odontologia, a repasses de recursos, contratações, federalizações, estadualizações, inspeções e proibições/cassações de funcionamento. No período entre 1937 e 1945 (Estado Novo), foram encontrados sete Decretos do Executivo 
proibindo o funcionamento de cursos no país, entre eles Itapetininga-SP, CampinasSP, Campo Grande-SP. As demais regras legais em todos os períodos referem-se à estruturação e à ampliação do Ensino Superior de odontologia.

Figura 1 - Produção Legislativa Federal sobre Saúde Bucal segundo o setor regulamentado e o período - Brasil - 1824 a julho 2007.

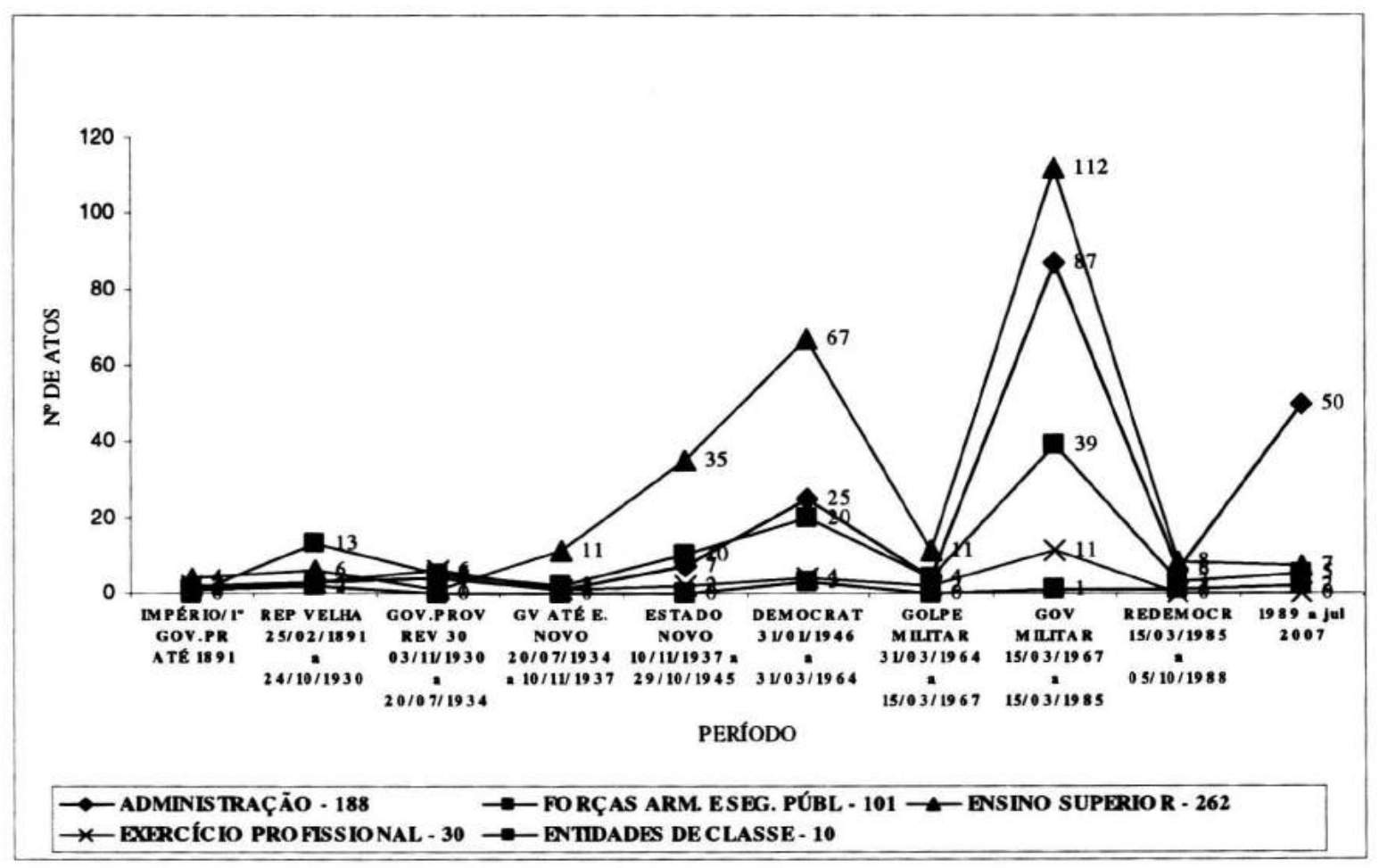

Fonte: Senado Federal - SICON

Os assuntos abordados nos documentos foram classificados a partir do conceito ampliado de Regulação, que tem como principais objetos os estabelecimentos, os profissionais, as relações contratuais, o exercício das profissões, a oferta e a demanda por serviços, os protocolos assistenciais, os fluxos de atendimento, a incorporação de tecnologias, além do controle e da avaliação dos custos e gastos em saúde (SCHILLING e col. 2006).

Assim, num primeiro momento, as regras legais foram classificadas por setores regulamentados. Numa segunda análise, o enfoque se deu sobre os temas regulamentados, a partir da Gestão e Regulação das ações e serviços. 
BAPTISTA (2003) elaborou classificação temática semelhante ao analisar a produção normativa do Ministério da Saúde, no Brasil, entre 1990 e 2002.

Porém, no presente estudo, essa classificação sofreu variações e recebeu aberturas que permitiram evidenciar vários assuntos relacionados à Saúde Bucal na produção Legislativa Federal. Os eixos-temáticos ficaram assim definidos:

- Gestão e organização do sistema e da atenção à Saúde Bucal

a) Regulamentação do sistema e da atenção/assistência: regulamentações gerais da atenção à Saúde Bucal, planos, indicadores, comissões, orientações técnicas;

b) Organização da estrutura: mudanças na estrutura dos ministérios relacionados à área técnica de Saúde Bucal;

c) Regulamentação de rotinas: fluxos e práticas gerenciais;

d) Licitações e cadastros com autorização, credenciamento ou descredenciamento para o funcionamento de unidades e serviços com assistência à Saúde Bucal.

- Financiamento

a) Transferência de recursos: transferências, incentivos, isenções; b) Tabelas e procedimentos: remuneração para prestadores de serviços.

- Programas e Ações de Saúde Bucal

a) Instituição de novos programas e ações relacionadas à Saúde Bucal;

b) Reformulação e criação de mecanismos de controle dos programas e das ações.

- Outras

a) Regulamentações sobre a fiscalização e o exercício profissional, regulamentação do trabalho, regulamentação do ensino superior, cobrança de taxas e tributos, datas comemorativas, regulamentação do exercício profissional.

O eixo-temático Outras aborda assuntos que não se referem diretamente à regulação das ações e serviços de Saúde Bucal, no entanto são 
importantes para o entendimento da conformação da profissão e das escolhas dos governantes em cada período.

Dessa forma, os resultados apontaram que das 591 regras, $489(82,74 \%)$ referem-se ao eixo-temático Outras, $59(9,98 \%)$ ao eixo Gestão e organização do sistema e da assistência à saúde, $39(6,60 \%)$ ao eixo Financiamento/transferência de recursos e $4(0,68 \%)$ ao eixo Programas e Ações .

Figura 2 - Produção Legislativa Federal selecionada sobre Saúde Bucal, segundo os eixos-temáticos, por períodos - Brasil - 1824 a julho de 2007.

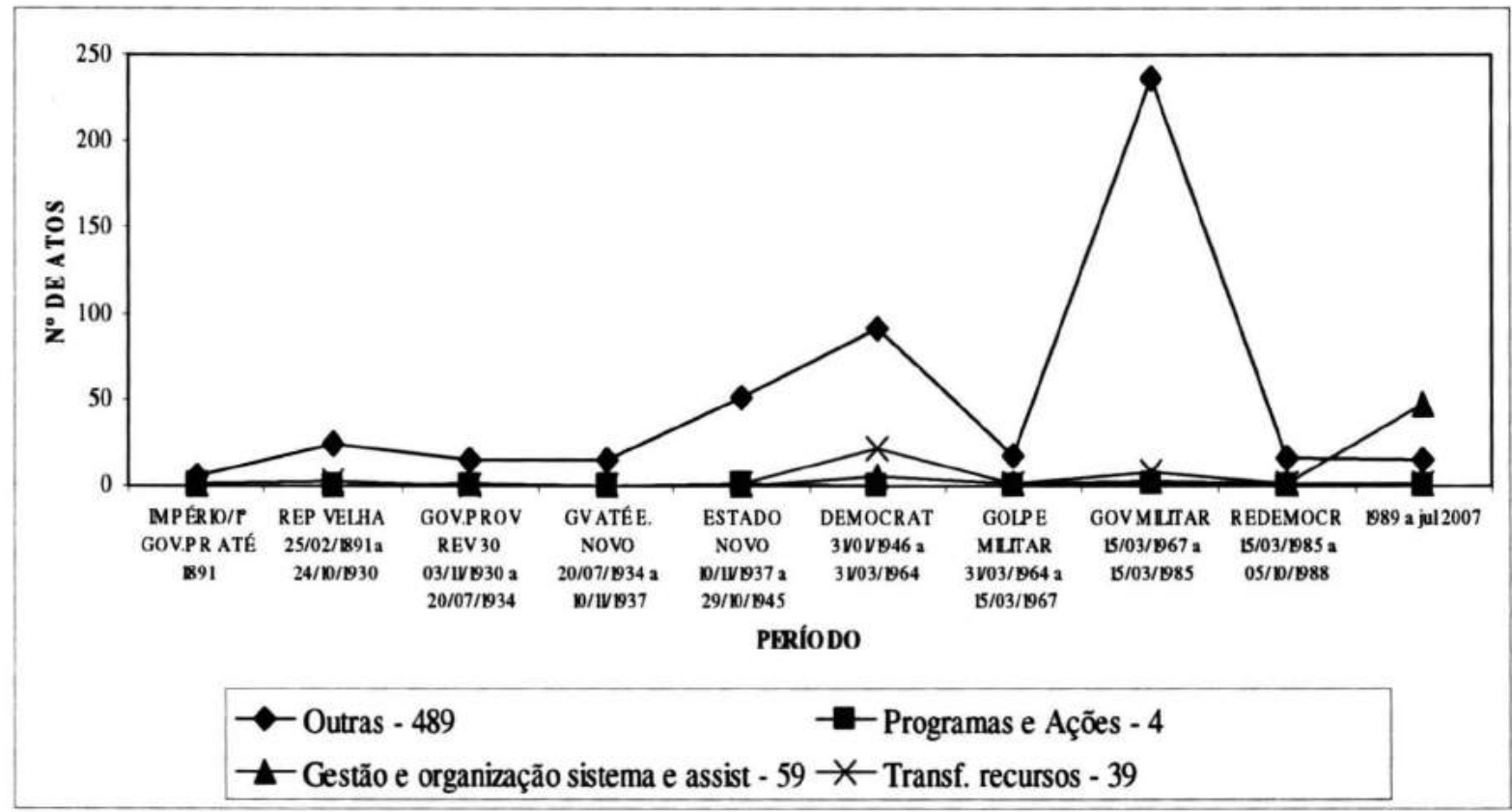

Fonte: Senado Federal - SICON

Observa-se que o eixo Programas e as Ações de Saúde Bucal não tiveram prioridade em termos de regulamentação em todo o período. Das quatro regras encontradas, duas referem-se à fluoretação das águas de abastecimento publicadas no Governo Militar, uma ao programa de assistência odontológica ao pessoal militar em tempos de guerra e uma à obrigatoriedade da assistência aos acidentados no trabalho, ambas publicadas durante o Estado Novo.

Na Gestão e Organização do Sistema, foram encontradas somente duas regras que regulamentam o sistema com diretrizes gerais para a saúde, citando explicitamente algum termo referente à Saúde Bucal: as Normas para Defesa e Proteção da Saúde (1954) e o Código Nacional de Saúde (1961) aprovadas durante o período Democratização (1946 a 1964). Vale destacar que mesmo nesses 
documentos, a ênfase se dá sobre a fiscalização dos estabelecimentos e o exercício profissional odontológico.

Das demais regras de Gestão, cinco referem-se à normatização da importação de equipamentos médico-odontológicos, uma ao controle de entorpecentes e distribuição de amostras grátis em consultórios odontológicos, quarenta e quatro relativas à regulamentação do setor de planos e seguros odontológicos e quatro relativas ao Serviço Nacional de Fiscalização Odontológica. Estas últimas, também com ênfase sobre a fiscalização de estabelecimentos.

No eixo Financiamento, foram identificadas vinte e nove transferências de recursos sob a forma de isenções, doações, materiais, recursos financeiros às escolas e unidades de ensino superior, nove às entidades da classe odontológica e uma à entidade assistencial.

No eixo temático Outras, mais de $65,64 \%$ das regras se referem à gestão e gerenciamento de Pessoal dos setores civil, militar, ensino superior e fiscalização de estabelecimentos e $29,24 \%$ ao Ensino Superior no que se refere à autorização de funcionamento de escolas, organização curricular e ao reconhecimento de cursos de odontologia, editadas, principalmente durante os períodos Democratização e Governo Militar.

Ainda nesse eixo, foram identificadas dezoito regras relativas à fiscalização do Exercício Profissional, sendo oito editadas no Governo Militar, sete entre o Governo Provisório de Getúlio Vargas até Estado Novo, duas antes de 1891 e uma no período Democratização.

Em todo o período, foram identificadas 5 regras relativas à cobrança de tributos profissionais, taxas para estabelecimentos odontológicos e reajustes de alíquotas de Imposto de Renda. Destaque para duas regras sobre data e semana comemorativa da profissão e da Saúde Bucal.

$\mathrm{Na}$ Figura 3, as prioridades temáticas podem ser observadas dentro dos setores regulamentados. 
Figura 3 - Produção Legislativa Federal selecionada sobre Saúde Bucal, segundo os setores regulamentados e os temas - Brasil - 1824 a julho 2007.

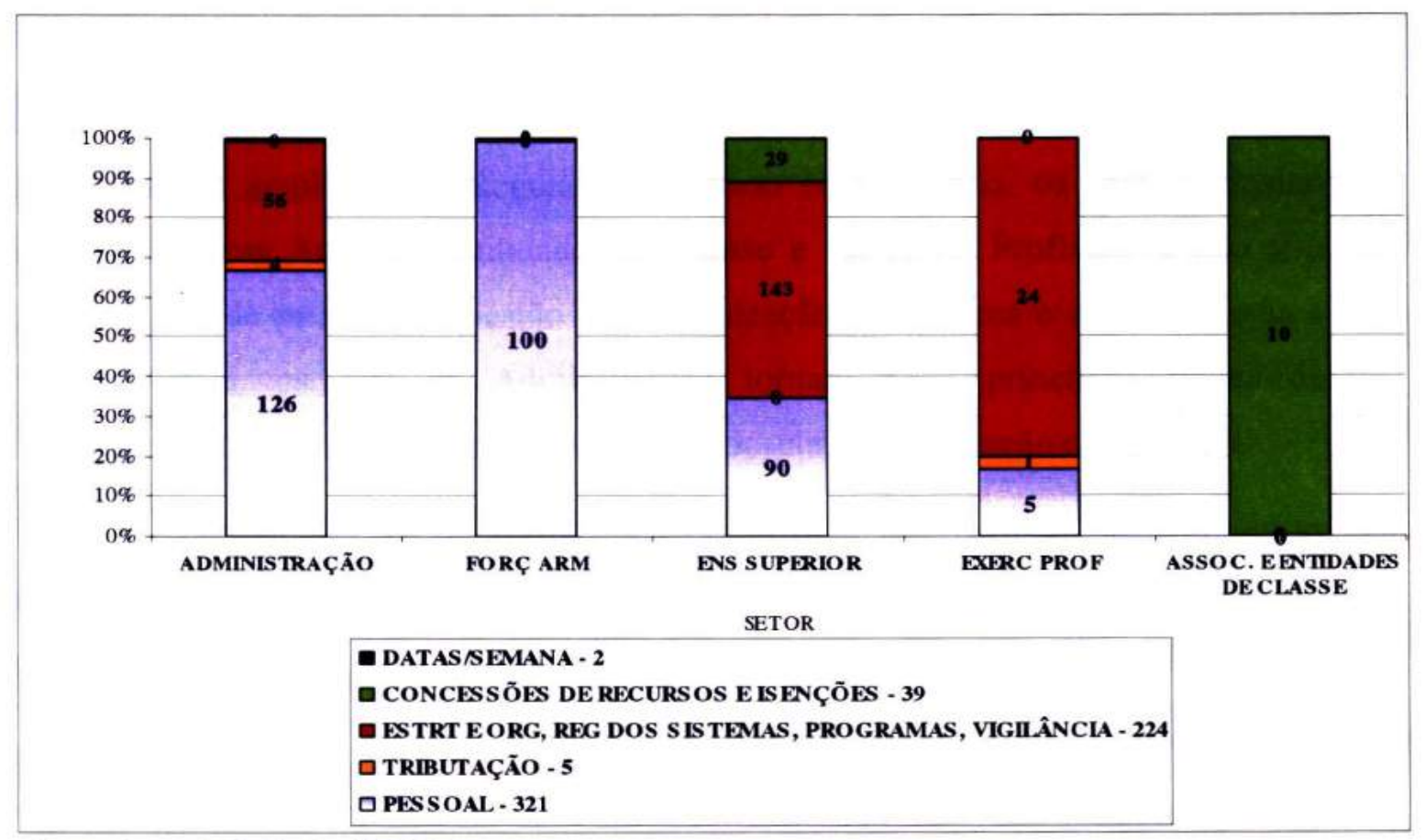

Fonte: Senado Federal - SICON

Figura 4 - Produção Legislativa Federal sobre Saúde Bucal, segundo os temas e setores regulamentados - Brasil - 1824 a julho 2007.

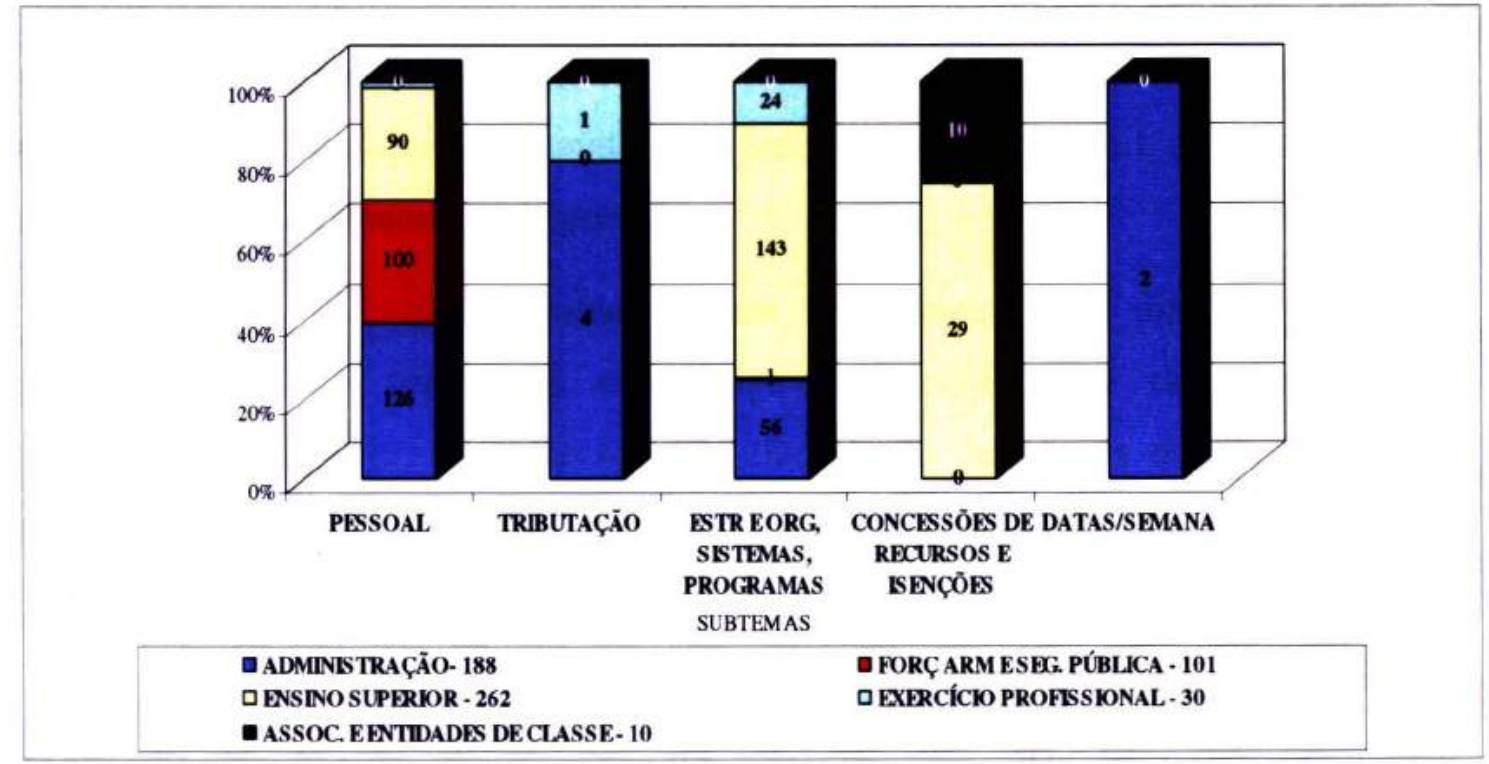

Fonte: Senado Federal - SICON

Os dados referentes à Gestão de Pessoal do setor

Administração apontam para o crescimento da rede assistencial em vários órgãos do 
Executivo Federal. Essa rede assistencial dirigida, principalmente, ao atendimento de funcionários públicos, pensionistas e aposentados teve seu maior crescimento durante o Governo Militar, considerando-se o ano de publicação das primeiras regulamentações identificadas.

Embora sejam setores regulamentados e estejam abarcados pelo conceito ampliado de Regulação utilizado neste estudo, os setores Ensino Superior, Forças Armadas, Entidades de Classe e Exercício Profissional não têm como finalidade principal a Gestão e a Organização do Sistema e da Assistência à Saúde. Assim, os atos da Administração tornam-se as principais fontes de regulamentação sobre os Programas e sobre a Gestão e Organização da Atenção.

Dessa forma, pode-se afirmar que do total de 591 regras identificadas no período, somente 56 regras legais da Administração $(9,48 \%)$ podem dizer respeito à Gestão e Programas, cabendo identificá-las para melhor análise.

Das 56 regulamentações identificadas, $53(94,64 \%)$ dizem respeito à Gestão e Organização do Sistema e 3 (5,36\%) dispõem sobre Programas.

Conforme a Figura 5, das 53 regras sobre Gestão, 45 dizem respeito à Saúde Suplementar do setor privado, 6 dispõem sobre normas de importação/exportação do mercado de equipamentos odontológicos e sobre a produção e distribuição de produtos da indústria farmacêutica e 2 dispõem sobre diretrizes gerais do sistema de saúde, com enfoque exclusivo sobre a fiscalização de estabelecimentos odontológicos privados.

Relativamente aos Programas, 1 dispõe sobre a obrigatoriedade da assistência odontológica ao contingente de trabalhadores acidentados e 2 sobre a implantação da fluoretação das águas de abastecimento público no Brasil. 
Figura 5 - Produção Legislativa Federal selecionada sobre Saúde Bucal no setor Administração, segundo os temas Gestão e Programas - Brasil - 1824 a julho de 2007.

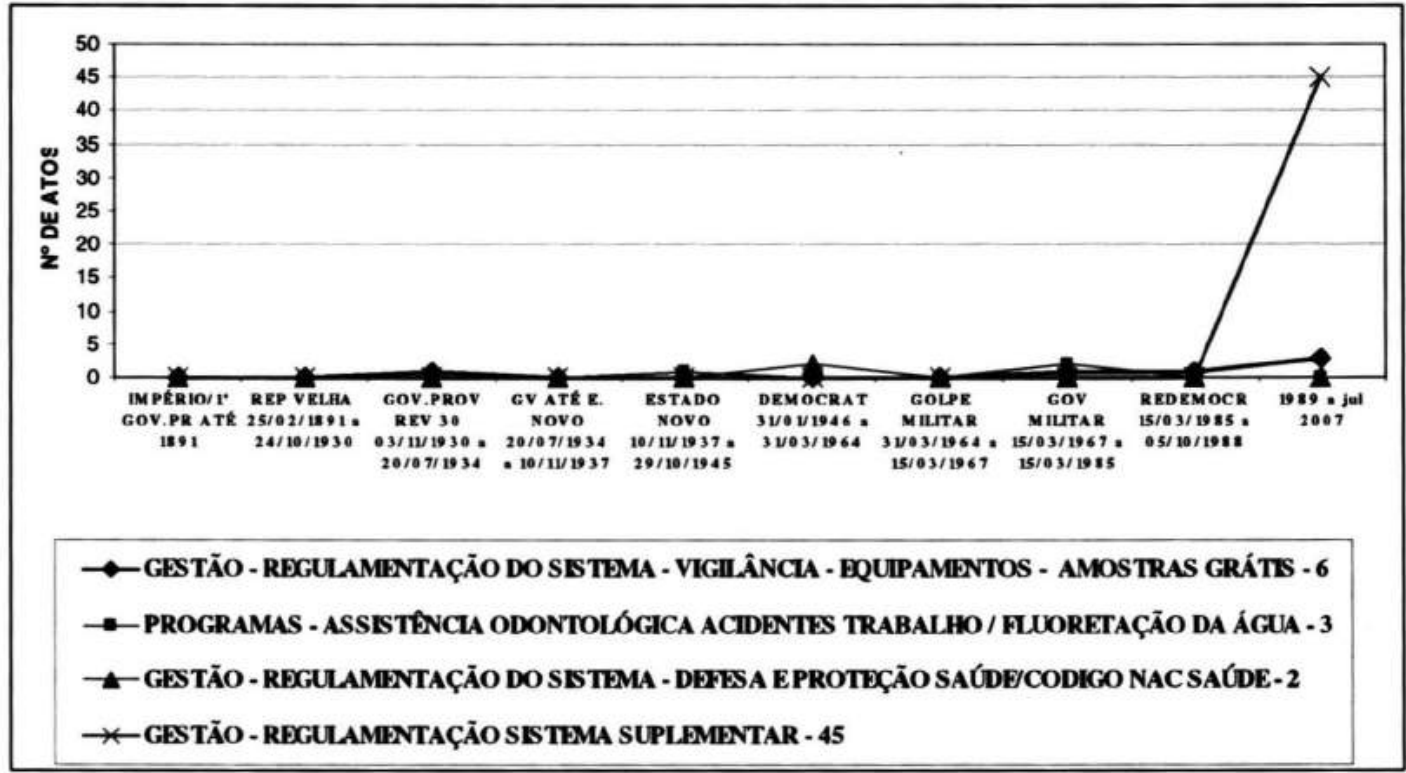

Fonte: Senado Federal - SICON 


\section{DISCUSSÃO}

Entre 1924 a julho de 2007, a maior parte da regulamentação da produção Legislativa Federal sobre saúde bucal teve origem a partir de iniciativas do Poder Executivo, demonstrando uma preponderância do Executivo sobre o poder Legislativo, fato também constatado BAPTISTA (2003) e DALLARI (2005).

Com a Constituição Federal de 1988 e a reorganização das estruturas do Estado brasileiro, as regras legais do Legislativo Federal passaram a não ser mais os principais instrumentos de regulamentação sobre vários assuntos de ordem técnica e administrativa. Com essa delegação de competências ao Executivo, os atos normativos ministeriais tornaram-se os principais instrumentos de regulação, na medida em que a reorganização do Estado e as novas exigências da sociedade determinaram uma legislação mais numerosa e técnica (DALLARI 2005; BAPTISTA 2003).

Tal fato também foi constatado na regulamentação sobre o setor saúde (BAPTISTA 2003) que, a partir da criação do Sistema Único de Saúde e sua posterior regulamentação, delegou ao Ministério da Saúde a competência de gestor sobre a esfera federal saúde.

Relativamente à saúde bucal, observou-se a mesma tendência, na medida em que $89,17 \%$ das regras analisadas foram publicadas anteriormente à Constituição de 1988. As regras legais associadas à saúde bucal encontradas no período pós-constituinte referem-se à saúde suplementar, em função da regulamentação desse setor a partir de 1998.

No período pesquisado, constatou-se que $60,23 \%$ das legislações sobre odontologia e saúde bucal foram editadas durante o Governo Provisório e Estado Novo de Getúlio Vargas e no período Golpe/Governo Militar (1964 a 1985).

Tal fato pode explicado por MEDEIROS (2001) que afirma que, entre 1930 e 1945, a legislação apresentava graus elevados de nacionalização e centralização de recursos e instrumentos institucionais e 
administrativos no Executivo Federal, com políticas de caráter conservador e autoritário voltadas para os trabalhadores urbanos. Durante o Governo Militar, o caráter populista assume um caráter produtivista com a privatização das políticas sociais, mantendo-se o caráter autoritário.

Relativamente à saúde bucal, a partir de Getúlio Vargas até o Estado Novo e no período do Governo Militar, dá-se início à estruturação dos serviços odontológicos da Administração Pública e das Forças Armadas dirigidos, principalmente, ao atendimento de funcionários públicos, pensionistas e aposentados. Essa rede teve seu maior crescimento durante o Governo Militar, considerando-se o ano de publicação das primeiras regulamentações identificadas. Destaque-se no Governo Militar a estruturação da fiscalização do Exercício Profissional odontológico.

De 1930 até 1988, o setor mais regulamentado em todos os períodos foi o Ensino Superior com $44,33 \%$ das regulamentações, tendo em vista a estruturação da profissão odontológica, sendo no Governo Militar a maior incidência de autorizações para cursos particulares de odontologia.

De acordo com (SCHILLING e col. 2006), o conceito ampliado de Regulação, que tem como principais objetos os estabelecimentos, os profissionais, as relações contratuais, o exercício das profissões, a oferta e a demanda por serviços, os protocolos assistenciais, os fluxos de atendimento, a incorporação de tecnologias, além do controle e da avaliação dos custos e gastos em saúde.

Sob esse enfoque, os Programas e as Ações de Saúde Bucal não tiveram prioridade em termos de regulamentação em todo o período, pois foram encontradas somente duas regulamentações sobre a fluoretação das águas de abastecimento público editadas no Governo Militar. Em que pese o valor da medida coletiva de prevenção para o controle da cárie dentária em todo o mundo, não foram encontradas regulamentações pertinentes relativas à organização de uma assistência pública para toda a população.

Essa constatação pode ser explicada por NARVAI (2006) ao afirmar que a Odontologia social e preventiva teve seu apogeu durante a ditadura militar (1968-1978), com formulações teóricas da odontologia sanitária associadas a 
esse contexto autoritário. Da mesma forma, esse autor destaca que a prática hegemônica da odontologia de mercado sempre permeou o trabalho odontológico desenvolvido a partir da mercantilização dos serviços e do monopólio do acesso aos recursos, e não a partir das necessidades das pessoas.

Os documentos identificados que poderiam nortear a atenção à saúde bucal ou a organização de um sistema foram representados pelas Normas para Defesa e Proteção da Saúde (1954) e o Código Nacional de Saúde (1961) aprovadas durante o período Democratização (1946 a 1964), entretanto, ao disporem sobre a odontologia, a ênfase se dá sobre a fiscalização dos estabelecimentos e o exercício profissional odontológico.

A ênfase sobre a odontologia de mercado também é percebida em relação às regulamentações sobre a importação e exportação de equipamentos médico-odontológicos, à regulamentação do setor de planos e seguros odontológicos, às transferências de recursos sob a forma de isenções, doações, materiais, recursos financeiros para escolas, unidades de ensino superior, entidades da classe odontológica e assistenciais, à cobrança de tributos profissionais, taxas para estabelecimentos odontológicos e reajustes de alíquotas de Imposto de Renda.

Em resumo, embora regulamentados e abarcados pelo conceito ampliado de Regulação, os setores Ensino Superior, Forças Armadas, Entidades de Classe e Exercício Profissional não têm como finalidade principal a Gestão e a Organização do Sistema e da Assistência à Saúde, nem o estabelecimento de Programas e Ações de Saúde Bucal.

Com exceção de duas normas legais pertinentes à fluoretação das águas de abastecimento público, não foram encontradas regulamentações na produção Legislativa Federal que pudessem conformar uma política de saúde bucal para toda a população, entre os anos de 1924 e 2007, sendo necessário que novos estudos aprofundem o tema, particularmente no período após 1988.

Os resultados desse 'não agir' são conhecidos, através dos levantamentos epidemiológicos nacionais (MS 2004), pelos profissionais de saúde e pela classe odontológica. 


\section{REFERÊNCIAS}

Adão MAA. Ética, liberdade, legalidade e legitimidade. Jus Navigandi [texto na internet]. 1999 [acesso em 25 abril 2007]; 37:1-4. Disponível em: http://jus2.uol.com.be/doutrina/texto.asp?id=19

Almeida ES de, Chioro A, Zioni F. Políticas públicas e organização do sistema de saúde: antecedentes, reforma sanitária e o SUS. Estado, políticas públicas e saúde: a história dos serviços de saúde no Brasil e o sentido político do SUS. In: Almeida ES de, Westphal MF, organizadores. Gestão de serviços de saúde: descentralização / municipalização do SUS. São Paulo: EDUSP; 2001.p.13-50.

Baptista TWFB. Políticas de saúde no pós-constituinte: um estudo da política implementada a partir da produção normativa dos poderes executivo e legislativo no Brasil [tese de doutorado]. Rio de Janeiro: Instituto de Medicina Social da UERJ; 2003.

Bobbio N. A era dos direitos. 13 tiragem. Rio de Janeiro: Campus; 1992.

Boyer R. A teoria da regulação: uma análise crítica. São Paulo: Nobel; 1990.

Botazzo C. Sobre a bucalidade: notas para a pesquisa e contribuição ao debate. Ciênc Saúde Coletiva. 2006;11: 7-17.

Carvalho EB. A regulamentação dos planos e seguros privados de assistência à saúde no Brasil: a reconstrução de uma história de disputas. Campinas; 2003. [Dissertação de Mestrado - Faculdade de Ciências Médicas da UNICAMP].

Carvalho GCM. O financiamento público federal do Sistema Único de Saúde - 1988 a 2001. São Paulo; 2002. [Tese de Doutorado - FSP/USP].

Carvalho GCM. Pactos do SUS 2005: comentários preliminares [artigo on line] 2005. Disponível em URL:http://www.idisa.org.br/site/paginas/vizualiza contendo.php [2006 Dez 19].

Chaves M. Odontologia social. 3ª edição: São Paulo; Artes Médicas; 1986.

Dallari DA. Elementos de teoria geral do Estado. $25^{\mathrm{a}}$ edição. São Paulo: Saraiva; 2005.

Freitas SM. Os direitos humanos e a evolução do ordenamento jurídico brasileiro. Site do Curso de Direito da UFSM [artigo na internet]. 2007 [acesso em 27 de abril 2007]. Disponível em: http://www.ufsm.br/direito/artigos/constitucional/direitosevolução.htm 
Heimann LS, Pessoto UC, Ibanhes LC, Castro IEN, Kayano J, Junqueira V et al. Desafios para a equidade em saúde na região metropolitana de São Paulo. In: Heimann LS, Ibanhes LC, Barboza R, organizadores. O público e o privado na saúde. São Paulo: Hucitec/OPAS/IDRC; 2005. p.169-242.

Medeiros M. A trajetória do welfare state no Brasil: o papel redistributivo das políticas sociais dos anos 1930 aos anos 1990 [texto para discussão $n^{\circ} 852$ online IPEA/Ministério do Planejamento, Orçamento e Gestão] 2001. Disponível em http://www.ipea.gov.br/pub/td/td 2001/td 0852.pdf [2005 out 16].

Ministério da Saúde. Fundação Nacional de Saúde. Programa Brasil Sorridente, a saúde bucal levada a sério - sub-componente fluoretação da água. Cartilha do Gestor. Brasília: Ministério da Saúde; 2006 a. Disponível em <URL:http://www.funasa.gov.br/> [2006 Nov 25].

Ministério da Saúde. Secretaria de Atenção à Saúde. Departamento de Atenção Básica. Coordenação Nacional de Saúde Bucal. Saúde Bucal. Brasília: Ministério da Saúde; 2006b. (Cadernos de Atenção Básica, nº 17 - Série A. Normas e Manuais Técnicos).

Ministério da Saúde. Secretaria de Atenção à Saúde. Departamento de Atenção Básica. Política nacional de atenção básica. Brasília: Ministério da Saúde; 2006c. (Série A. Normas e Manuais Técnicos, v.4).

Ministério de Saúde. Secretaria de Atenção à Saúde. Departamento de Atenção Básica. Projeto SB Brasil 2003: condições de saúde bucal da população brasileira 2002-2003. Resultados principais. Brasília: Ministério da Saúde; 2004. (Série C. Projetos, Programas e Relatórios). Disponível em http://www.saude.gov.br/dab/saudebucal/vigilancia.php [2006 dez 14].

Narvai PC. Integralidade na atenção básica à saúde. Integralidade? Atenção? Básica? In: Garcia DV (org). Novos rumos da saúde bucal: os caminhos da integralidade. Rio de Janeiro:ABORJ/ANS/UNESCO: 2005. p. 28-42.

Narvai PC. Saúde bucal coletiva: caminhos da odontologia sanitária à bucalidade. Rev Saúde Pública 2006:40 (N Esp): 141-7.

Narvai PC. Odontologia e saúde bucal coletiva. 2a edição. São Paulo: Santos; 2002.

Paim JS. O pensamento do movimento sanitário: impasses e contradições atuais no marco da regulação público-privado no SUS. In: Heimann LS, Ibanhes LC, Barboza $\mathrm{R}$, organizadores. O público e o privado na saúde. São Paulo: Hucitec/OPAS/IDRC; 2005. p. 111-26.

Pinto VG. Saúde bucal coletiva. $4^{a}$ edição. São Paulo: Saraiva; 2000. 
Scheffer M, Bahia L. Planos e seguros privados de saúde no Brasil: lacunas e perspectivas da regulamentação. In: Heimann LS, Ibanhes LC, Barboza R, organizadores. O público e o privado na saúde. São Paulo: Hucitec/OPAS/IDRC; 2005. p. 127-68.

Schilling C, Reis AT, Moraes JC (Org). A política de regulação do Brasil. Brasília, DF: OPAS; 2006. (OPAS - Série Técnica Desenvolvimento de Sistemas e Serviços de Saúde, 12). 
ARTIGO 2

REGULAMENTAÇÃO DA ATENÇÃO À SAÚDE BUCAL NO BRASIL: ANÁLISE DOS ATOS NORMATIVOS MINISTERIAIS ENTRE 1946 E JULHO DE 2007. 


\section{RESUMO}

Introdução - No Brasil, os atos normativos ministeriais definem instruções para a execução das leis, decretos e regulamentos aprovados pelo Poder Legislativo. No setor Saúde, tais atos vêm se constituindo em instrumentos de regulação de políticas públicas, com expressivo aumento no número de portarias editadas pelo Ministério da Saúde a partir de 1999. Objetivo - Identificar os atos normativos ministeriais criados pelo Poder Executivo para fazer a regulação sobre a atenção à Saúde Bucal e analisar o seu emprego pelos órgãos e instituições competentes. Método - Pesquisa documental dos atos normativos ministeriais da esfera Federal do setor Saúde publicados entre 1946 e julho de 2007. Foram identificados na base de dados do Sistema de Legislação em Saúde - SAUDELEGIS os atos normativos relacionados à Saúde Bucal, empregando-se termos de busca como "bucal", "odontologia", "dente", "cárie" e derivações dos radicais "fluor", "dent", entre outros termos. Os documentos foram submetidos à análise de conteúdo. Resultados - Localizaram-se 495 atos normativos, sendo 467 (94,54\%) editados a partir de 1989. Entre 1946 e 1988, destacam-se, em ordem decrescente, os seguintes temas: Exercício Profissional; Ensino Técnico e Cursos de Especialização; Normas sobre Equipamentos Odontológicos, Embalagens e Proteção Radiológica; Assessorias, Consultorias e Comissões do MS; Organização da Estrutura do MS; e Implantação e Controle da Fluoretação das Águas de Abastecimento Público. Entre 1989 e julho de 2007, a temática se altera em função da criação e da regulamentação do Sistema Único de Saúde - SUS e da Saúde Suplementar. Em ordem decrescente, surgem: Transferências de Recursos; Regulamentação da Atenção e da Assistência no SUS; Regulamentação da Saúde Suplementar; Regulamentação da Vigilância Sanitária; Tabelas e Procedimentos Odontológicos no SUS e Programas e Ações. Nesse período, ganham destaque as transferências de recursos e incentivos financeiros para as equipes de saúde bucal do Programa de Saúde da Família e para os Centros de Especialidades Odontológicas - CEO e Laboratórios Regionais de Prótese Dentária LRPD. Em relação ao eixo-temático Programas e Ações, a ênfase se dá na inserção das ações de Saúde Bucal junto às demais políticas setoriais, como portadores de deficiências, saúde penitenciária, saúde dos jovens e adolescentes, política de saúde para a população indígena, política nacional de oncologia, entre outras. Conclusão A temática emergente induz à reflexão sobre a relação entre as demandas sociais e as escolhas das prioridades na definição dos projetos políticos para a Saúde Bucal. A análise dos atos normativos evidenciou a importância assumida por esses intrumentos na gestão, na organização e no financiamento da atenção à Saúde Bucal, a partir de 2001.

Descritores: Saúde bucal. Instrumentos de regulação. Regulação. Regulamentação. Legislação. Saúde suplementar. 


\begin{abstract}
Introduction - In Brazil the normative ministerial acts define the instructions for execution of laws, decrees and regulations approved by the Legislative Power. In the Health field such acts have become public policies regulation instruments with an enormous increase in the number of orders issued by the Health Ministry effective from 1999. Objective - Identify the normative acts created by the Executive Power to elaborate the regulations on the Oral Health Care and analyse its application by the proper bodies and institutions. Method - Documentary research of the normative ministerial acts of the Health Sector Federal environment published between 1946 and July 2007. The normative acts related to Oral Health were identified in the database of the Health Legislation System - SAUDELEGIS, by being searched with terms like "bucal", "odontologia", "cárie", "dente", and derivatives of the radicals "fluor", "dente" among others. The documents were subjected to content analysis. Results - Four hundred and ninety five normative acts were located where 467 (94.54\%) were edited from 1989 on. Between 1946 and 1988, the following subjects were highlighted in descending order: Professional Practice; Technical School and Specialization Courses; Norms on Dental Equipment, Packing and Radiological Protection; Assistance, Consulting and MS Commissions; MS Structure Organization; and Implantation and Control of Fluoridation in public water supplies. Between 1989 and July 2007, the thematic altered due to the creation of the regulation for the Health Central System - SUS and the Supplementary Health. In descending order we find: Funds Transfer; SUS Care and Assistance Regulation; Supplementary Health Regulation; Sanitary Surveillance Regulation; Tables and Dental Procedures at SUS and SUS Practical Programs. In this period the funds transfers and the financial incentives for the Family teams of the Program, and for the Dental Speciality Centers - DSC/CEO and Dental Prosthesis Sectional Laboratories - DPSLLRPD were highlighted. Conclusion - Regarding the thematic core, programs and oral health actions, emphasis is given to the insertion of oral health actions towards policies to other sectors, such as disabled people, in-prision health care, youth and adolescents, health policies for the Indian population, national policy for oncology and others. Conclusion - The emerging thematic leads us to think about the relationship between the social requirements and choice of priorities when defining the political projects for oral health. The analysis of the normative acts pointed out the importance ascribed to these instruments in the administration, organization and financing of the oral health care effective from 2001.
\end{abstract}

Key words: Oral health. Regulation Instruments. Regulation. Legislation. Supplementary Health. 


\section{INTRODUÇÃO}

Analisar a atenção à Saúde Bucal no Brasil em termos de Regulação, pressupõe certa compreensão sobre as práticas e as finalidades da ação Estatal como garantidora de direitos, assim como uma análise da Política de Regulação sobre o Setor Saúde.

Relativamente ao direito à saúde, MEZZOMO (2006) afirma ser este um direito que pode ser analisado sob vários prismas:

É um direito individual, na medida em que qualquer pessoa tem direito à sua integridade física e psíquica como corolário do seu direito de personalidade. Neste caso, dispõe de ação e pode exercer pretensão objetivando a abstenção de comportamento de terceiros que venham a por em risco sua saúde. $\mathrm{O}$ direito à saúde também é um direito social $\mathrm{e}$ como tal é expressamente previsto nos artigos $6^{\circ}$, caput, e $196 \mathrm{da} \mathrm{CF} / 88$. Nesta condição, sua invocação pode ser feita como base de pretensões a comportamentos positivos por parte do Poder Público. Por fim, a saúde também é direito difuso e apresenta uma faceta política. De fato, a comunidade como um todo é titular de direito a comportamentos positivos e negativos em relação a particulares e ao próprio Estado. A gestão da saúde, de seu turno, deve ser democrática, de forma que também condensa direito político de participação democrática (p.4).

Conforme afirma CARVALHO (2002), a Saúde é um direito essencial contemplado na Constituição de 1988 como dever do Estado, que só se efetivará se todos exercerem a cidadania plena, como "contribuir com o fisco, sem sonegação; praticar a não corrup̧̧ão passiva e ativa; proteger o patrimônio, bem e serviços públicos; exercer o controle da sociedade tanto do público como do privado para que ambos utilizem bem os recursos públicos” (p. 23).

No decorrer da História, o conteúdo dos direitos fundamentais foi ampliado em quase todas as constituições do mundo, englobando uma série de prerrogativas e garantias que buscam assegurar o exercício da cidadania. 
As Constituições Brasileiras de 1824 e 1891 deram positividade e juridicidade aos direitos do homem e às garantias individuais, sem preocupação com os direitos sociais.

Com a Constituição de 1934, os direitos econômicos e sociais foram incorporados como direitos trabalhistas, sendo mantidos nas Constituições de 1937, 1946 e 1967. Somente com a Constituição de 1988 os direitos humanos foram positivados, tanto os individuais, como os difusos e coletivos, trazendo instrumentos constitucionais para garantir a eficácia desses direitos (ADÃO 1999; FREITAS 2007).

A organização da sociedade pressupõe a constituição de um poder que, embora político, é suscetível à qualificação jurídica, não sendo possível admiti-lo como estritamente político ou exclusivamente jurídico. Embora o poder não chegue a ser totalmente jurídico, ele age concomitante com o direito, buscando uma coincidência entre os objetivos de ambos DALLARI (2005).

Para esse autor, as decisões políticas devem ser enquadradas num sistema jurídico eficaz e flexível para permitir o aparecimento e a integração de novos meios e para assegurar a reformulação da concepção de objetivos fundamentais, quando isto for exigido pela alteração substancial das condições de vida social.

BOBBIO (1992) destaca que, as necessidades nascem em função da alteração das condições de vida social, num momento em que o desenvolvimento técnico permite satisfazê-las.

A evolução da sociedade trouxe exigências, sendo o Estado cada vez mais solicitado a agir, ampliando sua esfera de ação e intensificando sua participação nas áreas tradicionais, deixando como desafio a criação de mecanismos para garantir a efetividade dos direitos sociais básicos previstos nos textos legislativos (DALLARI 2005).

Para ADÃO (1999), o equilíbrio entre a liberdade individual e a autoridade estatal, somente pode ser atingido através da lei geral estatal elaborada segundo regras preestabelecidas e aceitas pela coletividade: "a lei limitadora do conteúdo da liberdade individual precisa ser normal, moral e legítima, no sentido de ser consentida por aqueles que a liberdade restringe" (p.1). 
Segundo esse autor, a liberdade geral está ligada ao princípio da Legalidade, na medida em que somente a legalidade garante a liberdade.

O princípio da Legalidade tem uma aplicação diferenciada para os indivíduos particulares e para a Administração Pública e que, ao contrário dos particulares, aos agentes públicos somente é facultado agir por imposição ou autorização legal. Inexistindo lei, não haverá atuação administrativa legítima. Os Poderes Públicos somente podem praticar os atos determinados pela lei e, como decorrência, tudo aquilo que não resulta de prescrição legal é vedado ao administrador (ADÃO 1999).

Para DALLARI (2005), tudo isso impôs uma legislação mais numerosa e mais técnica, incompatível com os modelos de separação de poderes, uma vez que "o legislativo não tem condições de fixar regras sem ter conhecimento do que já foi ou está sendo feito pelo executivo, e o executivo não pode ficar à mercê de um lento processo de elaboração legislativa" (p. 2). As tentativas para aumentar a eficiência do Estado tem sido a delegação de poderes, sobretudo a delegação de poder legislativo, e a transferência constitucional de competências por meio de reformas constitucionais ou até a promulgação de novas Constituições, no sentido de se aumentar as competências do executivo.

BAPTISTA 2003 observa o fortalecimento de alguns setores do executivo federal, no que se refere à delegação de competências e, dentro do Setor Saúde, o expressivo número de portarias editadas pelo Ministério da Saúde a partir de 1999, reforçando uma relação tutelar no processo de descentralização.

A partir dos anos de 1980, com a implementação do programa neoliberal caracterizado pela abolição do controle de preços, pela desregulamentação do mercado de trabalho, pelo desengajamento do Estado e pela desestatização, as formas de organização coletiva, de intervenção estatal e de regulamentação passaram a ser vistas sob suspeita de perturbação e de atrasos nos ajustamentos necessários de uma nova onda tecnológica (...) as análises, em termos de regulação inserem-se no contexto, fornecendo várias interpretações para esse período conturbado e, em alguns casos, recomendações sobre as formas de superar as atuais ameaças" (BOYER 1990, p.14). 
Para CARVALHO (2005) e CARVALHO (2003), o termo Regulação vem sendo adotado de modo indevido, uma vez que na legislação brasileira a Regulação ou Regulamentação refere-se à formulação de regras, segundo os trâmites legais observados na Constituição Federal, nas Leis, nos Decretos, nas Portarias, nas Normas, entre outras. Para esses autores, o termo Regulação não abrangeria as ações relativas à execução dessas regras, embora considere essas ações de suma importância no sistema de saúde.

Di Pietro (2002), citada por CUNHA (2003), afirma que a função inerente à regulação não se confunde com a de regulamentação:

Regular significa estabelecer regras, independentemente de quem as dite, seja o Legislativo ou o Executivo, ainda que por meio de órgãos da Administração direta ou entidades da Administração indireta. Trata-se de um vocábulo de sentido amplo, que abrange, inclusive, a regulamentação, que tem um sentido mais estrito. Desregular, como um dos instrumentos ora utilizados para a reforma do Estado, querse significar que deve diminuir o regramento da atividade privada, para diminuir a intervenção do Estado nas liberdades do cidadão. Por outras palavras, quer-se diminuir o poder de polícia do Estado, pela diminuição das limitações ao exercício dos direitos individuais. (....) Regulamentar significa também ditar regras jurídicas, porém, no direito brasileiro, como competência exclusiva do Poder Executivo. Perante a atual Constituição, o poder regulamentar é exclusivo do Chefe do Poder Executivo (art.84, IV), não sendo incluído, no parágrafo único do mesmo dispositivo, entre as competências delegáveis (p.53).

A gestão de um sistema público de saúde deve contemplar a definição da política de saúde e do correspondente projeto tecnoassistencial, implementados por meio do planejamento, financiamento, ornamentação, programação, informação/informática, gestão do trabalho e educação, ciência e tecnologia, funções administrativas e financeiras, macrorregulação e dos modelos de atenção à saúde (SCHILLING e col. 2006).

MEDEIROS (2001) relata que, até os anos de 1930, as políticas sociais eram fragmentadas e emergencistas, sendo que os conflitos entre o capital e o trabalho eram regulados por legislação esparsa com tratamento por forte aparato policial. As questões de saúde pública eram tratadas pelas autoridades locais, 
não havendo programas de ação por parte do governo central, cuja ação restringia-se às situações de emergência durante as epidemias nos centros urbanos.

Segundo esse autor, a partir de 1930 , constituiu-se no Brasil um Welfare State com políticas de caráter conservador e autoritário, em que os antagonismos entre classes eram encarados como nocivos ao bem-comum representado pelo Estado.

Entre os anos de 1930 e 1943, o Brasil definiu as bases modernas de seu sistema de seguridade social com políticas voltadas para os trabalhadores urbanos permanecendo intactas até 1966. De acordo com Draibe (1989), citada por MEDEIROS (2001), a legislação produzida nesse período apresentava graus elevados de nacionalização sob a forma de centralização de recursos e instrumentos institucionais e administrativos no Executivo Federal, destacando as principais características do período:

Entre 1945 e 1964, não foram observadas mudanças significativas na construção do Welfare State, embora o país tivesse adotado um regime democrático a partir de 1945 . Esse período foi marcado pela criação de instrumentos legais para o funcionamento de um governo democrático, permanecendo inalteradas as estruturas corporativas do Welfare State.

Entretanto, as mudanças na economia e na política exigiram do Estado a ampliação e a articulação de suas funções para suprir as necessidades advindas da urbanização e da modernização do país. Assim, ocorrem a unificação administrativa e a uniformização dos benefícios e dos serviços da previdência social, sendo que na saúde o enfoque se deu sobre as questões relacionadas às doenças de massa e à assistência médica. No trabalho, a ocorrência de lutas sindicais e política salarial, na educação, a democratização do ensino e a qualificação profissional e a habitação passa a ser considerada questão social. (MEDEIROS 2001).

Esse período é caracterizado pelos avanços nos processos de centralização institucional e de extensão da proteção social a novos grupos sociais, permanecendo, porém, o padrão seletivo, heterogêneo e fragmentado de beneficiários, benefícios e instituições. 
A partir de 1964, são implementadas políticas de massa de cobertura relativamente ampla, mediante a organização de sistemas nacionais públicos ou estatalmente regulados de provisão de serviços sociais básicos. De 1964 a 1970, o modelo de Welfare State perde o caráter populista, assumindo um caráter produtivista, com grande volume de recursos aplicados nas políticas sociais, estimulando a participação da iniciativa privada nos setores de habitação, educação, saúde, previdência e alimentação. A privatização da política social cria tensão entre os objetivos redistributivistas e as necessidades do processo de acumulação, com a transferência de recursos para extratos de maior renda que conseguiam orientar as políticas sociais, de modo a atender a seus interesses políticos e particulares, produzindo ações ineficazes ineficientes e regressivas.

Entre 1970 até o final da década de 1980 , as reformas ocorridas foram caracterizadas pela centralização política e financeira em nível federal, pela fragmentação institucional, pelo tecnocratismo, pelo autofinanciamento, pela privatização e uso clientelista das políticas sociais, sem funcionar como mecanismo redistributivo do produto da economia, resultando em ineficiência e ineficácia dos programas sociais (MEDEIROS 2001).

Com o início da Nova República em 1985 e a consolidação da democracia em 1988, ocorreram avanços na área política através do crescimento da atividade partidária e sindical e do aumento da participação popular no processo eleitoral. Ao mesmo tempo, seguiu-se a retração e o desmantelamento das políticas sociais, num contexto de pressões para cortes nos gastos públicos e mudanças institucionais e organizacionais no governo.

HEIMANN e col. (2005) afirmam que, no Brasil, a Regulação do setor Saúde, se assenta, por um lado, na Constituição Federal de 1988 e na Lei Federal 8.080/1990, com artigos direcionados à regulação do Sistema de Saúde no Brasil.

A legislação do SUS define, de forma ampla e abrangente, as atribuições e as competências necessárias à fiscalização, ao controle e ao estabelecimento de regras para o sistema, enquanto que a regulação com base na Reforma do Estado direciona-se à estruturação do mercado de planos de saúde, 
descaracterizando a assistência à saúde como direito universal (HEIMANN e col 2005; CUNHA 2003).

Não obstante, a concepção e as finalidades da regulação em saúde ainda não serem uniformes e não se apresentarem plenamente desenvolvidas no âmbito do SUS, as concepções de controle, avaliação e auditoria também variaram ao longo do tempo, resultando na criação de estruturas e práticas que foram incorporadas e reproduzidas pelas Secretarias Estaduais e Municipais de Saúde. Regular "não se resumiria ao ato de regulamentar, mas também incluiria uma gama de ações que verificam se a produção em saúde se dá conforme as regras estabelecidas" (SCHILLING e col. 2006; p.36).

Em decorrência, os principais objetos da Regulação seriam estabelecimentos, equipamentos, profissionais, habilitação a graus de complexidade, as relações contratuais, o exercício das profissões de saúde, a oferta e a demanda por seiviços, os protocolos assistenciais, os fluxos de atendimento, a produção, a venda, a incorporação e o uso de insumos, medicamentos e outras tecnologias, condições de trabalho e ambientes relativos ao setor Saúde, além do controle e da avaliação dos custos e gastos em saúde.

Relativamente à abrangência da ação regulatória e as estratégias de regulação para o setor Saúde, o Ministério da Saúde vem adotando os seguintes conceitos:

Regulação sobre Sistemas de Saúde - tem como objeto os sistemas
municipais, estaduais e nacional e, como sujeitos, o gestor federal e os
gestores estaduais e municipais. Comporta ações de regulação do gestor
da saúde na esfera federal sobre estados e municípios; do gestor da esfera
estadual sobre municípios e prestadores; e dos municípios sobre os
prestadores, assim como a auto-regulação de cada uma dessas esferas.
Também comporta a regulação do Estado sobre o setor privado de
produção de bens e serviços de saúde não conveniados e nem contratados
pelo SUS. Suas principais ações são: regulamentação geral, controle e
avaliação dos sistemas, regulação da atenção à saúde, ações de auditoria,
ações de integração com outras esferas de controle público (MP, TC), e
ações de controle social, ouvidoria, algumas de vigilância sanitária e a
regulação sobre a saúde suplementar (...)
Regulação da Atenção à Saúde - tem como objeto a produção de todas
as ações diretas e finais da atenção à saúde, dirigida aos prestadores de
serviços de saúde, públicos e privados. As ações da Regulação da
Atenção à Saúde compreendem a Contratação, a Regulação do Acesso à
Assistência ou Regulação Assistencial, o Controle Assistencial, a 
Avaliação da Atenção à Saúde, a Auditoria Assistencial e as regulamentações da Vigilância Epidemiológica e Sanitária (...) Regulação do Acesso à Assistência ou Regulação Assistencial conjunto de relações, saberes, tecnologias e ações que intermedeiam a demanda dos usuários por serviços de saúde e o acesso a estes (...) Complexo Regulador - estratégia da Regulação Assistencial, consistindo na articulação e integração de Centrais de Atenção Préhospitalar e Urgências, Centrais de Internação, Centrais de Consultas e Exames e Protocolos Assistenciais com a contratação, controle assistencial, avaliação, programação e regionalização. Os complexos reguladores podem ter abrangência intra-municipal, municipal, micro ou macro regional, estadual ou nacional, devendo esta abrangência e respectiva gestão, serem pactuadas em processo democrático e solidário, entre as três esferas de gestão do SUS (...) Auditoria Assistencial ou Clínica - processo regular que visa aferir e induzir qualidade do atendimento amparada em procedimentos, protocolos e instruções de trabalho normatizados e pactuados. Deve acompanhar e analisar criticamente os históricos clínicos com vistas a verificar a execução dos procedimentos e realçar as não conformidades (BRASIL 2006 h, p.35).

Em 1995, o Plano Diretor da Reforma do Estado publicado pelo Ministério da Administração e Reforma do Estado - MARE gerou uma tendência de diminuição dos custos e do tamanho do Estado, bem como de suas funções, a fim de que o mercado e a sociedade assumissem atividades por ele desempenhadas. O Estado deixa assim de ser o responsável direto pelo desenvolvimento econômico-social pela via da produção de bens e serviços, para fortalecer-se na função de promotor e regulador desse desenvolvimento, através de quatro setores:

Nesse contexto surgiram as agências reguladoras, entes administrativos autônomos, criados por lei, com personalidade jurídica de direito público, patrimônio e receitas próprios para exercer atividades próprias da Administração, com prerrogativas estatais típicas, em função da supremacia do interesse geral sobre o interesse particular. (CUNHA 2003).

ALMEIDA e col (2001) relatam que, até os anos 1930, a saúde foi voltada para amparar o modelo econômico agro exportador e a presença do Estado brasileiro não significou uma atuação semelhante ao modelo de Estado-social. Ao longo das primeiras décadas do século $\mathrm{XX}$, as pessoas que necessitassem de assistência médica procuravam profissionais liberais ou o auxílio das Santas Casas. De acordo com esses autores, a industrialização e o enfraquecimento do modelo agroexportador acarretaram o esvaziamento das ações campanhistas e o crescimento 
da atenção médica através da Previdência Social, contribuindo para a conformação de um novo modelo na saúde: o modelo médico-assistencial privatista.

A partir de 1980, com a redemocratização e a crise econômica, estabeleceu-se como prioridade um novo padrão de desenvolvimento crescimento com distribuição - e a definição de um novo arcabouço jurídicoinstitucional, que culminou com a convocação da Assembléia Nacional Constituinte, em 1986. Aliada a isso, a crise da Previdência Social possibilitou o discurso em defesa do direito universal à saúde. Em 1986, VIII Conferência Nacional de Saúde (CNS) formatou o projeto da Reforma Sanitária caracterizado por um conceito abrangente de saúde; saúde como direito de cidadania e dever do Estado e a instituição do Sistema Único de Saúde (ALMEIDA e col 2001).

A $7^{\text {a }}$ Constituição da República Federativa do Brasil, promulgada em 05/10/1988, criou o Sistema Único de Saúde a ser organizado segundo as diretrizes de descentralização político-administrativa com comando único em cada esfera de governo, da integralidade do atendimento e da participação da comunidade.

O Sistema Único de Saúde (SUS), regulamentado pelas Leis Federais $n^{\circ} .8 .080$ e $n^{\circ} .8 .142$ de 1990, incorporou os princípios da igualdade na assistência/eqüidade, da universalidade do acesso e uma nova lógica de organização da saúde assentada na utilização da epidemiologia para a definição de prioridades, na conjugação de recursos financeiros para a gestão e o financiamento do sistema, entre outros dispostos no Artigo $7^{\circ}$ da Lei Federal n ${ }^{\circ}$. 8080/90.

PAIM (2005) afirma que durante as décadas de $1970 \mathrm{e}$ 1980, a atuação do Movimento Sanitário teve como foco principal a defesa de um SUS público ou estatal diante das ameaças do movimento neoliberal representadas pela Reforma do Estado e pela redução de recursos financeiros e gastos públicos. Naquele momento, não houve espaço para uma investigação ou posição política mais clara em relação ao setor privado.

A partir dos anos de 1990 , com o recuo do Movimento Sanitário e os novos atores representados, particularmente, pelo Conselho Nacional de Secretários Municipais de Saúde (CONASEMS) e pelo Conselho Nacional de 
Secretários Estaduais de Saúde (CONASS), adotou-se uma postura pragmática permeada de interesses intrínsecos à condição de gestores políticos.

Entre o final dos anos de 1980 e meados da década de 1990, ocorreu a grande expansão do segmento da assistência suplementar, coincidindo com a transição epidemiológica e demográfica do País e com o crescente desfinanciamento da saúde pública. Esse segmento tornou-se atraente aos investimentos de grupos econômicos, implicando no reposicionamento das burocracias governamentais e do papel do Estado (SCHEFFER e BAHIA 2005).

Entre 1978 e 1987, com a reforma previdenciária e a constituição do INAMPS em 1978, as ações de controle e avaliação eram realizadas somente por esse Instituto, com foco contábil-financeiro sobre as internações hospitalares e as faturas ambulatoriais sem a participação dos estados e municípios (SCHILLING e col 2006).

Em 1988, a Constituição incorpora conceitos, princípios e uma nova lógica de organização da saúde: "o conceito de saúde entendido numa perspectiva de articulação de políticas econômicas e sociais; a saúde como direito social universal, derivado do exercício da cidadania plena e não mais como direito previdenciário; a caracterização dos serviços e ações de saúde como de relevância pública; criação do SUS (descentralizado, com comando único em cada esfera de governo, atendimento integral e participação da comunidade); e integração da saúde na Seguridade Social” (ALMEIDA e col. 2001, p.32).

Entre 1988 e 1990, apesar da implantação do Sistema Unificado e Descentralizado de Saúde - SUDS, da constituição legal do SUS e das Leis Orgânicas da Saúde, manteve-se a mesma prática de controle e avaliação sob a coordenação do INAMPS sem a participação dos estados ou municípios e sem a estadualização do controle e avaliação prevista pelo SUDS. Nesse período, as Leis $8.080 / 90$ e 8.142/1990 definiram, de forma genérica, as ações e competências das esferas de gestão no controle, avaliação, auditoria e regulação dos serviços e estabeleceram os Conselhos de Saúde como controladores e avaliadores das políticas, ações e serviços de saúde.

ALMEIDA e col. (2001) comentam sobre o início da década de 1990: 
com a fragilização do papel do Estado induzidas pelas propostas neoliberais, ocorre a criação de um sistema privado forte com baixa regulação pelo Estado: o da atenção médica supletiva que se consolidou pelo tipo de financiamento (sem recursos e dependência direta do Estado) e por sua expansão às custas da perda de qualidade do setor público (....). No sistema público, permaneceram apenas os prestadores privados mais tradicionais, mais dependentes do Estado e que não conseguiram modernizar-se e disputar o mercado da medicina supletiva, sofrendo nítido processo de deterioração e de intenso e seletivo descredenciamento (formal ou informal) por parte do setor mais moderno de prestação de serviços (p.39).

Esses autores destacam que nesse período em que o sistema privado passou a contar com forte apelo ideológico, diminuíram as pressões pela implementação do SUS, apesar das alterações institucionais ocorridas.

De 1991 a 1993, manteve-se a prática de controle e avaliação contábil financeira sob a gestão regionalizada do INAMPS, cabendo aos estados e municípios uma atuação marginal representada pelo repasse de dados. As Normas Operacionais Básicas - NOB 91 e NOB 92 estabeleceram a transferência de recursos do INAMPS para estados e municípios via convênio e pagamento por produção.

Entre 1993 e 2000, com a extinção do INAMPS e a publicação das NOBs 93 e 96, ocorre o início e o desenvolvimento da atuação do Ministério da Saúde, dos estados e dos municípios sobre a gestão dos recursos, das ações e dos serviços de saúde, ainda com visão contábil e financeira do extinto INAMPS, baseada no controle sobre as Autorizações de Internações Hospitalares AIH e o Sistema de Informações Ambulatoriais - SIA.

A NOB 93 instituiu três tipos de gestões (incipiente, parcial, semiplena) aos estados e municípios, além da transferência de recursos "fundo a fundo" e da criação das Comissões Intergestoras Bipartite - CIB e Tripartite - CIT.

A NOB 96 instituiu a Gestão Plena do Sistema e a Gestão Plena da Atenção Básica, estabelecendo o Piso da Atenção Básica, o Programa do Agente Comunitário de Saúde - PACS, o Programa de Saúde da Família - PSF, o Piso Básico da Vigilância Sanitária - PBVS, a Programação Pactuada e Integrada PPI, além da exigência dos requisitos comuns para a habilitação de gestão como: capacidade de contratação, de controle, de avaliação, de auditoria e de pagamento de 
serviços por parte de estados e municípios. Relativamente ao controle, enfatiza-se o controle sobre as consultas especializadas, os SADTs, os leitos e as referências intermunicipais. Em 1999, foram criados o Sistema Nacional de Vigilância Sanitária e a ANVISA - Agência Nacional de Vigilância Sanitária pela Lei nº. 9.782, de 26 de janeiro de 1.999 .

Para ALMEIDA e col. (2001), questões como o financiamento, as competências e atribuições das três esferas de governo, o relacionamento público/privado e a restrição de recursos financeiros, vêm determinando um período de retração no processo de implantação do SUS.

Em 2000, criou-se a ANS - Agência Nacional de Saúde Suplementar - Lei nº. 9.961, de 28 de janeiro de 2000, dando-se início às atividades de regulação sobre a saúde suplementar. Nesse mesmo ano, a ações de auditoria desvinculam-se das ações de controle e de avaliação, passando a ser competência do SNA "o controle dos recursos repassados aos estados, municípios e Distrito Federal e o exame analítico, a verificação 'in loco' $\mathrm{e}$ pericial da regularidade dos procedimentos executados. Ao controle e avaliação caberia o monitoramento contínuo das ações e serviços desenvolvidos no âmbito do SUS" (SCHILLING e col. 2006, p.22).

Entre 2000 a 2002, os executantes das ações de regulação, controle, avaliação e auditoria no setor saúde, no Brasil, passam a ser o Ministério da Saúde, a ANVISA, a ANS, os estados e os municípios.

As Normas Operacionais de Assistência à Saúde (NOAS 01/2001 e 01/2002) buscaram organizar a regionalização da assistência, cabendo aos estados organizar o fluxo da assistência municipal por meio do PDR - Plano Diretor de Regionalização, mantendo-se as mesmas condições de gestão da NOB 96, exceto para os municípios com Gestão Plena da Atenção Básica substituída por Gestão da Atenção Básica Ampliada, com financiamento pelo PABA - Piso da Atenção Básica Ampliado.

A NOAS 01/2002 aprofundou as exigências às gestões plenas dos sistemas municipais e estaduais para a operacionalização de centrais de controle de procedimentos ambulatoriais e hospitalares e para a viabilização de referências intermunicipais, definindo a regulação assistencial como "a 
disponibilização da alternativa assistencial mais adequada à necessidade do cidadão, de forma equânime, ordenada, oportuna e qualificada efetivada por meio de complexos reguladores que congreguem unidades de trabalho responsáveis pela regulação das urgências, consultas, leitos e outros que se fizerem necessários" (BRASIL 2002).

CARVALHO (2001) destaca que a NOAS/2001 possui uma série de incongruências e indefinições, representando um retrocesso na implantação do SUS, na medida em que tenta 'recentralizar' a gestão da saúde junto aos Estados.

Esse autor enumera os principais pontos de divergência: 1) definição de tetos e valores de procedimentos sem estudo prévio e sem consulta ao CNS ou à CIT; 2) indefinição de novos valores para a pactuação dos municípios; 3 ) gestor estadual adota critérios para habilitação dos municípios e para a organização regional em micro-regiões, sem considerar a autonomia municipal; 5) pactuação com a valor médio da $\mathrm{AIH}$, desconsiderando o risco de haver redução do atendimento devido ao teto financeiro; 6) indefinição da função da Auditoria e do conceito de Regulação; 7) número excessivo de planos exigidos dos municípios, como PPA, LDO, LO, Plano Regional, Plano de Saúde, Quadro de Metas, Pacto Indicadores da Atenção Básica; e 8) risco de habilitações cartoriais, já que grande parte dos municípios não têm condições para habilitação, entre outros questionamentos.

Posteriormente, as Portarias SAS/MS nº 423 e 729 de 2002 ratificaram as diretrizes da política de regulação descritas na NOAS, buscando definir competências em cada esfera de gestão do SUS e alguns indicadores para orientar a elaboração dos Planos de Controle, Regulação e Avaliação dos estados e municípios.

Em 2002, o termo Regulação, como regulação do acesso à assistência, ganhou maior divulgação a partir da Norma Operacional da Assistência à Saúde (NOAS 01/2002), quando o conceito de regulação assistencial passa a se disseminar no âmbito do SUS. Através do Decreto n 4.726, de 09/06/2003, o termo Regulação passou a fazer parte da denominação de um Departamento do MS, o Departamento de Regulação, Avaliação e Controle de Sistemas (DRAC). 
Em 2006, o Ministério da Saúde, o Conselho Nacional de Secretários da Saúde (CONASS) e o Conselho Nacional de Secretários Municipais de Saúde (CONASEMS) pactuaram responsabilidades no campo da gestão do sistema e da atenção à saúde, com vistas a superar a fragmentação das políticas e programas por meio da organização de uma rede regionalizada e hierarquizada de ações e serviços e da qualidade da gestão. $\mathrm{O}$ documento intitulado Diretrizes do Pacto pela Saúde em 2006 - Consolidação do Sistema Único de Saúde, publicado na Portaria GM/MS n. 399, de 22/02/06, contempla o Pacto firmado entre os gestores do SUS em suas três dimensões: pela Vida, em Defesa do SUS e de Gestão (MS 2006 c).

O Pacto de Gestão estabelece diretrizes da gestão do sistema para a Descentralização, a Regionalização, o Financiamento, o Planejamento, a Programação Pactuada e Integrada (PPI), a Regulação, a Participação e o Controle Social, a Gestão do Trabalho e a Educação na Saúde.

Relativamente à setor de saúde suplementar, esta já existia há pelo menos trinta anos no Brasil, funcionando sempre, como um setor não regulado, sendo exigido que diversos dispositivos fossem regulamentados, pois quase tudo carecia de definição, principalmente na dimensão da assistência à saúde.

MONTONE (2004) afirma que, antes da regulamentação do setor, as empresas se organizavam livremente para atuar, submetendo-se apenas à legislação do tipo societário escolhido, definindo livremente o produto a ser oferecido, a população de consumidores e as condições de operação e preço. Com o processo de regulamentação iniciado em 1988, as empresas passaram a ter uma atuação mais controlada no que se refere à autorização do funcionamento, às regras operacionais uniformes (balanços), a sujeição às intervenções/liquidações, à exigência de reservas financeiras, à obrigatoriedade da assistência integral à saúde, à proibição da seleção de risco e da rescisão unilateral de contratos, à limitação das carências e aos reajustes controlados dos produtos. Esse autor identifica quatro etapas no processo de regulamentação desse setor:

- a primeira etapa foi representada pelos dez anos transcorridos entre a Constituição Federal de 1988, que definiu a atuação privada no setor saúde e a definição de marco legal representado pela promulgação da Lei Federal $n^{\circ} 9.656$, de 
03/06/1998, que dispõe sobre "os planos e seguros privados de assistência à saúde", além da Medida Provisória n 1.665, de 05/06/1998, com as alterações exigidas pelo Senado (reeditada quase que mensalmente, até agosto de 2001, por força da legislação vigente, hoje é a Medida Provisória n².177-44/01);

- a segunda etapa ocorreu entre os meses de janeiro a setembro de 1999 com a vigência do modelo bipartite de regulação (Ministérios da Fazenda e da Saúde), ocasionando uma falta de unidade estratégica no processo de regulação;

- na terceira etapa do processo ocorrida entre os meses de setembro de 1999 à janeiro de 2000, criou-se a Agência Nacional de Saúde Suplementar vinculada ao Ministério da Saúde (Lei Federal $n^{\circ}$ 9.961/2000), como novo instrumento de atuação do Estado que assumiu todas as atribuições da regulação do setor;

- a quarta etapa é representada pelo início da atuação da ANS (janeiro de 2000) até os dias atuais, com a complementação do arcabouço normativo da regulamentação para o aperfeiçoamento dos instrumentos já implantados, a ampliação de sua efetividade e os ajustes decorrentes dos próprios impactos do processo na organização e gerenciamento do sistema. Dentre os principais desafios dessa etapa, destacam-se: a necessidade de acelerar a migração dos usuários de contratos antigos, anteriores à regulação, para planos novos e o monitoramento dos impactos do ajuste no modelo de gerenciamento do setor.

MALTA e col. (2004) ao analisarem os modelos assistenciais vigentes na saúde suplementar, afirmam existir uma grande heterogeneidade nos padrões de qualidade do setor, com fragmentação e descontinuidade da atenção, que comprometem a efetividade e a eficiência do sistema como um todo, atingindo as redes de cuidados básicos, especializados e hospitalares que atendem a clientela de planos de saúde. Esses autores afirmam que esses modelos assistenciais consistem em práticas fragmentadas, centradas em produção de atos, predominando a desarticulação e as queixas dos usuários e propõem que "cada usuário deva ser acompanhado segundo determinado projeto terapêutico instituído, comandado por um processo de trabalho cuidador, e não por uma lógica 'indutora de consumo"” (p.443).

Esses autores classificam os campos de intervenção no processo de regulação da Saúde Suplementar no Brasil. A macrorregulação ou a 'regulação da 
regulação', como o campo constituído pela legislação e regulamentação (Legislativo, Executivo/ ANS, CONSU - Conselho de Saúde Suplementar), as Leis Federais $\mathbf{n}^{\circ}$. 9.656/98 e 9.961/2000, as resoluções normativas, operacionais, instruções, dentre outras) e a auto-regulação ou regulação operativa, sendo as formas de regulação que se estabelecem entre as operadoras, os prestadores e os beneficiários.

O setor de saúde suplementar reúne mais de 2.000 empresas operadoras de planos de saúde, milhares de médicos, dentistas e outros profissionais, hospitais, laboratórios e clínicas. Toda essa rede prestadora de serviços de saúde atende a mais de $\mathbf{4 0}$ milhões de consumidores que utilizam planos privados de assistência à saúde para realizar consultas, exames ou internações (ANS 2006).

A Lei 9.961, de 28 de janeiro de 2000, criou a Agência Nacional de Saúde Suplementar - ANS, autarquia sob o regime especial, vinculada ao Ministério da Saúde, com sede e foro na cidade do Rio de Janeiro - RJ, como o órgão de regulação, normatização, controle e fiscalização das atividades que garantam a assistência suplementar à saúde, definindo ainda sua finalidade, estrutura, atribuições e receita.

A Agência Nacional de Saúde Suplementar - ANS tem por finalidade institucional promover a defesa do interesse público na assistência suplementar à saúde, regular as operadoras setoriais - inclusive quanto às suas relações com prestadores e consumidores, contribuindo para a construção de um mercado sólido, equilibrado e socialmente justo (ANS 2006).

Anualmente, a ANS elabora instrumentos de gestão com a pactuação de seus compromissos junto à União / MS e os resultados obtidos são disponibilizados integralmente na Internet. Os principais instrumentos contratuais para a avaliação periódica do desempenho institucional são os Contratos de Gestão, os Termos Aditivos e os Relatórios de Gestão.

Do ponto de vista organizacional, as ações de saúde bucal no Brasil são realizadas por múltiplos prestadores que atuam de forma independente, não articulada e sem obedecer a uma orientação ou coordenação geral, sendo o exercício da odontologia predominantemente privado e a prática liberal de consultório isolado a principal forma de atendimento (PINTO 2000). 
CHAVES (1986) explica que, durante muitos anos, a odontologia não foi representada na estrutura organizacional do Ministério da Saúde, não havendo seção, serviço, divisão ou assessoria de odontologia, com atribuições de coordenação, ou de assistência técnica ou auxílio financeiro aos programas desenvolvidos em outras esferas federais. Essa lacuna foi preenchida pela Fundação Serviços de Saúde Pública - FSESP, criada em 1942, que durante três décadas reuniu um acervo de experiências em programas incrementais destinados a escolares e na implantação de sistemas de fluoretação de água de abastecimento público.

Dados epidemiológicos do levantamento realizado pelo Projeto Saúde Bucal Brasil 2003 sobre as condições de saúde bucal da população brasileira, indicam diferenças na distribuição do ataque de cárie em crianças, tanto na dentição decídua quanto na permanente, evidenciando diferenças entre regiões do país e nos componentes do Índice CPOD/ceo-d. Da mesma forma, o ataque de cárie e o número de dentes perdidos entre adultos e idosos são elevados (BRASIL 2004).

Esse levantamento também indicou que cerca de $10 \%$ dos adultos brasileiros possuem bolsa periodontal em uma ou mais regiões da boca, $10 \%$ dos adultos com pelo menos um sextante da boca excluído, sendo que esse problema atinge mais da metade dos idosos. A perda precoce é grave e a necessidade de prótese começa a surgir a partir da faixa etária de 15 a 19 anos.

Segundo esse levantamento, as diferenças apontadas podem ser decorrentes do modelo de atenção em cada área geográfica, dos impactos de medidas gerais, como a fluoretação da água e do creme dental, e de medidas mais específicas relacionadas ao acesso e à utilização de serviços de odontologia.

Relativamente à fluoretação, a amostra apontou que $46 \%$ dos municípios pesquisados dispunham de água fluoretada com maior concentração nas regiões Sul e Sudeste.

NARVAI (2006) destaca que para o rompimento com a prática hegemônica da odontologia de mercado, o trabalho odontológico deverá ser desenvolvido a partir das necessidades das pessoas e não a partir da mercantilização dos serviços e do monopólio do acesso aos recursos.

De acordo com esse autor, o SUS assentado nos princípios de universalidade, integralidade e eqüidade, pode possibilitar a realização de ações 
para atender às necessidades de todas as pessoas, viabilizando seu acesso a todos os recursos odontológicos e de saúde geral de que necessitem e ofertando mais aos que mais necessitam.

No entanto, as ações assistenciais devem ser articuladas a um conjunto amplo de medidas para que os 'modelos de atenção' à saúde consigam, de maneira efetiva, produzir socialmente a saúde coletiva sem reduzir o modelo de atenção ao sistema assistencial.

Para NARVAI (2005), a atenção à saúde refere-se ao "conjunto de atividades intra e extra-setor saúde que, incluindo a assistência individual, não se esgota nela, atingindo grupos populacionais com o objetivo de manter a saúde, e requerendo ações concomitantes sobre todos os determinantes da saúde-doença" (p.4). Nesse sentido, conceitua a assistência como o "conjunto de procedimentos clínico-cirúrgicos dirigidos a consumidores individuais, doentes ou não" (p.4).

Esse autor ressalta a importância de se estabelecer uma agenda para a Saúde Bucal Coletiva, com base na $3^{\circ}$ Conferência Nacional de Saúde Bucal realizada em 2005 (CNS 2005)

A Coordenação Nacional de Saúde Bucal, órgão do Departamento de Atenção Básica (DAB) da Secretaria de Atenção à Saúde (SAS), tem como principal atribuição coordenar a implantação de uma Política de Saúde Bucal no SUS, articulada com as demais políticas de saúde, que objetive a redução das desigualdades e a inclusão social.

Em 17 de março de 2004, o Governo Federal criou a Política Brasil 'Sorridente' com diretrizes de ampliação e qualificação da atenção básica, visando o acesso da atenção a todas as faixas etárias e a oferta de mais serviços. Propõe-se, também, a ampliar os atendimentos nos níveis secundário e terciário para a busca da integralidade, da equidade e da universalização do acesso às ações e serviços públicos de saúde bucal.

Essa política apresenta como principais linhas de ação a viabilização da adição de flúor a estações de tratamento de águas de abastecimento público, a reorganização da Atenção Básica, especialmente por meio da Estratégia Saúde da Família. a reorganização da Atenção Especializada, através, 
principalmente, da implantação de Centros de Especialidades Odontológicas e dos Laboratórios Regionais de Próteses Dentárias.

Dados do Ministério da Saúde demonstram a evolução do credenciamento e da implantação das Equipes de Saúde Bucal (ESB) com base nacional: em março de 2001, havia 120 ESF implantadas com porcentual de cobertura populacional de $0,50 \%$; em março de 2007 esse porcentual subiu para $40,71 \%$ de cobertura com 15.492 ESB implantadas.

Os Centros de Especialidades Odontológicas (CEO) são estabelecimentos de saúde que oferecem à população o atendimento especializado em Saúde Bucal com, no mínimo, os seguintes serviços: 1) diagnóstico bucal, com ênfase no diagnóstico e detecção do câncer de boca; 2) periodontia; 3) cirurgia oral menor dos tecidos moles e duros; 4) endodontia; e 5) atendimento a portadores de necessidades especiais.

As Portarias GM/MS nº 599 e 600, de 23/03/2006 definiram critérios, normas e requisitos para a implantação e o credenciamento dos CEOs e instituiram o financiamento e o repasse dos recursos financeiros entre as esferas de governo. Os CEOs podem ser de três modalidades: CEO tipo I - com três cadeiras odontológicas, sendo destinados, mensalmente, $\mathrm{R} \$ 6.600,00$ para custeio, além de $\mathrm{R} \$$ $40.000,00$, em parcela única, correspondentes a custos com reformas, ampliação do espaço físico e aquisição de equipamentos; CEO tipo II - com quatro ou mais cadeiras, sendo destinados, mensalmente, $\mathbf{R} \$ 8.800,00$ para custeio, além de $\mathbf{R} \$$ $50.000,00$, em parcela única; e CEO tipo III - mínimo de sete cadeiras, custeio mensal de $\mathbf{R} \$ 15.400,00$ e R $\$ 80.000,00$ para os investimentos necessários.

A Portaria GM/MS no. 1.572, de 29/07/2004, estabelece o financiamento dos Laboratórios Regionais de Prótese Dentária (LRPD), podendo ser unidades próprias ou terceirizadas credenciadas para a confecção de próteses totais ou próteses parciais removíveis, sendo pagas por produção, com recursos extra-teto diretamente aos municípios. De acordo com o Cadastro Nacional de Estabelecimentos de Saúde (2007), existem 498 CEOs habilitados (158 tipo I; 332 tipo II e 8 tipo III) e 205 LRPD.

A evolução da produção ambulatorial SUS é abaixo representada com enfoque sobre as ações ambulatoriais de Saúde Bucal segundo os 
níveis de complexidade. Entre 2000 e 2006, observa-se aumento nos percentuais de procedimentos MAC ambulatoriais SUS, bem como sobre os procedimentos de odontologia.

Quadro 1 - Produção ambulatorial total e odontologia SUS segundo níveis de complexidade nos anos 2000, 2003 e 2006 - Brasil.

\begin{tabular}{|l|c|c|c|}
\hline $\begin{array}{l}\text { Produção ambulatorial } \\
\text { SUS }\end{array}$ & 2000 & 2003 & 2006 \\
& & & \\
\hline TOTAL SUS & 1.583 .844 .132 & 1.969 .314 .789 & 2.340 .915 .218 \\
\hline Atenção básica & 990.243 .733 & 1.163 .216 .381 & 1.154 .028 .700 \\
\hline MAC & 593.600 .399 & 806.098 .408 & 1.186 .886 .518 \\
\hline \multicolumn{3}{|l|}{} \\
\hline TOTAL ODONTOLOGIA & 183.605 .066 & 210.143 .769 & 211.877 .167 \\
\hline Atenção básica & 178.970 .926 & 203.530 .456 & 204.562 .408 \\
\hline MAC & 4.634 .140 & 6.613 .313 & 7.314 .759 \\
\hline média complexidade & 4.593 .353 & 6.524 .320 & 7.192 .168 \\
\hline alta complexidade & 40.787 & 88.993 & 122.591 \\
\hline
\end{tabular}

Fonte: Ministério da Saúde - SIA/SUS - TabNet Win [acesso 25/02/2007]

Notas:

MAC - soma da média e alta complexidade

Dados sujeitos a alteração.

Observa-se que entre 2000 e 2006, a produção ambulatorial total SUS apresentou um aumento de $48 \%$, enquanto suas componentes Atenção Básica e MAC tiveram um incremento de $17 \%$ e $100 \%$, respectivamente.

A prioridade geral dada aos procedimentos MAC, também pode ser verificada no aumento da composição percentual entre esses anos, ou seja, em 2000, 37,47\% dos procedimentos ambulatoriais era MAC, enquanto que em 2006 esse porcentual aumentou para $50,70 \%$.

No que tange à Saúde Bucal, os procedimentos ambulatoriais totais de odontologia SUS tiveram um incremento de $15,4 \%$, enquanto suas componentes Atenção Básica e MAC tiveram um aumento de $14,3 \%$ e $58 \%$, respectivamente.

Também aqui, é observado um aumento dos procedimentos MAC na composição porcentual: em $2000,2,5 \%$ dos procedimentos de odontologia ambulatorial era MAC, enquanto, em 2006, esse porcentual aumentou para 3,5\%. 
Ao se avaliar, separadamente, a produção da MAC em odontologia, destaca-se que o maior incremento ocorreu na Alta Complexidade com $200,56 \%$ de aumento, enquanto que na Média Complexidade o aumento foi de $57 \%$.

Tais resultados revelam que a oferta de procedimentos MAC em Saúde Bucal, ainda que insuficiente, vem tendo alguma priorização por parte do poder público, em função da política de incentivos financeiros estabelecida pelo Ministério da Saúde nos últimos anos.

BAPTISTA (2003) e ZANETTI (2005) afirmam que as portarias de financiamento se tornaram instrumentos prioritários na condução das políticas de saúde por parte do Ministério da Saúde.

ZANETTI (2005) ao realizar avaliação econômica sobre duas portarias relativas ao PSF/ESB afirma que "o ordenamento administrativo federal da saúde bucal vigente é inútil em termos racionais e não-razoável em termos de justiça, portanto nacionalmente inválido para reorientar a assistência básica em saúde bucal na observância dos princípios constitucionais de universalidade e eqüidade" (p.xi).

Esse autor concluiu em seu estudo que, somente $20,36 \%$ dos municípios que aderiram às duas regras têm potencial para assegurar acesso universal à população (Portaria $n^{\circ} 1444$, de 28/12/2000 que estabelece incentivo financeiro para ESB/PSF e sua sucedânea Portaria $n^{\circ}$ 673, de 03/07/2003 que atualiza e revê o incentivo financeiro às ações de saúde bucal, no âmbito do PSF).

Segundo o Ministério da Saúde, até o final de 2006, o Brasil 'Sorridente' receberá investimentos da ordem de R\$ 1,3 bilhão. Em 2003, investiu-se R\$ 90 milhões em incentivos para a Saúde Bucal na Estratégia Saúde da Família, superando os R\$ 40 milhões do ano anterior. Em 2004, o Tribunal de Contas da União reconheceu um crescimento de $45 \%$ nos atendimentos realizados.

Embora a maioria dos municípios brasileiros conte com serviços de abastecimento público de água por rede de distribuição, somente 45,74 \% do total de municípios com serviços de abastecimento público de água informaram realizar a fluoretação da água. A grande maioria dos municípios que conta com serviços de abastecimento público de água com fluoretação está localizada e Sudeste 
(70\%), região Centro-Oeste $(41,5 \%)$ e regiões Norte e Nordeste, $7,8 \%$ e $16,55 \%$, respectivamente.

No Brasil, $68,8 \%$ dos municípios têm a prestação dos serviços de abastecimento público de água delegada para as empresas estaduais de saneamento. Quanto à fluoretação, observa-se que, em 53,5\% ocorre a fluoretação da água distribuída a população.

Por outro lado, 45,5\% dos municípios brasileiros têm a prestação dos serviços de abastecimento delegada aos próprios municípios, observando-se a fluoretação em apenas $20 \%$. Portanto, a fluoretação tem maior abrangência nos municípios operados pelas companhias estaduais de saneamento. Quanto aos serviços de abastecimento público de água prestado por operadores privados, observa-se que tal modalidade de prestação ocorre em 8,4 \% dos municípios brasileiros, com 12,2\% de fluoretação (MS 2006 a).

Nesse sentido, a FUNASA estabeleceu como meta para 2005/2006 a implantação da fluoretação da água em cerca de 1.500 sistemas de abastecimento público, de modo a beneficiar cerca de 12 milhões de pessoas. de equipamentos e insumos.

Relativamente às informações sobre o controle e à vigilância dos teores de flúor das águas de abastecimento público, a Secretaria Nacional de Saneamento Ambiental do Ministério das Cidades, através do Sistema Nacional de Informações sobre Saneamento (SINIS), criado em 1996, vem monitorando, anualmente, a prestação dos serviços de água no Brasil.

O Ministério da Saúde possui um órgão responsável pela implementação da Política de Regulação no SUS.

O DRAC foi constituído, primeiramente, pelo Decreto $\mathrm{n}^{\circ}$. 4.726, de 09/06/2003, que aprovou a nova Estrutura Regimental Básica do MS, compondo a Secretaria de Atenção à Saúde (SAS) juntamente com os departamentos de Atenção Especializada (DAE), de Atenção Básica (DAB), de Ações Programáticas Estratégicas (DAPE) e com o Instituto Nacional do Câncer (INCA). Posteriormente, com o Decreto $n^{\circ} .5 .974$, de 29/11/2006, foi incorporado à SAS o Departamento de Gestão Hospitalar no Estado do Rio de Janeiro. 
O objetivo geral do DRAC é "coordenar e aprimorar a implementação da Política Nacional de Regulação, Controle e Avaliação, além de viabilizar financeiramente o desenvolvimento das ações e serviços de saúde na atenção ambulatorial e hospitalar do SUS" (SCHILLING e col. 2006, p.28).

Dentre as principais funções desse Departamento estão o controle sobre as transferências de recursos fundo a fundo aos gestores plenos estaduais e municipais para o custeio da Média e Alta Complexidade (teto MAC); o pagamento direto aos prestadores privados, segundo os tetos financeiros MAC dos estados não plenos; pagamento da produção dos hospitais universitários, o pagamento da modalidade co-financiamento aos estados de SP e PE, os pagamentos dos procedimentos realizados com recursos centralizados no Fundo de Ações Estratégicas e Compensação - FAEC (estratégicos, terapia renal substitutiva, alta complexidade, campanhas de cirurgias eletivas), entre outras funções (SCHILLING e col. 2006).

Administrativamente, o DRAC estrutura-se em quatro coordenações formais, conta ainda com a Coordenação de Programação Assistencial (CPA), com o Setor de Ressarcimento ao SUS das Operadoras de Planos de Saúde.

A Política Nacional de Regulação é formulada nesse órgão, partindo-se de um conceito ampliado da regulação estatal sobre o Setor Saúde, que abrangeria tanto as regulamentações como também as ações que assegurem o cumprimento destas, ficando marcadas as diferenças de conceituação entre a Regulação sobre Sistemas de Saúde, Regulação da Atenção à Saúde e Regulação do Acesso à Assistência. A Regulação sobre Sistemas de Saúde, enquanto regulação ampliada conteria as ações de Regulação da Atenção à Saúde e estas, enquanto ações sobre a produção direta das ações dos prestadores de serviços, conteriam as ações de Regulação do Acesso à Assistência.

Essa Política é um dos componentes do Pacto pela Saúde na sua diretriz Pacto de Gestão e está focada em três eixos estruturantes: a distribuição de recursos financeiros, definida no âmbito das Comissões Intergestoras Bipartite CIB, para a implantação e para o custeio dos Complexos Reguladores nos Estados e Municípios; a disponibilização de instrumentos para a operacionalização dos 
Complexos Reguladores, como o SISREG versão III; e o programa de capacitação permanente de recursos humanos (MS 2006 c).

Quatro tipos de serviços especializados de Saúde Bucal exigem habilitação específica para implantação e funcionamento, sem a qual os recursos federais, na forma de incentivos financeiros ou pagamento FAEC, não podem ser transferidos. Os Centros de Tratamento da Má Formação Labiopalatal Portaria SAS/MS $n^{\circ}$ 62, de 01/04/1994, os Laboratórios Regionais de Prótese Dentária, os Centros de Especialidades Odontológicas I (CEO I) e os Centros de Especialidades Odontológicas II (CEO II) - Portaria GM/MS $\mathrm{n}^{\circ} 1.570$, de 29/07/2004.

A Política Nacional de Atenção Básica, aprovada pela Portaria MS / GM nº.648, de 28/03/2006, estabelece a revisão de diretrizes e normas para a organização da Atenção Básica para o Programa Saúde da Família (PSF) e o Programa Agentes Comunitários de Saúde (PACS), considerando a Saúde Bucal como área estratégica para atuação em todo o território nacional (MS 2006 b).

A proposta deste trabalho é analisar as regulamentações e as normas pertinentes à Saúde Bucal identificadas nos atos ministeriais do Setor Saúde, entre os anos de 1946 a julho de 2007, tomando como referencial o conceito de Regulação enquanto Ação Soçial, com enfoque sobre as prioridades regulamentadas em diferentes períodos.

Também foram analisados documentos do Conselho Nacional de Saúde para servir de contraponto na análise das prioridades políticas estabelecidas e das demandas surgidas no CNS, entre 1988 e julho de 2007.

O referencial teórico tomado foi o da Regulação, enquanto ação social, ou seja, "o conjunto de ações meio que dirigem, ajustam, facilitam ou limitam determinados processos (...), abarcando tanto o ato de regulamentar (elaborar leis, regras, normas, instruções, etc) as próprias regulamentações, quanto as ações e técnicas que asseguram o cumprimento destas, como fiscalização, controle, avaliação, auditoria, sanções e premiações" (SCHILLING 2006, p.34). 


\section{MATERIAL E MÉTODO}

O estudo buscou identificar a regulação da atenção à Saúde Bucal nos atos normativos ministeriais editados pelo setor Saúde e nos documentos aprovados pelo Conselho Nacional de Saúde - CNS, tomando-se como base o conceito ampliado de Regulação Estatal sobre o Setor Saúde adotado pelo Ministério da Saúde (SCHILLING e col. 2006)..

Os atos normativos ministeriais do setor Saúde foram pesquisados junto às bases de dados do Sistema de Legislação em Saúde SAÚDE LEGIS, através de termos relacionados à odontologia e saúde bucal como bucal, oral, odontologia, fluoretação, flúor, dentista, exercício, dentária, entre outros.

A busca abrangeu os atos normativos aprovados em todo o período a partir do qual essas regulamentações ficaram disponíveis no sistema, 1946 , sendo que a amplitude geral das datas estendeu-se de 1946 a julho de 2007.

Outras regulamentações de interesse também foram rastreadas por vias não sistemáticas, a partir de referências secundárias, internet $\mathrm{e}$ leituras de rotina, destacando-se as portarias mais importantes na condução geral da política de saúde, em função de sua capacidade de regular o sistema e das mudanças introduzidas no cenário institucional.

Os documentos selecionados no Conselho Nacional de Saúde foram os previstos em seu Regimento Interno, ou seja, as resoluções, as deliberações, moções, as recomendações, as atas e as pautas aprovadas e disponíveis no site do CNS, desde 1988. A amplitude geral das datas estendeu-se 1988 a julho de 2007.

De forma semelhante aos estudos de BAPTISTA (2003, 2007), documentos foram agrupados de acordo com os seguintes eixos temáticos: gestão e organização do sistema e da atenção/assistência à saúde bucal; financiamento; programas e ações em saúde bucal; e outros. 
A amostra ficou composta por 495 atos normativos ministeriais e 109 documentos do CNS. 


\section{RESULTADOS}

Dos 495 atos normativos selecionados, 468 (94,54\%) foram publicadas a partir de 1989. Quanto à origem da norma, 2 são do extinto Ministério dos Negócios da Educação e Saúde Pública, 492 são do Ministério da Saúde, sendo localizada 1 norma conjunta dos Ministérios da Justiça e Saúde. A classificação dos assuntos por eixos temáticos foi a seguinte:

\section{Gestão e organização do sistema e da atenção à saúde bucal}

a) Regulamentação do sistema e da atenção/assistência à Saúde Bucal: estratégias para o controle e avaliação da atenção à saúde bucal, normas para credenciamento de serviços, planos, orientações técnicas específicas para a organização da atenção, pactuações, assessorias;

b) Organização da estrutura: alterações da estrutura do Ministério da Saúde, relacionadas à área técnica de Saúde Bucal;

c) Regulamentações de rotinas: organização dos fluxos e práticas gerenciais;

d) Cadastros: autorização, credenciamento ou descredenciamento para o funcionamento de unidades e serviços.

\section{Financiamento}

a) Transferência de recursos: incentivos com recursos específicos para programas, campanhas e ações verticais;

b) Tabelas e procedimentos: inclusão e revisão de procedimentos e valores para remuneração de prestadores de serviços.

\section{Programas e ações em saúde bucal}

a) Instituição de novos programas e ações de saúde bucal: instituição de novos programas, campanhas de cirurgia e integração das ações de saúde bucal às demais políticas setoriais;

b) Reformulação e criação de mecanismos de controle dos programas e das ações.

\section{$\underline{\text { Outras }}$}


a) temas diversos: conferências, datas comemorativas, exercício profissional, ensino superior, regulamentações do trabalho e educação.

Entre 1946 e 1988, foram publicadas 27 normas, sendo 10 sobre Gestão (37,04\%); 2 sobre Programas (7,41\%); e 15 Outras regulamentações $(55,56 \%)$.

Figura 1 - Atos normativos ministeriais sobre Saúde Bucal por eixos-temáticos e períodos - Brasil -1946 a 1988.

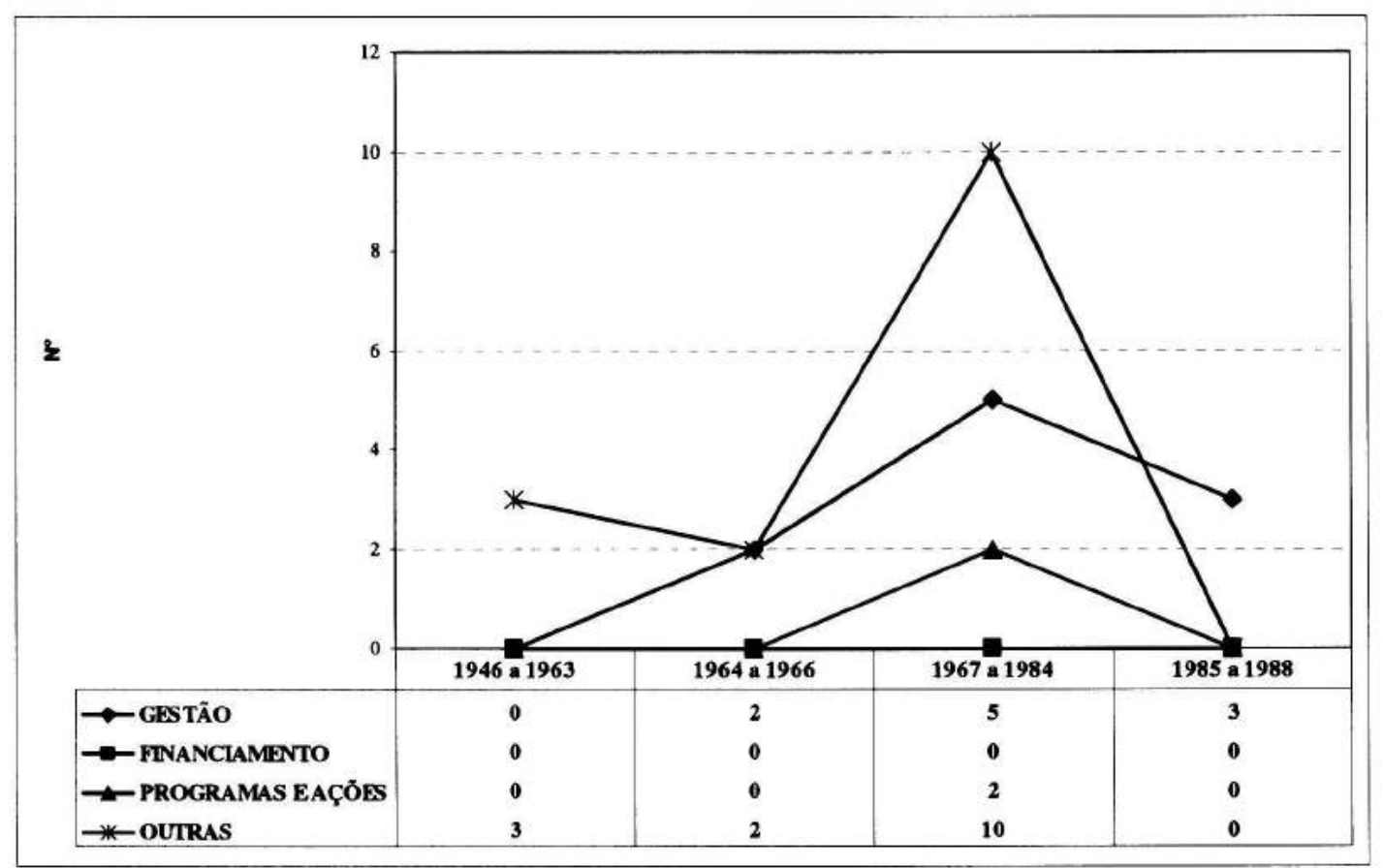

Fonte: Sistema de Legislação em Saúde - SAÚDE LEGIS - www.saude.gov.br/saudelegis

Nesse período, predominaram as regulamentações do eixotemático Outras (15), dispondo sobre vários assuntos desarticulados entre si que vão de data comemorativa (1989), exercício profissional, alguns aspectos sobre a gestão do trabalho e educação formal, como estágios em serviço, reconhecimento de cursos de prótese e comissões para estudo das funções de pessoal auxiliar.

Em segundo lugar, aparecem os assuntos relativos à Gestão (10) com regulamentações que dispõem sobre assessorias, consultorias, alterações de estruturas organizacionais, normas sobre equipamentos odontológicos, embalagens de produtos e proteção radiológica. Por último, os Programas e as Ações de Saúde Bucal (2) representados por duas regulamentações que dispõem sobre a fluoretação das águas de abastecimento público. Tais regulamentações não parecem capazes de 
desenhar uma política de Saúde Bucal para o período, na medida em que os assuntos são tratados de forma pontual e esparsa. As Figuras 2, 3 e 4 apresentam detalhes sobre essa questão.

Figura 2 - Atos normativos ministeriais sobre Saúde Bucal, eixo-temático Outras, por períodos - Brasil - 1946 a 1988.

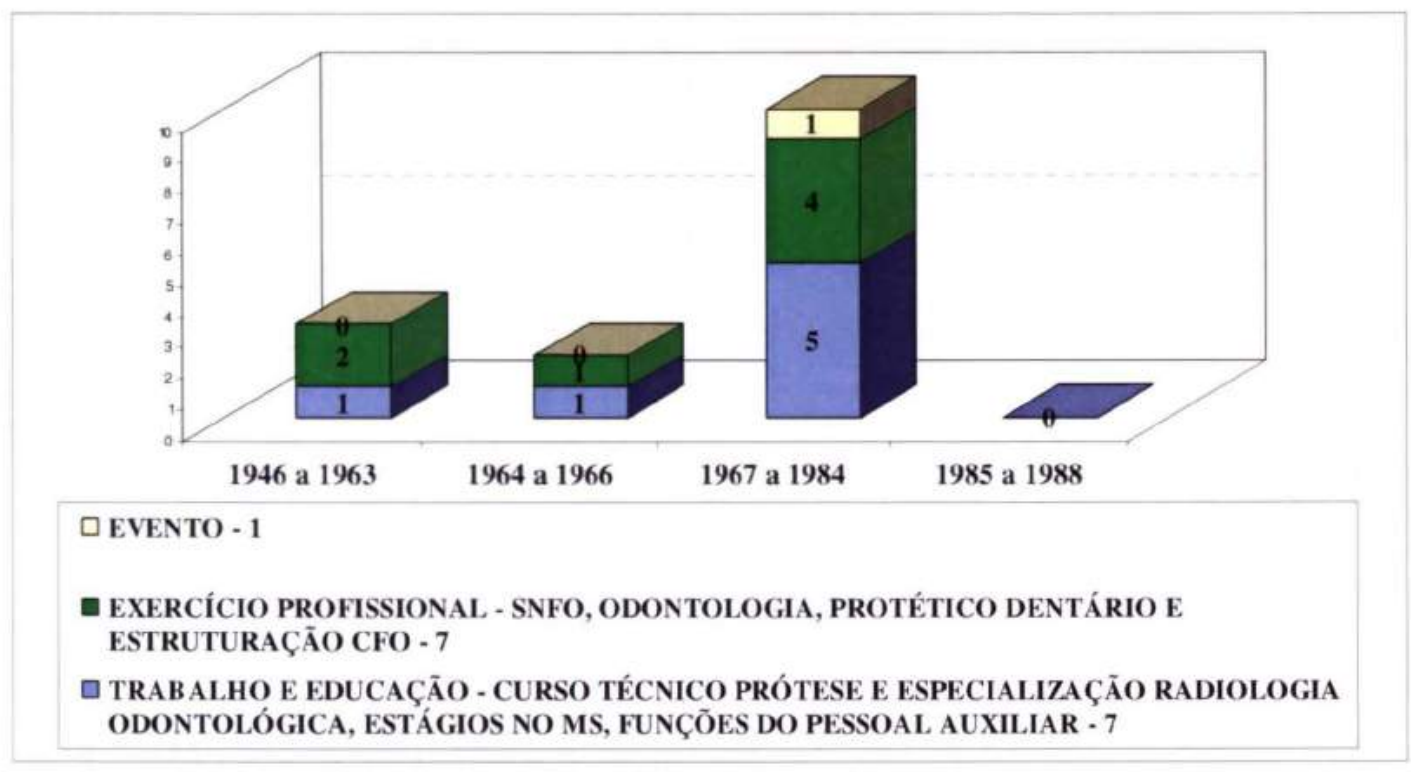

Fonte: Sistema de Legislação em Saúde - SAÚDE LEGIS - wwww.saude.gov.br/saudelegis

Figura 3 - Atos normativos ministeriais sobre Saúde Bucal, eixo-temático Gestão, por períodos - Brasil - 1946 a 1988.

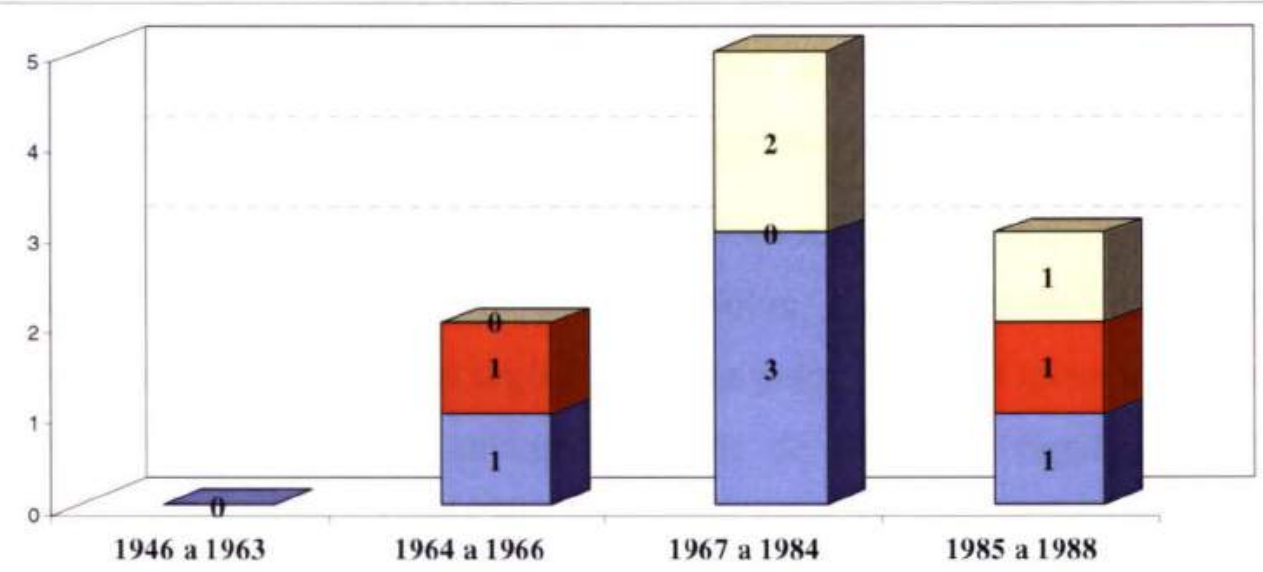

口 REGULAMENTAÇÃO DO SISTEMA - ASSESSORIAS, COMISSÕES, CONSULTORIAS - 3

ロ ORGANIZAÇÃO DA ESTRUTURA - SNFO, DNSB/SNPES - 2

口 REGULAMENTAÇÃO DO SISTEMA - VIGILÂNCIA SANITÁRIA - NORMAS SOBRE EQUIPAMENTOS, EMBALAGENS E PROTEÇÃO RADIOLÓGICA - 5

Fonte: Sistema de Legislação em Saúde - SAÚDE LEGIS - www.saude.gov.br/saudelegis 
Figura 4 - Atos normativos ministeriais sobre Saúde Bucal, eixo-temático Programas e Ações, por períodos - Brasil - 1946 a 1988.

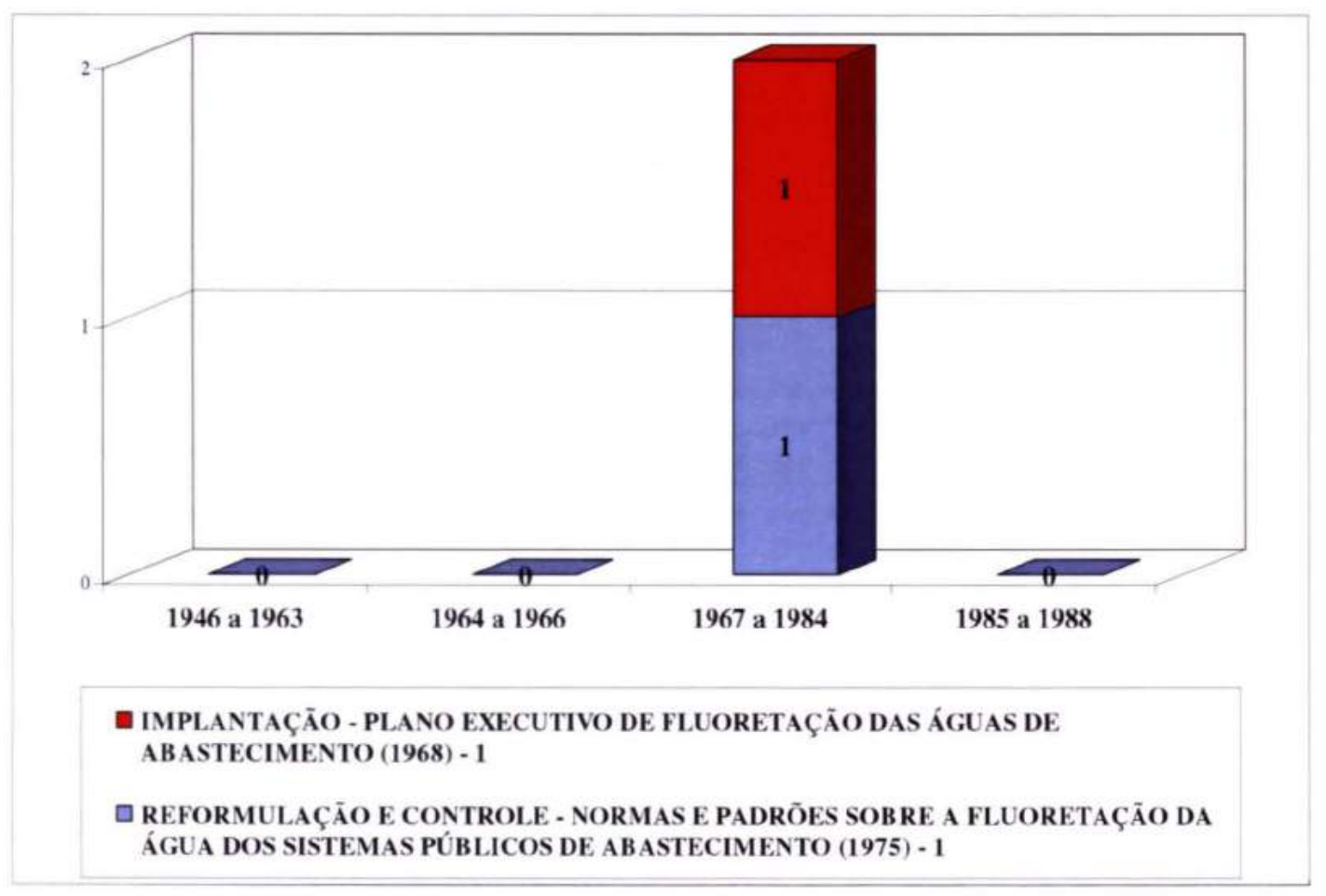

Fonte: Sistema de Legislação em Saúde - SAÚDE LEGIS - wwww.saude.gov.br/saudelegis

Entre 1989 e julho de 2007, foram publicadas 468 normas, sendo $128(27,35 \%)$ sobre Gestão; $297(63,46 \%)$ sobre Financiamento; $29(6,20 \%)$ de Programas; e 31(6,62\%) sobre Outras regulamentações.

Numa primeira análise dos resultados é possível observar um quantitativo superior das regulamentações sobre Financiamento. Em parte, tal fenômeno pode ser atribuído às regras propostas pelas Normas Operacionais entre os anos de 1991 e 1996. No entanto, a partir de 2000, as regulamentações de financiamento relativas à Saúde Bucal atingem um patamar que suplanta o número de regulamentações de gestão, com predomínio das portarias relativas à transferência de recursos (Figuras 5 e 6). 
Figura 5 - Atos normativos ministeriais sobre Saúde Bucal por eixos-temáticos Gestão, Financiamento, Programas e Outras - Brasil - 1989 a julho de 2007.

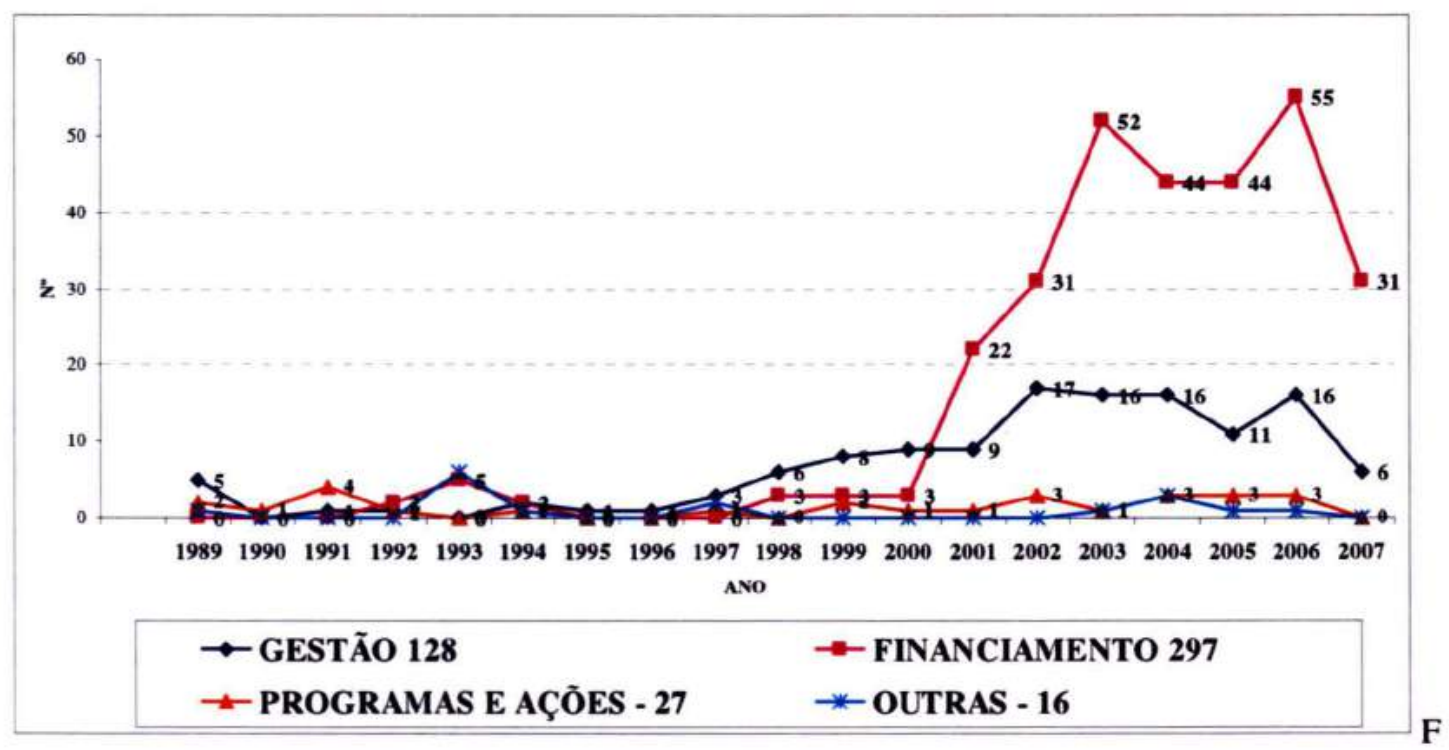

onte: Sistema de Legislação em Saúde - SAÚ́DE LEGIS - www.saude.gov.br/saudelegis

Figura 6 - Atos normativos ministeriais sobre Saúde Bucal, eixo-temático Financiamento - Brasil - 1989 a julho de 2007.

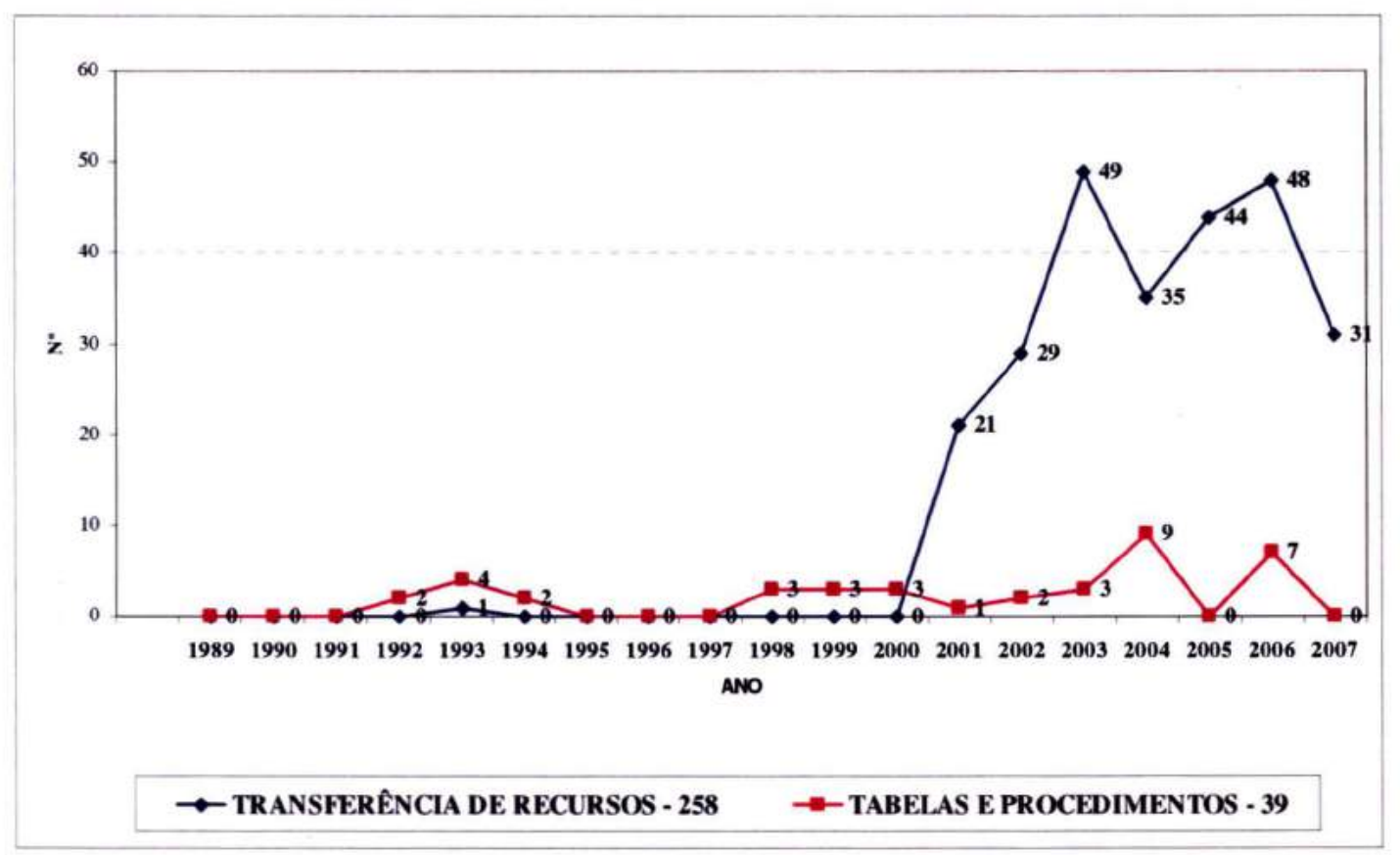

Fonte: Sistema de Legislação em Saúde - SAÚDE LEGIS - www.saude.gov.br/saudelegis. 
Entre 1991 e 1994, as portarias editadas sobre tabelas e procedimentos abordam a atenção da Média e Alta Complexidade (teto financeiro MAC) em Saúde Bucal, através de procedimentos ambulatoriais e hospitalares, destacando-se o atendimento ambulatorial na especialidade de cirurgia buco-maxilofacial, atendimento hospitalar para portadores de deficiências e atendimento hospitalar para a realização de implantes e lesões-lábio palatais.

Em 1992, a atenção básica é representada pela regulamentação dos procedimentos coletivos em Saúde Bucal (Figura 7).

Entre 1998 e 2002, novamente a prioridade MAC é observada, incorporando-se ao rol de procedimentos MAC o tratamento ortodôntico aos pacientes portadores de lesões lábio-palatais.

Há um aumento no número de portarias, que pode ser atribuído aos procedimentos definidos pelo Ministério da Saúde como estratégicos e remunerados com recursos do Fundo de Ações Estratégicas e de Compensação FAEC. No ano 2000 , foi localizada uma única portaria sobre a atenção básica relativa à criação de incentivos financeiros para a implantação de Equipes de Saúde Bucal (ESB) no Programa de Saúde da Família (PSF).

A partir de 2003, a ênfase se dá sobre a atenção básica através de portarias que redefinem os critérios de remuneração dos procedimentos coletivos em Saúde Bucal e dos incentivos das ESB/PSF. Além disso, são criados incentivos financeiros para assistência à saúde no sistema penitenciário, dos povos indígenas e das populações assentadas.

Em 2004, são criados os incentivos para a implantação e a atenção ambulatorial de média complexidade para a implantação dos Centros de Especialidades Odontológicas - CEO e os Laboratórios Regionais de Prótese Dentária - LRPD. 
Figura 7 - Atos normativos ministeriais sobre Saúde Bucal - subtema Tabelas e Procedimentos, segundo o nível da atenção - Brasil - 1989 a julho de 2007.

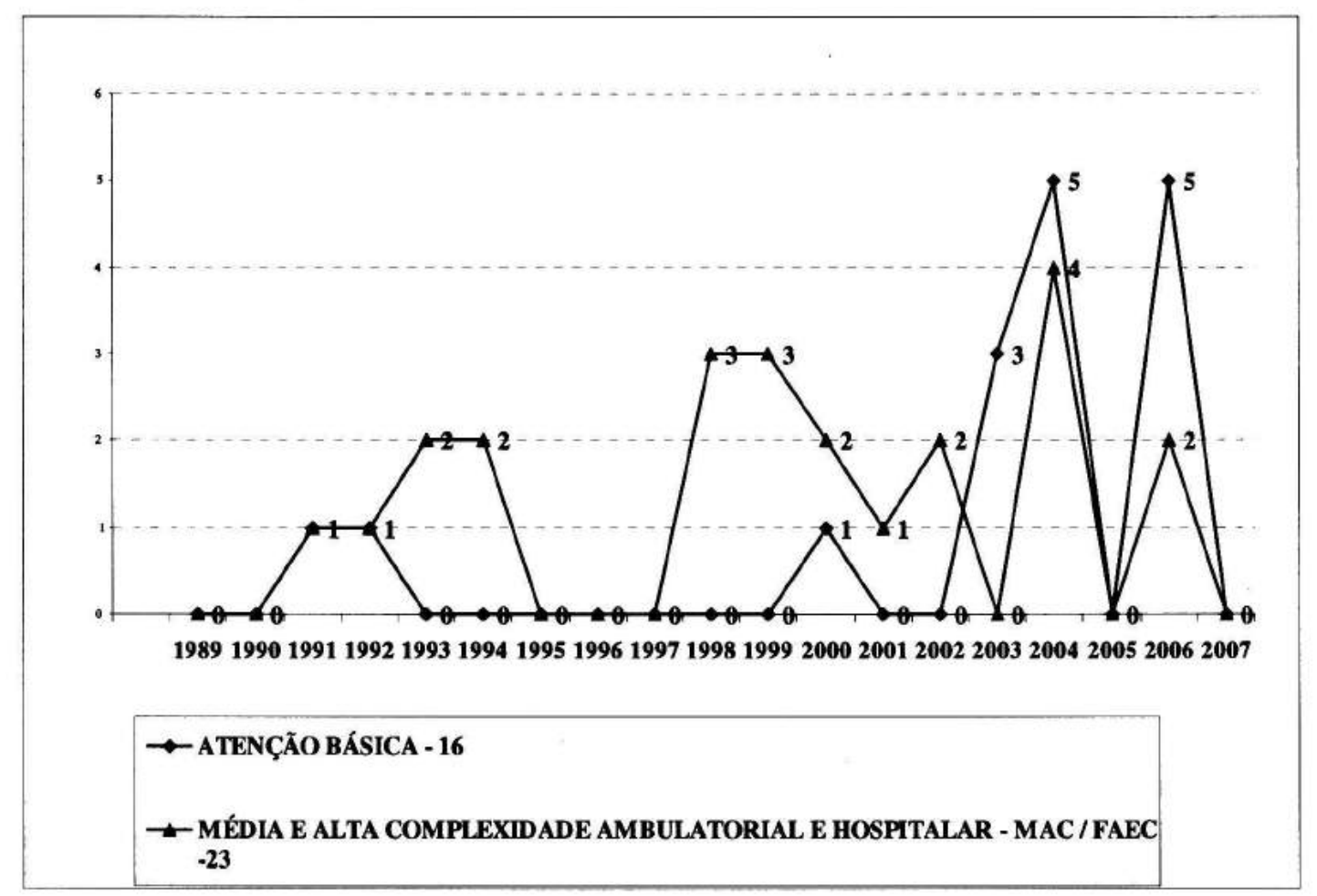

Fonte: Sistema de Legislação em Saúde - SAÚDE LEGIS - www.saude.gov.br/saudelegis

A partir de 2001, como resultado da política de incentivos estabelecida pelo Ministério da Saúde, ocorre um aumento no número de portarias que dispõem sobre Transferências de Recursos, sendo identificadas as portarias referentes à qualificação de municípios para recebimento dos incentivos financeiros ESB/PSF, à qualificação de municípios ao recebimento dos incentivos da assistência básica aos povos indígenas e à habilitação de municípios ao recebimento de incentivos do CEO/LRPD.

Destaca-se que, do total de 468 atos ministeriais editados, a partir de 1989, e selecionados para este estudo, $258(55,13 \%)$ são portarias referentes à Transferência de Recursos (Figura 8). 
Figura 8 - Atos normativos ministeriais sobre Saúde Bucal - subtema Transferências de Recursos segundo o nível de atenção e programa - Brasil - 1989 a julho de 2007.

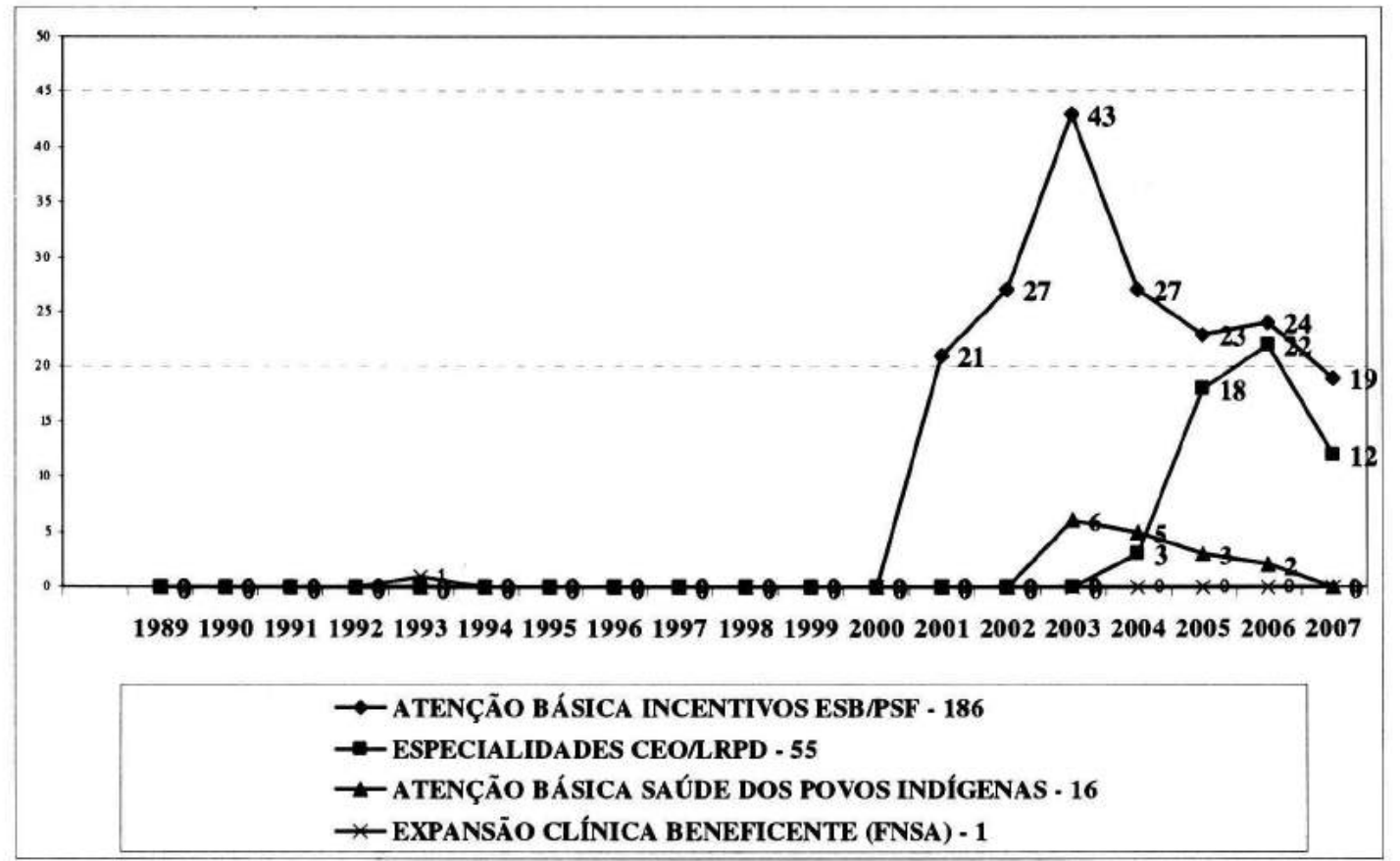

Fonte: Sistema de Legislação em Saúde - SAÚDE LEGIS - www.saude.gov.br/saudelegis

No eixo-temático Gestão, foram encontradas 128 normatizações classificadas por subtemas: 94 regulamentações do sistema, 6 regulamentações sobre a organização e estrutura do MS, 18 sobre cadastros e 10 sobre regulamentação de rotinas (Figura 9).

As portarias referentes à Regulamentação de Rotinas encontram-se atreladas à organização dos fluxos e práticas gerenciais, com enfoque sobre a definição de procedimentos e rotinas para novas ações, programas e para a operacionalização dos mecanismos para as ações definidas como estratégicas pelo MS.

Entre 1998 e 2002, essas portarias remetem à definição de procedimentos para a implantação do Piso da Atenção Básica - PAB, instrumentos e diretrizes sobre o funcionamento do Sistema de Informações Ambulatoriais - S I A e a regulamentação de rotinas sobre o registro de atividades das ESB/PSF. A partir de 2006, foram identificadas regulamentações sobre as ESB/PSF, CEO/LRPD, 
Programação Físico-Financeira de procedimentos ambulatoriais e sobre os blocos de financiamento do Pacto da Saúde 2006.

No subtema Cadastros, a totalidade de regulamentações encontrada se refere ao cadastramento de hospitais para a realização de procedimentos de Alta Complexidade em Lesões Lábio Palatais.

Figura 9 - Atos normativos ministeriais sobre Saúde Bucal - Gestão e organização do sistema - Brasil - 1989 a julho de 2007.

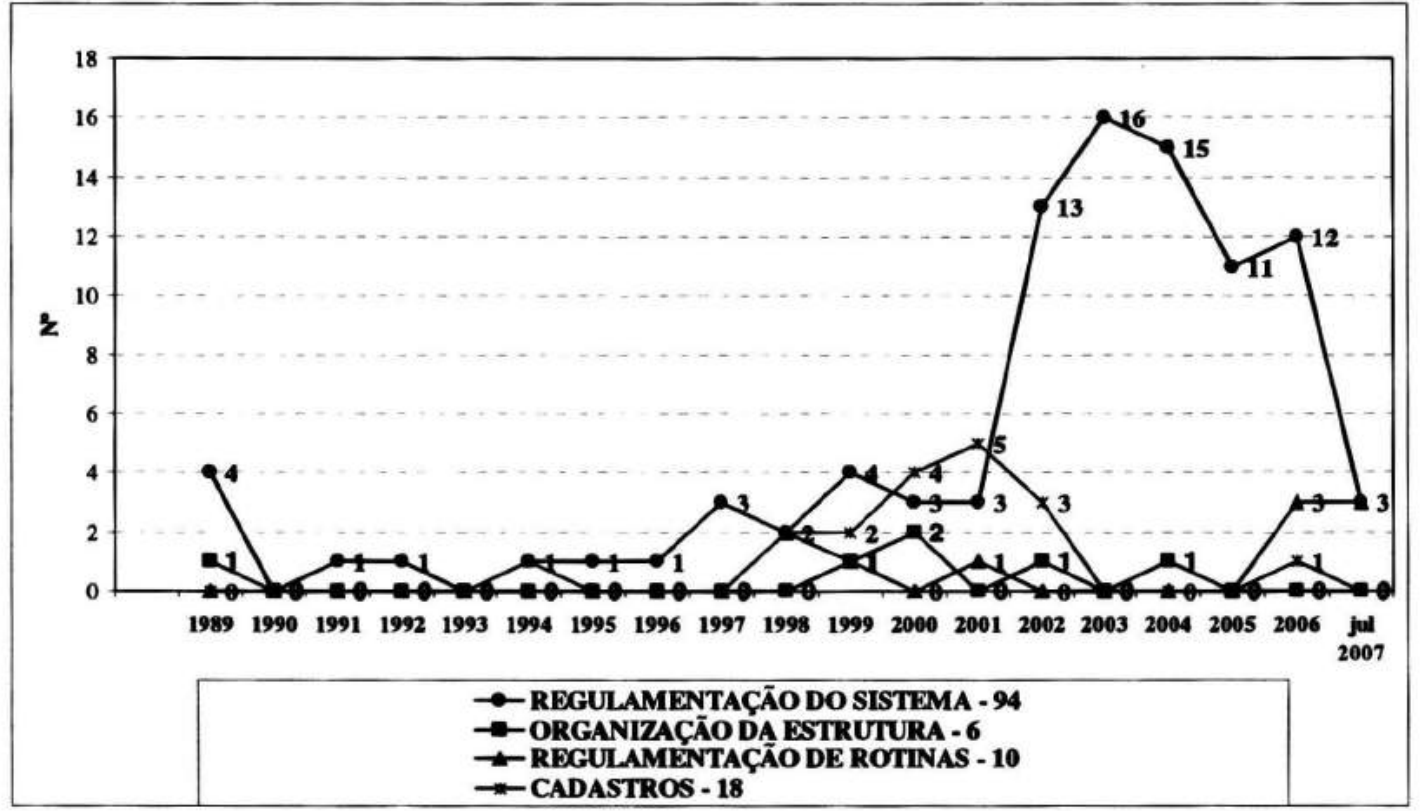

Fonte: Sistema de Legislação em Saúde - SAÚDE LEGIS - www.saude.gov.br/saudelegis

Relativamente à Organização da Estrutura, cargos, funções do MS foram identificados os seguintes assuntos:

1) 1989 - tentativa de criação de coordenações macro-regionais na Secretaria Nacional de Programas Especiais - SNPES;

2) 1999 - funções/cargos da ANVISA no que se refere às ações regulatórias sobre equipamentos, ambiente, insumos e materiais odontológicos;

3) 2000 - dispõe sobre a criação de áreas técnicas para p PSF, incluindo as ações de Saúde Bucal/PSF;

4) 2000 - dispõe que o Departamento de Atenção Básica - DAB abrangerá as áreas técnicas, incluída a de Saúde Bucal; 
5) 2002 - subdelega competências a consultor para coordenar as atividades de Saúde Bucal na DAB; e

6) 2004 - cria a comissão/função para o recebimento de materiais para a Coordenação Nacional de Saúde Bucal.

Os assuntos relativos à Regulamentação do Sistema abordam ações regulatórias normativas, executivas e judicantes sobre a Saúde Suplementar e sobre a Vigilância Sanitária, além das regulamentações sobre a atenção/assistência à Saúde Bucal (Figura 10).

Figura 10 - Atos normativos ministeriais sobre Saúde Bucal - subtema Regulamentação do Sistema - Brasil - 1989 a julho de 2007.

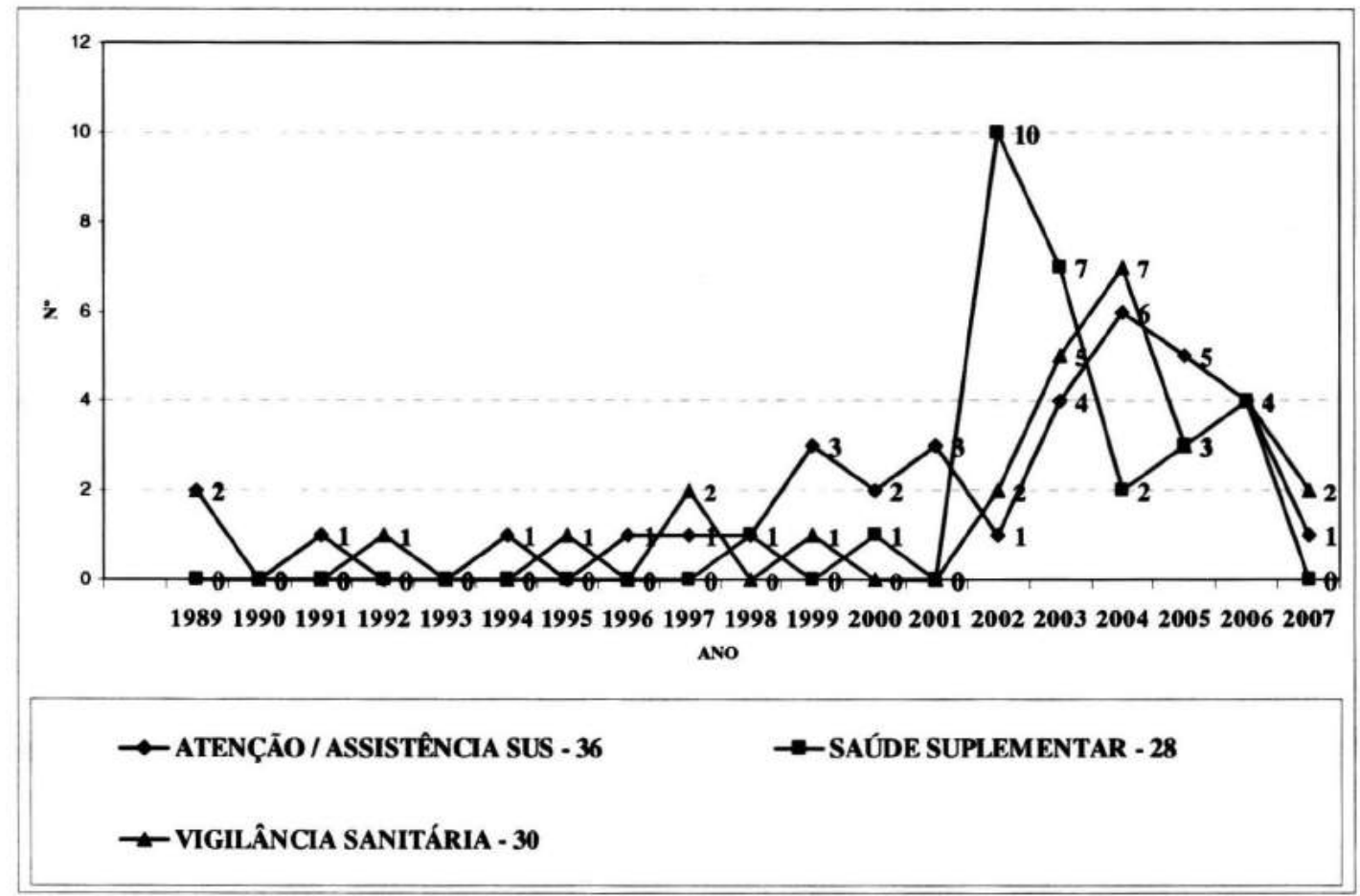

Fonte: Sistema de Legislação em Saúde - SAÚDE LEGIS - www.saude.gov.br/saudelegis

Resoluções emanadas das agências regulatórias ANS e da ANVISA foram publicadas e selecionadas nesse estudo.

Em todo o período avaliado, as ações identificadas da ANVISA se referem aos seguintes assuntos:

1)regulação normativa: normas para equipamentos odontológicos, proteção radiológica, enxaguatórios bucais e implantação do controle e da qualidade da água; 
2)regulação executiva: concessão a empresas de certificados de boas práticas de fabricação; medidas cautelares e suspensão de produtos 'anti-fumo'; interdição cautelar sobre produto creme dental com flúor; liberação da fabricação e do comércio de produto creme dental; apreensão produto escova dental falsificada; e apreensão produto escova dental por importação não informada.

Relativamente à ANS, as ações regulatórias referem-se à: 1) regulação normativa: delegação das ações de controle e avaliação da assistência para as operadoras; definição do rol de procedimentos odontológicos ambulatoriais a ser utilizado como referência mínima de cobertura pelas operadoras e planos da saúde suplementar; e estabelece minuta com requisitos mínimos para a celebração dos instrumentos jurídicos firmados entre as operadoras de planos e os consultórios odontológicos;

2) regulação executiva: dispõe sobre a instauração do regime de direção fiscal em operadora;

3) regulação judicante: decretação do regime de liquidação extrajudicial em operadora; institui comissão de inquérito para apuração da situação de insolvência de operadora; e institui comissão de inquérito para apuração da situação de falência de operadora.

Quanto à Regulamentação do Sistema e da Assistência à Saúde Bucal exclusivos do SUS, os documentos foram agrupados em dois períodos, tendo apresentado os seguintes assuntos:

- entre 1989 e 2002: comissões, assessorias e consultorias para a Saúde Bucal (oito); normatização do credenciamento de hospitais para o atendimento de pacientes portadores de lesões lábio-palatais (uma); estabelecimento dos indicadores anuais do Pacto da Atenção Básica (três); e discussão de parâmetros de planejamento para a Saúde Bucal (duas);

- entre 2003 e 2007: comissões, assessorias, consultorias para a Saúde Bucal (cinco); estabelecimento/redefinição do componente de avaliação da Atenção Básica (cinco); estabelecimento dos indicadores anuais do Pacto da Atenção Básica (quatro); caderno de orientações técnicas de Auditoria em Saúde Bucal (dois); Programação 
Pactuada e Integrada - PPI (uma); e Plano Nacional de Saúde com itens de Saúde Bucal (duas).

Se no período de 1946 a 1964, as regulamentações em torno do eixo-temático Outras diziam respeito ao exercício profissional e aos cursos técnicos e de especialidade em odontologia, entre 1989 e julho de 2007 , o enfoque se dá sobre as regulamentações que dispõem sobre as Conferências de Saúde Bucal.

No tocante aos Programas e às Ações, foram encontradas vinte e sete regulamentações. Treze dispõem sobre a implantação de novos planos, políticas e programas, bem como a inserção das ações de Saúde Bucal em outras políticas setoriais. Catorze dispõem sobre a reformulação e o controle dos programas existentes (Figura 11).

Nesse último grupo encontram-se as portarias relativas à revogação da fluoração do sal e da aquisição da compra de uniformes para as ESB/PSF

A partir de 1997, começam a surgir demandas para a inserção e a integração das ações de Saúde Bucal junto a outras políticas setoriais, como Programa de Saúde da Família, política para portadores de deficiências, política para a saúde penitenciária, política nacional para hospitais de pequeno porte, política nacional de oncologia, Política Nacional de Atenção Básica (Figura 12). 
Figura 11 - Atos normativos ministeriais sobre Saúde Bucal - subtema Programas e Ações - Brasil - 1989 a julho de 2007

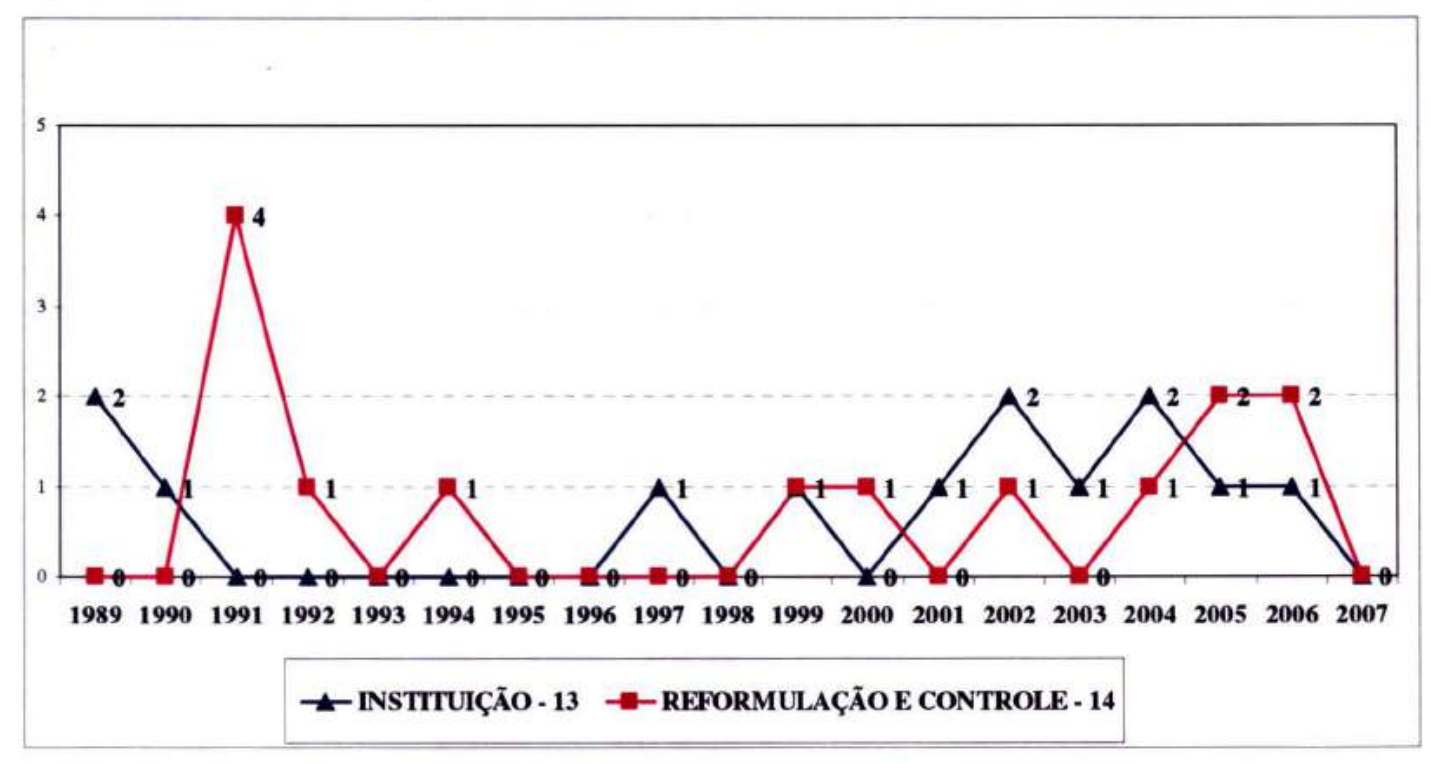

Fonte: Sistema de Legislação em Saúde - SAÚDE LEGIS - www.saude.gov.br/saudelegis

Figura 12 - Atos normativos ministeriais sobre Saúde Bucal - Programas e Ações segundo os assuntos dispostos nas regulamentações a cada ano - Brasil - 1989 a julho de 2007.

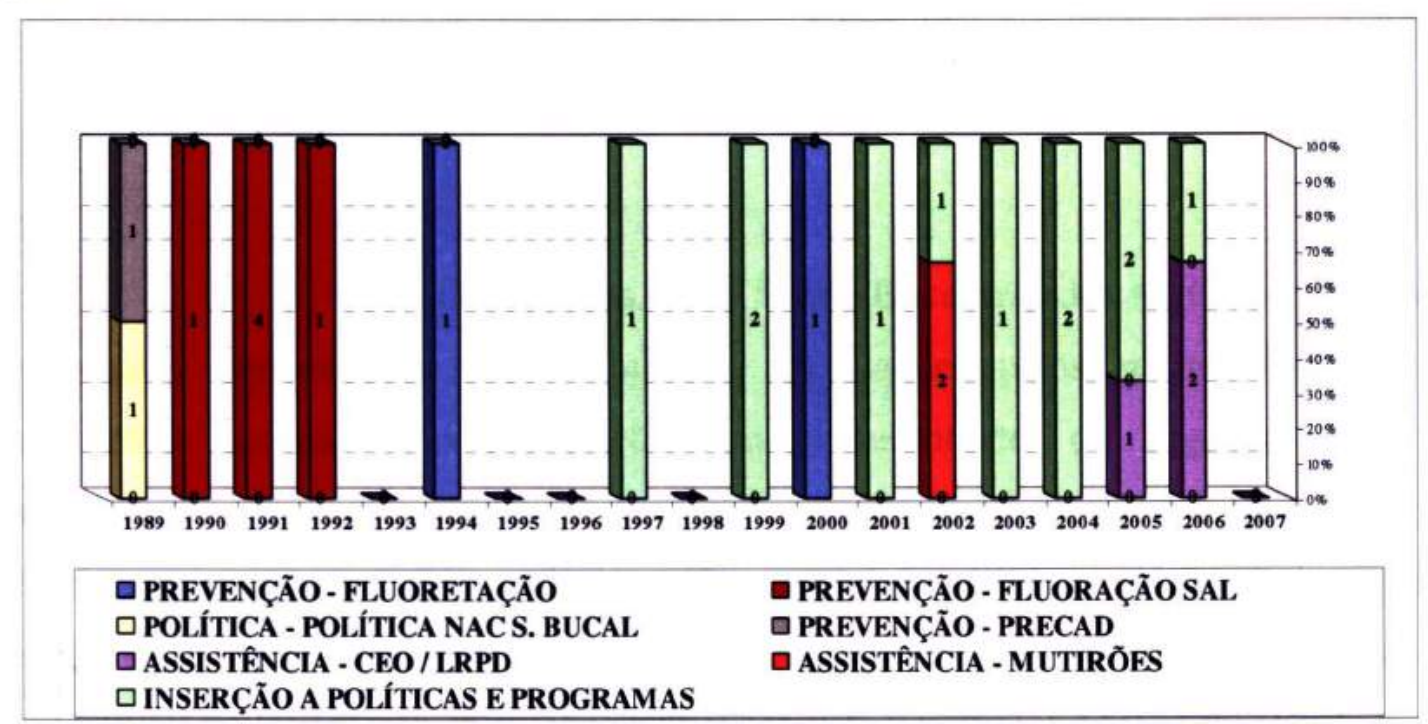

Fonte: Sistema de Legislação em Saúde - SAÚDE LEGIS - $\underline{\text { www.saude.gov.br/saudelegis }}$ 
Os documentos do CNS foram selecionados a partir da leitura e da identificação de 927 atos aprovados, entre 1988 e julho de 2007, e disponibilizados em sua página na internet. Para este estudo foram selecionados 109 $(11,76 \%)$ documentos, ou seja, 4 resoluções, 6 pautas e 99 atas, com assuntos relacionados à Saúde Bucal (Figuras 13 e 14).

Figura 13 - Número de documentos examinados e selecionados sobre Saúde Bucal CNS - 1988 a julho de 2007

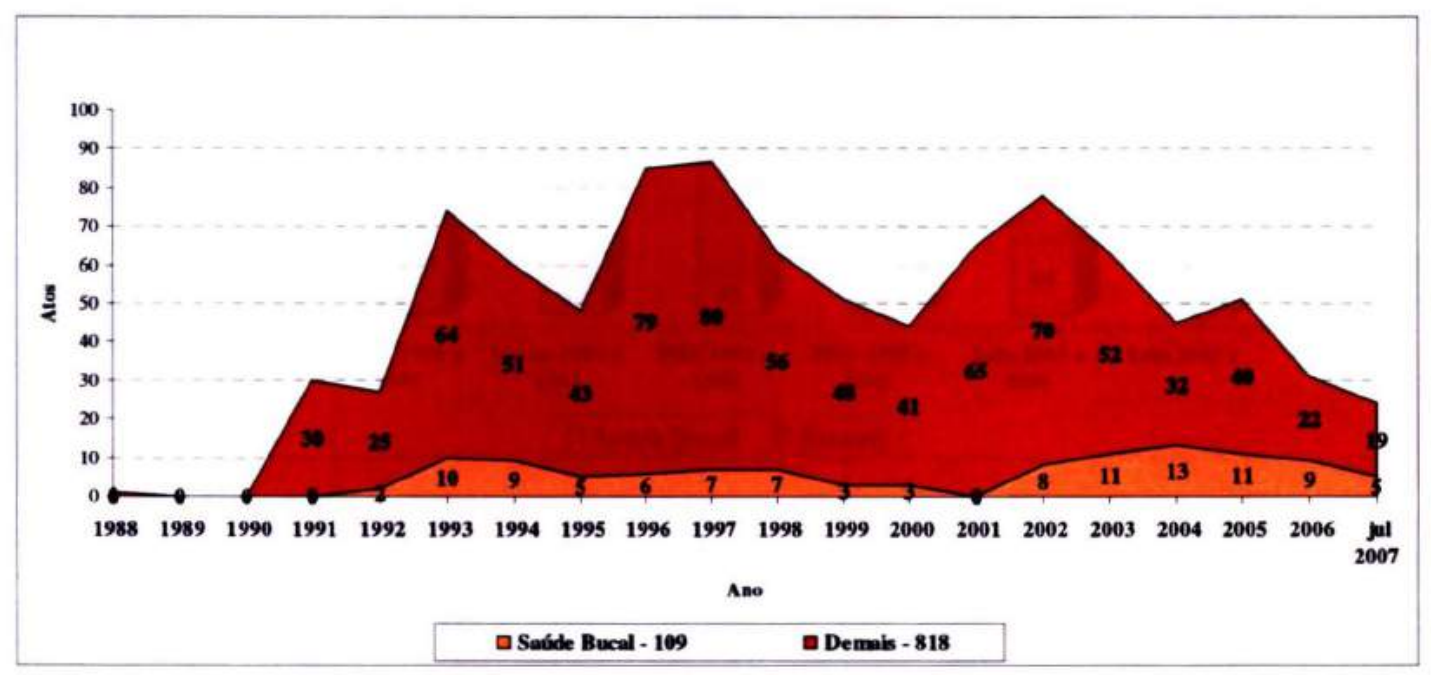

Fonte: CNS - http://www. conselho.saude.gov.br

Os assuntos sobre Saúde Bucal tratados no CNS partem de demandas apresentadas pelo Ministério da Saúde, pelos representantes dos segmentos sociais, pelas corporações, por representantes do Legislativo, pelos municípios, pela imprensa, entre outros grupos. Igualmente, apresentam-se sob várias formas: convites, informes, apresentações, discursos para aprovação de matérias, discussões, apresentações técnicas, dentre outras formas. Neste estudo, foram selecionados documentos com abordagens sobre Saúde Bucal, sem preocupação com a origem ou com a forma pela qual o assunto é apresentado. 
Figura 14 - Número de documentos examinados no CNS e selecionados sobre Saúde Bucal, segundo os períodos dos Governos pós-1985 - Brasil - 1988 a julho de 2007

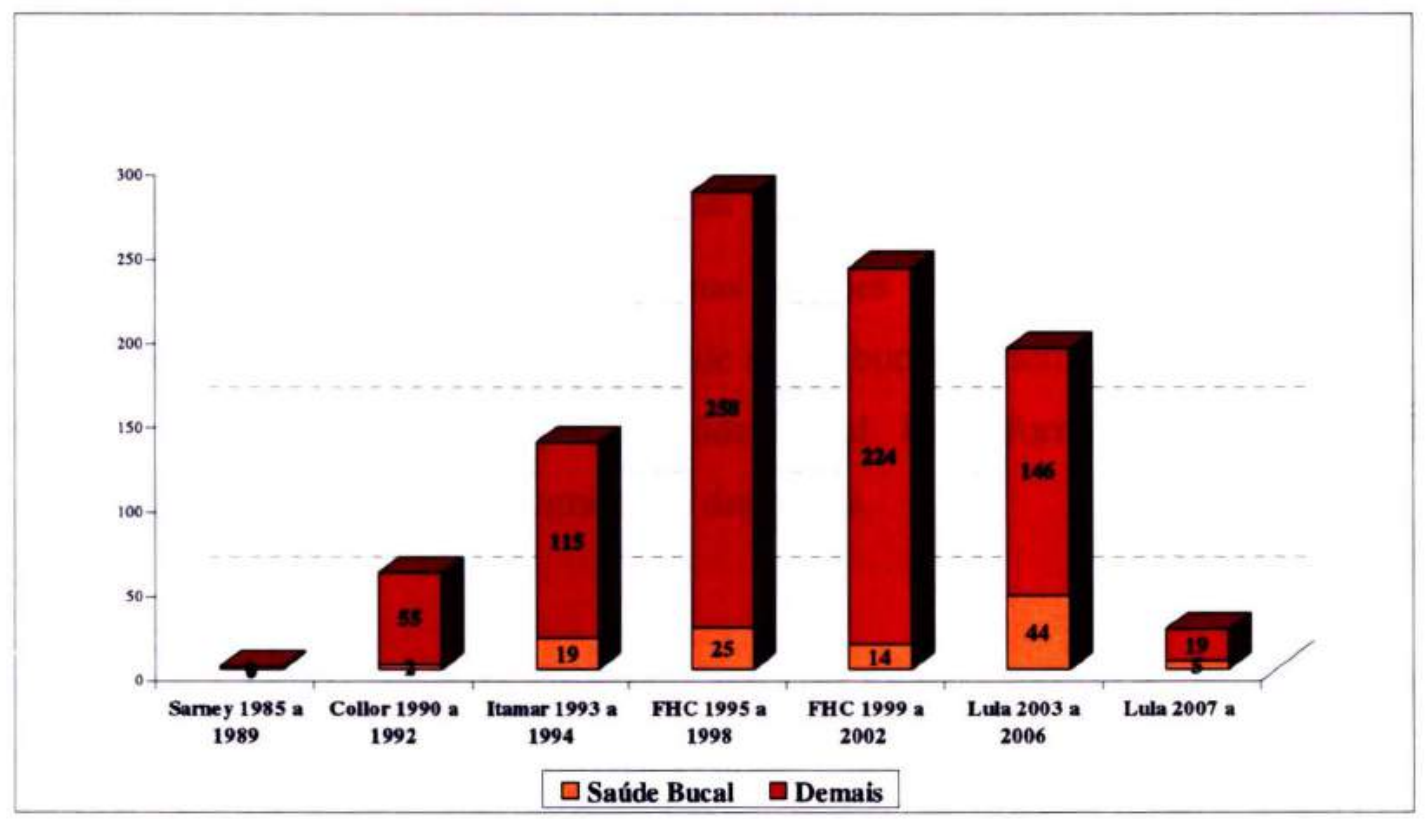

Fonte: CNS - http://www. conselho.saude.gov.br

Após criteriosa leitura das atas selecionadas, verificou-se que a Saúde Bucal era abordada sob vários aspectos numa única reunião. Após a identificação das idéias-centrais sobre as diferentes abordagens, a amostra total desse estudo ficou definida em 180 abordagens sobre Saúde Bucal classificadas nos seguintes eixos temáticos:

\section{Gestão e Organização do Sistema e da Atenção à Saúde Bucal}

a) Regulamentação do sistema e da assistência/atenção à Saúde Bucal: comissões para discussão de normas operacionais com alguma abordagem específica sobre Saúde Bucal; indicadores epidemiológicos, estratégias para o controle e avaliação da atenção à saúde bucal, normas para credenciamento de serviços, planos nacionais de saúde ou plurianuais, projetos de lei, assessorias/consultorias/comissões orientações técnicas específicas para a organização da atenção, pactuações; b) Organização da Estrutura: alterações da estrutura do Ministério da Saúde, relacionadas à área técnica de Saúde Bucal; c) Regulamentações de Rotinas: organização dos fluxos e práticas gerenciais; d) Licitações: licitações de materiais. 


\section{Financiamento}

a) Transferência de Recursos: incentivos com recursos específicos para programas, campanhas e ações verticais; b) Tabelas e Procedimentos: inclusão e revisão de procedimentos e valores para remuneração de prestadores de serviços; c) Orçamento: controle execução orçamentária, propostas orçamentárias.

\section{Programas e ações verticais em saúde bucal}

a) Instituição de novos planos, programas e ações de saúde bucal: instituição de novos programas e integração das ações de saúde bucal às demais políticas setoriais, planos e projetos para a atenção à Saúde Bucal; b) Reformulação e criação de mecanismos de controle dos programas e das ações.

\section{$\underline{\text { Outras }}$}

a) trabalho e educação: ensino superior, recursos humanos no SUS, pesquisas com equipamentos médico-odontológicos; b) controle social: conferências, representações, convites c) datas comemorativas, d) s/classificação: 'termalismo'.

As Figuras 15 e 16 apresentam os eixos-temáticos segundo os períodos dos Governos pós-1985 e por ano. 
Figura 15 - Número de abordagens sobre Saúde Bucal nos documentos selecionados do CNS, segundo os eixos-temáticos e os períodos dos Governos pós-1985 - Brasil 1988 a julho de 2007.

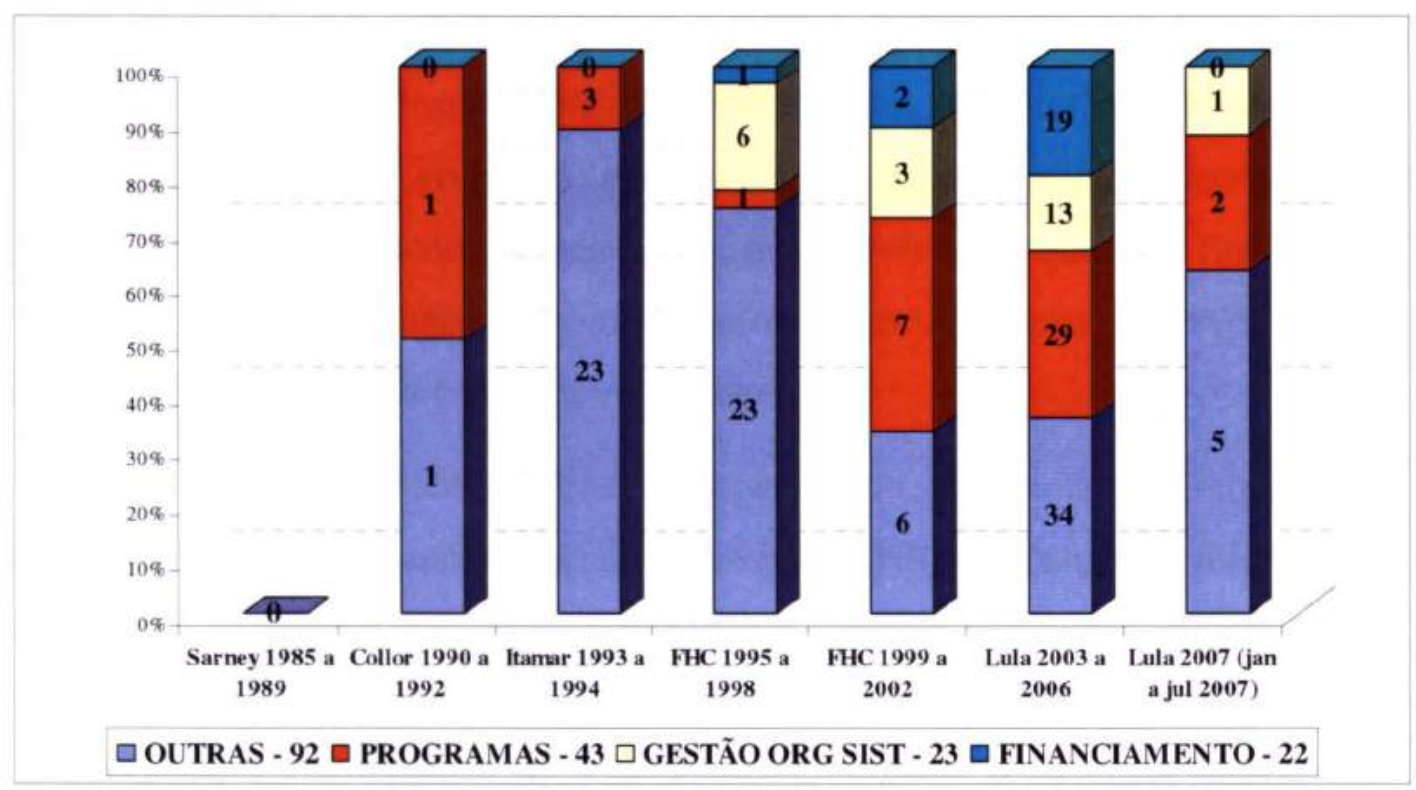

Fonte: elaborado a partir dos dados do CNS - http://www. conselho.saude.gov.br

Figura 16 - Número de abordagens sobre Saúde Bucal nos documentos selecionados do CNS, segundo eixos-temáticos e ano - Brasil - 1988 a julho de 2007.

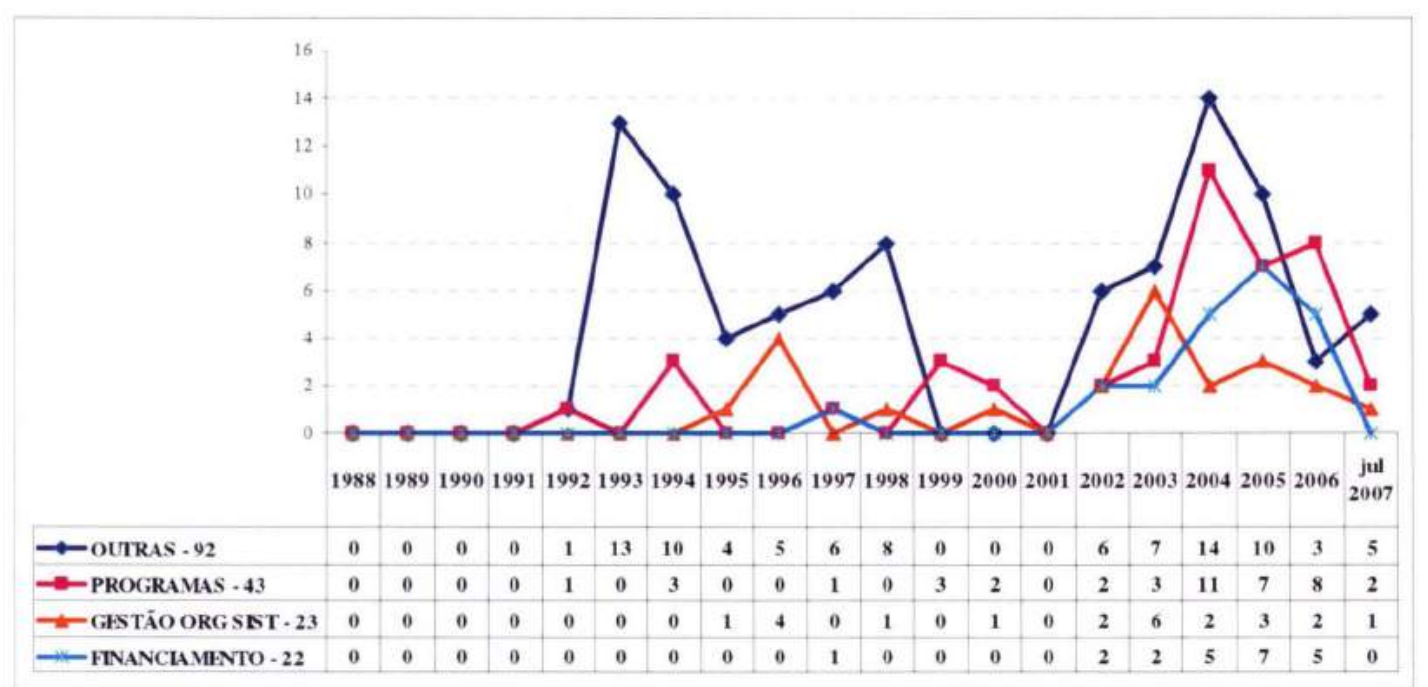

Fonte: elaborado a partir dos dados do CNS - http://www. conselho.saude.gov.br

No eixo-temático Outras, o enfoque se dá sobre o Ensino

Superior, particularmente, sobre a indefinição do papel do CNS no processo de 
autorização para abertura de novos cursos de odontologia, além da falta de clareza dos critérios para a emissão de pareceres. Em várias atas analisadas, observa-se que, apesar dos indeferimentos do CNS para a abertura de novos cursos, os mesmos assuntos retornam à Pauta seguinte para reconsideração dos indeferimentos.

Desde 1997, os trabalhos da Comissão Interministerial MEC/MS e dos diversos grupos de trabalho criados pelo CNS para a definição de tais critérios, não vem sendo suficientes para resolver essa questão. Em 2004, a Plenária do CNS decide não emitir mais pareceres, retomando-os em 2005, após os encaminhamentos propostos pelo Governo Federal.

Além do Ensino Superior, no eixo-temático Outras foram identificadas ações de Controle Social inerentes ao CNS, com assuntos referentes às conferências, representações, comissões e grupos técnicos instituídos. Relativamente à Saúde Bucal, destacam-se as Conferências de Saúde Bucal e a necessidade de se criar um Grupo Técnico para analisar as demandas específicas da Saúde Bucal.

Figura 17 - Número de abordagens sobre Saúde Bucal nos documentos selecionados do CNS, segundo eixo-temático Outras - Brasil - 1988 a julho de 2007.

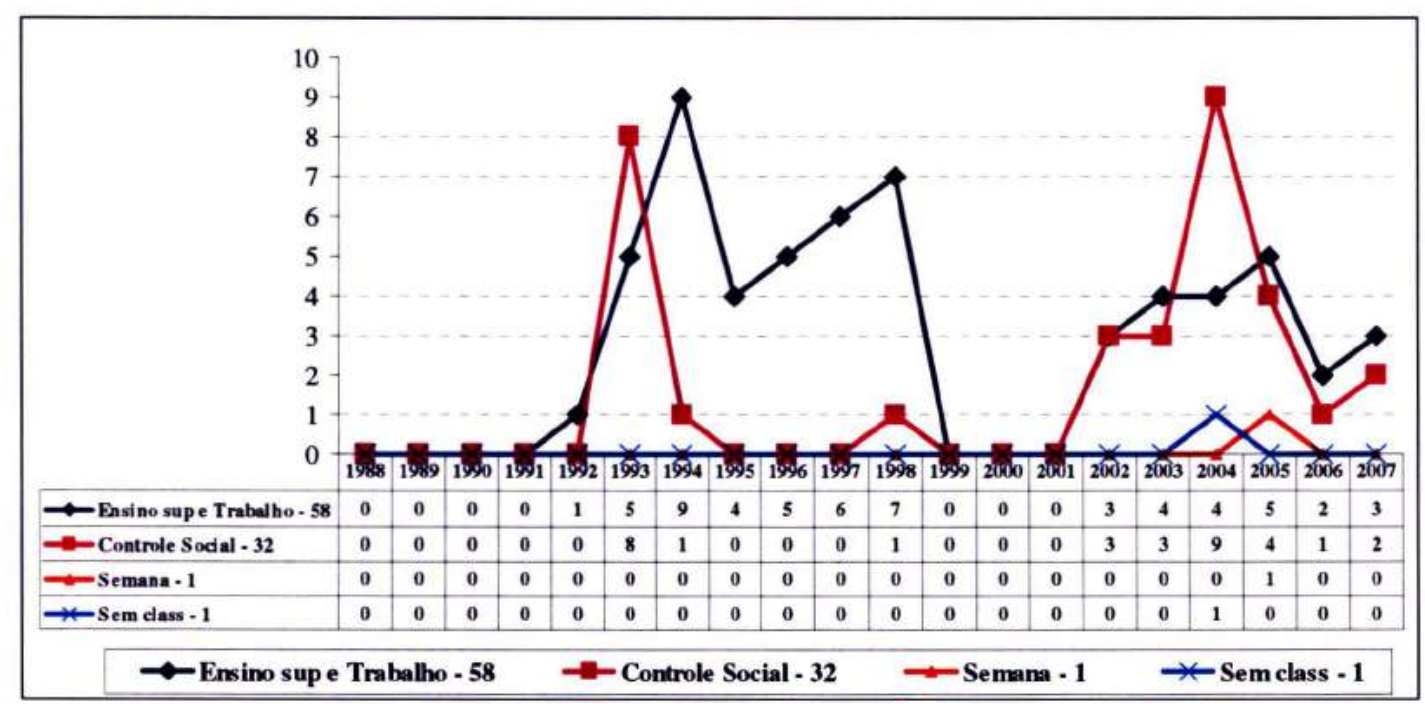

Fonte: elaborado a partir dos dados do CNS - http://www. conselho.saude.gov.br

Relativamente aos Programas e Ações de Saúde Bucal, destacam-se as abordagens e as demandas relativas à Inserção das ações de Saúde 
Bucal em diversas políticas setoriais. As primeiras abordagens foram identificadas em 1999, com o Programa do Agente Comunitário de Saúde - ACS e com a necessidade de atenção odontológica aos portadores de deficiências. Posteriormente, essa necessidade de integração vem sendo apontada junto a outras políticas públicas setoriais: PSF, saúde no sistema prisional, inserção das ações em hospitais de pequeno porte, política nacional do idoso, hanseníase, medicina natural e práticas complementares, programa nacional de atenção básica, atenção à saúde dos povos indígenas, atenção oncológica e atenção integral a jovens e adolescentes.

Com a Política Nacional de Saúde Bucal - Brasil "Sorridente" implementada pelo Governo Federal, desde 2004, o CNS vem insistindo na necessidade de se desenvolverem estratégias para controlar e avaliar o impacto dessa política sobre a saúde bucal da população, em função do montante recursos financeiros aplicados nessa Política.

Figura 18 - Número de abordagens sobre Saúde Bucal nos documentos selecionados do CNS - inserção Programas e Ações - Brasil - 1988 a julho de 2007.

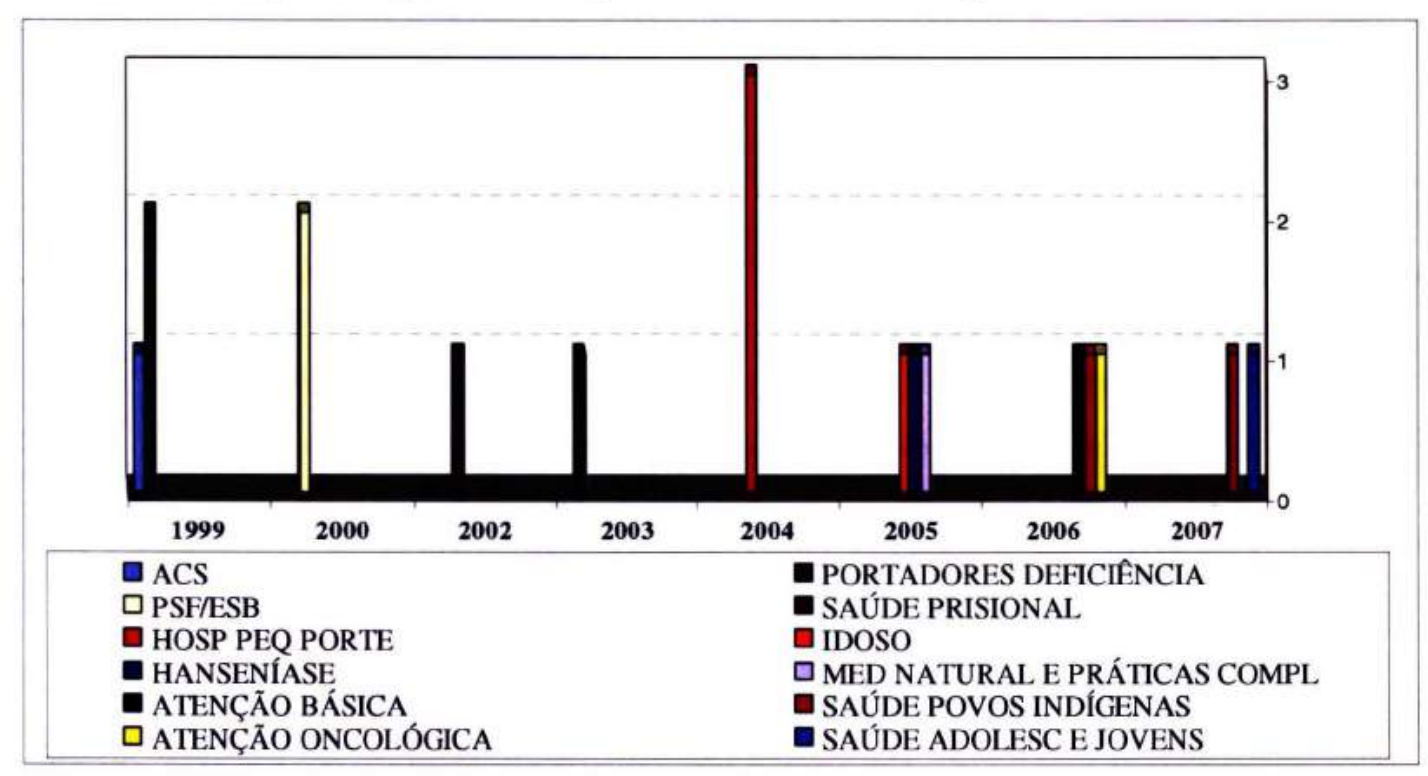

Fonte: elaborado a partir dos dados do CNS - http://www. conselho.saude.gov.br

No eixo-temático Financiamento, o Orçamento vem sendo um item de discussão permanente no CNS, no que tange à discussão das propostas 
orçamentárias, às fontes de financiamento do SUS, ao controle trimestral da execução orçamentária das rubricas de Saúde Bucal, à necessidade de compatibilidade entre o Plano Plurianual / Plano Nacional de Saúde / Orçamentos anuais e à necessidade de se melhorar a forma de apresentação do Orçamento aos Conselheiros.

Relativamente ao tema Tabelas e Procedimentos destaca-se a discussão sobre a alteração do valor dos incentivos financeiros para as ESB/PSF proposta pelo Governo Federal, como estratégia de expansão do PSF. Esse assunto foi pauta do CNS durante os anos de 2004 e 2005.

Figura 19 - Número de abordagens sobre Saúde Bucal nos documentos selecionados do CNS - eixo-temático Financiamento - Brasil - 1988 a julho de 2007.

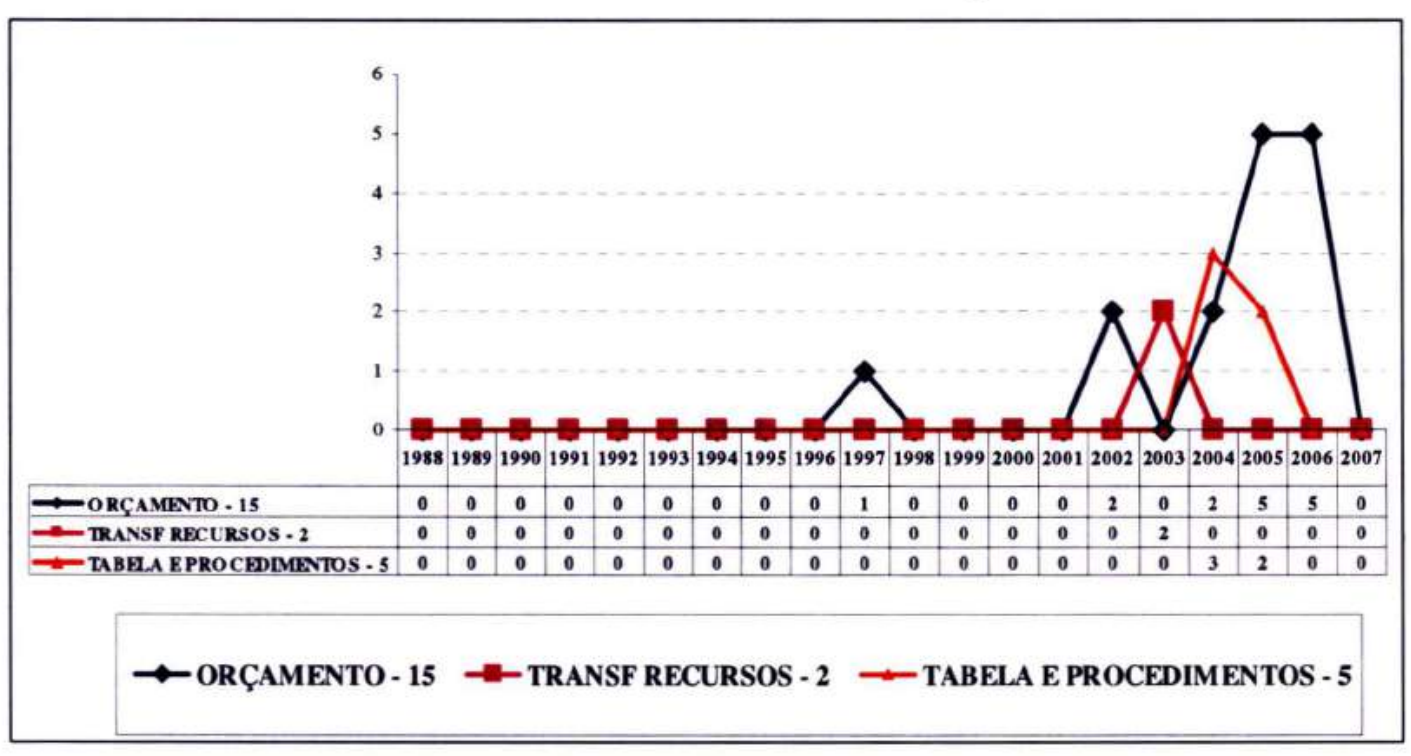

Fonte: elaborado a partir dos dados do CNS - http://www. conselho.saude.gov.br

No eixo-temático Gestão e Organização do Sistema e da Atenção à Saúde Bucal, as primeiras referências sobre o tema Regulamentação do Sistema são do período de 1995 a 1997, tendo em vista os trabalhos da Comissão NOB 96 que discutiria o rol de procedimentos odontológicos do PAB per capita. A partir disso, o tema reaparece em 2003, em função da necessidade de se finalizar o 
Levantamento Epidemiológico 2003 para o estabelecimento de parâmetros e indicadores que subsidiariam um Plano Nacional de Saúde Bucal.

Em 1996, a Regulamentação da Saúde Suplementar insere-se na pauta do CNS, pela discussão da regulação normativa que estabelece a obrigatoriedade do registro das operadoras nos Conselhos Profissionais. Além disso, discute-se a oferta das especialidades odontológicas nos planos e os contratos e serem estabelecidos entre as operadoras e prestadores. A partir de 2004, as discussões se tornam mais estratégicas e abrangentes, permeando a política regulatória da ANS e o aporte de recursos públicos para a Saúde Suplementar.

Figura 20 - Número de abordagens sobre Saúde Bucal nos documentos selecionados do CNS - eixo-temático Gestão - Brasil - 1988 a julho de 2007.

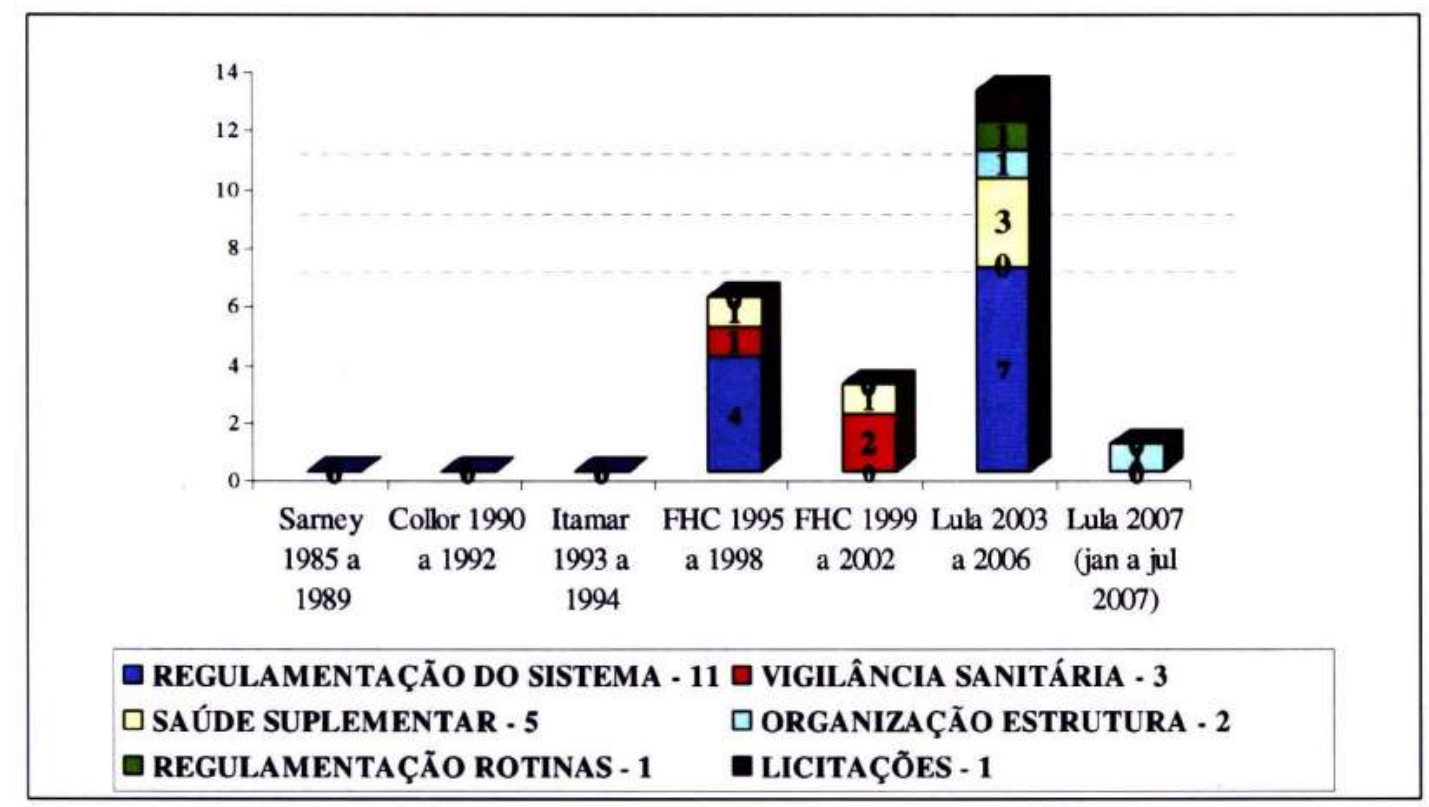

Fonte: elaborado a partir dos dados do CNS - http://www. conselho.saude.gov.br

Relativamente às ações de vigilância sanitária, numa reunião realizada em 1996, discutiu-se a necessidade de controle sobre a venda de produtos fluorados em áreas com água fluoretada, considerando-se urgente que o poder público tomasse providências no sentido de proibir a comercialização desses produtos em áreas com água fluoretada. Entre 1999 e 2002, as discussões sobre as ações de vigilância assumem caráter de regulamentação normativa, ao tratar de 
normas para o desenvolvimento e a comercialização de equipamentos odontológicos no âmbito do MERCOSUL.

Em termos de Regulamentação de Rotinas, encontrado um único registro em 2005, em que o CNS aprova as normas e os requisitos para a implantação do CEO/LRPD. No tema Licitações, o CNS vem se ocupando dos problemas ocorridos com a licitação dos kits de Saúde Bucal que não puderam ser adquiridos pelo MS.

Figura 21 - Número de abordagens sobre Saúde Bucal nos documentos selecionados do CNS - Assuntos - Brasil - 1988 a julho de 2007.
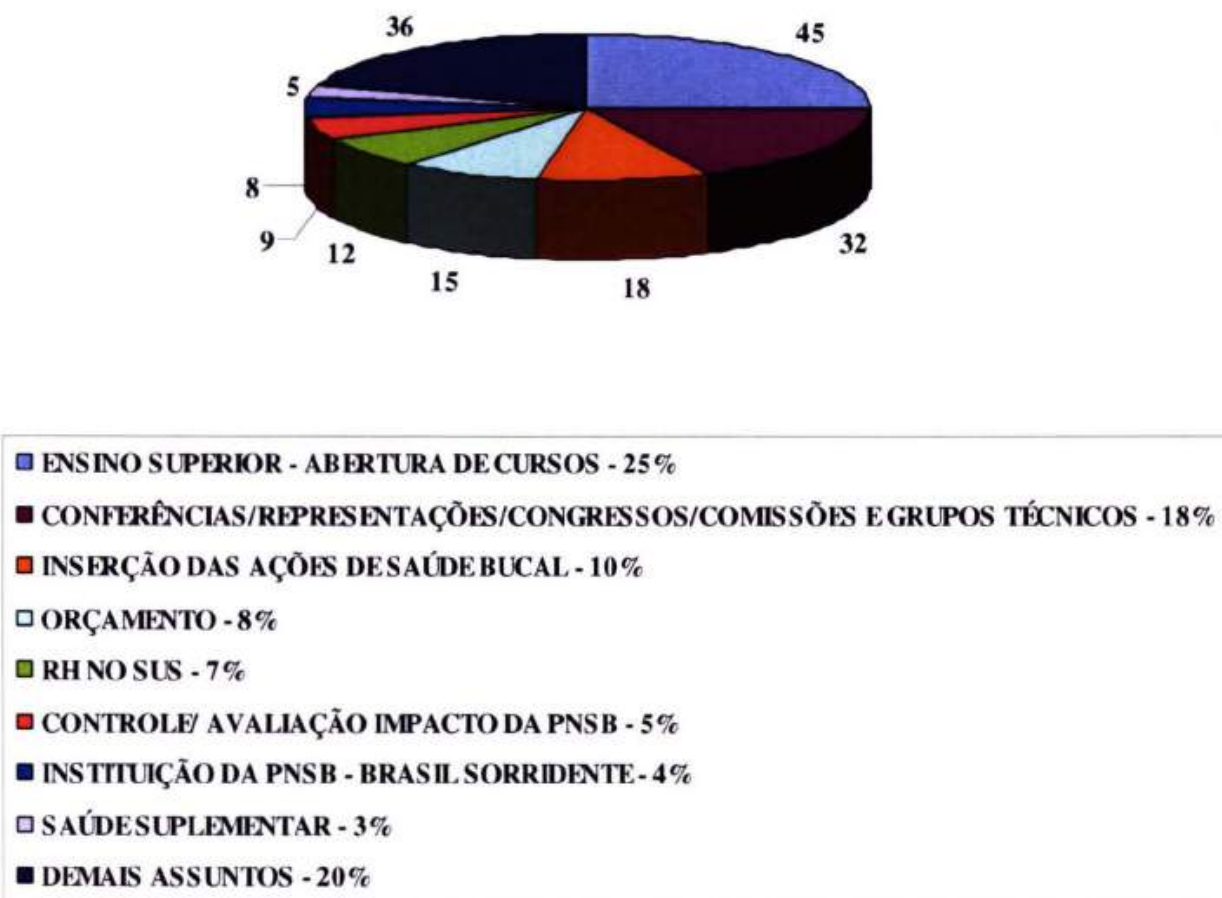

Fonte: elaborado a partir dos dados do CNS - http://www. conselho.saude.gov.br

Em linhas gerais, observa-se que as abordagens identificadas nos documentos do CNS abrangem vários aspectos da regulação da atenção à Saúde Bucal. Em especial a necessidade das ações serem inseridas nas demais políticas 
setoriais, as questões orçamentárias e a necessidade de serem instituídos mecanismos de controle e de avaliação do impacto sobre os indicadores de saúde da população. 


\section{DISCUSSÃO}

A maior parte das regulamentações foi editada após 1988, assumindo destaque na condução da política de saúde bucal, sendo originadas em sua maioria do Gabinete do Ministro.

Entre 1946 e 1988, no eixo temático Regulamentação do Sistema, foram encontradas regulamentações relativas à contratação de assessorias e consultorias para o setor de Saúde Bucal, para a elaboração de projetos específicos e para a elaboração de propostas de uma política para o setor. Nesse eixo temático, encontraram-se normas relativas ao padrão de equipamentos e embalagens e uma norma referente à proteção radiológica.

$\mathrm{Na}$ Organização da Estrutura foram identificadas duas regulamentações, uma referente ao Serviço Nacional de Fiscalização Odontológica e uma ao Departamento Nacional de Saúde Bucal do Serviço Nacional de Programas Especiais.

Dentre os Programas e Ações foram identificadas duas regulamentações referentes à fluoretação das águas de abastecimento público, sendo uma de 1968 e outra de 1975.

O eixo-temático Financiamento não apresentou nenhuma regulamentação no período. No eixo-temático Outros, foram identificadas sete regulamentações sobre o setor/atividade Exercício Profissional, sete regulamentações sobre o Trabalho e Ensino, referindo-se, basicamente, a cursos técnicos, especializações odontológicas, estágios no MS e evento.

Frente às normas selecionadas, pode-se afirmar que, no período, o setor Saúde Federal representado pelo Ministério da Saúde e pelo Ministério dos Negócios da Educação e da Saúde, praticamente, não regulamentaram a Gestão sobre a atenção à Saúde Bucal, com exceção de duas regulamentações relativas à fluoretação, duas alterações organizacionais do MS e três contratações de assessoria/consultoria para a Saúde Bucal, totalizando sete regulamentações entre 1946 e 1988.

Entre 1989 e julho de 2007, vários fatores alteram essa situação. Com a criação e regulamentação do SUS, a Lei Orgânica da Saúde e a 
edição das seis Normas Operacionais as portarias terminam por definir instruções para a execução das leis, decretos, conforme afirmam ZANETTI 2005 e BAPTISTA (2007). O Artigo 87 da Constituição Federal prevê esse ordenamento.

Nesse período, com a regulamentação da Saúde Suplementar e do Sistema Nacional de Vigilância Sanitária, além da mudança das atribuições e do papel do Conselho Nacional de Saúde que passa a ter caráter deliberativo, as regulamentações assumiram importantes instrumentos em termos de Regulação.

As portarias de Financiamento adquirem importância na condução e na indução das políticas públicas de saúde. Na Saúde Bucal, essas portarias passam a determinar a expansão de programas como o ESB/PSF e a implantação e expansão de unidades de assistência CEO/LRPD. Em resumo, as portarias de Financiamento tornam-se instrumentos de regulação prioritários do MS (BAPTISTA 2003; ZANETTI 2005).

BAPTISTA (2003) analisou toda a produção normativa do Ministério da Saúde entre os anos de 1990 e 2001, encontrando uma relação de 939 portarias de transferência de recursos/4.555 total de portarias $=20,61 \%$.

BAPTISTA (2007) analisou o aumento do quantitativo de portarias de financiamento para toda a Saúde, atribuindo essa variação às regras emanadas das Normas Operacionais. "Em 1991 e 1992, ocorreram mudanças nos valores das tabelas de procedimentos, associadas ao pagamento por produção, conforme regras propostas pela NOB 91. Em 1993 e 1994, as tabelas de procedimentos e as regras de transferências são resultados da edição da NOB 93, com estabelecimento de tetos e incentivos financeiros. A partir de 1999, como resultado da reorganização da política proposta na NOB/96, reformulada a partir de 1998 (definição de tetos e incentivos financeiros), e da política de incentivo a programas e ações estratégicas (FAEC e novos programas)" (p.622).

Relativamente ao tema Tabelas e Procedimentos, entre 1989 e 2002, a atenção de média e alta complexidade ambulatorial e hospitalar dirigida ao tratamento dos portadores de lesões lábio-palatais, tiveram a prioridade, sobretudo pela remuneração via FAEC. Tal fato pode explicar o crescimento identificado na produção ambulatorial SAI/SUS, entre os anos de 2001 e 2006 (Quadro I). 
A partir de 2003, a política de incentivos estabelecida passa a priorizar a atenção básica, através do PSF. A partir de 2004, as especialidades odontológicas passam a se constituir como prioridade em termos de Tabelas de procedimentos.

No tema Transferências de Recursos, destaque ao quantitativo de portarias relativas à atenção básica ESB/PSF, a partir de 2001, e às especialidades odontológicas CEO, a partir de 2004.

Em segundo lugar aparecem as regulamentações de Gestão e organização do sistema e da assistência, com enfoque sobre o quantitativo de regulamentações sobre a Saúde Suplementar e a Vigilância Sanitária, setores importantes, porém não diretamente relacionados à Gestão assistência, ações e serviços de Saúde Bucal.

Em terceiro, os Programas e Ações passam a enfocar a inserção das ações de Saúde Bucal junto às demais políticas setoriais, fato também constatado nos documentos do CNS, nos são abordagens semelhantes.

Observa-se a evolução quantitativa e qualitativa nas abordagens do CNS sobre Saúde Bucal, muito embora uma grande parte dos assuntos seja originada dos próprios representantes do Ministério da Saúde para a efetivação de suas prioridades de Governo. Um grande problema do CNS se refere à regulamentação sobre a abertura de faculdades de odontologia, no que tange aos critérios para emissão de pareceres, bem como no papel a ser desempenhado pelo CNS em todo o processo.

Em termos de Regulação, o CNS vem se empenhando em exigir mecanismos de controle sobre os impactos das ações do Programa "Brasil Sorridente", tendo em vista o montante de recursos que vêm sendo aplicados no Programa. Da mesma forma, as discussões sobre os incentivos das ESB/PSF passaram a ser motivo de preocupação para vários conselheiros. 


\section{REFERÊNCIAS}

Adão MAA. Ética, liberdade, legalidade e legitimidade. Jus Navigandi [texto na internet]. 1999 [acesso em 25 abril 2007]; 37:1-4. Disponível em: http://jus2.uol.com.be/doutrina/texto.asp?id=19

Almeida ES de, Chioro A, Zioni F. Políticas públicas e organização do sistema de saúde: antecedentes, reforma sanitária e o SUS. Estado, políticas públicas e saúde: a história dos serviços de saúde no Brasil e o sentido político do SUS. In: Almeida ES de, Westphal MF, organizadores. Gestão de serviços de saúde: descentralização / municipalização do SUS. São Paulo: EDUSP; 2001.p.13-50.

Agência Nacional de Saúde Suplementar. Qualificação as saúde suplementar: nova perspectiva no processo de regulação [relatório on line]. 2006 [acesso nov 2006]. Rio de Janeiro. Disponível em http://ans.br/portal/site/ qualificacao/pdf/texto base.pdf

Baptista TWFB. Políticas de saúde no pós-constituinte: um estudo da política implementada a partir da produção normativa dos poderes executivo e legislativo no Brasil [tese de doutorado]. Rio de Janeiro: Instituto de Medicina Social da UERJ; 2003.

Baptista TWFB. Análise das portarias ministeriais da saúde e reflexões sobre a condução nacional da política de saúde. Cad Saúde Pública. 2007; 23 (3): 615-26.

Bobbio N. A era dos direitos. 13 ${ }^{\mathrm{a}}$ tiragem. Rio de Janeiro: Campus; 1992.

Boyer R. A teoria da regulação: uma análise crítica. São Paulo: Nobel; 1990.

Carvalho EB. A regulamentação dos planos e seguros privados de assistência à saúde no Brasil: a reconstrução de uma história de disputas. Campinas; 2003. [Dissertação de Mestrado - Faculdade de Ciências Médicas da UNICAMP].

Carvalho GCM. O financiamento público federal do Sistema Único de Saúde - 1988 a 2001. São Paulo; 2002. [Tese de Doutorado - FSP/USP].

Carvalho GCM. Pactos do SUS 2005: comentários preliminares [artigo on line] 2005. Disponível em URL:http://www.idisa.org.br/site/paginas/vizualiza contendo.php [2006 Dez 19].

Castro JD. Regulação em saúde: análise de conceitos fundamentais. Sociologias 2002; 7: 122-35.

Chaves M. Odontologia social. 3ª edição: São Paulo; Artes Médicas; 1986. 
Conselho Nacional de Saúde. $3^{a}$ Conferência Nacional de Saúde Bucal [relatório on line]. Brasília,DF; 2005. 148p. (Série D. Reuniões e Conferências) Disponível em http://www.cns.gov.br

Costa RCR. Descentralização, financiamento e regulação: a reforma do sistema público no Brasil durante a década de 1990. Rev Soc Política [periódico on line] 2002 [acesso em 10 abr 2007]; 18; 49-71. Disponível em http://www.scielo.br

Cunha PCM. A regulação jurídica da saúde suplementar no Brasil. Rio de Janeiro: Lúmen Júris; 2003. (Coleção Direito Regulatório).

Dallari DA. Elementos de teoria geral do Estado. $25^{\mathbf{a}}$ edição. São Paulo: Saraiva; 2005.

Freitas SM. Os direitos humanos e a evolução do ordenamento jurídico brasileiro. Site do Curso de Direito da UFSM [artigo na internet]. 2007 [acesso em 27 de abril 2007]. Disponível em: http://www.ufsm.br/direito/artigos/constitucional/direitosevolução.htm

Heimann LS, Pessoto UC, Ibanhes LC, Castro IEN, Kayano J, Junqueira V et al. Desafios para a equidade em saúde na região metropolitana de São Paulo. In: Heimann LS, Ibanhes LC, Barboza R, organizadores. O público e o privado na saúde. São Paulo: Hucitec/OPAS/IDRC; 2005. p.169-242.

Malta DC, Cecílio LCO, Merhy EL, Franco TB, Jorge AO, Costa MA. Perspectivas da regulação na saúde suplementar diante dos modelos assistenciais. Ciênc Saúde Coletiva 2004; 9(2); 433-44.

Medeiros M. A trajetória do welfare state no Brasil: o papel redistributivo das políticas sociais dos anos 1930 aos anos 1990 [texto para discussão $n^{\circ} 852$ online IPEA/Ministério do Planejamento, Orçamento e Gestão] 2001. Disponível em http://www.ipea.gov.br/pub/td/td 2001/td 0852.pdf [2005 out 16].

Mezzomo MC. O direito à saúde em juízo. Jus Navigandi [texto científico em periódico eletrônico]. 2006 [acesso em 18 setembro 2007]; 944. Disponível em: http://jus2uol.com.br/doutrina/texto.asp?id=7894

Ministério da Saúde. Portaria $\mathrm{n}^{\circ} 373$, de 27 de fevereiro de 2002. Aprova a Norma Operacional da Assistência à Saúde - NOAS -SUS 01/2002. Diário Oficial da República Federativa do Brasil, Brasília, 28 fev 2002, v.89, n 40E, p.52.

Ministério da Saúde. Secretaria de Atenção à Saúde. Departamento de Atenção Básica. Coordenação Nacional de Saúde Bucal. Saúde Bucal. Brasília: Ministério da Saúde; 2006 a. (Cadernos de Atenção Básica, nº 17 - Série A. Normas e Manuais Técnicos).

Ministério da Saúde. Secretaria de Atenção à Saúde. Departamento de Atenção Básica. Política nacional de atenção básica. Brasília: Ministério da Saúde; 2006 b. 
(Série A. Normas e Manuais Técnicos, v.4).

Ministério de Saúde. Secretaria de Atenção à Saúde. Departamento de Atenção Básica. Projeto SB Brasil 2003: condições de saúde bucal da população brasileira 2002-2003. Resultados principais. Brasília: Ministério da Saúde; 2004. (Série C. Projetos, Programas e Relatórios). Disponível em http://www.saude.gov.br/dab/saudebucal/vigilancia.php [2006 dez 14].

Ministério da Saúde. Secretaria Executiva. Departamento de Apoio à Descentralização. Coordenação-Geral de Apoio à Gestão Descentralizada. Diretrizes operacionais dos Pactos pela Vida, em Defesa do SUS e de Gestão. Brasília: Ministério da Saúde; 2006 c. (Série A. Normas e Manuais Técnicos, v.1).

Montone J. Evolução e desafios da regulação do setor de saúde suplementar. In: Regulação \& Saúde: documentos técnicos de apoio ao Fórum de Saúde Suplementar de 2003; (3)1, 2003 jun/nov; Rio de Janeiro, Brasil. Rio de Janeiro: Ministério da Saúde; 2004, p.9-47.

Narvai PC. Integralidade na atenção básica à saúde. Integralidade? Atenção? Básica? In: Garcia DV (org). Novos rumos da saúde bucal: os caminhos da integralidade. Rio de Janeiro:ABORJ/ANS/UNESCO: 2005. p. 28-42.

Narvai PC. Saúde bucal coletiva: caminhos da odontologia sanitária à bucalidade. Rev Saúde Pública 2006:40 (N Esp): 141-7.

Paim JS. O pensamento do movimento sanitário: impasses e contradições atuais no marco da regulação público-privado no SUS. In: Heimann LS, Ibanhes LC, Barboza $\mathrm{R}$, organizadores. O público e o privado na saúde. São Paulo: Hucitec/OPAS/IDRC; 2005. p. 111-26.

Pinto VG. Saúde bucal coletiva. $4^{\mathrm{a}}$ edição. São Paulo: Saraiva; 2000.

Scheffer M, Bahia L. Planos e seguros privados de saúde no Brasil: lacunas e perspectivas da regulamentação. In: Heimann LS, Ibanhes LC, Barboza R, organizadores. O público e o privado na saúde. São Paulo: Hucitec/OPAS/IDRC; 2005. p. 127-68.

Schilling C, Reis AT, Moraes JC (Org). A política de regulação do Brasil. Brasília, DF: OPAS; 2006. (OPAS - Série Técnica Desenvolvimento de Sistemas e Serviços de Saúde, 12).

Zanetti CHG. A utilidade como função para a universalidade e equidade: uma análise formal da validade instrumental do ordenamento administrativo federal as assistência à saúde bucal no saúde da família. [tese de doutorado]. Rio de Janeiro: Escola Nacional de Saúde Pública Sérgio Arouca da FIOCRUZ; 2005. 
PARTE III

REFERÊNCIAS E ANEXOS 


\section{REFERÊNCIAS}

Adão MAA. Ética, liberdade, legalidade e legitimidade. Jus Navigandi [texto na internet]. 1999 [acesso em 25 abril 2007]; 37:1-4. Disponível em: http://jus2.uol.com.be/doutrina/texto.asp?id=19

Almeida ES de, Chioro A, Zioni F. Políticas públicas e organização do sistema de saúde: antecedentes, reforma sanitária e o SUS. Estado, políticas públicas e saúde: a história dos serviços de saúde no Brasil e o sentido político do SUS. In: Almeida ES de, Westphal MF, organizadores. Gestão de serviços de saúde: descentralização / municipalização do SUS. São Paulo: EDUSP; 2001.p.13-50.

Agência Nacional de Saúde Suplementar. Qualificação as saúde suplementar: nova perspectiva no processo de regulação [relatório on line]. 2006 [acesso nov 2006]. Rio de Janeiro. Disponível em http://ans.br/portal/site/ qualificacao/pdf/texto base.pdf

Agência Nacional de Saúde Suplementar. Planos odontológicos: uma abordagem econômica no contexto regulatório. Rio de Janeiro; 2002. (ANS - Série Regulação \& Saúde, v.2)

Baptista TWFB. Políticas de saúde no pós-constituinte: um estudo da política implementada a partir da produção normativa dos poderes executivo e legislativo no Brasil [tese de doutorado]. Rio de Janeiro: Instituto de Medicina Social da UERJ; 2003.

Baptista TWFB. Análise das portarias ministeriais da saúde e reflexões sobre a condução nacional da política de saúde. Cad Saúde Pública. 2007; 23 (3): 615-26.

Bardin L. Análise de conteúdo. 3a edição. Lisboa: Edições 70; 2004.

Beneton MAH. A racionalidade na teoria e prática jurídica enfocando a sociologia política e os tipos de dominação legítima em Max Weber. Rev Informação Legislativa [periódico na internet] 2001 [acesso em 15 de 2007]; 38(152). Disponível em http://senado.gov.br/web/cegraf/ril/Pdf/pdf 152/r 152-05.pdf

Bobbio N. A era dos direitos. 13a tiragem. Rio de Janeiro: Campus; 1992.

Boyer R. A teoria da regulação: uma análise crítica. São Paulo: Nobel; 1990.

Botazzo C. Sobre a bucalidade: notas para a pesquisa e contribuição ao debate. Ciênc Saúde Coletiva. 2006;11: 7-17. 
Braga R. A nostalgia do fordismo: modernização e crise na teoria da sociedade salarial. São Paulo: Xamã; 2003. [Resenha de G Druck]. A teoria da regulação transforma-se em "técnica de regulação" em tempos neoliberais? Rev Bras Ciênc Soc 2005; 38(57): 180-5].

Brasil. Constituição (1988). Constituição da República Federativa do Brasil. Brasília, DF: Senado; 1988.

Brasil. Decreto $n^{\circ} .5 .974$, de 29 de novembro de 2006. Aprova a estrutura regimental e o quadro demonstrativo dos cargos em comissão e das funções gratificadas do Ministério da Saúde, e dá outras providências. Diário Oficial da República Federativa do Brasil, Brasília, 30 nov 2006. Seção I, p.8.

Campos GWS. O público, o estatal e o particular nas políticas públicas de saúde. In: Heimann LS, Ibanhes LC, Barboza R, organizadores. O público e o privado na saúde. São Paulo: Hucitec/OPAS/IDRC; 2005.p.89-100.

Carvalho EB. A regulamentação dos planos e seguros privados de assistência à saúde no Brasil: a reconstrução de uma história de disputas. Campinas; 2003. [Dissertação de Mestrado - Faculdade de Ciências Médicas da UNICAMP].

Carvalho GCM. O financiamento público federal do Sistema Único de Saúde - 1988 a 2001. São Paulo; 2002. [Tese de Doutorado - FSP/USP].

Carvalho GCM. Pactos do SUS 2005: comentários preliminares [artigo on line] $2005 . \quad$ Disponível em URL:http://www.idisa.org.br/site/paginas/vizualiza contendo.php [2006 Dez 19].

Castro JD. Regulação em saúde: análise de conceitos fundamentais. Sociologias 2002; 7 : 122-35.

Chaves M. Odontologia social. 3ª edição: São Paulo; Artes Médicas; 1986.

Cohn A. As políticas sociais no governo FHC. Tempo Social. 2000; 11:183-98.

Conselho Nacional de Saúde. Relatório Final da $1^{\text {a }}$ Conferência Nacional de Saúde Bucal [relatório on line]. Brasília, DF; 1986a . Disponível em http://www.cns.gov.br

Conselho Nacional de Saúde. Relatório Final da $2^{\star a}$ Conferência Nacional de Saúde Bucal [relatório on line]. Brasília, DF; 1993a. Disponível em http://www.cns.gov.br

Conselho Nacional de Saúde. $3^{\mathrm{a}}$ Conferência Nacional de Saúde Bucal [relatório on line]. Brasília,DF; 2005. 148p. (Série D. Reuniões e Conferências) Disponível em http://www.cns.gov.br

Conselho Nacional de Saúde. Relatório Final da $7^{\text {a }}$ Conferência Nacional de Saúde [relatório on line]. Brasília, DF; 1980. Disponível em http://www.cns.gov.br 
Conselho Nacional de Saúde. Relatório Final da $8^{\mathrm{a}}$ Conferência Nacional de Saúde [relatório on line]. Brasília, DF; 1986b. Disponível em http://www.cns.gov.br

Conselho Nacional de Saúde. Relatório Final da $9^{a}$ Conferência Nacional de Saúde [relatório on line]. Brasília, DF; 1993b. Disponível em http://www.cns.gov.br

Conselho Nacional de Saúde. Relatório Final da $11^{\text {a }}$ Conferência Nacional de Saúde [relatório on line]. Brasília: Ministério da Saúde; 2001 (Série Histórica do CNS; $\mathrm{n}^{\circ}$. 2; Série D. Reuniões e Conferências; $\mathrm{n}^{\circ}$. 16). Disponível em http://www.cns.gov.br

Conselho Nacional de Saúde. 12a Conferência Nacional de Saúde: Conferência Sérgio Arouca [relatório on line]. Brasília: Ministério da Saúde; 2004. 230 p. (Série D. Reuniões e Conferências). Disponível em http://www.cns.gov.br

Conselho Nacional de Secretários de Saúde. CONASS 25 anos. Brasília, DF; 2007.

Cordeiro HÁ. As empresas médicas. Rio de Janeiro: Edições Graal; 1984.

Costa RCR. Descentralização, financiamento e regulação: a reforma do sistema público no Brasil durante a década de 1990. Rev Soc Política [periódico on line] 2002 [acesso em 10 abr 2007]; 18; 49-71. Disponível em http://www.scielo.br

Cunha PCM. A regulação jurídica da saúde suplementar no Brasil. Rio de Janeiro: Lúmen Júris; 2003. (Coleção Direito Regulatório).

Dallari DA. Elementos de teoria geral do Estado. $25^{\mathrm{a}}$ edição. São Paulo: Saraiva; 2005.

Freitas SM. Os direitos humanos e a evolução do ordenamento jurídico brasileiro. Site do Curso de Direito da UFSM [artigo na internet]. 2007 [acesso em 27 de abril 2007]. Disponível em: http://www.ufsm.br/direito/artigos/constitucional/direitosevolução.htm

Heimann LS, Pessoto UC, Ibanhes LC, Castro IEN, Kayano J, Junqueira V et al. Desafios para a equidade em saúde na região metropolitana de São Paulo. In: Heimann LS, Ibanhes LC, Barboza R, organizadores. O público e o privado na saúde. São Paulo: Hucitec/OPAS/IDRC; 2005. p.169-242.

Hochman G, Santos PX, Alves FP. História, saúde e recursos humanos: análises e perspectivas. In: Barros AFR, Santana JP, Santos Neto, PM organizadores. Observatório de recursos humanos em saúde no Brasil. Brasília, DF: Ministério da Saúde; 2004. v. 2, p. 37-50. (Série B. Textos Básicos de Saúde).

Lima ALGS, Pinto MMS. Fontes para a história dos 50 anos do Ministério da Saúde. Hist Ciênc Saúde - Manguinhos 2003; 10 (30); 1037-51. 
Malta DC, Cecílio LCO, Merhy EL, Franco TB, Jorge AO, Costa MA. Perspectivas da regulação na saúde suplementar diante dos modelos assistenciais. Ciênc Saúde Coletiva 2004; 9(2); 433-44.

Martins Filho, IG. O ordenamento jurídico brasileiro. Rev Jurídica Virtual [periódico na internet]. 1999 jul. [acesso em 25 setembro 2007]; 2(3). Disponível em: http://www.planalto.gov.br/ccivil 03/revista/Rev 03/ordenamento\%20jur\%20brasil. $\underline{\mathrm{htm}}$

Medeiros M. A trajetória do welfare state no Brasil: o papel redistributivo das políticas sociais dos anos 1930 aos anos 1990 [texto para discussão $\mathrm{n}^{\circ} 852$ online IPEA/Ministério do Planejamento, Orçamento e Gestão] 2001. Disponível em http://www.ipea.gov.br/pub/td/td 2001/td 0852.pdf [2005 out 16].

Melo MA. A política regulatória: responsabilização, credibilidade e delegação. Rev Bras Ciênc Soc 2001; 16 (46): 56-80.

Mezzomo MC. O direito à saúde em juízo. Jus Navigandi [texto científico em periódico eletrônico]. 2006 [acesso em 18 setembro 2007]; 944. Disponível em: http://jus2uol.com.br/doutrina/texto.asp?id=7894

Ministério da Administração e Reforma do Estado. Plano Diretor da Reforma do Estado. Brasília (DF): MARE; 1995. Disponível em http://www.planalto.gov.br/publi 04/COLECAO/TAB.HTM-36k [2006 jan 14].

Ministério da Saúde. Departamento de Regulação, Avaliação e Controle de Sistemas. Departamento Nacional de Auditoria do SUS. Curso básico de regulação, controle, avaliação e auditoria do SUS. Brasília: Ministério da Saúde; 2006 a. (Série A. Norma e Manuais Técnicos).

Ministério da Saúde. Fundação Nacional de Saúde. Programa Brasil Sorridente, a saúde bucal levada a sério - sub-componente fluoretação da água. Cartilha do Gestor. Brasília: Ministério da Saúde; 2006 b. Disponível em <URL:http://www.funasa.gov.br/> [2006 Nov 25].

Ministério da Saúde. Portaria $n^{\circ} 373$, de 27 de fevereiro de 2002. Aprova a Norma Operacional da Assistência à Saúde - NOAS -SUS 01/2002. Diário Oficial da República Federativa do Brasil, Brasília, 28 fev 2002, v.89, nº 40E, p.52.

Ministério da Saúde. Secretaria de Atenção à Saúde. Departamento de Atenção Básica. Coordenação Nacional de Saúde Bucal. Saúde Bucal. Brasília: Ministério da Saúde; 2006 c. (Cadernos de Atenção Básica, nº 17 - Série A. Normas e Manuais Técnicos).

Ministério da Saúde. Secretaria de Atenção à Saúde. Departamento de Atenção Básica. Política nacional de atenção básica. Brasília: Ministério da Saúde; 2006 d. (Série A. Normas e Manuais Técnicos, v.4). 
Ministério de Saúde. Secretaria de Atenção à Saúde. Departamento de Atenção Básica. Projeto SB Brasil 2003: condições de saúde bucal da população brasileira 2002-2003. Resultados principais. Brasília: Ministério da Saúde; 2004. (Série C. Projetos, Programas e Relatórios). Disponível em http://www.saude.gov.br/dab/saudebucal/vigilancia.php [2006 dez 14].

Ministério da Saúde. Secretaria de Atenção à Saúde. Departamento de Regulação, Avaliação e Controle de Sistemas. Diretrizes para a implantação de complexos reguladores. Brasília: Ministério da Saúde; 2006 e. (Série A. Normas e Manuais Técnicos, v.6).

Ministério da Saúde. Secretaria de Atenção à Saúde. Departamento de Regulação, Avaliação e Controle de Sistemas. Diretrizes para a programação, pactuada e integrada da assistência à saúde. Brasília: Ministério da Saúde; 2006 f. (Série B. Textos Básicos de Saúde, v.5).

Ministério da Saúde. Secretaria Executiva. Departamento de Apoio à Descentralização. Coordenação-Geral de Apoio à Gestão Descentralizada. Diretrizes operacionais dos Pactos pela Vida, em Defesa do SUS e de Gestão. Brasília: Ministério da Saúde; 2006 g. (Série A. Normas e Manuais Técnicos, v.1).

Montone J. Evolução e desafios da regulação do setor de saúde suplementar. In: Regulação \& Saúde: documentos técnicos de apoio ao Fórum de Saúde Suplementar de 2003; (3)1, 2003 jun/nov; Rio de Janeiro, Brasil. Rio de Janeiro: Ministério da Saúde; 2004, p.9-47.

Narvai PC. Frazão P. Epidemiologia, política e saúde bucal coletiva. In: Antunes JLF, Perez MA (org). Epidemiologia da saúde bucal. Rio de Janeiro: GuanabaraKoogan; 2006. p.346-62.

Narvai PC. Integralidade na atenção básica à saúde. Integralidade? Atenção? Básica? In: Garcia DV (org). Novos rumos da saúde bucal: os caminhos da integralidade. Rio de Janeiro:ABORJ/ANS/UNESCO: 2005. p. 28-42.

Narvai PC. Saúde bucal coletiva: caminhos da odontologia sanitária à bucalidade. Rev Saúde Pública 2006:40 (N Esp): 141-7.

Narvai PC. Odontologia e saúde bucal coletiva. 2a edição. São Paulo: Santos; 2002.

Paim JS. As AIS: por que não 2 passos atrás? Cad Saúde Pública [periódico on line] 1986. [Acesso em 17 set 2007]; 2: 167-83. Disponível em http://scielo.br.

Paim JS. O pensamento do movimento sanitário: impasses e contradições atuais no marco da regulação público-privado no SUS. In: Heimann LS, Ibanhes LC, Barboza $\mathrm{R}$, organizadores. O público e o privado na saúde. São Paulo: Hucitec/OPAS/IDRC; 2005. p. 111-26. 
Pimentel A. O método da análise documental: seu uso numa pesquisa historiográfica. Cad Pesqui. [periódico na internet]. 2001 [acesso em 17 janeiro 2007]; 114:179-95. Disponível em http://www.scielo.br/scielo.php?script=sci_pdf\&pid=SO100$15742001000300008 \& \operatorname{lng}=\mathrm{pt}$ \$nrm=isotlng=pt

Pinto VG. Saúde bucal coletiva. $4^{a}$ edição. São Paulo: Saraiva; 2000.

Pocol AP, Valentim LSO. Vigilância da qualidade da água para consumo humano. Bolet Epid Paulista [periódico on line] 2004; 9. Disponível em URL:http://www.cve.saude.sp.gov.br/agencia/bepa9 agua.htm [2007 Jul 11].

Salgado VAB. Formatos jurídico-institucionais da administração pública: conceito e características principais [diapositivos]. 2007. Brasília; Ministério o Planejamento, Orçamento e Gestão; [s.d]. 82 diapositivos, color.

Santos BS. A reinvenção solidária e participativa do Estado. In: Anais do Seminário Internacional Sociedade e a Reforma do Estado; 1999; Brasília, BR. SEGES/Ministério do Planejamento. Disponível em http://www.planejamento.gov.br/arquivos_down/seges/publicacoes/reforma/seminari o/Boaventura

Santos BS. O processo de globalização e as ciências sociais. São Paulo: Cortez; 2002. Os processos da globalização; 25-98.

Scheffer M, Bahia L. Planos e seguros privados de saúde no Brasil: lacunas e perspectivas da regulamentação. In: Heimann LS, Ibanhes LC, Barboza R, organizadores. O público e o privado na saúde. São Paulo: Hucitec/OPAS/IDRC; 2005. p. 127-68.

Schilling C, Reis AT, Moraes JC (Org). A política de regulação do Brasil. Brasília, DF: OPAS; 2006. (OPAS - Série Técnica Desenvolvimento de Sistemas e Serviços de Saúde, 12).

Soria ML, Bordin RC, Costa Filho, LC. Remuneração dos serviços de saúde bucal: formas e impactos na assistência. Cad Saúde Pública. 2002; 18(6): 1551-59.

Zanetti CHG. A utilidade como função para a universalidade e equidade: uma análise formal da validade instrumental do ordenamento administrativo federal as assistência à saúde bucal no saúde da família. [tese de doutorado]. Rio de Janeiro: Escola Nacional de Saúde Pública Sérgio Arouca da FIOCRUZ; 2005.

Zavascki TA. Direitos fundamentais de terceira geração. Rev Fac Direito UFRGS. [periódico na internet]. 1998 [acesso em 13 fevereiro 2007]; 15: 227-32. Disponível em

http://bdjur.stj.gov.br/dspace/bitstream/2011/121/1/Direitos fundamentais de terceir a.pdf 
ANEXO A 
Instrumento de coleta de dados

Anexo A

Instituição:

Data do levantamento:

Fonte:

\begin{tabular}{|c|c|c|c|c|c|}
\hline Data & Regra lega/documento & Origem & Assunto & Tema & Eixo temático \\
\hline & & & & & \\
\hline & & & & & \\
\hline & & & & & \\
\hline & & & & & \\
\hline & & & & & \\
\hline & & & & & \\
\hline & & & & & \\
\hline & & & & & \\
\hline & & & & & \\
\hline & & & & & \\
\hline & & & & & \\
\hline & & & & & \\
\hline & & & & & \\
\hline & & & & & \\
\hline
\end{tabular}


ANEXO B 
Quadro 9 - Produção Legislativa selecionada sobre Saúde Bucal segundo a origem e a regra legal - Brasil - 1824 a julho 2007.

Anexo B

\begin{tabular}{|c|c|c|c|c|c|c|c|c|c|c|}
\hline \multirow{3}{*}{ Constituiçōes } & \multirow{3}{*}{ Periodos } & \multicolumn{9}{|c|}{ Origem e regra legal } \\
\hline & & \multicolumn{4}{|c|}{ Legislativo } & \multicolumn{4}{|c|}{ Executivo } & \multirow[b]{2}{*}{ Total } \\
\hline & & Leis & $\begin{array}{c}\text { Decreto } \\
\text { Legislativo/CM }\left({ }^{*}\right)\end{array}$ & $\mathbf{R S F}\left({ }^{* *}\right)$ & Subtotal & Decreto & $\begin{array}{c}\begin{array}{c}\text { Decreto } \\
\text { Lei }\end{array} \\
\end{array}$ & $\begin{array}{c}\text { Medida } \\
\text { Provisória }\end{array}$ & Subtotal & \\
\hline $\begin{array}{l}1^{2} \text { Constituição do Brasil. } \\
\text { Única do Periodo Imperial. } \\
\text { De } 25 / 03 / 1824 \text { a 24/02/1891. }\end{array}$ & $\begin{array}{l}\text { Império e } 1^{\circ} \text { Gov Prov } \\
d_{a} \text { Rep } \\
24 / 02 / 1891\end{array}$ & 1 & 工 & - & 1 & 7 & - & - & 7 & 8 \\
\hline \multirow{2}{*}{ 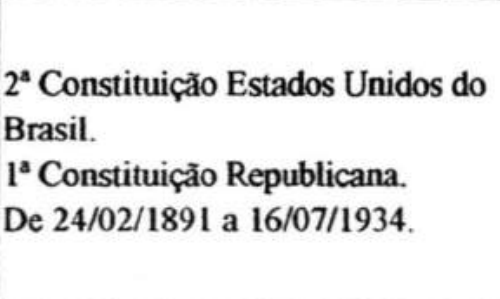 } & 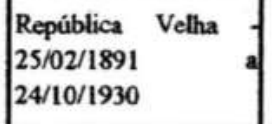 & - & 13 & - & 13 & 14 & - & - & 14 & \multirow{2}{*}{43} \\
\hline & $\left|\begin{array}{lll}\text { Governo } & \text { Prov } & \text { daf } \\
\text { Revoluçäo } & \text { de } & 30 \\
03 / 11 / 1930 & & \\
20 / 07 / 1934 & & \end{array}\right|$ & - & - & - & - & 16 & - & - & 16 & \\
\hline $\begin{array}{l}3^{\text {a }} \text { Constituição Estados Unidos do } \\
\text { Brasil. } \\
2^{\text {a }} \text { Constituição Republicana. } \\
\text { De 16/07/1934 a 10/11/1937. }\end{array}$ & 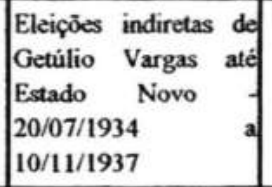 & 1 & - & - & 1 & 14 & - & - & 14 & 15 \\
\hline $\begin{array}{l}4^{a} \text { Constituição Estados Unidos do } \\
\text { Brasil. } \\
3^{\mathrm{a}} \text { Constituição Republicana. } \\
\text { De 10/11/1937 a 18/09/1946. }\end{array}$ & $\begin{array}{l}\text { Estado Novo } \\
10 / 11 / 1937 \\
29 / 10 / 1945\end{array}$ & - & - & - & - & 43 & 11 & - & 54 & 54 \\
\hline \multirow{2}{*}{ 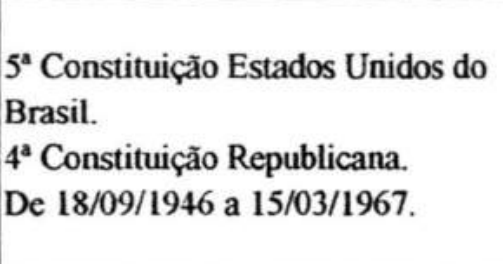 } & $\begin{array}{l}\text { Democratizarăo } \\
\text { 31/01/1946 } \\
31 / 03 / 1964\end{array}$ & 42 & 3 & 1 & 46 & 72 & - & - & 72 & \multirow{2}{*}{139} \\
\hline & $\begin{array}{l}\text { Golpe Militar } \\
\text { 31/03/1964 } \\
15 / 03 / 1967\end{array}$ & 7 & - & - & 7 & 11 & 3 & - & 14 & \\
\hline
\end{tabular}


Quadro 9 - Produção Legislativa selecionada sobre Saúde Bucal segundo a origem e a regra legal - Brasil - 1824 a julho 2007.

Anexo B

\begin{tabular}{|c|c|c|c|c|c|c|c|c|c|c|}
\hline \multirow{3}{*}{ Constituiçōes } & \multirow{3}{*}{ Periodos } & \multicolumn{9}{|c|}{ Origem e regra legal } \\
\hline & & \multicolumn{4}{|c|}{ Legislativo } & \multicolumn{4}{|c|}{ Executivo } & \multirow[b]{2}{*}{ Total } \\
\hline & & Leis & $\begin{array}{c}\text { Decreto } \\
\left.\text { Legislativo/CM ( }{ }^{\star}\right)\end{array}$ & $\operatorname{RSF}\left({ }^{\star *}\right)$ & Subtotal & Decreto & $\begin{array}{c}\text { Decreto } \\
\text { Lei }\end{array}$ & $\begin{array}{c}\text { Medida } \\
\text { Provisória }\end{array}$ & Subtotal & \\
\hline \multirow{2}{*}{$\begin{array}{l}6^{a} \text { Constituição República Federativa } \\
\text { do Brasil. } \\
5^{a} \text { Constituição Republicana. } \\
\text { De } 15 / 03 / 1967 \text { a } 05 / 10 / 1988 .\end{array}$} & \begin{tabular}{|l|} 
Governo Militar \\
$15 / 03 / 1967$ \\
$15 / 03 / 1985$
\end{tabular} & 13 & 1 & - & 14 & 222 & 14 & - & 236 & \multirow[b]{2}{*}{268} \\
\hline & 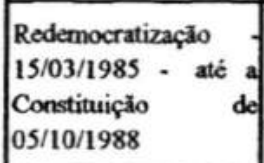 & 3 & - & - & 3 & 15 & - & - & 15 & \\
\hline $\begin{array}{l}7^{7} \text { Constituição República Federativa } \\
\text { do Brasil. } \\
6^{\mathrm{a}} \text { Constitução Republicana. } \\
\text { Promulgada em } 05 / 10 / 1988\end{array}$ & $\begin{array}{lll}\text { Constituiça de } & 1988 \\
\text { e o c SUS } & \text { I } & \text { Lei } \\
\text { Orgànica da } & \text { Saúde } \\
\text { Normas Operacionais }\end{array}$ & 6 & - & - & 6 & 15 & - & 44 & 58 & 64 \\
\hline Total & & 73 & 17 & 1 & 91 & 429 & 28 & 44 & 500 & 591 \\
\hline
\end{tabular}

Fonte: Legislação Federal - 1824 a julho de 2007 - dados obtidos do Sistema de Informações do Congresso Nacional - SICON -

http $/ /$ www6.senado.gov.br/sicon/PreparaPesquisaLegislacao.action

Notas:

(*) Conselho de Ministros

(**) Resolução do Senado Federal 
Quadro 10 - Produção Legislativa Federal sobre Saúde Bucal por setor/área regulamentados e períodos - Brasil - 1824 a jul. 2007

Anexo B

\begin{tabular}{|c|c|c|c|c|c|c|c|c|}
\hline Constituiçōes & Periodos & Administração & $\begin{array}{c}\text { Segurança } \\
\text { Pública, Forças } \\
\text { Armadas }\end{array}$ & $\begin{array}{l}\text { Ensino } \\
\text { Superior }\end{array}$ & $\begin{array}{l}\text { Fiscalização de } \\
\text { Atividades e } \\
\text { Exercicio } \\
\text { Profissional }\end{array}$ & $\begin{array}{l}\text { Entidades de } \\
\text { Classe }\end{array}$ & Subtotal & TOTAL \\
\hline $\begin{array}{l}I^{2} \text { Constituição do Brasil. } \\
\text { Única do Periodo Imperial. } \\
\text { De 25/03/1824 a 24/02/1891. }\end{array}$ & $\begin{array}{l}\text { Império e } 1^{\circ} \text { Gov Prov da } \\
\text { República - até 24/02/1891 }\end{array}$ & 1 & - & 4 & 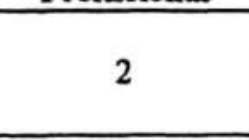 & 1 & 8 & 8 \\
\hline \multirow{2}{*}{$\begin{array}{l}2^{s} \text { Constituição Estados Unidos do } \\
\text { Brasil. } \\
1^{*} \text { Constituição Republicana. } \\
\text { De } 24 / 02 / 1891 \text { a } 16 / 07 / 1934 .\end{array}$} & $\begin{array}{l}\text { República Velha } 25 / 02 / 1891 \text { a } \\
24 / 10 / 1930\end{array}$ & 3 & 13 & 6 & 3 & 2 & 27 & \multirow{2}{*}{43} \\
\hline & $\begin{array}{l}\text { Governo Prov da Revolução de } 30 \\
\text { 03/1 1/1930 a 20/07/1934 }\end{array}$ & 4 & 5 & 1 & 6 & - & 16 & \\
\hline $\begin{array}{l}3^{2} \text { Constituição Estados Unidos do } \\
\text { Brasil. } \\
2^{2} \text { Constituição Republicana. } \\
\text { De 16/07/1934 a 10/1 1/1937. }\end{array}$ & $\begin{array}{l}\text { Eleições indiretas de Getúlio } \\
\text { Vargas até o Estado Novo } \\
20 / 07 / 1934 \text { a 10/11/1937 }\end{array}$ & 1 & 2 & 11 & 1 & - & 15 & 15 \\
\hline $\begin{array}{l}4^{2} \text { Constituição Estados Unidos do } \\
\text { Brasil. } \\
3^{2} \text { Constituição Republicana. } \\
\text { De } 10 / 11 / 1937 \text { a } 18 / 09 / 1946 .\end{array}$ & $\begin{array}{l}\text { Estado Novo } 10 / 11 / 1937 \text { a } \\
29 / 10 / 1945\end{array}$ & 7 & 10 & 35 & 2 & - & 54 & 54 \\
\hline \multirow{2}{*}{$\begin{array}{l}\text { 5 Constituição Estados Unidos do } \\
\text { Brasil. } \\
\text { 4ª Constituição Republicana. } \\
\text { De 18/09/1946 a 15/03/1967. }\end{array}$} & $\begin{array}{l}\text { Democratização 31/01/1946 a } \\
31 / 03 / 1964\end{array}$ & 25 & 20 & 67 & 3 & 3 & 118 & \multirow{2}{*}{139} \\
\hline & $\begin{array}{l}\text { Golpe Militar - 31/03/1964 até a } \\
\text { Constituição de 15/03/1967 }\end{array}$ & 4 & 4 & 11 & 2 & - & 21 & \\
\hline \multirow{2}{*}{$\begin{array}{l}\text { 6a Constituição República Federativa } \\
\text { do Brasil. } \\
\text { 5a Constituição Republicana. } \\
\text { De 15/03/1967 a 05/10/1988. }\end{array}$} & $\begin{array}{l}\text { Governo Militar 15/03/1967 até } \\
15 / 03 / 1985\end{array}$ & 87 & 39 & 112 & 11 & 1 & 250 & \multirow[b]{2}{*}{268} \\
\hline & $\begin{array}{l}\text { Redemocratização 15/03/1985 a } \\
05 / 10 / 1988 \\
\text { VIII Conferência Nacional de } \\
\text { Saúde }\end{array}$ & 6 & 3 & 8 & - & 1 & 18 & \\
\hline
\end{tabular}


Quadro 10 - Produção Legislativa Federal sobre Saúde Bucal por setor/área regulamentados e periodos - Brasil - 1824 a jul. 2007

Anexo B

\begin{tabular}{|c|c|c|c|c|c|c|c|c|}
\hline Constituiçōes & Periodos & Administração & $\begin{array}{c}\text { Segurança } \\
\text { Pública, Forças } \\
\text { Armadas }\end{array}$ & $\begin{array}{l}\text { Ensino } \\
\text { Superior }\end{array}$ & $\begin{array}{l}\text { Fiscalização de } \\
\text { Atividades e } \\
\text { Exercício } \\
\text { Profissional } \\
\end{array}$ & $\begin{array}{c}\text { Entidades de } \\
\text { Classe }\end{array}$ & Subtotal & TOTAL \\
\hline $\begin{array}{l}7^{\mathbf{a}} \text { Constituição República Federativa } \\
\text { do Brasil. } \\
6^{\mathbf{a}} \text { Constitução Republicana. } \\
\text { Promulgada em 05/10/1988 }\end{array}$ & \begin{tabular}{|l|} 
Constituição 05/10/1988 a jul. \\
2007 \\
Lei Orgânica da Saúde - \\
$19 / 09 / 1990$ \\
Normas Operacionais - 1991, \\
$1992,1993,1996,2001,2002$. \\
Lei dos Planos e Seguros - \\
03/06/1998 \\
Diretrizes Operacionais Pacto \\
pela Vida, da Saúde e de Gestão - \\
2006
\end{tabular} & 50 & 5 & 7 & - & 2 & 64 & 64 \\
\hline Total & & 188 & 101 & 262 & 30 & 10 & 591 & 591 \\
\hline
\end{tabular}

Fonte: Legislação Federal - 1824 a julho de 2007 - dados obtidos do Sistema de Informações do Congresso Nacional - SICON -

http://www6.senado.gov.br/sicon/PreparaPesquisaLegislacao.action 
Quadro 11 - Produção Legislativa Federal sobre Saúde Bucal, segundo o setor regulamentado e temas - Brasil - 1824 a julho de 2007

\begin{tabular}{|c|c|c|c|c|c|c|c|}
\hline \multicolumn{6}{|c|}{ Temas } & \multicolumn{2}{|c|}{ Total } \\
\hline Setores regulamentados & Pessoal (i) & Tributação (2) & $\begin{array}{c}\text { Concessōes de } \\
\text { recursos/isençōes (3) }\end{array}$ & $\begin{array}{c}\text { Estrutura e organização, } \\
\text { regulamentações dos sistemas, } \\
\text { implantação de programas, } \\
\text { vigilância (4) } \\
\end{array}$ & Datas/semana (5) & $\mathbf{N}$ & $\%$ \\
\hline Administração & 126 & 4 & - & 56 & 2 & 188 & 31,81 \\
\hline Forças Armadas e Segurança Pública & 100 & - & - & 1 & - & 101 & 17,09 \\
\hline Ensino superior & 90 & - & 29 & 143 & - & 262 & 44,33 \\
\hline Exercicio Profissional & 5 & 1 & - & 24 & - & 30 & 5,08 \\
\hline Entidades de classe & - & - & 10 & - & - & 10 & 1,69 \\
\hline Total & $321(54,32 \%)$ & $5(0,85 \%)$ & $39(6,60 \%)$ & $224(37,90 \%)$ & $2(0,34 \%)$ & 591 & 100 \\
\hline
\end{tabular}

Fonte: Legislação Federal - 1824 a julho de 2007 - dados obtidos do Sistema de Informações do Congresso Nacional - SICON -

http://www6.senado.gov.br/sicon/PreparaPesquisaLegislacao.action

Notas:

(1) - benefícios, transferências/transposições, quadros de cargos, carreiras e salários dos setores públicos civil, militar e do ensino superior, recrutamento serviço militar, uniformes, congressos.

(2) - tributos, taxas, reajustes de aliquotas do Imposto de Renda sobre as ações e serviços relacionados ao funcionamento, propaganda e fiscalização de estabelecimentos privados e ao exercício profissional

(3) - desapropriaçőes e doações de imóveis, declaraç̃̃es de utilidade pública, isenções, dotações orçamentárias e créditos financeiros especiais complementares ou suplementares à entidades de classe $\mathrm{e}$ ao ensino superior.

(4) - regulamentação sobre federalização, estadualização e autorização de funcionamento e reconhecimento de faculdades e cursos de odontologia; estruturação de serviços de controle e fiscalização do exercício profissional; criação de estrutura para o gerenciamento dos serviços de odontologia na Administração; regulamentação sobre operadoras e planos odontológicos da Saúde Suplementar, fluoretação das águas; acordos internacionais e regras de importação/exportação de equipamentos odontológicos programas; obrigatoriedade da assistência odontológica na Lei de Acidentes de Trabalho (1944); obrigatoriedade das Cartas de Habilitação da Junta de Higiêne; nosmas para a fiscalização do exercicio da odontologia; normas dos serviços odontológicos do exército nacional, fiscalização de amostras grátis de entorpecentes nos consultórios odontológicos, entre outros.

(5) - datas ou semanas comemorativas relacionadas à odontologia e à saúde bucal 
Quadro 13 - Legislação Federal selecionada sobre Saúde Bucal relativa aos temas Gestão e Programas - Brasil - 1824 a jul 2007.

\begin{tabular}{|c|c|}
\hline Ano & Legislação Federal selecionada \\
\hline 1933 & Decreto 2332, de 08/11/1933 - Regulamentação sobre a importação de aparelhos odontológicos \\
\hline 1944 & Decreto Lei 7036, de 10/1 1/1944 - Reforma a Lei de Acidentes de Trabalho e obriga o empregador à assistência dentária \\
\hline 1954 & Lei Ordinária 2312, de 03/09/1954 - Normas gerais sobre a Defesa e Proteção da Saúde e fiscalização sobre dentistas e estabelecimentos \\
\hline 1961 & Decreto 49974, de 21/01/1961 - Regulamenta o Código Nacional de Saúde e (...) a fiscalização do exercício das profissões. \\
\hline 1968 & $\begin{array}{l}\text { Decreto 62391, de 12/03/1968 - Dispöe sobre a fiscalização em lab da produção de substâncias tóxicas e entorpecentes, distribuição de amostras a dentistas e outros } \\
\text { profissionais. }\end{array}$ \\
\hline 1975 & Decreto 76872, de 22/12/1975 - Regulamenta a Lei 6050, de 24/05/1974 que dispõe sobre a fluoretação da água em Sistemas Públicos de Abastecimento \\
\hline 1988 & Decreto 96028 , de 10/05/1988 - Ato Internacional - $3^{\circ}$ protocolo adicional Acordo Comercial da Ind. de Material e Equipamentos, entre eles os odontológicos \\
\hline 1992 & Decreto 508, de 24/04/1992 - Ato Internacional - $8^{\circ}$ protocolo adicional Acordo Comercial da Ind. de Material e Equipamentos, entre eles os odontológicos \\
\hline 1993 & Decreto 855, de 02/07/1993 - Ato Internacional - $9^{\circ}$ protocolo adicional Acordo Comercial da Ind.e Material e Equipamentos, entre eles os odontológicos \\
\hline \multirow{6}{*}{1998} & Decreto 2717, de 10/08/1998 - Ato Internacional - $12^{\circ}$ protocolo adicional Acordo Comercial da Ind.e Material e Equipamentos, entre eles os odontológicos \\
\hline & MPV 1685-003, de 27/08/1998 - altera a Lei 9656, de 03/06/1998 \\
\hline & MPV $1685-004$, de 25/09/1998 - altera a Lei 9656 , de 03/06/1998 \\
\hline & MPV $1685-005$, de 26/10/1998 - altera a Lei 9656 , de 03/06/1998 \\
\hline & MPV 1685-006, de 25/11/1998 - altera a Lei 9656 , de 03/06/1998 \\
\hline & MPV $1730-007$, de 07/12/1998 - altera a Lei 9656 , de 03/06/1998 \\
\hline
\end{tabular}




\begin{tabular}{|c|c|c|}
\hline Constituiçōes & Periodos & Administração com regulamentação Pessoal $\mathrm{e}$ ano das primeiras regulamentações \\
\hline \multirow[t]{2}{*}{$\begin{array}{l}6^{\circ} \text { Constituição República Federativa do Brasil. } 5^{*} \\
\text { Constituiçâ Republicana. } \\
\text { De } 15 / 03 / 1967 \text { a 05/10/1988. }\end{array}$} & $\begin{array}{l}\text { Governo Militar 15/03/1967 até } \\
\text { 15/03/1985 }\end{array}$ & $\begin{array}{l}\text { Ministério do Trabalho e Previdência Social - } 1967 \\
\text { Departamento Nacional de Correios e Telégrafos - } 1967 \\
\text { Departamento Nacional de Estradas de Ferro - } 1968 \\
\text { Ministério dos Transportes (Estrada de Ferro Central do Brasil, Estrada de Ferro Leopoldina) } \\
-1968 \\
\text { Território Federal de Roraima - } 1968 \\
\text { Instituto de Previdência e Assistência dos Servidores do Estado - } 1968 \\
\text { Instituto Brasileiro do Sal - } 1968 \\
\text { Território Federal do Amapá - } 1969 \\
\text { Ministério da Justiça - } 1969 \\
\text { Departamento da Policia Federal - } 1969 \\
\text { Ministério da Fazenda - } 1969 \\
\text { Ministério da Saúde - 1969 } \\
\text { Instituto Nacional do Desenvolvimento Agrário - } 1969 \\
\text { Ministério das Relaç̃̃es Exterirores - } 1969 \\
\text { Instituto Nacional da Previdência Social - } 1969 \\
\text { Caixa Econômica Federal - 1970 } \\
\text { Departamento Nacional de Estradas de Rodagem - } 1975 \\
\text { Tribunal de Contas do DF - } 1976 \\
\text { Superintendência do Desenvolvimento da Amazônia - } 1976 \\
\text { Departamento Nacional de Obras e Saneamento - } 1976 \\
\text { Ministério do Interior - } 1976 \\
\text { Comissão Nacional de Energia Nuclear - } 1976 \\
\text { Departamento Nacional de Obras Contra as Secas - } 1976 \\
\text { Instituto Nacional de Colonização e Reforma Agrária - } 1976 \\
\text { Instituto do Açúcar e do Álcool - } 1976 \\
\text { Coordenação Nacional do Ensino Agropecuário - } 1976 \\
\text { Superintendência Nacional da Marinha Mercante - } 1976 \\
\text { Ministério do Trabalho - } 1976 \\
\text { Tribunais Regionais do Trabalho - } 1976\end{array}$ \\
\hline & $\begin{array}{l}\text { Redemocratização 15/03/1985 a } \\
05 / 10 / 1988\end{array}$ & - \\
\hline $\begin{array}{l}7^{\circ} \text { Constituição República Federativa do Brasil. } 6^{\circ} \\
\text { Constitução Republicana. 05/10/1988 }\end{array}$ & Constituição 05/10/1988 a jul. 2007 & - \\
\hline
\end{tabular}

Fonte: Senado Federal - 1824 a julho de 2007 - Sistema de Informações do Congresso Nacional - SICON - http://www6.senado.gov.br/sicon/PreparaPesquisaLegislacao.action 
Yuauı 0 1 4 - rıuuuyau Legıslatıva sobrc Saude Bucal segundo o tema Pessoal no setor Administração (exceto pessoal militar, ensino superior) - Brasil - 1824 a julho 2007

\begin{tabular}{|c|c|c|}
\hline Constituiçōes & Periodos & Administração com regulamentação Pessoal e ano das primeiras regulamentaçōes \\
\hline $\begin{array}{l}1^{\star} \text { Constituição do Brasil. Única do Periodo Imperial. } \\
\text { 25/03/1824 a 24/02/1891. }\end{array}$ & $\begin{array}{l}\text { Império e } 1^{\circ} \text { Gov Prov da República - até } \\
24 / 02 / 1891\end{array}$ & - \\
\hline \multirow{2}{*}{$\begin{array}{l}2^{*} \text { Constituição Estados Unidos do Brasil. } 1^{*} \\
\text { Republicana. 24/02/1891 a 16/07/1934. }\end{array}$} & República Velha $25 / 02 / 1891$ a 24/10/1930| & - \\
\hline & $\begin{array}{l}\text { Governo Prov da Revolução de } 30 \\
03 / 11 / 1930 \text { a 20/07/1934 }\end{array}$ & $\begin{array}{l}\text { Patronatos Agricolas - } 1931 \\
\text { Ministério de Educação e Saúde - } 1933\end{array}$ \\
\hline $\begin{array}{l}3^{3} \text { Constituição Estados Unidos do Brasil. } 2^{\circ} \\
\text { Constituição Republicana. } \\
\text { De 16/07/1934 a 10/11/1937. }\end{array}$ & $\begin{array}{l}\text { Eleições indiretas de Getúlio Vargas até o } \\
\text { Estado Novo 20/07/1934 a 10/11/1937 }\end{array}$ & - \\
\hline $\begin{array}{l}4^{*} \text { Constituição Estados Unidos do Brasil. } \\
3^{*} \text { Constituição Republicana. 10/11/1937 a } \\
\text { 18/09/1946. }\end{array}$ & Estado Novo 10/11/1937 a 29/10/1945 & $\begin{array}{l}\text { Ministério da Justiça e Negócios Interiores - } 1944 \\
\text { Departamento Nacional do Trabalho do Ministério do Trabalho - } 1944\end{array}$ \\
\hline \multirow[t]{2}{*}{$\begin{array}{l}\text { 5॰ Constituição Estados Unidos do Brasil. } \\
4^{*} \text { Constituição Republicana. } \\
\text { De 18/09/1946 a 15/03/1967. }\end{array}$} & Democratização 31/01/1946 a 31/03/1964 & $\begin{array}{l}\text { Ministério da Viação e Obras Públicas - } 1946 \\
\text { Ministério da Educação e Cultura - } 1948 \\
\text { Departamento Federal de Segurança Pública - } 1948 \\
\text { Ministério da Agricultura - } 1953 \\
\text { Instituto de Aposentadoria e Pensões dos Industriários - } 1957 \\
\text { Instituto de Aposentadoria e Pensões dos Empregados em Transportes e Cargas - } 1960\end{array}$ \\
\hline & $\begin{array}{l}\text { Golpe Militar - 31/03/1964 até a } \\
\text { Constituição de 15/03/1967 }\end{array}$ & $\begin{array}{l}\text { Superintendência do Plano de Valorização Econômica da Amazônia - } 1966 \\
\text { Departamento de Administração do Serviço Público - } 1967\end{array}$ \\
\hline
\end{tabular}




\begin{tabular}{|c|c|}
\hline Ano & \\
\hline \multirow{13}{*}{1999} & MPV $1730-008$, de 06/01/1999 - altera a Lei 9656 , de $03 / 06 / 1998$ \\
\hline & MPV $1801-009$, de $28 / 01 / 1999$ - altera a Lei 9656 , de $03 / 06 / 1998$ \\
\hline & MPV $1801-010$, de 25/02/1999 - altera a Lei 9656 , de $03 / 06 / 1998$ \\
\hline & MPV 1801-011, de 25/03/1999 - altera a Lei 9656 , de 03/06/1998 \\
\hline & MPV 1801-012, de 25/05/1999 - altera a Lei 9656 , de $03 / 06 / 1998$ \\
\hline & MPV $1801-014$, de $17 / 06 / 1999$ - altera a Lei 9656 , de $03 / 06 / 1998$ \\
\hline & MPV $1908-015$, de $29 / 06 / 1999$ - altera a Lei 9656 , de $03 / 06 / 1998$ \\
\hline & MPV $1908-016$, de $28 / 07 / 1999$ - altera a Lei 9656 , de $03 / 06 / 1998$ \\
\hline & MPV $1908-017$, de $27 / 08 / 1999$ - altera a Lei 9656 , de $03 / 06 / 1998$ \\
\hline & MPV $1908-018$, de 24/09/1999 - altera a Lei 9656 , de 03/06/1998 \\
\hline & MPV $1908-019$, de $26 / 10 / 1999$ - altera a Lei 9656 , de $03 / 06 / 1998$ \\
\hline & MPV $1908-020$, de $25 / 11 / 1999$ - altera a Lei 9656 , de $03 / 06 / 1998$ \\
\hline & MPV $1976-021$, de $10 / 12 / 1999$ - altera a Lei 9656 , de $03 / 06 / 1998$ \\
\hline \multirow{14}{*}{2000} & MPV $1976-022$, de $11 / 01 / 2000$ - altera a Lei 9656 , de 03/06/1998 \\
\hline & MPV $1976-023$, de 10/02/2000 - altera a Lei 9656 , de 03/06/1998 \\
\hline & MPV 1976-024, de 09/03/2000 - altera a Lei 9656, de 03/06/1998 \\
\hline & MPV $1976-025$, de $06 / 04 / 2000$ - altera a Lei 9656 , de $03 / 06 / 1998$ \\
\hline & MPV $1976-026$, de $04 / 05 / 2000$ - altera a Lei 9656 , de $03 / 06 / 1998$ \\
\hline & MPV $1976-027$, de $01 / 06 / 2000$ - altera a Lei 9656 , de $03 / 06 / 1998$ \\
\hline & MPV $1976-028$, de $29 / 06 / 2000$ - altera a Lei 9656 , de $03 / 06 / 1998$ \\
\hline & MPV $1976-029$, de $28 / 07 / 2000$ - altera a Lei 9656 , de $03 / 06 / 1998$ \\
\hline & MPV $1976-030$, de $28 / 08 / 2000$ - altera a Lei 9656 , de $03 / 06 / 1998$ \\
\hline & MPV $1976-031$, de $27 / 09 / 2000$ - altera a Lei 9656 , de $03 / 06 / 1998$ \\
\hline & MPV 1976-032, de 26/10/2000 - altera a Lei 9656 , de $03 / 06 / 1998$ \\
\hline & MPV 1976-033, de 23/11/2000 - altera a Lei 9656 , de 03/06/1998 \\
\hline & MPV $1976-034$, de $21 / 12 / 2000$ - altera a Lei 9656 , de $03 / 06 / 1998$ \\
\hline & MPV 2097-035, de 27/12/2000 - altera a Lei 9656 , de 03/06/199 \\
\hline
\end{tabular}


Quadro 13 - Legislação Federal selecionada sobre Saúde Bucal relativa aos temas Gestão e Programas - Brasil - 1824 a jul 2007.

\begin{tabular}{|l|l}
\hline Ano & \\
\hline & MPV 2097-036, de 26/01/2001 - altera a Lei 9656, de 03/06/1998
\end{tabular}

MPV 2097-037, de 27/02/2001 - altera a Lei 9656, de 03/06/1998

MPV 2097-038, de 27/03/2001 - altera a Lei 9656, de 03/06/1998

MPV 2097-039, de 26/04/2001 - altera a Lei 9656, de 03/06/1998

2001 MPV 2097-040, de 24/05/2001 - altera a Lei 9656, de 03/06/1998

MPV 2097-041, de 21/06/2001 - altera a Lei 9656, de 03/06/1998

MPV 2177-042, de 28/06/2001 - altera a Lei 9656, de 03/06/1998

MPV 2177-043, de 27/07/2001 - altera a Lei 9656, de 03/06/1998

MPV 2177-044, de 24/08/2001 - altera a Lei 9656, de 03/06/1998

Fonte: Legislação Federal - 1824 a julho de 2007 - dados obtidos do Sistema de Informações do Congresso Nacional - SICON -

http://www6.senado.gov.br/sicon/PreparaPesquisaLegislacao.action 
ANEXO C 
Quadro 14 - Atos normativos ministeriais de Saúde Bucal, segundo a origem da norma e período/ano de publicação - Brasil - 1946 a jul. $2007 . \quad$ Anexo C

\begin{tabular}{|c|c|c|c|c|c|c|c|c|c|c|c|c|c|c|c|c|c|c|c|c|c|c|c|c|}
\hline \multicolumn{24}{|c|}{ Período / ano } & \multirow[b]{2}{*}{ Total } \\
\hline Origem(*) & \begin{tabular}{|c|}
$1946 \mathrm{a}$ \\
1963
\end{tabular} & $\begin{array}{r}1964 \mathrm{a} \\
1966\end{array}$ & $\begin{array}{c}1967 \text { a } \\
1984\end{array}$ & \begin{tabular}{|c|}
$1985 a$ \\
1988
\end{tabular} & 1989 & 1990 & 1991 & 1992 & 1993 & 1994 & 1995 & 1996 & 1997 & 1998 & 1999 & 2000 & 2001 & 2002 & 2003 & 2004 & 2005 & 2006 & $\begin{array}{c}\text { jan a jul } \\
2007\end{array}$ & \\
\hline DNCR & 1 & - & - & - & - & - & - & - & - & - & - & - & - & - & - & - & - & - & - & - & - & - & - & 1 \\
\hline DNS & 2 & 2 & 2 & - & - & - & - & - & - & - & - & - & - & - & - & - & - & - & - & - & - & - & - & 6 \\
\hline GM & - & 2 & - & 3 & 6 & 1 & 1 & 1 & 4 & - & - & 1 & 3 & 2 & 3 & 3 & 26 & 35 & 50 & 46 & 44 & 55 & 32 & 318 \\
\hline SNFO/DNS & - & - & 6 & - & - & - & - & - & - & - & - & - & - & - & - & - & - & - & - & - & - & - & - & 6 \\
\hline SNFMF & - & - & 4 & - & - & - & - & - & - & - & - & - & - & - & - & - & - & - & - & - & - & - & - & 4 \\
\hline SNPES/DNC & - & - & 2 & - & - & - & - & - & - & - & - & - & - & - & - & - & - & - & - & - & - & - & - & 2 \\
\hline DNF & - & - & 1 & - & - & - & - & - & - & - & - & - & - & - & - & - & - & - & - & - & - & - & - & 1 \\
\hline Bbs & - & - & 1 & - & - & - & - & - & - & - & - & - & - & - & - & - & - & - & - & - & - & - & - & 1 \\
\hline CNS & - & - & 1 & - & - & - & - & - & 2 & 1 & - & - & 1 & - & - & - & - & - & - & - & - & - & - & 5 \\
\hline SNVS & - & - & - & - & 2 & - & - & 1 & - & - & - & - & - & - & - & - & - & - & - & - & - & - & - & 3 \\
\hline INAN & - & - & - & - & - & - & 3 & - & - & - & - & - & - & - & - & - & - & - & - & - & - & - & - & 3 \\
\hline \begin{tabular}{|l|} 
SNAS \\
\end{tabular} & - & - & - & - & - & - & 3 & 1 & - & - & - & - & - & - & - & - & - & - & - & - & - & - & - & 4 \\
\hline INAMPS & - & - & - & - & - & - & 1 & - & - & - & - & - & - & - & - & - & - & - & - & - & - & - & - & 1 \\
\hline \begin{tabular}{|l|} 
SAS \\
\end{tabular} & - & - & - & - & - & - & - & - & 2 & 4 & - & - & - & 6 & 4 & 7 & 5 & 3 & - & 5 & 5 & 6 & 2 & 49 \\
\hline FNSA & - & - & - & - & - & - & - & - & 1 & 1 & 1 & - & - & - & - & - & - & - & - & - & - & - & - & 3 \\
\hline SVS & - & - & - & - & - & - & - & - & - & - & - & - & 2 & - & 1 & - & - & - & - & - & - & - & - & 3 \\
\hline \begin{tabular}{|l|} 
CONSU \\
\end{tabular} & - & - & - & - & - & - & - & - & - & - & - & - & - & 1 & - & - & - & - & - & - & - & - & - & 1 \\
\hline INCA & - & - & - & - & - & - & - & - & - & - & - & - & - & - & 1 & - & - & - & - & 1 & 1 & 1 & - & 4 \\
\hline \begin{tabular}{|l|} 
ANVISA \\
\end{tabular} & - & - & - & - & - & - & - & - & - & - & - & - & - & - & 1 & - & - & 2 & 5 & 6 & 3 & 4 & 2 & 23 \\
\hline SPS & - & - & - & - & - & - & - & - & - & - & - & - & - & - & 1 & 2 & 1 & 1 & - & - & - & - & - & 5 \\
\hline \begin{tabular}{|l} 
SE/SAS \\
\end{tabular} & - & - & - & - & - & - & - & - & - & - & - & - & - & - & 2 & - & - & - & 7 & 5 & 2 & 2 & - & 18 \\
\hline ANS & - & - & - & - & - & - & - & - & - & - & - & - & - & - & - & 1 & - & 10 & 7 & 2 & 3 & 4 & - & 27 \\
\hline SGTES & - & - & - & - & - & - & - & - & - & - & - & - & - & - & - & - & - & - & 1 & - & - & - & - & 1 \\
\hline DENASUS & - & - & - & - & - & - & - & - & - & - & - & - & - & - & - & - & - & - & - & - & 1 & $\mathrm{I}$ & - & 2 \\
\hline SAS/GT & - & - & - & - & - & - & - & - & - & - & - & - & - & - & - & - & - & - & - & - & - & 1 & - & 1 \\
\hline SAA/GRL & - & - & - & - & - & - & - & - & - & - & - & - & - & - & - & - & - & - & - & 1 & - & - & - & 1 \\
\hline MS/MJ & - & - & - & - & - & - & - & - & - & - & - & - & - & - & - & - & - & - & - & - & - & 1 & - & 1 \\
\hline FUNASA & - & - & - & - & - & - & - & - & - & - & - & - & - & - & - & - & - & - & - & - & - & - & 1 & 1 \\
\hline Total & 3 & 4 & 17 & 3 & 8 & 1 & 8 & 3 & 9 & 6 & 1 & 1 & 6 & 9 & 13 & 13 & 32 & 51 & 70 & 66 & 59 & 75 & 37 & 495 \\
\hline
\end{tabular}

Fonte: Sistema de Legislação em Saúde - Saúde Legis - www.saude.gov.br/saudelegis

Nota:

(*) As siglas dos órgãos de origem encontram-se na Lista de Abreviaturas 
Quadro 15 - Documentos selecionados sobre Saúde Bucal segundo os eixos-temáticos, temas e assuntos CNS - Brasil - 1988 a jutho de 2007.

\begin{tabular}{|c|c|c|c|c|}
\hline Amo & Documentos & $\begin{array}{c}\text { Saúde } \\
\text { Bucal }\end{array}$ & Eiros temáticos / temas & \\
\hline 1988 & I RESOLUÇÃO & 0 & \\
\hline \multirow{2}{*}{1991} & 20 RESOLUÇÕES & 0 & - & \\
\cline { 2 - 5 } & 10 ATAS & 0 & - & \\
\hline
\end{tabular}

\begin{tabular}{l} 
cassuntos CNS - Brasil - 1988 a jullho de 2007. \\
\hline \\
\begin{tabular}{|c|c|}
\hline & Assuntos \\
\hline
\end{tabular}
\end{tabular}

\begin{tabular}{|c|c|c|c|}
\hline \multirow{3}{*}{1992} & IS RESOLUÇÖES & 0 & . \\
\hline & \multirow{2}{*}{12 ATAS } & \multirow{2}{*}{2} & 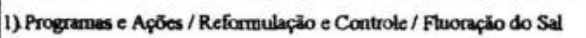 \\
\hline & & & 2) Outras / Gestăo do Trabalho e Educarăo / Ensino Superior / Análise \\
\hline
\end{tabular}

huoraçlo do Sal - revogafăo da Portaria do ex-Ministro Aloeni Gueme

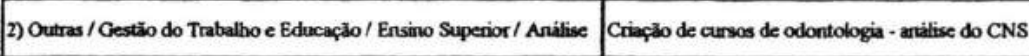

\begin{tabular}{|c|c|c|c|}
\hline \multirow{13}{*}{1993} & 61 RESOLUÇÕES & 1 & 1) Outras / Controle Social / Conferencia / II CNSB \\
\hline & \multirow{12}{*}{ 13 ATAS } & \multirow{12}{*}{9} & 1) Outras / Controle Social / Conferencia / II CNSB \\
\hline & & & 2) Outras / Controle Social / Conferéncia / II CNSB \\
\hline & & & 3) Outras / Gestäo do Trabalho e Educaçäo / Ensino Superior / Análise \\
\hline & & & 4) Outras / Controle Social / Conferència / II CNSB \\
\hline & & & 9) Outras / Gestăo do Trabalho Educação / Ensino Superior / Analise \\
\hline & & & ๑) Outras / Gestâo do Trabalho Educaçăo / Ensino Superior / Analise \\
\hline & & & 7) Outras / Controle Social / Conferència / II CNSB \\
\hline & & & 8) Outras / Gestio do Trabalho e Educafăo / Ersino Superior / Analise \\
\hline & & & 9) Outras / Controle Social / Conferència / II CNSB \\
\hline & & & 10) Outras / Controle Social / Conferència / 11 CNSB \\
\hline & & & 11) Outras / Controle Social / Conferčncia / II CNSB \\
\hline & & & 12) Outras / Gestăo do Trabalho $e$ Educąăăo / Greve \\
\hline
\end{tabular}

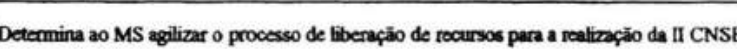

II Conferencia Nacional de Saíde Bucal (II CNSB) - reppecentapiono do CNS II CNSB - convocą̧̆̈̆

Criaçào de cursos de odontologia - análise do CNS

U CNSB - calendaino

Criarảo de arrsos de odontologia - analise do CNS

Criaģao de cursos de odontologia - anailise do CNS

II CNSB - recursos financeiros

Criaģo de cursos de odontologia - arialise do CNS

II CNSB - recursor financeiros e delegados do CNS

II CNSB - aproveạāo do relatório final

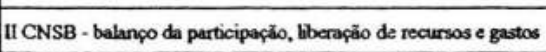

Greve dos dentistas de Anipotis - corrissio para verificaräo in boco

\begin{tabular}{|c|c|c|}
\hline SI RESOLUÇC̄ES & 1 & 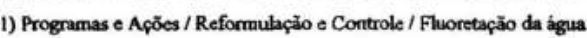 \\
\hline \multirow{7}{*}{9 ATAS } & \multirow{7}{*}{8} & $\begin{array}{l}\text { 1) Programas e Aç̄es / Reformulaçăo e Controle / Politica de Saide } \\
\text { Bucal }\end{array}$ \\
\hline & & 2) Outras / Gestăo do Trabalho e Educaç̄o / Ensino Superior / Anáfice \\
\hline & & 3) Outras / Controle Social / Congresso / II EPATESPO \\
\hline & & 4) Outras / Gestäo do Trabalho Educaçä / Ensino Superior / Análise \\
\hline & & 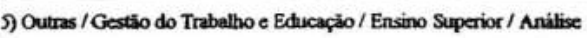 \\
\hline & & ๑) Outras / Gestäo do Traballho e Educapäio / Ensino Superior / Anilise \\
\hline & & 7) Outras / Gestäo do Trabalho E Educapio / Ensino Superior / Analise \\
\hline
\end{tabular}

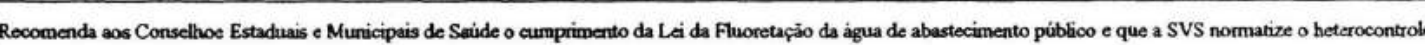

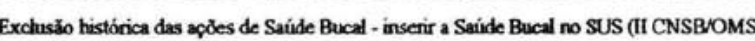

Criagräo de cursos de odontologia - suspender os processesos do CNS

Congresso II EPATESPO I I Congresso Paulista de Odontologia em Saide Coletiva

Criaçio de cursos de odontologia - oficio CROMG apoiando fimcionumento de curso

Criaģa de curso para dentistas praticos - carta an CNS

Criapajo de curso de adontologia - analise e parcecer do CNS indefoindo cursos

Criaplio de curso de odontologia - reconsiderasẫo de indeferimento 


\begin{tabular}{|c|c|c|c|c|c|}
\hline Quad & ro 15 - Documentos & selecion: & ados sobre Saúde Bucal segundo os cixos-temáticos, temas e a & assuntos CNS - Brasil - 1988 a jutho de 2007. & Anexo $\mathrm{C}$ \\
\hline Ano & Documentos & $\begin{array}{l}\text { Saúde } \\
\text { Bucal }\end{array}$ & Eiros-temáticos / temas & Assuatos & \\
\hline & & & 8) Outras / Gestä́o do Trabalho e Educą̧ăo / Ensino Superior / Análise & Criasāo de curso de odontologia - análise do CNS & \\
\hline & & & 9) Outras / Gestäo do Trabalho e Ectucą̧ăo / Ensino Superior / Analise & 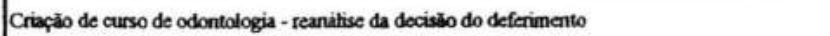 & \\
\hline & & & 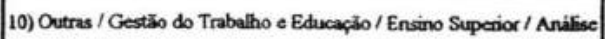 & Criaģăo de curso de odontologia - of cio CFO contestando funcionamento de curso & \\
\hline & & & 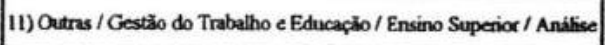 & 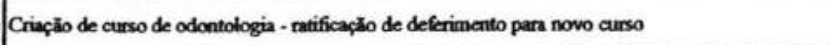 & \\
\hline & & & 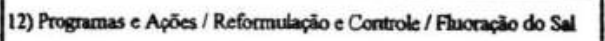 & Fluorachio do Sal - manifestapăo do CNS contrária so Projecto de Lei do Senado (arquivado 1994) & \\
\hline & 26 RESOLUCŌES & 0 & . & . & \\
\hline & $\begin{array}{c}12 \\
\text { RECOMENDAC̄ōES }\end{array}$ & 0 & - & . & \\
\hline & & & 1) Outras / Gestäo do Trabalho e Educą̧ăo / Ensino Superior / Anähise & 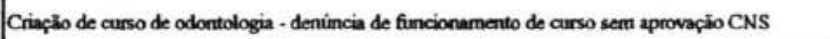 & \\
\hline 1995 & & & 2) Outras / Gestäo do Trabalho \& Educaçăo / Ensino Superior / Anithe & Criaçäo de curso de odontologia - fincionamento de curso sem anilise do CNS & \\
\hline & 10 ATAS & 5 & 3) Outras / Gestảo do Trabalho e Educarẳo / Ensino Superior / Análise & Criarăo de curso de odontologia - parcoceres favoriveis e contrinios do CNS. Curso sub judice. & \\
\hline & & & 4) Outras / Gestäo do Trabalho \& Educaşăo / Ensino Superior / Anáhisc & Criaşäo de curso de odoritologia - aniatise do CNS & \\
\hline & & & 5) Gestióo Ong do Sistema e da Assist / Regulamentapǟo do Sistena & Comiscäo NOB 96 - proposta PAB per coppita para a Atenç̧̄o ásicica (proced odontológicos) & \\
\hline & $\begin{array}{c}24 \\
\text { RECOMENDAÇÕES }\end{array}$ & 0 & - & . & \\
\hline & 33 RESOLUÇOEES & 0 & . & . & \\
\hline & 14 PAUTAS & 0 & . & . & \\
\hline & & & 1) Cestāo e Org do Sistena e da Assisct / Vigläncia Sanitária & 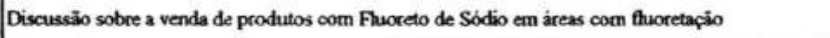 & \\
\hline & & & 2) Gestâo e Ong do Sistana e da Assist / Regulamentạẳo do Sistema & Comissāo NOB 96 - proposta PAB per capita para a Atençảo Básica (proced. odontológicos) & \\
\hline 1996 & & & 3) Outras / Gestăo do Trabalho c Educą̧áo / Ensino Supenior / Análise & Criafsa de curso de odontologia - pareceres favoriveis e contrinios do CNS & \\
\hline & & & 4) Outras / Gestäo do Trabalho e Educarfáo / Ensino Superior / Análise & Criefäo de curso de odomitologia - andilise do CNS & \\
\hline
\end{tabular}




\begin{tabular}{|c|c|c|c|c|c|}
\hline \multirow{7}{*}{ Ano } & \multirow{7}{*}{$\begin{array}{c}\text { Documentos } \\
14 \text { ATAS }\end{array}$} & \multirow{7}{*}{\begin{tabular}{|c|}
$\begin{array}{c}\text { Saúde } \\
\text { Bucal }\end{array}$ \\
6 \\
\end{tabular}} & & \multirow{2}{*}{\multicolumn{2}{|c|}{ Assuntos }} \\
\hline & & & Eixos-temáticos / temas & & \\
\hline & & & S) Gestäo \& Org do Sistama o da Assist / Sainde Suplementar / Registro & Registro das operndoras de plano nos Consechos Regionais & \\
\hline & & & 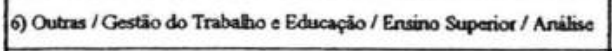 & Criagio de curso de odontologia - analise do CNS & \\
\hline & & & T) Outras / Gestä́o do Trabalho e Educaşăo / Ensino Superior / Analise & Criagăo de curso de odontologia - análise do CNS & \\
\hline & & & 8) Gestio e Org do Sistemae da Assist / Regulamathacio do Sistanas & 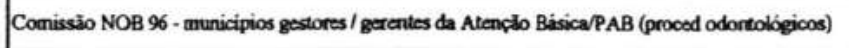 & \\
\hline & & & 9) Outras / Gestio do Trabalho e Ectucascho / Ensino Superior / Análise & Criaghio de curso de odontologia - parrocer contránio do CNS & \\
\hline \multirow{10}{*}{1997} & 7 RECOMENDAḈ̃ES & 0 & . & - & \\
\hline & SS RESOLUÇ̋̄ES & 1 & 1) Outras / Gestio do Trabalho e Educaglo / Profissionais de Saide & Reconheoce como profissionais de saivde II calcogonias profissionais & \\
\hline & 12 PAUTAS & 0 & . & - & \\
\hline & \multirow{7}{*}{ 13 ATAS } & \multirow{7}{*}{6} & 1) Outras / Gestio do Trabalho e Educaçä / Ensino Superior / Anilise & \multicolumn{2}{|l|}{ Criaçäo de curso de odortologia - análise do CNS } \\
\hline & & & 2) Outras / Gestäo do Trabalho e Educaçäo / Ensino Superior / Anilise & \multicolumn{2}{|l|}{ Criaçio de curso de odontologia - perocenes favorivecis e contrainos do CNS } \\
\hline & & & 3) Outras / Gestä́o do Trabalho e Educaçio / Ensino Superior / Análise & \multicolumn{2}{|l|}{ Criaşäo de curso de adontologia - análise do CNS } \\
\hline & & & $\begin{array}{l}\text { 4) Outras / Gestăo do Trabalho e Educasjo / Ensino Superior / } \\
\text { Comissio Interministerial (GT) }\end{array}$ & \multicolumn{2}{|l|}{ 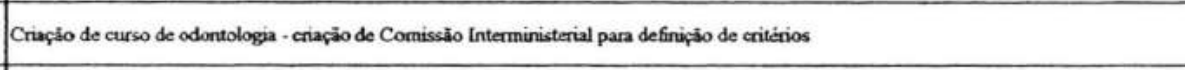 } \\
\hline & & & 9) Programas \& Ap̆̈es / Refornulaşäo e Controle / PAS X SUS & \multicolumn{2}{|l|}{ 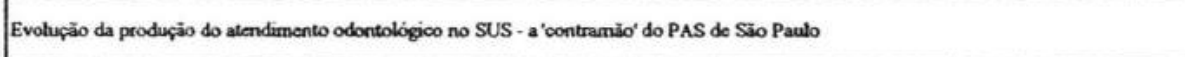 } \\
\hline & & & 6) Financiamento / Orgamento / Contingenciamento & \multicolumn{2}{|l|}{ Contingenciarnento de recursos de 1997 para 1998 - impacto sobre a prevenç̧o cm Saude Bucal } \\
\hline & & & $\begin{array}{l}\text { 7) Outras / Gestäio do Trabahtho Educaçio / Ensino Superior / } \\
\text { Comissäo Interministerial (GT) }\end{array}$ & \multicolumn{2}{|l|}{ Criaşäo de curso de odontologia - analise da regulamentaç̧o para atuā̧̧o do CNS } \\
\hline \multirow[t]{3}{*}{ ( } & 3 MOÇסES & 0 & . & - & \\
\hline & $\begin{array}{c}16 \\
\text { RECOMENDAÇÕES }\end{array}$ & 0 & . & - & \\
\hline & 22 RESOLUÇ̋̃ES & 1 & 1) Outras / Gestāo do Trabalho e Educap̧ăo / Profissionais de Saúde & Relaciona 14 categonas profisssionais de suide de nivel superior para fins de attuaçio no CNS. & \\
\hline
\end{tabular}




\begin{tabular}{|c|c|c|c|c|c|}
\hline \multirow{2}{*}{ Ano } & \multirow{2}{*}{ Documentos } & \multirow{2}{*}{$\begin{array}{l}\text { Saúde } \\
\text { Bucal } \\
\end{array}$} & & \multirow{2}{*}{\multicolumn{2}{|c|}{ Assuntos }} \\
\hline & & & Eiros-temíticos / temas & & \\
\hline \multirow{8}{*}{1998} & \multirow{2}{*}{11 PAUTAS } & \multirow{2}{*}{2} & 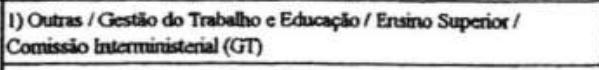 & \multicolumn{2}{|l|}{ Autonizacho para abertura de curnos de odontologia e composiç̧o de $G T$ para pareceres } \\
\hline & & & $\begin{array}{l}\text { 2) Outras / Cestho do Trabatho e Educarbio / Ensino Superior / } \\
\text { Comissio Interninisterial (GT) }\end{array}$ & Definifä̉o mentros dos GT MECMS & \\
\hline & \multirow{6}{*}{ II ATAS } & \multirow{6}{*}{4} & 1) Gestio e Org do Sistcana e de Assist / Regulanmentap̧äo do Sistema & Apresentaçäo dos componentes do PAB (Saúde Bucal - atendimento odontologico bisico) & \\
\hline & & & 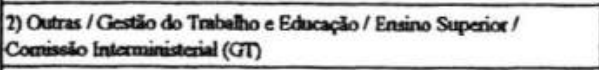 & Criegrio de curno de odontologia - definifizo de repressertantes do CNS para compor Grupos de Trabalho junto so MEC & \\
\hline & & & 3) Outras / Controle Social / Representiagio do CNS & Representapio do segmento Outros Profissionais de Saide Nä́l-Möticos no CNS - CFO & \\
\hline & & & $\begin{array}{l}\text { 7) Outras / Gestio do Trabaho e Educapio / Ensino Superior / } \\
\text { Conissio Interministerial (GT) }\end{array}$ & Criapso de curso de odontologia - representantes pera a Comiessảo Interinstitucional MECMS-CNS & \\
\hline & & & $\begin{array}{l}\text { 3) Outras / Gestäo do Trabahtho e Educasảo / Ensino Superior / } \\
\text { Comissio Interninisterial (GT) }\end{array}$ & Criaşäo de curso de odontologia - 5 representantes para OSontologia para Grupo Traballho MECMS & \\
\hline & & & $\begin{array}{l}\text { 6) Outras / Gestïo do Trabalho e Educaşäo / Pesquisa en Seres } \\
\text { Humanos }\end{array}$ & Portaria 196/106 - normas éticas para pesquises com novos equiparnentos médica-odonte hospit & \\
\hline \multirow{7}{*}{1999} & б MOÇŐs & o & . & - & \\
\hline & $\begin{array}{c}16 \\
\text { RECOMENDACÓES }\end{array}$ & 0 & . & . & \\
\hline & IORESOUCCOES & 0 & . & - & \\
\hline & 9 PAUTAS & 0 & . & - & \\
\hline & \multirow{3}{*}{ 10 ATAS } & \multirow{3}{*}{3} & 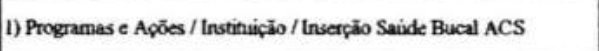 & \multicolumn{2}{|l|}{ Irviciativa de Programa reatizado por Agentes Cormunitatios de Saide (ACS) com apêes Sauide Bucal } \\
\hline & & & 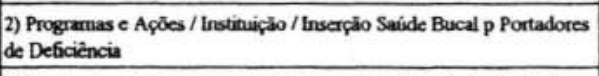 & Proposta de Pauta para a 97 Reunizä - Saride Bucal para os portadores de deficièncias & \\
\hline & & & $\begin{array}{l}\text { 3) Programas e Apöes / Instinuigão / Inecrpăo Savide Bucal p Portadores } \\
\text { de Deficiéncia }\end{array}$ & Proposta de Agenda para 2000 - Saúde Bucal dos portadores de deficiàncias & \\
\hline \multirow{7}{*}{2000} & 6 MOÇŌEs & 0 & - & - & \\
\hline & 8RECOMENDAÇÕES & 0 & - & - & \\
\hline & 8RESOLUÇŌES & 0 & . & - & \\
\hline & 11 PAUTAS & 0 & . & - & \\
\hline & \multirow{3}{*}{ II ATAS } & \multirow{3}{*}{3} & 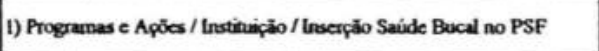 & \multicolumn{2}{|l|}{ 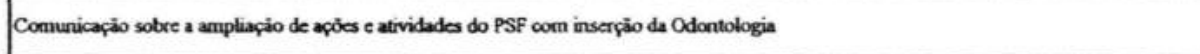 } \\
\hline & & & 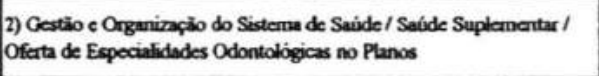 & 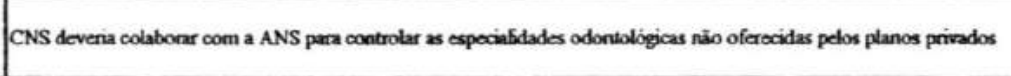 & \\
\hline & & & 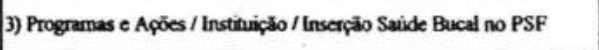 & Proposta para a Agenda 2001 - insereņ̧o da Saide Bucal no Programa Savide da Farnitia (PSF) & \\
\hline & 4 MOÇÕES & 0 & . & - & \\
\hline
\end{tabular}




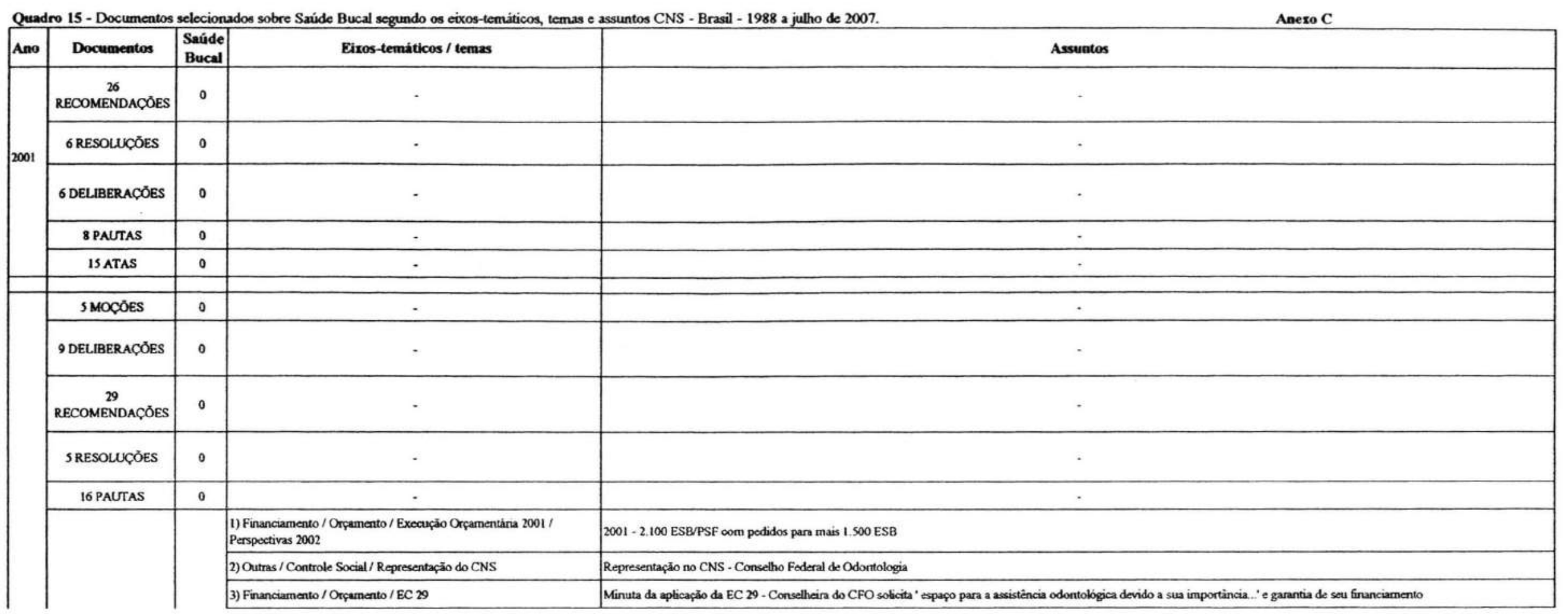




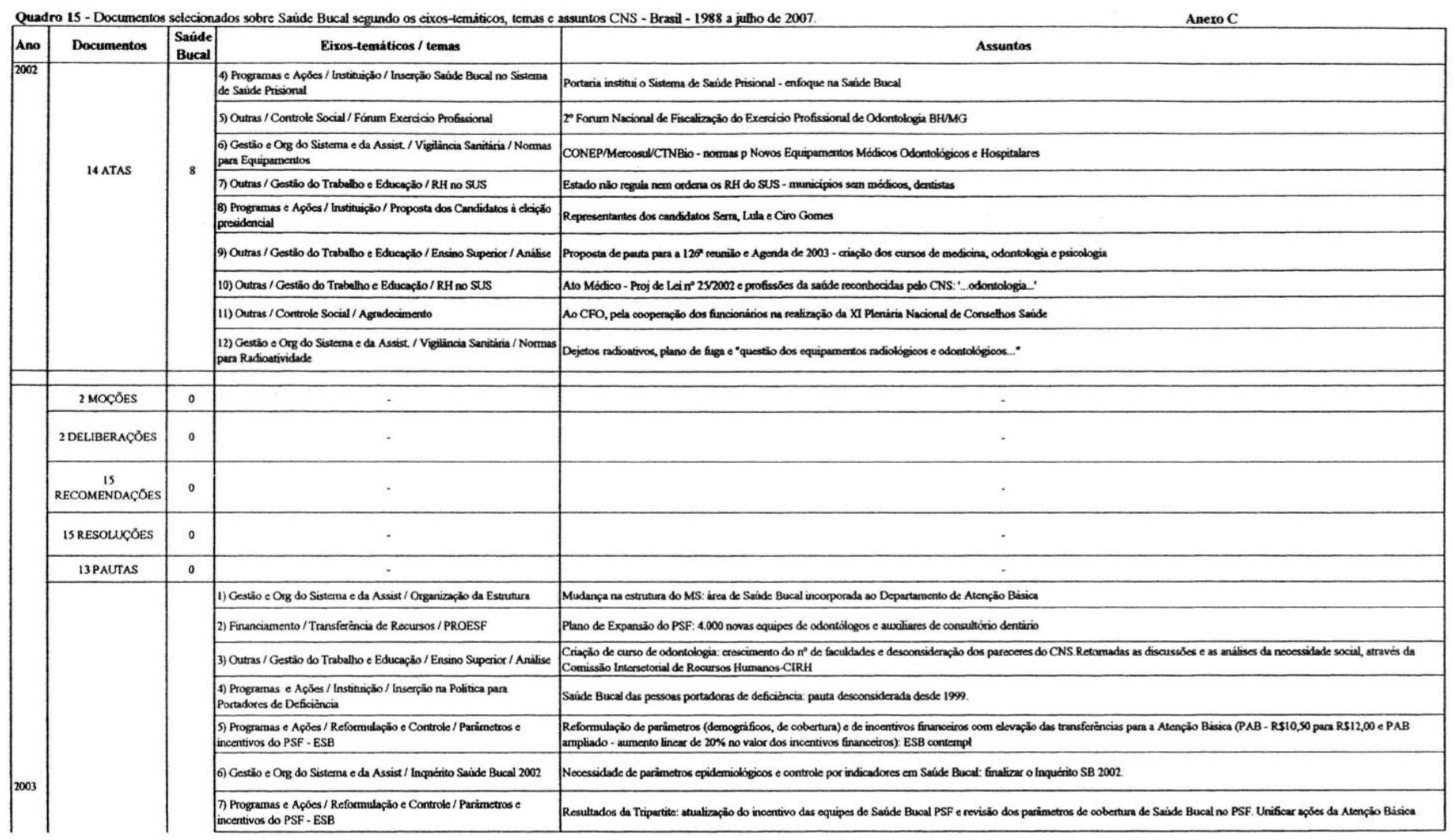




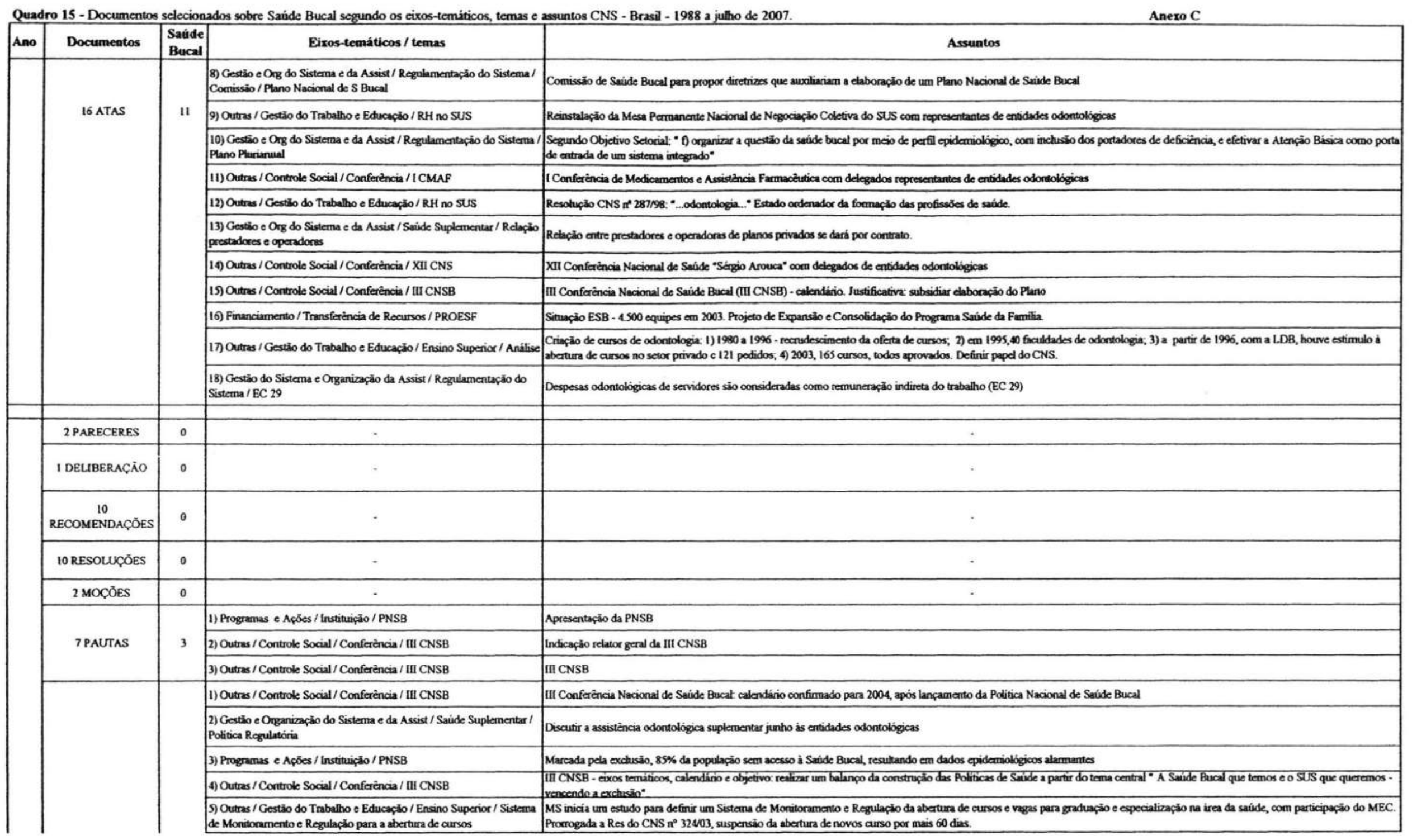




\begin{tabular}{|c|c|c|c|c|}
\hline \multirow{2}{*}{ Ano } & \multirow[b]{2}{*}{ Documentos } & \multirow{2}{*}{\begin{tabular}{l|} 
Saúde \\
Bucal
\end{tabular}} & & \multirow[b]{2}{*}{ Assuntos } \\
\hline & & & Eixos-temáticos / temas & \\
\hline \multirow{24}{*}{2004} & \multirow{24}{*}{ 13ATAS } & \multirow{24}{*}{10} & 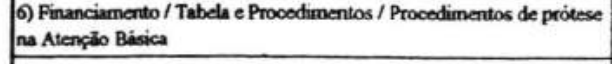 & 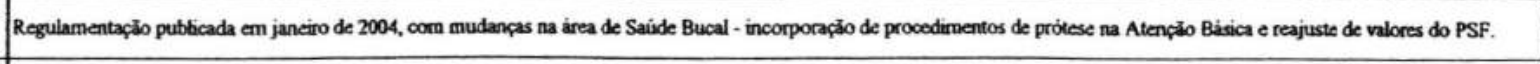 \\
\hline & & & 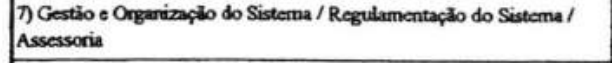 & 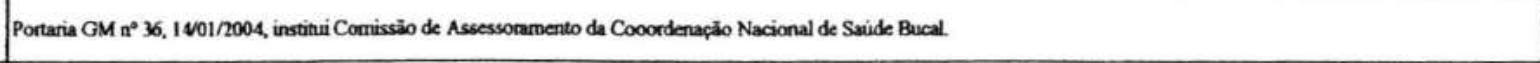 \\
\hline & & & 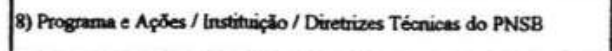 & 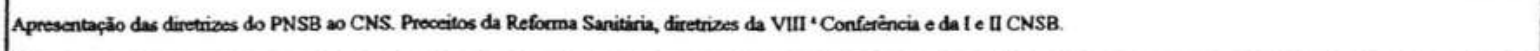 \\
\hline & & & 9) Progzama / /ustitutuiço/ Epidenniologia \& Prionidades PNSB & 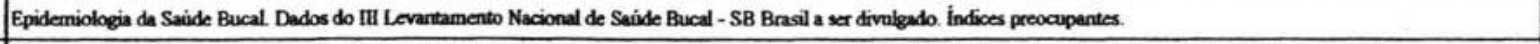 \\
\hline & & & 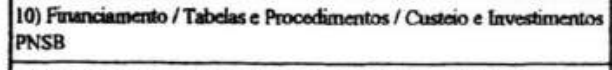 & 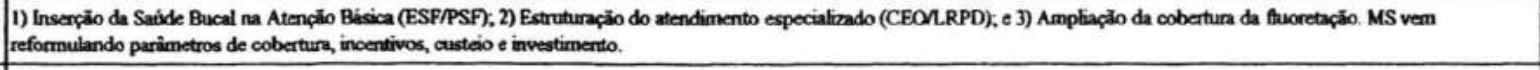 \\
\hline & & & 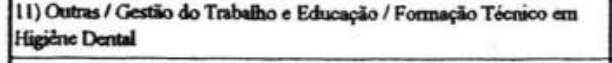 & 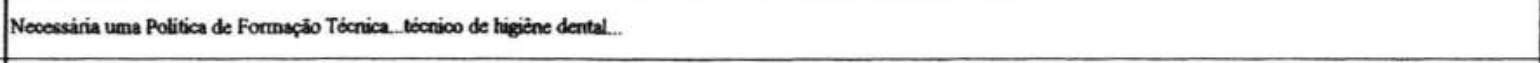 \\
\hline & & & $\begin{array}{l}\text { 12) Outras / Controle Social / Confertincia / Docurnento Bese da UII } \\
\text { CNSB }\end{array}$ & 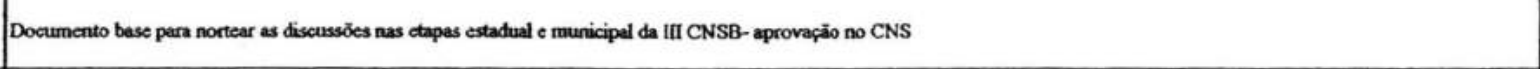 \\
\hline & & & 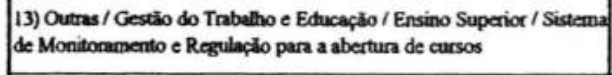 & 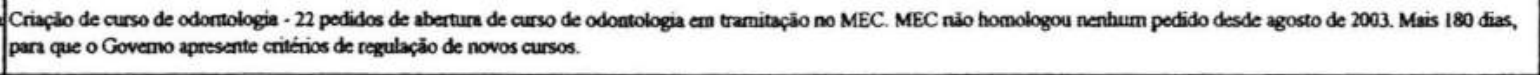 \\
\hline & & & 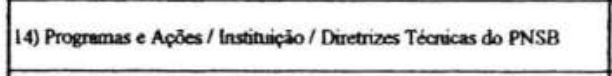 & 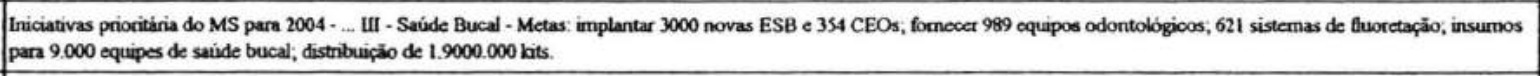 \\
\hline & & & 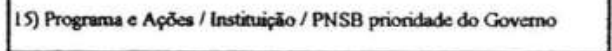 & Ministro reafirma Saide Bucal como prioridade do MS - bases lanfadas en 2003. \\
\hline & & & 19) Outras / Controle Social / Comissöes e GT & 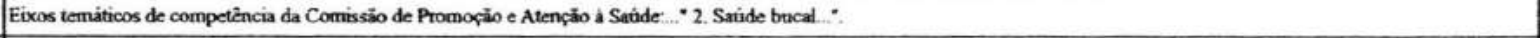 \\
\hline & & & 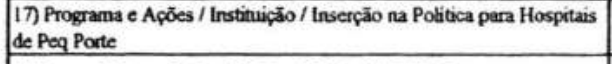 & Inseriu nos hospitais com menos de trinta leilos as urgéncias odontotógicas do PSFdo PSF \\
\hline & & & 18) Outras / Controle Social / Confernincia / III CNSB & 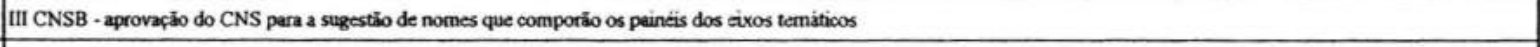 \\
\hline & & & 19) Outras / Controle Social / Canferenciaia / III CNSB & IIII CNSB - aprovaräio do calendärio final \\
\hline & & & 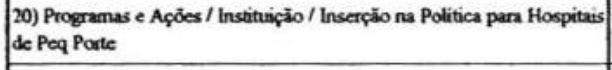 & 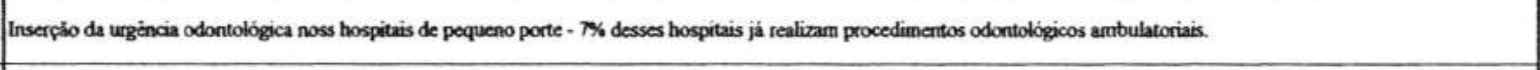 \\
\hline & & & 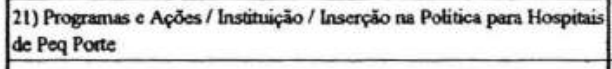 & DERAC / SAS considera importante incorporar a odontologia hospitalar à Reforma da Politica Nacional de Alençäo Hospitalar \\
\hline & & & 22) Financiamcento / Oryancento de 2005/Metas da PNSB & 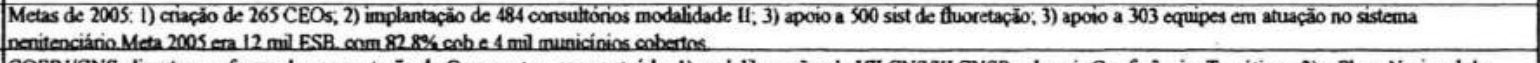 \\
\hline & & & 23) Orçamento / Propostad de Orgamento de 2005/ PPA 20042007 & 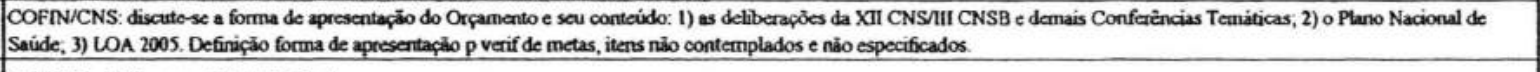 \\
\hline & & & 24) Outras / Controle Social / Confercincia / IIII CNSB & tul CNSB - CNS aprova Relatónio Final \\
\hline & & & 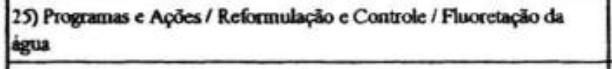 & 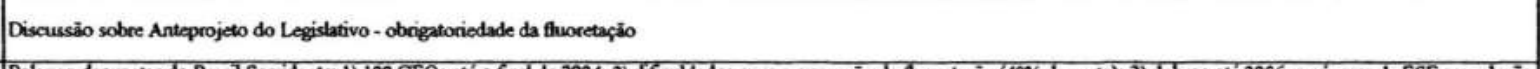 \\
\hline & & & 26) Programas e Ap̧ós / Instituigảo / Brasil Sorridente & 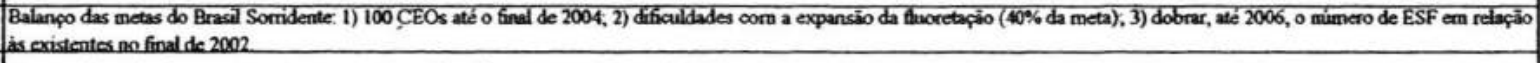 \\
\hline & & & 27) Outras / Meio Ambiente / Aguas naturalmente fluoretadas & Caracteristicas dass agguas quanto a composigäo quimica, fonte e potencial terapático (aguas fluoretadas). \\
\hline & & & 28) Financiamento / Tabclas e Procedimentos / Transifäo PSF - ESB & 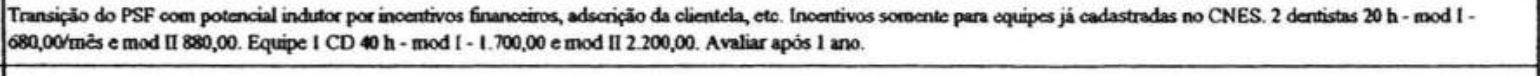 \\
\hline & & & 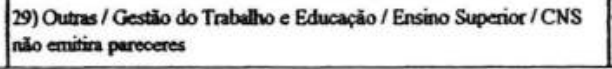 & 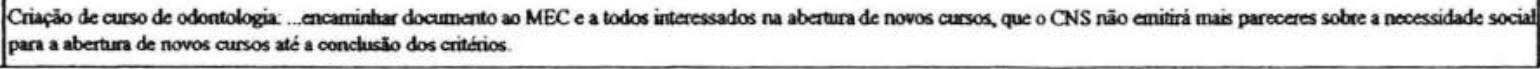 \\
\hline
\end{tabular}




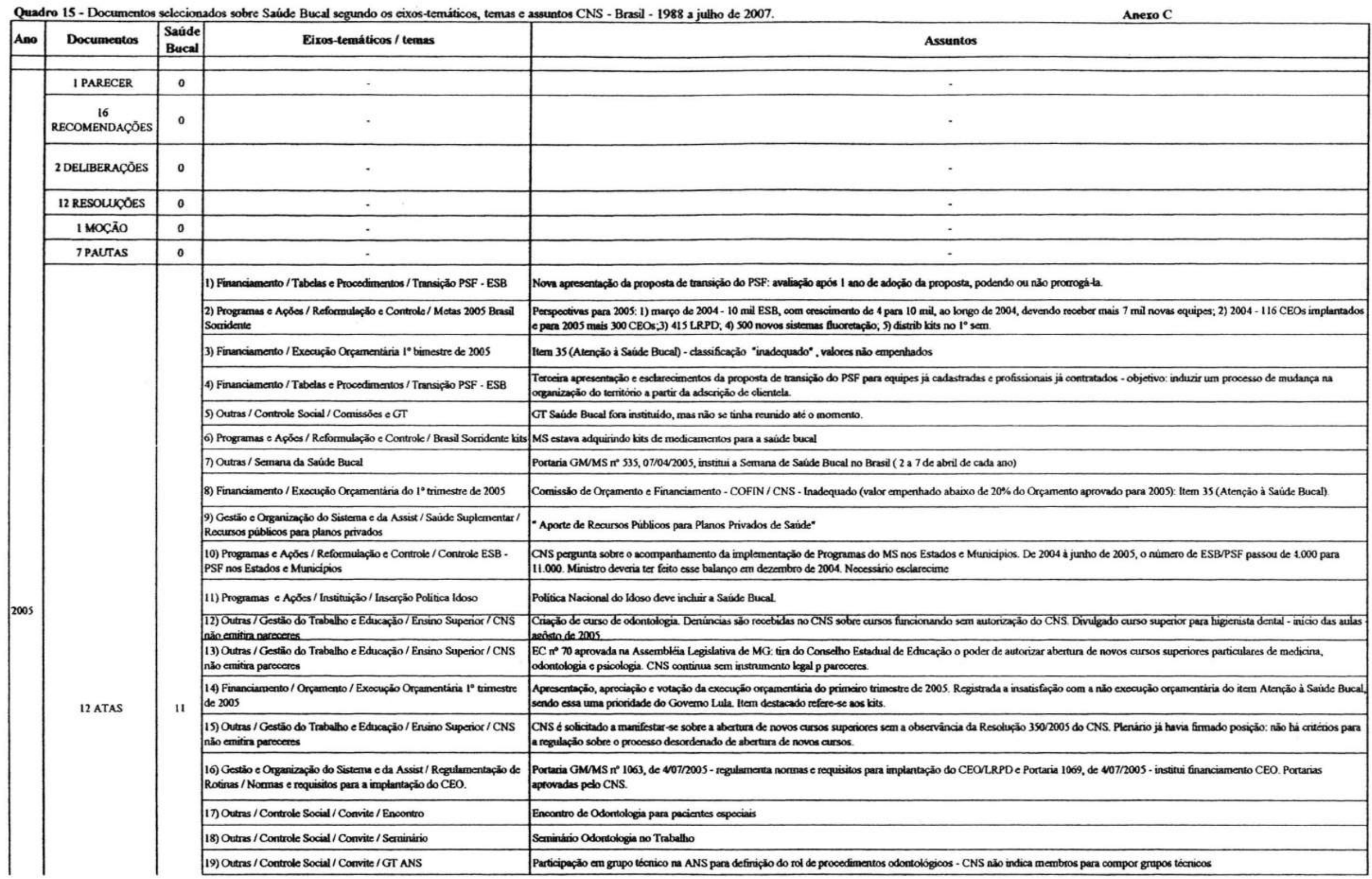




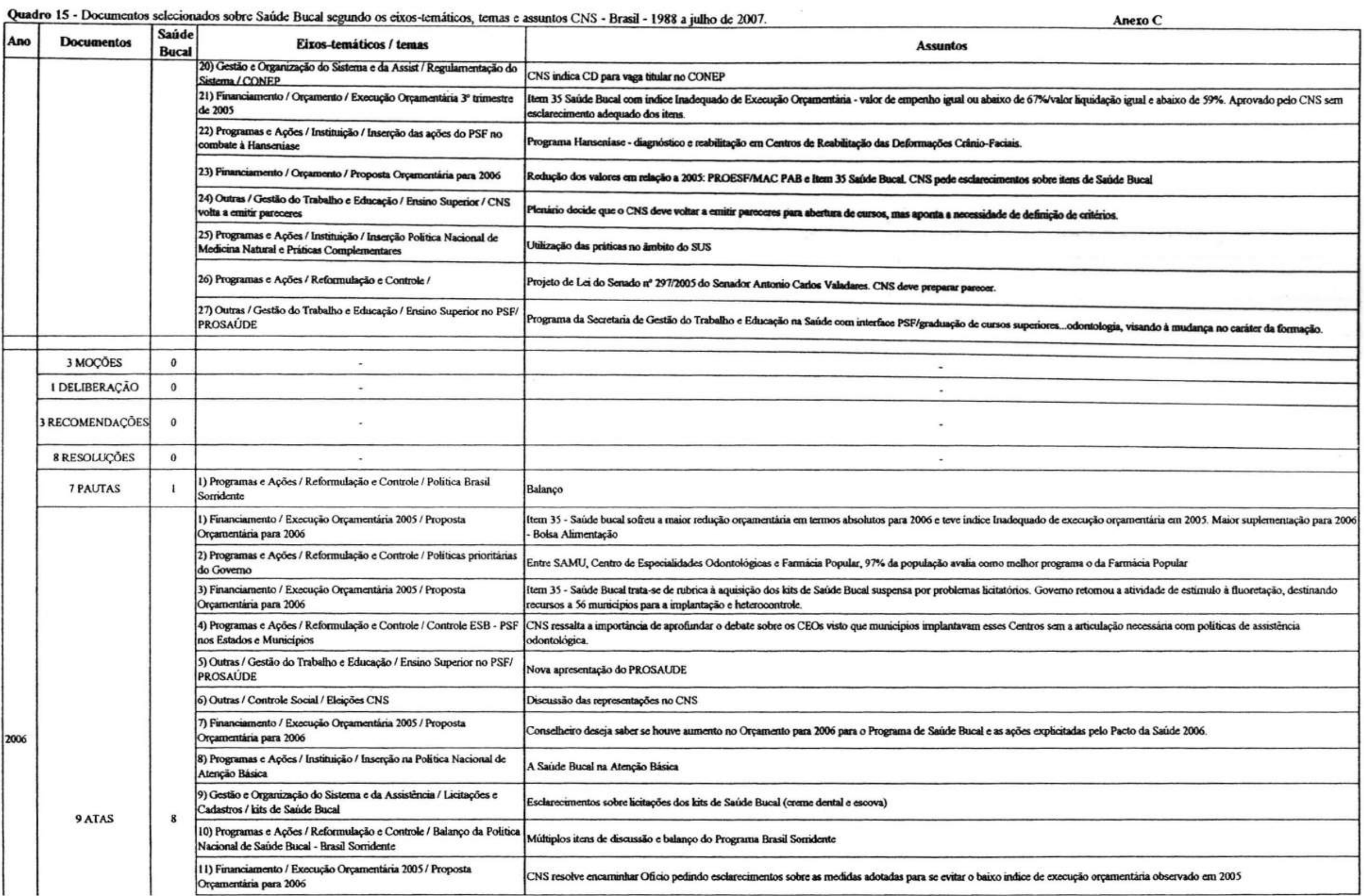




\begin{tabular}{|c|c|c|c|c|}
\hline \multirow{8}{*}{ Ano } & \multirow{8}{*}{ Documentos } & \multirow{8}{*}{$\begin{array}{l}\text { Saúde } \\
\text { Bucal }\end{array}$} & & \multirow[b]{2}{*}{ Assuntos } \\
\hline & & & Eixos-temáticos / temas & \\
\hline & & & 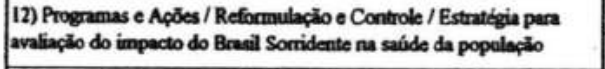 & 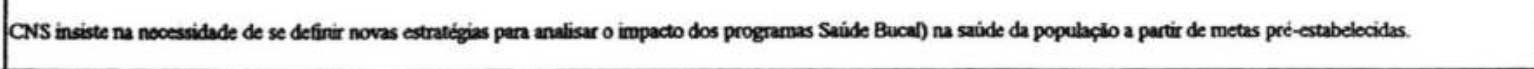 \\
\hline & & & 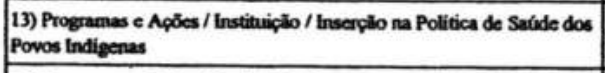 & 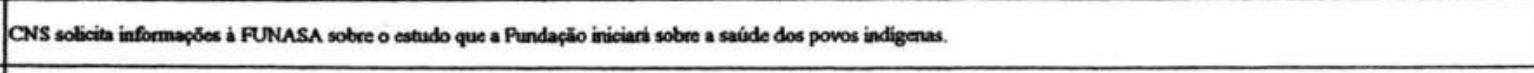 \\
\hline & & & 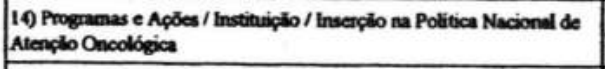 & Cinoer bucal \\
\hline & & & 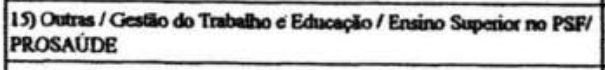 & Nove apresentaplo do PROSAUDE \\
\hline & & & 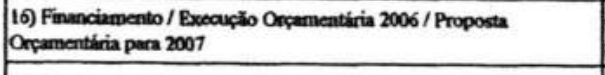 & 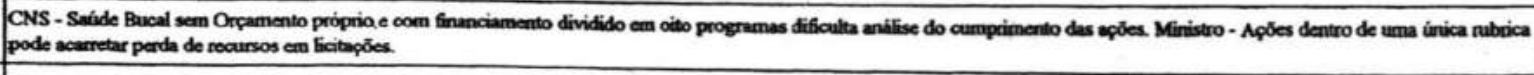 \\
\hline & & & 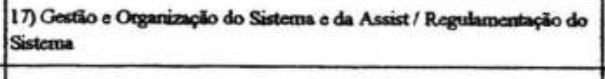 & 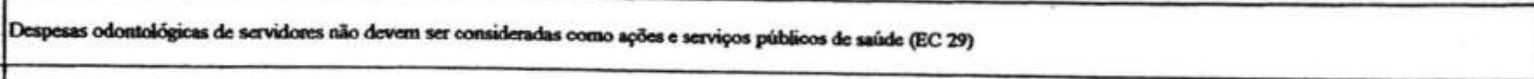 \\
\hline \multirow{6}{*}{$\begin{array}{l}\text { Ate } \\
\text { julho }\end{array}$} & 6 MOC̄ẼS & 0 & - & - \\
\hline & 4 RESOLUÇÕES & 0 & . & - \\
\hline & TPAUTAS & 0 & . & - \\
\hline & & & $\begin{array}{l}\text { 1) Outras / Gestio do Trabalho e Educasăo / Formas de contratarẳo RH } \\
\text { no sus }\end{array}$ & 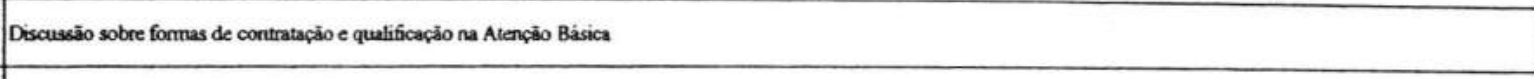 \\
\hline & & & 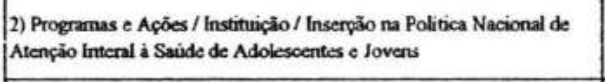 & Necessanio quatificar profissionais \\
\hline & & & 3) Outras / Controle Social / Comissōes e GT Saide Bucal & Grupo Técrioo de Saude Bucal para discussiäo das demandas que chegam ao CNS. \\
\hline
\end{tabular}


Quadro 15 - Documentos selecionados sobre Saúde Bucal segundo os eixos-temáticos, temas e assuntos CNS - Brasil - 1988 a julho de 2007.

Anero C

\begin{tabular}{|c|c|c|c|c|}
\hline Ano & Documentos & $\begin{array}{l}\text { Saúde } \\
\text { Bucal }\end{array}$ & Eixos-temiticos / temas & Assuntos \\
\hline \multirow[t]{6}{*}{2007} & \multirow[t]{5}{*}{ TATAS } & \multirow[t]{5}{*}{5} & $\begin{array}{l}\text { 4) Outras / Gestäo do Trabalho e Educaşäo / Ensino Superior / CNS } \\
\text { wolta a cmitir parcoceres }\end{array}$ & CNS volta a emitit parsoceres para a abertuna de cursos superiores, de acordo com a Portaria MEC ar' 147, de 2/02/2007 \\
\hline & & & S) Outras / Controk Social / Comissöes e GT Saide Bucal & 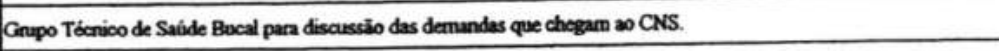 \\
\hline & & & 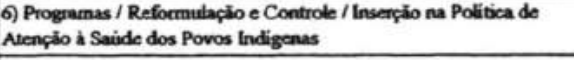 & Informes \\
\hline & & & $\begin{array}{l}\text { 7) Cestbo e Organizaplo do Sistema e de Assist / Organizacho da } \\
\text { Estrutura }\end{array}$ & 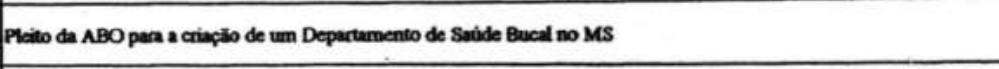 \\
\hline & & & $\begin{array}{l}\text { 8) Outras / Gestio do Trabalho e Educasajo / Ensino Superior / CNS } \\
\text { volta a entritir parecerers }\end{array}$ & 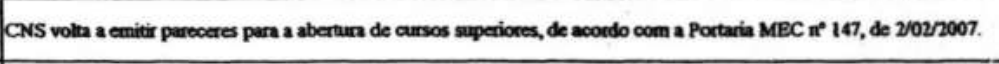 \\
\hline & 927 & 109 & 180 & \\
\hline
\end{tabular}

Fonte: claborado a partir da página do Consectho Nacional de Saide - hittp I/loonsetho. saude gov.br 
ANEXO D 


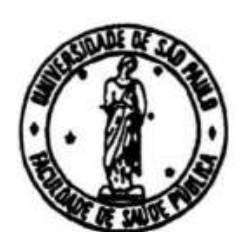

Universidade de São Paulo

Faculdade de Saúde Pública

COMITÊ DE ÉTICA - COEP

Av. Dr. Arnaldo, 715 - Assessoria Acadêmica - CEP 01246-904 - São Paulo - Brasil Telefones: (55-11) 3066-7779 - e-mail: coep@fsp.usp.br

\section{Of.COEP/16/06}

03 de fevereiro de 2006

Pelo presente, informo que o Comitê de Ética em Pesquisa da Faculdade de Saúde Pública da Universidade de São Paulo-COEP analisou de acordo com os requisitos da Resolução CNS/196/96 e suas complementares, o Protocolo de Pesquisa n. ${ }^{\circ} 1453$, intitulado: "A REGULAÇĀO DA ATENÇÃO À SAÚDE BUCAL NO BRASIL: ANÁLISE DAS AÇŌES REGULATÓRIAS SOBRE OS SERVIÇOS PÚBLICOS E PRIVADOS", apresentado pela pesquisadora Pola Alessandra Kalamatianos e por se tratar de pesquisa documental, não há necessidade de parecer deste Comitê.

Atenciosamente,

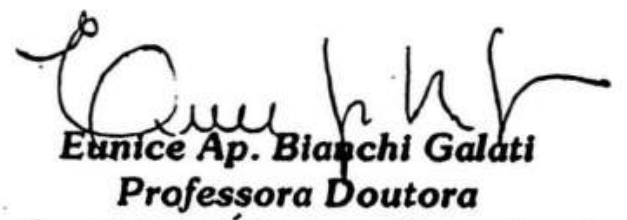

Coordenadora do Comitê.de Ética em Pesquisa da FSP - COEP 